






\section{INDEX.}

[The names of Synonyms or Plants incidentally mentioned are in italics. The page containing the description is printed in heavier type where there is more than one page.]

\begin{tabular}{|c|c|c|c|c|c|c|c|c|c|}
\hline & & & PAGE. & & & & & & PAGE. \\
\hline Aberrant Eucalypts ... & $\ldots$ & $\ldots$ & 223 & Bibble ... & ... & ... & $\ldots$ & ... & 339 \\
\hline Aconitum napellus, $\mathrm{L}$. & $\ldots$ & $\ldots$ & 248 & Big-leaf & $\cdots$ & $\cdots$ & $\therefore$ & ... & 133 \\
\hline Agonis flexuosa, DC. ... & $\ldots$ & $\ldots$ & 18 & Big-tree & $\cdots$ & $\ldots$ & - $\ldots$ & $\ldots$ & $\ldots$ \\
\hline Almond-leaved Stringybark. & .. & $\ldots$ & 300 & Bimbil ... & $\cdots$ & $\cdots$ & $\ldots$ & $\ldots$ & $\ldots$ \\
\hline Alternate-leaves $\quad \ldots . \quad$. & $\cdots$ & $\cdots$ & 6 & Black Ash & .. & $\ldots$ & $\cdots$ & $\cdots$ & 127,506 \\
\hline amygdalina, Broad-leaved. & $\cdots$ & $\cdots$ & 192 & Box & $\cdots$ & $\cdots$ & $\cdots$ & ... & $\ldots \quad 330$ \\
\hline Anderson, Dr. W. ... & $\ldots$ & $\cdots$ & 20 & Gum & $\cdots$ & $\cdots$ & $\cdots$ & $\cdots$ & $\ldots$ \\
\hline Angophora cordifolia, Cav. . & $\ldots$ & $\ldots$ & 18 & - Sally & $\ldots$ & $\ldots$ & $\ldots$ & $\therefore$ & $\ldots$ \\
\hline
\end{tabular}

Angophora cordifotia, Car.... ... ... 18 intermedia, DC... $\quad$... ... 19 lanceolata, Car. $\quad$... ...19, 137

Anther ... $\quad \ldots \quad$... $\quad \ldots \quad \ldots \quad \ldots \quad 10$

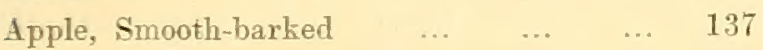

Apple-tree Eucalyptus $\quad \ldots \quad \ldots . \quad \ldots \quad \ldots \quad 19$

$\begin{array}{lllll}\text { Arbor versicolor Ay-alla } & \ldots & \ldots & \ldots & 17\end{array}$

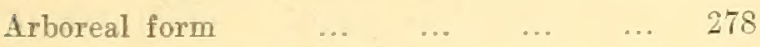

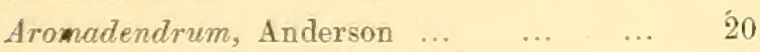

$\begin{array}{llllll}\text { Ash, Black } & \ldots & \ldots & \ldots & \ldots & 127,506\end{array}$

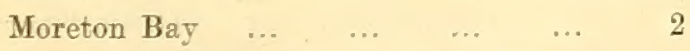

Mountain $165,177,184,275,289,306,322$

Rough-barked Mountain (Gippsland)... 308

$\begin{array}{llllll}\text { White } & \text { W } & \ldots & \ldots & \ldots & 279,309\end{array}$

White-topped Mountain _.. $\quad \ldots .161$

Baker, R. T. ...

24

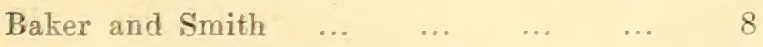

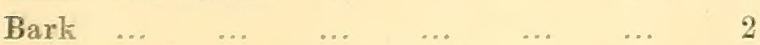

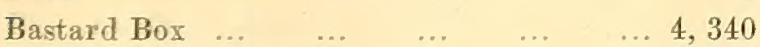

$\begin{array}{lllllll}\text { Ironbark } & \ldots & \ldots & \ldots & \ldots & 308\end{array}$

$\begin{array}{llllll}\text { Messmate } & \ldots & \ldots & \ldots & \ldots & 192\end{array}$

Peppermint ... ... . ... ... 131

Stringybark $\quad \ldots \quad 52,192,194,237$

Baudin's Expedition... ... $\quad \ldots \quad \ldots \quad \ldots \quad 117$

$\begin{array}{lllllll}\text { Bee-lang } & \ldots & \ldots & \ldots & \ldots & \ldots & 53\end{array}$

$\begin{array}{lllllll}\text { Bembil Box } & \ldots & \ldots & \ldots & \ldots & \ldots & 341\end{array}$

$\begin{array}{lllllll}\text { Benaroon } & \ldots & \ldots & \ldots & \ldots & \ldots & 27\end{array}$

$\begin{array}{lllllll}\text { Benarora } & \ldots & \ldots & \ldots & \ldots & \ldots & 39\end{array}$

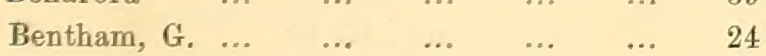

Blackbutt 5, 26, 33, 165, 184, 194, 300, 306,322, 332

$\begin{array}{lllllr}\text { Bulli } & \ldots & \ldots & \ldots & \ldots & 30 \\ \text { Great } & \ldots & \ldots & \ldots & \ldots & 26 \\ \text { Red } & \ldots & \ldots & \ldots & \ldots & 188 \\ \text { Spurious } & \ldots & \ldots & \ldots & \ldots & 183\end{array}$

Blackbutted Gum _.. $\quad \ldots \quad \ldots \quad \ldots 26,263$

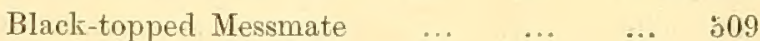

Mountain Ash _... ... $\quad 161$

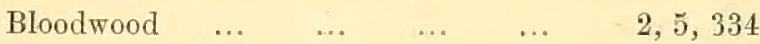

Blue Gum $\quad \ldots \quad \quad \ldots \quad \ldots \quad \ldots \quad \ldots 54, \pm 27$

Peppermint $\quad \ldots \quad \ldots \quad \ldots . \quad \ldots 191,192$

$\begin{array}{llllll}\text { Blue-leaf Ironbark } & \ldots & \ldots & \ldots & \ldots & 325\end{array}$

Stringybark $\quad \ldots \quad \ldots \quad 215, \approx 16$

$\begin{array}{llllllll}\text { Blume ... } & \ldots & \ldots & \ldots & \ldots & \ldots & 20\end{array}$

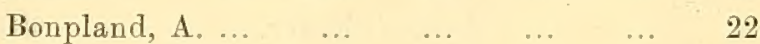

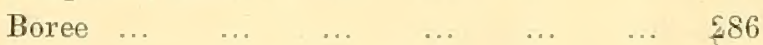

$\begin{array}{llllll}\text { Bour-rougne } & \ldots & \ldots & \ldots & \ldots & 211,302\end{array}$

$\begin{array}{llllll}\text { Box } & \ldots & \ldots & \ldots & \ldots & 4,149,332,342\end{array}$

\begin{tabular}{|c|c|c|c|c|c|}
\hline Bastard & $\ldots$ & $\ldots$ & $\ldots$ & .. & $\ldots 4,340$ \\
\hline Black & $\ldots$ & $\ldots$ & $\ldots$ & .. & .. $\quad 330$ \\
\hline Drooping & & $\ldots$ & $\ldots$ & .. & 343 \\
\hline Glossy or & Shiny & -leaved & $\ldots$ & .. & 339,341 \\
\hline Gum-toppe & ed & $\ldots$ & $\ldots$ & .. & 340 \\
\hline Ironbark . & ... & $\ldots$ & $\ldots$ & .. & $\ldots$ \\
\hline Mallee & $\cdots$ & $\ldots$ & $\ldots$ & . & $\ldots$ \\
\hline Minty & ... & ... & $\ldots$ & & 41 \\
\hline Pale & .. & $\ldots$ & $\ldots$ & & \\
\hline Peppermin & & $\ldots$ & $\ldots$ & & $\ldots$ \\
\hline Poplar-lea & aved & $\ldots$ & $\ldots$ & .. & $\ldots$ \\
\hline
\end{tabular}




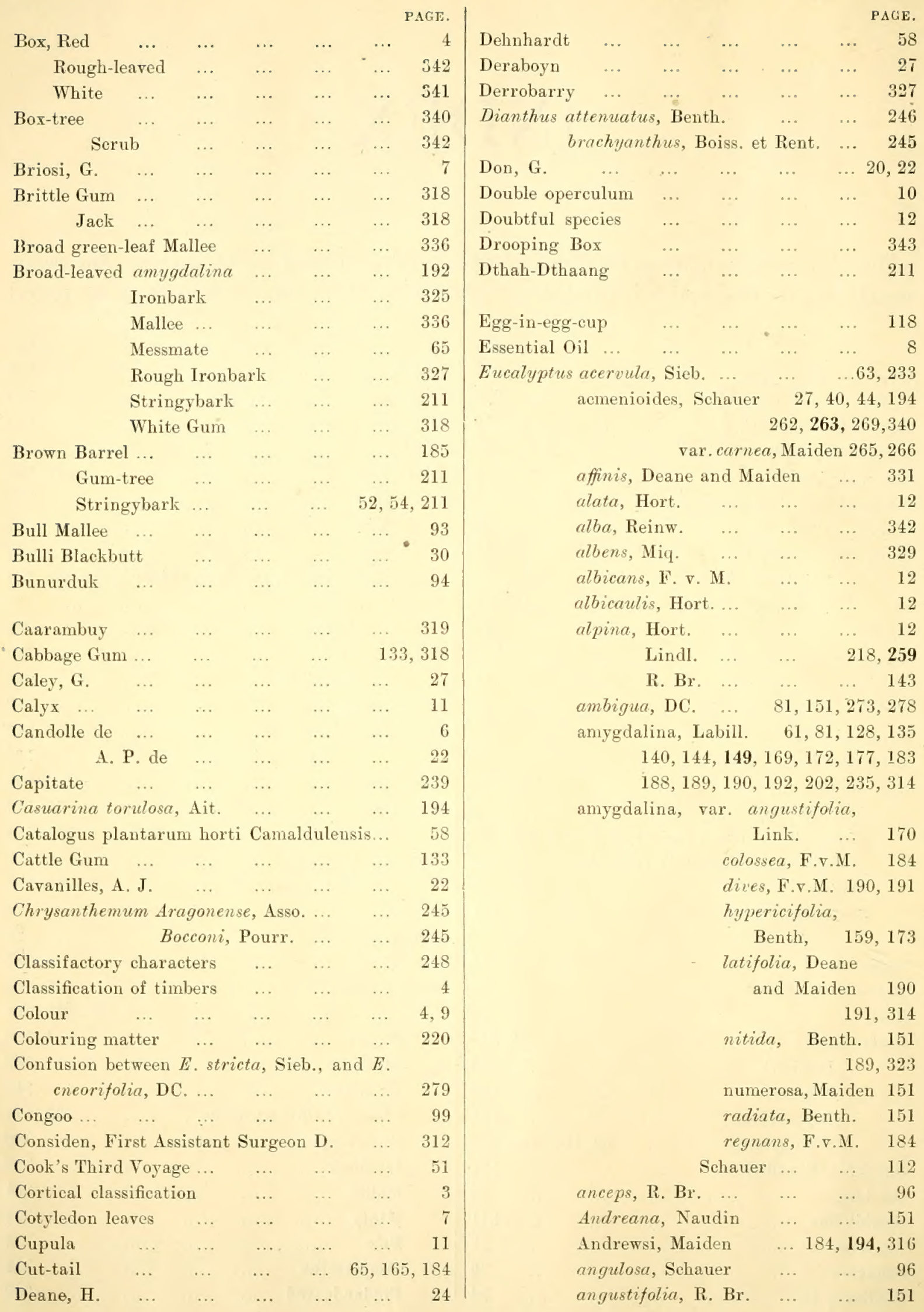


PASE.

Eucalyptus apiculata, Baker and Smith

Baileyana, F. V. M. ...

Baxteri, R. Br.

...

Behriana, F. v. M. rar. purpuresens,

F. . M. ... ... 337

bicolor, A. Cunn.

$89,251,336$

339,343

var. parviflora, F.v.M. 340

Bcormani, Deane and Maiden... 330

Bosistoana, F. . . M. ... 251,272

Bowmani, F. v. M. $\quad$.. $\quad$... 344

Bridgesiana, R. T. Baker ‥ 285

buprestium, F. v. M. ... … 243

Caleyi, Maiden ... $\quad$... $\quad$... 325

caljeogona, Turcz. _.. $\quad \mathbf{7 6}, 95,119$

var. celastroides,

Maiden ... ... 79

var.gracitis, Maiden 78

calyculata, Link.

151

capitellata, Sm. $\quad 27,29,34,43,53$

$139,203,211,224,225$

$230,232,239,259,299$

var. (?) latifotia,

Benth. ... ... 212

carnea, R. T. Baker ... 263, 270

celastroides, Turcz. $\quad$... $\quad$.. $\quad 79$

citryandra, (?) Vilmorin _... 143

cladocalyx, F,, . M. ... $\quad \ldots .341$

cneorifolia, DC. $\quad 81,98,199,280,286$

coccifera, Hook.f. 141, 142, 177, 203

var. parviflora, Benth. 143

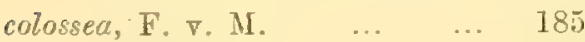

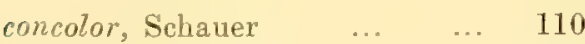

congesta, R. Br. $\quad \ldots \quad$... 212

conglobata, R. Br. $\quad \ldots . \quad \ldots .96$

connata, Dun.-Cours. ... 173, 199

J. Schaver ... ... 174

Consideniana, Maiden ... $\quad 309,312$

coriacea, A. Cunn. 53, 68, 128, 133

$145,166,189,275,310,323$ hybrid .... ... 140

var. alpina, Benth.... 135 sylvicultrix,

F. V. II. … 136

cornuta, Labill. ... ... $\quad 198,329$

corrugata, Luehmann ... ... 109

corymbosa, Sm... ... $\quad 153,279$

corynocalyx, F.. M. ... $\quad \ldots .344$
Eucalyptus cosmopihylla, F. v. M: ... $\quad 111,260$ costata, R. Br. ... … ... 96 - cotinifotia, Lodd. ... ... 12 crebra, F. v. M. 266, 324, 329, 332, 340 Cunninghamii, G. Don... 129, 286 Sweet ... 129, 286 $\begin{array}{lllll}\text { curoula, Sieb. } & \ldots & \ldots & \ldots & 12\end{array}$ cuspidata, Tausch. ... ... 199 Turez, ... ... 96 daphnoides, Miq. _.. _... 14 : elecurva, F。 . .I. . . . $\quad \ldots \quad 110$ deglupta, Blume $\quad \ldots \quad \ldots 12,13$ delegatensis, R. T. Baker $ז 2,177,310$ dextropinea, Baker ... 2 27, 31,240 discolor, Desf. ... ... ... 31 diversicalor, F. V. M. ... ... 185 diversifolia, Bonpl. 99, 106, 174, 197 $214,220,231,274$

[Erratum.-E. diversifolia, Bonpland, p. 198. I have followed Bentham in describing the anthers as reniform, and at fig. 6, Plate 36, I have figured them so. The anthers, however, have parallel cells, bringing this species into the parallelantheræ. I will deal with the matter at length when the Eucalyptus Gunnii section is reached.]

diversifotia, Otto _... ... 151 dives, Schauer 57, T0, 164, 185, 190 $196,285,314$

drepanophylla, F. v. M. 331, 332, 345 dumosa, A. Cunn. ... 81, 95, 199 var. conglobata, R.Br. 96, 213 punctitulate,

Benth. $\quad$... 96 rhodophloia, Benth. ‥ 86,98 scyphocalyx, F. . M. $\quad$... 96

elata, Dehnh. ... ... .... 151

Giordano ... $\quad \ldots \quad \ldots \quad 151$

elatus, Hook. f. ... ... ... 5 erythronema, Turcz. ... 110, 244 var. Roei, Maiden 110 eugenioides, Sieb. $36,42,67,99,211$ $218,220,225,227,232,233$ 263, 272, 299, 303, 314, 34. var. nana, Deane and Maiden ... 234

exserta, F. . M. - ... ... 249 fabrorum, Schlecht ... 40, 203,218 


\begin{tabular}{|c|c|c|}
\hline ucalyptus & sfalcata, Turez. ... & Eucalyptus hispida, $\mathrm{Sm}$. \\
\hline & falcifolia, Miq. ... & hypericifolia, $\mathrm{R} . \mathrm{Br}, \ldots$ \\
\hline & fasciculosa, F. v. M. ... . .. 86,88 & hypoleuca, Schauer \\
\hline & fastigata, Deane and Maiden 165, 183 & incrassata, Labill, $\quad \ldots \quad 86, \mathbf{9 3}, 117$ \\
\hline & $184,189,196$ & var. angulosa, Schauer $\quad 96$ \\
\hline & fibrosa, F. v. M... $\quad \ldots \quad 31,45,325$ & conglobata, R. Br. 96,200 \\
\hline & firma, F, v. M. .. $\quad$.. $\quad \ldots \quad 199$ & dumosa, F. v. M. 82,94 \\
\hline & fissilis, F.. M. ... … $\quad$.. 57 & 117,338 \\
\hline & flexilis, Regel $\ldots . \quad \ldots \quad$.. 14 & goniantha, Maiden $\quad 96$ \\
\hline & floribunda, Hügel $\quad \ldots \quad$.. 241 & grossa, Maiden .... \\
\hline & fœcunda, Schaver $76,80,88,109,112$ & $\begin{array}{rrr}r u g o s a & \ldots & \ldots\end{array}$ \\
\hline & var. loxophleba, J. G. & $\begin{array}{rrrrr}\text { Sieb. } & \ldots & \ldots & \ldots & 31\end{array}$ \\
\hline & $\begin{array}{llll}\text { Luehmann } \ldots & \ldots & 112\end{array}$ & inophloia, F. v. M. … ․ 184 \\
\hline & fraxinoides, Deane and Maiden 273 & Kitsoni, J. G. Luehmann $\quad$... 111 \\
\hline & fruticetorum, F. $\mathrm{F} . \mathrm{M} . \quad 79,112,119$ & levopinea, Baker $\ldots 27,31,220$ \\
\hline & galbulus, Hort. ... … … 34 & $\begin{array}{c}\text { var. minor, R. T. } \\
\text { Baker } \quad \ldots \quad 43,221,249\end{array}$ \\
\hline & $\begin{array}{l}\begin{array}{l}\text { gigantea, Hook. f. } \\
\text { glandulosa, Desf. }\end{array} \\
\text {... }\end{array}$ & lamprocarpa, F. ₹. M. ... … 96 \\
\hline & $\begin{array}{lllll}\text { glauca }(?) \ldots & \ldots & \ldots & \ldots & 153\end{array}$ & Inrgiflorens, F. v. M. ... ' \\
\hline & $\begin{array}{lllll}\text { Hoffing. } & \ldots & \ldots & \ldots & 15\end{array}$ & $\begin{array}{l}\text { var. parviflora, } \\
\text { Benth. }\end{array}$ \\
\hline & globularis, Hort. $\quad \ldots \quad \ldots \quad 151$ & $\begin{array}{rrrr}r \text { Benth. } & \ldots & \ldots & 340 \\
\text { leptophleba, F. } . \text { M. } & \ldots & 331,332\end{array}$ \\
\hline & globulus, Labill. $7,54,62,113,183,260$ & leucadendron, A. Cunn. \\
\hline & glomerata, Tausch. $\quad \ldots \quad$ ‥ 96 & lencoxylon, F. . . M. ... \\
\hline & I mphocephater, DC, .. 101, 111, 198 & ligustrina, DC. ... _.. \\
\hline & $\begin{array}{lllr}\text { goniantha, 'Turez. } & \ldots & \ldots & 96 \\
\text { goniocalyx, F. F. M. } & 6 \pm, 100,161,289\end{array}$ & Lindleyana, DC.... ... \\
\hline & $\begin{array}{l}\text { goniocalyx, F. v. M. } 64,100,161,289 \\
\text { gracilis, F.v.M. ... }\end{array}$ & linearis, Dehnh, ... $\quad \ldots \quad \ldots 14,168$ \\
\hline & var. brevifora, Benth.... & linopoda, R. Br... $\quad \ldots \quad$ ․ $\quad 96$ \\
\hline & Thosetiana, F. . M. T9 & Tongifolia, Lindl. $\quad \ldots \quad \ldots 151$ \\
\hline & Miq. $\quad \ldots \quad \ldots \quad \ldots$ & Inxophleba, Benth. $\quad \ldots \quad 80,112,113$ \\
\hline & grossa, F. v. M. ... … & var. fruticosa, Benth. 113, 114 \\
\hline & Gunnii, Hook, f。 $\quad \ldots \quad \ldots 6 \quad 62$ & Luehmanniana, F. v. M. $273,281,284$ \\
\hline & var. acervula, Deane and & 287,323 \\
\hline & Maiden $\quad \ldots \quad \ldots 31,62$ & var.altior, Deane and \\
\hline & var. maculosa, Maiden... 323 & Maiden 288, 309, 323 \\
\hline & hremastoma, Sm. $\quad 70,139,162,191$ & $\begin{array}{r}\text { macrormpneha, F. } \nabla . \text { M. } 29,34,43,61 \\
203,211,218,224\end{array}$ \\
\hline & $196,275,284,306,309,316,317$ & $\mathbf{2 2 5}, 232,240,301$ \\
\hline & hremastomn, var. capitata, & var.(?)brachycorys, \\
\hline & Maiden $\quad \ldots \quad \ldots, \quad \ldots$ & Benth. ... $\quad \ldots 43,226$ \\
\hline & hemastoma, var. micrantha, & maculata, Hook, $\quad$... \\
\hline & Benth.... ... & Mahogani, F. V. M. \\
\hline & hamastoma, var. montana, & marginata, $\mathbf{S m}$. \\
\hline & Deane and Maiden $\ldots . \quad 163,323$ & media, Link. ... … \\
\hline & hamastonza, var. $\quad \ldots \quad \ldots, \quad 221$ & melanophloia, F. v. M... .. 332 \\
\hline & hemiphloix, F. v. M. 99, 330, 331, 337 & melliodora, A. Cunn. ... 102, 108, 272 \\
\hline & 341,344 & micrantha, A. Cunn. ... ‥ 340 \\
\hline & var.albens, F.v.M. 58, 329, 344 & DC. $\ldots$ \\
\hline & heterophylla, Miq. & microcorys, F.v.M. $27,29,261,263,272$ \\
\hline & hirsuta, Link. ... & mierophylla, A. Cunn.... $\quad 129,286$ \\
\hline
\end{tabular}


PAGE. Eucalyptus microphylla, Willd. $\quad$.. $\quad \ldots . \quad 18$ moluccana, Roxb. ... ... 15 Moorei, Maiden and Cambage ... 286 mucronata, Link. _... ... 299 Muelleri, Miq. ... $\quad \ldots . \quad \ldots, 96$ Muelleriana, Howitt 27, 31, 214, 218 $219,229,231,238,240$ multiflora, Poir. 32 multiplinervis, Miq. ... $\quad \ldots \quad 136$ myrtifolia, Link. $\quad \ldots . \quad \ldots \quad 15$ nervosa, F. $\mathrm{F}, \mathrm{M} . \quad \ldots \quad \ldots \quad \ldots 7$ Hoffmg. $\quad . . \quad \ldots .16$ nigra, R. T. Baker 43, 221,26t,270 nitida, Hook. 1.... ... ... 151 nova-anglica, Deane and Maiden 238 mimerosa, Maiden 151,300 obliqua, L'Hérit. 36, 40, 44, 51, 174 1 个 $, 183,201,203,224,233$ $275,290,299,305,314$ var. alpina, Maiden $176,17 \%$ $185), 310$

oblonna, DC ...38, 233 obtusiflora, DC... ... $\quad 273,286$ achrophloia, F, v. M. ... ... 79 odorata, Behr... $\quad 82,113,119,337$

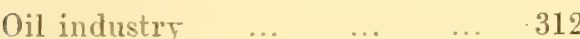
Oldfieldii, F. v. M. ... $\quad 198,201$ oleifotia, A. Cunn. ... ... 233 oleosa, F. ४. M, $88,108,110,280$ oppositifolia, Desf. $\quad \ldots . \quad \ldots .16$ orbicularis, Lodd. $\quad$... $\quad \ldots . \quad 16$ oreades, R. T. Baker ... T1, 288, 289 ornata, Sieb.

33,325 pachyloma, Benth. - 198,199 pachyphylla, A. Cunn,... ... 96 F. $\nabla$. M. ... ... 96

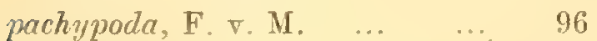

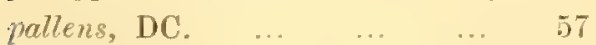
paniculata, Sm. 86, 88, 299, 324, 328, 329. patellaris, F.. . M.

... 332 pauciflora, Sieb. $58,131,133,135$ pedicellata, $\mathrm{R}$. Br. 241 penicillata, Hort.

... 233 perfolicita, Dumont ... ... 173 R. Br. $\quad \ldots \quad \ldots, 174$ Tausch. $\quad . . \quad \ldots .174$ perforata, Behr... ... ... 81 persicifolia, DC. ... ...31, 325 Lode. ... ...31, 263 phlebophylla, F.v.M. ... $\quad \ldots .135$
Eucalyptus phillyreoides, Lodd. ... ... 16 pilularis, Sn. 25, 67, 194, 220, 241, 262

$271,259,299,305,326,328$ var. acmenioides, Benth.

Muelleriana, Maiden

$34,203,214,219$

pinnata (?), Hort.

143 piperita, Sm. 27, 28, 34, 40,43, 67, 188 $191,194,211,235,239$ $240,267,272,299,306$

312,315 var. eugenioides, Benth. 304 laxiflora; Benth.... 301 pauciflora, DC. 135, 273

Planchoniana, F.v.M. 111, 198, 203, 291 plutyphylla, F. จ. M. ... ... 343 polyanthemos, Schauer ... ... 339 var. populifolia, F. ₹. M. ... 340 populifolia, Hook. ... ... 339 populifolius, Hook. ... . .. 342 populnea, F. V. M. ... 340,343 Preissiana, Schauer ... 104, 260 procera, Dehnh... ... ... 57 pruinosa, Behr... ... ... 335 pulchella, Desf.... ... ... 169 pulverulenta, Sims ... 175, 274 punctata, DC, ... ... 29, 128,314 purpurascens, Link. ... ... 337 var. petiolaris, DC. 153 petiolata, DC. 151, 153

radiata, Hook. f. ... 151, 173, 17 $\begin{array}{lllll}\text { var. } & \ldots & \ldots & \ldots & 4,69\end{array}$ Sieb. $\quad 112,135,150,151$ regnans, F. . . M. 67, 70, 134, 135, 165 $167,183,189,196,222$ var. fastigata... ... 316 resinifera, Hort. ... ... 18 Sm. 27, 29, 233, 326, 329 reticulata, Link. $\quad$... $\quad 16,299$ rigida, Hofimannsegg ... ... 273 R. Br. ... ... ... 273 Sieb. ... ... 2 73,285 var. Luehmanniana, F.v.M. 288 Risdoni, Hook. f. 172 var. elata, Benth. 69, 144 153,173

robusta, Hoffimg. 16 Sm. $\quad \ldots \quad \ldots \quad 93,95,241$ 


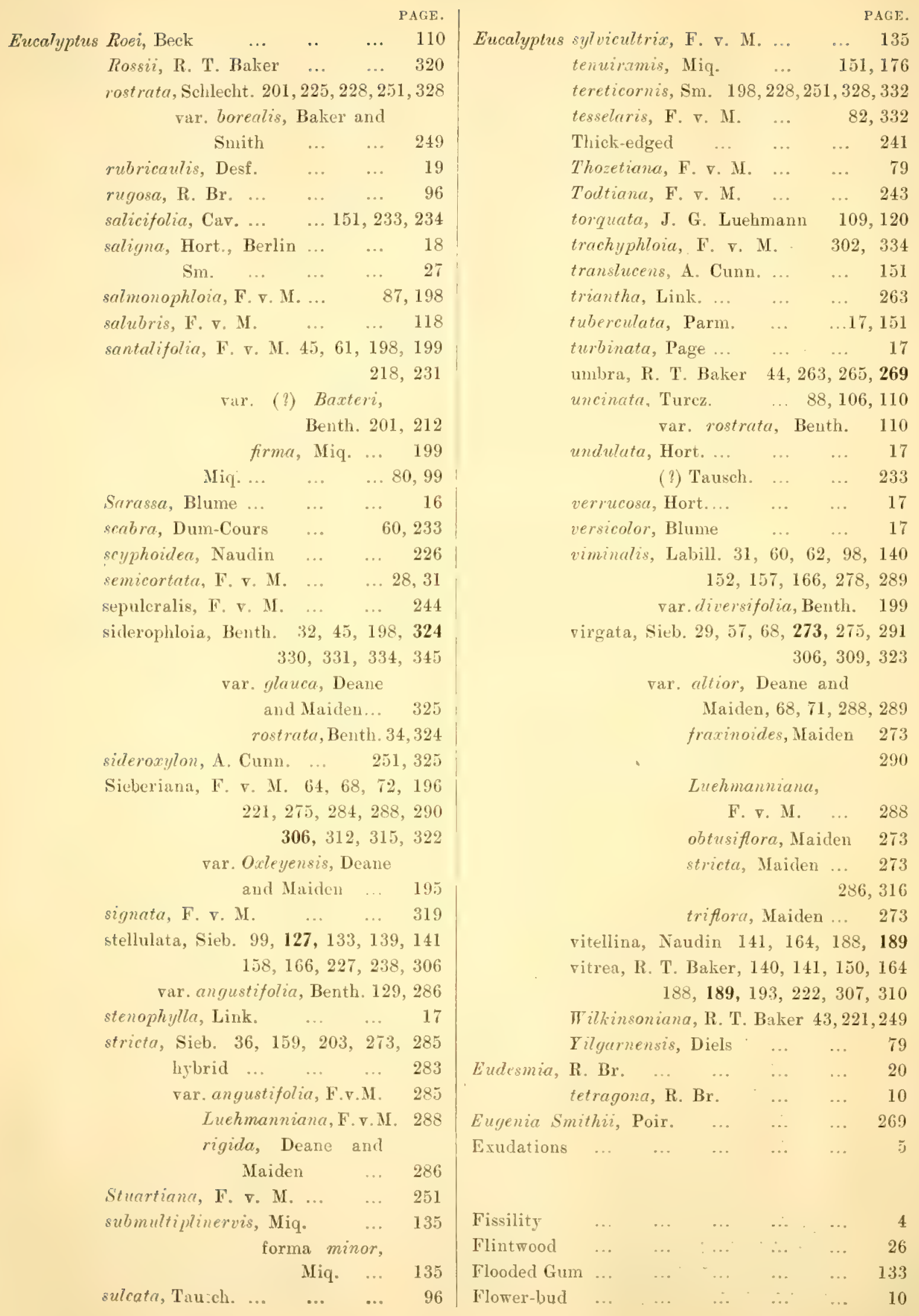


Flowers

Forest $\mathrm{Oa}$

Form with rugose buds

Froggatt, W. W.

Fruit

Gaertner, J.

Galls

Genetic relationships

Geral

Giant Gum-tree

Glassy Gum

Glossy or Shiny-leaved Box

Great Blackbutt

Blackbutted Gum

Greater Ironbark

Green Gum

Gum

Black

Blackbutted

Blue

Brittle

Broad-leaved White

Cabbage

Cattle

Flooded

Glassy

Great Blackbutted

Green

Large-leaved White

Lead

Lead-coloured

Mountain

Narrow-leaved White

Olive-green

Peppermint

Red

Ribbon

Ribibony

River (Camden)

River Thite

Scribbly $\ldots$

Scrubby (Blue Mountains)

Smaller Blackbutted

Snappy

South-eastern White

Spotied

Stringy

Stringybark

Sugar
PATE.

339,341

26

... 27

324

127

$2,1,172$

$12 \nmid$

(2) $(0,26:)$

int 127

318

318

1.3.), 318

133

133

133

27

127

$1 \pm 0$

127

128

$\ldots 49,161$

318

127

170

... 35

156,278

140

155

156

320

277

27

J. 39,318

.. 138

$137,278,319$

‥ 69

...59, 178

322 $\begin{array}{rlllll}\text { Gum, Swamp } & \ldots & \ldots & \ldots & \ldots & 163,187\end{array}$

$\begin{array}{lllll}\text { Tumble-down } & \ldots & \ldots & \ldots & \mathbf{1} 33,322\end{array}$

$\begin{array}{llllll}\text { Weeping ... } & \ldots & \ldots & \ldots & \ldots & 133\end{array}$

White $\ldots 127,133,153,184,288,310,317$

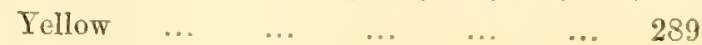

$\begin{array}{lllllll}\text { York } & \ldots & \ldots & \ldots & \ldots & \ldots & 113\end{array}$

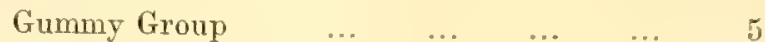

$\begin{array}{llllll}\text { Gum-top } & \ldots & \ldots & \ldots & \ldots & \ldots 68,308\end{array}$

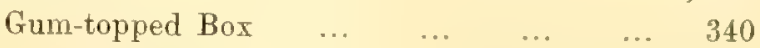

$\begin{array}{lllll}\text { Iroubark } & \ldots & \ldots & \ldots & 68\end{array}$

Stringybark $\quad . . \quad \ldots \quad \ldots 53,177$

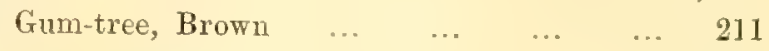

$\begin{array}{llllll}\text { Giant } & \ldots & \ldots & \ldots & \ldots & 18.3\end{array}$

of the Brisbane ... ... ... 266

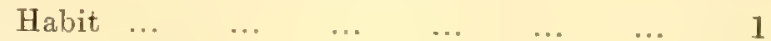

$\begin{array}{lllllll}\text { Hemlock } & \ldots & \ldots & \ldots & \ldots & \ldots & 248\end{array}$

$\begin{array}{lllllll}\text { Henslow } & \ldots & \ldots & \ldots & \ldots & \ldots & 7\end{array}$

$\begin{array}{lllllll}\text { Heterogenous } & . . & \ldots & \ldots & \ldots & \ldots & 8\end{array}$

$\begin{array}{llllll}\text { Hooker, J. D. ... } & \ldots & \ldots & \ldots & \ldots & 23\end{array}$

$\begin{array}{llllll}\text { W. J. } & \ldots & \ldots & \ldots & \ldots & 23\end{array}$

$\begin{array}{llllll}\text { Howitt, W. A... } & \ldots & \ldots & \ldots & \ldots & 24\end{array}$

Hybridisation $\quad \ldots \quad \ldots \quad \ldots 167,245,330$

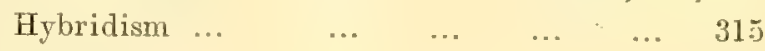

$\begin{array}{lllllll}\text { Hypanthium } & . . & \ldots & \ldots & \ldots & \ldots & \text { II }\end{array}$

$\begin{array}{lllllll}\text { Hypogenous } & \ldots & \ldots & \ldots & \ldots & \ldots & 8\end{array}$

$\begin{array}{lllllll}\text { Hles Steriles } & \ldots & \ldots & \ldots & \ldots & \ldots & 117\end{array}$

Inflation of the base of the stem $\ldots n_{1} \quad \ldots \quad 1$

$\begin{array}{lllllll}\text { Inflorescence } & \ldots & \ldots & \ldots & \ldots & \ldots & 9\end{array}$

$\begin{array}{lllll}\text { Insect-punctured buds } \quad \ldots & \ldots & \ldots & 227\end{array}$

Ironbark $\quad \ldots \quad \ldots \quad \ldots \quad 3,4,33,327,332$

$\begin{array}{llllll}\text { Bastard } & \ldots & \ldots & \ldots & \ldots & 308\end{array}$

$\begin{array}{llllll}\text { Blue-leaved ... } & \ldots & \ldots & \ldots & 325\end{array}$

Box ... ... $\quad \ldots \quad$... $\quad \ldots \quad 330$

Broad-leaved $\quad \ldots \quad \ldots . \quad \ldots \quad 325$

$\begin{array}{lllll}\text { rough } & \ldots & \ldots & 327\end{array}$

$\begin{array}{llllll}\text { Greater } \quad \ldots & \ldots & \ldots & \ldots & 324\end{array}$

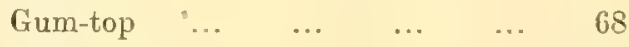

Large-leaved $\quad \ldots \quad \ldots \quad \ldots \quad \ldots \quad 324$

$\begin{array}{lllll}\text { Narrow-leaved } \quad \ldots & \ldots & \ldots & \geq 28\end{array}$

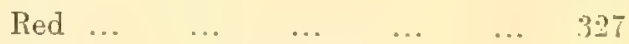

Rough-leaved rough-barked $\quad \ldots \quad 327$

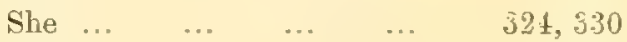

$\begin{array}{llllll}\text { White } & \ldots & \ldots & \ldots & \ldots & 308\end{array}$

White-topped $\quad \ldots \quad \ldots . \quad \ldots \quad 306$

$\begin{array}{llllll}\text { Yellow } & \ldots & \ldots & \ldots & \ldots & \\ & & & & & \end{array}$

\begin{tabular}{rrrrrrr}
\multicolumn{2}{c}{ Isellow } & $\ldots$ & $\ldots$ & $\ldots$ & $\ldots$ & 32 \\
Isogenous & $\ldots$ & $\ldots$ & $\ldots$ & $\ldots$ & $\ldots$ & 9
\end{tabular} 


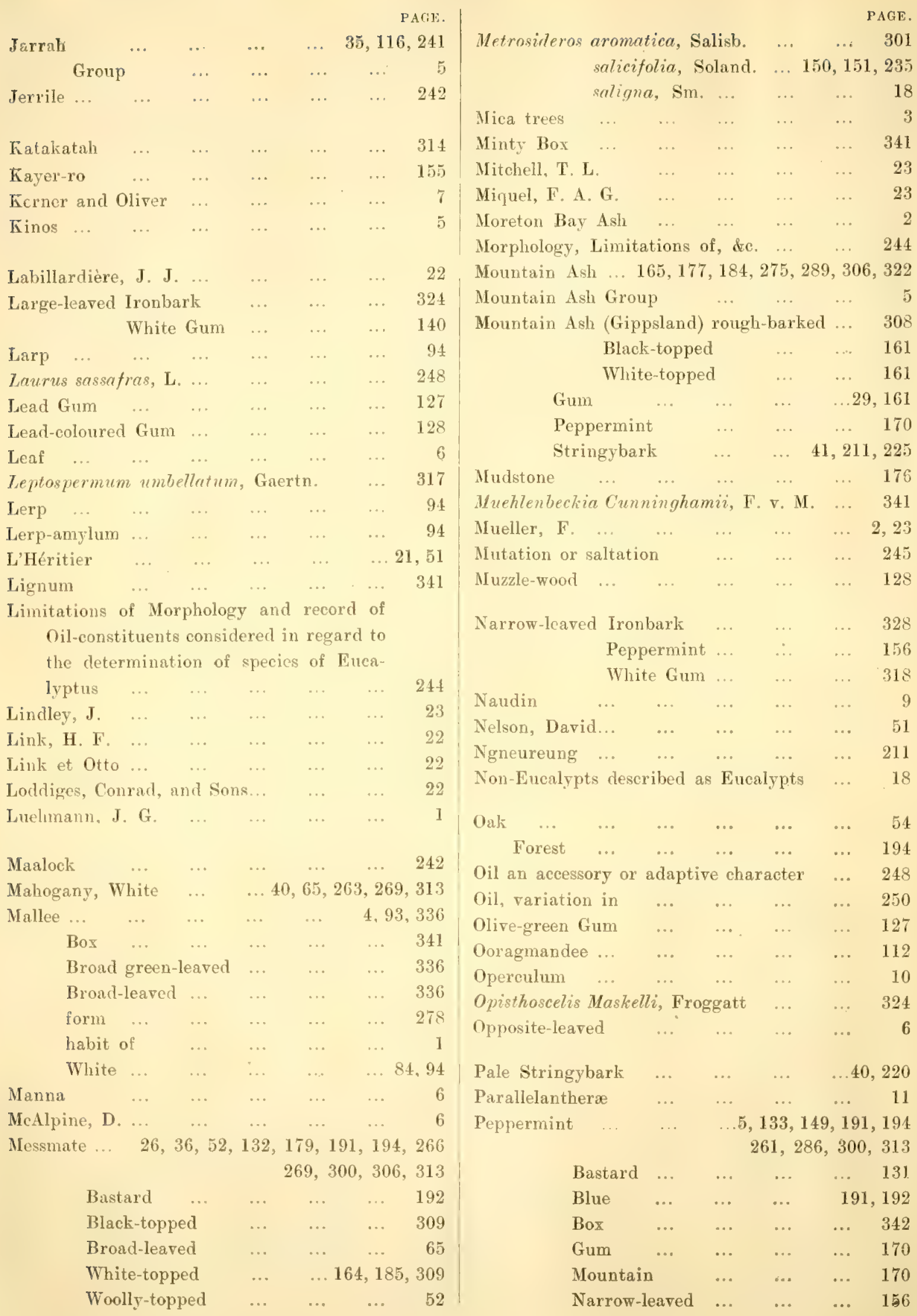




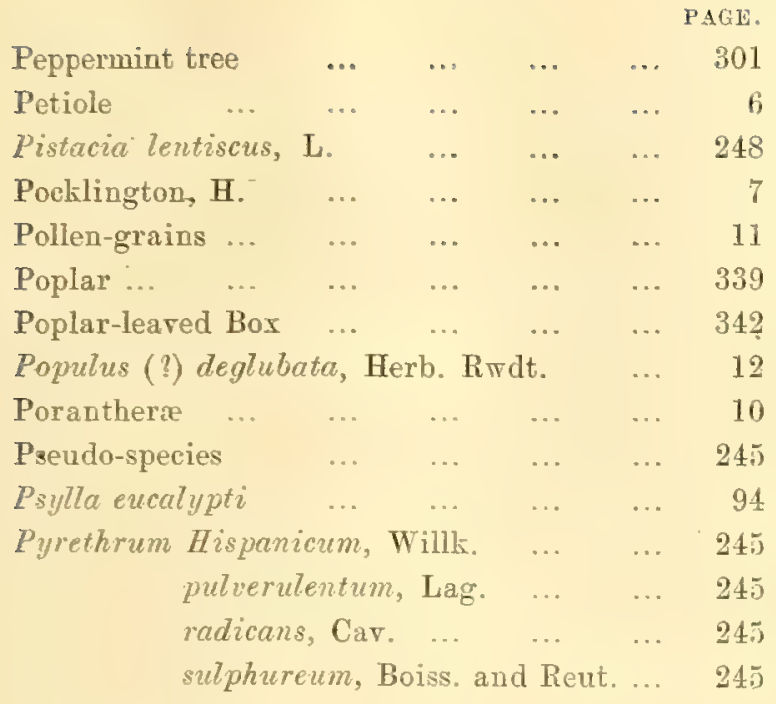

$\begin{array}{lllllll}\text { Red Blachbutt ... } & \ldots & \ldots & \ldots & \ldots & 188\end{array}$

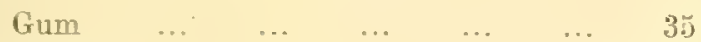

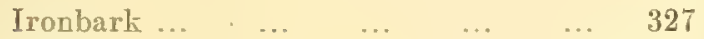
Stringrbark $\quad \ldots \quad \ldots 36,44,211,225,232$

Redwood

Remfrey, J.R. 183

Ribbon Gum ... ... ... .. $\quad$. 156,278

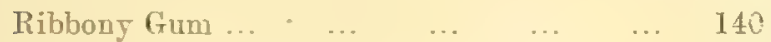

River Gum of Camden $\quad \ldots \quad \ldots \quad \ldots \quad \ldots \quad$ 15. $\begin{array}{llllll}\text { White Gum } & \ldots & \ldots & \ldots & \ldots & 156\end{array}$

Rough-barked Mountain Ash of Gippsland... 308

$\begin{array}{llllll}\text { Rough-leaved Box } & \text {... } & \text {.. } & \text {.. } & \text {... } & 342\end{array}$

Rough-leaved rough-barked Ironbark .... $32 \%$

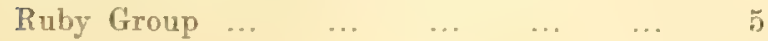

$\begin{array}{lllllllll}\text { Sally } & \ldots & \ldots & \ldots & \ldots & \ldots & \ldots & 127\end{array}$

$\begin{array}{llllllll}\text { Black } & \ldots & \ldots & \ldots & \ldots & \ldots & 127\end{array}$

$\begin{array}{lllllll}\text { Butt } & \ldots & \ldots & \ldots & \ldots & \ldots & 127\end{array}$

Schneider, Dr. Albert

Scribbly Gum..

Scrub Box-tree

Scrubby Gum (Blue Mountains)

Selection

Sequoia sempervirens, Endl. Wellingtonia, Seem.

She Ironbark ...

Silver-Top $\quad \ldots ., \quad 324,330$ Stringybark $\cdots, 70,185,217,308$

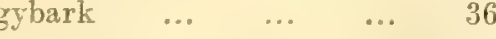

Smaller Blackbutted Gum ... $\quad \ldots \quad$... $\quad 27$

$\begin{array}{lllllll}\text { Smith, J. E. ... } & \ldots & \ldots & \ldots & \ldots & 22\end{array}$

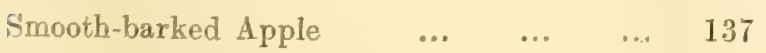

$\begin{array}{llllll}\text { Snappy Gum ... } & \ldots & \ldots & \ldots & 139,318\end{array}$

South-eastern White Gum ... $\quad \ldots . \quad \ldots .138$

Sponditaspis eucalypti, Dobson $\quad \ldots \quad$... 95 granulata, Froggatt ... ... 95 mannifera, Froggatt ... ...

Spotted Gum ... … ... ... 137, 278, 319

$\begin{array}{lllllll}\text { Spurious Blackbutt ... } & \ldots & \ldots & \ldots & 183\end{array}$

$\begin{array}{llllllll}\text { Sprengel, C. } & \ldots & \ldots & \ldots & \ldots & \ldots & 22\end{array}$

$\begin{array}{lllllll}\text { Stomata } & \ldots & \ldots & \ldots & \ldots & \ldots & 8\end{array}$

Stringybark $\quad \ldots \quad 3,26,36,52,149,225,232,263$

270,306

$\begin{array}{lllll}\text { (Camden) } & \ldots & \ldots & \ldots & 302\end{array}$

Almond-leaved ... ... ... 300

Bastard ... ... 52, 192, 194, 237

$\begin{array}{llll}\text { Blue-leaf } & \ldots & \ldots & 215,216\end{array}$

Broad-leaved ... $\quad \ldots . \quad \ldots .211$

Brown $\quad \ldots \quad \ldots \quad 52,54,211$

Group ... ... ... 5

Gum $\ldots \ldots \quad \ldots \quad \ldots 9,178$

Gum-top $\quad \ldots \quad \ldots . \quad \ldots .53,177$

Mountain _.. ... 41, 211, 225

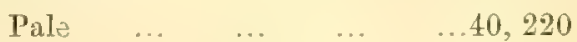

Red $\quad \ldots \quad \ldots 36,44,211,225,232$

$\begin{array}{lllll}\text { Silver-top } & \ldots & \ldots & \ldots & 36\end{array}$

White $\ldots \quad 36,40,52,215,232,300$

Yellow ... ... 26, 30, 35, 220, 235

$\begin{array}{lllllll}\text { Stringy Gum } & \ldots & \ldots & \ldots & \ldots & \ldots & 69\end{array}$

$\begin{array}{lllllll}\text { Sugar Gum } & \ldots & \ldots & \ldots & \ldots & \ldots & 322\end{array}$

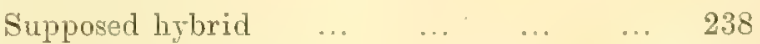

$\begin{array}{lllll}\text { Swamp Gum ... } & \ldots & \ldots & \ldots & 163,187\end{array}$

Symphyomyrtus, Schauer $\quad \ldots \quad$... $\quad \ldots \quad .20$

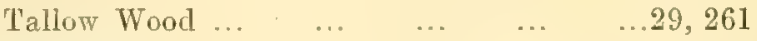

$\begin{array}{lllllll}\text { Tarundea } & \ldots & \ldots & \ldots & \ldots & \ldots & 27\end{array}$

$\begin{array}{lllllll}\text { Tate, } R, & \ldots & \ldots & \ldots & \ldots & \ldots & 1\end{array}$

$\begin{array}{lllllll}\text { Teheergun } & \ldots & \ldots & \ldots & \ldots & \ldots & 27\end{array}$

$\begin{array}{lllllll}\text { Terri-barri } & \ldots & \ldots & \ldots & \ldots & \ldots & 327\end{array}$

Teucrium Scorodonia, L. ... $\quad$... $\quad \ldots \quad$.. 246

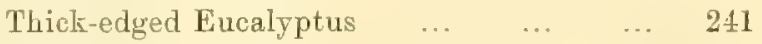

$\begin{array}{lllllll}\text { Timber } & \ldots & \ldots & \ldots & \ldots & \ldots & 3\end{array}$

$\begin{array}{llllll}\text { Classification of } & \ldots & \ldots & \ldots & 4\end{array}$

$\begin{array}{llllllll}\text { Toi } & \ldots & \ldots & \ldots & \ldots & \ldots & \ldots & 27\end{array}$

$\begin{array}{lllllll}\text { Tree-line } & \ldots & \ldots & \ldots & \ldots & \ldots & 137\end{array}$

$\begin{array}{llllll}\text { True Stringybarks } & \ldots & \ldots & \ldots & \ldots & \text { ป }\end{array}$

Tumble-down Gum ... . .. $\quad \ldots \quad$ 133, 329

$\begin{array}{llllll}\text { Turbid Group... } \quad \ldots & \ldots & \ldots & \ldots & 5\end{array}$

$\begin{array}{lllllll}\text { Turczaninow } & . . & \ldots & \ldots & \ldots & \ldots & \end{array}$

$\begin{array}{lllllll}\text { Turpentine } & \ldots & \ldots & \ldots & \ldots & \ldots & 261\end{array}$

$\begin{array}{lllllll}\text { Turru Turru } & . . & \ldots & \ldots & \ldots & \ldots & 39\end{array}$ 


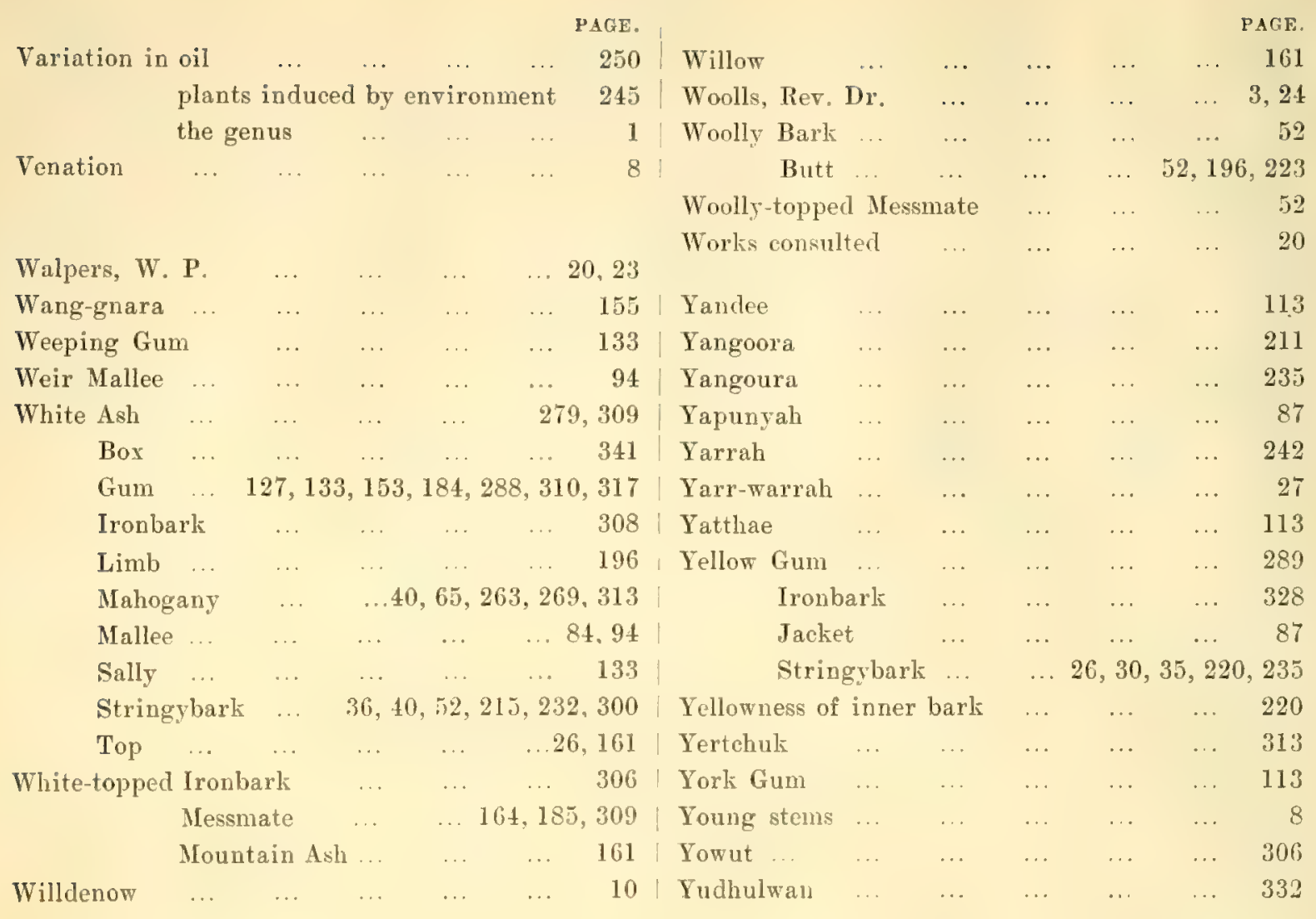




\section{A CRITICAL REVISION OF THE}

\section{GENUS EUCALYPTUS.}

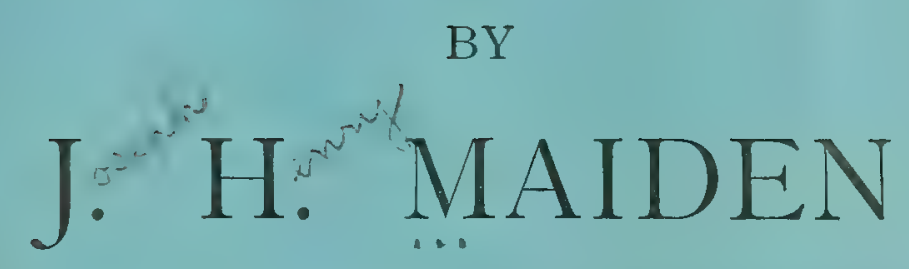

(Government Botanist of New South Wales and Director of the Botanic Gardens, Sydney).

\section{PART I}

(WITH FOUR PLATES).

Price Two Shillings and Sixpence.

Published by Authority of

THE GOVERNMENT OF THE STATE OF NEW SOUTH WALES.

Sugonen:

WILLIAM APPLEGATE GULLICK, GOVERNMENT PRINTER.

1903.

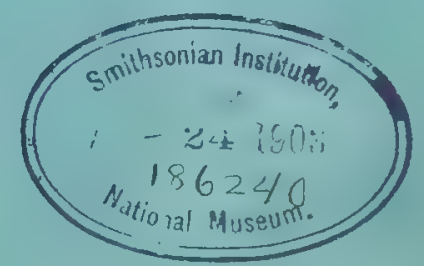





\title{
A Critical Revision of the Genus Eucalyptus,
}

BY

\author{
J. H. MAIDEN
}

(Government Botanist of New South Wales and Director of the Botanic Gardens, Sydney).

\section{PART I}

(WITH FOUR PLATES).

"Ages are spent in collecting materials, ages more in separating and combining them. Even when a system has been formed, there is still something to add, to alter, or to reject. Every generation enjoys the use of a vast hoard bequeathed to it by antiquity, and transmits that hoard, augmented by fresh acquisitions, to future ages. In these pursuits, therefore, the first speculators lie under great disadvantages, and, even when they fail, are entitled to praise."

$$
\text { Macaulay's "Essay on Milton." }
$$

Pullishal ly Aulterity of

THE GOVERNMENT OF TIIE STATE OF NEW SOUTH WALES.

Sưner :

WILLIAM APPLEGATE GULLICK, GOVERNMENT PRINTER, PHILLIP-STREET.

* $11838 \quad 1 \overline{903 .}$ 



\section{SyNOPSIS.}

Preface.

PAGE.

A. Variation in the genus . . . . . . . 1

B. Doubtful species . . . . . . I 2

C. Non-Eucalypts deseribed as Eucalypts . . I8

D. Works consulted . . . . . 20

I. Eucalyptus pilularis, Smith.

1. Description . . . . . . . . . 26

Notes supplementary to the description.

2. Synonyms (with descriptions). . . . . 3

Notes on the Synonyms.

3. Range.

Typical form . . . . . . 38

Varieties . . . . . . . 39

4. Affinities . . . . . . . . 42

5. Explanation of plates . . . . . . 45 



\section{Preface.}

DurING the twenty years that have elapsed since the publication of Mueller's "Eucalyptographia," which added valuable information to Bentham's masterly account of the genus Eucalyptus in the Flora Australiensis, we have obtained a large accession of facts. It seems to me that the time has arrived when these additional facts should be incorporated with the labours of the old workers. I have spared neither time nor expense to obtain access to the types. I have spent many years in field observations on the genus in every State of the Commonwealth (though of course particularly in my own State of New South Wales), and thus have endeavoured to secure what is an essential qualification for the study of this protean genus.

The admirable illustrations contained in the "Eucalyptographia" have the defect that it is not always possible to say precisely what they depict-that is to say, whether a type or co-type, or, if neither, the exact locality whence the originals were obtained. In all cases I shall inform my readers as to the history of the specimens depicted.

A very important departure in a work of this kind is the following :- While expressing my opinions as to affinities, synonyms, \&c., I shall in all cases give the original descriptions of the species whether considered to be synonyms or not. In this way my readers will be able to weigh the evidence for themselves, and, if they do not concur in my conclusions, they will at least be placed in possession of the data on which they are based.

The genus Eucalyptus is the most important in Australia. The individuals which comprise it are all pervading, while the number of species and varieties is very large. As the work proceeds I will give my views as to the grouping of the species.

The present part contains much prefatory matter referring to the genus. Then one species is taken in detail, and the other species will be treated in a like manner, the facts being grouped in the same way.

The rapidity with which this work can be issued depends mainly on the plates; I have only the partial services of one artist.

Botanic Gardens, Sydney,

$$
\text { January, I903. }
$$





\section{A CRITICAL REVISION OF THE GENUS EUCALYPTUS.}

\section{A.- Variation in the Genus.}

TuE genus Eucalyptus is such a large one that a number of schemes have bcen submitted for dividing it into sections with a view of associating those closely allied, or for arriving at the name of a species with facility. These schemes will be referred to in the bibliography, and I now propose to review each character, from timber to anther, to see if any satisfactory scheme can be evolved. In the Proc. Aust. Assoc. for Adv. of Science, Sydney Meeting, 1898, Professor Tate* and Mr. Luehmannt simultaneously gave prominence to the use of the fruit for purposes of classification. Both papers take cognizance of other characters as well. Both are the work of men who know the genus, and are valuable contributions to knowledge.

Habit.--Tate defines two habits of growth, viz:-Trees, and shrubby, stocky trees, to which he applies the vernacular names of gums and mallees, names well understood in Australia. He points out that in young plants of the genus there is a large inflation of the base of the stem, either at the surface or just below the surface of the soil. In gums (E. rostrata, leucoxylon, viminalis, \&c.) this is eventually outgrown; but in the mallees (incrassata, uncinata, \&e.) it persists and increases in size proportionately with the development of the branches which are emitted from it-in the mallee this rudely globose bole is partly subterranean. "The rmbrella-like disposition of the foliage of the taller mallees may be largely incidental to overcrowding, though it would seem to be an inherited character, as it is fairly pronounced in them when they are distinctly separated from one another." This classification is chiefly of practical use in Professor Tate's own State (South Australia) and in Western Australia.

It is, however, very difficult to group the species according to habit. Some are dwarf in their typical forms, but under different circumstances they take on a larger growth. Then, speaking generally, such species as are found in damp

* Tate, Ru. - A Review of the characters arailable for the classification of the Eucalypts, with a synopsis of the species arranged on a carpological basis."

+ Luehmann, J. G._" A short dichotonous key to the hitherto lrnown spacies of Euralyptus."

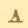


situations in good soil are umbrageous trees; such, for example, are stellulact, aggregata, Macarthuri, but this character is largely a matter of environment. Then some species, e.g., viminalis, have a more or less drooping habit as a rule, but this species is often nearly erect in less congenial soil. And further, to show variation in habit, we have only to point to the Eucalyptus plantations of California and the South of France, where the species are cultivated almost out of recognition.

Bark.-Mueller (Journ. Linn. Soc., iii, 99, 1858) arranged the genus in the following six groups in respect to their barks. With the additional information we have obtained since Mueller's paper was published, we are able to recast his list of examples. It will be found, however, that no two botanists agree as to the sections in which to place some of the species, and as further field-knowledge is available and we know more about the variation of the bark in the same species, the same authority modifies his own lists. See Woolls, "On the classification of the Eucalypts" (Proc. Linn. Soc. N.S.W. (2), vi, 60).

"i. Leiophloie.-Cortex post delapsum strati supremi undique laevis. ( Vulgo, flooded gum trees, white gum trees, blue gum trees partim, red gum trees partim, yarra trees.)"

Smooth barks ("gums" we call them).-Examples are-E. homastoma, tereticornis, rostrata, leucoxylon, viminalis, Gunnii, maculata, latifolia, aspera, stellulata, coriacea, saligna, Behriana, punctata, stricta, fasciculosa.

"ii. Hemiphloire-Cortex in trunci parte inferiore persistens rugosus et rimosus, in parte superiore ramisque delapsu strati superioris laevigatus. (Vulgo, Moreton Bay ash, blackbutted gum tree, box trees partim.)"s

ITalf barks, the barks of the lower part of the trunk persistent and the upper part smooth. Examples are-E. hemiphloia, pilularis, bicolor, longifolia, melliodora, amygdalina, dices. The Moreton Bay Ash (tesselaris) is better in section iii or vi.

"iii. Rhytiphloia.-Cortex ubique persistens rugosus et rimosus intus solidus. (Vulgo, bloodwood trees, box trees partim, peppermint trees partim. $)^{\prime \prime}$

With wrinkled persistent bark, rather solid. This is an unsatisfactory group, including heterogenous barks. Mueller intended it to include the bloodwoods (corymbosa, eximia, trachyphloia), also bicolor (which is better in ii) and E. microtheca, leptophleba, ferruginea. Odorata, robusta, botryoides may be added, and also Stuartiana, pulverulentu, microcorys, acmenioides, resinifera, polyanthema, populifolia, piperita.

Nos, ii and iii run into each other, and both of them into No. iv. 
"iv. Pachyphloia.-Cortex ubique persistens rugosus intus fibrosus. (Vulgo, stringybark trees.)"

"Stringybarks," with persistent, fibrous barks. A good natural group, including engenioides, capitellata, macrorhyncha, obliqua, pilularis var. Muelleriana, tetrodonta.

"v. Schizophloia.-Cortex ubique persistens profunde sulcatus intus solidus. (Vulgo, ironbark trees.)"

"Ironbarks," with hard, deeply-furrowed barks. Perhaps the best of all the groups. Examples-E. siderophloia, paniculata, crebra, sideroxylon, melanophloia.

"vi. Lepidophloie.-Cortex saltem in trunco persistens lamellaris friabilis. (Vulgo, melaleuca gum trees, mica trees.)"**

With persistent bark on the trunk only, and forming scaly separate pieces. Mueller's examples are miniata (aurantiaca), phænicea, peltata (meiissiodora), to which I would add tesselaris. The Rer. Dr. Woolls (Proc. Linn. Soc. N.S.W., vi, 709) ignores section $\mathrm{vi}$, and it certainly cannot be separately maintained as a section.

The cortical classification separates trees that are closely allied, e.g., hemiphloia and Baueriana, the first being a half bark, and the latter having rough bark to the branchlets. Similarly E. pilularis in its normal form has smooth branchlets, while its variety Muelleriana has rough branchlets. It places in juxtaposition those that are not elosely related, as will be observed from the examples given under each section. Prominent examples are:-

(a) E. paniculato, Sm., and E.fasciculosa, F.v.M. ; and

(b) E. sideroxylon, A. Cunn, and E. leucoxylon, F.v.M., respectively, nearly alike in leares, flowers, and fruits, but utterly dissimilar in bark and wood.

Absolute anomalies as regards barks are those of ironbark for E. stellulata, Sieberiana, and viminalis; $\uparrow$ a box-like bark for $E$.tereticornis, and observers will note many other anomalies within their own experience. At the same time, in careful hands, the bark is the most useful character the forester can employ.

Timber.-While the character of a timber is a matter of economic importance, its use in botanical diagnosis is very often overlooked. For many years I have insisted on the examination of the timber wherever possible, and recognition of this character has undoubtedly led to a better understanding of the genus.

\footnotetext{
* The meaning of this, which js not quite clear as it stands, is explained by the following passage :- "The bark of both is very lamellar and friable, outside of a yellowish or greyish-brown, on fracture partly glitterimg, and somewliat resembling mica-schist." (Eucalyptographia, uncler E. phonicea.)

+ See Luehmann, op. cit., page 524.
} 
Timbers can be classified in different ways, e.g., according to-

(1.) Fissility.--Some are fissile, such as stringybarks (E. engenioides), \&c., Mountain ash (E. Sieberiana), Victorian blackbutt (E. regnans), \&c. Others are short in the grain, such as many gums, snapping off like a carrot; while others are tough and interlocked, like boxes and ironbarks.

(2.) Colour.-In a lecture delivered in 1891 before the Sydney Architectural Association of New South Wales, I divided many of the Eucalyptus timbers into pale hardwoods, subdividing them into three groups(a) Hard, interlocked; (b) Fissile; (c) Inferior, such as Gums; which is a useful practical classification. In my "Notes on the Commercial Timbers of New South Wales," (1895), I submitted the classification1. Ironbarks. 2. Pale hardwoods. 3. Red hardwoods.

1. Gums.-These timbers are short in the grain; dry to a brown or reddish colour; crack radially in drying; have many gum-veins; and, as a rule, lack durability. Their barks are smooth, and more or less ribbony. Examplesstellulati, coriacea, homastoma, viminalis, Gunnii. They connect with the "Boxes" (Bastard), and also with the smootli-barked members of the Jarrah group.

2. Mallees.-Examples-oleosa, Behriana, incrassata. This is a group based on geographical considerations. They are arid country species, and connect the "Gums" and "Red Boxes."

3. Ironbarks.-These are fully described in my "Notes on the Commercial Timbers of New South Wales." They consist of-

(a) True Ironbarks, viz., paniculata, siderophloia, crebra, sideroxylon.

(b) Bastard Ironbarks.-Timbers very similar to ironbarks, but the barks belonging to the "Box" group. They include Boormani and affinis. Melanophloia, and, perhaps, microtheca connect the two groups.

4. Boxes.-These are tough, interlocked timbers, usually with fibrous bark on the trunk, and may be subdivided into-

(a) Pale.-Examples-hemiphloia, melliodora, Bosistoana, Baueriana, populifolia, quadrangulata, Cambagei, goniocalyx, tesselaris, leucoxylon, corynocalyx, globulus.

(b) Red.-Examples-bicolor, microtheca, polyanthema, odorata, fasciculosa.

These two groups include some smooth barks or "Gums" but their timbers are provisionally elassified with the "Boxes."

(c) Bastard.-Examples-Stuartiana, pulverulenta, Macarthuri, aggregata.

The timber of $(c)$ is inferior, and closely resembles that of the "Gums." 
5. Stringybark Group.-This includes a number of fissile timbers that pass into each other, and may be subdivided as follows :-

(a) True Stringybarks.-Examples-eugenioides, macrorrhyncha, capitellata, obliqua, Baileyana.

(b) Blackbutts.-Examples-pilularis (which absolutely connects with the Stringybarks through its variety Muelleriana), acmenioides. These are the most valuable timbers of the group.

(c) Peppermints.-Examples-amygdatina, regnans, dives, piperita. These timbers have gum-veins, and are altogether inferior in quality.

Allied to these is the-

6. Mountain Ash Group.-Fissile timbers usually pale in colour, and with bark not so fibrous as the preceding. Examples-Sieberiana, Planchoniana, virgata and its varieties, Risdoni, cordata.

7. Tallow-wood and Spotted Gum.-microcorys and maculatu (two valuable pale-coloured timbers), sui-generis.

8. Bloodwoods.--These have gum-veins, and are coarse-grained; comymbosa is red, and eximia and trachyphloia, which are pale, connect with maculata.

9. Jarrah Group.-Containing a number of heterogenous species, and which I name after the best-known member. Some have fibrous barks, others are smooth; but they are all deep-red, durable timbers. Examples-marginata, resinifera, diversicolor, propinqua, punctata, saligna, botryoides, robusta, tereticornis, rostruta, longifolic.

This group connects with the Red Boxes.

The timber of the same species varies a good deal according to the soil and situation, and our knowledge does not yet enable us to discriminate between some timbers not closely allied botanically. In other words, a man who professes to discriminate between all species of timber attempts the impossible.

Exudations.--In Proc. Linn. Soc., N.S.W., 1890, I proposed examination of the kinos as an aid in the diagnosis of eucalypts, and I divided them into three groups according to their behaviour in water or alcohol (spirit).

1. Ruby Group.-Consisting of ruby-coloured kinos, soluble in water and alcohol in all proportions. Examples are-all Renantheræ except microcorys.

2. Gummy Group.- Soluble in water, but insoluble in alcohol owing to the gum they contain. Examples- the ironbarks.

3. Turbid Group.-These kinos are soluble in hot water or hot alcohol, but deposit sediments on cooling. Examples-most of the Parallelantheræ. This 
section, however, includes heterogeneous substances, and brings together species little allied. It is doubtless capable of further elaboration, but only serves to accentuate variation in the genus. Some kinos, e.g., $E$. maculata, are characteristic in appearance, having an olive-green colour; perhaps also that of $E$. corymbosa, of an intense, almost vermilion colour.

An exudation of less importance is that of Manna. A number of species exude saccharine substances from the leaves and, a very few, from the trunk. The list is being added to slowly, but in most cases the mannas are mere scientific curiosities, and of little value in a scheme of classification. They include viminalis, Gunnii, punctata, pulverulenta, Stuartiana.

Petiole.-D. McAlpine and J. R. Remfrey, in Trans. Roy. Soc. Vict., 1890, published a paper entitled, "The transverse sections of petioles of Eucalypts as aids in the determination of species." The method of classification on the comparatively few experiments made is ingenious, but of little practical value to us for diagnosis, thousands of sections being required in order to obtain data for generalisation. The paper is, however, of more than ordinary value, and is well worthy of perusal.

Leaf.- $(a)$ Suckers. De Candolle (Prodromus, vol. iii, 1828), classified eucalypts according to the opposite or alternate character of the leaves, a character of special importance at that time, since species were often described from seedlings grown in pots. Field observations have, however, shown that all species have opposite leaves in at least an early stage. In seedlings this is best observed, but in many cases suckers show the character quite as well. In a few species, e.g., gamophylla, this opposite-leaved character persists through life. In many eases the young leaves are broad, and become alternate and narrower, with a lanceolate or falcate shape as maturity is reached. Often these young leaves are glaucous, becoming glabrous as growth proceeds. But there is a group in which the seedling and sucker leaves are narrow. Such species include amygdalina, pilularis, riminalis.

The list is, however, so incomplete that it is impossible at present to use them as a broad basis of classification. For diagnostic purposes, I personally use the shape of the roung leaf wherever possibie; it is an atavistic character, and data are accumulating by whieh we shall be in a better position to interpret it.

The difference between suckers and mature leaves has been studied in Europe for many years, although in Eucalyptus the systematic comparison of such forms is of comparatively recent date. It is of practical importance to the Australian forester, for the reason that the occurrence of these young or sucker leaves is so very frequent in the bush.

When a trunk is injured, new shoots make their appearance either from the "eyes" in the stem or from reserve buds of the branches and twigs, or by buds produced from the roots below the ground. The leaves of these shoots, or suckers, as they are called, differ very much from the stems or branches which have been broken, eaten, cut, or frozen off. 
Instances of differences are given, and it is added:-

Hundreds of trees and shrubs might be mentioned in which there is a distinct difference between the foliage of the suckers and of the normal branches of the crown. (Kerner and Oliver, ii, 515-6.)

Nor has the description of species and varieties from suckers or seedling leares been confined to writers on Eucalyptus :-

Gardeners and descriptive botanists have frequently determined and described mutilated plants as other species, hybrids, or varieties. They are neither the one nor the other. The peculiar appearance of the altered members, resulting from mutilation, is exactly determined beforehand in each species; it is due to the specific constitution of the species, and thus is part of its being. It is not produced by the external influences which lead to the formation of the varieties, but is brought about by inherent necessity quite independent of the influence of climate and soil. (Op. cit., ii, 518.)

Practically all the researches on the anatomy of Eucalyptus leaves have been made on those of the readily available $E$. globulus, in which species both sucker and mature leaves are readily available. The most complete research is the masterly paper of G. Briosi.* See also a study by H. Pocklington.†

Then Henslow says :-

The chief differences between the two forms of leaves I find to be as follows:- In the horizontal leaf the upper epidermis is composed of small cells, and there are no stomata. There is a palisade tissue of one layer of cells, with lax mesophyll below the lower epidermis. This latter has larger cells than the upper, and is provided with stomata. The pendulous leaf is a good deal thicker than the horizontal. Both epidermides are provided with a very dense cuticle, in which the stomata are deep-seated. There are four rows of palisade cells on both sides, with a chlorophyllous mesophyll between them. The petiole is flattened so that the leaf can swing much in the same way as that of the poplar:

A useful paper by Dr. Albert Schneider§ speaks of the sucker ("dorsiventral") leaves with palisade cells on the upper side and stomata on the under side only. The mature leares, "isolateral leaves or phyllodes," take a vertical position with the convex edge directed upward. The epidermis is alike on both sides. It will be observed that his results do not agree with those of Henslow;--evidence of variation. The anatomical characters of the leaves of Eucalyptus offer, however, much room for research. See "Stomata," p. 8.

(b) Cotyledon leaves. - The shape of the cotyledon leaves we know less about, and data are being collected. The work has been hindered because of the difficulty of obtaining seed from certain interesting forms. Mueller's Eucalyptographia and Lubbock's "A contribution to our knowledge of seedlings," form the basis of our present available information on the subject.

Other characters of Eucalyptus leaves we require to know more about are their size, texture, and prominence of venation. They are minor characters, and some species present much variation in this respect.

\footnotetext{
- Ricerche intorno all'anatomia delle foglie dell' Eucalyptus globulus. 23 pl., Mrilano, 1892.

t The Microscope in Pharmacy; Eucalyptus globulus. Pharm. Joum. (3), iii, 930; iv, 549. A. useful histological study of bark, leaves, \&c. foliage.

¥Origin of Plant Structures, p. 68 (note). His "horizontal" are sucker leaves, and "pendulous" the mature

\$ Structure of Eucalyptus globulus leaves. Journal of Pharmacology, iv, 169. Pharm. Journ., 28th Aug., 1597, p. 191.
} 
(c) Venation.--Messrs. Baker and Smith, in Proc. Roy. Soc.of N.S.W., 1901, have grouped certain Eucalyptus leaves into sections in regard to the disposition of their veins, pointing out that the oil-content of the leaves can in a measure be gauged from the venation. The suggestion is ingenious; but as the venation is, like other characters, variable within such large limits, the method will only be practically useful in the hands of experts.

(d) Young stems. - Some eucalypts have marked quadrangular stems, e.g., globulus, Maideni, goniocalyx, quadrangulata, tetragona, and many others; but, as a rule, this quadrangular appearance, often well marked at an early stage of growth, passes away as growth proceeds.

(e) Essential oil.-The perfume of Eucalyptus leaves is owing to the presence of an oil. It varies in different species in regard to both character and amount. In young it is commonly more abundant than in mature foliage, the high proportion of resinous matter in the former being, however, a drawback to distillation. In some cases the perfume is not easy to define, but the crushing of the fresh or even dried leaves in the warm hand has been used as a diagnostic character for many years. It affords a rough but ready test, which is always available and really valuable in skilled hands. Incidentally it may be mentioned that some few leaves, e.g., corymbosa, contain a substance allied to caoutchouc in their tissues, especially in their young state.

Some years ago, when Superintendent of Technical Education, I determined to ascertain whether this qualitative test of Eucalyptus odour was capable of leading up to further results. Accordingly I obtained samples of commercial Eucalyptus oils, and also watched their distillation in the country, but found, as a general rule, that the various kinds of leaves were not rigidly kept apart. I therefore resolved, with the advice of $\mathrm{D}_{1}$. T. L. Bancroft, of Brisbane, and the active co-operation of Mr. Owen Blackett, C.E., of the Technical College, to erect a model still capable of holding large charges of leaves, and to distil only those leaves obtained by my own collector or through agencies which permitted their origin to be precisely checked from a botanical point of view. In this way, and in this way only, could Eucalyptus oils of many species, absolutely true to name, be obtained for research. My transfer to the Botanic Gardens remored me from this domain of botanical technology, and the work thus initiated has been continued and extended by my late assistants, Messrs. Baker and Smith.

(f) Stomata.-Mueller, in Eucalyptographia, under E. pachyphylla and $\boldsymbol{E}$. phonicea, has classified some of the eucalypts according to the number and distribution of the stomata. He styles the leaves-

1. Hypogenous, according to the presence of stomata on the under surface only.

2. Heterogenous, according to their presence on both surfaces, but less numerous above than below. 
3. Isogenous, when they are present on both surfaces, but approximately equal in number above and below. "This almost equal distillation of the stomata coincides with the similarity of the colour of both sides of the leaves."

This method cannot, however, be used for diagnostic purposes with any degree of certainty, because of the variation in the distribution of stomata even in the same tree.

Galls.-At one time I inclined to the opinion that the shapes of the leaf-galls in Eucalyptus would be a useful character for classification. Mr. W. W. Froggatt, who has of late years been giving specia! attention to Brachyscelidx, finds that the same insect frequents so many species that no general grouping of the trees based on their galls can be made.

Inflorescence.-Professor Tate points out that the usual form of inflorescence is an umbel which, by lengthening of the axis, passes to the panicle or aorymb. The transition from one to the other is so easy, he goes on to remark, and often exemplified in the same tree, that it is obvious the form of the inflorescence is not reliable as a specific character. Bentham had previously drawn attention to the unsatisfactory character of the arrangement of the inflorescence from the point of rien of the systematist. Naudin's grouping (second memoir) of fifty-six species (or reputed species) known to him as growing in the gardens of Provence, is mainly based on the inflorescence, but also depends on the fruits and leaves. It doubtless was of local value, but it is based on characters which present so much variation as to preclude its general application.

Following is an abstract in Gardeners' Chronicle, 7th February, 1891:-

Section I.-Inflorescence in cymes or axillary umbels.

Capsules longer than the calyx tube.

Capsules shorter than the calyx tube.

(a) Cymes 3-flowered.

Lerves uniform, opposite.

Leaves uniform, alternate.

Leaves of two shapes.

(b) Cymes of 3 to 7 or more flowered.

Cymes 7 -flowered.

Leaves uniform opposite.

Leaves of two shapes, opposite at first.

Leaves uniform, always alternate.

(c) Cymes or umbels, axillary, more than 7 -flowered.

Leaves uniform.

Leaves of two shapes.

Section II.-Flowers in terminal panicles or corymbs.

Flowers. - With reference to individual flowers, there is much variation in the number of flowers in an umbel, and, to a less extent, in the colour of their filaments. The colour in the vast majority of species is white or cream, but in a few species, e.g., leucoxylon, sideroxylon, viminalis, ficifolia, calophylla, pyriformis, it may be 
pink also. In some species, e.g., ficifolia, miniata, phonicea, it may be red, even a vermilion or orange-red. In a few species, e.g., pilularis, the filaments of dried flowers turn red in course of time.

The pedicel is normally rounded, but owing to compression it is very often strap-shaped, as in botryoides, and extreme cases are afforded by obcordata (platypus) and occidentalis.

Flower-bud.-The shape of the operculum was first used as a classification character by Willdenow in his Species Plantarum, 1799. He divided the twelve species then known into two groups- "operculo conico" and "operculo hemisphaerico." It is undoubtedly a useful character for the purpose, but variable, like everything else about Eucalyptus. E. tereticornis is usually looked upon as a species to be diagnosed by its operculum, but (Bull. Herb. Eoissier, 1902, 579), I have shown that this character breaks down completely as between that species and E. rostrata. E. capitellata and E. macromhyncha were at one time separated by their opercula, but they pass into each other as regards those organs. As this work progresses it will be obvious how very variable the operculum is. At the same time, it will always remain, in the hands of a judicious observer, one of the most practically useful diagnostic characters we have.

Some species possess a double operculum, or membranous bract, enveloping the whole of the young inflorescence. It was first observed by Robert Brown (see his description of Eudesmia tetragona), but a few years ago it was only recorded from a very few species. In some it is very early deciduous and in others infrequent; but I have observed it in such a large number of species that I am inclined to the opinion that extended research will show that it occurs in all. Brown's and Jussieu's interesting observations on the single and double opereulum will be found supplementary to the former's description of Eudesmia tetragona (Bot. App. to Flinder's' Toyage).

Anther.-Bentham (Flord Australiensis) first grouped species according to the shape and mode of dehiscence of the anthers. He made five groups, but laid no stress on the importance of the dehiscence on the top on the anther. He, however, alludes (B.Fl. iii, 186) to "truncate" anthers, and at page 189 . to the truncate anthers of E. lencoxylon. Mueller, finding that Bentham's five groups could not be separately maintained, reduced them to three, viz. :-

Renantherce, the anthers large and the cells divergent at the base.

This section mostly includes the stringybarks, although it includes several white gums,-plants otherwise very different.

Poranther $\mathscr{C}$, the anthers small and opening in pores.

This section mostly includes boxes and some mallees, and includes the silverleaved ironbark (melanophloia), while E. crebra, which is very closely allied to it, is placed in another section. 
Parallelanthere, the cells parallel, and the longitudinal slits consequently parallel.

This section comprises the remainder of the eucalypts, and a most heterogeneous and extensive collection they are, variable in many ways.

As a matter of fact, the anthers refuse to be rigidly marshalled into sections. They sometimes display such rariation of divergence of shape of cell, size, and mode of dehiscence, that classification on the anthers alone becomes a matter of difificulty.

In the old collections, the difficulty is enhanced through the partiality of insects for these organs ; nevertheless, examination of the anthers is always carried out by me, and it is a most useful character.

Pollen-grains.-Mueller (Eucalyptographia, under E. erythrocorys) has shown that the size of pollen-grains varies in different species, but we require very many more measurements than are available, to be in a position to place any interpretation upon the results. The shape of the pollen-grains also varies, but we have few data on the subject.

Calyx.-The calyx, "cupula" of De Candolle and other botanists, the "hypanthium" of Schauer, is no longer used for classification purposes, having been proved to be so utterly variable. De Candolle (and his translator, G. Don) offered a classification of the eucalypts consisting of opposite or alternate leaves combined with a comparison of the size of operculum with cupula.

Fruit.-While many botanists have more or less used the fruit as a diagnostic character in Eucalyptus, and it is undoubtedly the best character we have, it is due to Professor Tate to say that (op. cit.) he was the first to submit a scheme for classification of the genus based on the fruits alone. He deals with $(a)$ shape; (b) external sculpture and ornament; (c) capsular teeth; $(d)$ capsule cells; (e) fertile seeds. But examination of Professor Tate's scheme shows (through no fault of his) how very imperfect and full of exceptions it is. Taking item by item we find the shape in cach species to vary within wide limits. The truth of this will be observed in contemplation even of the single species, E. pilularis, dealt with in this part. Personally, I very largely use the fruit (unripe fruits may be very misleading) for diagnostic purposes; but in many cases it must be carefully used, for it displays an enormous amount of variation. This much is proved, and I go further and say that some fruits only appear to have an approximately constant shape because we have so much to learn in regard to the range of the species and consequent possibilities of variation. Of course, I at once admit the fact that some species are "stronger" than others.

To sum up, for herbarium work the anthers and fruits are the best characters to go by; for the scientific forester, the bark and the timber; but all characters display a puzzling amount of variation. 


\section{B.-Doubtful Species.}

THE following list includes doubtful species and perhaps some nomina nuda. Some of them are probably indeterminable, and I trust that further inquiry will be made into them. It is quite possible that some of these so-called species of Eucalyptus may prove to belong to other Myrtaceous genera.

1. E. alata, Hort. Ex G. Don in Loud. Hort. Brit., p. 198 (1830). New Holland, 1816.

I cannot trace a description.

2. E. albicans, F.v.M. The seedlings are described in Fragm., vii, 42, in the following words:- "Caulis laevis, fere teres; folia rigidula, sparsa, brevipetiolata, cordato-v. orbiculato-ovata, acutiuscula, $1 \frac{1}{2}-2 \frac{1}{2}$ " longa, $1 \frac{1}{3}-2^{\prime \prime}$ lata."

I cannot ascertain where the species itself was described.

3. E. albicaulis, Hort. Ex G. Don in Loud. Hort. Brit., p. 198 (1830). New Holland, 1810.

Does not appear to have been described.

4. E. alpina, Hort. "Native of Mt. Wellington, V.D L." (Tasmania). Loudon's "Trees and Shrubs of Britain," p. 2567 (vol. iv.).

3. E. colinifolia, Lodd. Ex G. Don in Loud. Hort. Brit., p. 198 (1830).

I cannot trace a description.

6. E. curvula, Sieb. "Operculo conico, pedunculis sub-3 floris incrassatis compressis divaricatis, foliis inaequaliter oblongo-lanceolatis acutis." (Spreng. Syst., iv, Cur. Post. 195.) "The short diagnosis equally applicable to several species." (Benth.)

7. E. deglupta, Blume. Following is the original description:-

"207. Encalyptus deglupta, Bl., ramulis compresso-tetragonis marginatis; foliis sparsis (plerumque alternis) breviter petiolatis orato-lanceolatis acuminatis basi acutiusculis coriaceis glabris penninerriis subtus tenuissime reticulatis.Populus? deglubata, \#erb. Rwdt.-Arbor excelsa, corticem resinosum aromaticum per magnas laminas delibrans; ramulis nonnihil flexuosis, siccis obscure rubiginosis, pruinosis, glanduloso-punctatis, glabris. Folia alterna ষ. passim opposita, patentia, petiolis $3-5$ lin. longis instructa, $4 \frac{1}{2}-7$ poll. longa, 
$1 \frac{5}{4}-2 \frac{1}{3}$ poll. lata, longe acuminata, sicca supra obscure fusca, subtus flavofuscescentia et nervo medio venisque prominentibus ramulis concoloribus. - In sylvis montanis Celebes." (Blume, Mus. Bat. Lugd. Bat., vol, i, p. 83, 1849.)

It was therefore, as Bentham states (Journ. Linn. Soc., $\mathrm{x}, 143$ ), described from a Celebes specimen in leaf only, which Blume found in Reinwardt's collection under the doubtful name of Populus? deglubato.

Following is Reinwardt's amplified account of the supposed species :-

"103. E.? deglupta, Bl. Ramulis compresso-tetragonis foliis ovatooblongis, acuminatis, integerrimis, glaberrimis, coriaceis, petiolo et nervis primariis flavis, graveolentibus, pellucido-punctatis." Insula Celebes sec. Reinwardtii sched. mss. E. deglupta, Bl., Mus. Bot., i, p. 83. Miq. flor. ind., p. 398.

An revera Eucalyptus? Affirmare certo non audeo. Reinwardtii schedulae herbarii haec habent adscripta :-

"1516. Populus deglubata (dein); Eucalyptus deglubata, Bl. Sylvae Celebicae prope Pogowat., m., Sept., 1821."

"1516. Habitat in sylvis insulæ Celebes, prope flumina Pogowat., Taludujunam, etc. Tambuli-lato incolis Celebicis dicitur. Arbor Populi instar balsamea."

In relatione itineris Reinwardtii in insula Celebe haec de hac arbore adnotata lego. "Die veneris, qui erat duode-trigesimus, m., Sept, 1821., Pogowattam reliqui, iter facturus in loca ubi aurum colligitur, nempe versus Taludujunam. Inter alias arbores, quas vidi, una erat species trunco excelso, crasso instructa atque ad basin expansionibus laminaribus undique se expandens, vulgo epidermide destituta, glaberrima et versicolor quod superficiem attinet. Horum truncorum unum securi percutere jussi et visa mihi est haec arbor esse populi species, cujus magna est cum Populo balsamea analogia, tum quod attinet folia, tum vero luxuriem incrementi ramorum, flavicantem colorem petiolorum, ruborem ramorum et foliorum novellorum, sed maxime etiam propter odorem balsamicum quem folia juniora, ubi fricantur, spargunt."

Haec in sylvis Celebicis notavit jam beatus Reinwardtius. Quodsi in museo suo Lugduno-Batavo stirpem Celebicam examinavisset et si lentis augmenti ope eam conspexisset, nullus dubito quin folia pellucido-punctata botanico praestantissimo istiusmodi determinationem protinus dissuasissent.

Cel. Reinwardt de planta illa haec adnovit. "1516. Eucalyptus ? deglupta, BI., Mus. 1, p. 82. Diospyros? P. foliis ovato-oblongis, actminatis, integerrimis, glaberrimis. Arbor egregia, excelsa, protinus e longinqua dignoscitur trunco erecto, altissimo, deglubato, id est, epidermide plerumque exuto, variegato, flavo-virente, nudo. Cortex ipse tenuis est, intus (quod lignum) alba. Rami habent folia alterna; ramuli ultimi alato-tetragoni sunt. Folia breviter sunt petiolata, crassa, coriacea, petiolis et nervo primario flavis. Foliorum et ramulorum contritorum odor est fortis, balsamicus,-Populi balsamiferae. Hanc ob causam, tum vero etiam propter habitum, ramosque juniores quadrangulares, turiones rubentes resinosos cet., praeterea etiam ob celere incrementum, Populum esse suspicor. Lignum est molle, inutile, populorum ligne simile. Folia optime descripsit Cl. Blume, 1 c., p. 83." (Reinwardt in de Vriese Pl. Ind. Bat. Or., p. 65.) 
8. E. Alexilis, Regel.

"Eucalyptus flexilis, Rgl., Ramossima; ramis ramulisque flexuosis, teretibus, verruculosis; foliis alternis, anguste lineari-lanceolatis, plus minus falcatis, integerrimus apice acuminatis $\mathrm{v}$. subuncinatis; umbellis lateralibus, 5-8-floris ; operculo conico, capsula tenuiore et eadem circiter duplo longiore.

"Ein neuer Eucalyptus aus Neu-holland. Stark verästelt. Aeste und Aestchen hin und her gebogen, stielrund, mit Wärzchen besetzt. Blätter: abwechselnd, sehmal linien-lanzettlich, mehr oder weniger sichelförmig, ganz-

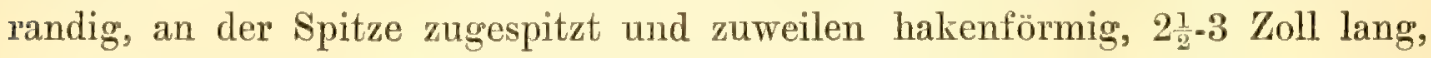
$\frac{1}{10}-\frac{1}{5}$ Zoll breit, am Grund in den Blattstiel verschmälert, lederartig, punktirt, einnervig oder ausser dem Mittelnerven mit 2 undeutlichen Seitennerven. Blüthendolden seitenständig, zerstreut oder mehrere zusanmengedrängt, 5-8 blumig. Blüthenstiel $\frac{1}{4}$ Zoll lang, aufrecht, wie die Blüthenstielchen vnmerklich zusammengedrückt und mit kleinen Wärzchen besetzt. Blüthenstielchen ungefähr $\frac{1}{8}$ Zoll lang; so lang als die Kelchröhre. Der Deckel des Kelches kegelförmig, röthlich, glatt, zweimal so lang als die Kelchröhre und schmäler als dieselbe, Blumen mittelgross, weiss.

"Schöner Kalthausstrauch aus Neu-holland, der, gleich den andern Eucalyptus-Arten, in eine mit Lehm versetzte Heideerde gepflanzt wird.

"Steht dem E. linearis, Dehnh. und E. falcata, Turez. zunächst. Der erstere derselben unterscheidet sich durch drüsigen Deckel, glatte Aeste und schwach gezühnte Bïtter; der andere durch herabgebogene Blüthenstiele, die viel länger als die Blattstiele, und einen spitzen Deckel, der 4 mal längeir als die Kelchröhre. (E.R.)" Regel in Gartenflora, vii, 284 (1858).

Following is a translation :- “A new Eucalyptus from New Holland. Much branched. Branches and branchlets flexuous, terete, covered with warts. Leaves alternate, narrow linear-lanceolate, more or less falcate, the margins entire, the point acuminate and occasionally hooked, $2 \frac{1}{2}$ to 3 inches long, $\frac{1}{10}$ to $\frac{1}{5}$ of an inch broad, the base narrowed into a petiole, of leathery texture, punctate, one-nerved or with two indistinct side-nerves beside the mid-rib. Umbels of flowers lateral, scattered or several crowded together, with 5 to 8 flowers. Peduncle $\frac{1}{4}$ of an inch long, erect, slightly compressed as well as the pedicels, and covered with small warts. Pedicels about $\frac{1}{8}$ of an inch long, as long as the calyx-tzibe. Operculum conical, reddish, smooth, twice as long as the calyx-tube and narrower. Flowers of middle-size, white.

"A beautiful green-house shrub from New Holland, which, like the other species of Eucalyptus, should be planted in a loamy, heathy soil.

"It is nearest allied to E. linearis, Dehnh., and E. falcata, Turcz. The former is distinguished by its warty operculum, smooth branches, and slightly dentate 
leaves; the latter by the peduncles being bent down and much longer than the petioles, and by the pointed opereulum, which is 4 times as long as the calyx-tube."

The juxtaposition of $E$. linearis and E. falcata shows that the description has probably been based on horticultural considerations.

9. E. glancu, Hoffing.

"(164.) Eucalyptus glauea. Synonymon absolute nullum reperio. Simillimus est E. piperitae, ut eundem diceres; at vere differre videtur diutius observata foliorum acumine parumper magis producto, substantiâ multo magis rigidâ et coriaceâ (fere ut fol. Launi nobilis, vel Citri medicae), quod in E.p. non ita." (Hoffmannsegg, Terz. Pfl. Nachtr., p. 215.)

The name glauca was a favourite both with botanists and horticulturists during the first half of the 19th century, and before it was realised that so many species are glaucous at one period or another of their growth. Following is an instance of its use by Allan Cunningham in his Journal, dated 17th August, 1817, when near Bathurst from the west.

"A species of Eucalyptus (glanca), with conical blunt deciduous operculum and angular umbel of flowers, forming a tree 30 or 40 feet high is frequent, and being now in flower induced me to gather specimens."

10. E. moluccana, Roxb.

"Lid conical, shorter than the calyx. Panicles lateral, compressed of peduncled heads, of 6 or 7 flowers. Jeaves alternate, petioled, lanceolate, entire, firm and polished.

"A native of the Molucca Islands, differing from all the species described by Dr. Smith in the 3rd Vol. of the Transactions of the Linnean Society, in having lateral panicles, composed of heads of 6 or 7 sessile flowers." (Fl. Ind. ii, 498 ; Hort. Beng., 92.)

"E. moluccana, Roxb., described from a tree in the Calcutta Garden, said to be a native of the Moluccas, but without any record as to when or by whom introduced, and I cannot find that any drawing or specimen has been preserved. Viquel refers it to E. alba, but that is mere guess work, and Roxburgh's short description is quite at variance with that species.". (Benth. Journ. Linn. Soc., $\mathrm{x}$, 142.)

11. E. myrtifolia, Link.

"224. E. myrtifolia. Fol. pet. 3-4" longo, lamina cum pet. 2' longa, 1' lata acuta reticulata, nervis in margine connexis, punctata. Hab. in Australia. Non floruit." (Link's Enum. Hort. Berol., ii, 30; DC. Prod. iii, 222.)

"Very doubtful." (Bentham.) 
12. E. nervosa, Hoffmg.

"(165.) Eucalyptus nervosa. Foliis oppositis alternatisque petiolatis ovato-oblongis acuminatis uninerviis costato-renosis marginatis subrepandiusculis

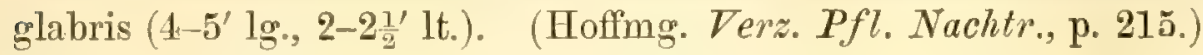

E. nervosa, F.v.M., is E. obliqua, L'Herit.

13. E. oppositifolia, Desf., "à feuill opposées N. Holl. or." (Desf. Tabl. Ecol. Bot. Ed. 1, 1804, p. 222.) I cannot trace any ampler description.

14. E. orbicularis, Lodd.

15. E. phillyreoides, Lodd. Both ex G. Don in Loud. Hort. Brit., p. 198 (1830). I cannot trace any description.

16. E. reticulata, Link.

"215. E. reticulata, Fol. lanceolata subfalcata acuminata basi subovata obliqua 6-7' lga., 2' et uitra lata, subtus reticulatim venosa. Hab. in Australia. Nondum floruit. Nervi foliorum subtus non paralleli ut in pr." (Link's Enum. Hort. Berol., ii, 29 ; DC. Prod. iii, 222.)

"Very doubtful." (Bentham.)

17. E. robusta, Hoffing.

"(433.) Eucalyptus robusta. In Syn. ap. Willd. Sp. Pl. pedunculi compressi quidem dicuntur, et in mea (versus apicem) depressi sunt; at cogitans, plerosque scriptores hediernos terminorum veram acceptionem parum curare, puto, quod et hic compressus pro depresso sumtum sit, et hoc scrupulo (licet per se gravissimo) non morabor. Necesse est se temporibus accommodare. (!) Caeterum et aliae spp. tales habent petiolos. Certitudinem vero definitionis ullius $E E$. Sp. nemo acquiret, nisi qui opercula viderit, quum pleraeque aliae partes, quibus plantae vulgo distingui solent, vix memoratae sint; quod igitur in plurimis manet 'seros nepotes.'

"Caulis teres, asper, cum petiolo $<6$ " lg., nervoque primario supra, purpurascens. Folia coriacea, asperula, ad lentem punctis numerosissimis minutis, secus lucem albidis, contra eam pellucidis, tuberculisque rarioribus majoribus depressi subglabratis." (Hoffmg. Verz. Pfl. Nachtr., ii, p. 115.)

18. E. Sarassa, Blume.

"209. Eucalyptus Sarassa, Bl. Kaju Sarassa Rumph. Herb. Amb. iii, p. 122. In montanis Moluccarum." (Mus. Bot. Lugd. Bat., i, 84, 1849.)

" "Founded on Rumphius" incidental mention of the Sarassa tree in the same article (see $E$. versicolor), all three species, this,-versicolor and deglupta, conjecturally referred by Blume to Eucalyptus on account of their resinous bark, described as detaching itself in particles." (Benth., Journ. Linn. Soc., $\mathrm{x}, 143$. 
19. E. stenophylla, Link.

"226. E. stenophylla. Fol. linearia basi attenuata obtusiuscula venosa punctata nervis ante marginem connexis. Hab. in Australia. Fol. pet. 4" lgo., lamina 3 ' lga, 4"' lata." (Link's Enum. Hort. Berol., ii, 30; DC. Prod. iii, 222.)

"Very doubtful." (Bentham.)

20. E. tuberculata, Parm.

"Parm. h. engh, ex Otto hort. Berol. foliis oppositis sessilibus, amplexicaulibus oblongo-linearibus acutis membranaceis glabris, ramis filiformibus tuberculatis. In Nova-Hollandia v.s. sine fl." (DC. Prod. iii, 221.)

"Very doubtful." (Bentham.)

21. E. turbinata, Page.

By name only in Page's Prodromus, 1818. I cannot trace where, if at all, it was described.

22. E. undulata, Hort.

23. E. verucucosa, Hort. Both ex. G. Don in Loud. Hort. Brit. p. 198 (1830).

New Holland, 1820. I cannot trace the description, if any.

24. E. versicolor, Blume.

"(208.) Eucalyptus versicolor, Bl., foliis sparsis $\nabla$. sub-oppositis breviter petiolatis orato-lanceolatis acuminatis basi acutiusculis coriaceis glabris penninerviis. Arbor versicolor Rumph. Herb. Amb., iii, p. 122, tab. 53. Ay-alla Amboinensium. Truncus strictus, altissimus; cortice tenui, laerigato, albido, in lamellas secedente excellentem gerens colorem ex rubro luteo et viridi variegatum, qui e longinquo iridis colorem refert. Folia 5 poll. longa, 2 poll. lata, laurina, nervo medio subtus argute prominente, sicca supra nigricantia. In Moluccis." (Blume, Mus. Bot. Ludg. Bat., vol. i, 1849, p. 84.)

From the Moluceas, taken up from Rumphius' description and rude figure of Arbor versicolor Ay-alla (Herb. Amb., iii, p. 122, t. 80, not t. 53, which is an Eugenia) without flowers or fruit." (Bentham, Joum. Linn. Soc., x, 143.)

"44. Encalyptus, nov. sp. ramulis rubellis, etc, e specimine incompleto non describenda. Van Diemen's Land (Stuart n, 19)." Miq. in Ned. Kruidk. Arch., iv, 141 (1856).

I have not been able to see a specimen of Stuart's No. 19 from Tasmania, so that I cannot say if it would be possible to express an opinion as to the species to which it belongs. 


\section{C.-Non-Eucalypts described as Eucalypts.}

THe following non-Eucalypts have been described or referred to as Eucalyptus.

The following three specimens are from Herb. Vindob:-

1. E. saligna, Hort, Berlin (labelled E. saligna, Sm.).

2. Metrosideros saligna (in 18th century handwriting).

3. Eucalyptus resinifera, Hort. Argentorat et Nessler (sic.) ded. Sept., 1828.

These are all Agonis flexuosa, DC.

The prominent wing on the young branchlets of the var. latifolia is often very faint on the common narrow-leaved form, but always discernible. Bentham omits this character in Fl. Aust.

4. E. microphylla, Willd.

"E. microphylla, W.E., 515. Fol. pet, 4" longo, lamina 1' 4" lga. 4" lata, apice falcata, in ramulis conferta parva." (Link's Enum. Hort. Berol., 225.)

Bentham says this is probably not a Eucalyptus at all. I have seen a specimen (in leaf only) in Herb. Vindob. doubtfully referred to this species, and I agree with him.

5. Sieber's No. 471 .

"E. hispida, Sm. De la Nouvelle Hollande. No. 471, M. Sieber, 1825," in Herb. Barbey-Boissier is Angophora cordifulia, Cav.

6. E. hirsuta, Link.

"229. $E$. hirsuta. Foliis subpetiolatis cordatis obtusis, subtus nervis pubescentibus ramis pedunculisque strigosis. Hab. in Australia. Rami strigis longis densis rubescentibus patentibus. Fol. petiolo brevissimo, lamina $3^{\prime}$ lga., $1^{\prime} 6^{\prime \prime}$ lata, juniora pubescentia rubescentia, adultiora subtus tantum in nervis pubescentia discolora. Pedunculi l' longi triflori, pedicelli $8^{\prime \prime}$ longi. Operculum hemisphaericum." (Link's Enumeratio Hort. Berol, ii, 31.) This is Angophora cordifolia Cav. 
7. E. media, Link.

"219. E. media. Fol. pet. 6" longo, lamina lanceolata longe acuminata basi subovata obliqua, lata angustieraque 6-7" Iga, $1^{\prime} 2^{\prime \prime}$ ad $2^{\prime}$ lata, subtus nerris parallelis. Hab. in Australia, non floruit." (Enum. Hort. Berol., ii, 30; DC. Prod. iii, 222.)

Specimens in Herb. Vindob. in flower, labelled "Eucalyptus media, Link., Ferd. Bauer, Hb. Bauer" are Angophora lanceolata, Cav.

8. '1846, No. 397. 'Apple-tree Eucalyptus,' sub-tropical New Holland. Lieut.: Col. Sir T. L. Mitchell," Herb. Cant. ex Herb. Lindl. is Angophora intermedia, DC., with lanceolate leaves, also with broad cordate leaves (suckers).

9. E. mubricaulis. "Ramis asperis ; ramulis filiformibus; foliis alternis, angustolanceolatis acutis petiolatis. Folia uncias 2-3 longa, lineas 3 lata." (Desf. Cat. Pl. Hort. Par., ed. 3, 1829, p. 408; also, Dehnh. Cat. Pl. Hort. Camald., ed. 2, p. 20.)

A specimen in leaf only. "Eucalyptus rubricaulis, Desf. ex hort Celsiano, Paris, 1819," Herb. Vindob. (Herb. Boos.) appears to me not to be a Eucalyptus at all, but probably a Proteacea. Underside of leaves reddish. 


\section{D.-Works consulted.}

EUCALYPTUs being naturally such a well-defined genus, it has very few generic synonyms. Those that are accounted synonyms are not synonyms of the whole genus, and comprise two only, viz. :-

(a) Eudesmia, R.Br., which was the name given to one species (tetragona) looked upon by Brown as connecting Eucalyptus with Angophora.

(b) Symphyomyrtus, Schauer., which consists of a form of E. cornula, Labill., with the walls of the fruits fused together.

Aromadendrum, Anderson (Dr. W. Anderson, the surgeon of Cook's second and third voyages), is a nomen nudum. A second Aromadendrum (Blume) is a genus of Magnoliaces.

The vast majority of species are Australian. The known exceptions are two species extending to Timor, and two or three or perhaps one single somewhat doubtful species from the Indian Archipelago; one from New Britain. Species have been described by Naudin from cultivated specimens in the south of France and by Kinney from California, but, in my opinion, they are referable to Australian species.

The botanical literature of Eucalyptus is very scattered. Most of the original descriptions of Robert Brown remain in manuscript, while later work has rendered some of them of only historical value. I do not hesitate to say that the suppression of these descriptions has been a heavy blow to British botanical science, whether this suppression eventually met with the acquiescence of Robert Brown himself or whether he was controlled, in this respect, by superior authority.

The first published attempt to get the increasing number of species of Eucalyptus into order was by Augustin Pyramus de Candolle in his Prodromus, vol. iii, 216 et seq. (1828). The Eucalyptus portion of Don's "General History of Dichlamydeous Plants," vol. ii, 818 et seq. (1832), is mainly a translation of the preceding.

Then follows the important work of W. P. Walpers, "Repertorium botanices systematicae." (Leipzig.) Vols. ii and $\mathrm{v}$ contain an important series of descriptions of species. This trork was continued as "Annales botanices Systematicae," and vols. $i$ and ii also contain descriptions of Eucalyptus. 
In 1866 appeared the third volume of Bentham's Flora Australiensis, which will always remain a classic as far as the genus Eucalyptus is concerned.

From 1879 to $188 \mathrm{t}$ there was published Mueller's Monograph of One Hundred Species of Eucalyptus, which is of the highest value.

There can be no doubt that the time has arrived when a process akin to the consolidation of legal statutes is desirable as regards the National Genus of Australian Plants. The literature is very scattered, and so are the types; a few I have not been able to see, and do not even know where they are. Perhaps European botanists will kindly assist me with specimens or drawings, for which I will make the amplest recompense I can.

Following is a list of herbaria of Eucalyptus examined by me. In a number of cases the collections have very kindly been remitted to me in Sydney:-

Berkeley, University of California, U.S.A.

Berlin, Royal Botanic Garden.

Calcutta, Royal Botanic Garden.

Cambridge, University.

Edinburgh, Royal Botanic Garden.

Genera, Herbier Barbey-Boissier.

Glasgow, University.

Kew, Royal Gardens.

Melbourne, National Herbarium.

Natal (Durban), Colonial Herbarium.

Oxford, University.

Vienna, Imperial and Royal Natural History Museum.

Washington, U.S., United States National Herbarium (Smithsonian Institution).

Following are the works consulted by me up to date. Others will be referred to under separate species.

\section{L'Heritier.}

Sertum Anglicum, seu plantae rariores, quae in hortis justa Londinum imprimis in horto regio Kewensi excoluntur.**

This work contains the first description of Eucalyptus, the first specie described being E. obliqua.

- L'Heritier de Bratelle, a French botanist, came to England in 1786-7, and studied the Kew collections, which appear to have been fally placed at his disposal. He published in 1788 at Paris a large folio with 34 plates. He brought over Redoute, the celebrated French botanical artist to make the drawings. (Kew Bulletin, 1891, p. 296.) 


\section{Gaertner, J.}

De Fructibus et Seminibus Plantarum. 3 vols. 4to., 1788-1807.

\section{Cavanilles, Antonio José.}

Icones et descriptions plantarum, \&c. 6 rols. Folio, 1791-1801.

\section{Smith, J. E.}

(a) A specimen of the Botany of New Holland. Vol. i. London, 1793.

(b) Transactions of the Linnean Society.

\section{Lalillardiere, J. J.}

(a) Novæ Hollandixe plantarum specimen. 2 vols. Paris, 1804-6.

(b) Voyage in seareh of La Pérouse (translated from the French and published by J. Stockdale, London, 1800).

\section{Bonpland, Aimé.}

Description des plantes rares cultivées à Malmaison et à Navarre. A Paris de l'Imprimerie de P. Didot L'Ainé, 1813. Folio.

Contains a description and plate of Bonpland's $E$. diversifolia.

\section{Loddiges, Conrad, and Sons.}

Botanical Cabinet. (1817, \&c.)

Link, H. F.

Enumeratio Plantarum Horti Regii Botanici Berolinensis Altera. Pars 1, Berlin, 1821. Pars 2, Berlin, 1822.

\section{Link et Otto.}

Icones Plantarum Selectarum. 4to. Berlin, 1820-8.

\section{Sprengel, C.}

Systema Vegetabilium. (Vol. iv, Pars 2, Curæ Posteriores), 1827.

Candolle, Aug. Pyr. de

Prodromus Systematis. Naturalis Regni Vegetabilis. Vol. iii (1828).

Mémoire sur la Famille des Myrtacées. (Posthumous work). Genève, Cherbuliez, 1842; Mém. de la Soc. de Phys. et d’hist. nat. de Genève. Vol. ix.

Don, G.

General System of Dichlamydeous Plants. Vol. ii (1832). 
Hooker, W. J., and Hooker, J. D.

(a) London Journal of Botany.

(b) Icones Plantarum.

(c) Botanical Magazine.

\section{Hooker, J. D.}

The Botany of the Antarctic Voyage. Part 3. Flora Tasmaniæ. 1860.

\section{Lindley, J.}

Edwards' Botanical Register. 1838, \&c.

\section{Walpers, W. P.}

(a) Repertorium botanices systematicæ. ii, 163, 924; v, 743 (1843, \&c.).

(b) Annales botanices systematicæ. i, 309 ; ii, 619.

\section{Mitchell, T. L.}

(a) Three Expeditions into the Interior of Eastern Australia. London, 1838 (2nd ed., 1849).

(b) Journal of an Expedition into the Interior of Tropical Australia. London, 1849 .

\section{Turczaninow.}

Bull. Phys-Wath. Acad. Pétersb. 10. 1852.

\section{Miquel, F. A. G.}

Stippes nova Hollandas a Ferd. Mullero Collectas, Determinavit F. A. G. Miquel.*

Neder'andsch Kruidkundig Archief. Vol. iv, Part 2 (Vierde deel, tweede stuk), pp. 97-150. Leyden, 185€.

The date of this part is 1856 and not 1859 as quoted in B.Fl., iii.

\section{Mueller, F.}

(a) Proceedings, Linnean Society. Vol. iii (1858).

(b) Fragmenta phytographiæ Australiæ.

(c) Eucalyptographia.

(d) Western Australia. "General information respecting the present condition of forests and timber trade of the southern part of the Colony, together with a report on the forest resources of the Colony by Baron von Mueller." Perth, 1892. The report was previously published by I. Reeve \& Co., London, in 1879.

\footnotetext{
"In clescribendis et definiendis his stirpibus eximiis etiam annotationibus mss. cl. Müller, ad vivum factis, usus sum.
} 


\section{Bentham, G.}

Flora Australiensis. Vol. iii (1866.)

Woolls, W.

(a) A contribution to the Flora of Australia. Sydney, 1867.

(b) Lectures on the Vegetable Kingdom with special reference to the Flora of Australia. Sydney, 1879.

Howitt, W. A.

The Eucalypts of Gippsland. Trans. R.S. Vict. Vol. ii, Pt. 1, 81.

Deane, H. and Maiden, J. H.

Proc. Linn. Soc., N.S.W. 1895 to 1901.

\section{Maiden, J. H.}

Proc. Limn. Soc., N.S.W.; of Roy. Soc., S.A.; of Roy. Soc., Tas.; Victorian Naturalist; Agric. Gazette, N.S.W.; Bulletin, Herbier Boissier, \&c. [See also Deane and Maiden.]

Baker, R. T.

Proc. Linn. Soc., N.S.W. 1899 onwards. 


$$
1 .
$$

\section{EUCALYPTUS PILULARIS}

(Smith). 


\section{DESCRIPTION.}

FoLLOWING is the brief original description of the species :-

Operculo conico medio constricto longitudine calycis, umbellis lateralibus, fructu globoso foliis lineari-lanceolatis.

The leaves are much narrower than in the preceding, " and the flowers not half so large; neither is the cover, as in that, more in diameter than the calyx. The fruit is globose. I suspect that of E. robusta to be turbinate with a reflexed margin, but I have seen it only half ripe. - Smith, in Trans. Linn. Soc., iii, 284, 1797.

It has been more amply defined in Bentham's Flora Australiensis (iii, 208), and in Mueller's Eucalyptographia.

Vernacular Names.-It is the tree which most usually goes under the name of "Blackbutt," and sometimes by way of distinction, for it attains enormous size, as will be seen presently, the "Great Blackbutt." It is a stately, shapely tree, and perhaps the best knomn of all the genus to Sydney residents, as it is so abundant. It belongs to the group of cucalypts called "half-barked," because its rough outer bark is confined to the trunk of the tree, the branches being smooth and white. From the lattel circumstance it shares with some other species the designation of "White-top." The outer bark of this tree is fibrous and closely matted, forming, if I may make the comparison, a sort of middle link between such fibrous-barked trees as the Stringybarks, and such smooth ones as our White gum. I do not know that the term "black," as applied to the butt, is particularly appropriate; the word "grey" "rould be better, though exception could be taken to this adjective also.

Before the term "Gum" was restricted to those eucalypts which have smooth or nearly smooth bark it was termed "Blackbutted Gum."

"Flintwood" is an old name for this species, in allusion to the hardness of the dry wood.

It shades off imperceptibly into the Stringybarks, and forms of it are known as Yellow Stringybark (from the yellow cast of the inner bark, at some seasons), Messmate, and Stringybark. Other adjectives applied to Stringybark will be noted under the forms described. 
Aboriginal Names.--"Yarr-warrah" of the Illawarra blacks, according to the late Sir William Macarthur. Another New South Wales aboriginal name was "Benaroon." By the aborigines of South Queensland it was known as "Tcheergun" and "Toi."

In a collection of specimens made by George Caley are three twigs which belong to this species and which are labelled as follows by him, Tarundea being the aboriginal name:- $(a)$ "Pilularis? Smaller Blackbutted Gum. Tarundea. Feb. 15, 1805." (b) "Great Blackbutted Gum with large capsules. Tarundea. Jan., 1808." (c) "This is neither Deraboyn" nor Tarundea. I only know a single tree of it, nor do the natives know any other."

Seedling Leaves. - The seedling leaves are narrow (those of two forms are depicted on Plates 1 and 2), thus affording a ready difference from E. capitellata, Sm., and Stringybarks in general. Those of the type form are toothed and hirsute (" in the earlier stages those of $E$. Muelleriana are frequently more less beset with tufts of hairs."-Howitt). Those of variety Muelleriana that I have seen have the leaves a little broader; but Howitt speaks of them as "narrow lanceolar," and the two forms run into each other. The width of some of those of E.pilularis are broader still, approximating to those of the true stringybarks.

Mature Leaves.-They are often hooked at the tips, and sometimes are glossy, particularly in var. Muelleriana. Usually there is no marked difference in the glossiness of the two sides. There are, however, more stomata on the lower side. As regards the type form, the venation is more prominent on the under surface of the leaf. This character, which appears to be almost confined to coast species, is shared by E. acmenioides and E. microcorys, of the Renanthere, and E. saligna, E. resinifera, and several others of the Parallelanthere. The petiole is broadish and flattened. Mueller (Eucalyptographia) lays emphasis on the flatness of the flower-stalks, but this character belongs to many other species, to some to a greater extent than to E.pilularis. In the variety Muelleriana it is sometimes much less marked.

I am not aware that an account of the oil yielded by the leaves of typical blackbutt has yet been published, but Gildemeister and Hoffmann $\uparrow$ hare published the following account of the oils of two trees which, as will be presently shown, are forms of this species.

The oil of Eucalyptus dextropinea, Baker, has been prepared by Baker and Smith+, as has also the oil of E. levopinea, Baker, from the fresh leaves of these trees. Both are indigenous to New South Wales. The yield was in one case 0.825 , in another 0.850 per cent. The deep, red-coloured, and stronglydextrogyrate oil has the sp. gr. 0.8743-0.8763 at $17^{\circ}$. By distillation the following fractions were obtained:-156-162 ; 62 per cent.; $162-172^{\circ}, 25$ per cent.

E. piperita, Sm.

† "The Volatile Oils," E. Gildemeister and F. Hofmann (trans. E. Kremer's), 1900.

¥Journ, Roy. Soc, N.S.W., xxxii, 195. 
The oil consists almost entirely of $d$-pinene. The main fraction, finally boiling at $156-157^{\circ}$, had the sp. gr. $\frac{1 x^{\circ}}{16^{\circ}} 0.8629 ;[\mathrm{a}]_{\mathrm{D}}=+41 \cdot 2^{\circ}$ at 18 .

For the identification of the pinene, the following derivatives were prepared :-Pinene nitrosochloride (m.p. $103^{\circ}$ ), and from the nitrosopinene (m.p. 128-129 ) further terpin hydrate, as well as pinene monohydrochloride (m.p. 121-124\%).

Besides pinene, the oil contains small amounts of cineol, which was recognised by the behaviour of the higher boiling fractions toward iodol and bromine.

From the fresh leaves of Eucalyptus lovopinea they obtained 0.66 per cent. of a reddish oil, having the sp. gr. 0.8732. The following fractions were collected :-157-164, 60 per cent.; $164-72^{\circ}, 28$ per cent. Just as the foregoing oil consists almost entirely of d-pinene, this oil consists almost entirely of l-pinene. The fraction boiling at $157-158^{\circ}$, which can probably be considered as fairly pure pinene, had the sp. gr. 0.8626 at $\frac{19^{\circ}}{16^{\circ}}$ and $[a]_{D}=-48.63^{\circ}$. The same derivatives of the pinene were prepared as with the foregoing oil. This oil likewise only contains small amounts of cineol.

Operculum.-In the type form the pointed, even acuminate, operculum is associated with a globular narrow-rimmed fruit. In northern specimens (e.g., E. semicorticata, F.v.M.), the pointed operculum is associated with a broad-rimmed fruit. In the variety Mueileriana the rounded (sometimes nearly hemispherical) operculum is associated with a broad, sometimes very broad, -rimmed fruit, and there is a very considerable amount of variation.

Stamens. - The filaments often turn red. The dark colour of the stamens has already been referred to in B.Fl. iii, 208. They are, however, not noticed in fresh specimens, but the colour deepens with age.

Fruits.-Smith's original description refers simply to "fructu globoso," an expression which is not appropriate to the broad-rimmed forms. Smith's specimens were in all probability collected in the vicinity of Port Jackson, and are our Form 2, Plate 4, to which the term globular or pilular, as applied to the fruits, is especially appropriate.

Bentham (B.Fl. iii, 208) speaks of the fruit as "semi-globose or sub-globose, truncate . . . the rim rather broad," \&c. At page 190 he says, "Fruit rim usually broad and flat." Mueller speaks of the fruit as "semi-ovate or almost truncate-ovate," and figures (Eucalyptographia) a broad-rimmed form. He adds, "the systematic name for this species is not happily chosen." Again (loc. cit.), "Whereas the globular fruit of E.pilularis, as aptly described in the Linnean Transactions of 1797 , would not apply to that species as now understood, but to E. piperita of the present day."

Mueller was not familiar with the typical pilularis, and his mistaken reference to $E$. piperita will be dealt with when that species is under review.

The fact is that $E$. pilularis displays very considerable variation in regard to the rim. It may be thin (narrow) or broad, and the absolutely imperceptible way in which the various forms run into each other is brought out in the drawings 
(Plate 4). The variety Muelleriana is a broad-rimmed form, but fruits are figured that have broader rims than any hitherto attributed to variety Muelleriana. Not only is the rim broad, but it may be domed, imperceptibly shading off into both $E$. capitellata and E. macrorrhyncha in this respect.

The fruits vary in size from $\frac{3}{\mathrm{~S}}$ to $\frac{1}{2}$ inch in diameter, and also in the size of the opening. In some trees the fruits are large, $\frac{7}{16}$ inch in diameter, and nearly spherical, but with a small opening. In others, the opening is very wide.

Many of our eucalypts have large fruited forms. E. resinifera, E. punctata, $\boldsymbol{E}$. virgata will occur to many in this connection. E. pilularis has one also belonging to the broad-rimmed section. I figure such a form collected by Mr. F. Williams at Dapto. (Fig. 18, Pl.4.)

The valves are quite sunk in the typical form. Variety Muelleriana shows exserted ralves, and they are even evident in the form (Fig. 3, Pl. 4), which otherwise would be typical. The specimens of "Mountain Gum" (Fig. 16, Pl. 4) show an extreme broad-rimmed form, with the valves exceptionally exserted, so that the size and shape of the fruits, the shape of the rim, and the valves all display considerable variation in this species, as will be at once observed if Plate 4 be studied.

Bark.-Has fibrous bark on the butt, while the branches are smooth, like those of a gum. The rariety Muelleriana, however, frequently shows more rough bark on the branches than does the normal species.

Timber.-Characteristics.-Pale-coloured, more or less fissile, though sometimes quite interlocked in grain. It is a strong, durable, thoroughly safe, and well-tried timber. It is usually readily diagnosed by the presence of narrow, concentric gum-veins, but sometimes these gum-veins are nearly or wholly absent. As a rule, they are too narrow to cause deterioration. Sometimes, particularly on the Northern Rivers, it is free from gum-veins, and then presents considerable similarity to tallow-wood (E. microcorys), for which it is occasionally substituted. It occasionally, though rarely, shows pin-holes.

In the Bateman's Bay and Moruya districts, where it occurs plentifully, it is said that although white ants are found in the heart of the living tree, they never attack the timber when it is dry.

Principal Uses.-It is one of the best hardwoods we have for house and ship building. It is useful for bridge-planking, though inferior to tallow-wood for that purpose. It has been tested for many years for blocks for wood-paving, with most satisfactory results; in fact, it is one of the best timbers we have for the purpose, both as regards wear and durability. It takes tar well. After ironbark, I would place this timber second only to tallow-wood, amongst oux hardwoods, for 
general purposes. Of late years it has been used for railway sleepers, and it has been exported to Europe for sides and head-stocks for railway waggons as an experiment.

That variety known as Yellow Stringybark in Gippsland is not so well known as the Blackbutt, and, therefore, at page 35, I have given an ample account of it. It may be stated generally that all forms of E. pilularis yield valuable timber.

Size.- It is one of the largest of our eucalypts, and giant trees have been recorded over the greater portion of the area in which it abounds.

A tree at Bulli was measured by me in 1891 with the following results:Girth at ground, measuring from buttress to buttress, $57 \mathrm{ft} .6 \mathrm{in}$; the girth at 3 feet from the ground was 45 feet, and at 6 feet above the ground, 40 feet. The taper was then very gradual for about 90 feet (estimated), where the head is broken off. There are ten principal buttresses of an average diameter of over 2 feet, but they practically cease to flute the trunk at a height of 10 to 15 feet. This is, probably, the identical tree measured by the late Sir William Macarthur in 1861 at "Bullai, Illawarra, still in full vigour, and with no external symptoms of decay, 41 feet in circumference, with the bole of immense height." Mr. A. G. Hamilton speaks of "Bulli Blackbutt, 22 yards in circumference at ground, and at stump height would be not much less, as it does not taper much."' One at Gosford was measured 156 feet high, and 23 feet in circumference at a height of 6 feet.

Propagation.- - It is well known that the blackbutt reproduces itself more freely and more rapidly than most other hardwoods, so much so that when a large one is felled, a dense growth of seedlings, growing into straight saplings, is the usual consequence. It, however, reproduces itself most abundantly upon rich, moist flats, which is the description of land in greatest demand for agricultural pursuits, so that it will, no doubt, be necessary in future to revoke portions of the most easily accessible and richest land in the blackbutt forests in the interests of selectors and for encouragement of agriculture. Wherever practicable, I would recommend the retention of blackbutt forest reserves, even although the mature timber may have been remored therefrom, and also the proclamation of additional blackbutt reserves in suitable localities not likely to be required for settlement, and, at the same time, the preservation and conservation of other useful species of hardwoods, which are not so abundant as blackbutt.

A self-sown seedling was measured at Gosford in 1889 on the land which was cleared for a nursery site. In eighteen months it had attained a height of 25 feet and a circumference of 18 inches. 


\section{SYNONYMS.}

1. E. discolor, Desf. (probably).

2. E. persicifolia, Lodd.

3. E. persicifolia, DC.

4. E. incrassata, Sieb.

5. E. semicorticata, F.v.M.

6. E. fibrosa, F.v.M.

Var. Muelleriana, var. nov. :-

7. E. Muelleriana, Howitt.

8. E. dextropinea, R. T. Baker.

9. E. lavopinea, R. T. Baker.

\section{NOTES ON THE SYNONYMS.}

1. E. discolor, Desf.

Following is the original description :-

"Eucalyptus discolor. Ramulis teretibus, purpureis; foliis oppositis, sessilibus, connatis, latolanceolatis, acuminatis, subtus glaucis." (Desf., Cat. Pl. Hort., Ed. 3, 1829, p. 408.) Tabl. Ed., ii, 198 (name only).

I have recently seen a specimen belonging to the Vienna Herbarium. Following is the label:-

"Eucalyptus discolor, Desf. In Spreng. syst. deest. ex horto Paris, 1820." In leaf only. I agree with Bentham that it is doubtful; but it resembles E. pilularis, Sm, a good deal, and I think it is that species. (See Fig. 1, Pl. 3.)

2. E. persicifolia, Lodd.

Bentham (B.Fl., iii, 240) states that E. persicifolia, Lodd. Bot. Cab. t. 501, "from the figure," is $E$. viminalis. If his surmise is correct, he refers to var. pedicellaris, F.v.M., which is multi-flowered.

But De Candolle (who doubtless saw Loddiges' specimens) referred them to Sieber's Nos. 593 and 477, which I have dealt with below, p. 32.

E. persicifolia, Miq., is E. Gunnii, Hook. f. var. acervula, Deane and Maiden. 
3. E. persicifolia, DC.

Following is a copy of the original description :-

(Lodd. Bot. Cab, t. 501). Opereulo conico cupulâ paulo breviore, pedunculis axillaribus et latioribus ancipitibus petioli longitudine, pedicellis brevibus compressis, foliis oblongis basi attenuatis apice acuminatis nervulo margine, subparallelo tenuissimo notatis. Novâ Hollandia. Folii petiolus 4-5 lin. longus, lamina 3 poll. longa, 6 lin. lata. Umbellæ 8-10-floræ. 3 foliis paulo latioribus, pedunculis brevioribus Eucalyptus. Sieb., plant. exs. Nov. Holl. n. 593 (v.s.). v. foliis paulo longioribus pedunculis petiolum paululum excedentibus. E. incrassata, Sieb., plant exs. Nova Holl. n. 477. E. multiflora, Poir. suppl. 2, p. 594 ? (V.s.). (Prod. iii, 217.)

De Candolle, therefore, states that the umbels are 8-10 flowered. He quotes two varieties :-

(a) With broader leaves and shorter peduncles. Sieber's No. 593.

(b) With longer leaves, and the peduncles slightly exceeding the petioles. This is Sieber's No. 477, and is stated to be E. multiflora, Poir.

A specimen in Herb. Barbey-Boissier in bud and leaf only bears the label, "Eucalyptus persicifolio, Lodd., DC. De la Nouvelle Hollande, M. Sieber, 1825, No. 593." The leaves are broader than specimens of No. 477 in the same herbarium, but I can see no other difference.

Specimens of Nos. 477 and 593 in the Berlin Herbarium are so similar that I cannot detect any difference between them, and they also are referable, in my opinion, to E. pilularis.

These specimens are all in bud only, and there is no doubt that the resemblance to specimens of $E$. siderophloia in bud is considerable, and deceived Mueller; Bentham followed him.

Mr. Backhouse, the Quaker botanical traveller, collected E. pilularis at Elizabeth Bay, Sydney, in February, 1836, and labelled it "E.persicifolia." The specimens are at Kew. The late Rev. Dr. Woolls and other botanists, who worked prior to the publication of Vol. III of the Flora Australiensis, used to style the blackbutt E. persicifolia.

\section{E. incrassata, Sieb.}

Following is De Candolle's description of this species :-

"Foliis paulo longioribus (than E. persicifolia, Lodd.), pedunculis petiolum paululum excedentibus. E. incrassata, Sieb., plant. exs. nov. Holl., n. 477. E. multiflora, Poir., suppl. 2, p. 594 (")" (Prod. iii, 217). It is identical, of course, with $E$. persicifolia, DC.

An original specimen of Sieber's No. 477 in Herb. Barbey-Boissier bears the following additional label:- "Eucalyptus incrassata, Sieb. De la Nouvelle Hollande, Sieber, 1825." On the same label was added a little later, "Eucalyptus persicifolia, Lodd., v.y., DC."

Like other specimens of No. 477, it is in leaf and bud only, and is E. pilularis. 


\section{E. semicorticata, F.v.M.}

Arborea, ramulis angulatis, foliis alternis lanceolatis subfalcatis modice petiolatis sensim acuminatis opacis subtilissime venosis imperforatis, vena peripherica a margine remota, umbellis axillaribus et lateralibus solitariis 5-8 fl ris, pedicellis angulatis pedunculo compresso bis terve brevioribus calycis tubo vix longioribus, operculo acuminato calycis tubum semiovatum ecostatum aequante, fructibus hemisphaericis 3-4 loculatis vertice planis, valris brevissime exsertis, seminibus apteris. Hab.-In nemoribus montium fertiliorum ad flumen Brisbane (Illawarra, Macarthur, Sydney Woods, in Paris Exhib., No. 88, hb. Hook.). Anth. aestate.

Arbor procera, "Blackbutt" colonorum. Cortice trunci extus nigrocinereo intus fusco fibroso, ramis denudatis albidis laevibus. Folia $24^{1} 4^{\prime \prime}$ longa, $7-10^{\prime \prime \prime}$ lata. Pedunculi 6-10"' longi. Operculum $2^{\prime \prime \prime}$ longun semiovatum subrostratum. Fructus $3-4^{\prime \prime \prime}$ longi. Semina fusca $1^{\prime \prime \prime}$ longa, angulata subtilissme punctulatorugulosa.

E. persicifolia Lodd, non Schl., huc forsan pertinet ex nomine vernaculari "Blackbutt" ad hanc a Cunninghamino citato.

(Journ. Linn. Soc., iii, 86, 1859.)

I have seen the specimen, Paris Exh., No. 88, Herb. Hook. (Herb. Kew). Bentham endorsed the label "Blackbutt of Brisbane River; long pedicels and a rim. (E. pilularis.)"

I have a specimen of the type, and the figure of the fruits (Fig. 6, Pl. 3) of $E$. semicorticata showing that while undoubtedly conspecific with $E$. pilularis, it is intermediate in character between it and var. Muelleriana, possessing the foliage and buds of the former and the fruits of the latter.

"E. persicifolia, Lodd. Bot. Cab. t. 501, Syn. E. semicorticata, F.v.M. (Proc. Linn. Soc., iii, 86)."

Mueller, Fragm., ii, (i1, gives the above synonymy, and gives the range from Moreton Bay to the Goulburn and Macalister Rivers, Victoria. He states that it is sometimes called "Blackbutt and Ironbark." The calyx-tube is $1 \frac{1}{2}$ to $2 \frac{1}{2}$ lines in length, and the operculum $2 \frac{1}{2}$ to $3 \frac{1}{2}$ lines, "acute et longuiscule rarius obtuse $\mathrm{V}$. ancipiter rostratum." Peduncles $\frac{1}{3}$ to 1 inch, pedicels $2-3$ lines; umbels $4-14$ flowered."

The fact that Mueller speaks of the species as "sometimes called Blackbutt and Ironbark" points to obvious confusion between two species.

Bentham (B.Fl., iii, 20S) gives E. ornata, Sieb., as a synonym of E. pilularis, Sm.; but it is really a synonym of E. siderophloia, Benth, and affords another instance of the confusion of $E$. pilularis with $E$. siderophloia. In fact, E. siderophloia's identity as a distinct species was not recognised until Bentham described it in 1866.

\section{E. fibrosa, F.v.M.}

Arborea, ramulis compresso-tetragonis, foliis alternis modice petiolatis lanceolato-falcatis acuminatis. indistincte vel subtile venosis opacis imperforatis, vena peripherica a margine remota, umbellis axillaribus solitariis geminisque vel terminalibus paniculatis 5-6 floris, peduniculo angnloso petiolum vix aequante, pedicellis calycis tubo semiovato aequilongis, operculo tenui-conico obtusiusculo quam tubus angustiore et duplo longiore, fructibus hemiphaericis 3-4 loculatis ecostatis, valvis infra marginem affixis breviter exsertis, seminibus apertis. Hab. - In montibus nemorosis ad flumen Brisbane. Anth. aestate. Arbor 
magna, suo tractu "Stringybark tree" colonis vocata, trunco recto cum ramis corticem extus rugosum nigrescenti cinereum intus fibrosum gerente. Folia $3-5^{\prime \prime}$ longa, $\frac{1}{2}-1^{\prime \prime}$ lata. Calyx in pedicellum angulatum desinens. Operculum $3^{\prime \prime \prime}$ longum ; fruetus lignosi, 3-4" longi.

(Jou'n. Linn. Soc., iii, 87, 1859.)

"E. fibrosa, F.v.M., seems to be a variety of E. siderophloia with a longer lid'Stringybark tree of Brisbane River,' (Eucalyplographia, under E. siderophloia)."

Bentham himself says:- "E. fibrosa, F.v.M., from the Brisbane, is only known from specimens in young bud, in which state I am unable to distinguish them from var. rostrata of $E$. siderophloia. F. Mueller, however, designates it as a Stringybark. It may, therefore, prove to be distinct." (See B.Fl., iii, 220.) If the note in regard to the texture of the bark be correct (and there is no reason to doubt it), the plant would come under $E$. pilularis, besides which I have specimens of that species from South Queensland, which have a rather long operculum. The balance of evidence is therefore, in my opinion, in farour of it being a synonym of E. pilularis.

"Euc. galbulus, aff. hort. Neapol. Tenore" Herb. Monac., is E. pilularis, Sm.

\section{Var. Muelleriana, var. nov.}

We now come to the forms which, in my opinion, constitute a new variety of E. pilularis, viz., Muelleriana. E. Muelleriana, Howitt, is the type of the variety, and the E. dextropinea and E. levopinea of Mr, R. T. Baker are identical with it.

\section{E. Muelleriana, Howitt.}

Following is the original description of the species :-

The bole is straight and rather massive, with moderately-spreading branches, and a fibrous and dark-grey bark, which is more deeply and coarsely fissured than that of $E$. piperita -in fact, resenabling the bark of E. capilellata where that species grows to a good size in favourable localities. The bark is persistent up to the small boughs, which are more or less smooth. The leaves of the aged trees are lanceolar, falcate, and more or less unequal-sided, rather dark green in colour, equally shining on both sides, and usually three to five times as long as broad, with a sharp apex.

The seedlings have narrow lanceolar opposed leaves of a dark green, shining, but paler on the underside. In the earlier stages they are frequently more or less beset with small tufts of hairs. I have noticed that the leaves are still opposed in young plants 2 feet to 3 feet in height. In young saplings, and those some feet in height, the leaves are rather broad, lanceolar, or ovate lanceolar in shape, less shiny on the lower face, much dotted with transparent pores, and rather thin in substance. $\Lambda$ marked feature in the saplings of this eucalypt, and one by which it can be distinguished almost at a glance from those of other stringybarks, is that the broadly lanceolar and pointerl leaves have a tendency to assume a horizontal position rather than a vertical one, and this gives the saplings a shining appearance. The stems of these saplings and joung trees are somewhat smoother than those of E. piperita, E. capitellata, or $E$. macrorhyncha. The umbels are usually solitary, and there is a marked tendency in the eucalypt for them to become strongly paniculated. The buds are from 3-12 in most of the umbels. The stalk is frequently slightly flattened, and not much longer than the buds, and the stalklet nearly as long as the calyx-tube, the lid semiovate to hemispheric, smooth, and occasionally slightly pointed, the stamens (rather sparse) are large and reniform like those of $E$. capitellata. Fruit almost hemispherical to approaching semiovate; the rim flat or even slightly inverted, not wide, valves deltoid, small, and inserted or, rarely, more slightly prominent; 4-valved, less frequently 3 to 5-valved.-(Howitt, Trans. R. S. Vict., 1890), 
Timber.-The timber of this tree is usually darker in tint than $E$. piperita. It is fissile, free from gum veins or shakes, clear in the grain, and enjoying a great reputation for durability. It is used for fencing and sawing, and, according to Mr. Macalpine, of Yarraville, who has lived for forty years in South Gippsland, fences are still standing with posts split from this eucalypt, which have been from thirty to forty years in the ground. I have myself observed posts of this timber standing in fences at Woodside since 1859 . The local name of this tree is "Yellow Stringybark."-(Howitt, Trans. Roy. Soc. Fict., 1890).

\section{The late Mr. Clement Hodgkinson, a Commissioner of the Melbourne} Harbour Trust, interested himself in ascertaining the value of the timber of the Yellow Stringybark, and there is no doubt that it is one of the best Victorian timbers. Following are extracts from Mr. Hodgkinson's report to the Harbour Trust, of the 17th January, 1891 :-

The Inspector-General of Public Works having (on the 6th December last, in reply to a letter from me to him on the 23rd November) informed me that the piles of the Welshpool Jetty were driven during 1859 and that, after the recent burning of that jetty it was repaired, "the stumps of the piles were found to be in such excellent preservation that they were not withdrawn, but short pieces were spliced on," my colleagues and myself were able to obtain specific and reliable evidence to the effect that these piles were Yellow Stringybark cut during August, 1859, and driven during that year. We carefully scrutinised these old piles when the tide was low and found them to be perfectly sound, uninjured by sea-worms, and having the appearance of clean, well-seasoned timber, in excellent condition, notwithstanding that these piles had been in sea water more than thirty-one years.

With reference to the whare at Port Albert, the Inspector-General of Public Works, in his letter to me, already alluded to, stated that "Yellow Stringybark and Gum are in use in the wharf and approaches to Port Albert. It is reported that, whereas the gum is fast decaying, the stringybark remains sound." My colleagues and self, after examination of the Port Albert wharf, now corroborate this statement; the Yellow Stringybark used in the construction of this wharf is quite sound.

We also inspected many old posts and rails, beams, planks, weatherboards, de., of this kind of Eucalyptus and we all noticed that it seemed less liable to warp than any other kinds of Eucalyptus, a fact mentioned in one of my previous reports on Yellow Stringybark. As, in addition to the specially important quality of great durability in the sea water, Yellow Stringybark has a specific strength very much greater than that of Red Gum and than that of Jarrah (as shown in the tabulated results of my tests of Yellow Stringybark inserted in my report of 5 th July, 1890), my colleagues and myself have arrived at the conclusion that this species of Eucalyptus may be used for piles and other purposes in the Melbourne Harbour Works.

Determination by Commissioner. Hodgkinson of the specific strength and specific gravity of five seasoned samples of Yellow Stringybark Timber, each being 6 feet $11 \frac{7}{8}$ inches long, $1 \frac{7}{8}$ inch square, and weighing $9 \frac{1}{2} 76$., the distance between the bearers being 6 feet :-

\begin{tabular}{|c|c|c|c|c|}
\hline $\begin{array}{l}\text { Number of } \\
\text { Sample. }\end{array}$ & $\begin{array}{l}\text { Breaking } \\
\text { Weight. }\end{array}$ & Deflection. & $\begin{array}{l}\text { Specific } \\
\text { Strength. }\end{array}$ & $\begin{array}{l}\text { Specific } \\
\text { Gravity. }\end{array}$ \\
\hline 1 & $\begin{array}{l}1 \mathrm{~b} . \\
952\end{array}$ & $\begin{array}{l}\text { in. } \\
4\end{array}$ & 2599 & 0.898 \\
\hline 2 & 800 & 31. & 2185 & 0.898 \\
\hline 3 & 866 & $3 \frac{3}{8}$ & 2368 & 0.898 \\
\hline 4 & 905 & 35 & 2172 & 0.898 \\
\hline 5 & 1,016 & $4 \frac{1}{2}$ & 2775 & 0.898 \\
\hline Average & 908 & $3 \frac{4}{6}$ & 2479 & 0.898 \\
\hline
\end{tabular}

Reported to IIarbour Trust, 5th July, 1890. 


\section{Eucalyptus dextropinea, R. T. Baker. "Messmate or Stringybark."}

"A tree attaining a height from 60 to 100 feet or higher, and a diameter up to 5 feet. Bark dark or black on the outside, fibrous, and longer in fibre than that of the other species. Branches smooth for a considerable distance down, but this feature varies. Leaves almost identical with those of E. lavopinea of this paper, and resembling also those of E. obliqua, L'Hér., and $E$. Muelleriana, A. E. H. Young leaves broad, rounded at the base, and very acuminate, opposite or nearly so, on a short petiole, the venation well defined, the intramarginal vein being much removed from the edge. Mature leaves lanceolate, falcate, acuminate often very oblique, shining on both sides, rather thick, the intramarginal vein removed from the edge. Umbels axillary with about 8 flowers, peduncle flattened, operculum hemispherical, shortly acuminate. Calyx-tube obconical, stalklet 4-6 lines long. Buds longer and larger than those of $E$. lovopinea. Anthers reniform, connested above by a prominent connective, valves opening in longitudinal slits. Ovary flat-roofed. Fruits 4-6 lines in diameter, hemispherical, truncate to rounded, occasionally domed, rarely countersunk, valves slightly exserted.

"Hab.-Monga, on granite formation, but in soil that is fairly rich (W. Bauerlen); Barber's Creek, mostly in the gullies (H. Rumsey).

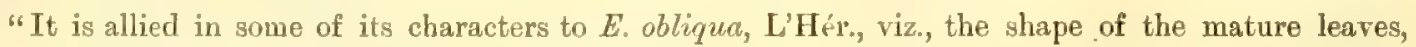
venation, buds, and in one particular form of fruit which has a contracted orifice and countersunk rim, but their sucker leaves are quite distinct, and the fruits are mostly hemispherical and usually with a thickened convex rim. The individual fruit figured by Baron von Mueller in his plate of $E$. obliqua in the Eucalyptographia, much resembles the fruit of this species. The timber, bark, and constituents of the oils of the two species are quite distinct, but herbarium specimens of them might easily be considered as belonging to one species. The form of the fruit referred to above is common also to $E$. pilularis, E. stricta, E. Muelleriana, E. piperitu, but its other specific characters are too marked for it to be ranked with any of these. It differs from $E$. capilellata and $E$. macrorryncha in the nature of its timber, its fruits, buds, bark, and oil. The leaves do not contain any myrticolorin. It bears in some respects alliance to E. lecropinea, but the bark is more fibrous and persistent, the timber is inferior, the fruits never so distinctly domed in the rin, and the valves much less prominent. E. Muelleriana has a much superior timber and a very different bark to $E$. dextropinen. The leaves of the former are shining only on one side; the fruits and buds are distinctly diferent. It differs from $E$. levepinea in the shape of its fruits, its inferior timber and nature of its bark, and the chemical composition of its oil. 'The buds and leaves are very similar ; in fact, are identical with several other species, and like the venation, no specific difference can be based on these parts of the eucalypt. As the investigations of cognate species are not yet complete its exact systematic position cannot be given at present, but provisionally it might precede E. obliqua.

"Timber.-A dark brown-coloured timber. Seasons very badly, and is evidently worthless.

"Kino.-See remarks under E. levopinea." (Proc. Linn. Soc., N.S.W., xxiii, 417.)

For an account of the oil, supra, p. 27.

\section{Eucalyptus leevopinea, R. T', Baker. "Silver-Top Stringybark."}

"A very tall tree in favourable situations. Bark fibrous but brittle, a feature that distinguishes it from that of "Red Stringybark," E. macror"hyncha, F.v.M., and "White Stringybark," $E$. eugenioides, Sieb.; ultimate branches smooth. Young leaves alternate or scarcely opposite, broad at the base but not cordate, acuminate, about 3 inches long, the intramarginal vein removed from the edge, the lateral ones very distinct on the under side, scarcely showing on the upper surface. Mature leaves varying in size and shape, mostly very oblique, of a dark green colour, and shining on both sides, lanceolate, falcate, acuminate, the intramarginal vein removed from the edge, lateral veins fairly distinct. Petiole varying from $\frac{1}{2}$ to 1 inch. Umbels axillary bearing about 5 to 7 flowers; stalk flattened, under an inch long, stalklet varying from 3 to 8 inches long, lid hemispherical, shortly acuminate, calyx not angular. Stamens all fertile, inflexed in the bud. Anthers divergent from the connective which surmounts them and is very prominent, opening by longitudinal slits. Roof of ovary flat and free from the placenta. Fruits hemispherical, petiolate; the rim very variable, at first thick and flat, or truncate, and then, as it matures gradually becoming exserted, and eventually quite domed, when it is not easy to distinguish it from E. macrorrlyncha, F.v.M. 
"Timber.-A very hard, close-grained, interlocked, pale brown coloured timber, difficult to distinguish from E. pilular is (Blackbutt), and no doubt of equal excellence. It is durable in the ground, and free from gum-reins as a rule. Suitable for bridge-decking, wood-blocking, posts, rails, and general building purposes requiring a hard, durable timber. In the case of "Red" and "White "Stringybark, the bark soon becomes detached after the timber is felled, but in this species the bark remains attached until the timber decays.

"Kino.-The exudation belongs to the ruby group, consisting principally of a tannic acid and water. Contains neither gum, like the kinos of the "Ironbarks," nor eudesmin or aromadendrin, like the "Boxes." In constitution it is practically identical with that of $E$. deatropinea, described below.

"0il. - A deep reddish colcur, and it could not be distinguished from that of $E$. dextropinea, except by chemical analysis. The leaves gave a yield of 0.66 per cent., and it consists very largely of lævo-rotatory pinene, chennically identical with the lævo-rotatory pinene obtained from trees of the Natural Order Coniferz.

"For the chemistry of this pinene, see paper by my colleague, Mr. H. G. Smith, Proc. Roy. Soc., N.S.W., Oct., 1898.

"Hab.-Nullo Mountain, Rylstone (J. Dawson), Never Never Mountain, Rylstone (R.T.B.), Gulf Road, Rylstone (R.T.B.).

"This tree has always been regarded by local residents of the Rylstone district as quite distinct from any of the other "Stringybark" trees in the locality, owing to its peculiar bark and tough wood, and the glinting of the leaves in the sun, making them appear glaucous, and hence its vernacular name of "Silver-Top Stringybark." When seen growing in its native habitat it somewhat resembles E. macrorrhyncha, F.v.M., and the mature fruits, with the domed rim and well-exserted valves, might easily lead one to diagnose it as that species; but it differs therefrom in its hard, durable timber, and also from it and cognate species by its characteristic bark, as well as in its hemispherical operculum, terete calyx-tube, in its oblique leaves, and the physical constituents of its leaves and oil. Except for its domed fruits, there is little to connect it botanically with E. macrorrhyncha, F.v.M., from the leaves of which is extracted (1) the dye myrticolorin; (2) an oil, very rich in the new solid camphor or stearoptene eudesmol, and also cineol. These bodies are entirely absent from the leaves of this particular eucalypt, and the oil is almost entirely composed of lævo-rotatory pinene.

"The presence of pinene of course allies it with the other species described in this paper, whilst the optical characters remove it from that species. It differs from E. capitellato and $E$. eugenioides in the shape of its fruits, its bark, buds, and leaves, and the chemical constituents of its oil, but yet it is a "Stringybark," and the timber shows affinities with that group of eucalypts, while the hemispherical base and size of the fruits are not unlike those of E. capitellata. In botanical sequence it may be placed after E. capitellata.

"It is distinguishable from $E$. obliqua by its fruits and timber as well as its oil, but resembles that species sometwat in the shape of its leaves and buds. It differs from $E$. dextropinea of this paper in its fruits never having a countersunk rim, the superior quality of its timber, and the presence of a dextrorotatory pinene in its essential oil. The leaves and buds of the two are identical. The oblique leaves and immature fruits led me at one time to consider this species as $E$. obliqua, L'Hér., and I so recorded it." (Proc, Linn. Soc., N.S.W., xxiii, 414.) 


\section{RANGE.}

\section{Typical Form.}

Extending into Queensland on the north and to Twofold Bay on the south, from the coast up the slopes and spurs of the Dividing Range to the Table-land, but apparently not found more than 100 miles from the coast, and scarcely crossing on to the western slope in any place.

This species attains its greatest development in New South Wales. The type came from Port Jackson and is the coastal form of the species as a rule. The variety Muelleriana is, in New South Wales, found further from the sea, extending to the ranges and table-lands as a rule.

As a matter of geographical convenience let us deal with Victoria first.

\section{VICTORIA.}

In the forest near Mount Macedon (C. Walter), with coriaceous broadish leaves like var. Muelleriana, but with globose fruits with thin sunk rims like the type.

Mueller (Census) records E. pilularis from Victoria, but the preponderating form in that State is, undoubtedly, var. Muelleriana.

\section{New South Wales.}

Following are some Port Jackson specimens :-

Sieber's No. 593 (E. persicifolia, DC.)

Sieber's No. 477 (E. persicifolia, DC.)

both labelled "Nov. Holland," and probably collected around Sydney.

"Eucalyptus, near E. oblonga, DC., black-butted gum, Colonies, 80 feet high, Port Jackson," is a label in Allan Cunningham's handwriting on a specimen collected by him in 1836 (xvi).

E. pilularis is very common in the Sydney district, and even as regards specimens that are closer to the type than to variety Muelleviona, there is a certain amount of variation. For example, specimens from Gladesville (J. L. Boorman) have fruits smaller than those of the type; specimens from the National Park (J. H. Camfield) have ovoid fruits; and specimens from Kogarah Bay (J. L. Bruce) have the valves slightly exserted. 
Following are some southern localities:-Twofold Bay (Oldfield); Mogo, near Moruya (W. Bäuerlen); Currawang and Nelligen (W. Bäuerlen); Conjola (W. Heron); Jervis Bay (J.H.M.) ; Otford (J.H.M.).

Following are New South Wales localities north of Sydney:-_Stringybark," St. Albans (A. Murphy), very small fruits; and near Booral (A. Rudder); Mount Seaview (J.H.M.) ; Macleay Rirer, near coast (W. Macdonald).

A "Stringybark," Attunga, near Tamworth, growing on a hill of Serpentine formation (R. H. Cambage), has domed fruits and resembles both E. macrorrhyncha and E. eugenioides.

Moonambah (W. Bäuerlen).

The northern New South Wales and Queensland forms are, as indicated at page 41 , intermediate in character between typical $E$. pilularis and its variety Iuelleriana.

\section{QUEenstand.}

"Benarora (?) Blackbutt, at the sandstone ranges towards Beroa."

"Turru Turru, a kind of stringybark, but not yellow."

The abore are copies of labels in Leichhardt's handwriting. The specimens are in leaf only, but referable, I believe, to $E$. pilularis.

E. semicorticata, F. Mueller, Brisbane River (collector ?); specimen examined by Bentham.

Stradbroke Island, North Coast line; also Glass House Mountains and Highfield (F. M. Bailey).

\section{Variety Muelleriana.}

\section{VICTORIA.}

Following is Howitt's original account of the range of his E. Muelleriana :-

This eucalypt has an extensive range in the western half of Gippsland. It is a littoral species, and is principally found between the Hoddle Ranges and the sea coast. There it forms the bulk of the forest, growing upon sands and sandy clays, from the Monkey Creek, 20 miles from Sale, to Shady Creek, west of Alberton in an east and west direction, and from Currajung southwards to the coast. The area thus covered by this tree is about 300 square miles. It also occurs in lesser colonies on the ridges extending from Tertiary tracts up to the high ranges forming the spurs of the mountains. I have not observed it west of Toongabbie, where it ascends the hills of Upper Silurian sediment for about 6 miles northwards to a 1,000 feet in elevation. I have also seen it growing extensively on the hills across which the roadknown as the Insolvent Track, runs from the Stockyard to Cobannah Creek. The formations here are Upper Devonian, resting on sediments which may be either Devonian or. Upper Silurian. Its range north and south in this locality is at least 25 miles, and its highest elevation probably over 1,200 feet. I have noted a third locality where this tree occurs under precisely similar conditions, extending northwards on the spurs of the mountains skirted by the Tambo Valley Road. There it grows for several miles on the Silurian sediments, northwards from the edge of the Tertiary Marine beds, and reaches an elevation of at least 1,000 feet. I have little doubt that it will be found in the intervening localities, and perhaps further to the eastward, but of this I have no direct evidence.-(Trans. Roy. Soc. Vict., 1890).

On another occasion he said :-

It appears to grow to the largest size on the sands and sandy clays of South Gippsland, where it forms most valuable forests. 


\section{And again :-}

It grows principally in the tract of country lying between Sale and Yarraville, commencing at a point about 20 miles from the former place, where the "White Striugybark" (E. piperita) abruptly ceases to grow. Nortlwards it extends towards Tom's Cap. A second area is at the Nine-mile Creek, between Alberton and Toora.

- These areas are in themselves not large, and have lessened so far as the supply of this tree is affected by alienation of the land. A small timber reserve, however, is reserved at Wonwron.

Small colonies of this tree occur about 3 miles out of Toongabbie on the Walhalla Road, between Baimsdale and Mount Taylor, along the "Insolvent Track," and at one place on the Tambo Valley Road, but none of these areas are of sufficient size to be of much economic value. Its maximum height is 170 feet or thereabouts, but more frequently from 100 to 150 feet.-(Howitt.)

The following Gippsland specimens were labelled E. Muelleriana by Howitt himself:-Agnes Creek Bridge; Four-mile Creek, Port Road ; Lily's Leaf; Mount Morinch; Insolvent Track, 4 miles; Muddy Creek, Stockyard Creek Road; Toongabbie; Long Cutting, Tambo Road; Woodside, German's Creek, Port Albert Road; Bircham Road; Drouin West.

Following are other Victorian specimens examined by me:-Grampians (C. Walter) - the young buds angular, showing transit to capitellata (Fig. 21, Pl. 4); the Wimmera (F. Reader) - From the Wimmera is no great distance to South Australia, the climatic conditions of which it much resembles.

\section{South Australia.}

Mount Lofty (March, R. H. Cambage; November, W. Gill). (Fig. 20, Pl. 4 ) Mr. Gill observes that the inner bark of this tree has not a bright yellow colour. This is not an infallible guide, as it varies according to the season of the year and with the district. Mr. Cambage labelled it "Pale Stringybark."

"E. fabrorum, Schlecht. In montibus sterilioribus elatis. November, 1848, Dr. M." This specimen was collected by Mueller, and labelled capitellata by Bentham. There is no doubt that the South Australian specimens show affinity to E. capitellata, Sm. (Most South Australian specimens labelled E. fabrorum, Schlecht., are E. obliqua.)

\section{New South W Wles.}

"Messmate," south of Eden (J. S. Allan); 'Twofold Bay (Oldfield), in Herb. Barbey-Boissier; also Herb. Cant. These are identical with the Barber's Creek specimens. There is typical $E$. pilularis by the same collector, from the same locality, in the same herbarium.

Currawang Creek, near Nelligen (W. Bäuerlen). Typical for E. dextropinea, R. T. Baker. (Fig. 6, Pl. 4.)

In the Goulburn district (e.g., Box Point to Barber's Creek, Wingello, \&c.) it is known as "White Mahogany"; but it is not to be confused with E. acmenioides. Its branches are rough to the top, forming a ready local distinction between it and 
the typical form. The bark is very yellow when freshly cut, also the timber, hence its Gippsland name of "Yellow Stringybark." The timber is valued for building purposes, being used for flooring and weatherboards, \&c. It occurs in many places in the coast mountain ranges, both north and south. It is a very clean timber, and grows large. Mr. Crawford, of Wingello, who was born in the district, and who has been a worker among timber all his life, writes to me: "While I call it "White Mahogany,' and sometimes 'Yellow Stringybark," the coast people call it "Blackbutt.",

"Towards and under Table Mountain, Milton;" also Mount Kembla (R. H. Cambage).

Western New South Wales localities are:-

"Stringybark," Kanimbla Valley. A small-fruited form. Botanists may look upon as a large-fruited form of E. eugenioides, Sieb. (Fig. 7, Pl. 4.) The seedlings would settle the relative closeness to E. pilularis or E. eugenioides.

Nullo Mountain, Rylstone, and Gulf Road, Rylstone (R. T. Baker); and typical of his E. lavopinea.

"Mountain Stringybark" (A. Rudder)." Identical with the Gulf Road specimen. The ralres well exserted, and the rim exceptionally broad. (Fig. 16, Pl. 4.)

Moonan Flat (J.H.M. and J. L. Boorman). Large fruits. (Fig. 22, Pl. 4).

Murrurundi (J.H.M. and J. L. Boorman).

"Stringybark," Warrah Creek (Jesse Gregson). (Fig. 17, Pl. 4.)

Tenterfield, via Cottesbrooke, to Sandy Flat, just west of Dividing Range (J.H.MI). (Fig. 25, Pl. 4.)

Mr. Henry Deane (No. 302) collected a very interesting Stringybark or "Blackbutt" from the Glen Innes District (Hartley's Mill). (Fig. 19, Pl. 4). The fruits are larger than those of $E$. eugenioides usually are, and have a well-defined prominent rim, grooved on the outer edge, and show a tendency to exsertion of the valves. The specimens undoubtedly present affinity to E. eugenioides; but I think they come nearer to E.pilularis, var. Muelleriana, the fruits being a little more pear-shaped than usual. They are identical with the small fruit from Warrah. (Fig. 17, PI. 4.)

\section{QUEENSLAND.}

The Tenterfield specimens were collected a few miles from the Queensland border, and I do not doubt that a precisely similar form extends into that State. The Southern Queensland forms (E. semicorticuta, \&c.), already alluded to, would by many botanists be placed under var. Muelleriana. In fact, they help to prove that it is quite impossible to maintain E. pilularis and E. Muelleriana as separate species.

- These specimens were referred to by Deane and Maiden, Proc. Limn. Soc., N. S.W., 1896, 803.

F 


\section{AFFINITIES.}

Turs species is an excellent one with which to study the variation so pronounced in the genus.

I have shown, with evidence that appears to me quite incontrovertible, that E. pilularis and E. Muelleriana are not specifically distinct. The following extract (Trans. Roy. Soc. Vict., 1880) shows Howitt's views in regard to the relations of his E. Muelleriana with E. eugenioides and E. capitellata.

This eucalypt, therefore, is to be placed between $E$. eugenioides and $E$. capitellata. It resembles both, but the dissimilarities are more marked than the resemblances. The characteristic distinctions are quite as constant as those which distinguish those two species, and the occurrence of these species over so large an area, as well as in independent lesser colonies, negatives the probability of it being a mere hybrid.

The affinity of E. pilularis and its forms with a number of species will now be dealt with seriatim.

1. E. eugenioides, Sieb.-The affinity of E. pilularis, var. Muelleriana, and $E$. engenioides is closest than between any other species. These species are, indeed, frequently confused through omission to keep the typical forms in mind. The matter will be further dealt with when the type specimens of $E$. eugenioides are figured.

Like many other species and varieties of Eucalyptus, there is more or less variation in the size and shape of the fruit of var. Maelleriana and E. eugenioides, not to mention leaves and other characters. Thus some small-fruited specimens of var. Muelleviana are, in my opinion, inseparable from some large-fruited specimens of $E$. eugenioiles. There will always be hesitancy in regard to placing these forms; the same botanist may justifiably place them in both species at different times. In such cases a specimen should be labelled, I think, E. pilularis, var. Muelleriana, transit to $E$. eugenioides, or vice versa.

These transit forms are very common in Victoria and also in New South Wales, south, west, and north. Often they are termed Yellow Stringybark (owing to the bright yellow inner bark at certain seasons), which is a common name for var. Muelleriana. In fact, almost typical eugenioides is sometimes known as "Yellow Stringybark."

Bentham has cursorily referred to the affinity of $E$. pilularis and $E$. eugenioides (under E. piperita, B.Fl. p. 208), and with additional knowledge gained by so much field work, we are now able to amplify his remarks. 
Mr. R. T. Baker's E. Willinsoniana, E. nigra, and E. lavopinea, var. minor, are transit forms, but as, in my opinion, they are nearer to typical eugenioides than to the present species, I shall defer consideration of them.

It will be found that not only have we connecting links between E. pilularis and $E$. eugenioides, but $E$. pilularis also connects them with other stringybarks, E. capitellata and E. macrorrhyncha.

2. E. piperita, Sm.-This species and $E$. eugenioides are so closely related that any species possessing affinity to the one may be looked upon as possessing affinity to the other. The proper way to study the matter is to examine the series connecting E. eugenioides and E. piperita, such specimens being largely developed in Victoria and southern New South Wales.

I have specimens from the National Park, 20 miles south of Sydney, collected by Mr. Julius Camfield, with the inflorescence in a dense raceme and the fruits large and ovoid, showing, in the latter respect, an approximation to E.piperita. (Fig. 1, Pl. 4.) The operculum is not as long as that of E.pilularis usually is, and the filaments are white although they have been collected for a considerable period.

Bentham alludes to the affinity of $E$. pilularis to $E$. piperita in the following words. While the former is not related to the latter so closely as to some other species, the affinity is there and must not be neglected :-

E. piperita is sometimes difficult to distinguish in the dried state from some forms of $E$. obliqua, and on the other hand it approaches E. pilularis, differing from both of them generally but not strictly, as well in the foliage as in the bud and operculum, but more readily in the fruit. The variety eugenioides ( $E$. eugenioides, Sieb.) is, however, in some respects almost intermediate between E. piperita and E. pilularis, var. acmenioides (E. acmenioides, Schauer).--(B.Fl., iii, 208.)

3. E. capitellata, Sm.-Both in Victoria and South Australia plants have been named $E$. capitellata by excellent botanists which have proved to be E. pilularis, var. Muelleriane; for example, specimens from the Grampians and Wimmera in the former State and Mount Lofty Range in the latter. In our own State, specimens from Mount Wilson and other localities are nearer to var. Muelleriana than to E. capitellata. Of course, true E. capitellata occurs in all three States. The most obvious characters of the latter species are its sessile, compressed fruits and angular buds, the former a consequence of the latter.

4. E. maerorrhyncha, F.v.M.-The affinity of E. pilularis to this species s so close that I must frankly say that I have a number of specimens which I hesitate to place under one species rather than under another. A connecting link is Bentham's var. brachycorys of E. macrorrhyncha of which I give some particulars under E. pilularis as a matter of convenience.

\footnotetext{
E. macrorrhyncha, F.v.M., var, brachycorys, Benth. New England, C. Stuart. A mountain species. Bark separating in fibres like the V.D. Land E. gigantea (C. Stuart).
} 
In other words, a Stringybark like E. obliqua. The above is a copy of Stuart's label with Bentham's determination thereon.

The following specimens are very near typical var. Zrachycorys:-

1. "Stringybark," Emmaville (J. L. Boorman).

2. "Stringybark," Bluff River, near Tenterfield.

Specimens collected by Mr. H. Deane and myself in this locality at different times show angular and rounded buds on the same twigs.

3. "Red Stringybark," Moona Plains, Walcha (A. R. Crawford), shows rounded buds also.

4. Stanthorpe, Queensland (F. M. Bailey).

The angularity of the buds so usual in E. macrorrhyncha is not a constant character and breaks down in var. brachycorys, some of the leaves and buds being quite indistinguishable by me from the var. Muelleriana of E. pilularis. As a rule, the buds of var. brachycorys get more rounded as they get older. The rim of var. brachycorys is sometimes very broad and hardly angular, showing transit to the northern forms of pilularis, var. Muelleriana, as regards the shape of the fruits.

The colour of the timber, texture of the bark, \&c., of E. pilularis and of E. macrorrhyncha and the other stringybarks varies just as do other characters of the eucalypts. E. pilularis and E. macrorrhyncha both include trees whose filaments become red on drying. I propose to again refer to the affinity between $E$. pilularis and E. macrorrhynch when dealing with the latter species.

5. E. obliqua, L'Herit.-The "E. fabrorum, Schlecht., Lofty Ranges, S.A. Ferd. Mueller, Pharm. Cand." (collected in 1847 or 1848) is E. obliqua, but undoubtedly very close to E. pilularis, var. Muelleviana.

The affinity of E. pilularis (through its variety Muelleriana) is too close to be neglected. The buds and leaves are frequently obriously a good deal similar, and there are other resemblances. The seedlings of $E$. obliqua are much broader.

6. E. acmenioides, Schauer,-Bentham (B.Fl., ii, 208) says, "I have much doubt whether this might not be adopted as a distinct species, although it seems sometimes to pass into typical E. pilularis." In the Eucalyptographia, Mueller recognised Schauer's species, and, I think, rightly so. But of the affinity of $E$. pilularis to $E$. acmenioides there is no doubt, the transit being through the small-fruited forms of the var. Muelleriand of the former. E. umbra, R. T. Baker, is another form referred by most botanists to $E$. acmenioides (and rightly, I think), but which has obviously a dash of the $E$. pilularis strain in it. 
7. E. santalifolia, F.v.M.-The affinity of E. pilularis to this species is not close, but the shape of the fruits and the renation, \&c., of the leaves show undoubted affinity to the rariety Muelleriana of the latter species which occurs in the State (South Australia) in which E. santalifolia is found.

8. E. siderophloia, Benth.-Herbarium specimens (in leaf, bud, and flower) of these two species are sometimes a good deal alike (unless the anthers be examined), and the species have hence been confused by the older botanists, who often described eucalypts on what we deem to be imperfect material for such a purpose; moreover, E. siderophloia was not defined until 1866. I have dealt with the matter under E. persicifolia, Lodd. and DC., while E. fibrosa, F.v.M., is really a form of E. pilularis, and not of E. siderophloia. See page 34 .

Finally, via var. Muellerianu, E. pilularis shades off into the infinity of gum-topped stringybarks.

\title{
Explanation of Plates.
}

\author{
PLATE 1. \\ Eucalyptus pilularis, Sm. Typical from Port Jackson.
}

1. Young shoot, portion of a seedling. Note the dentate margin and tufts of hairs.

2. Buds with pointed opereula.

3. The fruits are nearly globular (pilular).

\section{PLATE 2.}

Eucalyptus pilularis, Sn., var. Muelleriana, Maiden. Typical for E. Muelleriana, Howitt. Drawn from Gippsland (Victoria), specimens collected and named by Mr. Howitt.

1. Young shoot (sucker foliage). The young foliage has tufts of hairs. See Howitt, page 34. This shoot is not so young as the corresponding specimen of $E$. pilularis.

2. Buds more clavate than in typical pilularis.

3. The fruits are nearly globular, with rims of medium thickness, and with non-exserted valves. 


\section{PLATE 3.}

1. Eucalyptus discolor, Desf. (ex horto Paris, 1820). Foliage only.

2. Mature leaves and buds of Sieber's No. 477 (E. persicifolia, DC., E. incrassata, Sieb.). Typical E. pilularis

3. Mature leaves and buds of Sieber's No. 593 (E. persicifolia, DC.). Typical E. pilularis. The leaf broader than (2). The opercula are pointed.

4. 4a. Two heads of fruits from typical E. pilularis, from Hurstrille, near Sydney. They are from the same tree; in 4 a the rim is thin and sunk; in 4 the rim is broad and the valves almost protruding.

5. 5a. 5b. The fruits and buds are taken from the same tree of typical E. dextropinea (R. T. Baker), near Barber's Creek, Goulburn District, N.S.W. 5 closely resembles typical pilularis; $5 a$ shows the broad rim and slightly exserted valves so common in the species. The buds are nearly clavate, but some are more pointed than shown.

6. 6a. The fruits and buds of typical E. semicorticata, F.v.M., Brisbane River, Queensland. The broad rims of the fruit are commonest seen in var. Muelleriana, while the pointed opercula are typical for pilularis.

\section{PLATE 4.}

\section{A. Some forms of Fruits from the Sydney Distriet to Jervis Bay.}

1. Ovoid form, National Park, Sydney, showing transition to $\bar{E}$. piperita.

2. Large pilular fruits, common in the Sydney District; rims thin and sunk.

3. Kogarah Bay, Sydney; narrow rim and exserted valves.

4. Fruits of intermediate size, Hawkesbury River.

J. Jervis Bay, N.S.W. All the above, with thin rims and more or less globular fruits.

\section{B. Some Miscellaneous Forms.}

6. Currawang Creek, near Bateman's Bay, N.S.W. Typical for E. dextropinea, R.T.B. Fruits nearly globular, and rim thicker than the preceding.

7. Stringybark from Lowther Road, Kanimbla Valley, Blue Mountains, N.S.W. Thicker rim, but otherwise close to No. 3. Partakes of the characters of both E. pilularis and E. eugenioides.

8. Port Macquarie, N.S.W. Small fruits, hardly ripe.

9. Mount Seaview, Upper Hastings River. Thick rim.

10. Kempsey, N.S.W.

11. Fruits. 11a. Buds (both from same tree). W. MacDonald, Macleay River, N.S.W., near the coast The rim much sunk.

12. Bolivia, near Tenterfeld, N.S.W. Small fruits, with broad rims.

13. Gladesville, Sydney.

\section{Fruits with Flat Tops and Broad Rims.}

14. Fruits. 14a. Buds (from same tree). "Stringybark," St. Albans, Hawkesbury District, N.S.W. Note the pointed opercula associated with the broad rims of the fruits.

15. Tenterfield, N.S.W. Very broad rims, and slightly angled fruits; valves prominent.

16. Fruits. 16a. Buds (from same tree). "Mountain Stringybark" (A. Rudder). Figured as "E. sp." Figs. 11-12, plate LX. Proc. Linn. Soc., N.S.W., 1896. A very broad-rimmed form often seen in var. Muelleriana. 
17. Small fruit, with tendency to doming. 17a. Fruit larger, with flat top with tendency to doming. 17b. Buds all from same tree, Warrah Creek, Liverpool Plains, N.S.W.

18. Very large-fruited, broad-rimmed form, Dapto, N.S.W.

19. "Blackbutt," Hartley Mill, Glen Innes, N.S.W. Small fruit, more pear-shaped than usual, and inserted at this place to show the resemblance to 17 , and also to macrorrhyncha forms, e.g., 23, $24,27$.

D. Domed Fruits tending to E. macrorrhyncha and capitellata, with and without Angled Buds.

20. "Stringybark," Mt. Lofty, near Adelaide, S.A. (often referred to as E. capitellata).

21. Fruits. 21a. Angled buds (from same tree). Grampians, Victoria. The valves more exserted than 20 ; the buds resembling those of capitellata.

22. Moonan Flat, Upper Hunter River, N.S W. Large fruits, broad rims.

23. "Red Stringybark," Moona Plains, Walcha, New England, N.S.W. Transit to macrorrhyncha (close to var. brachycorys). 23a. Mount Seaview, Upper Hastings River. Practically identical with 23.

24. Fruits. 24a. Larger fruits. 24b. Angled buds (all from same tree), with very broad rims, and the valves less prominent than macrorrhyncha; near to capitellata. The angled buds nearer to capitellata. Bluff River, near Tenterfield.

25. Flat-topped fruits. 25a. Angled buds. 25b. Pointed buds (all from same tree). On the wholo tending to capitellata. Bluff River, near Tenterfield.

26. Rounded buds. From same locality as No. 25 and from similar trees. The same tree often displays much variation as regards the buds.

. Stanthorpe, Queensland. Fruits of maerorrhyncha, var. brachyeorys, Bentham. It will be observed that the transit from typical pilularis to this form is quite gradual. 

PL. 1.

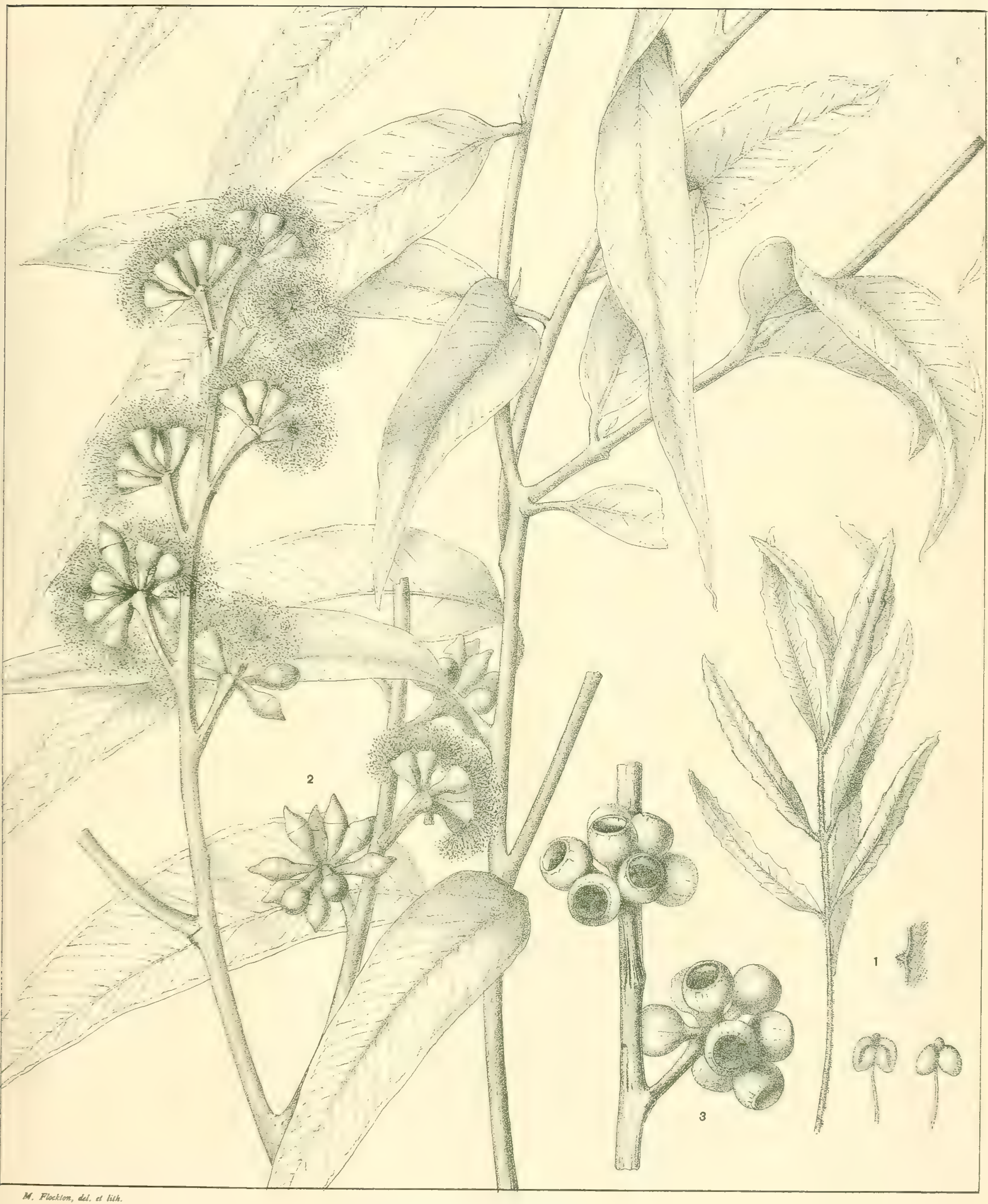

EUCALYPTUS PILULARIS, SM. 



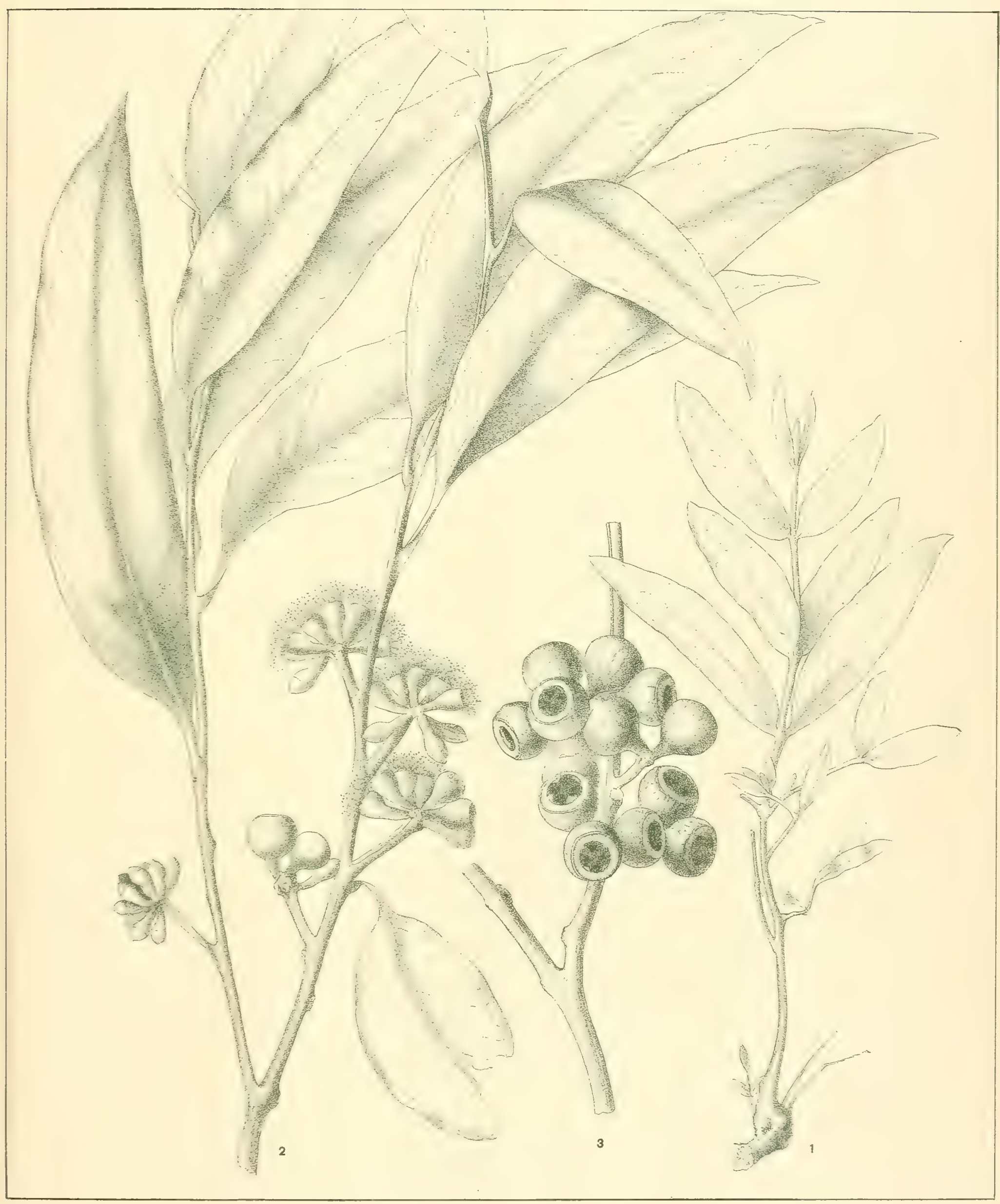

M. Flocklom, del. \& lith. 



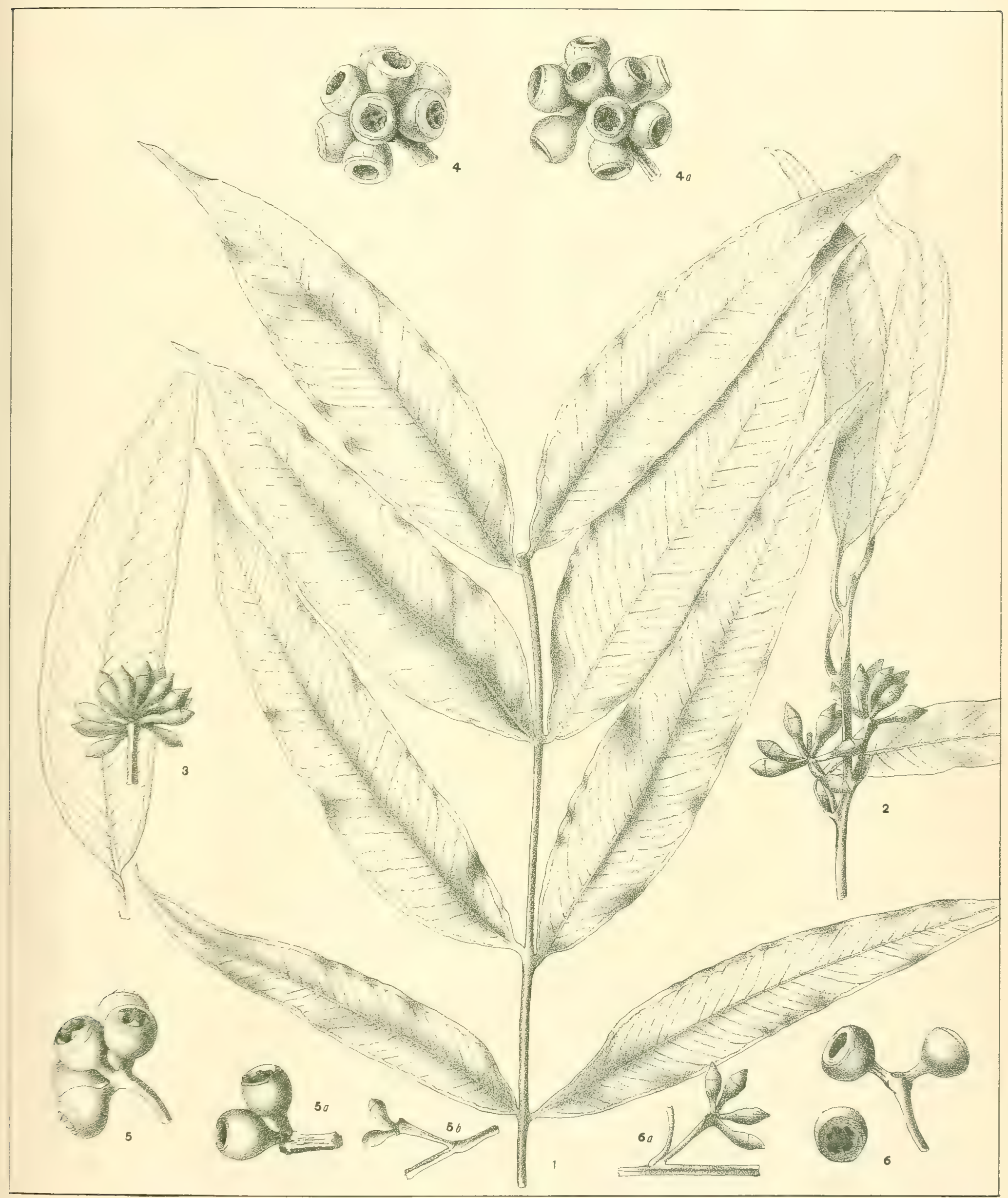

4. Flockton, del, es lith. 



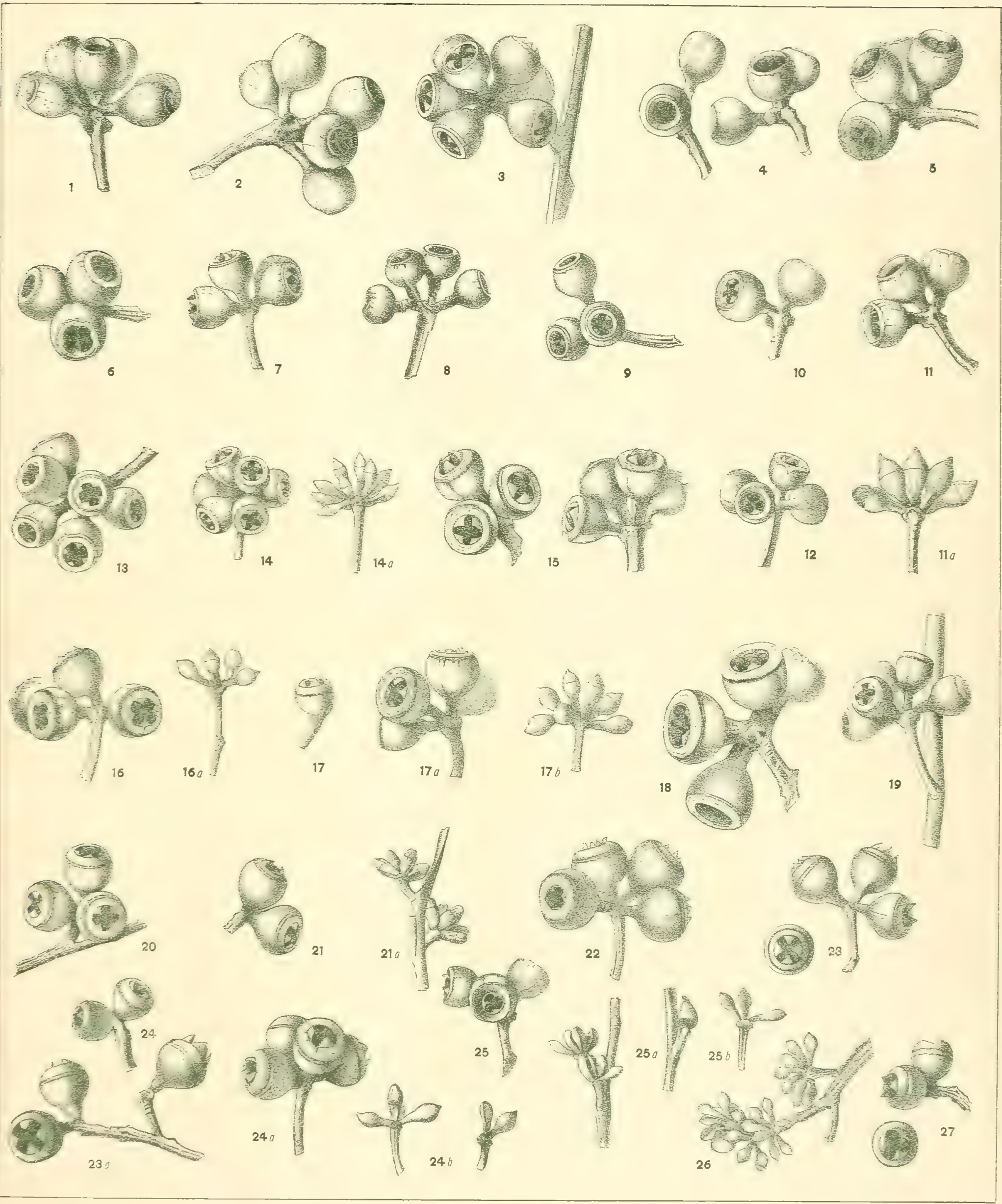

1. Flection, del. \& tith. 

A CRITICAL REVISION OF THE GENUS EUCALYPTUS

$$
\text { J. H. MAIDEN }
$$

(Government Botanist of New South Wales and Director of the Botanic Gardens, Sydney).

\section{PART II}

(WITH FOUR PLATES).

Price Two Shillings and Sixpence.

Published by Authority of

THE GOVERNMENT OF THE STATE OF NEW SOUTH WALES.

Sugomen:

WILLIAM APPLEGATE GULLICK, GOVERNMENT PRINTER. 



\section{A Critical Revision of the Genus Eucalyptus}

BY

\section{J. H. MAIDEN}

(Government Botanist of New South Wales and Director of the Botanic Gardens, Sydney).

\section{PART II \\ (WITH FOUR PLATES).}

"Ages are spent in collecting materials, ages more in separating and combining them. Even when a system has been formed, there is still something to add, to alter, or to reject. Every generation enjoys the use of a vast hoard bequeathed to it by antiquity, and transmits that hoard, augmented by fresh acquisitions, to future ages. In these pursuits, therefore, the first speeulators lie under great disadvantages, and, even when they fail, are enitled to praise."

$$
\text { Macaulay's "Essay on Milton." }
$$

Pullished ly Aulhority of

THE GOVERNMENT OF THE S'IATE OF NEW SOUTH WALES.

\section{Sugney:}

WilitaM APPLEGATE GULIICK, GOVERNMENT PRINTER, PHILLIP-STREET.
14231
(a)
1903. 

2.

EUCALYPTUS OBLIOUA

(L'Héritier). 


\section{Eucalyptus obliqua, L'Héritier.}

1. Description . . . . . . . . . 51

Notes supplementary to the description.

2. Synonyms (with descriptions) . . . . . 57

Notes on the Synonyms . . . . . 57

3. Range . . . . . . . . . . 63

4. Affinities . . . . . . . . . . 67

3. Explanation of plates . . . . . 73 


\section{DESCRIPTION.}

THis is the first species of Eucalyptus known to science, it having been originally collected by David Nelson, assistant botanist on Cook's 'I hird Voyage (1776-9), and described by L'Eéritier in 1788. At the time of its collection, and for long afterwards, Tasmania mas lookcd upon as part of Australia; morcover, like other early species, it was badly described, and the specimens themselves were imperfect and not easily accessible. The result was that it was not recognised, until the sixties, that E. obliqua is tlie common Tasmanian stringybark. Hooker, in his Flora of Tasmania, was not aware of its identity, and consequently in that classical work it is not mentioned, but a new species, E. gigantea, takes its place.

Following is the original description by L'Héritier :-

Encclyptus.-Perianthium: Operculum superum, integerrimum, truncatum. Petalum: Calyptra obverse hemisphærica, margini calcycis imposita, ante anthesin discedens.

Filamenta numerosissima, calyci inserta. Germen inferum, turbinatum. Stylus unicus. Capsula subquadrilocularis, apice duntaxat dehiscens. Semina plurima angulata.

Eucalyptus obliqua, Tab. 20. Habitat in Nova Cambriâ. Nelson. Guil. Anderson (L'Hérit. Sert. Angl., p. 18).

A reproduction of the figures accompanying the description will be found at Plate 5.

I have seen a specimen labelled "E. obliqua, V. D. Land., D. Nelson, ex. herb. Lambert" in Herb. Cant. It is in leaf only.

The following description of E. obliqua from Sir J. E. Smith's "Specimen of the Botany of New Holland," p. 43 (London, 1793) is interesting as an example of the brief descriptions formerly deemed to be adequate, and may be convenient. for reference :-

Eucutyptus obliqua, operculo hemisphærico rnucronulato, umbellis lateralibus solitariis; pedunculis ramulisque teretibus. Lid hemispherical, with a little point. Umbels lateral, solitary; flower-stalks and young branches round.

Syn. E. obliqua, Ait. Hort. Kew. v. 2, 157, L'Hérit. Sert. Ang]. t. 20.

From the only specimen we have seen of this, which is in Sir Joseph Banks' herbarium, it appears the branches are all round to the very top. General flowering stalks round, the partial ones only slightly angular, not compressed. Bark rough from the scaling of of the cuticle, but this may be an unnatural appearance. Leaves ovate-lanceolate, aromatic, but without the favour of peppermint. 


\section{Following is Cavanilles' description :-}

Eucalyptus obliquus, 375. Eucalyptus foliis ovato-lanceolatis, nervo unico ramoso, nervulis ad ipsum raris: umbellis axillaribus. In hac specie folia non videntur coriacea; nervuli adsurgunt formantque angulum acutum cum nervo principali: umbellae quinqueflorae: et calyptra hemisphaerica. Videtur eadem species quam D. do Lamarek figuravit tab. 422, ill. gen, cujus descriptionem nondum evulgavit. (Cav. Ic., Vol. IV, p. 25, 1797).

Lamarck's figure is practically a copy of L'Héritier's, with the details arranged differently on the smaller-sized plate of Lamarck's work.

Link, in the following brief description, attributed the species to Smith, and quotes Willdenow's Enumeratio :-

218. E. obliqua, Smith, W. E., 515. Fol. ut in pr. parum breviora, ultra 2' lata. Pedunculi breves 1" longi axillares 6 flori; perlicelli brevissimi. (Link. Enum. Berol. ii, 30.)

The species is likewise attributed to Smith in the following label in Herb. Calcutta:- "Eucalyptus obliqua, Smith, Serres de M. Noisette, 6 Août, 1816." This specimen is $E$. obliqua, L'Hérit.

Following is Hoffmansegre's hrief reference to the species, which is given here to save botanists searehing after this rane work:-

(430.) Encalyptus oblirgu. Male in Willd foliorum nulla mentio, id quod in Link Linum. probe emendatum. (Hoffmg. Fer . I' . Narlotr. 2, p. 114.)

It will be found to be fully defined in Bentham's "Flora Australiensis" (iii. 204), and in Mueller's "Eucalyptographia."

Vernacular names.-It is usually known as "Stringybark" in Tasmania and South Australia, and to a less extent in Victoria; in the last State, however, it is usually known as "Messmate," because it is associated or mess-mates with other" stringybarks and fibrous-barked eucalypts. The same name is in use in southern New South Wales, as for instance at Sugar Loaf Mountain, Braidwood, and at Tantawanglo Mountain, near Cathcart. Apparently this is the most widely used name for it in New South Wales, and the term "Stringybark" does not seem to be usually applied to it in this State.

Because it is usually rough-barked to the ends of the branches, it sometimes goes by the name of "Woolly-topped Messmate" in the Braidwood district (Monga, \&c.). Other names are "Bastard Stringybark," "Woolly Butt," "Woolly Bark," and "White Stringybark," all in use in New England, New South Wales. For a note on the use of the terms Brown and White Stringybark in Tasmania, see p. 54 .

Cotyledon lenves.--Small, reniform to obtusely quadrangulal, glabrous, triplinerved, thin, more or less suffused with purple. 
Sucker leaves.-Broadly ovate, somewhat cordate, tending to become unequal, but not always so, and apparently alwars attenuate, as pointed out by Howitt. Venation well marked and more transverse than in the foliage of the mature tree.

Inture leaves. - It is a coarse-foliaged tree, by which characteristic alone it can usually be distinguished from those species with which it is usually associated, or with which it is likely to be confused. Its strikingly oblique, unsymmetrical leaves have, no doubt, given origin to its name. Obliquity is a character of nearly all Eucalyptus leaves, but in the species under consideration, and in $E$. capitellata, it is particularly observable.

Fruit.-Fruit ovoid, more or less pear-shaped, and slightly contracted at the orifice. 'They vary in shape, however, from subcylindrical to nearly hemispherical. They are three to five lines in diameter. The drawings will make the shape of the fruit quite clear. The fruits depicted at Plate 7, fig. 4 have unusually thick rims, and show transit to E. coriacea. Perhaps they are E. coriacea.

Bark.-Rough-barked to the ends of the branches; the bark of the trunk and branches is decidedly fibrous, but the fibres are not so clean and tenacious as those of the true Stringybarks, and the bark is not so suitable for roofing. In some districts, particularly in Tasmania, it tends to become less fibrous, forming one of the "Gum-topped Stringybarks." See p. 69.

A figure of a basket (Bee-lang), showing good workmanship, and made by Yarra natives out of this fibre, is in Brough Smith's "Aboriginals of Vicioria," i, 344 .

Timber.-That from New South Wales localities is a rather inferior, coarse, open-grained, porous wood, liable to shrink and warp. It is not esteemed for public works in New South Wales. Its open nature may be, at least in part, a consequence of rapid growth, for which, according to several authorities, E. obliqua has the reputation.

It has been used in the Braidwood and Cooma districts for many years for building purposes. In Victoria and Tasmania it is largely used, and a recent official publication of the latter State says "It is our most valuable wood." In considering the value of this observation, it should, of course, be borne in mind that neither of these States possesses a series of excellent timbers such as New South Wales can boast of. At the same time it is quite possible that Tasmanian and Victorian grown timbers of this species are superior to that grown in New South Wales. Howitt, a leading Victorian authority, groups it as a "second-class timber," adding that "although a fairly durable and useful timber, it has generally the fault of being more or less full of gum-veins, and is thus unsuitable for many purposes." 


\section{Another authority states:-}

Although of an inferior class, it is used for a great variety of building purposes, notwithstanding some liability to warp or twist. . . . . . . Supplies a good deal of second-class sawn timber in the market. (Mueller, in Cat. Tech. Mus., Melbourne.)

As this work seeks to impartially report on the qualities of the products of the various species, in whatever State they are produced, some lengthy statements in regard to Tasmanian-grown timber are given at this place.

Following is a report by Mr. Allan Ransome, of London, on a Tasmanian sample-(See Kew Bulletin, May, 1889):-

A very strong tough wood, with a straight grain, in appearance somewhat resembling American ash. From its great strength and toughness it is well adapted for carriage, cart, and waggon building, wheel-work, and agricultural machinery, as well as for the framing of railway carriages and trucks. It is also a valuable wood for the stronger description of building constructions, and would make excellent rail way sleepers. From the peculiar strength of the fibre of the grain, it will not maintain a good surface, as, even when perfectly dry, the grain rises, so as to render it impossible to polish it successfully.

An official report says:--

Stringybark can be obtained in patches all over Tasmania, but is most abundant in the south; like the blue gum it can be grot of any reasonable length or size. It is of quicker growth than the gum, and is of a lighter and milder nature generally. The timber is much used in Tasmania and in the adjacent colonies for house-building, \&c. To ensure durability the wood requires fair seasoning. The different varieties are-Gum-top Stringybark, Brown and White Stringybark (the brown being the older growth). The White Stringybark makes good palings and shingles.

Another official report says :--

Eucalypens obliqua (Stringybark) is our most valuable wood. It difters from and is better than the Stringybark of Australia. The timber is light-coloured, and varies considerably, from a brown wood resembling oak to a much lighter-coloured wood resembling ash; and because of the great variety of its uses and its abundance is more valuable economically than blue gum. The bark might be made a source of income, as it is suitable for the manufacture of paper.

The timber, as I have already hinted, appears to be more valued in Tasmania than on the mainland; its utilisation, as a paper-making material, is not likely to have any commercial importance.

The following account of E. obliqua timber is taken from $\mathrm{Mr}$. A. O. Green's pamphlet on "Tasmanian Timbers" (1902). It and the Blue Gum (E. globulus) are the two most valuable timbers of Tasmania, hence the comparison by Mr. Green and by the author already quoted:-

Stringybark trees are very nuch mole widely distributed through the Island than the Blue Gum (E. globulus), growing over large tracts of poor, hilly country. They attain to an immense size-up to 300 feet in beight, and from 2 to 10 feet in diameter. The wood is, on the whole, of a lighter colour than Blue Gum, and varies from a pale straw to a reddish brown. In appearance Brown Stringybark is somewhat like oak, and it would be a difficult matter for most people to distinguish a picture-frame made of Stringybark from one made of oak. The timber varies considerably, according to the situation and soil in which the tree grows. In appearance it is freer than blue gum, but lacks the purplish tint, and is more subject to gum-veins. It is the most general timber for all sorts of constructive work in Tasmania. It makes excellent piles, especially for fresh water, but is not considered quite so good as blue gum for salt water, being more subject to the attacks of the teredo. 
It is also used for shipbuilding, the coastrnction of wharves and bridges, and for railway sleepers, for the dado, flooring, and fitting of houses, and for furniture; it is also an excellent wheelwrights' wood. When polished it very much resembles oak, but has a more sparkling grain; it has a very pretty effect when used for a ballroom floor, or for wainscotting.

Besides being sawn for alnzost every purpose, Stringybark is split into fence-rails, palings, and shingles. It is certain that if this wood and the blue gum, properly prepared, were exported to London, a ready sale would be found for it for the construction of carts and rans. It would very well take the place of English oak and ash used for this purpose, whith aro every year becoming scareer. In the Tasmanian International Exhibition before-mentioned, a Stringybark sleeper was shown by the Government that had been twenty-five years under trafice. The usual life of this timber in bridges is from twenty to twenty-fire years; sleepers average about fourteen years; and none of the Government railway buildings, some of which were built trenty-seven years ago, chiefly of this timber, have yet been renewed.

Specimens of this timber from Bullarook Eorest, Victoria, were examined by Mr. F. A. Camplell (Proc. R. S. Fict., 1879). ITis values of the tensile strength in pounds per siqure inch are S,500, 8,500, and S,200. They broke with a short fracture. The wood was well seasoned, clean, but not quite free from shakes. Mr. Campbell, horrever, remarked that this should not affect its tensile strength to any extent. It was known locally as messmate. Rankin gives the following particulars in regard to the timber of E. gigantec (obliqua): Modulus of elasticity in pounds ou square inch, 1,700,000; modulus of rupture, 13,900; weight, 54 lb. per cubic foot.

Experiments on the transverse strength of the wood of E. obliqua by Baron Mueller and J. G. Luehmann. The specimens were 2 feet long and 2 inches square.

\begin{tabular}{|c|c|c|c|c|c|}
\hline \multicolumn{2}{|c|}{ Deflection. } & \multirow{2}{*}{$\begin{array}{l}\text { Total weight } \\
\text { rerpuired } \\
\text { to break each } \\
\text { lipe. }\end{array}$} & \multirow{2}{*}{$\begin{array}{l}\text { Value } \\
\text { of strength } \\
S=\frac{L W}{411)^{n}}\end{array}$} & \multicolumn{2}{|c|}{ Specific Gravity. } \\
\hline $\begin{array}{l}\text { With the } \\
\text { apparati:- } \\
\text { weighing } 780 \mathrm{lb} \text {. }\end{array}$ & $\begin{array}{l}\text { At the criais } \\
\text { of brealing. }\end{array}$ & & & Air-drietl. & $\begin{array}{c}\text { Alsolntely } \\
\text { dried. }\end{array}$ \\
\hline inches. & inches. & pouncls. & & & \\
\hline$\cdot 12$ & $\cdot 50$ & 2,053 & 1,540 & $1 \cdot 045$ & $\cdot 867$ \\
\hline$\cdot 14$ & 48 & 1,776 & 1,332 & .935 & 783 \\
\hline
\end{tabular}

Some experiments by Mr. James Mitchell on Tasmanian stringybark will be found in Proc. Roy. Soc. V. D. Land, II, part i, p. 124 (1852).

It has also been tested by Mr. James Marn ("Australian Timber," 1900), and by Mr. A. O. Green ("Tasmanian Timbers," 1902).

Essential 0il. - The leaves yield 0.5 pex cent. of a reddish-yellow oil of mild odour and bitter taste; specific gravity, 0.899. It boils from 171-195 (Wittstein and Mueller). An oil obtained in Portugal had the specific gravity 
0.914 and the rotatory power $a_{d}=-7^{\circ} 28^{\prime}$. It was soluble in an equal part of 80 per cent. alcohol and contained cineol (iodod reaction) and phellandrene (nitrite). (Gildemeister and Hoffmann, "The Volatile Oils.")

Messrs. Baker and Smith ("Research on the Eucalypts") give the specific gravity of this oil as 0.8902 , its specific rotation $[a]_{0} 29 \cdot 5$, its saponification number as 8.03 ; it is soluble in one volume of 80 per cent. alcohol. It contains phellandrene, eucalyptol, and aromadendral. E. obliqua is, howerer, not a species whose oil will render it of commercial importance.

This tree has been introduced extensively in India on the Nilgiris, and, on a smaller scale by way of experiment, in the Punjab, and in several places in the north-west Himalayas (Brandis). It has also been tried at Changa Manga, but has failed at Lucknow (Gamble).

In the second edition of his "Manual of Indian Timbers," Gamble says it is "cultivated in the Nilgiris, especially in Aramby, Rallia, and Coonoor Peak plantations." 


\section{SYNONYMS.}

1. E. pallens, DC. (probably).

2. E. procera, Delınh.

3. E. gigantea, Hook. f.

4. E. elatıs, Hook. f.

๖. E. fabrorum, schlecht.

6. E. fissilis, F. v. Mi

7. E. falcifolia, Miq.

8. E. nervosa, F. v. M.

9. E. heterophylla, Miq.

\section{NOTES ON THE SYNONYMS.}

1. E. pallens, DC. non F. V. M.

E. pailens, operculo hemisphaerico submutico cupulâ breviore, pedunculis axillaribus compressis petioli longitudine, umbellis 5-7 floris, ramulis angulatis, foliis lanceolatis acuminatis subcoriaceis penniveniis, venis ante margines confluentibus. In Novâ Hollandia, Sieb. plant. exs. n. 606. Petioli 5 lin. longi. Folia 5 poll. longa, basi rix obliqua, fere sesquipoll. lata, utrinque albida (De Candolle, Prodromus, rol. III, p. 219).

The specimens of Sieber's No. 606 are in early bud only, 'They very strongly resemble specimens of E. obliqua from the Goulburn (N.S.W.) district.

Superficially they perhaps as strongly resemble specimens in a similar stage from $E$. dives, but I have no hesitation in saying that the determination of $E$. dives is much less likely as the leaves possess very little aroma when crushed. Sieber was known to have collected in the Goulburn district.

The specimen, figured in Plate 7, fig. 1, shows transit to $E$. virgata, and affords a rery good instance of the difficulties surrounding many plants that depart from types in the Renuntherea.

The drying pale (referred to in the specific name) of the leaves is not unusual in many species of the Renantherece. 
"Sieber's No. 606. Short diagnosis, might perhaps do for either albens or" dealbalu. I have not seen it." (Bentham in B. Fl. III, 200.)

Specimens labelled "E. pullens, DC., Broken River," in Mueller's handwriting, in Herl), Kew, are E. hemiphoia, var. albens.

\section{E. procera, Dehnh.}

Eucalyptus procera, Dehnh., E. foliis late-ovatis longissimis obliquis coriaceis parallele venosis marginatisve subcrenulatis utrinque glanduliferis apice uncinatis, petiolis muricatis coloratis, ramulis teretibus glanduliferis rubioundis.

Cortice laevi aestivo tempore in squamas secedente Nov. Holl.

(I)ehmhardt, Catalogus plantam horli Camaldulensis. Ed. IT, 1832, p. 20.)***

Bentham (B. Fl., ii, 200), who had not scen any specimens, speaks of the description as "far" too imperfect to render identification possible."

I have secn some cxecllent specimens, in bud, flower, and ripe fruit, communicated by Dehnhardt himself to the Vienaa herbarium (Herb. Mus. Cres. Palat. Vindob.), which show that the species is E. obliqua, L'Hérit. The label states that the tree (Iort. Camaldul.) was raised from "unknown seed," and that the tree (? that from which the original seed was taken) was 70 feet high. The seed probably came from Tasmania.

\section{Following is Walper's' description:-}

Eucalyptus procer, Dehnlardt, 1.c., p. 1个4.-Operculo hemisplhwrico mucronulato, calyce breviore; pedunculis subancipitib., umbellis lateralib., 5-2-10ris parvis; foll. alternis ovato-lanceolatis longissinis obliquis falcatis coriaceis parallele venosis, apice uncinatis, margine subcrenulatis integerrimisve, juniorib., utrinq, glanduliferís; ramis teretib. rubicundis. Crescit in Novâ Hollandî̀. (Walpers' Repertorium Botanices Systematica, ii, p. 164.)

Mueller (in "Encalyptographia," under E. pauciflora) quoting Walpers" wording of the description of the speries, refers it to panciflora (coriacea), but the specimens set the matter at rest.

\section{E. gigantea, Hook. f.†}

N. sp.; ramis ramulisque levibus elongatis gracilibus, folis alternis sublonge petiolatis amplis oblique curvatis ovato-lanceolatis longe acuminatis basi valde infqualibus costa distincta, nerris lateralibus

* The following information abnut Hortus Camaldulensis is abbreviated from Dehnhardt's Preface to Ed. 2, of the Cat. Pl. Horb. Camaldulensis (1832).

The hills of the Vomer (Ploughshare), and of the district of Camalduli, bencath which lies the city (Naples), are foremost amongst the most picturesque parts of Campania. The olimate is especially mild. On those hills the Count of Camalduli has an immeuse farm, and excellently laid out gardens. The variety and plenteousness of the trees and vegetation-products both of practical utility and of pure delight-draw crowds of inhabitants and strangers; the immense size and joyous shapes of the truly exotic plants only to be found elsewhere in hot-houses, and which here are planted in the open air as thongh native of the soil, must cause the greatest delight and wonder in the spectator.

The following particulars about the Count are given in his preface to Ed. I (1829), and from the last sentence it would appear that Dehnhardt was superintevdent or head gardener of this garden :- "After the Count of Camalduli, Franciscus Riccardi, had obtained permission to retire from the splendid position whose duties he bad most diligently performed, he withdrew to the lueatiful hills of the Ploughshare and of Camalduli. The garden attacherl to the country house (described in poetry by those most noble knights Angelo M. Riccio, in the veracular, and Jacobo Farina, President of the Supreme Court, in Latin), were given me to lay out and beautify."

$+E$. gigantea, Delmhl., is E. glohulus, Labill. 
divergentibus, pedicellis elongatis multifloris, alabastris lineari-clavatis obtusis, cupellis (florentibus)

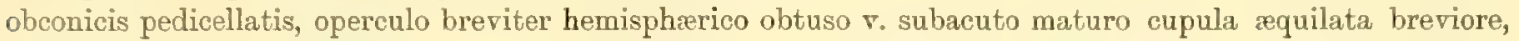
capsula jnajuscula pedicellata obconico-hemisphærico $\mathrm{v}$. turbinata ore paulo contracto $\mathrm{v}$. subglobosa ore valde contracto, _ "stringybark" colonorum.

Hab.-Throughout Tasmania, rery abundant, v.v.n.

Arbor excelsa, 150-250 pedalis; trunco basi num, 20-26 ped. diameter. Rami ramulique graciles,

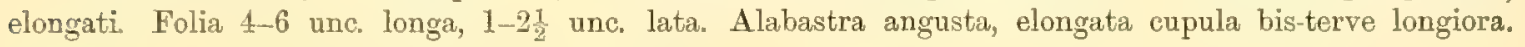
(Hooker, f. in Lond. Journ. Bot., vi, 479, 1847.)

This was amplified by Hook. f., in the following words:-

12. Eucalyptus gigantea; arbor gigantea, ramulis gracilibus pendulis, foliis amplis gracile petiolatis e basi ovata lanceolatis sensim acuminatis opacis basi valde inrequilateris costa distincta nervis divergentibus, pedicellis elongatis multiflorus, calycibus subclavatis pedicellatis, operculo breviter hemisphærico obtuso v. subacuto, capsula majuscula pedicellata turbinata obconica hemisphærica $\mathrm{v}$. subglobosa lignosa ore subcontracto intus plano v. abrupte depresso, valvis inclusis. (Gunn., 1,095, 1,104, 1,106, 1,965, 1,966.) (Tab. XXVIII.)

Hab.-Abundant in most parts of the Island, forming a great proportion of the hill forests, ascending to 4,000 feet. (Fl. Oct., Dec.), (v.v.), "Stringy-bark Gum."

Distrib.-South-eastern Australia.

This forms a gigantic tree; specimens have been felled in the valleys at the base of Mt. Wellington 300 feet high and 100 feet in girth, of which a full account is given in the "Proceedings" of the Royal Society of Tasmania." It is also a most abundant species, and forms the bulk of the forests of the elevated table-land of the interior and flanks of the southern mountains. It is dificult so to define its characters that it shall be recognised by them; but it is a well-known and readily distinguished species in the forest. At all periods of growth it has a tall, straight trunk, and few terminal branches, never very leafy or umbrageous. In some varieties the young branches have a fine glaucous-purple bloom on them, especially in alpine localities; such is the case with Mr. Gunn's No. 1,095, from the banks of Lake St. Clair, where it forms a forest on one side of the lake only, to the exclusion of all other timber.

Bark flaking off in stringy masses, used formerly by the natives for huts, canoes, dzc.

Branchlets slender, pendulous.

Leares broader than in most other species of this section, $4-7$ inehes long, ovate at the broad oblique base, then lanceolate, and tapering to an acuminate point, surface not polished, nerves diverging.

Peduncles, flower, and fruit so variable that it is difficult to characterise them; usually the peduncles are stout, woody, as long as the petioles; the flowers very numerous, and forming a capitate head; the pedicels stout; calyx turbinate; operculum hemispherical. Capsule woody, gradually or suddenly contracted at the pedicel, spherical or oblong obconic, with a contracted, not thickened, mouth, and sunk valves. As in other species, I have found very great differences in the flowers and fruits from upper and lower, older and younger, slender and stout branches. (The Botany of the Antarctic Voyage of H.M.S. Erebus and Terror, 1839-43. Flora, Tasmanice. J. D. Hooker, I, 136). 1860.

As already pointed out, E. obliqua, L'Hérit., was not known to Hooker at the time he wrote Fl. Tas., nor clearly to Mueller in Fragm. ii, 44, 45, where the supposed differences between E. obliqua, L'Hérit., and E. gigantea, Hook. f., are discussed. See also Fragm. ii, 171, 172. I am not quite clear as to the precise date when the identity of L'Héritier's species was placed beyond doubt. Mueller ("Eucalyptographia") says, "As surmised by me (in the Fragmenta, ii, 45), it is this very species which was collected during Furneaux's voyage at Adventure Bay, and this was proved subsequently by Mr. Rich. Kippist, who, at my request, compared the original specimen in the Banksian collection." 


\section{Eucalyptus elatus, Hook. f.-Gunn's specimen in Herb., Kew, bears the name in Hooker's handwriting.}

Eucalyptus clatus, H. f.-Trunk erect, branching at top, only 140 feet high, 3,000 ft. alt. Dee tier very large tree, many dead.

The fruits are not ripe, but the plant is E. obiiqua, L'Hérit., as so noted in Herb. Kew.

-Another of Gunn's specimens ("Kangaroo Bottom," 9/25, 1840), also bears the name "Eucalyptus elatus, J. D. H.," in Hook. f.'s. handwriting.

\section{E. fabrorum, Schlecht.}

177. Eucalyptus frobrom, Schldl. - Rami rigidi, ut reliquae partes glabri, ultimi angulati, aetate provectiores teretes cortice fusco. Umbellae brevissime pedunculatae in axillis foliorum inferiorum annotinorum, nec non in apicibus ramulorum hornotinorum paniculam brevem, ex umbellulis paucis, una scilicet terminali, reliquis oppositis brevissime pedunculatis aphyllis (foliis cito deciduis) compositam, formant. [Pedunculus communis 1-2 lin. longus crassus, 3-7 flores brevissime crasseque pedicellatos, pedicellis $\frac{1}{2}$ lin. longis, ferens. Folia oblonga (c. petiolo 3-6 lin. longo, 4-6 poll. longa, 6-10 lin. inferne lata), ex inferiore paullo latiore in ipsa basi acuta parte sensim angustata, atque in acumen attenuatum acutum producta, inaequilatera, leviter falcatim curvata, crasse corincea, obscure pellucide punctata vel impunctata, nervo medio ntrinque et margine crassiuseulo prominente et simul pallidius, vel ex rubro tincto; renas" emittit nervus laterales levissime prominulas in nervum marginalem, qui cum margine ronulis transversis conjungitur. Pagina superior folii viridior, infera magis glaucescens. Alabastrưm

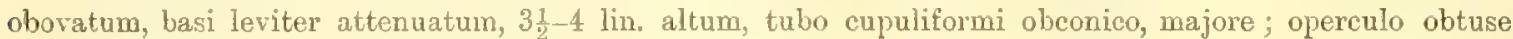
et depresse conico. Stamina tubo calycino longiora, 2 lin. paullo longiora. Stylus brevior, linea paululum longior. ]*

E. scabra similis, sed omnino glaber, viridior, floribus paullo minoribus, brevius pedicellatis, alabastris laete viridibus laevibus nec canescentibus rugulosis, calyptra obtusiore.

Hoher Baum, Wälder bildend, an felsigen Stellen in den höheren Berggegenden. März. Das Holz est nutzbar.-(Stringer Bark der Kolonisten.) (Linnrea' $\mathbf{x x}$, 656.)

The description in Walper's' Annales Botanices Systematica, i, 309, has the above portion [ ] (my brackets) omitted.

E. fabrorum, Schlecht. is referred by F. Mueller to E. obliqua, owing to the author"s stating it to be the "Stringybark of the Colonists, and very possibly some of Behr's specimens many be of that species; but the only authentic one I have seen in a perfect state is evidently $E$. viminalis.-(B. Fl. ịi, 205.)

The following specimens, however, show that Mueller's view is correct:-

1. "Eucalyptus fabrorum, Schlecht. Lofty Ranges (S. A.) Ferd. Müller Pharm. Cand." (1847 or 1848.)

2. "Plantæ Müllerianæ, Eucalyptus fabrorum, Schlecht. Nov. Holland Méridional."

3. "Eucalyptus fabrorum, Schlecht. Adelaide, Dr. F. Mueller, Herbar. W. Sonder."

I have scen all these specimens, which are identical, and all are $\boldsymbol{E}$. obliqua. No. 2 was the specimen examined by Miquel for his paper in Ned. Kruidk. Arch., iv.

- These brackets [ ] have been inserted by me. 
I have seen specimens in European herbaria, "Eucalyptus fabrolum, Schldt., Port Lincoln scrub, legit Carl Wilhelmi, exam. Dr. Ferd. Mueller," which are E. santalifolic, F. V. M.

In the Reports of the Victorian Exhibitions of 1861 and 1866, the following specific gravities of timbers are given :-

Eucalyptus fabrorum, Stringybark, ·990, ·941, 809 (steam-dried) respectively.

\section{E. fissilis, F. จ. M.}

"Messmate (Eucalyptus fissilis) has many of the characteristics of the white gum, is hard and straight-grained, and splits readily into posts, rails, palings, and shingles for fencing and building purposes. Wheelwrights use it for shafts and framing of drays, for plough-beams, and many similar applications." (Intercolonial Exhibition of Australasia, Melbourne, 1866-7, Official Record, 1867, p. 216.)

The oil from the leaves of Eicalyptus fissilis has the specific gravity, $0 \cdot 928$, and is optically inactive. (W. P. Wilkinson in Proc. Roy. Soc. Vict., 1893, p. 198, where there are other data given in regard to this oil.)

In quoting this, Gildemeister and Hoffmann have the note:-

According to Maiden, Eucalyptus fissitis, F. .. M., is synonymous with E. amygdalina, Labill., the oil of which is strongly lærogyrate. Its specific gravity also does not agree with that obtained by Wilkinson from $E$. fissitis.

I understood for some years that $E$. fissilis was a form of amygdal'na, but Mr. J. G. Luehmann has informed me that it is referable to E. obliqua. Mueller frequently used the name fissilis in his earlier reports (chiefly those referring to economic plants), but I cannot trace where he described the supposed species.

7. E. falcifolia, Miq.

Following is the original description :-

28. Eucalyptus fulcifotia, Miq.-(Eue. fabrorum, Müll. Herb. et mss. non Schldt.): Ramulis tenuibus, supremis angulatis viridulis, ramis fuscescentibus, foliis longuiscule petiolatis e basi ut plurimum inaequali et inaequilonga ovato-lanceolatis vel lanceolatis inaequilateris vulgo falcatis attenuato-acuminatis pergamaceis, costâ subtus prominulâ, venis patule adscendentibus ante marginem unitis utrinque praesertim subtus distinctis tenere reticulatis, umbellis $4-10$ floris haud raro paniculato-confertis, pedunculis leviter compressis, floribus pedicellatis, calycis tubo turbinato operculum semiglobosum acutiusculum superante.

In montibus sterilissimis memora aperta extensa constituens, arbor excelsa, rarius humilis, $f$. aestate (idem).- Lofty Range trans. Fl. Murray (Müll. Herb.).

Cortex rimosus nigricanti-cinereus. Rami mox nigrescentes. Umbellarum pedunculus passim 4 lineas longus, foliorum paginae concolores nitentes. Alabastra decolora. Fructus hemisphaerico-turbinatus. -(F. Müll.).

Species $E$. acmenoide, Schaver, affinis, notis certis ab $E$. fabromu tuto discernenda. Petioli vilgo $\frac{1}{2}-\frac{3}{4}$ poll. longi ; folia 4-6 poll. longa, $\frac{1}{2}-1 \frac{3}{4}$ lata. Pedunculi circiter 4, pedicelli 2 lin. longi. Arch. iv).

Hujus speciei formae videntur n. 13, 22, et 23, e New South Wales-(Miquel, Ned. Kruidk. 
The description of the bark "rimosus nigricanti-cinereus" would apply to E. Gunnii or E. viminalis, and not to $E$. obliqua, and there is evidently some confusion of notes here. The drawing (Plate 8, fig. 4) shows that the specimen in Herb. Kew is but a small one, and it is obliqua, although perhaps superficial examination of the specimen might lead some to look upon it as a form of E. Gunnii, Hook. f., var. acervula, Deane and Maiden, not uncommon in South Australia.

The specimen in Herb., Kew, is labelled "Eucalyptus falcifolia, Miq., in Ned. Kruidk., Arch., iv. 130 = obliqua, L’ITér.; fabrorum, F. Müller, near Adelaide, S. Australia," and is in bud and with fully-developed flowers. It has kidney-shaped anthers, and it is E. obliqua, L'Hér., as stated.

\section{E. nervosa, F. v. M.}

Following is the description :-

38. Eucalyptus nervosa, Ferd. Müll,, ramulis teretibus, foliis ovatis, oblongo-ovatis, ellipticis vel oblongo-lanceolatis, vulgo obliquis, costâ venisque adscendentibus prominulis, pendunculis $2-5$ floris, foliis deciduis in paniculam etiam confertis, floribus pedicellatis, fructu ovato-truncato. Lofty Range, m. Nov. (F. Müller). Proxima E. Behrianae, a quî teste F. Miiller differt folis fructibusque majoribus. Folia majora, $4 \frac{1}{2}-5$ poll. longa, $1 \frac{1}{2}-2 \frac{1}{2}$ lata. Fructus 2 lin. longi. (Miquel in Ned. Kruidk. Arch. iv, 138, (1856.)

This is E. obliqua (B. Fl. iii, 20t).

\section{E. heterophylla, Miq.}

This is described in Ned. Kruidk. Aroh., iv (1856), 141, briefly as follows :-

45. Eucalyptus heterophylla, Miq., n. sp. foliis suboppositis et oppositis, alternisve, longiuscule petiolatis, elliptico vel ovato-oblongis, sursum attenuatis, basi aequale vel inaequale acutis vel obtusis,

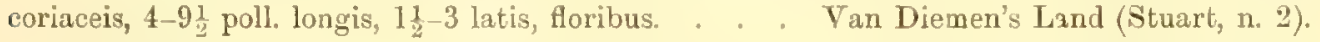

Bentham, while pointing out that it was described from barren leafy branches, states that it "appears to be one of the forms assumed by the saplings or by the adventitious shoots of $E$. obliqua (B. Fl. iii, 205).",

Mueller, however, ("Eucalyptographia," under E. globulus), thinks that it may be $E$. globulus.

Stuart's No. 2 is not at Kew. The matter is not of the first importance, but I am making an endeavour to trace every described species of Eucalyptus, and would like to see the specimen.

The plant labelled "Eucalyptus marginata, Smith (?) Hab. near Sydney, New South Wales-imperfect specimens," in Wilkes' U. S. Exped., 1838-42Botany, Asa Gray, i, 553), is probably E. obliqua. The original specimen in the United States National Museum has sucker leaves, mature leaves; also a few flowers; no opercula. E. marginata is a Western Australian species. 


\section{RANGE.}

AттнобGH usually regarded as chiefly a Tasmanian and Victorian tree, it has during the last few years been found to extend over very large areas in New South Wales, though its curving boundary is a matter for further investigation. It is abundant in many places along the top of the eastern slope of the coast range from Mittagong south. Thence there is a gap in our localities until the Upper Williams River and Eastern and Northern New England are reached. We do not know the comnecting links between the southern and northern localities; it doubtless will be found in various spurs of the Great Dividing Range. It extends to South Australia.

At the time of the writing of the "Eucalyptographia," Mueller gave the range, "St. Vincent's Gulf to Gippsland, scarcely passing into the territory of New South Wales."

\section{Tasmania.}

As has been already stated, $\boldsymbol{E}$. obliqua is common in hilly country all over the island, but chiefly in the south.

Following are localities of some of R. Gunn's specimens :-

No. 1,095: Lake St. Clair.

No. 1,104: Black River, Circular Head.

No. 1,106: Locality (P).

Lhotsky collected it in Van Diemen's Land (Herb. Cant. ex herb. Lemann), and labelled it $E$. acervula (?), Sieb.

The following specimens of this timber, exhibited by the 'Tasmanian Government Railway, give some localities for merchantable timber :-

No. 18: Deck plank from Bridgewater Bridge, fifty years old.

No. 20: Sleeper, twenty-five years under traffic, cut in 1868, on the Western

Tiers, for the Western Line.

No. 21 : Six split sleepers, from Fingal.

No. 22 : Two split sleepers, from Rhyndaston.

No. 25: Twelve sleepers, from Mersey Line; barren land.

No. 26: Sleeper, from Mersey Line; good land.

No. 30 : Two planks of red stringybark, 6 feet by $8 \frac{1}{2}$ inches by 5 inches, from Scottsdale Line.

Further particulars in regard to Tasmanian localities have been already given. Ante p. 54 . 


\section{South Australia.}

Mount Lofty Ranges, near Adelaide; in places upon the southern slopes of the main range running through Kangaroo Island; along the coast from the Glenelg River to Lake Bonney in places around and near Mount Gambier; Mounts Burr and MeIntyre Forest Reserves; Cave Range Forest Reserve; in places near Narracoorte, on the Kingston and Narracoorte railmay line; and several other districts of less importance in the south-east. ("The Forest Flora of South Australia," by J. Ednie Brown.)

The late Professor Ralph Tate gave the range in South Australia as "Adelaide district, Kangaroo Island, and the volcanic area of the south-east corner of the State, or the Mount Gambier district."

"Eucalyptus fabrorum, Schlecht., Lofty Ranges, Ferd. Müller, Pharm. Cand." This is a specimen collected by Mueller, in 1847 or 1848, named as above by Schlechtendal, and referred to by Miquel in Ned. Kruidk. Arch. IV.

\section{Victoria.}

"In vast masses, constituting on the more barren ranges in nearly all parts of our territory the prevalent timber." - (Mueller, in C'at. Tech. Mus., Melbourne.)

Mr. A. W. Howitt, reporting on Victoria as a whole, says:-

The Messmate, also locally called "Stringybark" (E. obliqua), grows in almost all parts of Victoria, excepting the ncrthern areas, from the sea coast up to about 4,000 feet above the sea.

It is found extensively in Gippsland, in the Cape Otway Ranges, and generally in the mountains of the Dividing Range. It also occurs (so far as I remember) in the Ballarat and in the Creswick and Bullarook forests.

The following refers to Gippsland only:-

This eucalypt is principally found in the western and south-western portions of Gippsland, where it, in many places, forms the whole of the forests, or is in others mixed with $E$. goniocalyx, E. viminalis, $\boldsymbol{E}$. Gunnit, and $\boldsymbol{E}$.globulus. It appears to be essentially a littoral form, but ascends the mountains to considerable elevations in the cool, shady, moist gullies on the southern slopes. For instance, in the Great Dividing Range, where the Nicholson River rises, E. obliqua follows up the damp gullies on the south side and forms part of the forest on the summit, together with E. Sieberiana (b), E. viminalis (a), and E. amygdalina (b). It occurs also in Eastern Gippsland, as, for instance, at Buchan, Gelantipy, Bonang, and Bendoc. It varies but little in character, although the form of the fruit is, in some cases-as, for instance, near Port Albert, in the sanily coast country - not quite so truncate orate as in the typical forms, yet in all cases the peculiar unequal-sided ovate lanceolar or even cordate lanceolar and pointed form of the leaves always marks the saplings and large seedlings from those of any other species. (Trans. Roy. Soc. Vict., 1890-1, vol. II, p. 92.)

\section{New South Wales.}

It extends from south to north of the State. Its northernmost limit is a matter for further investigation, but it extends nearly to the Queensland border. It is found growing in company with $E$.goniocalyx and other species on the Irish Corner Mountain, Reidsdale, Sugarloaf Mountain, and around Monga, both on the 
eastern and mestern fall of those mountains. The trees are fairly abundant, and are to be found growing to a height of from 100 to 150 feet, with a girth of from 6 to 10 feet. In New England (Yarrowitch) it is associated with E. viminalis.

Howitt (Trans. Roy. Soc. Vict. II, Pt. 1, 1890, p. 92), makes the statement, as regards Gippsland, that "it appears to be essentially a littoral form, but ascends the mountains, \&e." The first part of this statement does not appear to hold true in New South Wales. The tree grows right on the top of the rangas with us, and never in the littoral lands, as far as observed. It frequents situations where it ean be reached and enveloped in the sea-fogs; in this remote sense alone can the word "littoral" be applied to trees with us. On the Tantawanglo Mountain it grows abundantly, in company with "Cut-tail" and other eucalypts, at a height of about 3,000 feet above the sea. At Reidsdale it occurs at an elevation of from 2,000 to 2,500 feet, and in New England nearly 4,000 feet.

\section{Southern.}

Tantawanglo Mountan (H. Deans and J. H. M.).

"Messmate," Candelo (A. Rudder), "Tororago" (? Tarago), Twofold Bay, S. E. Australia, No. 266, S. Mossman." In Herb. Cant. ex herb. Lemann. Doubtless Tarago, via Braidwood, on an old route to Twofold Bay.

"Woolly-topped Messmate," Irish Corner Mountain, Reidsdale, Sugar-loaf Mountain, and around Monga (Forester J. S. Allan).

"Broad-leaf Messmate," Wingello. (J. H. M. and J. L. Boorman). Mr. Boorman's note on anothel occasion is :- "Large trees, wood of a yellowish colour. Fibrous bark to tips of branches. Inner bark pale yellow, leaves large."

"White Mahogany," Wingello (A. Murphy), but not to be confused with either E. pilularis, var. Muelleriana or E. acmenoides.

\section{Northern.}

Three miles past Myrtle Scrub (near Yarrowitch, Hastings River to Walcha), one comes across a handsome forest, in basalt country, consisting mainly of a smoothbarked eucalypt (viminalis), and a rough-barked one (obliqua). The discovery of the latter species in this part of the State was quite unexpected, and extends its northern range very considerably. The trees were over 100 feet high, and their trunks 3 feet and more in diameter, so that the trees are fine specimens, and not the depauperate forms of mere outliers or pickets. One of my travelling companions (Mr. J. F. Campbell, L.S., of Walcha), stated that this belt of country extended for 30 miles in a general direction of north and south, roughly following the county boundary, and he believed that this species occurred over the greater portion of that county. Mr. Nivison, of Yarrowitch, states it occurs at least as far north as the Clarence River, and also in Callaghan's Swamp. It would be interesting now to 
collect the species at points intermediate between Braidwood and New England. In the latter district it is sometimes known as "messmate " and "bastard stringybark." At Yarrowitch it is known as "white stringybark," and has been used for building purposes, e.g., verandah floors; but it lacks durability in the ground. The sucker-foliage is very coarse. I have leaves 6 × 5 inches.-(Maiden in Proc. Aust. Assoc. Adv. Science, 1898, p. 539.)

\section{Upper Williams River (A. Rudder).}

The following letter to me is interesting, not only because it brings the recorded localities of the species some miles to the west, but because it embodies other experiences of a well-known observer:--

The eucalypt mentioned by you $(E$. obliquc) is abundant here. In this country it is found on poor stony ranges chiefly. It attains a great size, up to 8 or 9 feet or even more in diameter; such trees are usually short-stemined. It is said it will not last as posts, but I have never been given satisfactory proof as to its unfitness. A mile or two of fence is erected; the posts are mixed, probably split from three or four different kinds of stringybark. Then twelve or fifteen years later, who can say which is the best? Certainly not the average bushman. It is often, I know, too short to run into rails. I have seen trees that you could not run into 7 foot posts even if struck 6 inches thick. I split a tree of this species 85 feet in length of barrel by 2 feet in diameter; it flowered here last season in January, the trees being great masses of bloom, very noticeable, although distant on the ranges from 1 to 2 miles. It is known here as Woolly-butt, Woolly-bark, or White Stringybark.-(A. R. Crawford, Moona Plains, Walcha, July, 1898.)

I have a specimen collected by Leichhardt, in 1843, at the head of the Gwydir. It is in leaf only, but there is no doubt as to its identity.

Mr. W. Baeuerlen has since collected it at Mount Mackenzie, near Tenterfield. This is near the Queensland border, and it may be expected to be found about Stanthorpe, in the latter State. 


\section{AFFINITIES.}

THE "Messmate" from the Dandenong and other parts of Victoria is, according to F. Mueller's specimens, also referable to $E$. obliqua, although it has the leaves rather thinner with the veins more conspicuous. (B. Fl. iii, 205.)

There is a certain amount of variation in the thickness of the leaves of E. obliqua, as in other allied species of Eucalyptus, e.g., regnans. At the same time, I have never seen any well-marked-variety of $E$. obliqua. The nearest approach to a variety is one of the "Stringy-barked Gums" referred to at p. 69, but one would hesitate to add another name to this already long list, unless absolutely compelled to do so.

\section{Howitt says :-}

The seedlings of $E$. obliqua are usually free from hairs, but are very commonly warty and the leaves are lanceolar, shining on one side, and thinner in texture than those of E. macrorrhyncha. They become scattered somewhat sooner than those of $E$. macrorkyncha and very much sooner than those of E. Muelleriana, and soon show the marked unequal-sidedness which is so characteristic of this tree.(Trans. Roy. Soc. Vict., 1900-1, vol. 2, p. 93.)

\section{E. pilularis, Sm.-A similarity to E.pilularis (in its var. Muelleriana)} has already been alluded to. The similarity exists in leaves, fruits, bark, and other characters. The differences are not easy to define, except with considerable verbiage, and in doubtful cases I can only enjoin careful attention to the types.

2. E. eugenioides, Sieb.-I think the reason that E. obliqua has only been recognised in this State during recent years is because it was confused with this species. E. eugenioides is a stringybark and shades off into the obliqua stringybark on the one hand and the capitellata stringybark on the other. The foliage of $E$. obliqua is less coarse than that of E. eugenioides, its opercula is less conical, its fruits less hemispherical and with thinner rims.

\section{E. piperita, Sm.}

$E$. obliqua can be distinguished readily enough from E. piperita by its thicker and usually larger leaves with more prominent and less divergent veins, the underpage of the leaves neither evidently paler nor less shining than the under side (hence the stomata are in almost equal number on either side of the leaves), in less crowded umbels, in calcyes less smooth, with shorter and blunter lid, the greater elongation of the calyx-tube into the stalklet and also the rather larger fruit with comparatively less constricted orifice. The two are the only species among closely-allied kinds which have the summit of the fruit very considerably contracted, hence no difficulty can arise for reeognising $E$. obliqua. -(Mueller in "Eucalyptographia.")

I hardly think these two species are likely to be often confused. The coarse, thick foliage of $E$. obliqua, its stringy bark, in contradiction to the sub-fibrous bark 
of $E$. piperita, are usually sufficient to at once distinguish the species in the field. The orifice of the fruit is sometimes a little contracted, reminding one in this respect, and in its general shape of the capsule, of some forms of E. piperita; but it is larger than the fruit of that species. Drying accentuates the contraction of the orifice in both. The two may be at once separated by the venation and shape of the leaves, shape of the buds, \&c.; but the two species approach one another sometimes very elosely in the shape of fruits.

4. E. coriacea, A. Cunn.-The fruits of E. abliqua sometimes have great similarity to those of E. coriceca. This is shown in Plate 7, fig. 4, but very rarely is the rim so thick as depicted therein. Mueller says :-

The veins of the leaves are occasionally so much longitudinal as to bring $E$. obliqua thus far into close approach to $E$. pauciftora (corincea), which species is allied also in many other respects, but has a smooth, whitish bark, the outer stamens not all fertile, the fruit hardly contracted at the summit, the rim not so narrow, and the valves nearer to the oritice; the wood of the two is also different. The calyx, however, is likewise somewhat rough in E. pauciflora. ("Eucalyptographia.")

They could never be mistaken in the field; one is a White Gum and the other is a Stringybark. The suceulence and thick rim of the fruits, and the straight (longitudinal) veins and suceulence of the lcaves of E. coriacea, are usually quite sufficient to distinguish the species.

\section{E. Sieberiana, F. v. M.}

$E$. Sieberiana, in comparison with $E$. obliqua, can be easily recognised by its more rugged and solid bark, which partially secedes, by its less fissile wood, the less prominent veins of its leaves, generally broader and more compressed flower-stalks, outer stamens sterile, fruit less contracted at the oritice, with flatter rim and with valves near the summit. (Mueller, in "Fucalyptographia.") E. Sieberiana is our common Mountain Asin.

6. E. virgata, Sieb. - The variety altior of this species is closest allied to E. abliqua, and may readily be confused with the "gum-topped" form of the latter" species (see page 69).

The following paper, read by me before the Royal Society of Tasmania in 1902, and entitled, "The Gum-top Stringylurks of Tasmania : a Study in Variation," has a direct bearing on the affinities of $E$. olliqua with other species. I would specially invite attention to "C," (E. obliqua), p. 69.

The Gum-top or Gum-topped Stringybark appears to attain its greatest development in Tasmania, although it also occurs in Victoria and New South Wales. It is a tree which may have a smooth, or nearly smooth, bark, with all stages of fibrous covering up to nearly a normal striugrbark. Apparently, as a general rule, the bark becomes more fibrous as higher elevations are reached.

I brought the matter of these "Gum-tops" under notice of the Australasian Association for the Advancement of Science at its Hobart meeting (January, 1902); gave considerable attention to the trees in the field in Tasmania; have received 
most valuable information on the subject from Messrs. L. Rodway and T. Stephens, of Hobart, and R. H. Cambage, of Sydney, and now beileve that I am able to offer a key to the better understanding of what has hitherto been considered a very difficult group of plants.

A. E. Risdoni, Hook. f., var. elata, Bentham; (E. radiata, Hook. f., var. 4, non Sieb.).

I have a specimen of Gunn's No. 1,100, 1812, "J. D. Hooker, Marlborough, Tasmania, 17th October, 1840."

B. This is the var. 4 of E. radiata, Hook. f. (non Sieb.). See Fl. Tas., I, 137, as follows :-

13. Eucalyptres radiata (Sieb., P1., Kxsicc., p. 475); arbor mediocris, ramulis gracilibus saepe pendulis, foliis anguste ellipticis lanceolatisve mediocribus vix nitidis-nerviis rectis falcatisve, pedunculis subelongatis multifloris, floribus pedicellatis, calyce obconico v. clavato, operculo brevi, capsula pedicellata.

Variat insigniter. . . . . 4, foliis majoribus lanceolatis nitidis, capsulis ut in forma 3.-Arbor mediocris, ad E. coriaceam tendens. (Gunn, 1,100, 1,110.)

This is a tree which, e.g., on Mount Wellington, may be nearly a White Gum, with but a little ribbon at the butt. It is a variety of $\mathbb{E}$. Risdoni, Hook. f., namely, var. elata, Bentham, (B. Fl. III, 203). In typical Risdoni the sucker leaves are more or less cordate; but in the varieties they tend to become oblong, and even nearly orbicular, and the leaves, as higher levels are reached, become more aromatic.

My identification of Gunn's No. 1,100 appears to be the key to the quastion, and all the Gum-topped Stringybarks may be looked upon as more or less closely related to this form.

C. E. olliqua, L'Hérit, var" "Gum-topped Stringybark," Waterworks, Mount Wellington, Tasmania. We have trees at an elevation of 1,100 feet, with the leaves, capsules, \&c., of E. obliqua; but bark smooth from the base. The character passes in all forms from this to E. regnans, which in turn passes into broad-leaved forms of amygdalina. (L. Rodway.)

This form undoubtedly shows affinity to E. obliqua. A second specimen Mr. Rodway labelled "The extreme form of $E$. obliqua, that Mueller considered a form of haemastoma."

(a) "Stringy Gum," Huon Road (L. Rodway). The suckers are glaucous and lose their "opposite" character at an early stage.

(b) Guildford Junction, Tasmania, "Something between E. amygdalina and E. obliquo in bark; glaucous, wood pale." (R. H. Cambage.)

Another specimen of Mr. Cambage's, from the same district, is labelled, "Bark something like E. amygdalina for, perhaps, 20 feet, then gradually clear." 
An official pamphlet, issued by the Tasmanian Railway Department, refers to "Stringybark Gum, Euc. obliqua. No.300, T.G.R. Two planks $6 \mathrm{ft} .6$ in. by 9 inches by 5 inches, Scottsdale Line."

I believe this is the same as the following timber, sent to the Colonial and Indian Exhibition of 1886 :-

"Stringy Gum."-This wood bears a strong resemblance in general appearance and texture to stringybark ( $E$. obliqua), but the grain is crossed diagonally with long spots of a lighter shade, which should show a good figure if the wood could be polished. Stringy gum, however, is open to the same objection as stringyhark, but in a still more marked degree, for not only does the grain rise after the board is planed, but, unless it is absolutely dry, fibres of the wood become detached from the surface which renders this wood quite unfit for any but rough work. (Allen Ransome, in Kew Bulletin, May, 1889.)

In Victoria also (e.g., Port Road, Gippsland, Howitt) the Gum-top Stringybark runs into E. obliqua.

At comparatively low elevations the leaves of the Gum-top Stringybark are but little glaucous, and have but little aroma. Their affinity to E. obtiqua is undoubted: While, as a matter of classification, they may, perhaps, be looked upon as belonging to $E$. Risdoni, var, elata, I cannot say that those botanists who look upon them as belonging to $E$. obliqua are wrong. In fact I think they must be looked upon as a variety of E. obliqua.

D. and E. E. regnans, F. T. M., and, therefore, since Mueller (wrongly, I think) has merged this species in E. amygdalina, Labill., E. amygdalina, also.

"Sucker leaves (glaucous when fresh) from base of stem of typical $E$. regnans, 120 feet high; bark fibrous, but not thick, for about 10 feet. Mount Wellington, 1,500 feet." (L. Rodway.)

"Silver 'Top," Darlimurla, S. Gippsland, Victoria, "Bark rough, resembling that of stringybark; limbs smooth and white, hence local name." (H. Deane).

'There is justification for looking upon these trees as forms of E. regnans.

F. E. dives, Schauer. [See E. hemastoma, Sm., E. Sieberituna, F. v. M.] I have given reasons (Fict. Naturalist, July, 1901, p. 124; Aust. Assoc. for Adv. Science, Hobart, 1902) for looking upon certain Gum-top stringybarks as forms of $E$. dives; but while I now think that they may be considered to belong to $E$. Risdoni, var. elata, I think it is instructive to look upon them as forms of E. dives, with which they have undoubted affinity.

G. E. hemastoma, Sm.-I believe Mr. 'T. Stephens first drew attention to a "Gum-top stringybark," and Mueller called it a form of E. hemastoma. The name is not now justifiable, and Mueller withdrew it as further information reached him; but as the determination has been so frequently published, it is desirable to draw attention to it now for completeness sake. In "Notes on a species of Eucalyptus 
(E. hemastoma), not hitherto recorded in 'Tasmania," by T. Stephens ( Froc. R.S. Tus., 1881, p. 24), he refers to it as "Gum-topped stringybark," and speaks of it as follows :-

The chief peculiarity of this tree is that while the lower part of the butt is clothed with a thick fibrous bark closely resembling that of the common stringybark ( $E$. obliqua), the upper part, and the smaller limbs and branches are quite smooth, whence its popular name. The timber is highly prized by splitters, and, for general purposes, it is described by many competent authorities as second only to the blue gum, thongh opinions seem to differ as to its durability. It is found in most parts of the Colony, and appears to grow as freely on the table-lands of the interior, reaching an altitude of not less than 3,000 feet above the sea, as along the coast-line.

It seems to be the same as the following timbers referred to in a Tasmanian official catalogue :- "Gum-topped stringybark, Euc. homastoma (?)."

No. 30 B., T.G.R. 'Two planks, 6 feet by $9 \frac{1}{2}$ inches by 6 inches, Scottsdale Line.

Eucalyptus hemastoma (Gum-topped stringybark), is more a builders' tree for inside work or cart bodies. So far no determination has been made as to its strength and weight, though it is used extensively where it grows. It is not known, however, as a distinct timber in the market. Sce also "Tasmanian Official Record for 1891" (R. M. Johnston), p. 135.

Nr. A. O. Green, in his useful paper on "Tasmanian timbers," also refers to the Gum-topped stringybark as Eucalyptus hamastoma, which should now be dropped.

Following is a copy of a label in Herb., Melb._-"Euc. hemastona, Sm. : Gum-topped stringybark of Lake Sorell, Tasmania (T. Stephens). Lower part of stem exactly like common stringybark, but if anything rather less furrowed, the bark being quite loosely fibrous, and easily rubbed into what bushmen call 'bull's wool."' (a) Parattah, Midland Railway, Tasmania, 1,200 feet above sea-level ; also (b) Russell Falls River, 50 miles N.W. of Hobart, 500 feet above sea-level (T. Stephens). 'These specimens were sent in response to my request for "Gumtop stringybark."

"E. homastoma. A messmate (fibrous bark), Mount Mueller, near Mount Baw Baw, Victoria (Jas. Melvin)," so named by Mueller.

H. E. virgala, Sieb. var. altior, Deane and Maiden, and

K. E. oreades, R. T. Baker, from the Blne Mountains, N.S.W., are further removed from E. Risdoni, Hook. f., var. elcte Bentham, but are still referable, I think, to the Gum-top stringybarks. Their affinity is towards obliqua.

In my paper read before Aust. Assoc. Adv. Science (Hobart, 1902), I suggested that one form of the Gum-top stringybark was referable to E. virgata, and addressed an appeal to Tasmanian botanists to make further inquiries in regard to these trees, but I am of opinion that some of the Tasmanian stringybarks may be justifiably considered as extreme forms of virgata, should any botanist see fit to do so. 
L. E. Sieberiana, F. V. M.

"Euc. Sieberiana, F. V. M., Gum-topped Stringybark, East Mt. Field, 1,0001,500 ft., 1869." (Mueller's determination.) E. Sieberiana, F. v. M., Mt. St. Bernard, Victoria (J. H. M.). Reference to my paper on "The Occurrence of Eucalyplus dives, Schauer, in Victoria" (Victorian Naturalist, 1901, p. 124) shows that I submit that these specimens belong to $E$. dives. I have in that paper dealt with the matter so fully that I do not intend to repeat myself on the present occasion.

M. E. delegatensis, R. T. Baker, Delegate Mountain, N.S.W. (W. Baeuerlen). See Proc. Lin. Soc., N.S.W., 1900, p. 305.

I do not give E. coriacea, A. Cunn. (E. pauciflora, Sieb.), as having been confused with E. Risdoni, Hook. f., var. elata, Bentham, but the general resemblance of some herbarium specimens of the Gum-top Stringybarks to $E$. coriacea is so marked that botanists may well be reminded of it. Hooker first noted the resemblance. (See E. radiata, ITook, var. 4, Fl. Tas. II).

To sum up, we have the following names for the Gum-topped Stringybarks of Tasmania (which extend to Victoria and Southern New South Wales):-

(1) E. Riscloni, Hook. f., var, elato, Bentham.

(b) E. raliata, Hook. f., var. 4., non Sieber.

(c) E. obliqua, L'Hérit.

(d) E. regnans, F. v. M.

(e) E. amygdalina, Labill.

(f) E. dives, Schauer.

(g) E. haemastoma, Sm.

(h) E. virgata, Sieb., var. altior, Deane and Maiden.

(k) E. oreades, R. T. Baker.

(l) E. Sieberiana, F. V. M.

(m) E. delegatensis, R. T. Baker.

The Gum-topped Stringybarks have, therefore, been duly named, and have been given ten synonyms in addition, not hastily, but by men who have worked on the genus, and have given reasons for their determinations. The great majority of the determinations can still be defended, and the trees may be looked upon as forms of the species referred to. Study of the Gum-topped Stringybarks presents one of the best instances of variation in the genus that I have met with, and affords a most instructive example of the necessity, in this protean genus, of endeavouring to ascertain what is the type, and of bearing it closely in mind. 


\section{Explanation of Plates. \\ PLATE 5.}

Fae-simile of L'Héritier's plate of $E$. obliqua, Sert. Angl, t. 20, which was reproduced (only with rearrangement of details) as Pl. 422 of Lamarck's "Recueil de Planches de l'Encyclopedie Méthodique" (Botanique). It was labelled "Eucalyptus obliqua," and the numbers are those in L'Héritier's original plate, see p. 51. The original drawing was by L. J. Redouté, and the pen-and-ink drawing, from which the lithograph was made, was the work of Miss M. Smith, of Kew Gardens.

\section{PLATE 6.}

Eucalyptus obliqua, L'Héritier.

1. Twig bearing mature leaves, buds, and flowers.

2. Fruits.

3. Sucker leaf.

Nos. 1-3 are from near Yarrowitch, New England, N.S.W. See p. 65.

t. (Partly in shade). Seedling of a few months' growth from Agnes Bridge, Gippsland, collected by Mr. A. W. Howitt.

\section{PLATE 7.}

1. Sieber's No. 606 (E. pallens), from a type specimen. See p. 57.

2. Twig in bud.

3. Immature fruits.

4. Mrature fruits (with exceptionally thick rims). Perhaps E. coriccect.

5. Anthers.

(Nos. 2-5 are drawn from specimens on one sheet in the Kew Herbarium, labelled "Eucalyptus giganteus, Hk. f., Hobarton, Sassafras Valley, J. D. H." by Miss M. Smith, Kew.) See p. 58.

6. Fruits (smaller than usual, and displaying slight angularity) from Nine-mile Creek, Gippsland, A. W. Howitt.

1. Twig, bearing buds and two flowers.

\section{PLATE 8.}

2. Fruits.

3. Top view of a fruit.

(Nos. 1-3, "Eucalyptus fabrorum," Schlecht, Plantæ Muellerianæ, Nov. Holl. Coll., Lofty Ranges,

Ferd. Müller, Pharm. Cand. This specimen was exanined by Miquel). See p. 60.

4. Twig in flower.

5. Anthers.

(Nos. 4 and 5 were drawn from a specimen in the Kew Herbarium, bearing the following label :-

"Eucalyptus falcifolia, Miq. in Ned. Kruidk. Arch. iv, 136=obliqua, L’Hér. fabrorum, F. Miüller, nr. Adelaide, South Australia." See p. 62.

6. Seedling showing cotyledon leaves, raised by Mr. W. Forsyth, Centennial Park, Sydney.

7. Seedling, younger than Plate 6, fig. 4, and, like it, collected at Agnes Bridge, Gippsland, by Mr. A. W. Howitt.

Figures $1-5$ are from drawings by Miss M. Smith, Kew.

Sydney : William Applegate Gullick, Government Printer. -1903. 



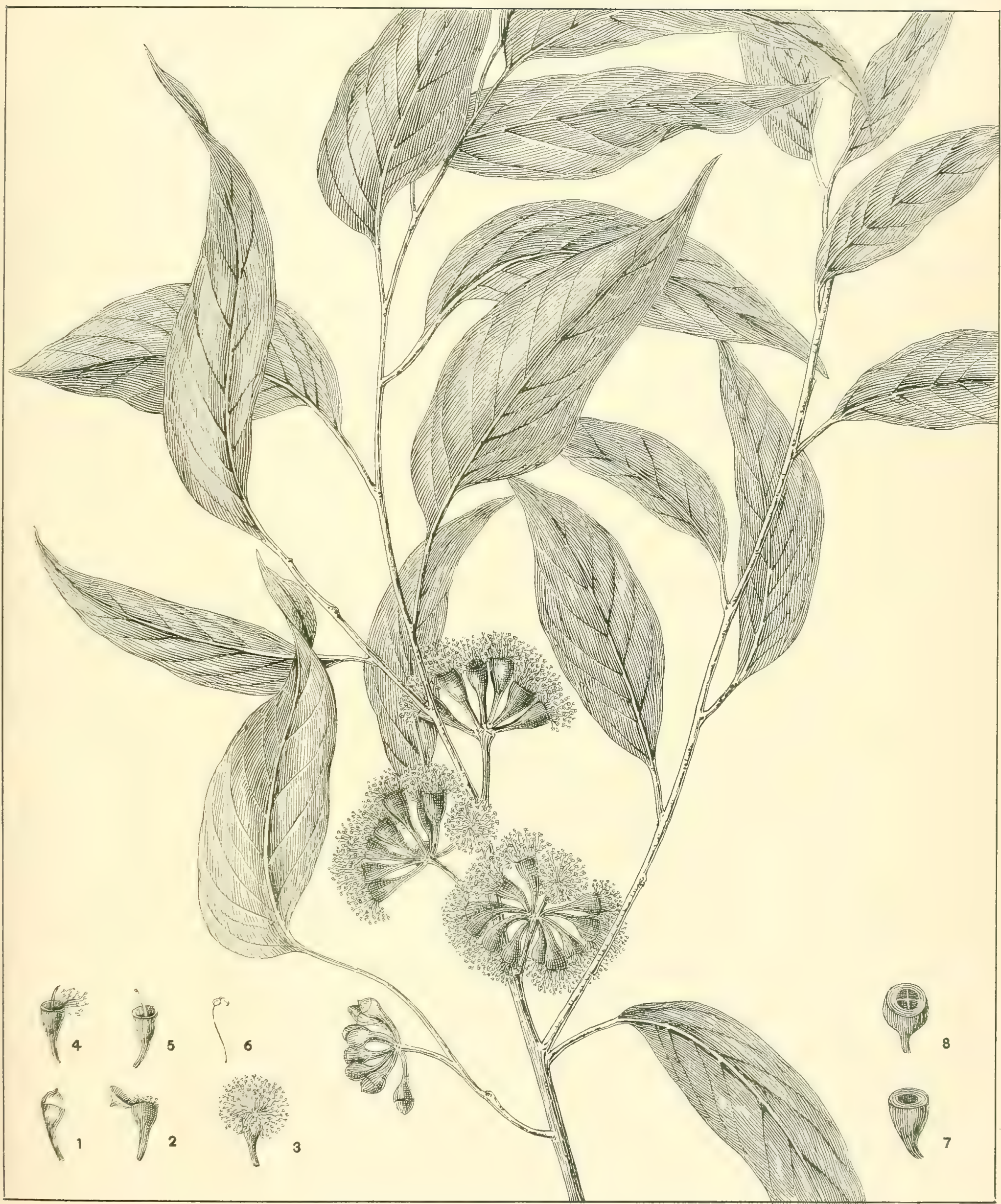

EUCALYPTUS OBLIQUA, L'HÉRIT. 



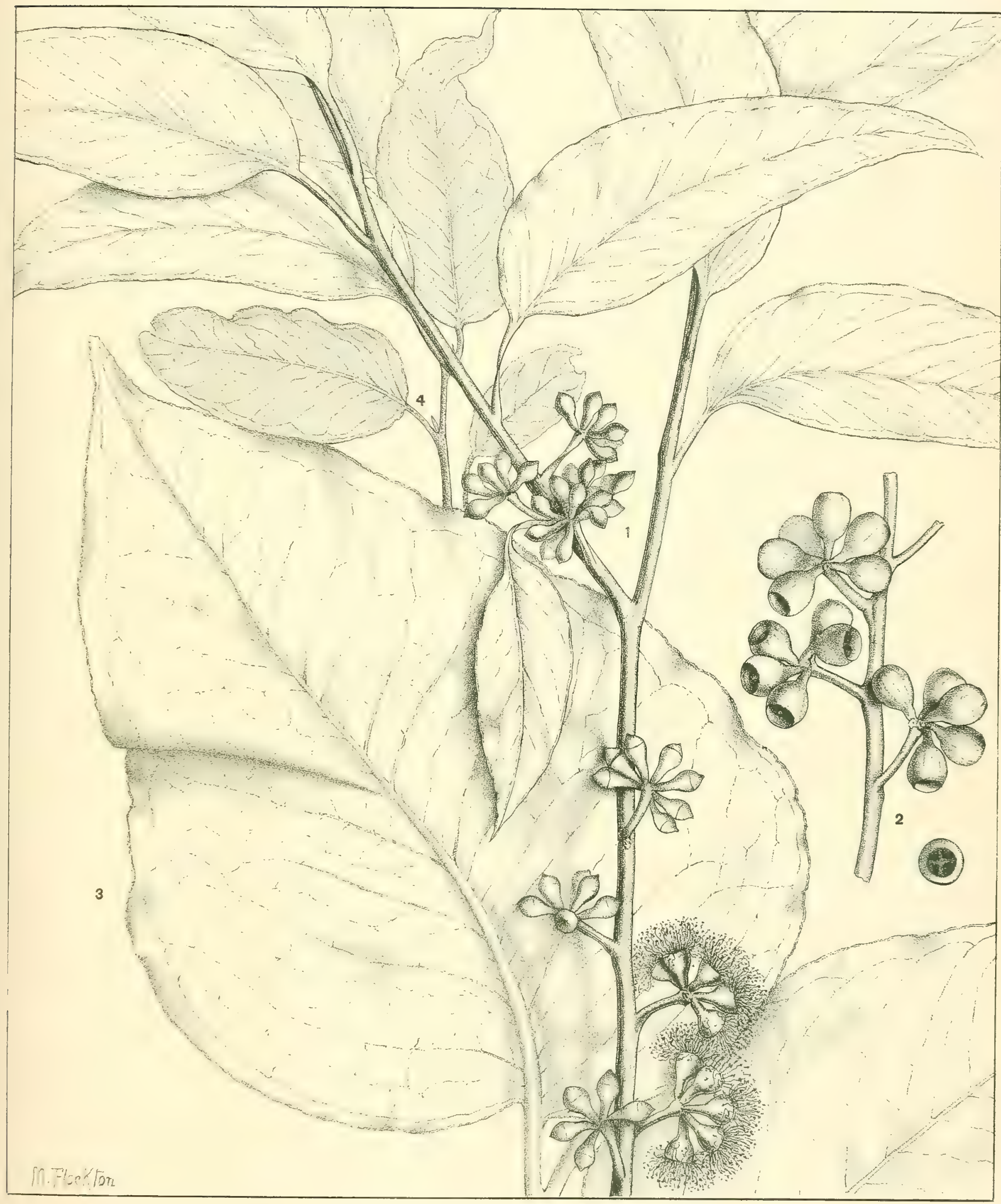

EUCALYPTUS OBLIQUA, L'HÊRIT. 



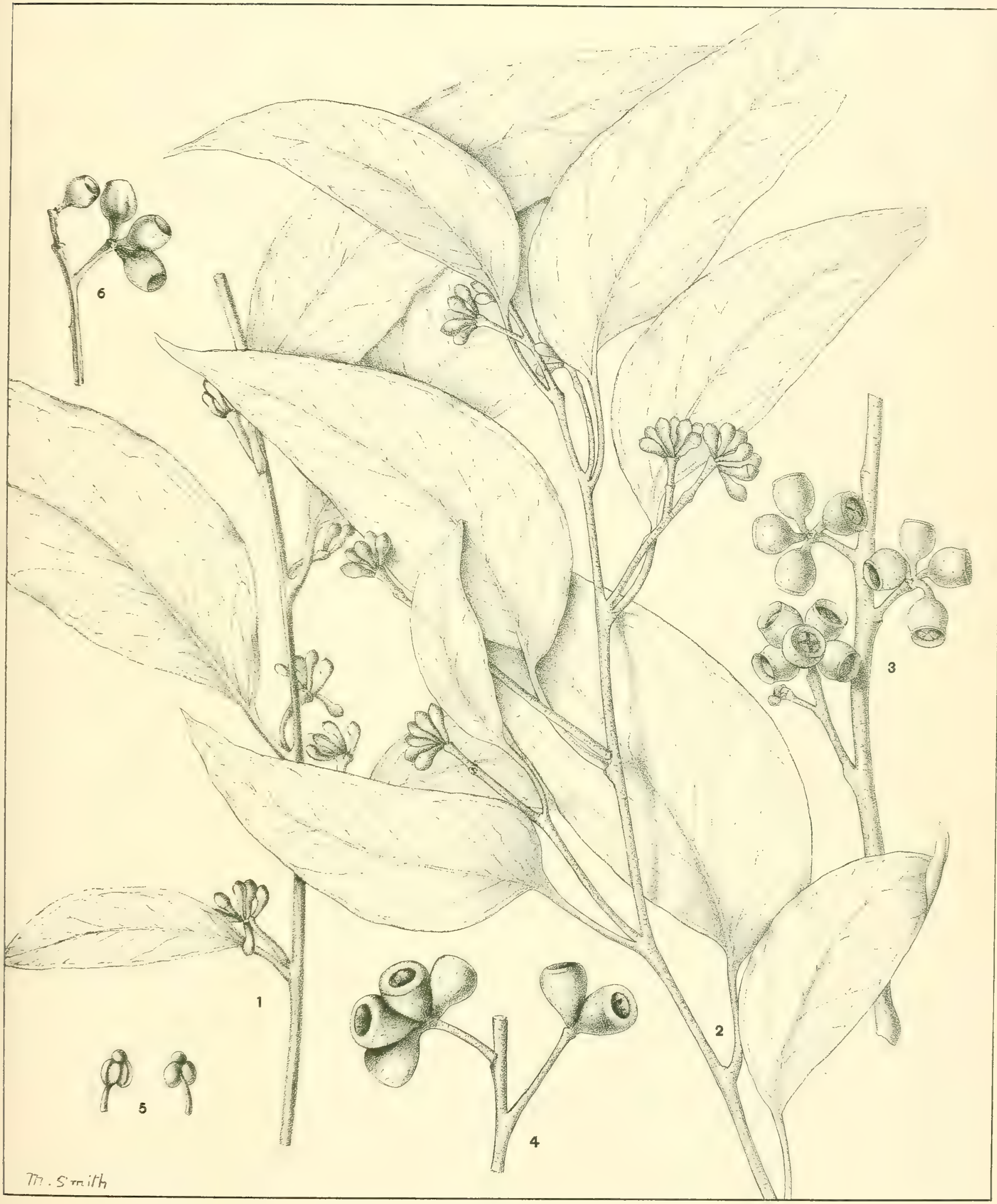

EUCALYPTUS OBLIQUA, L'HÉRIT.

(E. pallens, DC., and E. giganteus, Hook. f.) 



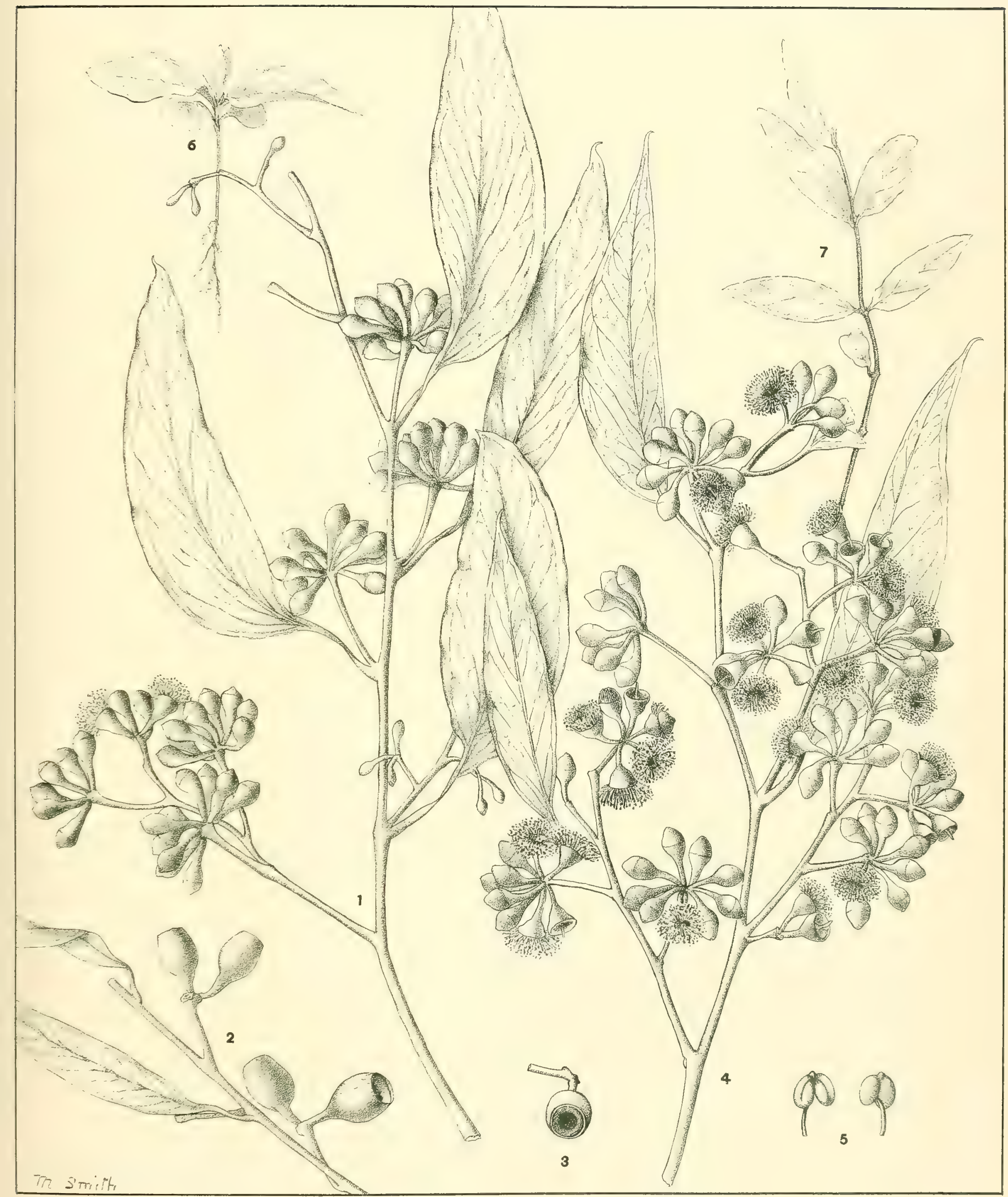





\section{A CRITICAL REVISION OF THE}

\section{GENUS EUCALYPTUS}

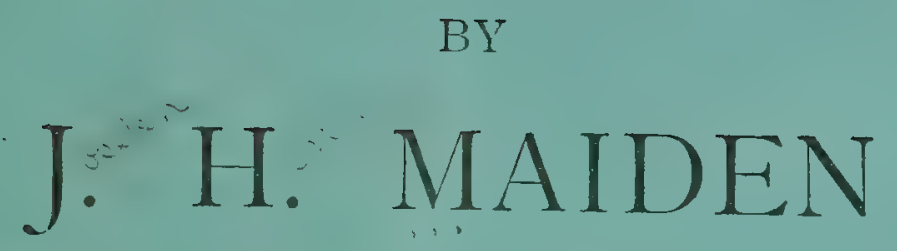

(Government Botanist of New South Wales and Director of the Botanic Gardens, Sydney).

\section{PART III}

(WITH FUUR PLATES).

\section{Price Two Shillings and Sixpence.}

Published by Authorily of

THE GNERAMENT OF THE STATE OF NEIV SOUTH WALES.

Sudreñ :

TVILIIAM APPILGATE GLIIICK, GOVERNMENT PRINTER. 



\section{A Critical Revision of the Genus Eucalyptus}

BY

\section{J. H. MAIDEN}

(Government Botanist of New South Wales and Director of the Botanic Gardens, Sydney).

\section{PART III}

(WITH FOUR PLATES).

"Ages are spent in collecting materials, ages more in separating and combining them. Even when a system has been formed, there is still something to add, to alter, or to reject. Every generation enjoys the use of a vast hoard bequeathed to it by antiquity, and transmits that hoard, augmented by fresh aequisitions, to future ages. In these pursuits, therefore, the first speculators lie under great disadvantages, and, even when they fail, are entitled to praise."

Macaulay's "Essay on Milton."

Published by Authorily of

THE GOVERNMENT OF THE S'IATE OF NEW SOUTH WALES.

Sponev :

WILIIAM APPLEGATE GULLICK, GOVERNMENT PRINTER, PHILLIP-STREET.

17880

(a)

1903. 

3.

EUCALYPTUS CALYCOGONA

(Turczaninow). 
III. Eucalyptus calycogona, Turczaninow.

1. Description . . . . . . . 77

Notes supplementary to the description.

2. Synonyms (with descriptions). . . 79

Notes on the Synonyms.

3. Range . . . . . . . 83

4. Affinities . . . . . . 86

5. Explanation of plates. . . . . 90 


\section{DESCRIPTION.}

FollowING is the original description :-

49. Eucalyptus calycogona (Drum. 5, n. 184), E. glabra; ramis teretibus; foliis alternis linearilanceolatis utrinque attenuatis acuminato-mucronatis: mucrone interdum uncinato, marginatis pellucidopunctatis; umbellis lateralibus $3-6$ floris; pedunculis angulatis petiolo paulo brevioribus; cupulis obpyramidatis tetragonis, nigro-punctatis subsessilibus vel cum pedicello confluentibus, pedunculo longioribus; operculo conico laevi, cupula plus quam duplo breviore. $E$. foecunda, Schauer, cujus operculum ignotum, stirps nostra affinis est, sed folia minora, pellucida et cupula angulis 4 acutis marginata. Filamenta alba. Capsula 4-locularis, cupula duplo brevior. Folia bipollicaria, $2 \frac{1}{2}$ lin. lata. (Turez., Bull. Phys.-Math. Acad. Pétersb., 10, 1852, p. 338.)

The type is, as Turczaninow states, No. 184, of Drummond's 5th collection.

I have not seen this publication; I doubt if there is a copy in Australia, and I am indebted to Kew for the extract. It is probably that quoted in Scudder (Catalogue of Scientific Serials), "3707(b). St. Petersburg. Académie impériale des sciences. (Bulletin de la classe physico-mathématique. 1 vol., 1-17, 1842-59 (1843-59). 17 v. $4^{\circ}$."

Mueller ("Eucalyptographia") quotes the reference as "Turczaninow in Mélrnges biologiques tirés du Bulletin physico-mathématique de l'académie impériale des sciences de St. Petersbourg, tome i, 417."

Scudder, under No. 3707, gives (g) "Mélanges biologiques tirés du bulletin physico-mathématique. Vol. 1-9, iv. 1849-75 (1853-76). 9 v. 8०." So that, according to Mueller, the date of Turczaninow's species is 1849 , three years earlier even than the date quoted by Kew.

Leaves. - In E. calycogona and its varieties the venation of the lower leaves is spreading; the top or young leaves, are more penniveined. This is a matter of considerable importance, and, speaking generally, it may be stated that the lower leaves of eucalypts are usually more characteristic than the terminal ones. When fragmentary, or small specimens are alone available for examination or figure, one requires to be very careful to interpret the venation in consequence. I have referred to the variation of venation in Eucalyptus at page 8, Part I, 
78

Oil.- "The oil of Eucalyptus gracilis, F.v.M., has the sp. gr. 0.909; $[a]_{\mathrm{D}}=+9.3 "$ (W. P. Wilkinson). Baron won Mueller found that $1,000 \mathrm{lb}$. of fresh twigs of this plant (comprising, perhaps, $500 \mathrm{lb}$. of leaves) yielded $54 \frac{\mathrm{I}}{2} \mathrm{oz}$. of essential oil. Probably var. gracilis was experimented upon in both these cases.

Messes. Baker and Smith ("Research on the Eucalypts") give the following in regard to the oil of this species. Probably the E. gracilis referred to by them is Eucalyptus calycogona, var. gracilis, but the authors add, "The species shows very little variation in specific characters wherever it occurs on this continent," an expression of opinion which I will presently show is very unfortunate.

Specific gravity at $15^{\circ} \mathrm{C} ., 0.9098$; specific rotation $[a]_{\mathrm{D}}=+1.48^{\circ}$; saponifiction number, 6.17; solubility in alcohol, 1 vol. $80 \%$ Constituents foundpinene, eucalyptol, aromadendral. 


\section{SYNONYMS.}

(a) Var. celastroides, Maiden.

1. E. celastroides, Turez.

2. E. fruticetorum, F.v.M.

(b) Var. gracilis, Maiden.

3. E. gracilis, F.v.M.

4. E. gracilis, F.v.M., var. breviflora, Benth.

5. E. yilgarnensis, Diels.

Doubtful varieties :-

(c) E.gracilis, F.v.M., var. Thozetiana, F.v.M. (E. Thozetiana, F.v.M.)

(d) E. ochrophloia, F.v.M.

\section{NOTES ON THE SYNONYMS.}

\section{Variety celastroides.}

1. E. calycogona, Turez., and E. celastroides, Turez., were omitted by Bentham from the Flora "Australiensis" by accident, together with seventy-five other species of Myrtaceæ described by Turczaninow. (Bull. Phys. Math. Acad. Sc. St. Pétersb., p. 321, 1852.)

Mueller ("Eucalyptographia," also Fragm., viii, 184) simply gives E. calycogona, Turcz., and E. celastroides, Turcz., as synonyms of E.gracilis, F.v.M., but makes no reference in the text to them, the date of publication of Turczaninow's species being presumably unknown to him. (See p. 77.)

Following is the original description of E. celastroides, Turez. :-

50. Eucalyptus celastroides (Drum. 5, n. 34). E. glabra; ramis teretibus superne subangulatis; foliis alternis lineari-lanceolatis utrinque attenuatis abrupte et breviter acuminatis subinaequilateris, 
marginatis, obscure trinerviis venosisque; umbellis axillaribus $3-6$ floris; pedunculis angulatis petiolum subaequantibus, pedicellos triplo, cupulam paulo superantibus; cupula obconica 4-costata, operculum depresso-hemisphaericum muticum quadruplo excedente. Folia bipollicaria aut parum longiora, 3-3 $\frac{1}{2}$ lin. lata, punctis aliis opacis, interdum nigricantibus, aliis paucioribus pellucidis conspersa, petiolus fere trilinealis. Filamenta alba. Cupula fructus parum aucta, prope orificium leviter constricta. Capsula inclusa, vertice plana 4-locularis. Ad descriptionem E. amygdalino, Labill, in multis accedit, sed nullam reticulationem in foliis video, folia breviora, operculum depressum nec subconicum, forsan etiam operculi forma prae caeteris dignoscitur. E. cneorifotia et $E$. stricta floribus sessilibus recedunt. E. pallens pedunculis compressis et foliis 5-pollicaribus, E. obtusiflora calycibus ecostatis. (Turcz, in Bull. Phys. Math. Acad. Pétersb., 10, 1852, p. 338.)

The type is, as Turezaninow states, No. 34 of Drummond's 5th collection.

There is a glaucous form with fruits slightly urceolate, slightly rimmed, and showing slight angularity. I think it is a well-marked variety of $E$. calycogona, Turcz., and therefore proposed the name of var. celastroides for it in Proc. Linn. Soc., N.S.W., 1902, p. 222.

\section{E. fruticetorum, F.v.M.}

I do not think that the original description of E. fruticetorum, F.v.M., had been published in Australia until I transcribed it for the Proc. Linn. Soc., N.S.W., 1902.

17. Eucalyptus fructicetorum, Ferd. Müll. MSS: frutex vel arbuscula, ramulis angulato-teretiusculis, foliis nitidulis lanceolatis vel lanceolato-linearibus acuminatis crasse coriaceis, tenuiter patule venulosis, pedunculis lateralibus et axillaribus 4-6 floris, floribus sessilibus, calycis tubo obconico anguloso ruguloso quam operculum hemisphaerico-conicum acutatum triplo longiore.

Frequens in deserto ad f. Murray, fl. vere (F.M.).

Decempedalis. Petioli semipollicares. Folia $2 \frac{1}{2}-3 \frac{1}{2}$ poll. longa, 3-6 lin lata Pedunculi 2 lin. Alabastra operculata $2 \frac{1}{2}$ lin. longa.

Affinis $E$. strictae Sieb. foliis latioribus lanceolatis vulgo rectis et operculo magis conico differt. (Miq. in Nederl. Kruidk., Arch. IV, 131, 1856.)

I am aware of the confusion that has gathered around $E$. fruticetorum, but Mr. Wilkinson's specimens, named E. fruticetorum by Mueller himself, although gathered many years after the original type specimens were collected, answer the description very well. Bentham (B.Fl. iii, 252) states that the West Australian specimens referred to by Mueller in Fragm. $i, 57$, are referred to $E$. loxophleba, Benth., (E. foecunda, Schauer). They are also stated to be the $E$. santalifolia, of Miq., (op. cit.) and Mueller in Trans. Tict. Inst. $i, 35$.

Examination of old herbarium specimens has shown me that confusion of material, such as that indicated by Bentham, is by no means rare.

E. fruticetorum, F.v.M., is glaucous, and is so very close to E.celastroides, Turcz., that I think its proper place is under E. calycogona, Turcz., var. celastroides, Maiden.

The E. gracilis, F.v.M., figured by Mueller in the Eucalyptographia is not typical E. calycogona, but in part a slightly angled form nearest to $E$. fruticetorum. 


\section{E. gracilis, F.v.M.}

\section{Variety gracilis.}

Fruticose; leaves coriaceous, alternate, shining, narrow-lanceolate, hooked-acuminate, a little oblique, thinly veined-dotted; umbels axillary and terminal pedunculate: flowers small, short-stalked; lid blunt, depressed-hemispherical; tube of the calyx obconical, bell-shaped, a little broader and three times longer than the lid; fruit nearly hemispherical; not contracted at the top; valves of the capsule almost enclosed.

In the desert on the Murray River, where it forms the mallee scrub, together with E. dumosa, santalifolia and other species (Trans. Vict. Inst. i, 35, 1855).

Miquel's description is in the following words :-

3. E.gracilis, Ferd. Mull., E. perforata, Behr. Herb. partim; arbuscula gracilis, ramulis teretibus apice angulatis lanceolato linearibus vulgo subfalcatis in acumen vel apiculum uncinatum excurrentibus glabris coriaceis crebro pellucido-punctatis; umbellis axillaribus et lateralibus $3-6$ floris, calycis tubo turbinato operculum depresso-hemisphæricum apiculatum triplo excedente.

Ab E. amygdatina proxime affine differt foliis non venosis, ab $E$. ambigua operculo vix apiculato, petiolis longioribus, umbellis plerumque 5-floris ab E. cneorifolia floribus breviter pedicellatis (Müller).

Frutex vel saepe arbuscula gracilis 5-8 pedum altitudinis, partem magnam fruticetorum extensorum aliquot millaria a fl. Murray remotorum sistens, restate florens, ramuli juniores rubri (F. Müller Herb. et

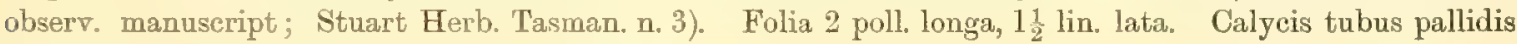
122 lin lata (Ned. Kruidk., Arch. IV. 1856).

C. Stuart's Tasmanian specimens No.3 are E. amygdalina, Labill. I have seen them. Miquel's statement that E. gracilis, F.v.M., is near to E. amygdalina, Labill., applies with a good deal of force to Tasmanian specimens, the superficial resemblances of herbarium specimens being frequently very considerable.

The type of E. gracilis, F.v.M., is a South Australian specimen, and was collected by Dr. H. Behr. It was labelled by Mueller in Herb. Melb. as "Eucalyptus gracilis, Ferd. Muell., Murray Scrub., Dec., 1848, Behr, Nov. Holl. Austr., Dr. Ferd. Müller."

It will be observed that neither in Mueller's nor Miquel's description is there any mention of an angular calyx which is so obvious a feature of the typical E. calycogona, Turez.

It, however, passes by insensible gradations into the angular form.

\section{E. gracilis, F.v.M., var. breviflora, Benth.}

Calyx-tube scarcely angled, $1 \frac{1}{2}$ to nearly 2 lines long. Fruit about 2 lines only, but the deeply-sunk capsule and the stamens entirely as in the ordinary form,-Darling and Murray Desert, also F. Mueller's Spencer's Gulf specimens, which being in fruit only are somewhat doubtful (B. FI. III, 211).

Bentham's specimens cannot be traced in Herb. Melb., but I am indebted to Kew for a fine drawing of the original specimens (Plate 12) and for fragments of the specimens which place its identity beyond doubt.

I am of opinion that E. gracilis, F.v.M., and E. gracilis F.v.M., var. breviflora, Benth., are so closely allied that it is impossible to separate them even as two varieties. I think that they should form one variety readily noted by its 
hemispherical operculum and almost entire absence of angularity in calyx or operculum. I proposed the name gracilis for this variety, i.e., E. calycogona, Turcz., var. gracilis, in Proc. Linn. Soc. N.S.W., 1902, p. 223.

\section{Eucalyptus yilgarnensis, Diels.}

"No. 332, Plantæ Australiæ occidentalis, v. (May), 1901, Yilgarn and Coolgardie Goldfields in silvis valde apertis, E. Pritzel," is referable to the above variety.

\section{Doubtful Varieties.}

(c) E. gracilis, F.v.M., var. Thozetiana, F.v.M. (E. Thozetiana, F.v.M.) occurs :-

In the "Eucalyptographia" (under E. gracilis) the following passage

Either as a variety, or perhaps even as a species can be distinguished from $\boldsymbol{E}$. gracilis, an Eucalyptus gathered by the lamented late Monsieur A. Thozet in his last botanical journey to Expedition Range.

This Eucalyptus, which should bear his name, can be distinguished by its longer leaves, narrowellipsoid flower-buds, smaller, more or less conspicuously angular calyces and also smaller and particularly narrower fruit, irrespective of the size of the tree, which rises to a height of 60 feet, according to Mr. E. Bowman and Mr. P. O'Shanesy, who noticed it near the Mackenzie and Comet River."

All the localities mentioned are in Queensland.

I have examined specimens from-

(a) Expedition Range, Queensland. (M. Thozet, in Herb. Melb.)

This is the specimen referred to in the preceding passage.

(b) "Eucalyptus from the Mackenzie River, Queensland. It sheds all the bark except that on the butt of the trunk." (W. Woolls, who labelled it E. tesselaris.)

(c) and $(d)$ Warrego and Flinders River, Queensland (F. M. Bailey). The fruits are small, narrow, and sub-cylindrical, but perhaps not perfectly ripe.

The buds are very narrow and pointed when young; as they become mature they become plumper, and somewhat resemble those of $E$. odorata. The leares are coriaceous and with inconspicuous veins.

While these specimens probably belong to E. calycogona, in my opinion these Queensland trees appear to show transit to the narrow-leaved forms of $E$. odorata. Additional material, including ripe fruits, and further particulars as to habit, bark, timber, etc., are necessary before the position of this tree can be stated without doubt.

(d) For a second doubtful variety, further removed (if a variety) from $E$. calycogona than E. Thozetiana, see E. ochrophloia, F.v.M., below p. 86. 


\section{R A N GE.}

\section{Typical Form.}

\section{Westeri Australta.}

THE original specimens came from "Swan River to Cape Riche," Western Australia. I have examined co-types from many herbaria. [See Plate $9(\alpha)$.]

L. Diels, No. 766, Kent Facup Creek.

Coolgardie (L. C. Webster).

\section{South Australia.}

I have seen a specimen from the Murray Desert, and labelled E. gracilis, by Mueller.

\section{VICTORIA.}

"The Mallee Country" (a very angled, coarse form).

Lake Albacutya (also a very angled, coarse form. Both from C. Walter).

Swan Hill, Murray River (J. G. Luehmann). [See Plate $9(b)$.

Lake Hindmarsh (C. Walter).

The Wimmera (F. Reader). Very coarse form.

Kamerooka, "No. 1 Mallee" (A. W. Howitt). "Tall, up to 15 feet, bark smooth." Broad, shiny, thick leares, with angled buds and fruits. The coarsest form of the species I have seen. [See Plate $9(c$ and $d)$.]

"Kamerooka is near Bendigo, being on the fringe of the country where Mallee is found, not in large tracts, but in patches." (A. W. H., in litt.)

\section{Variety celastroides.}

\section{Western Australia.}

It appears to be mainly confined to Western Australia. Following are some specimens in the National Herbarium of New South Wales:-Elder Exploring Expedition, camp 63, W.A., $27 / 9 / 91$, and 40 miles N.W. of Fraser's Range 
(R. Helms, 4/11/91). These specimens were labelled $E$. frecunda by Professor Tate. They have leaves rather broader than the Coolgardie specimens, see Plate $10(b)$;

"Goldfields" (Conservator of Forests, Perth).

Coolgardie (L. C. Webster), see Plate 10 (c).

\section{VICTORTA.}

Two specimens in Herb., Melb., collected by W. Percy Wilkinson, and obtained from (a), Mildura; (b), Lower Avoca scrub, Wedderburn, Victoria. They were labelled E. fruticetorum, F.v.M., by Mueller. See above, p. 80, and also Plate 11 $(g$ and $h)$.

\section{Variety gracilis.}

\section{Western Australia.}

"No. 2843, Arbor ca. $8 \mathrm{~m}$. alta, floribus minutis albis. Southern Cross in limoso-lapidosis, 19th May, 1901" (L. Diels). See Plate $12(g, h, i)$.

"332, Eucalyptus yilgarnensis, Diels. Yilgarn and Coolgardie Goldfields; in silvis valde apertis, May, 1901." (E. Pritzel.)

Coolgardie (Nos. 100 and 101, 1899; R. Helms). Sap-green leaves, very shiny ; fruits small, pear-shaped, constricted at the mouth, but not ripe; operculum a little pointed. See Plate $12(k, l)$. Melb.)

Fifty miles west of Golden Valley, W.A. (E. Merrall, 1888; in Herb.

The two last specimens show transit to $E$. odorata.

\section{Sotth Australia.}

Murray Scrub (Behr.), ante p. 81.

York Peninsula. (J. G. O. Tepper, 1880, No. 938.) "Middle-sized trees, 10-20 feet by 3-8 in., coast plain." Herb. Melb., labelled E. gracilis by Mueller.

"White Mallee," Flinder's Range, foot hills of Mt. Brown (Port Augusta); W. Gill, Conservator of Forests, with the note, "as figured in Brown's 'Forest Flora of South Australia.",

Ninety-mile Desert. "Clear bark, wood brown." (R. H. Cambage, March, 1901.) The Ninety-mile Desert is the modern name for the Murray Desert, where the type of the variety was collected.

Specimens from South Australia [no locality] (W. Gill, 1596 and 1900) are very close to the Coolgardie specimens above referred to. 
VICTORIA.

Mildura (A. W. Howitt's No. 130). See Plate $9(e)$.

l'he Wimmera (C. Walter). See Plate $12(e, f)$.

Swan Hill (Dr. Griffiths).

\section{New South W Ales.}

Gol Gol, near Wentworth ("No 3 Mallee," A. W. Howitt). With slender, rather tapering fruits; the leaves and buds precisely those of Tepper's 938 (South Australia).

Mt. Hope Road to Euabalong, Condobolin district (August, 1899; R. H. Cambage). The Mallee referred to (see Plate 11, $a, b$ ) in Mr. Cambage's paper, Proc. Linn. Soc., N.S.W., 1901, p. 209. 


\section{AFFINITIES.}

\section{E. ochrophloia, F.v.M.}

I have some doubts, as already stated, that E. ochrophloia may not be a variety of $E$. calycogona. Following is the original description :-

Arborea, ramulis parum angulatis, foliis sparsis falcato- $v$. oblongo-lanceolatis concoloribis utrinque nitentibus irregulariter poroso-punctatis, venis parum patentibus cum venulis anastomosantibus, peripherica a margine remota, umbellis axillaribus solitariis vel corymboso-confertis, pedicellis pedunculo haud dilatato longioribus sensim in tubum calycis obconicum longiusculum leniter quadrangularem transientibus, operculo conico acutato longitudinem tubi calycis vix semiæquante, staminibus exterioribus anantheris numerosis, antheris cordatis $\mathrm{v}$. renatis saepe truncatis, stigmate crassitiem styli haud excedente, fructibus clavato-ovatis truncatis trirarius quadri-loculatis, margine orificii tenui ultra valvas alte protenso, seminibus sterilibus perbrevibus.

Ad ripas et in planitiebus secus fluveos Warrego et Paroo.

Arbor 50-pedalis v. humilior. Cortex laevis, dilute fuscescenti-flavidus quare arbor "Yellow Jacket" vocata (Giles, Bailey). Folia 4-6" longa, sæpe inter $\frac{2}{3}$ et 1" lata, parum inaequilatera, in petiolum vix longiusculum angustata; penæ haud crassæ, sed prominulæ; poræ copiosæ, difformes, nec in modum copioso oleigerarum regulariter rotundatæ, sed anguliter effuentes et magnitudine variantes, quo charactere sicut modificatione columnæ, placentigeræ species sæe clare separabiles. Calycis tubus addito pedicello ad pollicem usque longus, passim brevior. Operculum fere $3^{\prime \prime \prime}$ altum. Stamina ante expansionem inflexa. Antherae utrinque rimula irregulari sape verticali dehiscentes. Stylus staminibus conspicue brevior. Fructus circiter semipollicares, vix ultra $3^{\prime \prime \prime}$ crassi, minus angulati; valvæ perbreves. Semina pleraque (saltem sterilia) vix $\frac{1}{2} "$ metientia.

Haec nova species ab $E$. gracili removetur folis majoribus prominule venosis minus, perspicue punctatis, pedicellis calycibusque longioribus, filamentis pallide flavidulis procerioribus, antheris majoribus distinctius rimigeris, operculo acutiore, fructibus bis terve majoribus sensim conice contis ab $E$. paniculata* divellitur foliis magis nitentibus, venis eorum crassioribus minus patentibus, peripherica parum a margine remota, calycibus longioribus, staminibus sterilibus valde numerosis, stigmate haud peltato, fructibus magis elongatis sensim in pedicellum contractis, nec non corticis coloratione et structura. (Fragm. XI, 36.)

Mueller himself observed the affinity of E. ochrophloia and E. calycogona (gracilis) in the following words :-

E. ochrophloia, F.v.M., is removed from E. gracilis on account of its larger leaves, with rather prominent veins and less conspicuous oil-dots, its larger flowers, more pointed lid, fruits of larger size, and more tapering into an elongated stalklet, also its outside yellowish bark, which gave rise to its odd vernacular appellation "Yellow Jacket," by which it is known from the Darling and Lachlan Rivers to the Paroo and Warrego. (Eucalyptographia, under E. gracilis.)

Luehmann (Proc. Aust. Assocn. Adv. Science, Sydney Meeting, 1898, p. 528) also surmises that it may be a variety of $E$. gracilis.

I have specimens from River Darling (W. Woolls and others). Dr. Woolls looked upon it as E. incrassata. Also from Paroo River (E. Betche), both New South Wales localities. 
Its Queensland aboriginal name is "Yapunyah," but its common name in western New South Wales and Queensland is "Yellow Jacket," owing to the colour of its bark.

Its wood is of a brownish colour, hard, heavy, and close-grained, and it is said to attain a height of about 50 feet.

The leaves resemble in a marked manner those of the more coriaceous forms of E. calycogona, and particularly the Kameruka specimens. But the buds are less blunt and less angled than those of E. calycogona. The fruits of E. ochrophloia, while angled, are not so much so as those of $E$. calycogona; they are also more slender and tapering, with a rim at the top, though this last character is sometimes seen in E. calycogona, e.g., F. Reader's Wimmera, Victoria, specimens.

E. ochrophloia, as regards buds and fruits, might be looked upon as a coarse form of E. calycogona, var. (?) Thozetiana. The leaves of the latter are much more narrow than those of the former usually are. With narrow-leaved forms of $E$. ochrophloia (e.g.), some from Thargomindah, which show but little venation, the resemblance of such leaves to those of var. (?) Thozetiana is so great as to be worthy of note.

E. ochrophloia differs from incrassata in the leaves, which, although very thick and shiny as in the latter species, have more marked venation, the spreading veins and intramarginal vein (at some distance from the edge) being alike conspicuous.

I trust that more evidence will be forthcoming both as regards $E$. ochrophloia and $E$. calycogona, var. (?) Thozetiana. We want herbarium specimens from more localities than we have at present, and we require notes on, and specimens of, the bark and timber and other particulars, in order that a final judgment may be pronounced.

2. E. salmonophloia, F.v.M.-It is worthy of note that specimens in bud or with undeveloped fruits of this species may very pardonably be confused with $E$. calycogona, var. gracilis.

The notes concerning the following species, which are in italics, are taken from Mueller's "Eucalyptographia," under E. gracilis, except No. 3, which is under $E$. foecunda. Where gracilis is given $E$. calycogona var. gracilis should be read, and Mueller's references were doubtless given with that variety in mind. Typical E. calycogona could not be confused for a moment with any of the species named. 


\section{F. fæeunda, Schauer.}

$E$. frecunda might from great external resemblance be confounded with $E$. gracilis, but the latter has the outer stamens sterile, the anthers roundish and opening by pores, and the fruits shorter as well as eomparatively broader.

The fruits of $E$. focunda are larger than those of var. gracilis, and may be usually at once distinguished by the style which persists until the fruit is well advanced, and the prominence of the midrib. The calyx of var. gracilis is dotted. At the same time the superficial resemblance is undoubted. Turczaninow originally drew attention to it, and Tate labelled some specimens $E$. foecunda.

\section{E. fasciculosa, F.v.M.}

$\boldsymbol{E}$. paniculata, particularly in its variety fasciculosa, coincides also in many of its characteristics with $E$. gracilis, with which it is intermingled in the mallee scrub: but the leaves are larger, less shining, slightly paler beneath than above, not distinctly dotted, with several times less stomata above than beneath, and have the margin slightly recurved, as is customary in the species with heterogeneous and hypogenous stomata; the circumferential vein is rather nearer to the margin of the leaf, while the lateral veins are more spreading and prominent, the flowers are on the whole larger and mostly paniculated, the anthers truncated and open with terminal pores.

It is generally recognised now that $E$. faciculosa is a good species. Its fruits and flowers are much larger than those of $E$. calycogono, var. gracilis, while its comparative dullness of foliage at once renders the two plants little liable to be confused.

\section{E. uncinata, Turez.}

$E$. uncinata, another of the mallee species, is best separated from $E$. yracilis by its often narrower leaves with more spreading veins, usually still more abbreviated stalklets, not at all angular calcyces, less inequality in the length of their tube and lid, not flexuous filaments but all fertile, anthers opening by terminal pores, proportionately longer style, upwards very narrow acutely pointed and partially emersed capsular valves and thicker rim of the fruit, which as a rule is smaller and more roundish.

E. uncinata may most conveniently be distinguished from E. calycogona, var. gracilis, by the reflexed filaments of the former. It is also more ereet in its habit than the latter.

\section{E. oleosa, F.v.M.}

$E$. oleosa, recedes from $E$. gracilis in having the veins of the leaves rather more transverse, the marginal vein closer to the edge, the calyces never angular, the lid very seldom shorter than the tube of the calyx, the latter often more suddenly contracted into the stalklet, the stamens all fertile, the anthers opening rather by slits than pores, though amply so, the style longer, the fruit more contracted at the rifice with pointed and partly protruding valves, the latter forming a conical summit before expansion and the rim thicker; moreover the bark of $E$. oleosa remains persistent on aged stems and becomes finally rough.

E. oleosa has the anthers opening in slits; it has a far longer operculum and duller foliage than E. calycogona. 
7. E. incrassata, Labill., var. dumosa.

$E$. dumosa, in comparison with $E$. gracilis, can mainly be recognised by the absence or extreme shortness of the stalklets, the calyces not or less angular, the stamens all fertile, larger anthers opening by ample slits and mostly larger fruits. Nearly the same characteristics remove E. incrassata, but that species is, besides, larger in all its parts, its leaves are broader, the flower stalks very much flattened, the calyces often furrowed-streaked; both form the transit from the parallelantheræ to the micrantheræ.

If anthers be available, those of $E$. calycogona, which open in pores, cannot well be confused with those of any variety of $E$. incrassata.

Some of the smallest forms of the variety dumosa are not unlike specimens of $E$. calycogona, var. gracilis, but the more pointed operculum of the former serves at once to distinguish them.

\section{E. bicolor, A. Cunn. (E. largiflorens, F.v.M.)}

$E$. gracitis differs from $E$. largiflorens in shining leaves not of a greyish hue, more numerous and still finer veins and more perceptible oil-dots in the numerous sterile stamens, anthers opening laterally, less copiously paniculated, more angular calyx, the lid not rarely pointed, often somewhat larger fruit with not distinctly contracted summit, and also in not extensively persistent bark; but seemingly a variety of E. largiflorens from Northern Queensland exhibits also shining leaves of vivid green.

$E$. bicolor is a large tree with red timber and dull-coloured foliage. These characters are usually sufficient to distinguish them from the species under consideration. 


\section{Explanation of Plates.}

\section{PLATE 9.}

A. Drummond's No. 184 (5th collection, 1849). Type of E. calycogona, Turcz.

B. Specimen, showing buds, from Swan Hill, Murray River, (J. G. Luehmann.)

C, D. Coarse form, from Kamerooka, Bendigo, Victoria. (A. W. Howitt.)

[B, C, D are E. calycogona, Turcz. ; typical form.]

E. A small fruited form, from Mildura, Victoria, showing slight angularity of the fruits; it shows transit to var, gracilis.

\section{PLATE 10.}

A. Drummond's No. 34 (5th collection, 1849). Type of E. celastroides, Turcz., (and of $E$. calycogona, Turcz, var. celastroides, Maiden).

B. Specimen of var. celastroides in fruit. Camp 63, Elder Expedition, Western Australia, 27th July, 1891. (R. Helms.)

C. Coolgardie, Western Australia. (L. C. Webster.) This also belongs to var. celastroides. The operculum is slightly pointed, and shows transit to $E$. fruticetorum, F.v.M.

\section{PLA'TE 11.}

A, B. Eucalyptus calycogona, var: gracitis. Mount Hope Road to Euabalong, N.S.W. (R. H. Cambage.)

C, D. "E. gracilis, var. Thozetiana, F.v.M." Mueller's type from Expedition Range, Queensland. (Thozet.) See p. 82 .

E, F. A form similar to C, D, from the Mackenzie River, Queensland. (Comm. by late Rev. Dr. Woolls.)

G, H. Both these specimens were labelled "E. fmuticetorum, F.v.M." by Mueller himself; G is from Lower Avoca scrub, Wedderburn, Victoria (W. Percy Wilkinson); $(\mathbf{H})$ is from Mildura, Victoria (W. Percy Wilkinson). Both are referable, in my opinion, to var. celastroides.

\section{PLATE 12.}

A, B, C, D. "Eucalyptus gracilis, F. Muell., Murray and Darling Desert. Victorian Expedition. var. breviflora." (Copy of label of type of $E$. gracilis, var. breviflora, Benth.).

The specimens are a twig in fruit (A), a twig in flower (B), front and back view of anther (C) and immature fruit (D) magnified, showing the characteristic oil-dots.

[A, B, C, D are from drawings made by Miss M. Smith, of the Kew Herbarium, from the type.]

E, F. Specimens in bud and fruit. The Wimmera, Victoria. (C. Walter.)

G, H, I. Specimens in bud and fruit. Yilgarn and Southern Cross, Western Australia. (L. Diels, No. 2843.)

(These specimens are not to be distinguished from E. yilgarnensis, Diels, No. 323, E. Pritzel, May, 1901.)

K, L. Specimens in bud and fruit. Coolgardie, Western Australia. (R. Helms.)

[All the specimens on this plate are $E$. calycogona, Turcz.; var. gracilis, Maiden.] 


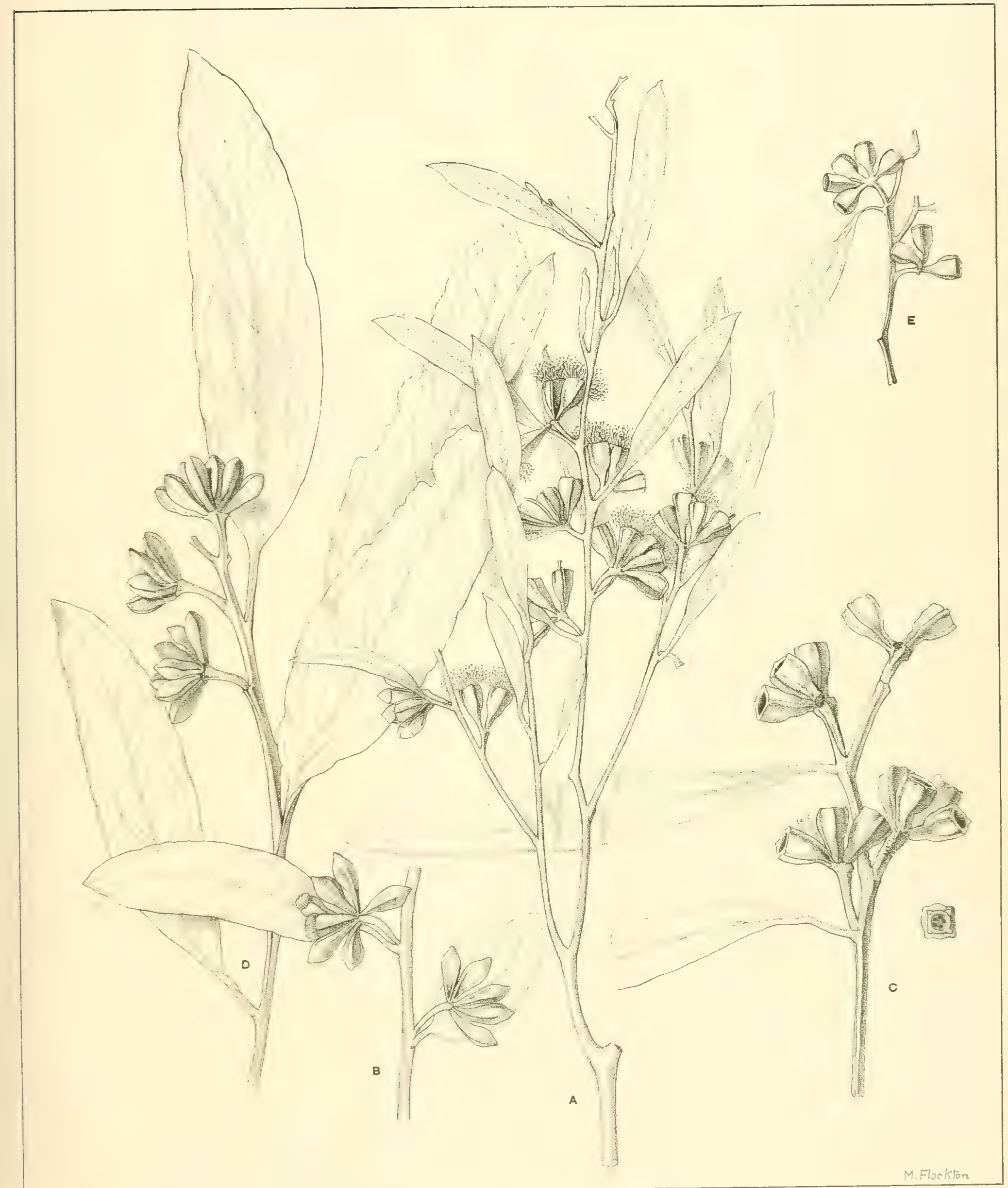

EUCALYPTUS CALYCOGONA, TuRcz.

(a. Drawn from type.) 



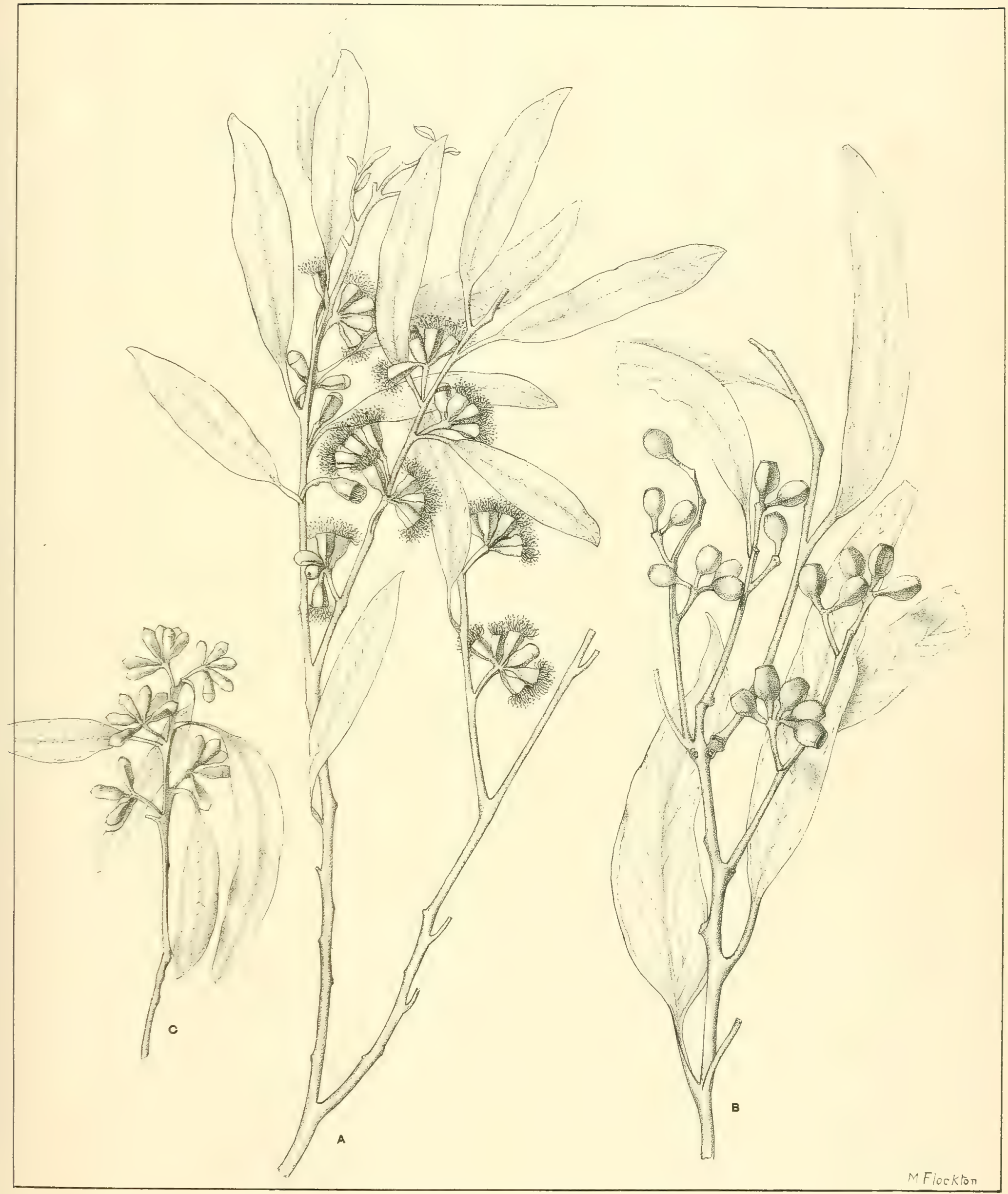

EUCALYPTUS CALYCOGONA, TuRCZ.

Var. CELASTROIDES, MaIden. 

PL. 11.

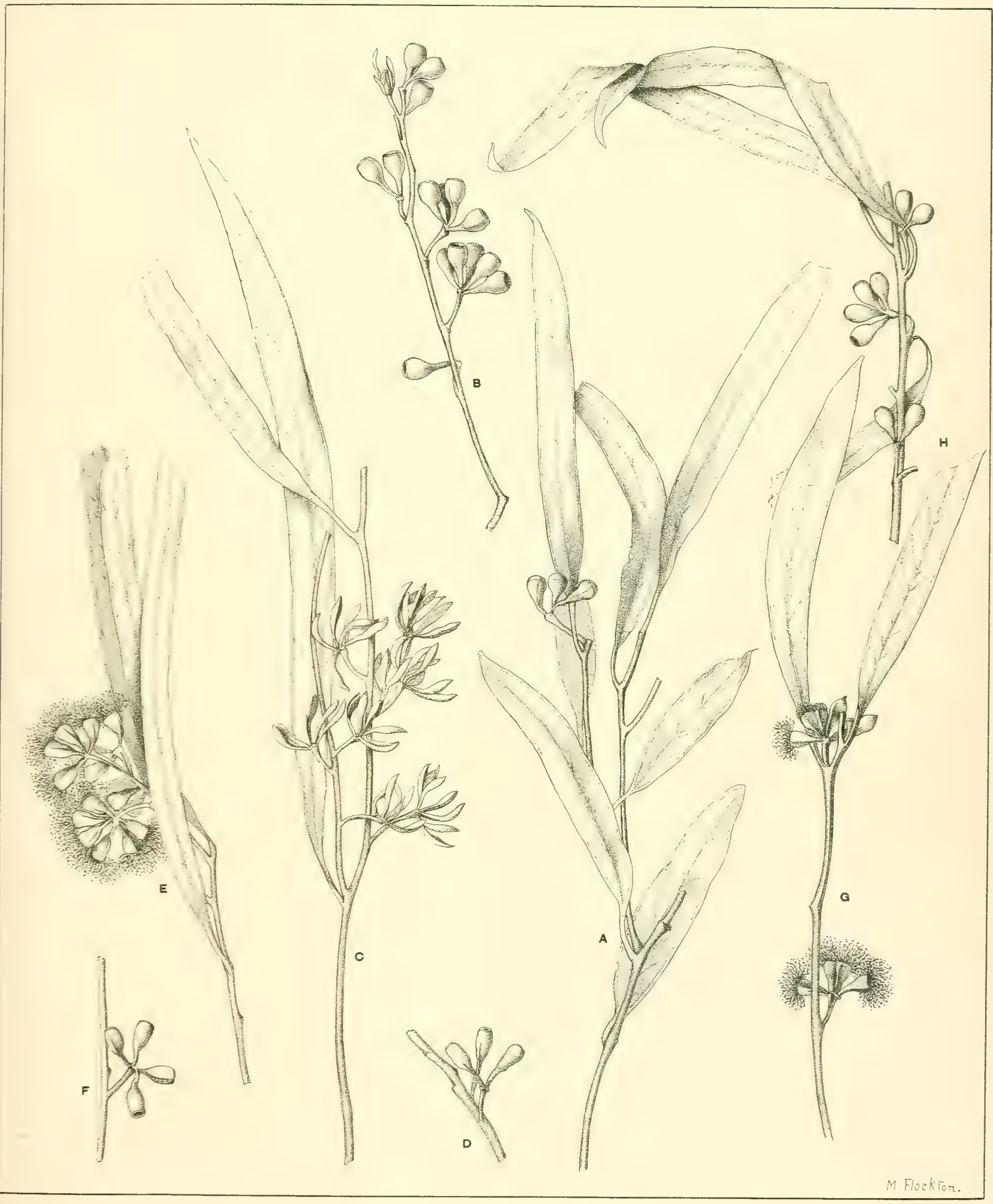





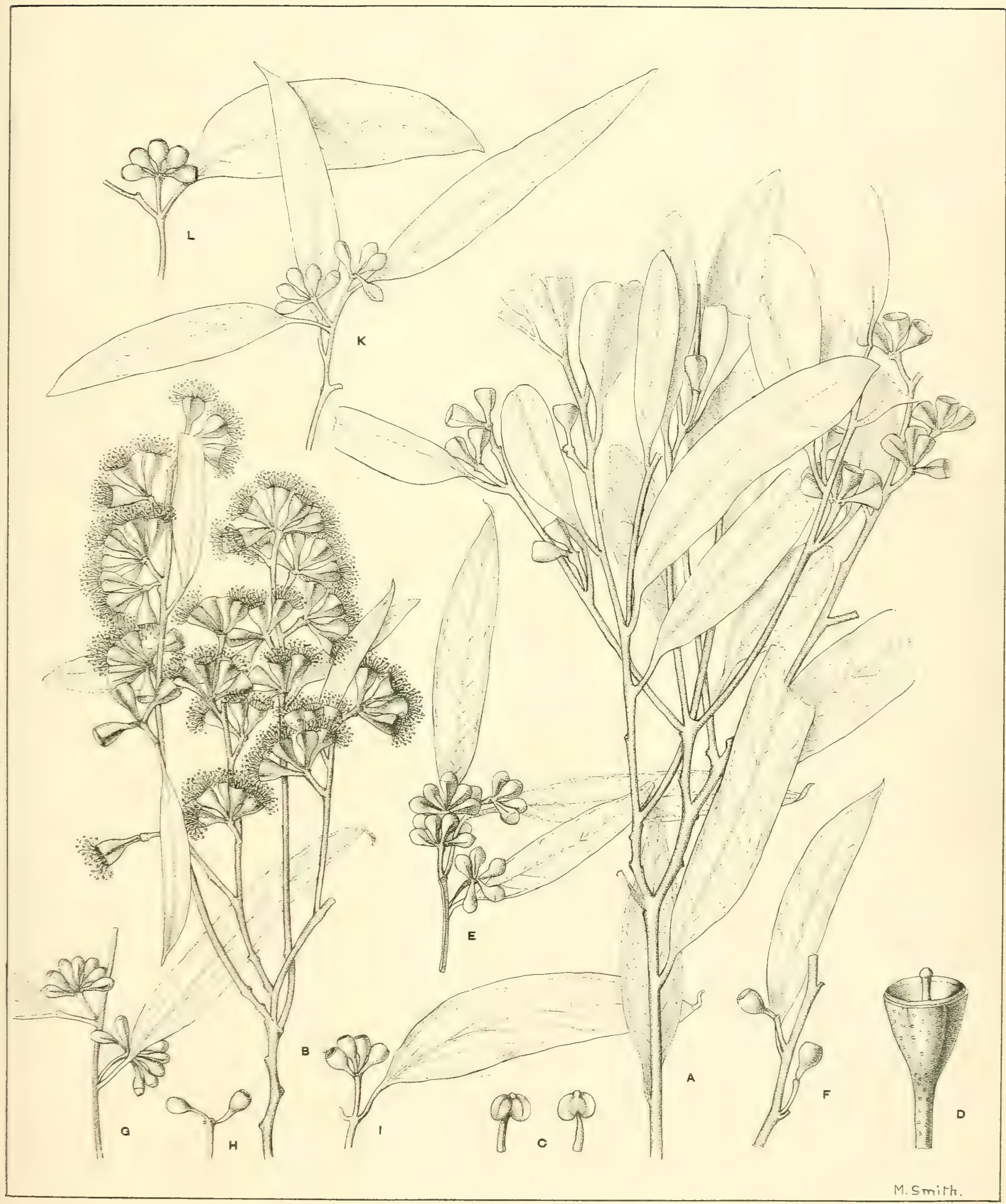

EUCALYPTUS CALYCOGONA, TURCZ.

Var. GRACILIS, MAIDEN.

(E. gracilis, F.v.M., partim.) 



\section{A CRITICAL REVISION OF THE GENUS EUCALYPTUS}

\section{BY

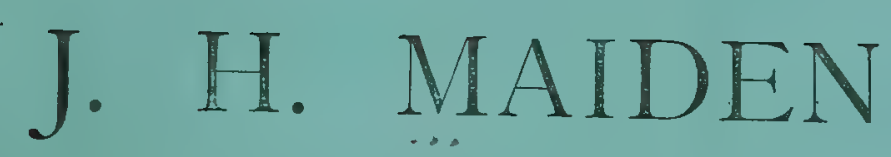

(Government Botanist of New South Wales and Director of the Botanic Gardens, Sydney).

\section{PART IV}

(WITH TWELVE PLATES, AND ONE ILLUSTRATION IN THE TEXT).

\section{Price SiX Shildings.}

\section{Published by Authority of}

THE GOVERNMENT OF THE STATE OF 'NEW SOUTH WALES.

Sñonry :

WIILIAM APPI.EGATE GULLICK, GOVERNMENT PRINTER. 



\section{A Critical Revision of the GENUS Eucalyptus}

BY

\section{J. H. MAIDEN}

(Government Botanist of New South WaTes and Director of the Botanic Gardens, Sydney).

\section{- PART IV}

(WITH TWELVE PLATES, AND ONE ILLUSTRATION IN THE TEXT).

"Ages are spent in collecting materials, ages more in separating and combining them. Even when a system has been formed, there is still something to add, to alter, or to rejeet. Every generation enjoys the use of a vast hoard bequeathed to it by antiquity, and transmits that hoard, augmented by fresh acquisitions, to future ages. In these pursuits, therefore, the first speculators lie under great disadvantages, and, even when they fail, are entitled to praise."

Macaulay's "Essay on Milton."

\section{PRICE SIX SHILLINGS.}

Published by Authority of

THE GOVERNMENT OF THE STATE OF NEW SOUTH WALES.

\section{Syoney :}

Wilitam APPLEGATE GULLICK, GOVERNMENT PRINTER, PHILLIP-STREet. 



\section{4. \\ EUCALYPTUS INCRASSATA (Labillardière).}

5.

EUCALYPTUS FECUNDA

(Schauer). 


\section{Eucalyptus incrassata, Labillardière.}

1. Description . . . . . . . . . . 93

Notes supplementary to the description . 93

2. Synonyms . . . . . . . . . 96

Notes on the Synonyms . . . . 97

3. Range . . . . . . . . . . 105

4. Affinities . . . . . . . . 109

5. Explanation of plates . . . . : I2I

V. Eucalyptus frecunda, Schaner.

1. Description . : . . . . . . I I2

2. Synonyms . . . . . . . . . II2

Notes on the Synonyms . . . . 112

3. Range . . . . . . . . . II5

4. Affinities . . . . . . . . I17

5. Explanation of plates . . . . . . 123 


\section{DESCRIPTION. \\ E. inerassata, Labillardière.}

Followivg is the original description of the species:-

Eucalyptus operculo conico, calycis longitudine; umbellis ancipiti pedunculo axillaribus; foliis oblongis, crassiusculis, subacuminatis.

Sesquiorgyalis frutex, ramulis angulatis. Folio oblonga, acurainata, in petiolum subdecurrentia, crassiuscula, coriacea, nervulis exarata depressis, alterna. Flores pedicellis brevibus umbellati, ancipiti pedunculo longitudine petiolorum axillares. Calyx turbinatus, subangulatus, germini adnatus, ultra productus, subcampanulatus. Operculum coriacem, calycis latitudine. Stamina numerosa, summo calyci affixa; antheris subglobosis, bilocularibus, apici filamentorum pedicellatis. Germen calyce immersum. corticatum; stylus vix staminibus longior, subulatus infra dilatatus, tetragonus; stigma acutum. Capsula ovato-turbinata, corticata calyce ultra producto, dilatato, quadrilocularis, intus et apice quadrifariam dehiscens; seminibus numerosis, oblongis, angulatis, ferrugineis, affixis receptaculo subcrustaceo-fungoso, oblongo, ad singuli loculamenti angulum internum, axi fructûs adnato.

Habitat, in terrâ Van-Leuwin.

1. Calycis sectio longitudinalis, intacto pistillo.

Obs. Quantum differat, praesertim foliis, ab Eucalypto rostrato, Cavan., ic. 4, p. 23, tab. 342 (E. robusta, Sm. J.H.M.), et ab Eucalypto marginatâ, Smith, Linn. Trans. 6 p. 302, omnibus patet. (Labillardière in Nov. Holl. $P l$. ii, 12, t. 150.)

See also an abbreviated description in DC. Prod. iii, 217.

Vernacular names.-It is a "Mallee." A mallee has a large massy stock or dwarf trunk, from which spring a large number of stems. These stems sometimes take on a circular'arrangement. Mallee roots or stumps are an esteemed article of fuel wherever they can be obtained, and the following gives a good idea of their massiveness and toughness.

A well-established bull mallee is a problem to the ordinary grubbing contractor. The butt is a great flattened bulb of curly timber, sometimes 8 or 10 feet through. It is set firmly into the soil, and even if all the roots were cut off, the tree would stand in its place just the same, as the upper growth is very insignificant compared with the base. Chopping a mallee out is an obvious impossibility, and as the wood is full of moisture it would be an almost endless task to attempt burning it out. Dynamite and rack-a-rock have proved equally useless.

Before or rather behind the traction engine the difficulty disappears. For the rapid removal of timber from land there is nothing to equal it. The only preliminary trouble lies in obtaining rope and tackle sufficiently strong to enable the power of the engine to be exerted. The cable used for hauling out the mallee stumps, at Mildura, is a steel-wire rope having a breaking strain of 100 tons, and the shackles and anchoring gear are correspondingly stout. The first operation is to cut down all the trees, leaving the stumps about 2 or 3 feet high. The trunk and branches are chopped up for firewood, and the leaves and litter are raked up into heaps and burned. The traction engine, with an attendant gang of a dozen men, then comes on the scene. The front end of the engine is first moored up to a stump, and the hind wheels are chocked up with heavy billets of wood carried for the purpose. The main axle carries a revolving drum 
on which is wound the steel cable before referred to. The engine being securely fastened forward, the cable is unwound from the drum and is then carried back to a stump, and the running noose at the end is dropped over it. Then the drum is set in motion, and when the rope straightens the stump starts up out of its resting-place and hurries towards the engine. It must come. Sometimes it is necessary to try back and give a few tugs, but the stump has finally to come up. It faoilitates the work to cut the surface roots and clear away the earth to the depth of a foot or so round the biggest ones, but with the small stumps this is not necessary. When the timber is light, the rope is carried round in a semicircle to a stont stump, and as it is straightened by the strain the intervening small fry are literally "rubbed out." Belar and pine are easily cleared in this way, and the gang makes short work of a 10-acre block, unless the mallee is extraordinarily heavy. When all the stumps are uprooted, the adhering earth is knocked off, and they are readily burned. The holes are then filled and the firewood carted off, and the work of clearing is completed. 1889.)

(N. B. MeKay, of Mildura, in Tict. Roy. Comm. Tey. Prod., 8th Anmal Report, pp. 118-119,

Var. dumosa is usually known as "White Mallee" because of the paleness of its smookh bark.

It was called "Weir Mallee" by Victorian aborigines, and "Bunurduk" by the aborigines of Lake Hindmarsh Station, Victoria.

Fruits.-The fruits vary in size, shape, constriction of orifice, smoothness (ribbed or not), shininess, prominence of rim, exsertion of valves (they are usually sunk).

0il.-Baron von Mucller found that 1,000 1b. of fresh twigs of this tree (comprising, perhaps, $500 \mathrm{lb}$, of leaves) yielded $140 \mathrm{oz}$, of essential oil.

Lerp.- This mallee yields a kind of manna, ealled Lerp, or Larp, by the aborigines. It is probably formed on the leaves of other species.

This substance occurs on the leares, and consists of white threads, clotted together by a syrup proceeding from the insect ( $P s y l l a$ encalypti) which spins those threads. It contains, in round numbersof water, fourteen parts; thread-like portion, thirty-three parts; sugar, fifty-three parts. The threads possess many of the characteristic properties of starch, from which, however, they are sharply distinguished by their form. When lerp is washed with water the sugar dissolves, and the threads swell slightly, but dissolve to a slight extent, so that the solution is coloured blue by iodine. The threads, freed from sugar by washing, consist of a substance called Lerp-amylum.

Lerp-anylum is very slightly suluble in cold water, not perceptibly more so in water at $100^{\circ}$, but entirely soluble to a thin, transparent liquid when heated to $135^{\circ}$ in sealed tubes with thirty parts of water. This solution, on cooling, deposits the original substance in flocis, without forming a jelly at any time. The separation is almost complete.

If the material emplojed in this experiment were entirely free from susars, the liquid left after the separation of the flocks will also be free from sugar. The flocks deposited from solution are insoluble in boiling water, therefore lerp-amylum suffers no chemical change on being heated to $150^{\circ}$ with water. Heated in the air-bath to $190^{\circ}$ while dry, it turns brown, and is afterwards merely reddened by solution of iodine; at the same time it becomes partly soluble in hot water, hence it appears that lerp-amylum undergoes a change similar to that which occurs when starch is conrerted into dextrin. By oxidation with nitric acid it yields oxalic acid, but no mucic acid; it is neutral to vegetable colours, and is not precipitated by lead acetate, and is, therefore, not to be confounded with the gums, drc.

It gave, by analysis, 43.7 and 43.07 carbon, 6.6 and 6.1 hydrogen, agreeing with the formula $\mathrm{C}_{6} \mathrm{H}_{10} \mathrm{O}_{5}(44.4 \mathrm{C}$, and $6.24 \mathrm{H}$.). Like starch, lerp-amylum rotates the plane of polarisation to the right, and on digestion with dilute sulphuric acid, \&c., forms a crystallisable carbo-hydrate which agrees in its properties with dextrin. It is insoluble in ammonia cuprate, and is homogeneous, 
Though the behaviour of lerp-amylum to iodine and to water, and its insolubility in cupr-ammonia distinguish it from cellulose, it is to be borne in mind that there are forms or conditions of cellulose which are blued by iodine and dissolve in water. (Flückiger, in Watts' Dict., vir, 2nd Suppl., 733.)

See also a paper "On a new kind of manna from New South Wales," by Th. Anderson (Journ. für Pralkt. Chemie, xlvii, 499); Edin. New Philosoph. Journ., July, 1819, reprinted in Papers and Proc., R.S., V.D. Land, vol, i, 1851.

A modern analysis of Lerp is a desideratum.

The Lerp described by Dobson is now Spondilaspis eucalypti, Dobson. Mr. W. W. Froggatt informs me that he has described two more species, viz, S. gramulata on E. robusta and S. mannifera on E. gracilis (calycogona) and $E$. dumosa. He is about to describe a fourth species.

Exudation.-For analyses of the kinos of two mallees belonging to this species, collected by the Elder Exploring Expedition, see Trans. Roy. Soc. S.A., тоі. xri, p. .

Timber.-This is not a timber tree, although its massive stock or "root" is a common article of fuel. Its stem or stems are too small to be used as timber. The sap-wood is white, and the remainder of the wood is brown, of one shade or another. 


\section{SYNONYMS.}

(a) Typical form.

1. E. dumosa, A. Cunn., var. scyphocalyx, F.v.M.

(b) Var. dumosa, F.v.M. (by implication, in Eucalyptographia under E. inerassata).

2. E. dumosa, A. Cunn., with perhaps var. punctilulata, Benth., and var. rhodophloia, Benth.

3. E. lamprocarpa, F.v.M.

4. E. Muelleri, Miq.

5. E. glomerata, Tausch.

(c) Var. conglobata, R.Be. (E. dumosa, A. Cunn., var. conglobata, R.Br., in B.Fl. iii, 230).

6. E. conglobata, R.Br.

7. E. anceps, R.Br.

8. E. pachyphylla, F.v.M.

(d) Var. angulosa, Benth., B.Fl. iii, 231.

9. E. angulosa, Schauer.

10. E. cuspidata, Turez.

11. E. costata, R.Br.

12. E. linopoda, $\mathrm{R} \cdot \mathrm{Br}$.

13. E. rugosa, R.Br. (E. inerassata, Labill., var. rugosa of some herbaria).

14. E. sulcata, Tausch.

15. E. pachyphylla, A. Cunn.

(e) Var. goniantha, var. nov.

16. E. goniantha, Turcz.

(f) Var. grossa, var. nov.

17. E. grossa, F.v.M.

18. E. pachypoda, F.v.M. 


\section{NOTES ON THE SYNONYMS.}

\section{(a) Typical Form.}

1. E. dumosa, A. Cunn., var. scyphocalyx, F.r.M.

(a) In B.Fl. iii, 230, we have:-

E. dumost, A. Cunn., var. scyphocalyx, F. Muell. Leaves narrow ; flowers large ; operculum very obtuse, broader than the calyx; peduncles very short and thick. This approaches in some measure E. gomphocephala.

On Plate 13 a specimen of this form, named by Mueller himself many years ago, is figured. I do not think it is sufficiently remored from the type of $E$. incrassata to be even called a variety. It shows transit to var. dumosa, and is one of the intermediate forms. Mueller worked under great difficulties in the early days, and as late as 1860, when he wrote Fragm. ii, 59, I doubt if he had seen complete specimens of typical incrassata.

\section{(b) Var. dumosa.}

2. E. dumosa, A. Cunn.

3. E. lamprocarpa, F.v.M.

4. E. Muelleri, Miq.

๖. E. glomerata, Tausch.

Mr. J. G. Luehmann, speaking of $E$. incrassata, says*:-

An extremely variable species. E. dumosa seems to pass into it by almost imperceptible degrees, although it can generally be distinguished by smaller flowers and fruits and less flattened peduncles,

I agree with him, and point out that the large fruited form of $E$. dumosa very closely approaches the typical form of E. incrassata. I am of opinion that much of the hesitancy of some writers to place $E$. dumosa with $E$. incrassata arises from the fact that they have not realised what is the type of the latter species. The var. angulcsa is by many people looked upon as typical incrassate. The large drawing to the left in the Eucalyptographia plate of E. incrassata is really var. angulosa. The drawing in the centre of the plate is one of the intermediate forms between the type and var. angulosa. The left hand of the two small drawings to the right of the plate is the only specimen close to typical incrassata, while the fragment to the extreme right is var. dumosa. There is, in fact, an absolute series between E. incrassuta and var. dumosa. 
2. E. dumosa, A. Cunn.

Following is an extract from Allan Cunningham's Journal, under date 23rd May, $1817:--$

Eucalyprus dumosa.-Leaves alternate, ovate lanceolate, fruit rough. This plant forms the principal shrub in a tract of confined bushy scrub.

A little later, Oxley made the entry:-

June 10th, 1817.-Mr. Cunningham named those thick brushes of Eucalyptus that spread in every dircction around us Eucalyptus dumosa, or the dwarf gum, as they never exceed 20 feet in height, and are generally from 12 to 15 , spreading out into a bushy circle from their roots in such a manner that it is impossible to see farther than from one bush to another, and these are very often united by a species of vine (Cassytha), and the intermediate space covered with prickly wire-grass, rendering a passage through them equally painful and tedious. (.Toumals of two Expertitions, Oxley, 1820, p. 63.)

About this time, say between 23rd May and 10th June, Allan Cunningham was mainly between $33^{\circ}$ and $34^{\circ} \mathrm{S}$. lat. and $146^{\circ}$ and $147^{\circ} \mathrm{E}$. long., i.e., in the Wyalong-Booligal country.

In 1828 A. De Candolle described (Prod. iii, 220) E. cneorifolia, but unfortunately there are two species in the Prodromus Herbarium under this name. I am obliged to M. Casimir. De Candolle for permission to examine the specimens. The following, which is figured at plate 16, is E. incrassata, var. dumosa.

Its original label reads-

Eucalyptus viminalis, Nouvelle Hollande, Cité Orientale, Musée de Paris, 1821.

An additional label bears the words-

3. E. cneorifulia, DC, altera species. (2) Species foliis oblongo-lanceolatis.

I think the following is the first formal description of E. dumosa, A. Cunn.:-

Fruticosa : ramulis rigidulis teretib. ; foll, cortaccis firmis oblongis lanceolatisve, basi subobliqua in petiolum attenuntis, breviter acuminatis, utrinq. lerib. pallide virentib. subopacis imperforatis; umbellis axillarib. 3-5 floris; pedunculo tereti $v$. subangulato petiolum requanto; pedicellis angulatis cupula breviorib. ; opereulo coriaceo subdepresso-hemispharico ariculato radiatim costato cupula cyathiformi vix costata nonnihil latiore vix longiore ct cum ea nitido. Foliorum lamina 2-3 uncias longit., 6-9 lin. latit., petiolus 8 lin. long. metientes; alabastra adulta cum pedicello 5 lin. longa, operculo 2 lin. alto. In frueticetis Nova Cambrix australis interioris. A. Cunn., Herb., No. 206, 1817. Schaucr in Walp. Rep. ii, 925.

Var. puncliculata, Benth.

Leaves copiously black-dotted, flower's sma11. I. Australia, from Gordon River, Olrffeld, to Mount Barren Ranges, Marvell. (B.Fl. iii, 230.)

Var. (:) rhodophloia, Benth.

Bark salmon-coluurd, leaves hlack-dotted, flowers rather small, the operculum conical or almost acuminate. Capsule on a level with the rim of the furit. Possibly a distinct species. W. Australia, Phillips Bluffs, near Eyre's Relief, M/arwell. (B.Fl. iii, 230.)

Both the above were described by Bentham as forms of E. dumosa. I have not seen them to my recollection. At Plate $21 \mathrm{I}$. submit drawings indicating essential parts of these so-called varieties. It is not an uncommon circumstance for the leares of $E$. incressuta to be hlack-dotted. See additional observations at p. 122. 
Backhouse's Blue Nountain specimens (Herb., Kew) referred by Bentham (B.Fl. iii, 230) to E. dumosa, A. Cunn., are in plump bud and in early fruit, with a few stamens remaining on the specimens. The opercula are blunt, nearly hemispherical, and the calyces are somewhat angular by compression. They are referable to $E$. eugenioides, Sieb., and the materials available exhibit a remarkable superficial resemblance to some specimens of $E$. dumosu, A. Cunn.

A specimen collected by Backhouse on the Upper Hunter, N.S.W., No. 9 (Herb., Kew) has the buds so swollen by the punctures of an insect that the specimen presents an appearance so peculiar that it has been referred doubtfully to E. drmosa. It, however, belongs to E. hemiphloia, F.r.M., and this swelling of the calyx is not uncommon in the genus. It will be figured when $E$. stellutata is dealt with.

Speaking of synonyms of $E$. dumost, Bentham says :-

E. santalifolia, Miq. 1.c. 133 (except the var. frrma), not of F. Muell. (B.Fl. iii, 230.)

With regard to the confusion of E. santalifolia, Miq. with E. dumost, var., I will deal with the matter when treating of $E$. diversifolia, Bonpl.

Bentham makes the very pardonable statement (B.Fl. iii, 230) that $E$. fruticetorum, F.v.M., is partly referable to $E$. dumosa. I have shown that it belongs to E. calycogona, Turcz. See Part III of this work; p. 80 .

Bark.-The blacks in South Australia powder the bark of the root of this, and, perhaps, other mallees, and eat it alone, or mixed with portions of other plants. They call it "Congoo" (Proc. P. S., S.A.). fare:-

Eyre in his overland journey from Adelaide to King George's Sound had this

At night we all made up our supper with the bark of the young roots of the green scrub. It appears to be extensively used for food by the natives in this district (Fowler Bay), judging from the remnants left at their encamping places. The bark is peeled off the young roots, put into hot ashes until nearly crisp, and then, the dust being shaken off, it is pounded between two stones and ready for use. Upon being chewed, a farinaceous powder is imbibed from between the fibres of the bark, by no means unpleasant in flavour, but rather sweet, and resembling the taste of malt; how far a person could live upon this diet alone I have no means of judging, but it certainly appeases the appetite, and is, I should suppose, nutritious. (Journ. of Exped. of Discovery, i, 371.)

He repeats his account somerrhat at ii, 250 , and adds,-

Several of the roots of other shrubs are also used for food, and some of them are mucilaginous and very palatable. At page 251 he speaks of the natives feeding on "the bark from the roots of many trees and shrubs."

Oil.-Messrs. Baker and Smith (Research on the Eucalypts, p. 285) give the following particulars in regard to the oil of this variety. Specific gravity at $15^{\circ} \mathrm{C}$, 0.9016 to 0.9151 ; specific rotation, $[\mathrm{a}] \mathrm{D}=+2 \cdot 44^{\circ}$ to $+6.34^{\circ}$; saponification number, 2.93; solubility in alcohol, $1 \frac{3}{4}$ vols., 70 per cent.; constituents found, eucalyptol, pinene, aromadrendral. 
Messrs. Gildemeister and Hoffmann (The Volalile Oils, Kremers' translation) have the note:-Eucalyptus dumosa* yields about 1 p.c., sp. gr. 0.884 to $0.915, \AA_{\mathrm{D}}=$ $+0^{\circ} 6^{\prime}$ to $+6^{\circ} 30^{\prime}$. It contains large amounts of cineol. $\dagger$

\section{E. lamprocarpa, F.v.M.}

14. Eucalyptus lamprocarpa, Ferd. Miill., ramulis rigidis nunc rubello-fuscis quadrangulis, foliis haud raro per paria subarproximatis e basi acutâ subaequali lanceolatis vel ovato-lanceolatis attenuatoacuminatis crasse et rigide coriaceis, costâ utrinque distinctâ, venis erecto-patulis fere obtectis, pedunculis axillaribus et lateralibus compressis crassis 2-5 floris, floribus sessilibus, ealycis tubo obconico striato nitido operculum breviconicum radiatum subacutum paullo superante.

In desertis Murray Scrub, Salt's Creek, Traveller's Rest (perhaps an inn "Traveller's Rest," J.H.M.) Ponindi, Angas park, \&c. Novae Holl. Austr. (1F. Müller), Fl. autumno.

Fruticosa ad modum E. odoratae teste cl. Behr. Petioli circiter semipollicares antice leviter sulcat, transverse rugulosi. Folia 21-3 poll. longa, 5-7 lin. lata. Pedunculi 1-1 $\frac{1}{2}$ lin. longi. Calycis tubus 2 lin. aequans. Ab E. angulosa foliis minoribus minute glandulose perforatis differt. Miq. in $N_{e d .}$ Kruidk. Arch. IV, $129(1856)$.

I have examined a co-type ("Plantae Mullerianae-Murray Scrubs")-in herb. Vindob. It is ordinary dumosa.

\section{E. Muelleri, Miq.}

15. Eucalyptus Mülleri, Miq. n. sp. ramulis teretiusculis superne angulatis, gracilibus, foliis anguste lanceolatis attenuato acuminatis, basi aequali acutis, aequilateris, crasse coriaceis, costâ utrinque distinctâ, venis exceto-patulis subobtectis, pedunculis axillaribus et lateralibus cylindraceis 3-6 floris, lloribus sessilibus, caljcis tubo obconico sulcato, operculo conico 10-costato sulcato paullo latiore.

Madam Pepper-weath $\ddagger$ ad fl. Murray (F. Müller).

E. limprocarpae valde aftinis, ramulis cylindraceis, operculo longiore et acutiore diversa. Petioli semipollicares. Folia 2-t lin. long. [sic] 4-43. lin, lata. Pedunculi $2-3$ lin. longi. Alabastra cum operculo $3 \frac{1}{2}$ lin. longa. Antherae ellipsoidcae. Fed. Kruidk. Arch. IV, 130 (1856).

I have examined the type. Like lamprocarpa it is sessile-flowered. Bentham places it under var. angulosa, but although it is smaller than var. angulosa, and rather larger than typical dumosa, I think it is better placed under dumosa.

5. E. glomerata, Tausch.

Coll. Ferd. Bauer, ex herb. Bauer in herb. Vindob. is rar. dumosa.

\section{(c) Var. conglobata.}

6. E. conglobata, R.Br.

7. E. anceps, R.Br.

8. E. pachyphylla, F.v.M.

\section{E. conglobata, R.Br.}

Peduncles shorter than broad. Flowers closely sessile, the calyx-tube shorter than broad, angular, and operculum conical, as in E. goniocalyx, but leares of $E$. dumosa. Port Lincoln, Wilhelmi; S Coast, R. Brown (B.Fl. iii, 230, as var. conglobata, R.Br.).

- The Useful Native Plants of Australia, Maiden, p. 267. + Bericht von Schinunel \& Co., Oct., 1889, p. 26.

¥ An amusing misprint for In modum pepper-menth (like peppermint). 
I have seen the specimens described by Bentham, and have, indeed, duplicates of them. Robert Brown's specimens bear the labels, in his handwriting, "Eucalyptus conglobata," and the localities "Bays 9 and 10, South Coast," 180?-5. "Island viii, South Coast," 1802-5.

Wilhelmi's specimens are identical, and so are those from $\mathrm{Mr}$. W. Gill, both from Port Lincoln, South Australia.

7. E. anceps, R.Br.

No. 4748. Kangaroo Island, South Australia, R. Brown, 1802-5, labelled by him E. anceps.

A specimen in Herb., Kew, has buds and fruits, and from the drawing (Plate 17), it is seen that the fruits are of the smaller fruited form (E. dumosa, A. Cunn.) or E. incrassata, Labill., but would have become (when ripe) larger than those of typical E. clumosa.

The fruiting specimen is detached from the specimen in bud. The specimen in bud is var. conglobata. The specimen in fruit (3b), is nearest var. dumosa. As the specimens are separate I prefer to say no more.

The affinity of this variety to other species will be dealt with below.

8. E. pachyphylla, F.v.M.

"E. pachyphylla, Ferd. Mueller, Port Lincoln proper", legit Carl Wilhelmi," communicated to the Vienna herbarium, probably by Mueller himself, is var. conglobata.

The name above may be a slip of the pen for pachyphylla, $\Lambda$. Cunn, the foliage of which it resembles. See also No. 15 (E. pachyphylla, A. Cunn.), p. 103.

\section{(d) Var. angulosa, Benth.}

9. E. angulosa, Schauer.

10. E. cuspidata, Turez.

11. E. costata, R.Br.

12. E. linopoda, R.Br.

13. E. rugosa, R.Br. (E. incrassata, var. rugosa).

14. E. sulcata, Tausch.

15. E. pachyphylla, A. Cunn.

\section{E. angulosa, Schau.}

Ramulis angulatis; foll. firmis rigidis lanceolatis $v$. oblongo-lanceolatis in petiolum contractis, a basi sensim in acumen attenuatis $\mathrm{v}$. breviter acuminatis, utrinq. lrevissimus nitidisq. imperforatis; capitulis axillarib. sub-5-floris; pedunculo valido compresso brevi; alabastris adultis obovatis, jugis subdecem elevatis inrequalib. costatis nitidis; operculo coriaceo hemisphrerico obtuso v. subacuto, cupula obconica paullo latiori et breviori. Lamina foliorum 3-413 poll. longa, 9-12 lin. lata, petiolus 6-9 lin. longus; alabastra cum pedicello crasso continuo adulta 5 lin. cixciter longa; opereulo 3 lin. fere æequante. Species valde insignis, cum $E$. dumosa ex affinitate $E$. gomphocephalce, DC. In Nova Hollandia (Walp. Repert. ii, 925 (1843).) 
I have seen the type, which is similar to $E$. costata, Behr.

Specimens I have also examined are labelled "E. angulosa, Schauer, Murray R., F. Mueller," "E. angulosa, Schauer, S.W. Bay, W.A. (Oldfield)" (Herb. Barbey-Boissier).

10. E. cuspidata, Turez.

Eucalyptus cuspidata. Caule ramisque teretibus, cortice fusca lacvi obtectis, ramulis subquadrangulis; alternis petiolatis ovato-lanceolatisve basi foliis contractis, apice in cuspidem abrupte attenuatis, opacis, marginatis ; pedunculis compressis cuneatis petiolo duplo brevioribus bi-rarius uni-trifloris ; pedicellis subtetragonis pedunculis cupulisque brevioribus; alabastro grosse costato rugoso; cupula turbinatoobconica operculum conicum acutum duplo fere excedente; staminibus exsertis (rufescentibus). Pedicelli cupulis duplo breviores, alabastra majuscula 8 lin. longa. Drum. 4, n. 75". (Turcz. in Bull. Soc. Nat. Mosc. 22, 1849, pt. 2, p. 22.)

The type is therefore No. 75 of Drummond's 4 th Collection.

11. E. costata, R.Br.

The plant is thus described by Mueller:-

shrubby, leaves alternate, rigid, coriaceous, shining, ovate or narrow-lanceolate, uncinate-acuminate, thinly veined, with scanty pellucid dots; umbels axillary, on a valid compressed peduncle; flowers large with a short and thick pedicel; hid from a hemisplyerical base contracted into a narrow cone, with radiating ribs; tube of the calyx campanulate, slightly constricted in the middle; generally twelve-ribbed, a little longer than the lid; fruits large, nearly bell-shaped, with scarcely contracted orifice; valves of the capsule inclosed: seeds blackish without streaks.

In the Mallee scrub, from the Murray River to Spencer's Gulf.

The nearest alliance of this species appears to be with E. cuspidata. (Trans. Vic. Inst., 1855, 33.)

The following year it was again described in the following words :-

27. Eucalyptus costata, Behr. et Müll. mass., Fruticosa, ramulis angulatis, foliis lanceolatis apice longiter attenuatis, basi inaequali in petiolum angustatis, coriaceis nitidis, tenere venosis, pedunculis axillaribus angulato-compressis petiolum subrequantibus 3-6-floris, pedicellis angulosis, calycis tubo conoideocyathimorpha costato, apice ampliato viridi, operculo fusco-nitente depresso hemisphacrico rostro brevissimo obtusiusculo acuto quam tubus duplo breviore.

Locis arenosis Sand-Scrub dictis prope Angastown (Behr).

Frutex 15 pedalis. Folia usque 4 poll. longa, 1 lata. Calycis tubus circiter $\frac{3}{4}$ pollices longus, 4 lin. in diam. operculum 2 lin. aequans. E. angulosae shauer [sic] in Walp. Repert. $\mathrm{ii}_{3}$ 925, affinis, operculi formâ autem diversa. (Miq. in Ned. Iruidk. Arch. IV, 136, 1856.)

I have seen a specimen labelled by Brown himself, as follows :-

E. costata, South Coast, Memory Cove and Bay 10, No. 58.

It will be observed that Brown's name was adopted by Mueller or Behr and Mueller, and following old precedent (e.g., that of E. melliodora and E. dumosa, named by Cumningham, but described by Schauer), the authority for the name is that of R. Brown.

E. costata, Behr and Müller, Boston Point.* (Herb. Barbey-Boissier. Label in Miquel's handwriting; "Plantæ Müllerianæ.")

* Port Lincoln, South Australia, 
These specimens were probably collected by Wilhelmi; I have seen specimens collected by him at this place, also from localities "coast opposite Tumby Island" and "Galway."

"E. costata, Behr et Müller, Marble Ranges, Nov. Holl. Austr. Frutex 10-12'. Leg. Dr. Ferd. Müller, Herbar. W. Sonder.' Herb. Cant. ex Herb. Lindl.

12. E. linopoda, R.Br.

From Memory Cove. Collected by Robert Brown.

13. E. rugosa, R.Br.

Collected by R. Brown at "Bay iii, 1802."

14. E. sulcata, Tausch.

Coll. Ferd. Bauer in herb. Baucr, ex herb. Vindob. is E. incrassata, Labill.

15. E. pachyphylla, A. Cunn. non. F.r.M.

Eucalyptus pachyphyllus, Cumningh.* MSS. "Grand arbrisseau croissant par" les bateaux. Le passage de Roi George (Cunningham)." No. 40, D'Urville. Evidently a specimen presented by Allan Cunningham. In flower and early fruit. It is $E$. incrassata, var. angulosa.

\section{(e) Var. goniantha, var. nov.}

16. E. goniantha, Turczaninow.

Eucalyptus goniantha ramis teretibus; foliis lanceolatis utrinque attenuatis viridibus opacis impunctatis; umbellis axillaribus 6-8 floris in paniculas collectis; pedunculis deflexis camplanatis; pedicellis, cupulis operculisque angulatis rugosis; pedicellis clavatis operculisque conicis obtusis cupulam duplo excedentibus, latitudine requalibus. Nova Hollandia, Drum, n. 71. (Turcz. in Bull. Soc. Nat. Iosc. $\mathrm{xx}[18 \pm 7]$, pt. 1, p. 163.)

Discussing the affinity of $E$. goniantha and $E$. incrassuta, Mueller says :-

E. goniantha comes still nearer" (than E. oleosa) to $E$. incrassata, but the leaves are somewhat more distinctly sickle-shaped, not so shining nor of such even smoothness, but slightly reticulated on their surfaces, the tube of the calyx is comparatively still more deeply furrowed, the attenuated upper portion of the lid broader and more blunt, while the anthers seem invariably heartshaped-globular, so far as this plant, of which we have as jet no ripe fruit, is known. (Eucalyptographia under E. incrassata.)

I am not aware that fruits of this form have been described; I have not seen them. But this form (from buds and flowers) is apparently so closely allied to var. ungulosu (and particularly to certain Victorian specimens, that I scarcely hesitate to describe it as a new variety of $E$. incrassata. The operculum is bluntish and the ribs of the buds are very pronounced.

Probably identical with "E. puchyphylla, Cunn. MSS., from King George's Sound (No. 231 of 4th voyage)." Footnote, Journ. Linn.Soc, iii, 98. 


\section{(f) Var, grossa, val, nov.}

17. E. grossa, F.v.M.

18. E. pachypoda, F.v.M.

\section{E. grossa, F.r.M.}

F. Muell. Herb. A stunted shrub (Maxwell); leaves from ovate and obtuse to lanceolate and acute, very thick and shining, under 3 inches long, the veins oblique, rarely conspicuous, the intramarginal one at a distance from the edge; peduncles axillary or lateral, often recurved, thick, and much flattened, with usually three large sessile flowers; calyx-tube turbinate, prominently ribbed, 4 to 5 lines long; operculum oblong, very obtuse, thin and smooth as in the Cornutre, as long as or rather shorter, perhaps sometimes longer than the calyx-tube ; stamens half an inch long, inflected in the bud ; anthers ovate-oblong, with parallel distinct cells; ovary short, convex in the centre; fruit not seen. W. Australia, Phillip's River and its tributaries. Maxwell.

I feel uncertain as to the aftinities of this species, the smooth cylindrical obtuse operculum is like that of the Cornutr, but the stamens are much inflected in the bud, and the flowers are otherwise quite those of the larger forms of $E$. incrassata. (B. Fl. iii, 232.)

\section{E. pachypoda, F.v.M.}

Fruticosa, divaricata, glabra, ramulis, validis mox teretiusculis apice sensim acuminatis crassocoriaceis concoloribus nitidus copiose et pellucide angulari-porosis, venis primariis lateralibus leniter patentibus cum venulis anastomosantibus, vena peripherica a margine tenuiter cartilagineo modice distante, pedunculis crassis solitariis vix latitudine propria longioribus 4-8 floris pedicellis nullis, calyeis supra medium circumscissi tubo semiovato-cylindrico vix angulato operculo semiovato coriaceo-chartaceo filamentis flaridis praefloratione infractis omnibus fertilibus, antherarum oblongo-0valium loculis parallelis longitudinaliter dehiscentibus, fructibus truncato-ovatis, margine orificii tenui, valvis 4 inclusis deltoideis, seminibus fertilibus parvis apteris. (Mueller, in Fragm. vii, 41.)

\section{Mueller gives a reference to B.Fl. iii, 233, where Bentham says :-}

In a specimen sent by F. Iucller from a tree grown in the Melbouine Botanic Garden from W. Australian seeds, and named by him $E$. pachypoda; the leaves are acute, as in Maxwell's specimen, but the peduncle is very thick and scarcely flattened, bearing more than three flowers, with ovoid calyces. The tree had not yet fruited, but it will probably not prove specifically distinct from E. Preissiana.

\section{Mueller says:-}

E. grossa (from which E. pachypoda, F.v.M., Fragmenta Phytographix Australix vii, 41, anno 1869 , is only separable as a variety) can best be distinguished from $E$. incrassata by its not distinctly compressed though stout umbel stalks, by the slightly angular but not furrowed tube of the calyx, by the semiellipsoid even lid, by the filaments inflexed near or towards the summit only, and by its not angular fruit with no narrow apex of the valves. (Eucalyptographia under $E$. incrassata.)

I do not think that $E$. grossa is specifically different from E. incrassata. Compared with the type it is a coarser form, and the buds and fruits have fewer corrugations. The operculum is less conical, the whole bud being nearly oval in shape. The fruits are more nearly cylindrical than those of the type, and the rim is more marked. 


\section{RANGE.}

IT extends along the coast of Western Australia and South Australia from near Shark Bay (the extreme northern range is as yet unknown) to near the Victorian border.

In dry inland localities it is found in Western Australia, South Australia, Victoria, and western and south-western New South Wales.

\section{WEstern Australia.}

Labillardière's type is from "Terra Van Leuwin," probably from the vicinity of King George's Sound.

No. 65 (3rd) Drummond, with sub-cylindrical fruits, shiny and not much corrugated.

Between Albany and William Rivers; Webb. (These specimens are very near to R. Bromn's No. 474S, and to Drummond's 65/184.ّ.)

"2990. Eucalypíns incrassatr, Lab., Arbor parva, 2-3 m. alt., trunco gracili. Stirling Range in fruticetis lapidosis collium." L. Diels, 30th May, 1901.

Var. scyphocalyx, F.v.M., Eyre's Relief Camp. Mueller's label is "Eucalyptus dumose, A.C., var, scyphocalyx."

The above are all near the type, and are figured on Plate 13.

Sand plains $\mathbf{N}$. from the Stirling Range, 10 feet. A small fruited form near var. dumosd. See Plate 16.

"Shrub, 6-8 feet. Bark, red. Limestone Hill, Lynton, Pt. Gregory, W.A." (Oldficld), Herb. Barbey-Boissier. A small fruited form, E. dumosu.

Elder Exploring Expedition Camp 49, Victoria Desert. R. Helms, 12/9/91. Blunt operculum, smallish fruit. The above are nearest to var. dumosc.

Coolgardie, R. Helms, June, 1899. Large sub-conical fruits, opercula blunt.

Near Coolgardie, E. Lidgey, Nov, 1900. Very similar to the preceding, but with smaller buds and fruits.

The above are connecting forms approaching var, angulose. 
Specimen collected by R. Brown (1802-5), South Coast. Coarse foliage, and approaching the blunt operculum form (E. rugosa).

No. 75. Drummond. Coarse foliage, broad foot-stalk, corrugated ealyx, and conical operculum. See Plate 14.

5448. 5th Nov., 1901. "Frutex $\frac{3}{4}-2 \mathrm{~m}$. alt. foliis glaucis. Gregaria in planitiebus limoso-arenosis subsalsis. Circa $50 \mathrm{~km}$. N. of Esperance" (L. Diels). In bud only.

3465. 19th July, 1901. Frut. 2-3 m. alt., ramis adscententibus. In humosis arenosis prope Cape Riche, una cum aliis Eucalyptis" (L. Diels). Large, ribbed fruit with broad foot-stalk. Very close to No. 75, Drummond.

S.W. Bay, W.A., Oldfield, in Herb. Barbey-Boissier, labelled "E. angulosa, Schaner."

"S.W. Bay, Australia" (Oldfield) Herb. Barbey-Boissier. A coarsc form in flower only. Reminds one of $E$. tetragona, but the anthers different.

"Euculyptus pachyphyllus, Cunningh. MSS., King George's Sound (1'Urville)." Doubtless a specimen collected by Allan Cunningham, and presented by him to the French Expedition. From Herb. Mus. Paris. No. 40. In flower and early fruit only. Foliage coarse and thick, with thick marginal veins; twigs angular. Not E. pachyphylla, F.v.M., which is E. diversifolia, Bonpl.

The above belong to var. angulose.

I have var. grossa from W. Australia. Bentham gives the locality "Phillip River and its tributaries (Maxwell)." I know no other.

\section{Soutif Australia.}

Sandy ridges, near Murray Bridge, W. Gill, 3/6/03. Fruit rather larger than typical var. dumosa, flattened foot-stalk and nearly sessile.

Gawler River (Dr. Behr), labelled dumosa by Mueller.

Gosse's Range, Central Aust. (Revd. Messrs. Schwartz and Schulze), with small fruits.

The above are near var. dumosa.

I have receired some Red Mallee from Mr. W. Gill, from Redhill, Hundred of Redhill, S.A., 30th November, 1901. Also from Halbury Station, between Gladstone and Balaklava, 50 miles south of Redhill. The valves are slightly exerted and it is indubitably var. dumos", with even smaller fruits than the type. It seems to show some resemblance to $E$. uncinata, and I may further refer to it when dealing with that species. 
Then we have var. conglobata, specimens of which have been collected at or near Port Lincoln by Wilhelmi and Gill. Probably the "Bays 9 and 10 and Island viii," of Robert Brown's labels are in the vicinity.

Eucalyptus costata, Behr and Mueller, "Boston Point" (Port Lincoln). Described by Miquel in his Plantre Müllerianæ (Ned. Kraidk. Arch IV, 1856). Leaves very thick and highly polished and the fruits very ribbed.

Ninety-mile Desert, Murray Desert, Tintinarra (W. Gill and R. H. Cambage). Varies a good deal in shape of fruit. Sometimes it tends to hemispherical, in others to sub-cylindrical and to be urceolate. Length of pedicel varies; sometimes it is nearly sessile.

The above are referable to var. angulosa.

Emu Flat, Ninety-mile Desert, W. Gill, 4/01.

Smallish conical fruits, with valves slightly exserted; blunt opercula, which are markedly ribbed and the buds show a marked constriction between operculum and calyx. This specimen connects with var. dumoso, also with the conical fruited and blunt operculum forms.

179. Eucalyptus incrassata, Labill., DC., Pr. iii, 217, No. 7. Differt a specimine auctoris; foliis fere crassioribus, in altera tantum pagina venas primarias nervumque marginalem conspectui praebentibus (in icone nimis fortiter et perspicue delineabantur), longius et fere subulato acuminatis, umbella paullo longius pedunculata. Attamen eandem habeo speciem, cujus calyptram in specimine unico non vidimus.

Auf kalkig-sandigem Boden (Sandplaine) bei Bethanien, Strauchartig, die Blätter voll von ätherischem oele. (Schlecht. in Linnæa, vol. 20, p. 658.)

I have not seen this specimen.

\section{ViCTORIA.}

Lake Hindmarsh (Bosisto) typical var. dumosu.

Lake Bogan, River Murray (A. W. Howitt).

The Wimmera, also Murray River (Mueller).

A coarse form of var. dumosa, intermediate between it and the type.

Dimboola (F. Reader). Fruits a little smaller than the preceding, a little ribbed, and the valves slighly protruding. Another intermediate form.

Lake Hindmarsh, C. Walter, Oct. 1899. Sub-conical fruits and intermediate in character between var. dumosa and the type.

All the above are, perhaps, nearest to var, dumosd. 
Dimboola (F. Reader). Fruits tending to hemispherical and sessile or nearly so. Of medium size. Very similar to those from South Australia. (Murray Bridge, W. Gill, 6/03.)

Wimmera. F. Mueller.

Euston to Swan Hill (A. W. Howitt).

Lake Ilindmarsh (C. Walter). Fruits of medium size. Similar to Ninetymile Desert.(S.A.) specimens.

Dimboola (St. Eloy D'Alton, F. Reader, and H. B. Williamson). Operculum more or less rostrate, buds and fruits ribbed and rather large and show much constriction in drying unless fruits are quite ripe.

Typical var. angulosa.

Nhill; St. Eloy D'Alton, with fruits less ribbed and with purple bases to the filaments. Rim well defined, reminding one of E. leucoxylon and melliodora.

All the above are referable to var. angulosa.

\section{New SoUTH Wales.}

I have no record of typical var. angulosa, the large-fruited form of incrassate, being found in this State, all the forms being referable to var. dumosa.

I have already pointed out that $\Lambda$. Cunn.'s $E$. dumosa came from what is now the Wyalong-Booligal mallee country. Much of it is in the county of Bland. The mallee country (it is by no means all rar. dumosa) probably covers 15,000 or 20,000 acres.

Wyalong (H. Deanc, W. S. Campbell). A type locality, see Plate 16.

The latter wrote:- "Light-coloured stems, rather narrow leaves, and lightcoloured bark." The mallee trees are up to, say, 20 feet in height, with a stem diameter of, say, 6 inches.

Balranald (G. S. M. Grant).

Red Mallec, Barham, Murray River (Asst. Forester Chanter).

Gol Gol. (1. W. Howitt.) Sub-conical fruits with slightly exserted valves.

Coolabah, J. L. Boorman, June, 1901. "Mallee. Small stunted trees, growing on high ridges, stems thin, leaves large. Stems slightly ribbony at the base."

Darling River (Burke and Wills Expedition).

Messis. R. H. Cambage and J. L. Boorman have collected it this side of the Darling (Cobar District). The former says it is known as White Mallee, because it has white smooth bark to the ground, and that it is usually found growing with E. oleosa, these two forming mallee scrubs. 


\section{AFFINITIES.}

1. E. torquata, J. G. Luehmann (Vict. Nat., xiii, p. 147, 1897).

Luehmann says :- "It seems to have the greatest affinity to E. incrassato, especially as regards the anthers."

Mr. Luehmann, at the time of describing his species, had not seen the fruits. A figure is given at Plate 13, and they may be described as follows:-About half an inch long, with a width of half as much; nearly cylindrical. The outside of the fruit has corrugations, but tapering from half-way up the fruit the corrugations gradually enlarge in size to the base of the fruit, forming about nine wing-like processes. These wings then sharply taper into the elongated pedicels forming incipient wings on the pedicels, a very rare occurrence in any Eucalypt. The rim of the fruit is well defined, sloping to the mouth, which is very slightly constricted. The slender valves are free, but the tops appear never to rise flush with the mouth.

M[r. L. C. Webster, who states that he originally found E. torquata, has furnished me with the following particulars in regards to its occurrence in the Coolgardie district of Western Australia :-

I have traced this eucalypt growing in a belt over 25 miles long by about a quarter of a mile wide. The belt runs almost east and west (a ferv points south of east), and outside of this belt I have only been able to discover a few isolated trees.

The country through which they run is composed of diorite, with traces of ironstone occurring here and there through the diorite.

The trees for the most part follow the course of a ridge of low hills, and grow more plentiful on these hills than where they cross the plains. The trees grow from 20 to 30 feet high; the trunks usually range from 4 to 10 feet from the ground to the branches; the rough bark goes from the ground to the branches, then the branches are smooth; very free flowerer; blooms first week in September to end of December. [S'ee illustration, p. 120.]

2. E. corrugata, Luehmann (Vict. Not. xiii, p. 168, 1897).

Mr. Luehmann says :-

This species is evidently allied to E. incrassuta, but none of the forms of that species have such high ridges nor the same hemispheric shape of the calyx and operculum.

It is evidently closely allied to the var. goniantha of E. incrassata and to the form with hemispheric operculum, figured at Plate 15, fig. 6a. I have not seen the species.

3. E. frecunda, Schauer.

E. incrassatc shows close affinity to this species, but their relation will require a more detailed explanation than is convenient at this place. The matter will be gone into at some length when $E$. foecunda is dralt with. (See p. 117.) 


\section{E. erythronema, Turez.}

There is a form of this species which I have termed var. Roei.

1. (E. Roei, Beck, in Herb. Vindob), "inter Swan River and King George's Sound." Roe (Hügel), (Herb. Vindob).

2. No. 5,831. "W. Australia inter Norseman et Esperance Bay in fruticetis apertis in lapidosis limosis." (L。 Diels, 2nd Nov., 1901.)

It has fruits which might readily be confused with those of the typical form of $E$. incrassala, and this note is inserted as a caution.

\section{E. falcata, Turcz.}

The affinity of $E$. incrassata with this species will be dealt with when treating of $E$. decurva, a species to which the former is closely related.

\section{E. oleosa, F.v.M.}

The foliage of the species is that of $E$. dumose, but it is well distinguished by the longen' pedicels, the shape of the calyx, the thinner operculum, and the shape of the fruit. (B. Fl. iii, 249.)

Mueller also drew attention to the possibility of confusion between the two species :-

Among the species constituting the mallee scrub on an extensive scale, only $E$. oleosa belongs also to the Parallelantheræ, from which E. incrassata can be distinguished by its often broad and flat flower stalks, furrowed or streaked and mostly larger shining calyces, with a lid more depressed towards the base, generally more elongated anthers, as also shorter and therefore less exserted fruit-valves.-(Eucalyptographia under $E$. incrassata.)

I do not think the two species are very likely to be confused. I do not know a large-fruited form of $E$. oleost, so that the similarity rests between E. oleosa and $E$. incrassata, var. dumosa. As a rule, the longish operculum of $E$.oleosa is quite sufficient to distinguish the forms, and the cohesion of the valves common in E. oleosa is rarely, if ever, seen in var. dumosa. To put observers on their guard, it will probably be quite sufficient to publish this note that it is possible to confuse them.

7. E. uncinata, Turez.

E. uncinata, Turcz, var. rostrata, Benth. (B.Fl. iii, 216), Drummond's No. 186 of the 5th Collection, shows affinity in anthers and some other respects to $E$. incrassata. I will deal with this specimen when I come to E. uncinata.

\section{E. concolor, Schauer.}

Is related to $E$. incrassata through the var. conglobala of the latter, but since drawings of the former species will make the matter quite clear, I will postpone my explanation until dealing with $E$. concolor. 


\section{E. Kitsoni, J. G. Luehmann.}

In the globular head of fruits and in the shape and sculpture of individual fruits this species shows undoubted resemblance to $E$. incrassata, var. conglobata.

\section{E. Planchoniana, F.r.M.}

E. Planchoniana approaches in some of its characteristics $E$. incrassata, but irrespective of its not belonging to the desert country, it is a comparatively tall tree, the leaves are longer, not so shining, have more spreading, more distant, and more prominent veins, and their stomata only on the lower page; the tube of the calyx is less turgid, the lid more gradually attenuated upwards; the anthers are never elongated to an oblong form; the outer stamens are not bent downwards while in bud, but are somewhat flexuous; the valres of the fruit are not narrowly attenuated at their apex, and the fertile seeds are more angular.(Encalyptographia, under $E$. incrassata.)

Mueller is alluding to the coarse-fruited form (var. angulosa) of E. incrassata. Undoubtedls the buds, fruits, and flattened foot-stalks present considerable similarity to each other. The anthers are of course different and the leares of E. Planchoniana are longer and more falcate, usually thinner and of quite a different colour. $E$. Planchoniana is a small timber tree with pale timber.

\section{E. cosmophylla, F.v.M.}

To this smooth-fruited variety approaches very closely $E$. cosmophylla, from the stringy-bark tree forests of the mountains of St. Vincent Gulf, which species shows, however, more pointed, generally broader, and less shining leaves, with more visible veins, the flowers less in number and on a shorter common stalk, and rather an increase in the number of fruit-valves,-(Eucalyptographir, under $E$. incrassata.)

I do not call to mind a smooth-fruited form of $E$. incrassate with fruits as large as those of cosmophylla; still there is a certain amount of superficial resemblance between the foliage and early fruit of $E$. cosmophylla and that of the large-fruited form of $E$. incrassata.

12. E. gomphocephala, D́C.

Speaking of $E_{0}$ dumosa, var. scyphocalyx, Bentham remarks, "This approaches in some measure E. gomphocephala." (B.Fl. iii, 230.)

The swollen operculum and the more open-mouthed fruit of E. gompho. cephala are sufficient to separate the trro species; at the same time, in foliage, flowers, \&c., there is a likeness between the two plants which is obrious. 


\title{
DESCRIPTION.
}

\author{
E. frecunda, Schauer.
}

\section{Follow ing is the original description :-}

Fruticosa, lavis; foliis coriaceis, alternis, anguste lanceolatis, sensim in petiolum attenuatis; in acumen tenue contractis, viridibus, nitidis ; umbellis axillaribus terminalibusque, 5-8-floris, subpaniculatis ; pedunculo compresso, petiolum subæquante; pedicellis hypanthio continuis et subæqualibus; hypanthio (fructus) turbinato; operculo...... (fructibus umbellatis $3 \frac{1}{2}$ lin. longis truncatis). In clivulis calcareis haud procul ab colonia Fremantle, Aug. M. 1839, fructifera.-Herb. Preiss. No. 231.

Frutex 5-pedalis, ramis virgatis. Folia cum petiolo $2 \frac{1}{2}$ poll. longa, 4-6-lin. lata, sicca tenuiter reticulata, imperforata. Capsula 3-rarius 4-locularis, vertice valvis subulatis paulloque ultra marginem hypanthii exsertis dehiscens. - E. radiata, Sieb. affinis (in Lehmann, Pl. Preiss, i, 130).

Aboriginal Name,-By the aborigines of the ILurchison River it is known as "Ooragmandee,"

\section{SYNONYMS.}

\section{NOTES ON THE SYNONYMS.}

\author{
Var. loxophleba, J. G. Luehmann.
}

1. E. loxophleba, Benth.

2. E. amygdalina, Schauer non Labill.

\section{E. loxophleba.}

A tree from 10 to 30 feet high, with a rough ashy-grey fibrous bark (Oldfield), 40 to 45 feet, the bark separable in layers (Preiss). Leaves lanceolate, acuminate, narrow, and often 4 to 5 inches long, or the lower ones shorter and broader, all rather rigid with very oblique, rather distant and prominent veins, the intramarginal one distant from the edge. Peduncles axillary or lateral, terete or slightly flattened, each with a dense umbel of 6 to 12 flowers. Calyx tube obconical, 2 to 21 or rarely nearly 3 lines long, tapering into a short pedicel. Operculum hemispherical or obtusely conical, shorter than the calyx tube. Stamens scarcely exceeding 2 lines, inflected in the bud, the filaments usually dark coloured in the dry specimens; anthers small, with parallel distinct cells. Fruit narrow-obovoid, truncate, straight or slightly contracted at the orifice, rarely above 3 lines long and 2 lines diameter, the rim narrow, the capsule deeply sunk.

E. amygdalina, Schau. in Pl. Preiss I, 130 (from the description given), not of Labill., E. fruticetorum, F. Muell. Fragm. ii, 5 T (as to W. Australian specimens). W. Ausl`alia, Swan River and Darling Range, Collie; Drummond 2nd Coll. No. 82; York District, Preiss. n. 246 (and 248?); Murchison River and Champion Bay, "York Gum," Oldfield. (B.Fl. iii, 25.) 
A figure is given by Mueller in Rep. Forest Resources, W.A., t. 5 .

Never a very high tree, seldom exceeding 80 feet, not rarely of crooked growth; stem rarely above 4 feet in diameter. The bark is persistent and rough, and draws this species into the Rhytiphloiæ; inside it is red like that of the Morrel Eucalypt, E. longicomis. (Mueller, Forest Resources of W.A.).

Vernacular Name.--"York Gum," as it is very abundant near the town of York, Western Australia.

Aboriginal Names.-Its most common aboriginal name is "Yandee."

The "Yandee," a tree of 40 to 45 feet, with a nearly black persistent furrowed bark consisting of strap-like pieces, from the Murchison River, Oldfield, appears to be otherwise precisely the same as E. loxophleba. (B.Fl. iii, 252.)

I have the name "Yatthae" as an aboriginal name for this species.

Timber.-The aborigines use the wood of this tree for making spears, on account of its hardness and elasticity. (Waleott.) Samples of this timber were sent to the Colonial and Indian Exhibition under the name "York Gum." Mr. Allan Ransome reported as follows :-

This is a light pink wood, close-grained, hard, and heavy. The samples submitted being very small, only spokes could be made from them; for which purpose the wood seems eminently adapted.

The wood is regarded as the very best in Western Australia for naves and felloes, on account of its toughness; though not sufficiently fissile to be split into rails, it is for this very reason preferentially sought for many superior purposes by artisans.-(Mueller, Forest Resources of W.A.)

0il.-Eucalyptus loxophleba, Benth., ${ }^{*}$ is usually called York Gum. The oil has a highly unpleasant odour, and produces fits of coughing when inhaled. Sp. gr. 0.8828 at $15.5^{\circ}$; angle of rotation about $+5^{\circ}$. Upon distillation the following fractions were obtained:- $168-171^{\circ} 68$ p.c.; $171-176^{\circ} 14$ p.c.; $176-182^{\circ} 2$ p.c.; $182-187^{\circ} 8$ p.c.; residue 8 p.c.

The oil contains phellandrene and cineol. The amount of the latter is estimated at 15-20 p.c., which allows of the conclusion that a considerable amount of aldehydes and ketones is present. Amyl alcohol, of which small quantities were found in the oil of E. globulus, and to which, no doubt, are partly due the irritating action of this oil, is not present. (Parry.)

loxophleba, Benth., var. fruticosa, Benth.

A shrub branching from the ground, the leaves rather broader, the peduncles more flattened. Murchison River, Oldfield; Salt River, Maxwell. (B.Fl. ii, 252.)

This supposed variety is figured from two specimens kindly furnished by the Director of the Royal Gardens at Kew. Plate 23.

I have three leaves, a fruit, a bud, and one flower containing a few stamens. It seems to me that the specimens are nearer to E. odorata, Behr, than to

* Pharm. Journ., 61, p. 198. This article by Parry gives the species name as toxophleba. 
E. focunda, Schauer. The anthers appear to be nearer to those of E. odorata than to $E$. foecunda. The fruit seems to be that of $E$. odorata. The leaves with the mucrones are precisely the same (as far as I can see) as young foliage of $\boldsymbol{E}$. odorata; I have not seen any of the same shape belonging to $E$. frocunda.

E. fxecunda is, so far as we know at present, limited to Western Australia (the localities for E. loxophleba, var. fruticosa, are Western Australian), and $E$. odorata is not certainly known to extend to Western Australia. Allowance must be made for the paucity of tha material at my disposal, but I submit my determination for consideration.

\section{E. amygdalina, Schau.}

Arborea; lrevis, foliis firmis, alternis, anguste lanceolatis, in petiolum attenuatis, cuspidato acuminatus, pallidis, nitidis, areolis retis magnis lanceolatis; umbellis axillaribus, 5-8-floris; pedunculo subancipiti, petiolum aequante; pedicellis brevibus; hypanthio obconico-cyathiformi ; operculo subconicohemispherico, obtuso, hypanthio multo breviori. Lab. Nov. Holl, pag. 14, tab. 154? .In solo sublimoso arenoso districti York, Martio M. a 1840 cum alabastria adultis. Herb. Preiss. No. 246, et similibus in locis montis Mathilda distr. York, cum fructibus No. 248 (v. sp. orig. in Herb. Willd. n. 9,598?).

Arbor 45 pedes circiter alta, cortice per strata solubili ramulis gracilibus. Pedicelli in nostra longiores, fructus minores quam in planta Billardierana, quae ceterum omni nota congruere videtur, quantum quidem ex speciminibus satis mancis judicare licet (in Lehmann, Pl. Preiss, i, 130).

\section{E. foecunda and E. loxophleba.}

But the real affinity of the species here under consideration ( $E$. focunda) is with $E$. loxophleba; indeed it remains unascertained, whether that tree is or is not the arboreously-developed state of $\boldsymbol{L}$. focunda, arisen in humid mountain regions and in a deeply pervious soil; it differs irrespective of its tall growth (to about 100 feet, with a stem diameter to 4 feet) in generally longer leaves with rather more distant, also often more prominent and less spreading veins, the intramarginal one not close to the edge of the leaf, in the oil-glands being to a large extent pellucid, and the anthers generally shorter ; but these particular characters are subject to some variations, and unless it can be shown that $E$. frecunda in its youngest state has not the roundish cordate leaves of $E$. loxoplleba, we could not venture to keep the two specifically apart. Under these circumstances no distinct plate and description will be devoted to L. loxoplleba in this work, but on the present oceasion some references may aptly be given of that useful tree.-(Eucalyptographia under E. foecunda.)

J. G. Luehmann (Prcc. A.A.A.S. VII, 1898, Sydney Meeting, p. 529), states: E. focunda. Leaves nearly straight, very shining. E. frecunda (includes loxophleba as a variety).

I have on the strength of this specific statement attributed this variety to iuehmann. I quite agree with him. As compared with E. feecunda, the var. loxophleba has longer leaves, rather more distant and often more prominent, and less spreading veins, the intramarginal vein is not close to the edge of the leaf. The most obvious character of the variety is its marked venation. 


\section{RANGE.}

\section{Typical Form.}

IT is confined to Western Australia so far as we know at present. Following are specific localities :-

Limestone Hills, near Fremantle, Preiss No. 231. (Type.)

"Inter Swan River et K. G. Sound." Roe (Hügel). Herb. Vindob.

Drummond, 2nd Coll. No. 87 (Bentham). Figured at Plate 22. I have seen specimens in Herb. Kew, Herb. Cant, \&c.

Yenert, Gilbert No. 263 (Bentham).

Shark Bay and Dirk Hartog's Island, Milne (Bentham).

Port Gregory, Murchison and South Hutt Rivers, Oldfield (Bentham).

"Murchison R., W.A., Oldfield, 782 B."

"2nd Valley, near Yadthoo, Murchison R., W.A., Oldfield." Bentham.

Both specimens in Herb. Barbey-Boissier, and both labelled E. frecunda by

"Red Sandstone Hill, Minara, Murchison R., W.A. (Oldfield)." Herb. Syd. ex. Herb. Kew.

" 3,295 , frutex $\frac{3}{4}-1 \mathrm{~m}$. alt. Greenough River in fruticetis limoso-arenosis." (L. Diels, 2/7/01.)

South Australia? "Specimens in young bud and in fruit from the S. coast, $\boldsymbol{R}$. Brown, appear to belong to this species." (B.Fl. iii, 253.) I cannot be certain as to the specimens referred to by Bentham. Perhaps they are those from "Bay iii," referred to below.

\section{Variety loxophleba.}

This variety appears to be confined to Western Australia.

On the eastern tracts of the Darling Ranges a main constituent of the forests, extending only through a narrow strip of country eastward beyond them, spreading northward in a variety called by the natives "Yandee," and according to Mr. J. Forrest, eastward as far as Kojenup, and thence southward to near King George's Sound. 
This tree occupies more particularly the eastern slopes of the Darling Range, not entering the western tracts where the Jarrah ( $E$. marginata) forms the main forest. It is content with poor soil. (Mueller, Forest Resources of W.A.)

Following are specific localities, and notes on specimens :-

Drummond's No. 82.

"Tree, 25-30 feet; bark rough, fibrous. Hills near Okagee, Champion Bay. (Oldfield), W.A." Specimen in Herb. Barbey-Boissier, labelled $E$. loxophleba, by Bentham.

"Shrub, 6-8 feet, branching from root; main branches oblique; bark, red. Limestone Hill, Lynton, Pt. Gregory, W.A." (Copy of label in Oldfield's handwriting. This specimen has thick coriaceous leaves, and is figured at Plate 24. Bentham labelled it "E. loxophleba, Benth.")

No. 509. "District Avon; in silvis valde apertis prope. E. Pritzel. Plantæ -Australiæe occidentalis." August, 1901.

“ 2,579. Arbor $20 \mathrm{~m}$. alt. basi ramosa foliis atro-viridibus. Prope Newcastle una cum Acaciis silvas formans in solo limoso." (L. Diels, W. Australia, 26th February, 1901.)

3,037. "Una cum Acaciis silvas formans in solo limoso pr. Minginew (Irwin River), Western Australia." (L. Diels, 9th June, 1901.)

2,914. "Arb. 8-15 m., foliis sordide albidis, stylo rubro. Pr. York frequens. W. Australia." (L. Diels, 24th May, 1901.)

"Northam, W.A., July, 1898. Stamens pale yellow." (W. V. Fitzgerald.) 


\section{AFFINITIES.}

\section{E. incrassata, Labill.}

........" also in the collection of Baudin's Expedition. Different as the long and the short fruits appear, there are numerous intermediate forms, and the specimens do not otherwise differ." (B.Fl. iii, 253.)

Doubtless Bentham referred to the following specimens, which I also have examined, in the Paris Museum and in other collections.

"Voyage du Capitaine Baudin, 1801, Nouv. Hollande. Iles Steriles." In bud only : buds dark, small lanceolate coriaceous leaves, venation not prominent.

This series appears to me to show transit between $E$. foecunda, Schauer, and $E$. incrassata, Labill. In fact the coarser specimens seem undoubtedly to approach $E$. incrassata. The rim of the fruit is reminiscent of $E$. incrassata; the buds of the smaller forms remind one a good deal of var. dumosa of that species; the anthers are also, though slenderer, similar to those of incrassata (as well as of $E$. foecunda). In other respects, even to the blue-green of the foliage (particularly noticeable in some leaves) the affinity of these forms is with $E$. foecunda.

The localities for the plants collected by Captain Baudin's Expedition that are available to me áre labelled either "Iles Steriles,"* "Ile Decrès," (Kangaroo Island) or simply "Côté Occidentale." If by this is meant (in any instance) the west coast of Western Australia, I shall be glad of any information as to his collecting grounds.

Let us examine some further specimens.

"No. 3,226. Frut. 1-2 m. alt. White Peak, pr. Champion Bay, in limosis lapidosis." (L. Diels, 28th June, 1901.)

These specimens are in bud and fruit only.

- "Iles Steriles." It is very important to trace the localities whence the old collectors obtained their plants. We see this locality again quoted "Iles Steriles (Récherché Archipelago?) Herb. Mus. Par. I am not sure which of the islands off the south or west coast are provisionally designated under the above name, which appears never to have been published." (Bentham in B.Fl. vi, 67.)

The Recherche Archipelago is between $120^{\circ}$ and $125^{\circ}$ east longitude (e.g., between King George's Sound and the Great Australian Bight). See Flinders" Charts, \&c., "South Coast, sheet i" (to aceompany his Voyage to Terra Australis).

There is a coast discovered by Capt Nicholas Baudin, 1802, in Flinders' Charts (South Coast, sheet iv), which is now included in South Australia, including The Coorong to the vicinity of Cape Buffon (approaching the South AustralianVictorian boundary).

So that the localities of Captain Baudin's plants are probably either from the south coast of Western Australia or from the South Australian coast. 
The buds and the peculiar bluish-green tint of the twigs remind one of Captain Baudin's specimens of $E$. frecunda. The sub-conical fruits remind one irresistibly of some $E$. incrassata from Victoria (e.g., C. Walter, Lake Hindmarsh, Oct., 1899), in fact, I am unable to distinguish between them. I go so far as to say that Diels' specimens would have been named $E$. incrassata had they been found in Victoria, and Walter's specimens would probably (except, perhaps, because of the more pointed operculum) have been named focunda had they been found in Western Australia.

While, partly in view of Baudin's specimens, feeling that they belong to $E$. fecunda, I label them as undoubtedly showing transit to $E$. incrassata.

A specimen collected by R. Brown, and bearing the only label in his handwriting "Bay iii"* (south coast of Australia, South to West Australia), is in bud only. It was collected 1802-5, and was distributed by the British Museum in 1876. I have figured it at Plate 19, fig. 5.

I do not remember to have seen anything precisely like it.

I look upon it as another of the forms between $E$. frecunda and E. incrassata. I will content myself with pointing out that the "egg-in-egg-cup " arrangement of the buds, i.e., the swollen calyx, of larger diameter than the ovate operculum, remind one of $E$. salubris. The egg-in-egg-cup arrangement is less frequently seen in $E$. incrassata, but it is sometimes seen in that species. The fruits of E. salubris also remind one of those of Robert Brown's specimens of $E$. incrassata var. conglobata of "Bay ix." Perhaps these few suggestions will help botanists to elucidate the "Bay iii" specimens, but I think further collecting on the South Australian and south coast of Western Australia is necessary.

It is sometimes not easy to define the boundary between $E$. foecunda and the var. dumosa of $E$. incrassata. E. incrassata has usually broader leaves, and the timber is paler. The buds and fruits of E. focunda are not at all, or only very slightly, angular; those of var. dumosa usually show, even in the smoothest forms, a slight corrugation. The buds of $E$. frecunda are usually more pointed, but this is not an absolute criterion. The fruits sometimes tend to those of E. piperita in shape. No form of $E$. incrassata attains large size, so far as is known, and E. frecunda, in its typical form, is but a shrub.

I frequently cannot distinguish between the anthers of E. incrassata and E. foecunda. Turning to the Flora Australiensis and Eucalyptographia for guidance we find :-

incrassata. - Anthers ovate-oblong with distinct parallel cells (B.Fl.). Anthers from roundish-oval to almost oblong, opening by ample longitudinal slits (Eucalyptographia).

"In Robert Brown's handwriting a number of his apecimens collected on the south coast of Australia are labelled with provisional localities, e.g., "Bay iii," "Bay viii," "Bay ix," and so on. I cannot trace them in Flinders' Chart or Journal, and perhaps some of Brown's MS. notes or ampler labels in some herbaria may give clues to their precise localities, and then we shall be in a position to collect additional material and set at rest the identity of a number of Bruwn's specimens. 
The peculiar quadrangular anthers figured in that work seem somewhat diagrammatic.

foecunda.-Anthers ovate, with parallel distinct cells (B.Fl.) Anthers nearly ovate, opening by parallel slits (Eucalyptographia).

I cannot find the connective a double gland, as shown in that work. (B. Fl.).

loxophleba (considered a separate species in B.Fl.).-Anthers small, with parallel distinct cells

It is further stated that the filaments are usually dark-coloured in the dried specimens. I find this in focunda also.

If the above definitions be analysed it will be observed how little different the anthers of the two species are. When one comes to what I usually call "transit" forms, it becomes frequently perplexing to say to what species a certain anther belongs. As a rule, the anthers of $E$. focunda are smaller and paler than those of $E$. incrassat", but this character has its exception. I have, therefore, thought it best to submit a number of drawings of anthers of the two species, from illustrative specimens, and I think the anthers assist in strengthening the evidence afforded by other parts of the plants, which I advance to show that there is real affinity between $E$. incrassata and $E$. focunda, and that indeed they run into each other.

2. E. odorata, Behr.

$E$. focunda and $E$. odorata specifically resemble each other very closely, and frequently the leaves and fruits are difficult to separate. At page 114 I have expressed the opinion that $E$. loxophleba, Benth., var. fruticosa, Benth., is really E. odorata.

As a very general rule Bentham's description of the anthers ("very small with globular distinct cells") holds good for E. odorata. At the same time I would like to emphasise the point that anthers vary like every other organ in Eucalyptus, that they vary in size and also in shape. I have never seen them quite of the shape of those figured by Mueller in Eucalytographia,* but certainly the openings do sometimes tend to depart from the circular form (pores) and tend to parallel openings.

The timbers of $E$. focunda and $E$. odorata resemble each other a good deal. But the two species are sharply separated by their juvenile foliage, that of $E$. facunda being broadish, as figured (Plate 24) that of $E$. odorata being narrow, oblong, and often with a mucrone.

3. E. fruticetorum, F.v.M., Fragm. ii, 57.

This is (as regards the Western Australian specimens) identical with E. loxophleba, Bentb. (B.FI. iii, 252.) I have shown (Part III, p. 80 of this work) that $E$. fruticetorum is a synonym of $E$. calyco'jona, Turcz.

- As figured in Eucalyptographia they are nearly square in outline; the openings, as shown, are certainly not pores and not parallel cells, but intermediate between Parallelantheræ and Renantheræ. 


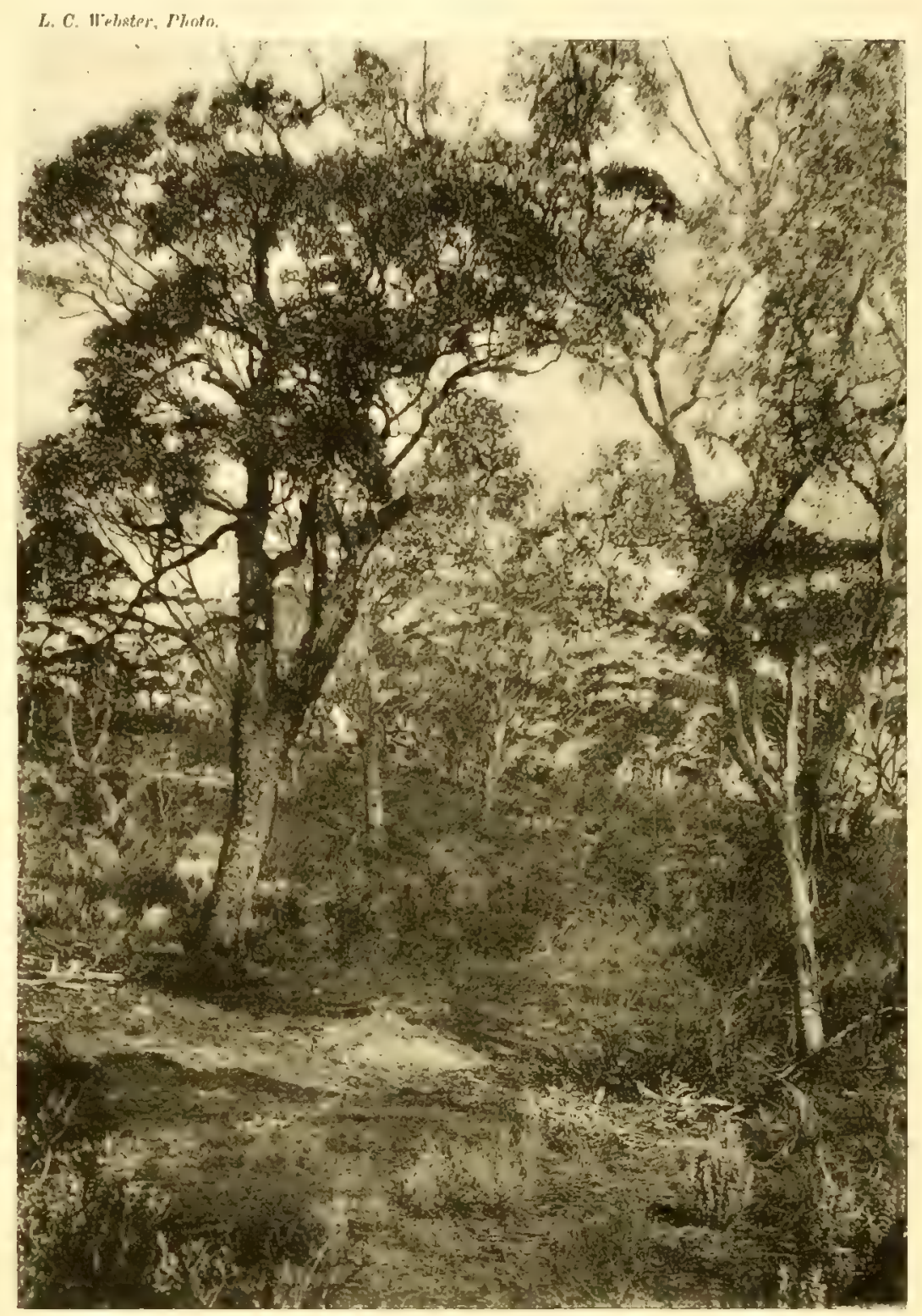

Eucalyptus torquata, Luehmann. Coolgardie, W.A.

(The tree with the rough bark.) 


\section{Explanation of Plates.}

\section{PLATE 13.}

1. Facsimile of portion of drawing of type of $E$. incrassata, Labill., from tab. 150, "Novæ Hollandire Plantarum Specimen," vol, ii.

The renation is, as Mueller has pointed out, too straight.

2œ. Flowering trig; ; 2b, Fruits. Both No. 65 (3rd Collection), Drummond, Western Australia.

3a, 3b. Leares and fruits. "Between Albany and Williams River," Western Australia (Webb.), from Melbourne Herbarium. (See page 105.)

4. Diels' No. 2,990. Western Australia. See page 105.

(Compare with $E$. erythronema, Turez, var. Roei, Maiden, as regards shape of fruits. See page 110.)

כa. Flowering twig; 5b, Front and back view of anther; 5c, Fruits, of Eucalyptus dumosa, var. scyphocalyx" (so labelled by Mueller), Eyre's Relief Camp, Great Australian Bight, W.A. Near typical incrassata. See page 105.

6a. Buds and flower; 6b, Front and back view of anther; $6 c$, Fruits. All of E. torquata, Luehmann. From Coolgardie, Western Australia (L. C. Webster). See page 109.

\section{PLATE 14.}

1. Flowering twig; of No.75, Drummond. Note the broad foot-stalk, the corrugated calyx, and conical operculum.

2. Fruits and leaf of "Eucalyptus costata," Behr., and Müller, Boston Point, in Miquel's "Plantæ Mülleriana." See page 102. Fruits very ribbed (costate).

3a, 3b. Twig (in flower) and early fruit of Eucalyptus angulosa, Sehauer. "S. W. Bay, W. Australia" (Oldfield). See page 10 ?

t. Twig showing buds of E. rugosa. Robert Brown (1802-5), southern coast of Australia. This specimen is in Herb. Mus., Paris, which it reached vid Kew. Note that this specimen approaches the blunt operculum form, Plate 15, figs. 5 and 6.

5. Fruits. Near Port Lincoln, South Australia. (Walter Gill.)

\section{PLATE 15.}

1a, 1b. Buds and anthers (three views), Dimboola; Victoria. (F. Reader.)

2a, 2b. Ninety-Mile (Murray) Desert, South Australia. (W. Gill.) Constricted and sub-cylindrical forms of fruit taken from the same branch.

3a, 3b. Buds and fruits. Murray Desert (Tintinarra), South Australia. (R. H. Cambage.) The fruits are nearly sessile.

4. Fruits. Dimboola, Victoria. (F. Reader.) Even more sessile than the preceding.

5a. Twig with buds; $5 b$, Anthers, front and back view; $5 c$, Twig with fruits; $5 d$, Top view of fruit. All from Coolgardie, Western Australia. (R. Helms.) Note the blunt opercula, and the large, sub-conical fruits. See page 105. Note the similarity (except in size) to 6.

6a. Twigs with buds and flowers; 6b, Anthers; three different views. Camp 49, Victoria Desert, Elder Exploring Expedition, 12th September, 1891. (R. Helms.) Note the blunt operculum and smallish fruits. See page 105.

7a. Buds. 7b. Fruits. Emu Flat, Ninety-Mile Desert, South Australia. (W. Gill.)

Note the shape of the opercula, bluntish, corrugated, and less in diameter than the calyx, tending to form the "egg-in-egg-eup" arrangement. This connects the type with var. dumosa, and with the conical-fruited and blunt operculum forms. See page 107. Compare Plate 21, tigs. 1a, 1b,

The fruits are sub-conical in shape, and intermediate in size between $5 c$ and 76 .

8. Fruits. Gol Gol, near Wentworth, N.S.W. (A. W. Howitt.) Sub-conical in shape. 


\section{PLATE 16.}

1a. Twig with buds and flowers; 16 and $1 c$, Fruits, $E$. dumosa, A. Cunn., from near Wyalong, N.S.W., and one of the localities whence Allan Cunningham collected his type.

$2 a, 2 b$. Front and back views of anthers of $E$. dumosa from Coolabah, N.S.W., and Cobar, N.S.W., respectively, from plants absolutely typical for Cunninghams plant.

3. Fruits of var. dumosa, Dimboola, Victoria. (F. Reader.) Note the exserted valves, which are occasionally observed in the species.

4. Specimen of variety dumosa from De Candollean (Prodromus) Herbarium. De Candolle's label was "34, E. cneorifolia, DC., altera species. (2). Species foliis oblongo lanceolatis." This specimen is fully discussed at p. 98 .

5a. Twig with buds; 5b, Fruits. Lake Bogan, River Murray; N.S.W. (A. W. Howitt.) A rather coarse form of variety dumosa and tending to the typical form of the species.

6a. Buds and flowers; 6b, Front and back views of anther; $6 c$, Fruits. Sand plains north from the Stirling Range, Western Australia. A rather coarse, sessile-flowered form of the variety dumosa, illustrative of the great amount of the variation in the species incrassata. See p. 105. Compare Plate 21, figs. $2 a, 2 b$.

\section{PLATE 17.}

var. conglobata, R. Br.

1a, 1b. Twig and separate head of fruits of Eucalyptus incrassata, Labill.; var. conglobata, R. Br. Port Lincoln, South Australia. (W. Gill, Dec, 1901.) See p. 101.

$2 a, 2 b$. Flowering twig and anthers of "E. dumosa, A. Cunn.; var. conglobata, R. Br." Port Lincoln, Wilhelmi (Herb. Melbourne). A type of E. dumosa, var. conglobata (R. Br.; B.Fl. iii, 230). See p. 101 .

3a, 3b. "E. dumosa, var., Kangaroo Island, South Australia. Iter 1802-5. Robert Brown." No. 4,748 of the British Museum collections, distributed by Mr. J. J. Bennett in 1876.

As regards $3 b$, see my remarks at p. 101. It is probably a detached twig; nearer to var. dumosa than to var. conglobata.

4. "E. dumosa, var." "Island viii, South Coast" (South Australia). Robert Brown, 1802-5. Another specimen.

$5 a$, 5b. "E. dumosa, var." In early and riper fruit. "Bay ix, South Coast." Robert Brown, $1802-5$. Ex herb., Royal Botanic Garden, Edimburgh.

6. Head of fruit. "South Coast." R. Brown. Ex, herb., Berlin.

Nos. 3, 4, 5, 6 are doubtless from the same batch of specimens collected by Robert Brown on the South Australian coast, and perhaps near what is now called Port Lincoln.

\section{PLATE 18.}

var. goniantha, var. nov.

1a, 16, 1c. Encalyptus goniantha, Turcz. No. 71 Drummond. See p. 103.

Twig bearing buds and flowers; anthers and top view of joung fruit.

var. grossa, var. nov.

2a, 2b, 2c. Twig with buds and flowers; anthers; cluster of fruits. See p. 104.

Euc. grossa, F.v.M.

2a. From a specimen cultivated in the Botanic Garden, Melbourne.

2c. Western Australia. (C. Walter.) 


\section{PLATE 19.}

1. Sucker of $E$. incrassata, Labill, ; var. dumosa, F.v.M., from Wyalong, N.S.W.

?. "E. obtusiflora, DC" (incorrectly labelled). "Voyage du Capitaine Baudin. Nouv. Hollande. Côté Occident." No. 25,490, U.S. National Herbarium. This is one of the numerous forms connecting $E$. incrassata, Labill., and $E$. focunda, Schauer. All the remaining plants depicted on Plate 19 may be also so designated, in my opinion. See page 117.

3a, 3b, 3c. "E. obtusiflora, DC." (inoorrectly so labelled). "Australia," Ex. Herb. Mus., Paris.

$3 a$, in bud and early fruit; $3 b$, in flower; $3 c$, anthers taken from $3 b$.

ta, 4b. Twig with buds; fruits. No. 3,226, West Australia (L. Diels). Herb., Berlin.

5. Robert Brown. "Bay iii," Iter Australiense, 1802-5. See p. 118.

\section{PLATE 20.}

$1 a$, Twig with buds; $1 b$, Twig with fruits; $1 c$, Fruit showing marked rim.

Oldfield, 1866 (W. Australia), Ex. Herb., Barbey-Boissier.

2a, 2b. "Voyage du Capitaine Baudin. Ile des Amiraux, Nouv, Hollande." Ex. Herb. Mus., Paris. U.S. Nat. Herb., No. 25,516.

3a. "Voyage du Capit. Baudin. Côté Occid., 1801." Twig with buds. 3b. Anthers from the same. Ex. Herb. Mus., Paris; 3c, 3d. Twig with fruits. "Voyage du Capit. Baudin, 1801. Nouv. Hollande." Ex. Herb. Mus., Paris.

4. "Capit. Baudin, 1801. Ile Decrès" (the modern Kangaroo Island). Ex. Herb. Mus., Paris.

5. "Voyage du Capitaine Baudin, 1801. Nouv. Hollande, Iles Stériles." Herb. Mus., Paris. Kew, Ex. Herb. Mus., Paris; also, No. 25,515, U.S. Nat. Herb.

All the plants depicted in Plate 20 are, in my opinion, forms connecting E incrassata, Labill. and E. focunda, Schauer. So are some of those depicted on Plate 19, but those of Plate 20 are larger forms than those on Plate 19. I have gone very fully into the matter at pp. 117-119.

\section{PLATE 21.}

1a, 1b. Fruits and buds of E. dumosa, A. Cunn., var. (?) rhodophloia, Benth. (B.Fl. iii, 230). Phillips' Bluff, near Eyre's Relief, W.A. (Maxwell.) Drawn by Miss M. Smith from a specimen in Herb., Kew. See p. 98.

Compare Plate 15, 7b, where we also see another plant with sub-conical fruits.

2a, 2b. Buds and fruits of E. dremosa, A. Cunn.; var. punticulata, Benth. (B.Fl. iii, 230.) "Shrub, 6-8 ft., Stony Hills, Gordon River, W.A." Drawn by Miss M. Smith from a specimen in Herb., Kew. See p. 98 .

Compare Plate 16, 6c, a form exceedingly close to this.

3. Var. dumosa, Redhill, Hundred of Redhill, S.A. (W. Gill.) A small fruited form, with exserted valves. See p. 106.

$4 a, 4 b, 4 c$. Buds, flowers, fruits, of E. focunda, Schauer. Murchison River, W.A. (Oldfield.) Drawn from a specimen in Herb., Barbey-Boissier, labelled in Bentham's handwriting. 


\section{PLATE 22.}

1 a. Buds; $1 b$, Flowers (and anther); 1c, fruits of $E$. focunda, Schaner. No. 87 of J. Drummond, coll. 1843. Swan River, W.A.

2a. Buds; 2b, flowers (with anthers) of E. foecunda, Schauer. "Inter Swan River et K. G. Sound, Roe (Hügel)." Ex. Imperial and Royal Herbarium, Vienna,

(N.B.-The type of E. foecunda, Schauer, is in that herbarium.) This specimen has red filaments, and dark pollen masses, as often seen in $E$. incrassata.

3a. Unripe fruits; 3b, ripe fruits of $E$. focunda, Schauer. "Red Sandstone Hill, Minara, Murchison River, W.A. Herb., Kew. (Herb. Hookerianum, 1867). "Flora Australiensis." Named by Mr. Bentham, iii, p. 232.

ta. Leaf ; $4 b$, fruits of E. foccunda, Schauer. "No. 3,295, W. Australia, 2nd July, 1901 (L. Diels)." Jueaves very thick.

\section{PLATE 23.}

1a. Very young buds; $1 b$, ripe buds and flowers; le, unripe fruits of E. loxophleba, Benth. No. 82 of Drummond's collection, 1844.

$2 \alpha$. Inthers; $2 b$, fruits of $E$. loxophleba, Benth. (in Bentham's handwriting). "Trce, $25-30$ feet; bark rough, fibrous. Hills near Okagee, Champion Bay, W.A." (Oldfield.) Herb. Barbey-Boissier.

3a. Buds; $3 b$, fluwers and anthers; $3 c$, fruits of $E$. loxophleba, Benth. "Stamens, pale yellow. Northam, W.A., July, 1898." (W. V. Fitzgerald.)

4a, 4b. E. loxophleba, Benth.; var. fruticosa, Benth. Flowers and leaves from Murchison River, W.A. (Oldfield.)

4a. Two leaves, a bud, and two thowers without anthers (Sheet 1, Herb., Kew).

46. One leaf, one fruit (Sheet 2, Herb, Kew). See p. 113, where I surmise that these ( $1 a$ and 46 ) specimens probably belong to $E$. adorata, Behr.

\section{PLATF 24.}

1a. Fruits; $1 b$, fruit, end view. E. loxophleba, Benth. (in Bentham's handwriting). "Shrub, 6-8 ft. ; branching from root; main branches, oblique; bark, red. Limestone Hill, Lynton, Pt. Gregory, W.A." (Oldfield.) Herb. Barbey-Boissier. Thick coriaceous leares.

2. Sucker leaves. 2,579A. E. loxophleba, Benth. "Avon, nordwestlich von Newcastle, W.A." (L. Diels.)

3. Fruits. No. 2,914. E. loxophleba, Benth. "W. Australien, pr. York, frequens 24th May, 1901." (L. Diels.)

4a. Buds and flowers; 4b, anthers; $t c$, fruits. "No. 2,579. E. loxophleba, Benth. Newcastle, W.A., "26th February, 1901." (L. Diels.) 


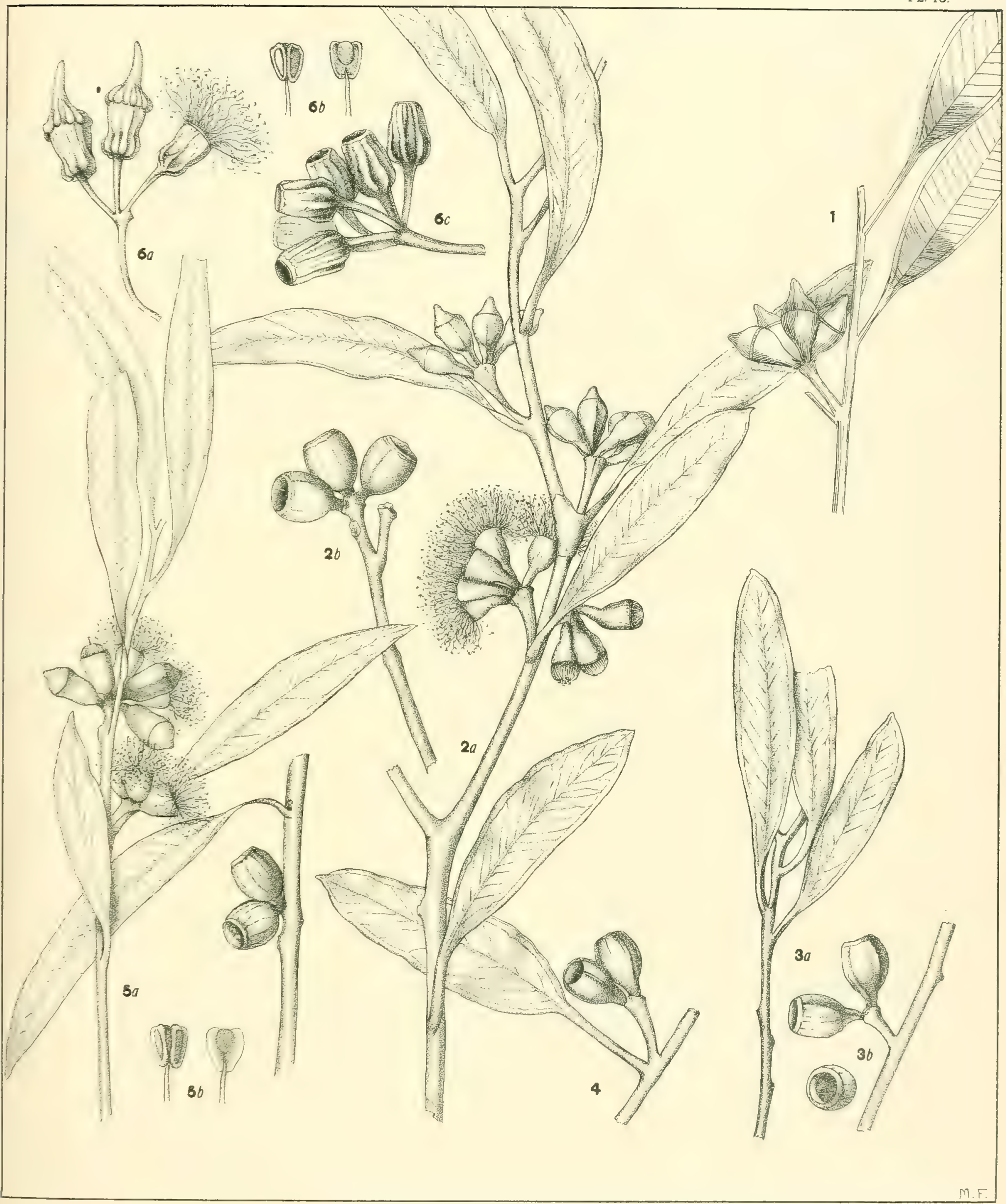





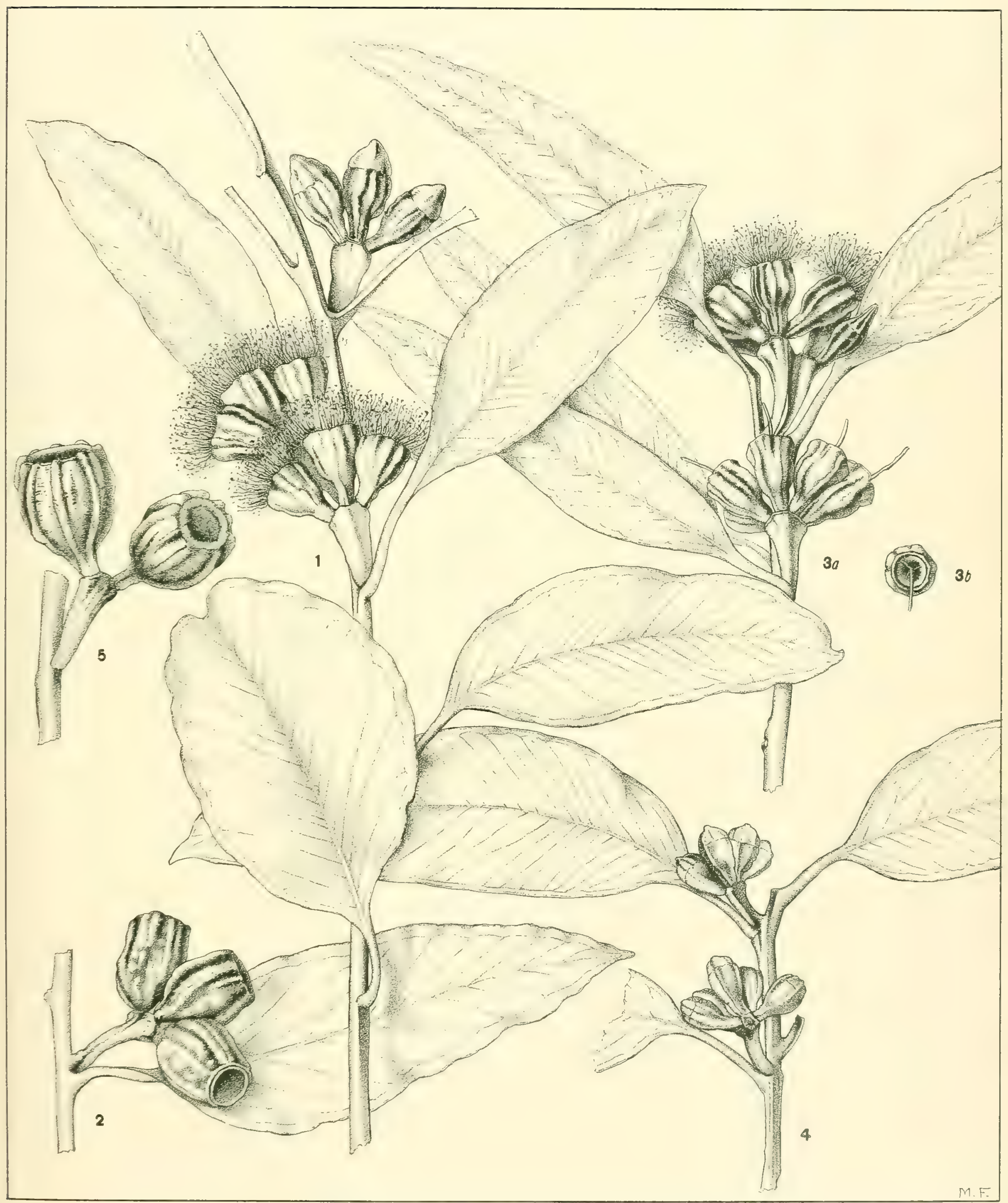

EUCALYPTUS INCRASSATA, LABILL.

(Variety ANGUlosa, Bentham.) 



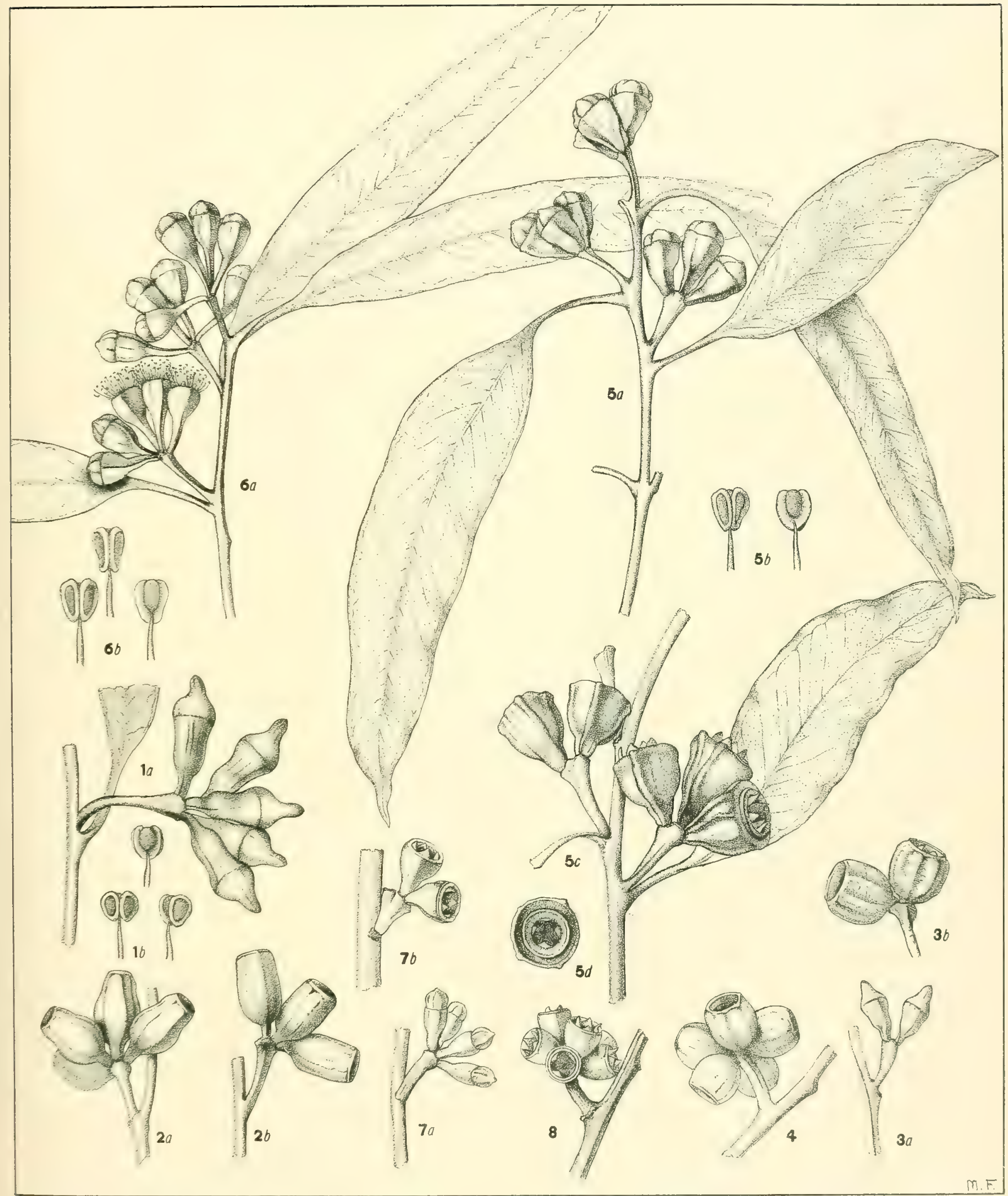





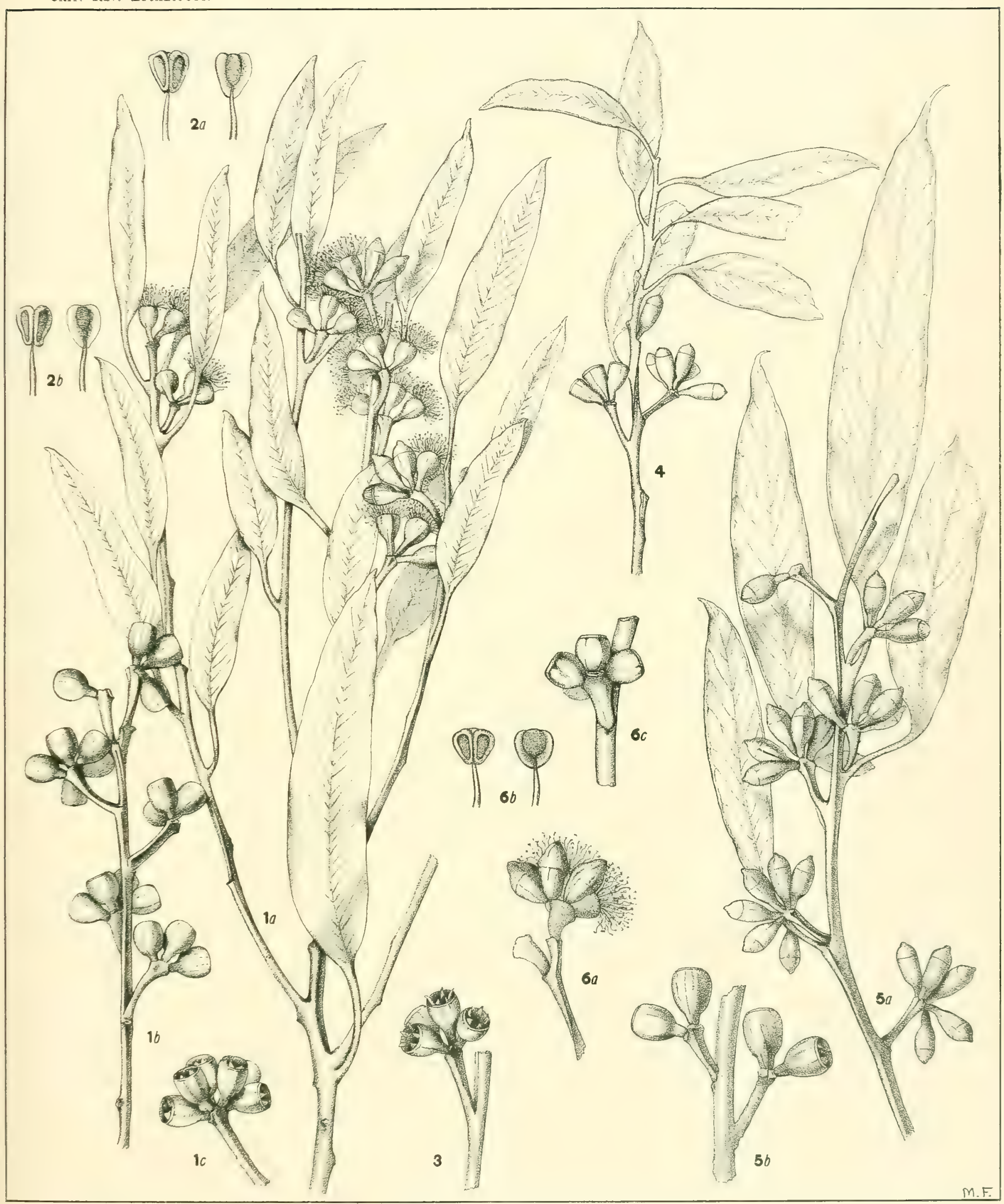





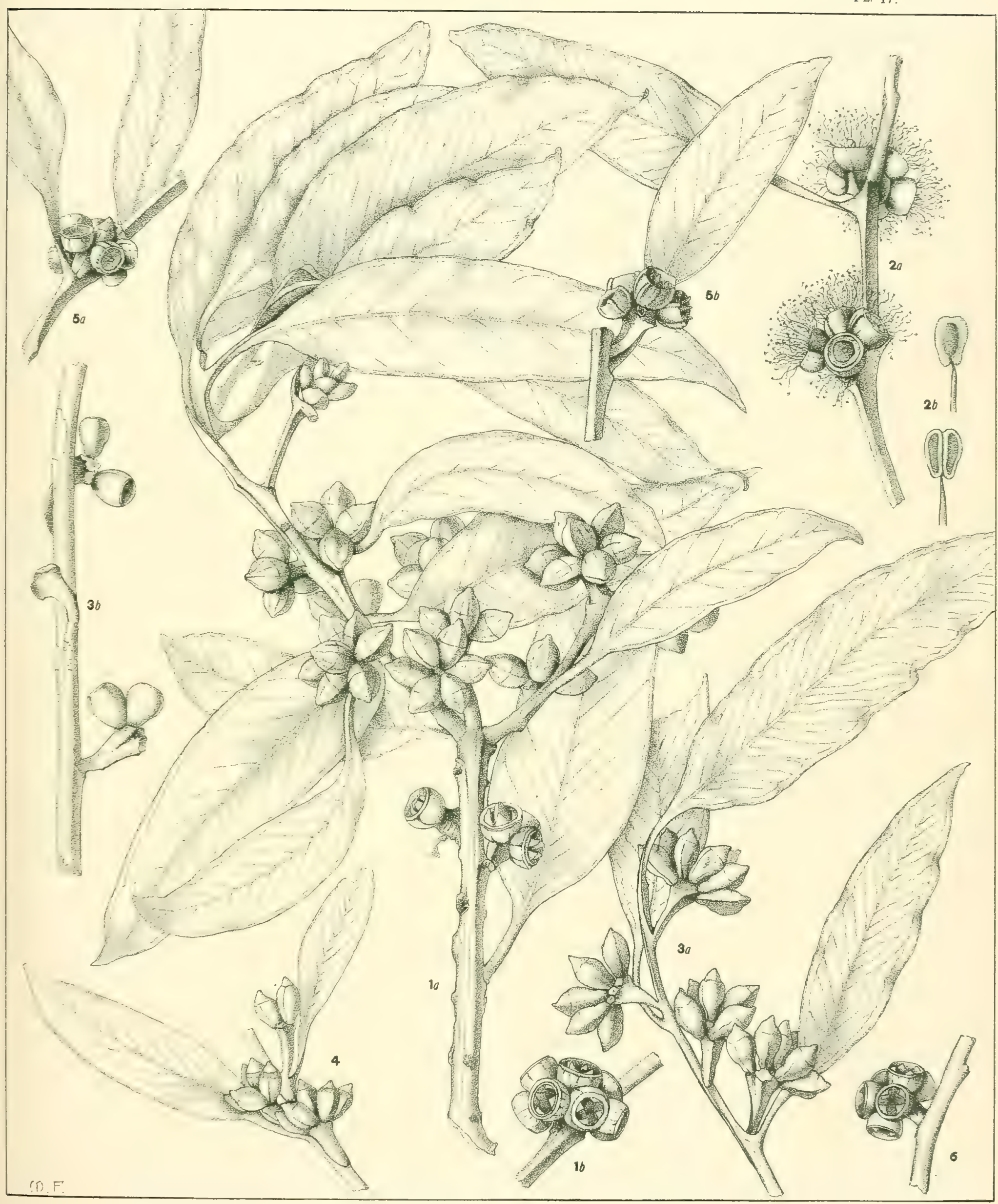

EUCALYPTUS INCRASSATA, LABILL.

Var. CONGLOBATA, R.Br. (except 3b). 



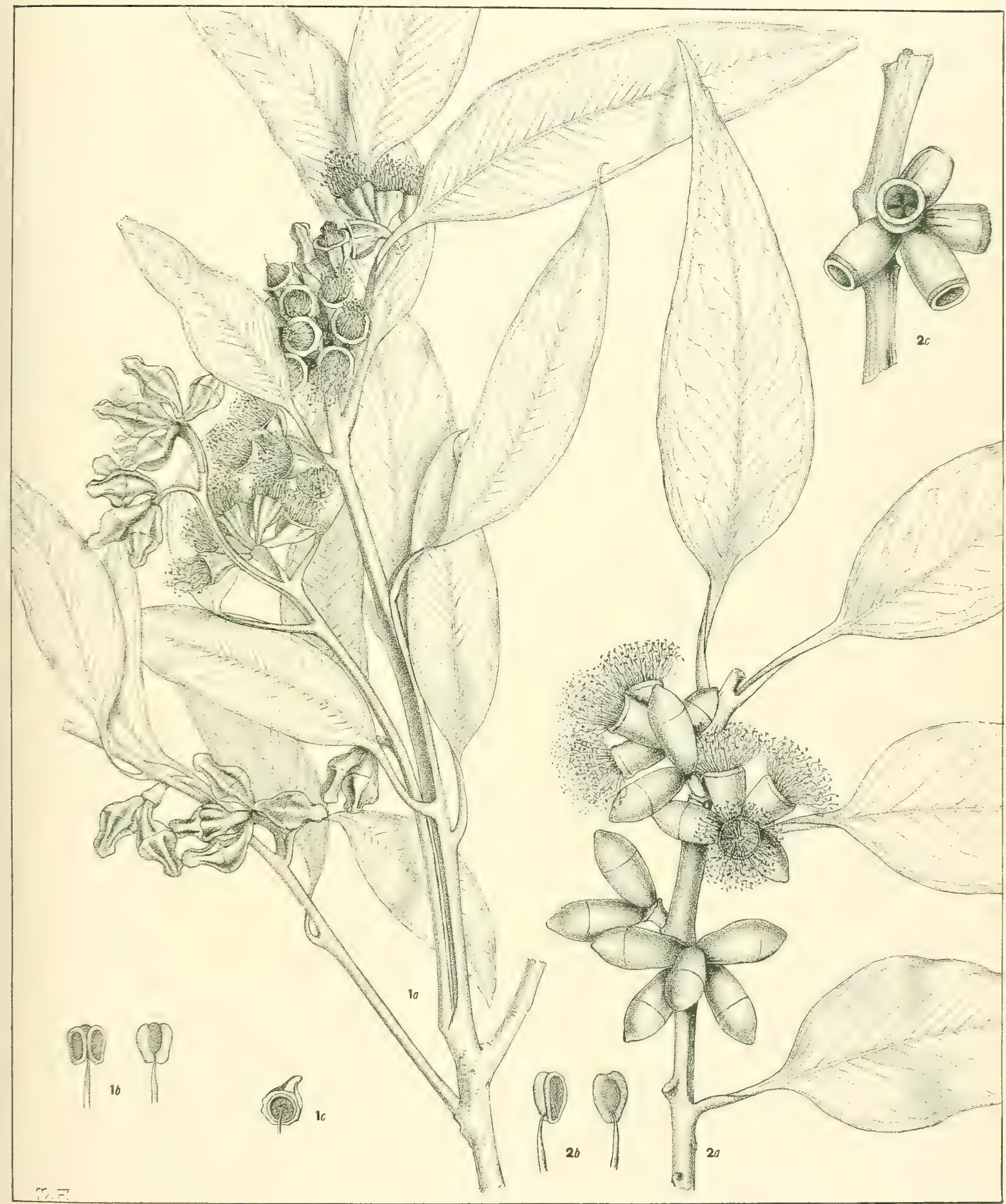

1. EUCALYPTUS INCRASSATA, Labill.

Var. GONIANTHA, var. nov.

2. EUCALYPTUS INCRASSATA, LAPILl. 



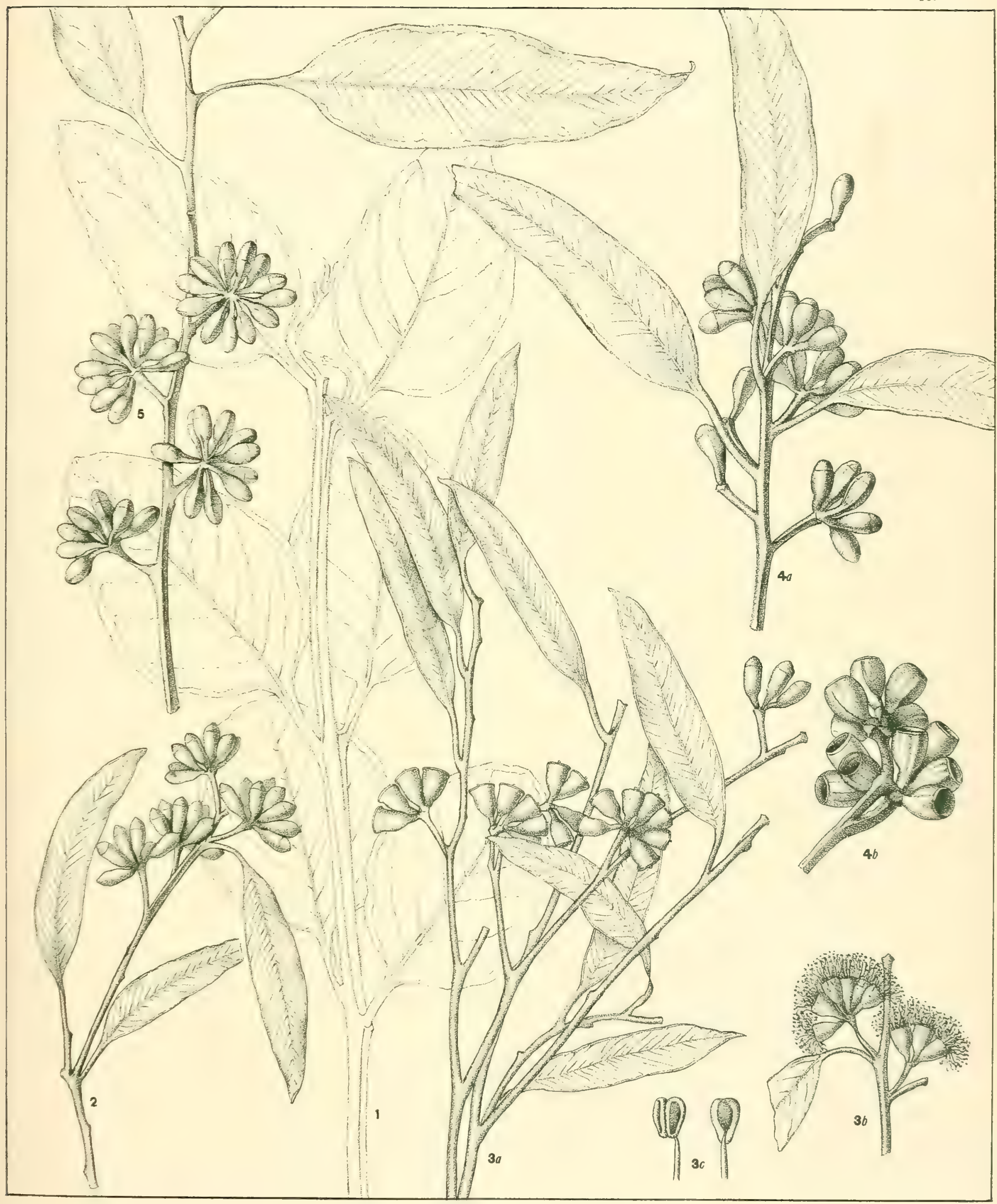

1. Young foliage of EUCALYPTUS INCRASSATA, LABILL.

Var. DUMOSA, F.t.M.

The remainder ars forms connecting E. INCRASSATA, LABILL, and 



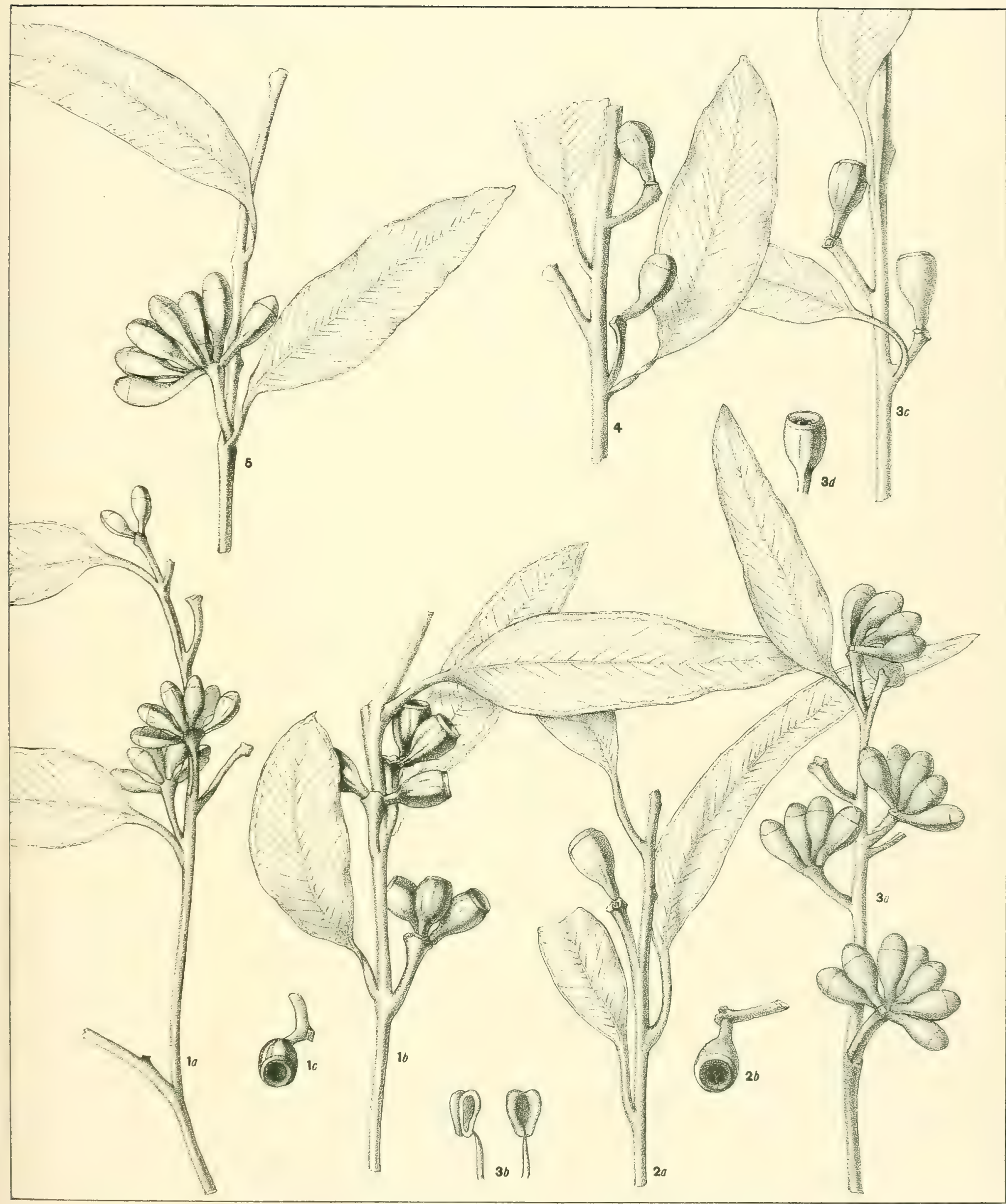

Forms (larger than those of Plate 19) connecting E. INCRASSATA, LABILL., and E. FCECUNDA, SCHAUER. 



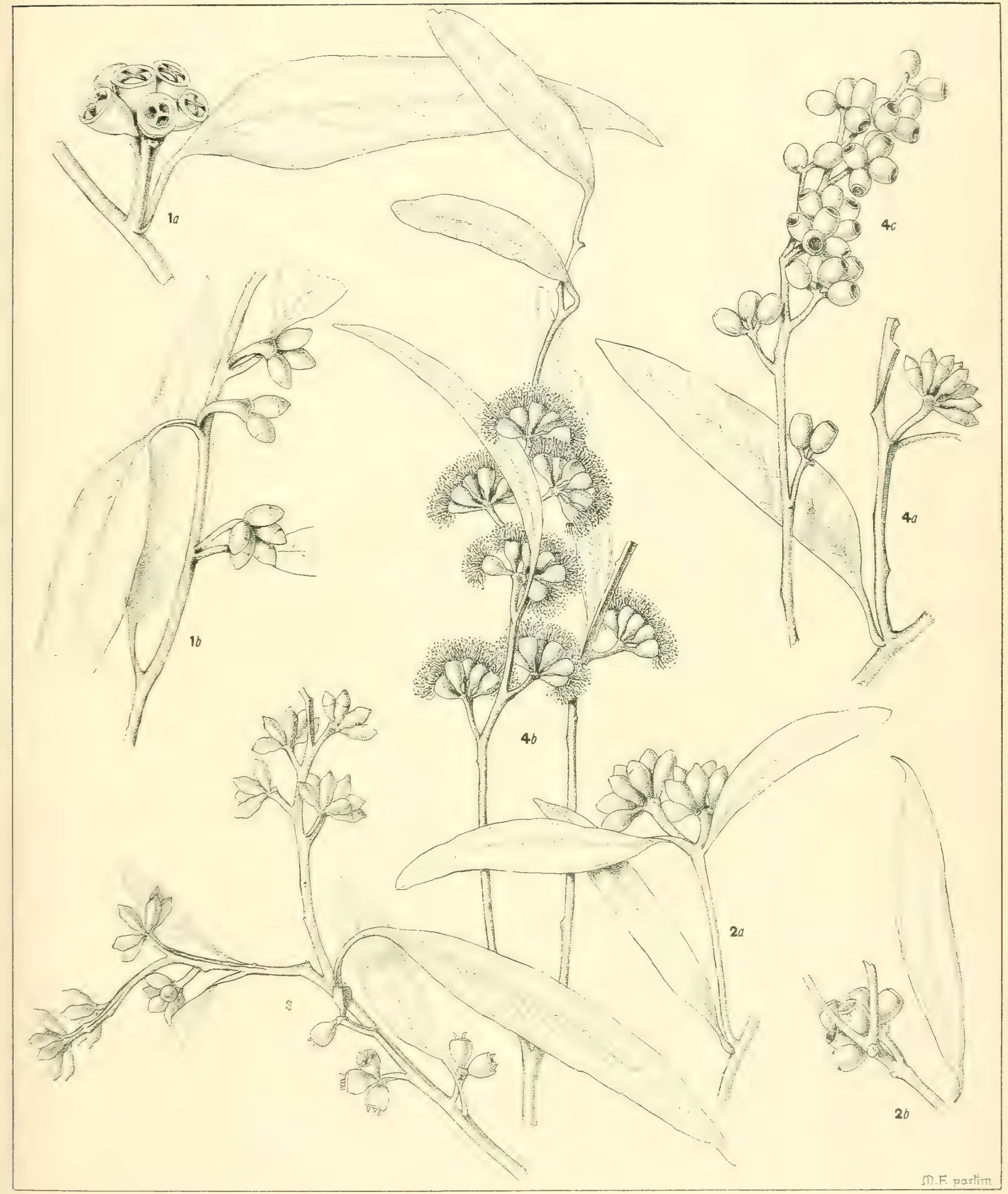

1-3. Varieties of EUCALYPTUS INCRASSATA, LABILL.

4. EUCALYPTUS FECCUNDA, SCHAUER. 



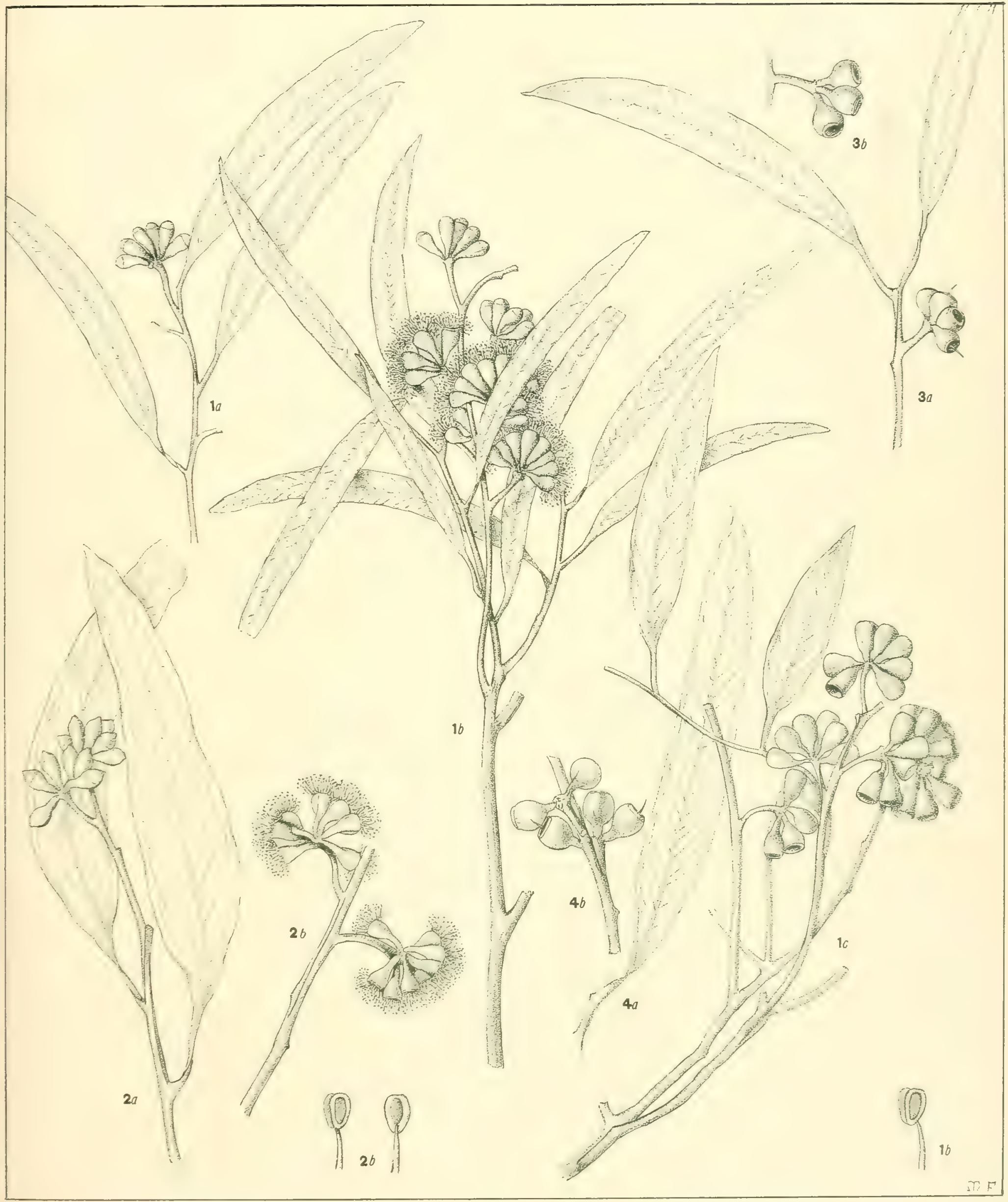





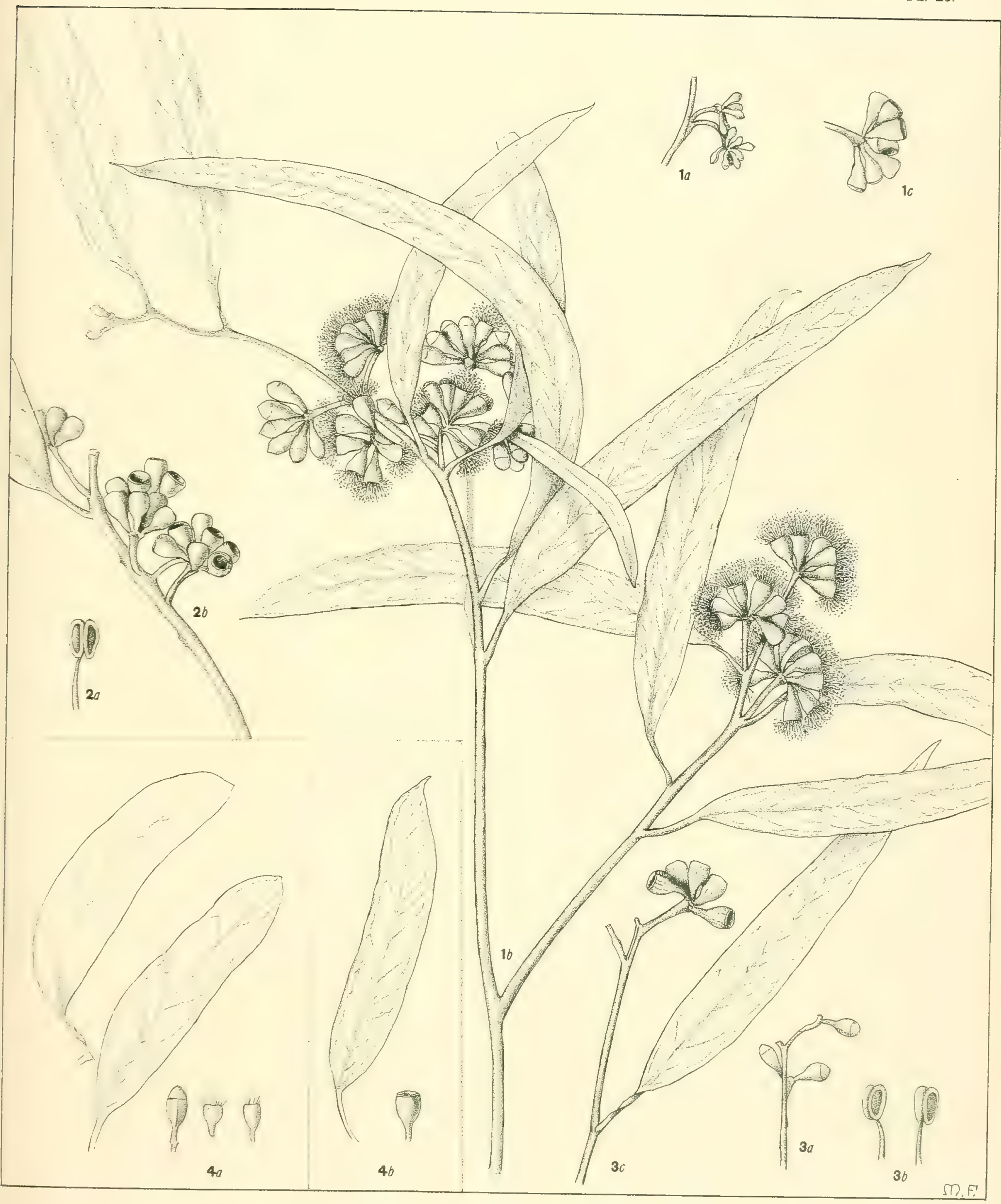

EUCALyPtus F(ECUNDA, Schauer. 



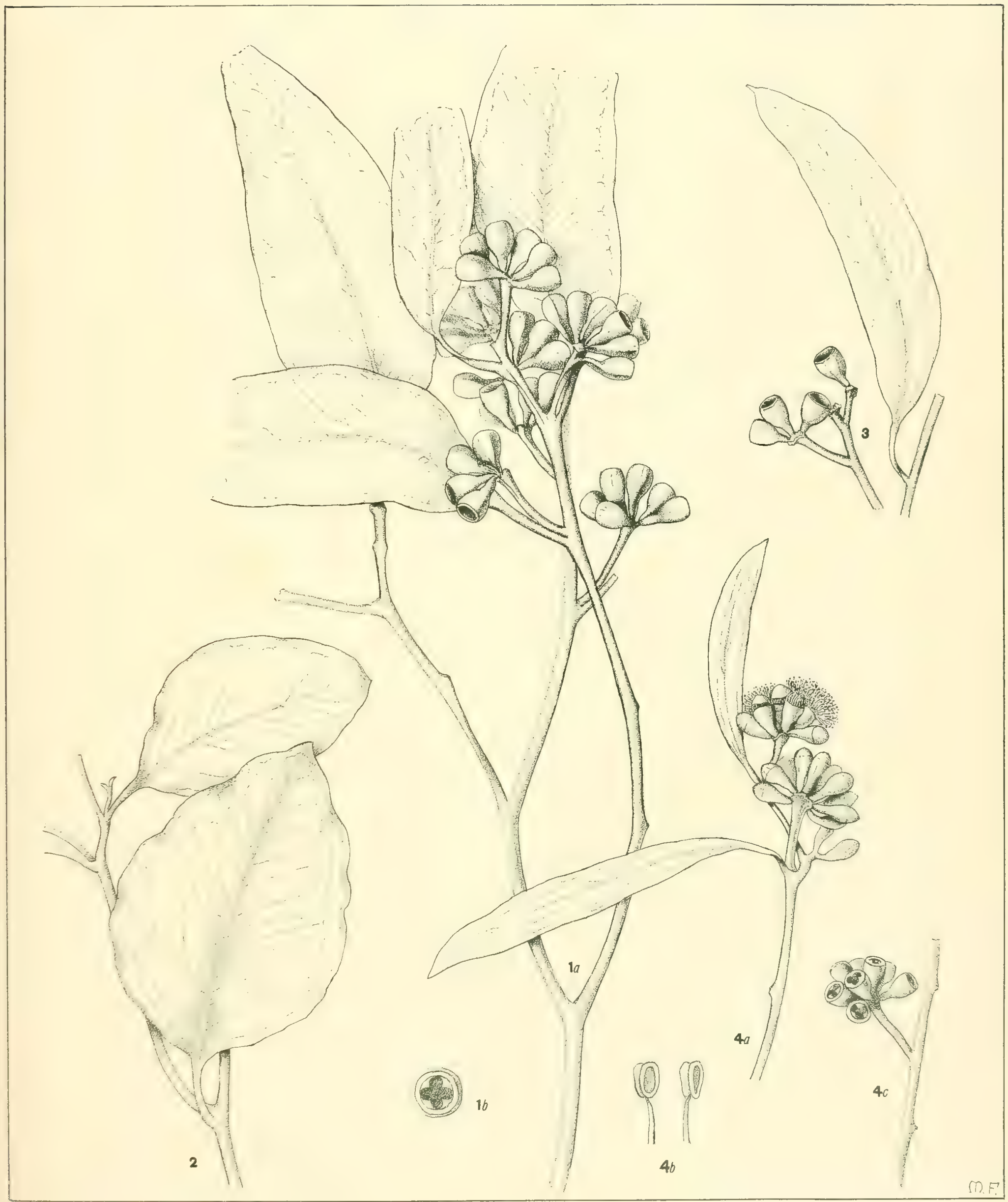

EUCALYPTUS FCEUNDA, Schauer. 



\section{A CRITICAL REVISION OF THE}

\section{GENUS EUCALYPTUS}

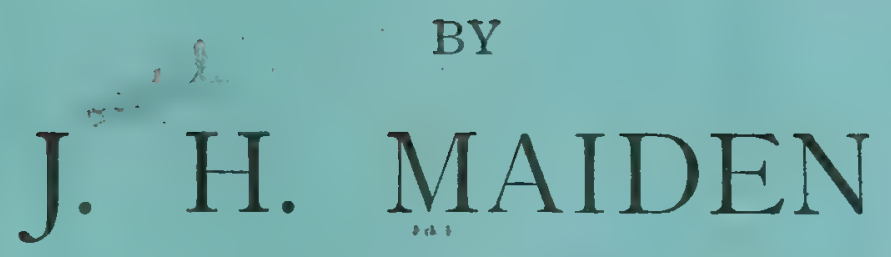

(Government Botanist of New South Wales and Director of the Botanic Gardens, Sydney).

\section{PART V}

(WITH FOUR PLATES)

Price Two Shillings and Sixpence.

Published by Authority of

THE GOVERNMENT OF THE STATE OF NEW SOU'TH WALES.

Sugnent:

WILLIAM APPLEGATE GULLICK, GOVERNMENT PRINTER.

1904. 



\title{
A Critical Revision of the GENUS Eucalyptus
}

BY

\author{
J. H. MAIDEN
}

(Government Botanist of New South Wales and Director of the Botanic Gardens, Sydney).

\section{PART V \\ (WITH FOUR PLATES).}

"Ages are spent in colleeting materials, ages more in separating and combining them. Even when a system has been formed, there is still something to add, to alter, or to reject. Every generation enjoys the use of a vast hoard bequeathed to it by antiquity, and transmits that hoard, augmented by fresh aequisitions, to future ages. In these pursuits, therefore, the first speculators lie under great disadvantages, and, even when they fail, are entitled to praise."

Macaulay's "Essay on Milton."

\section{PRICE TWO SHILLINGS AND SIXPENCE.}

Published ly Authority of

THE GOVERNMENT OF THE STATE OF NEW SOUTH WALES.

\section{Sủneñ:}

William APPLEGATE GULLICK, GOVERNMENT PRINTER, PHILLIP-STREet.
* 36755 A
1904 . 

6.

\title{
EUCALYPTUS STELLULATA \\ (Sieber).
}

\author{
7. \\ EUCALYPTUS CORIACEA \\ (A. Cunn.). \\ 8. \\ EUCALYPTUS COCCIFERA \\ (Hook. f.).
}




\section{Eucalyptus stellulata, Sieber.}

1. Description . . . . . . . . . . 127

Notes supplementary to the description. . I27

2. Synonyms . . . . . . . . . . . . I 29

Notes on the Synonyms . . . . . 129

3. Range . . . . . . . . . . . I3I

4 Affinity . . . . . . . . . $\mathrm{I}_{32}$

VII. Eucalyptus coriacea, A. Cunn.

1. Description . . . . . . . . . . I33

Notes supplementary to the description . . 133

2. Synonyms . . . . . . . . . . . . 135

Notes on the Synonyms . . . . . . 135

3. Range . . . . . . . . . . ${ }^{\mathrm{I}} 38$

4. Affinities . . . . . . . . I4I

VIII. Eucalyptus coceifera, Hook. f.

1. Description . . . . . . . . 142

Notes supplementary to the description. . I42

2. Synonyms . . . . . . . . . I43

Notes on the Synonyms . . . . . I43

3. Range . . . . . . . . . . 144

4 Affinities . . . . . . . . I44

Explanation of plates . . . . . . I45 


\title{
DESCRIPTION.
}

\author{
E. stellulata, Sieb.
}

Foldowivg is the original description:-

Sieber, plant exs. nov. holl. No. 478. Operculo conico cupulæ longitudine, pedunculis lateralibus brevissimis subteretibus, umbellis $15-20$ floris, foliis oblongis utrinque attenuatis basi $3-5$ nerviis. Novâ-Hollandiâ. Pet. et pedune. 3 lin. vix longi. Folia 3 poll. longa semipoll. lata subcoriacea sublucida. Alabastra oblonga utrinque attenuata 2 lin. longa. (v.s.) - (DC., Prod. iii, 217.)

It is more fully described in Bentham"s Flora Australiensis and Mueller's Eucalyptographia.

E. stellulata is an easy species to determine, with its straight-veined leaves and star-like umbels of buds. The specific name is rather happy, referring to the disposition of the buds.

It is a forest-tree of medium size in the Monaro, e.g., in the Snowy River Valley, forming a shapely tree 50 feet in height and more, with a stem-diameter of 2 to 3 feet, and with dense foliage. In New England it attains a scarcely less size, As a rule it is a straggling tree of half the size, while the narrow-leaved variety is frequently only a tall bush.

Vernacular Names.--"Black Sally," Gippsland and Southern New South Wales at least as far north as Goulburn; also New England Ranges. "Black Gum," Bombala. It is often called "Black Ash" in New England. The above names have been given on account of the rough, hard black bark on the butt.

"Sally Butt," between Bathurst and Orange. The name "Sally," without a qualifying adjective, is in use at Bombala, Boro, Braidwood, and Yass. The name is in allusion to the species being often found on the banks of streams, like a Sally (sallow or willow). "Olive-green Gum" (Leichhardt). "Green Gum," county of Argyle and Blue Mountains (Macarthur); New England and high land near Braidwood (Dr. Woolls). "White Gum," county of Argyle and Blue Mountains (A. Cunn.). "Blue Gum," (Forestex Mecham, Tumut). "Lead Gum," county of Argyle and Blue Mountains; Berrima (Macarthur), Hartley and Mudgee (Woolls). 
All the above names, "Olive-green Gum," \&c., are attempts to describe the appearance of the smooth portion of the bark, which varies from white with a bluish or lead-coloured cast to even a dirty olive-green.

The species is a stunted gum growing at high elevations, smooth-barked (except at the butt), and looking as if it were blue or lead-coloured with the cold. There are so many white gums that I think the name "Lead-coloured Gum " is a useful one, while Black Sally is better still, and the most widely spread of existing names.

It is sometimes called "Muzzle-wood," as on account of its toughness it is often selected for making muzzles for unweaned calves.

Seedlings or Sucker Leaves.-Ovate-acuminate, larger in size and thinner in texture than the mature leaves. The average dimensions of some seedling leaves in my possession are $3 \frac{1}{2}$ inches long by a width of $1 \frac{3}{4}$ inch.

When travelling in New England I made the following notes ${ }^{*}$ on this species:- "The sucker leaves present a variety of shapes and sizes. In their early stages they are more or less stem-clasping and orbicular. Other's are nearly reniform, while some might be described as almost bilobed, or with the outline more or less emarginate. Very many are about as broad as long, and scarcely acuminate, and from these shapes the gradation into the normal shape of the mature leaf is very gradual. Measurements gave up to $2 \frac{1}{2} \times 2 \frac{1}{2}$ inches, and even a little more."

Mature Leaves.-The tips are often hooked like those of E. coriacea, and of some forms of other species, e.g., amygdalina. The leaves of both species when dry are smooth, and usually show black dots (like $E$. punctata), while the parenchymatous tissue is more or less channelled. These appearances are also seen in some forms of $E$. amygdalina and other species, and I draw attention to them in order that too great importance be not attached to them. In E. punctata these black dots were considered to be of specific value.

The shape of the leaves is lanceolate to broadly lanceolate. The leaves are smaller than those of $E$. coriacea. The venation springs from the petiole, and the primary veins are prominent and roughly parallel to the mid-rib.

Messr's. Baker and Smith (Research on the Eucalypts) give the following particulars in regard to the oil of this species :-

\begin{tabular}{|c|c|c|c|c|}
\hline $\begin{array}{c}\text { Specific gravity } \\
\text { at } 15^{\circ} \mathrm{C}\end{array}$ & $\begin{array}{c}\text { Specific rotation, } \\
{[a] \mathrm{p}}\end{array}$ & $\begin{array}{c}\text { Saponification } \\
\text { number. }\end{array}$ & $\begin{array}{c}\text { Solubility in } \\
\text { Alcohol. }\end{array}$ & Constituents found. \\
\hline & & & & \\
\hline & $-26.1^{\circ}$ & 2.1 & Insoluble & $\begin{array}{c}\text { Phellandrene, sesquiter- } \\
\text { pene. }\end{array}$ \\
\hline
\end{tabular}

- See Proc. Aust. Ass, Adv. Science, vii, 538. 
Buds.-The calyx is sometimes swollen, while the operculum remains stationary in size. (See figure 7, pl. 25.) Mr. Froggatt informs me that this is the work of probably a parasitic wasp (one of the Chalcidece). I have noticed the same appearance in the buds of some other species.

Bark.-This tree attains its fullest development in the alpine country of North-eastern Victoria and South-eastern New South Wales. There the butt is rough, more or less furrowed, hard and black, almost like an ironbark, with the upper part of the trunk and the branches quite smooth. This species is remarkable for the large quantity of chlorophyll in this smooth portion, it being the greenest barked of all Eucalypts, but in many districts the smooth portion is rather of a lead colour. In districts where the tree is stunted the amount of rough bark is usually very small, so that it passes for a "gum" (i.e., a smooth-barked tree).

Timber.-Pale coloured, rarely free from gum-veins, warps seriously; a sound $\log$ of any size very rare; of little value for purposes other than fuel. Timber that shrinks much in drying may do so regularly or irregularly. Those of the first class have, when dry, practically the same shape as the original piece, but those of the second class take on irregular shapes. The timbers of $E$. stellulato and $E$. coriacea belong to the latter class.

\section{SYNONYMS.}

1. E. leucadendron, A. Cunn.

Var. angustifolia, Benth.

2. E. microphylla, A. Cunn., partim.

3. E. Cunninghamii, Sweet, partim.

4. E. Cunninghamii, G. Don, partim.

\section{NOTES ON THE SYNONYMS.}

1. "Eucalyptus leucadendron, C. (Allan Cunningham).

"White Gum of the south-western interior, New South Wales, 1824." Specimens collected by Allan Cunningham are in Herb. Kew, and also in Herb. Cant. (ex Herb. Lindl.), and are E. stellulata, Sieb. 
Variety angustifolia, Benth.

Leaves narrow, very thick and smooth, scarcely showing the venation.-(B.Fl. iii, 201.)

This form occurs in the highest parts of the Blue Mountains, also in the southern ranges, e.g., near Braidwood, often occurring with the normal form.

The variety angustifolia is usually shrubby, but it grows into a small tree.

In the highest parts of the Blue Mountains it has the fruits sometimes in dense globular umbels.

\section{E. microphylla, A. Cunn.}

Foliis lineari-lanceolatis subfalcatis acutis: margine incrassatis, umbellis multifloris foliisque confertis, Forming brushes upon the more elevated parts of the (Blue) Mountains.-(Field's New South Wales. p. 350.)

In Allan Cunningham's MS. Journal under date 9th April, 1817, we find the entry :- " King's Table-land.*-This exposed situation is covered with a shrub of the Eucalyptus (E. microphylla), forming thick brushes of underwood."

On a specimen of E. stellulata, Sieb., var. angustifolia, Benth., collected by himself, Allan Cunningham has the label-"Eucalyptus, apparently E. punctata, Sieb. DC. King's Table-land, N. S. Wales, 1827, A.C." showing that he was uncertain as to the designation of the form.

\section{E. Cunninghamii, Sweet.}

The meagre description is :-

46. Cunninghamii (white), N.S.W., 1825. Greenhouse shrub. Microphylla, F. T. non Link (Sweet Hort. Brit. ed. 2, page 209).

\section{E. Cunninghamii, G. Don.}

Leaves linear-lanceolate, rather falcate, acute, with thickened margins; umbels many-flowered, and are as well as the leaves, crowded. Native of New Holland, forming bushes upon the more elevated of the mountains. E. microphylla, Cunningham in Field's New South Wales. p. 350. Cunningham's Eucalyptus, Cult. 1824, Shrub.-(Gen. Syst. ii, 821.)

Bentham (B.Fl. iii, 821) has already pointed out that Cunningham's specimens of $E$. microphylla consist of a mixture of leaves of the narrow-leaved form of E. stellulata and of E. stricta, Sieb.

It is often impossible to separate the narrow-leaved forms of these species when foliage is alone available. The same remarks apply to Sweet's and G. Don's species. 


\section{RANGE.}

IT is very partial to the depressions in shallow, rounded, grassy valleys, with good soil and a moist bottom. It is confined to Victoria and to New South Wales, being far more extensively distributed in the latter State.

\section{VICTORIA.}

As regards Victorian localities, Mueller states :-

Along elevated river-valleys, or flats, and in cooler mountain regions up to the sub-alpine zone; thus on the Upper Hume River (Findlay), on the Mitta Mitta, around the Barkly Range, towards Lake Omeo, and on the Upper Genoa (Mueller), Dargo Flat (Howitt).--(Eucalyptographic.)

\section{Howitt says;-}

This is also an alpine species, ascending almost, if not quite, to the same elevation as E. pauciflora (coriacea), but does not descend, according to my observations, lower than 700 feet at Dargo and Ensay. No varieties occur as far as my observations go.--(Trans. Roy. Soc. of Victoria, 1890, p. 84.)

I have specimens collected by Mr. Howitt at Buchan and Omeo.

\section{NeW South WALES.}

As regards New South Wales it follows the tops of the ranges on the New South Wales-Victorian border, thence following the Dividing Range and its spurs at least as far north as the New England Ranges, and as far west as 18 miles west of Bathurst, on the Silurian; also at Rylstone. I have specimens from these localities, but it may be reasonably expected to be found further north and further west, in mountainous districts.

Following are some specific localities :-Mount Kosciusko district (J. H. Maiden and W. Forsyth), Kiandra (E. Betche), Bombala (J.H.M.). Here it is called "Sally," and Mr. Ronald Campbell says: "Not much used because scarce, except on flats." Occurs all over the Monaro. "Sally" or "Black Gum" timber very cross-grained, of a soapy nature, knotty; of a flesh colour when fresh. Diameter, 2 to 3 feet; height, 30 to 50 feet; Haydon's Bog, Delegate.-(W. Baeuerlen). Tumut (J.H.M.), Braidwood, together with the narrow-leaved form (W. Baeuerlen); Queanbeyan (H. Deane), Yass (W. W. Froggatt), Goulburn (H. Deane), Wingello, "Bastard Peppermint" and "Sally" (J.H.M. and J. L. 
Boorman). "Lead-coloured Gum" of Berrima, No. 35, London Cat., 1862; 226, Paris Cat., 1855. Diameter, 18 to 30 inches; height, 30 to 40 feet. "Of no value for timber, but excellent for fuel." The above are all southern localities.

Following are western localities:-Wentworth Falls, narrow-leaved form (J. H. Camfield); Blackheath, narrow-leaved form, also a form with the fruits in dense globular umbels (J.H.M.); Mount Victoria and Kanimbla Valley, normai and narrow-leaved forms (J.H.M.); Mount Wilson, narrow-leaved form (Jesse Gregson); Jenolan Caves, "Black Sally" (W. Blakeley); Wallerawang (H. Deane and J.H.M.) ; Rylstone (R. T. Baker) ; "Messmate," trees from 30-50 feet; bark rough, dark; sap-wood white; the heart-wood dark brown and gummy, branches pendulous, tips of the branches and buds yellow, branches slightly ribbony. - Sunny Corner (J. I. Boorman); Charlton, Bathurst (R. H. Cambage); Millthorpe (A. W. Howitt).

Coming to the north, I have not seen it north of Sydney or Bathurst until New England is reached, but doubtless there are intermediate localities. It is more or less plentiful all over the table-land. There are copses or thickets of it at Yarrowitch, also umbrageous small trees. At Tia, and elsewhere, the trunks are 2 to 3 feet in diameter. These localities are on the Port Macquarie-Walcha road.

On the Grafton-Armidale road I followed it from Bald Hills to Guy Fawkes and right on to the Round Mountain. Its furthest northern locality is a matter for enquiry.

\section{AFFINITY.}

ITs only real affinity is with E. coriacea, A. Cunn., but the two species will rarely be confused. 


\title{
DESCRIPTION.
}

\author{
Eucalyptus coriacea, A. Cunn.
}

FoLLowING is the original description :-

Schauer MSS.-Ramulis elongatis pendulis teretib. nitidis; foll. firmis rigidisq. lanceolatis oblongisve breviter petiolatis acuminatis, apiculo subfiliformi saepe deflexo, nervosis imperforatis viridib., untrinq. lucidis; capitulis axillarib. 5-8-floris; pedunculo petiolum aequante subtereti ; cupula (fructus) turbinata truncata; operculo . . . ? capsula 3-4 loculari. Planta insignis valida; foliis 4-6 poll. longis, 1-2 poll. latis; fructib. 4 lin. altit. totidemq. diametro metientibus nitidis. In Novae Cambrix australis interioris planitiebus.-A. Cunn. Herb., no. 35-1824.--(Schauer in Walp. Rep. ii, 925.)

It is fully described by Bentham (B.Fl. iii, 201), and also by Mueller, in the Eucalyptographia; by the latter under the name $E$. pauciflora, Sieb. I have adopted the name given in the Flora Australiensis. Sieber's name, E. pauciflora, has doubtful priority, and it is especially inappropriate (no Eucalypt flowering more freely than this), while Cunningham's name is remarkably appropriate.

Vernacular Names.-One of the "White or Cabbage Gums," but not to be confused with $E$. hemastoma, var. micrantha, which goes by the same names. Its usual name' with us is "White Gum," though it is very frequently called "Cabbage Gum" also. In New England apparently not known as "White or Cabbage Gum," but "White Ash," in contradistinction to E. stellulata (Black Ash). The species goes under the name of "Weeping Gum" in Tasmania, owing to its scrambling habit; the name is also in use at Uralla, N.S.W. At Glen Innes it is locally known as "Tumble-down Gum," also by reason of its aspect. "Glassy Gum" is a name in use at Guyra, on account of the vitreous appearance of the bark. "White Sally" is a name in use at Queanbeyan. On the Monaro I have known it to be called "Bigleaf," for obvious reasons. Sometimes it is called "Cattle Gum," because cattle feed on its leaves when grass is scarce. The names "Flooded Gum" and "Peppermint," under which this species is known in Victoria (B.Fl.) would not appear to be in use in this State, and may, perhaps, have arisen through a misapprehension.

Suckers or Seedling Leaves.-Broader than the mature leaves; more or less ovate. Near Yarrowitch (New England) I noticed the leaves of some seedlings which were 2 or 3 feet high. The foliage was very coarse, being both large and thick. Following are actual measurements of individual leaves: $-7 \frac{1}{2} \times 3 \frac{1}{2}$ inches, $8 \frac{1}{2} \times 3 \frac{1}{4}$ inches, $6 \frac{1}{4} \times 3 \frac{1}{2}$ inches. Large leaves such as these were not scarce. They 
are a little oblique, acuminate, nearly ovate, occasionally nearly circular, and then pass through all gradations up to ovate lanceolate-(Proc. Aust. Ass. for Adv. of Science, vii, 538.)

Mature Leaves.-Coriaceous, yet often succulent, and hence eaten by stock. They are comparatively large, 6 inches being a common length, while 5 inches is, perhaps, under the average. The width is usually about $1 \frac{1}{2}$ inch. They are usually shiny, but in the coldest districts often glaucous. The venation is as stated under stellulata, and in this respect not only shows affinity with that species, but also with regnans and allied species. Besides cattle, opossums have a predilection for the young foliage of this tree, so that they often kill trees of this species.

Mr. F. B. Guthrie (Agric. Gazette, Oct., 1899) has analysed the leaves, with the view to ascertain their value for feeding stock, and following is his analysis :-

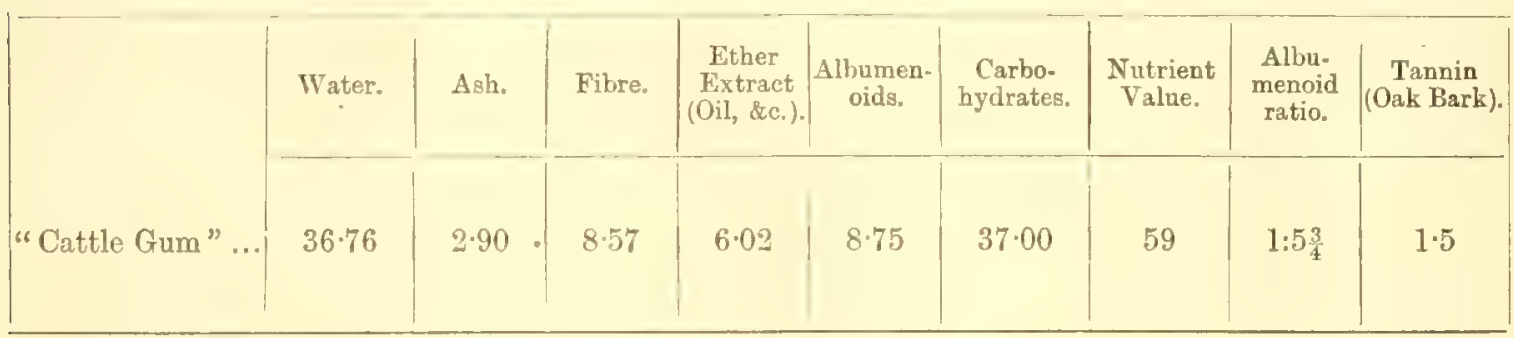

As regards the oil obtained from the leaves, I have three authenticated analyses before me. No. 1 is from Messrs. Baker and Smith's "Research on the Eucalypts," and Nos. 2 and 3 are by W. B. Wilkinson.*

\begin{tabular}{|c|c|c|c|c|}
\hline $\begin{array}{l}\text { Sp. gravity } \\
\text { at } 15^{\circ} \mathrm{C} \text {. }\end{array}$ & Sp. motation, & $\begin{array}{l}\text { Saponification } \\
\text { number. }\end{array}$ & $\begin{array}{l}\text { Solubility in } \\
\text { Alcohol. }\end{array}$ & Constituents found. \\
\hline 1. 0.8947 & $-32 \cdot 8$ & $4 \cdot 62$ & 1 vol. $80 \%$ & $\begin{array}{l}\text { Phellandrene, peppermint } \\
\text { ketone, eucalyptol, ses- } \\
\text { quiterpene. }\end{array}$ \\
\hline 2. .8943 & $+16 \cdot 7$ & n....... & $\ldots \ldots \ldots$ & No phellandrene. \\
\hline 3. .9200 & +6.0 & ......... & ......... & Do. \\
\hline
\end{tabular}

Mr. Wilkinson aiso gives columns "Refractive index" and "Specific refractive energy."

It is remarkable how these analyses vary. My view is that we require hundreds of analyses of the oils of each species, taken under circumstances as different as possible, before we shall be able to make accurate generalisations in regard to them. These should be made in all the States, just as the material for botanical diagnosis is obtained orer areas as wide as possible.

Timber.-Pale coloured, full of gum-veins; warps a good deal. Some notes on the timber will be found under "Range."

- Preliminary survey of Eucalyptus Oils in Victoria.-(Proc. Roy. Soc., Vic. VI. (New Series), 197-8, 1894). 


\section{SYNONYMS.}

1. E. pauciflora, Sieb.

2. E. piperita, Sm.; var. pauciflora, DC.

3. E. submultiplinervis, Miq.;

Do forma minor, Miq.

4. E. sylvicultrix, F.T.M.

5. E. phlebophylla, F.v.M.

There is a variety, alpina, Benth.--(B.Fl. ii, 201).

\section{NOTES ON THE SYNONYMS.}

1. E. pauciflora, Sieb. The original description is-

pauciflora, Sieb. 26. E. operculo conico, pedunculis abbreviatis sub-6 floris, foliis oblongolanceolatis falcatis nervosa-venosis elongatis.--(Spreng. Syst. IV. Cur. Post., 195.)

A specimen of the type in Herb. Barbey-Boissier bears the following label:-

Sieber's No. 470. Eucalyptus pauciflora, Sbr. De la nouvelle Hollande, M. Sieber, 1825, with the addition later on, "Eucalyptus piperita, Sm.; E. pauciflora, DC."

It is figured on Plate 26, and there can be no doubt that it is correctly referred to $E$.coriacea, A. Cunn. I have seen a further specimen, stated to be Sieber's No. 475, and labelled Eucalyptus pauciflora, Sieber, from Herb. Berol. It consists of a leaf and a cluster of buds. The leaf is narrow, and has rather straight veins, which one reasonably associates with E. coriocea, A. Cunn. But the buds do not belong to that species, and careful examination of the specimens shows that they probably belong to one of the New South Wales "Messmates."

$E$. amygdalina and E. regnans are so closely allied that it is not possible to say absolutely from the material available which species it is, since it matches $E$. radiata from the Blue Mountains, which we know Sieber visited, and E. regnans from southern and western localities. The texture of the leaf is amygdatina, or regnans, and not coriacea. Nothing further need be said, as there is apparently a misplacement of a label. 
2. E. piperita, Sm. ; var. pauciflora.

This is the name as given in DC. Prod. iii, 219,

\section{E. submultiplinervis, Miq.}

34. Eucalyptus submultiplinervis, Miq., n. sp., ramulis gracilibus teretiusculus vel hic illic angulatis, foliis e basi attenuatâ lanceolatis breviter acutis, herbaceo-coriaceis, venis plerisque adscendentibus versus basin adproximatis utrinque distinctis submultiplinervis, marginibus subincrassatis subfuscescentibus, pedunculis rugosis 5-10 floris, floribus subsessilibus, calycis tubo obpyramidato-turbinato striato-sulcato glanduloso, operculo brevi-hemisphaerico subumbilicato quam tubus breviore, antheris albidis didymis. Van Diemansland (Stuart n. 10, 13, 14, 15)_-Petioli circiter semipollicares antice canaliculati, angulosi. Pedunculi 3-4 lin. longi. Flores $2 \frac{1}{2}$ lin. æquantes. Forma præsertim quod a flores minor : E. sylvicultrix, Müll. Herb.-(Nederl. Kruidk. Arch., iv, 138, 1856.)

4. E. sylvicultrix, F.v.M., is briefly referred to in the preceding paragraph. Bentham also noticed it:-

E. submultiplinervis, Miq. in Ned. Kruidk. Arch., iv, 138, or E. sylvicultrix, F. Muell. in Herb. Sond, is a narrow straight-leaved variety, with the flowers of the ordinary size.-(B.Fl. iii, 201.)

Following are the specimens on which the names submultiplinervis and sylvicultrix were founded:-

(a) Specn. No. 34 (species number in Ned. Kruidk. Arch. iv). " Eucalyptus sylvicultrix, Ferd. Mueller', 'Tasmania, in Mueller's handwriting, and $E$. submultiplinervis, forma minor," in that of Miquel, have buds, and are undoubtedly coriacea as so marked by Bentham on the specimen.

I fail to see that Miquel's forma minor is really smaller than other specimens.

(b) "E. sylvicultrix, F.v.M. Syn. E. coriacea, A. Cunn., var. sylvicultrix, F.v.M. (Herb. Melb.). Syn. E. multiplinervis, Miq. (Herb. Melb.) (a slip of the pen for submultiplinervis). No. 765, near Woodhall, Tasmania, March. Charles Stuart."

The material of $(b)$ is in twigs bearing leaves, very young buds, and flowers. The specimens, as far as they go, in the venation of the leaves and their hooked apices, their length and breadth, in the very young buds, in the calyces and flowers, resemble many from New South Wales.

\section{E. phlebophylla, F.v.M.}

40. Eucalyptus phlebophylla, Ferd. Müll., Herb. ramulis teretibus fuscescentibus, foliis longiuscule petiolatis lanceolatis vel oblongo-lanceolatis in apiculum tenuem fuscum curvulum exeuntibus, basi attenuatâ inæquilateris, vulgo totis falcato-curvatis, rigide coriaceis, punctatis, venis plurimis e basi ortis submultiplinervis, umbellis axillaribus et terminalibus confertis, $3-5$ floris, pedunculis pruinosis, floribus sessilibus, calyce obovato-turbinato. Crescit in montibus Buffalo Range (F. Müller). Van Diemansland (Stuart).

Petioli $\frac{1}{2}-3$ poll. longi rugosuli, in siccis pallidi vel fusculi; folia $3-7$ poll. longa, $1 \frac{1}{2}$ lata; pedunculi $2-3$ lin.; calycis tubus in fructu 2 lin. æquans.-(Ex. Miq. in Nederl. Kruidk. Arch. iv, 140, 1856.) 
I have seen the type from Mount Aberdeen, which is a very markedly veined, large, young leaf ; also specimens marked "Gippsland, Mueller," in flower.-(Herb. Calcutta.) I have examined a specimen (Van Dieman's Land, C. Stuart) bearing, in Miquel's handwriting, the words "E. phlebophylla, M.," with the words " $E$. submultiplinervis affinis" cancelled.-(Herb. Melb.)

Some of Gunn's specimens in European herbaria labelled "Eucalyptus radiata," with glaucous buds, really belong to $E$. coriacea. Some of them are labelled "very common about Hobart Town," and "Weeping Gum of Norfolk Plains." The true $E$. radiata, Sieb., is much less likely to be confused with E. coriacea, A. Cunn., than the forms (E. radiata, Hook., f. non Sieb.) that Hooker took to be $E$. radiata.

Var. alpina, F.v.M. (B.Fl, iii, 201).

Leaves short and nearly straight. Flowers rather smaller and peduncles shorter.

Mountains on Macalister River, Vic. (B.Fl.). Specimens of this variety from Mount Kosciusko, in our own State, are very glaucous. Leaves 2 inches long, or a little more.

Following is an account of the Mount Kosciusko trees:- The Snow Gum is a small-leaved form of E. coriacea, resembling E. stellulata a good deal in leaf outline, and might be mistaken for it. At low elevations it is a large tree; as the mountain is ascended it becomes smaller and smaller, till at length it becomes a dense whipstick scrub, and finally (at 6,000 feet, about) disappears altogether. It forms the limit of tree vegetation. It is usually as glaucous as if it had been sprinkled with flour, but not invariably so, and at the Jindabyne level it is frequently scarcely glaucous.*

"Forming the 'Tree line.'-The trees of this species at the highest elevations are remarkable for their bare stems, surmounted with a dome or flattish top of leaves. The bare stems are, doubtless, the consequence of winds, the leaves being concentrated on the top as a thin 'layer,' and offering minimum resistance to the wind. These dwarf trees are in masses of a fairly uniform height; a different arrangement would result in the crown of leaves of the smaller plants being beaten against the bare stems of their taller brethren, and denuded of their foliage. The grotesque leaning forms of the stems, like guys or supports to resist wind-pressure, are shown in one of the illustrations. In many cases the butt of the tree forms a huge protuberance at the ground level, taking on a peculiar plastic appearance often seen in the coast districts in E. maculata (Spotted Gum) and Angophora lanceolata (Smooth-barked Apple). In E. coriacea, from this protuberance there spring out as many as four (and even more) stems of equal diameter, such stems being equidistant from each other, or nearly so." $\dagger$

-J. H. Maiden : A Contribution towards the Flora of Mount Koscinsko (Agric. Gazette, N. S. W., July, 1898).

†J. H. Maiden: A Second Contribution towards a Flora of Mount Kosciusko (Agric. Guzette, N.S.W., October, 1899). 


\section{RANGE.}

This tree is confined to Tasmania, South Australia, Victoria, and New South Wales. In Tasmania it is common, except the extreme south and south-west (Rodway). I have examined the following classical Tasmanian specimens :- -

(a) Gunn's No. 684, 1,105 (Plenty Bridge); 1,107 (Glen Leith); 1,108 (Glen Leith, also road foot of Grass-tree Hill); 1,109 (Marlborough) ; 1,111, "Weeping Gum," Formosa. These are typical E. coriacea and are E. piperita, var. pauciflora, DC., Prod. iii, 213, as pointed out by Hooker in Fl. Tas. i, 136.

(b) Col. Paterson ex. Herb. Lambert in Herb. Cant.

\section{VICTORIA.}

As regards Victoria, Mueller gives the south, north-east, and east. Speaking of Gippsland, Howitt says :-

This Eucalypt is extremely constant in character, whether found in small isolated colonies in the littoral tracts, as at Providence Ponds and Mlorwell, or forming forests over large areas in the Gippsland Alps up to an elevation of 5,000 feet, as on the Wonnongatta Plains, at Omeo, Woolgulmerang and Delegate. It appears to be essentially an alpine species, yet able to maintain itself, to some extent, in localities but little elevated above sea-level.

Following are some Victorian localities represented in the National Herbarium, Sydney :-

Mount Hotham, Victorian Alps (J.H.M., var. alpina). Buffalo Mountains (Mr. West, comm., C. Walter"), "Cabbage Gum," Caledonia River ; Upper Broken River, Wando Dale, Hotspur (A. W. Howitt). Hills near Mansfield, Strathbogie (H. B. Williamson); Camel's Hump, Mount Macedon (C. Walter).

\section{Soutil Australia.}

J. E. Brown figures it in his Forest Flora under the name "The Southeastern White Gum :"-

In this State the species is as yet only known to exist in the south-eastern district, and there merely in patches within a short distance of the sea-coast. The localities are-Dismal Swamp (Rev. J. E. Tenison-Woods) and Benara Estate (Beale).

The late Professor Tate records it from the volcanic area of the south-east corner of the Province, or the Mount Gambier district. Both in Victoria and South Australia it is recorded from the coast, a habitat I believe to be quite unknown in New South Wales. 
New South Wales.

It occurs usually at fairly high elevations, preferring undulating grassy country in the ranges and high table-lands, from south to north of the State. As already indicated, it ascends to the greatest elevation of any tree in the State. It consequently forms the limit of arboreal vegetation-the "tree-line" -which, on Mount Kosciusko, is about 6,500 feet. Following are some southern localities:Mount Kosciusko has already been dealt with in referring to var. alpina. In the Delegate district the bark is scribbled like E. homastoma, and the young leaves are sometimes larger and thinner than those of the type. This scribbling of the bark is observed in other localities also. Again, in the same district we have a small fruited form, the fruits being hardly larger than those of E. stellulata. Leaves thinner and dull looking. It may be that these trees show the effects of hybridisation.

Then again, in the Cooma district (Cooma-Braidwood Road), we have leaves straight, or nearly so, about $4 \frac{1}{2}$ inches long, seldom falcate, fruit more nearly sessile; sometimes glaucous, and apparently connecting with variety alpina. The bark is smooth, grey, and striped, and marked with scribbles.

"Cattle Gum," because eaten by stock. Gungahleen Estate (Gungarlin is an older spelling), Goldsbrough, Mort, \& Co., Sydney. Yarrangobilly Caves, and Adaminaby to Cooma (E. Betche). Tumut (J. H. Maiden and J. L. Boorman); top of Dividing Range, Nimbo River, Cooma district (H. Deane). This is a smallleaved form, showing transit to variety alpina. Jingera Mountains, Michelago (W. Baeuerlen); "White Sally," Queanbeyan (H. Deane); Rob Roy (H. Deane).

On the Monaro, where it is known as "White Gum," "Cabbage Gum," "Big Leaf," it is looked upon as the best firerood and best to stand in the ground for wire fences. There is not much timber in the Monaro of good quality; at the same time testimony to its value is not universal.

I have specimens from the top of Mount Tabletop, Kiandra district (E. Betche). The fruits are of unusual form, being nearly hemispherical and compressed, after the fashion of $E$. capitellata, Sm. A tendency for fruits to take on a similar character is shown in specimens from other elevated localities in southern New South Wales.

In the Braidwood district of New South Wales this tree goes by the name of "Cabbage Gum," on account of the softness of its timber; and reports from that district are consistent in stating, "Very durable underground, though of no use above it." It there attains a diameter of 5 feet and a height of 80 feet, extending from the lowest level up to the highest elevation (5,000 feet). Jembaicumbene, Araluen to Braidwood (J.H.M.) ; Gidley, Bungendore (W. Forster Rutledge); No. 370, S. H. Mossman, from Twofold Bay, herb. Cant. ex herb. Lemann (probably from near 'Tarago). Barber's Creek (H. J. Rumsey); "Snappy Gum," Paddy's River and Wingello, _ " used for posts and rails in the district" (J. L. Boorman). 
At Berrima (on the banks of the Wingecarribee, opposite the Rectory) is a Ribbony Gum, with rough black bark up to the first fork. The rough bark is much like that of $E$. viminalis. The habit of the tree is more erect as to foliage than . that of the normal coriacea close by. The timber is white and full of gum veins, like coriacea. The fruits are more hemispherical than the rest of the trees in the neighbourhood. The species is, however, very close to E. coriacea; and in all my travels I have not previously seen an E. coriacea a real Ribbony Gum as this is. E. coriacea is a species that does not present much evidence of variation as a rule, and I am inclined to think that this particular tree may present evidence of hybridisation, perhaps with E. amygdalina. It may be conspecific with Mr. Baker's E. vitrea.

Following are some western localities:-_"Snappy Gum," Jenolan Caves._ Bark smooth and mottled; there are two or three tints of slate colour with white streaks (W. F. Blakely). "Cabbage Gum," Capertee-LLarge trees plentiful all through the low lands of the district. Tendency to be pipy. Ribbony at base and clean for the most part throughout. Timber soft, useless (J. L. Boorman.) Tarana.-A large white shining gum tree, considered in the locality a great lasting timber in the ground (A. Murphy). "Large-leaved White Gum," Sidmouth Valley. -Cattle and horses are fond of the leaves (W. Woolls). Sidmouth Valley was formerly called Lowe's Swamp, and is described in Wells' Gazetteer, 1848, as "a broad and very difficult morass, in the county of Westmoreland, 102 miles from Sydney." The Sidmouth Valley Creek, a small southern tributary of the Fish River, runs through it. Millthorpe.-- "White Gum," thin bark, stands well in ground (R. H. Cambage). Top of Canoblas, about 4,500 feet above sea-level (R. H. Cambage); this is var. alpina. Canoblas, near Orange (Elliott Bros., Sydney).--Transit between the normal and alpine form. Kerr's Creek, near Orange.- "Cabbage or White Gum," found in broken, sour, pipe-clay country. Timber soft, inferior, does not stand the ground well; used for rails (Forest Ranger Martin). Peak Hill (J. M. Curran).

As regards the north, it is found all over New England, as far north as Tenterfield. I expect it will be recorded from elevated localities between Orange and New England. In New England we find about Walcha (J. F. Campbell and J.H.M.) the ordinary and the alpine form. It is called "Weeping Gum" at Salisbury, Uralla (H. Deane), and "Glassy Gum," Guyra (H. Deane). It has not been recorded from Queensland, but I should not be surprised if it were to be found in the ranges about Stanthorpe. 


\section{AFFINITIES.}

1 E. stellulata, Sieb.

As already indicated, the closest relations of $E$. coriacea are with $E$. stellulata, of which, in some respects, it strongly resembles a coarse form.

2 E. coccifera, Hook. f.

It seems to me that the alpine forms of $E$. cocciferc are very close to the Tasmanian E. coccifera, Hook. f., and this word of caution may be useful to the student.

3 E. vitrea, R. T. Baker, or E. vitellina, Naudin.

In a specimen from the Blue Mountains in Herb. F. Muell. the leaves are long and almost linear lanceolate, but very thick with the longitudinal veins of $E$. coriacea, of which it has also the flowers. -(B.Fl. iii, 201.)

In the above passage Bentham is doubtless speaking of specimens very similar to those I have from Jenolan Caves (W. F. Blakely). They are nearest to Mr. R. T. Baker's E. vitrea, though not typical. E. vitrea is, in my opinion, a hybrid between E. coriacea and E. amygdalina.

I will go into the matter at some length when dealing with $E$. amygdalina. Suffice it to say, at this place, that the tree referred to in the Flora Australiensis could not be confused, in the field, with E. coriacea; the former being a roughbarked tree and the latter a specially smooth gum. 


\section{DESCRIPTION.}

\section{Eucalyptus coccifera, Hook., f.}

Followivg is the original description :-

Ramis ramulisque teretibus lævibus plerumque glaucis, foliis alternis parvis uniformibus lineariellipticis lanceolatis $v$. anguste ovatis acuminatis utrinque attenuatis apicibus juniorum unicinato-hamatis, pedunculis brevibus 3-floris rarissime 4-8-floris, alabastris ancipiti-compressis obovato-obconicis, operculo depresso apice concavo capsula latiore rugoso, capsula obconico-hemispherica latiore quam longa basin versus bicarinata brevissime pedicellata, pedicello compresso, ore plano dilatato rarius convexiusculo $\mathrm{v}$. concavo, valvis axi capsule parvis. Tops of mountains, Lawrence, Gunn.

Arbor parva, 10-pedalis, e basi ramosa. Folia coriacea, sublonge patiolata, petiolo $\frac{1}{2}$ unc. longo, lamina $1 \frac{1}{2}-2 \frac{1}{2}$ unc. longa, $\frac{1}{2}-1$ unc. lata, elliptico-ovata v. lanceolata, v. lineari-lanceolata, omnia I-nervia. Pedunculi breves, fere omnes 3 -flori. Alabastra longitidine et diametro varia, longiora $\frac{1}{2}$ uncialia, obovatoJbconica, pedicellata, breviora $\frac{1}{4}$ unc. Ionga, sessilia, breviter obconica, omnia compressa. Capsulæ $\frac{1}{3}-\frac{1}{2}$ unc. latae, utrinque carinate, carine cum angulis pedicelli continuæ, nunc ad orem capsulæ productæ, nunc supra basin evanidæ-(Lond. Journ. Bot., vi, 1847, 477). It is described by Bentham in B.Fl, iii, 204.

This plant received its specific name because its foliage was infested with a Coceus, which circumstance was drawn attention to by Mr. Iawrence, who first sent it to the describer. This condition is by no means peculiar to this species, nor is this species particularly liable to such attacks; debilitated Eucalypts of perhaps any species may become thus infested.

It is a hardy species as regards temperature, and has succeeded in many parts of the United Kingdom. Its glaucous foliage renders it a pleasing object; its foliage also emits a more than ordinarily pleasant fragrance.

It is quite a small tree, of under 20 feet in height. It has a smooth white bark, and except occasionally for firewood, I know of no use to which it is put. Its leaves do not appear to be distilled for oil. It has no vernacular or aboriginal name that I know of. 


\title{
SYNONYMS.
}

\author{
1. E. alpina, R.Br., MS. \\ 2. E. daphnoides, Miq. \\ 3. E. citryandra, (? Vilmorin). \\ 4. E. pinnata (?). \\ Var. parviflora, Benth.
}

\section{NOTES ON THE SYNONYMS.}

1. E. alpina, R.Br., MS., top of Table Mountain (Robert Brown, 1802-5).

\section{E. daphnoides, Miq.}

22. Eucalyptus daphnoides, Miq. n. sp., ramulis densis glauco pruinosis subangulatis, veteribus fuscescentibus, foliis longiuscule petiolatis lanceolatis utrinque attenuatis apiculo curvulo terminalis, rigide coriaceis impunetatis, marginibus incrassatis, venis obtectis; pedunculis axillaribus et lateralibus $3-5$ floris, floribus sessilibus, calycibus obconicis pruinosis, fructibus brevissime pedicellatis semiglobosis truncatis, capsula 5-loculari (p. 133).—Van Diemensland (Stuart n. 9.)

Petioli 2-5 lin, folia 1 1 $2-23$ poll. Ionga, 2- vulgo 3 lin. lata. Calyx 2 lin. longus. Opercula desungt. (p. 134).-(Nederl. Kruidk. Arch., iv, (1856), 133.)

Stuart's specimens are from Mount Laperouse.

3. In Herb. Barbey-Boissier is a specimen of E.coccifera, labelled "Eucalyptus citryandra, Verrières près Paris, 27 Avril, 1891. Cult. Vilmorin, Gélé, 1890-1891.”"

4. I have received a specimen of a Californian-grown Eucalyptus from Santa Monica, labelled E. pinnata, which may be this species. I have seen neither ripe buds nor ripe fruits.

Var. parviflora, Benth.

Flowers much smaller, the peduncles exceedingly short. Mount Fatigue, Gunn.-(B.Fl., iii, 204.) I have not seen authentic specimens of this form. 


\section{RANGE.}

THIs species is confined to Tasmania, and to the highest tops of the mountains. It is readily obtained on Mount Wellington, Hobart, where it is abundant at about 4,000 feet.

Following are some specimens examined:-E. alpina, R.Br., MS., Mount Wellington (R. Brown, 1802-5). Robert Gunn, Nos. 411 and 1,076; tree, 120 feet, Mount Wellington (Oldfield, in Herb. Barbey-Boissier). No. 53 of "Voyage de l'Astrolabe et de la Zélée, 1838-40," M. le Guillou, 1841.-(Herb. Paris). Mount Laperouse (C. Stuart). Hartz Mountains (A. H. S. Lucas).

\section{AFFINITIES.}

\section{E. amygdalina, Labill.}

This species has much the aspect of some thick-leaved forms of $E^{\prime}$ amygdalina, but is readily known by the depressed operculum and longer calyx.-(B.Fl. iii, 204.)

- On Ironstone Range the buds are shorter in proportion to length, the operculum though flat, less rough, and the fruit about 4 lines diameter, thus approximating to forms of $E$. amygdalina.-(The Tasmanian Flora, L. Rodway.)

The affinity of this species to the alpine Tasmanian forms of E. amygdalina is undoubtedly great. The leaves of both species are very similar as regards the venation, etc. Further observations are required to absolutely settle their relations, though $E$. coccifera is quite a distinct species; the seedling-leares settle this.

\section{E. Risdoni, Hook. f., var. elata, Benth.}

This variety and E. coccifera are so similar, as regards dried specimens, that it is frequently difficult to separate them unless a full suite of specimens be available. 


\section{E. coriacea, A. Cunn.}

The affinity of $E$. coccifera with E. coriacea, var. alpina, is so pronounced as to be apparent to the most superficial observer; but it is distinguished from that species by its more prominent and more spreading veins, showing its closer relationship to $E$. amygdalina. The tuberculate-corrugate surface of the flower-buds reminds one slightly of those of E. globulus, but the flat shape of the operculum of $E$. cocciferc is quite different. The buds are very different to those of $E$. amygdalina and $E$. coria $e a$. The fruits of $E$. coccifera often display a puzzling similarity to those of $E$. coriacea. Both may have sunk and domed rims, but I do not call to mind any fruits of $E$. coriacea so angled as those of $E$. coccifera sometimes are.

\section{Explanation of Plates.}

\section{PLATE 25.}

Eucalyptus stellulata, Sieb.

1a. Leaves; 16 , buds of the type (Sieber's No. 478).

2a. Immature fruits, conoid in shape, but quite normal; $2 b$ ripe fruits from Nimitybelle, N.S.W. (J.H.M.).

3a. Juvenile leaves; $3 b$, mature leaf, Jindabyne, N.S.W. (J.H.M.).

4. Juvenile leaves, Yarrowitch, New South Wales, New England, N.S.W. (J.H.M.).

$5 a$. Twig in flower; $5 b$, front and back view of anther, of var. angustifolia, Benth., Mount Victoria, N.S.W., February 10, 1901 (J.H.M.).

5. Fruits of var. angustifolia in dense heads. Blackheath, N.S.W. (J. H. Camfield).

7. Buds deformed by insect galls, Jindabyne (J.H.M.).

\section{PLATE 26. \\ E. coriacea, A. Cunn.}

1. Sieber's No. 470 (E. pauciflora, Sieb.) type.

2x. Twig with flowers; $2 b$, buds; $2 c$, front and back view of anther of No. $165, \boldsymbol{L}$. silvicullrix, F. Mueller, the E. submultiplinervis, forma minor, of Miquel. (Charles Stuart, near Woodhall, Tasmania.)

3a. Leaf; 36, fruits of No. 40 "Eucalyptus (6) E. phlobopluylla, M. (Miquel), affinis subnultiplinervis." Van Diemen's Land, C. Stuart.

4. Leaf and fruits of "E. phlebophylla, Ferd. Mueller, Mount Aberdeen (Vict.), 4,000 feet, Mueller, February, 1853." Drawn by Miss M. Smith fiom a specimen in the Herbarium, Royal Gardens, Kew.

5. Leaf and buds from a second sheet of specimens from Mount Aberdeen; also in the Herbarium, Royal Gardens, Kew, and drawn by Miss M. Smith. Originally also labelled E. phlebophylla.

6. E. coriacea, A. Cunn, var, alpina, F.v.M., Mount Kosciusko, N.S.W. (J.H.M.). 


\section{PLATE 27.}

E. coriacea, A. Cunn.

1a. Twig with fruits; $1 b$, buds, of $E$. coriacea, var. alpina, from top of the Canoblas, Orange, N.S.W. (R. H. Cambage). Note the domed rim of the fruit and the hemispherical opercula.

2. Var. alpina, Mount Tabletop, Kiandra, N.S.W. (E. Betche). Note the broad rim and the tendency to angularity in the fruits.

3. Jurenile foliage, Pretty Point, Mount Kosciusko, N.S.W.(J.H.M.). The stem of this specimen was flat and ribbon-like.

4. Richmond Road, near Risdon, Tasmania (No. 266, Rodway). Note the hooked leaves (by no means rare) and the small fruit.

5a. Leaves and buds; 5b, fruits; Berrima, N.S.W., September, 1901 (J.H.M.). See p. 140. This form probably exhibits hybridism, and will be dealt with under $E$. vitrea.

\section{PLATE 28.}

\section{Eucalyptus coriacea, A. Cunn.}

$1 a$ and 1b. Jurenile foliage; $1 a$, nearly orbicular; from the Canoblas, near Orange (Messrs. Elliott Bros., Sydney); and

1b. Broadly lanceolate, from between Tenterfield and Sandy Flat, New England, N.S.W. (J.H.M.).

2. Markedly domed-rimmed fruits, from Delegate River, N.S.W. (W. Baeuerlen).

$$
\text { Eucalyptus coccifera, Hook. f. }
$$

2a, 2b. Two pairs of seedling leaves from Mount Wellington, Holbart, Tasmania (J.H.M.). Stem markedly tuberculate.

$3 a, 3 b, 3 c$. Leaf, front and back view of anther and fruits, from Mount Wellington (J.H.M.).

ta. Leaf; $4 b$, buds ; $4 c$, fiuits; of the type, viz., 1,076, R. Gunn, Mount Wellington, 1844.

$5 a$. Leaf and flower buds; $5 b$, flowers of the type of $E$. daphnoides, Miq., from Mount Laperouse, Tasmania (C. Stuart).

There is a good figure in Hooker's Fl. Tas. That in Bot. M $\mathrm{Fag} .78,4,967$, has expanded fowers ouly and is less good. There is a poor figure in Journ. Hort. Soc. vi, 222, and one in Gard. Ghron., 27th March, 1880, page 395 (young buds and expanded flowers). I luelieve there are figures in $F l$. des Serres, vi, 736, and Lem. Jard. Fl., 242, but I have not seen them. Mueller does not figure this species in his Eucalyptographia. I intend the drawings in the present work to supplement those of Fl. Tas. 


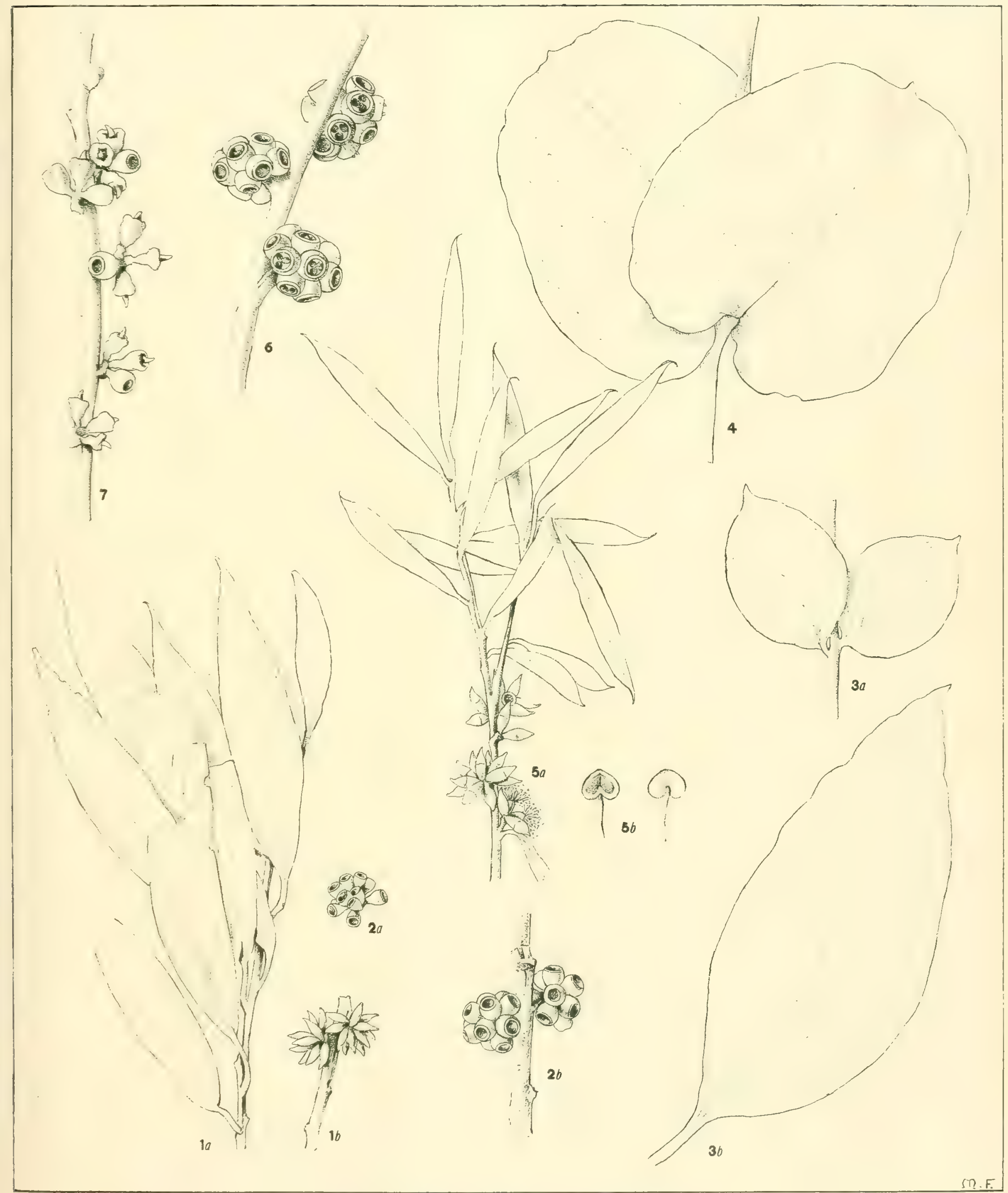





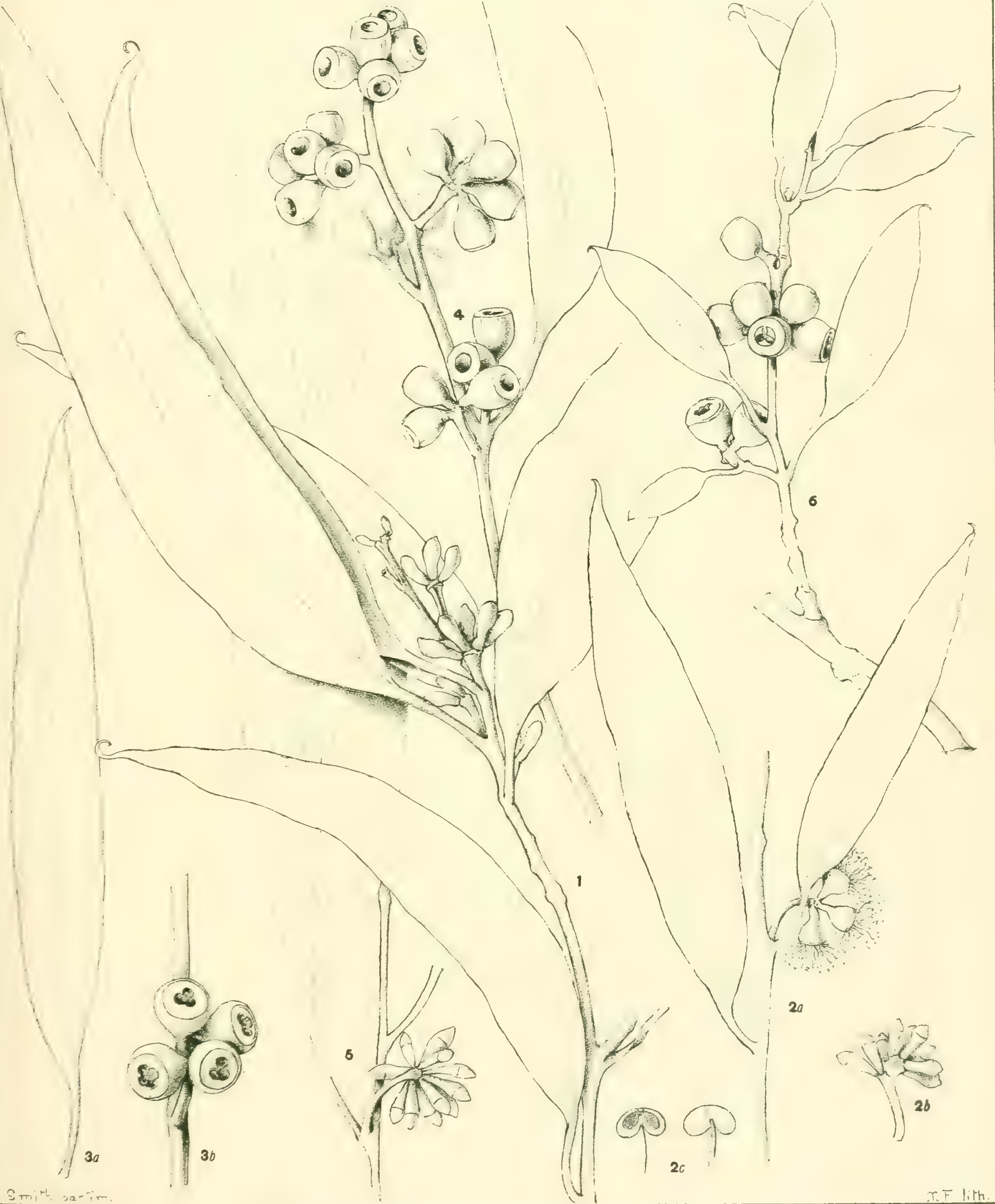





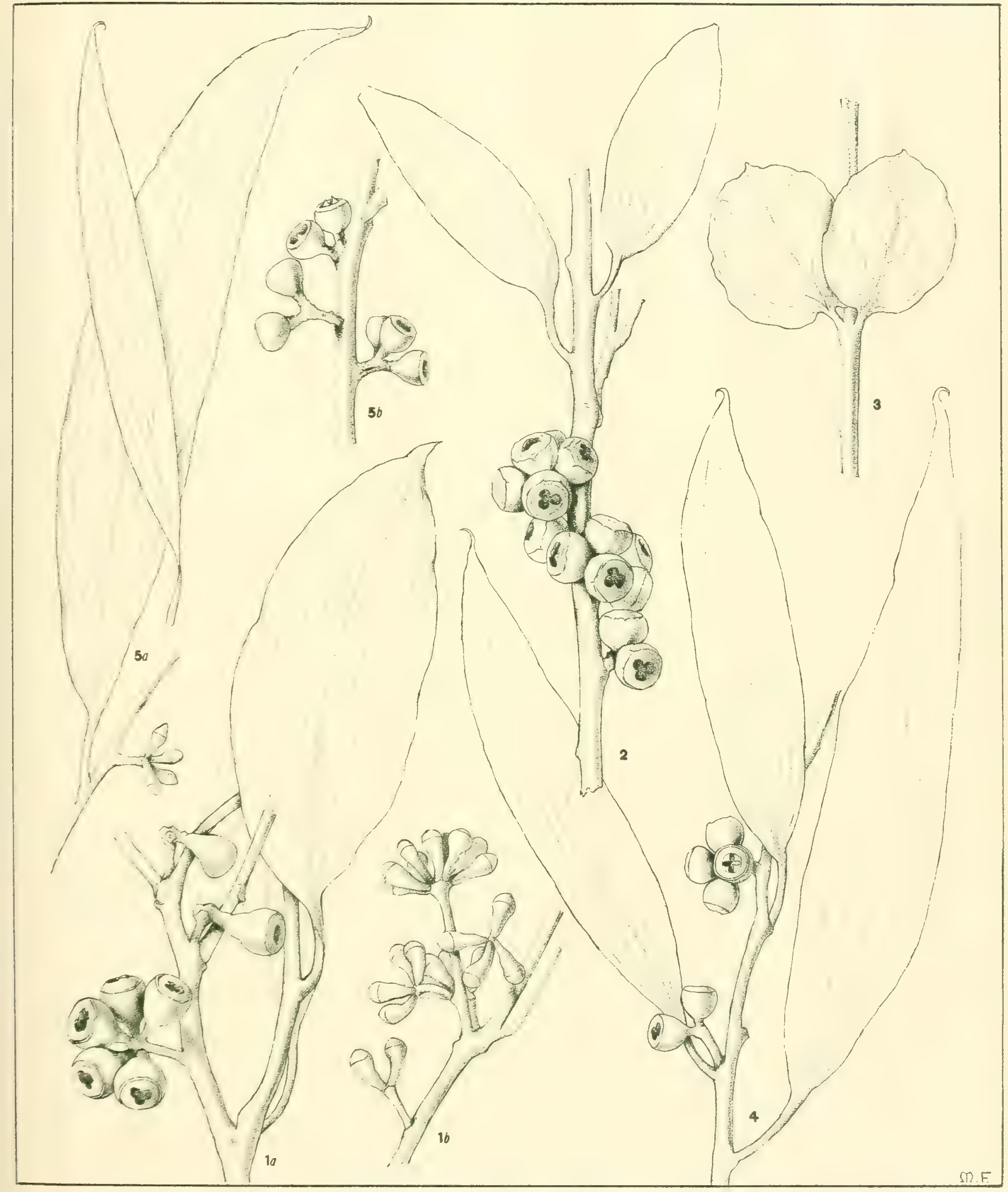




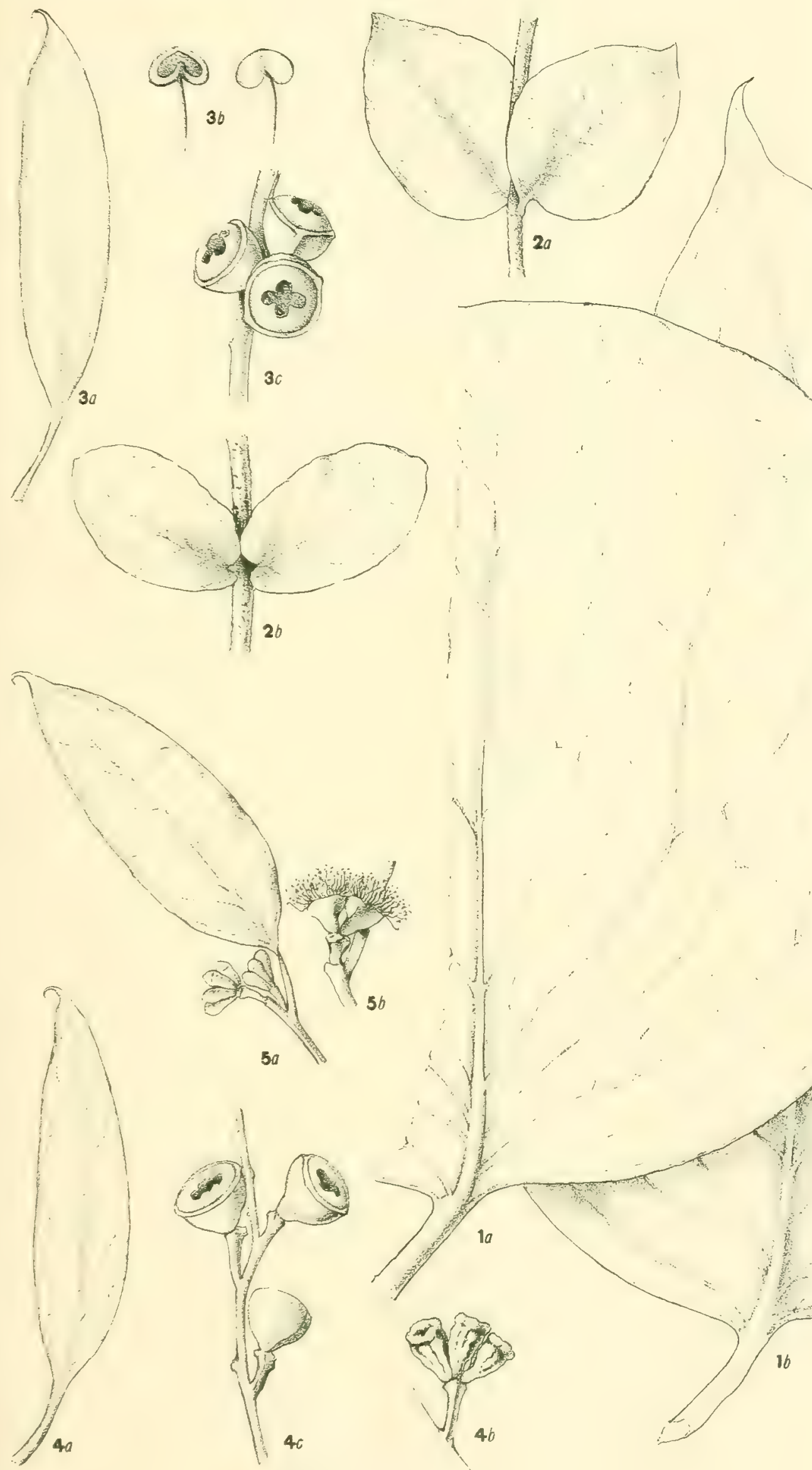



\title{
A CRITICAL REVISION OF THE GENUS EUCALYPTUS
}

\author{
BY \\ J. H. MAIDEN
}

(Government Botanist of New South Wales and Director of the Botanic Gardens, Sydney).

\section{PART VI}

(WITH FOUR PLATES)

Price Two Shillings and Sixpence.

Published by Authority of

THE GOVERNMENT OF THE STATE OF NEW SOUTH WALES.

Spunew:

WILLIAM APPLEGATE GULLICK, GOVERNMENT PRINTER.

1905. 



\title{
A Critical Revision of the genus Eucalyptus
}

\begin{abstract}
BY
J. H. MAIDEN

(Government Botanist of New South Wales and Director of the Botanic Gardens, Sydney).

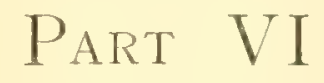

(WITH FOUR PLATES).

"Ages are spent in collecting materials, ages more in separating and combining them. Even when a system has been formed, there is still something to add, to alter, or to "reject. Every generation enjoys the use of a vast hoard bequeathed to it by antiquity, and transmits that hoard, augmented by fresh acquisitions, to future ages. In these pursuits, therefore, the first speculators lie under great disadvantages, and, even when they fail, are entitled to praise."

Macaulay's "Essay on Milton."
\end{abstract}

PRICE TWO SHILLINGS AND SIXPENCE.

Pullisheci ly sulhornly of

THE GOVERNMENT OF THE STATE OF NEW SOUTH WAI.ES.

Sulney :

WILLIAM APPLEGATE GULLICK, GOVERNMENT PRINTER, PHILLIP-STREET.

* 44236 A $1 \overline{905 .}$ 
192044 
9.

\section{EUCALYPTUS AMYGDALINA (Labillardière).}

10.

EUCALYPTUS LINEARIS (Dehnhardt).

11.

EUCALYPTUS RISDONI (Hook., f.). 


\section{Eucalyptus amygdalina, Labill.}

Description . . . . . . . . I49

Notes supplementary to the description. . I50

Synonyms . . . . . . . . I5I

Notes on the Synonyms . . . . I 52

E. numerosa, n. sp. or var. of E. amygdalina . $\quad \mathbf{I} 55$

Two hybrids of E. amygdalina and E. coriacea,

A. Cunn., viz., E. vitellina, Naudin, and

E. vitrea, R. T. Baker . . . . 164

Range . . . . . 160

Affinities . . . . . . . . . 64

X. Eucalyptus linearis, Dehnh.

Description . . . . . . . 168

Notes supplementary to the description. . I68

Synonym . . . . . . . . 169

Notes on the Synonyms . . . . . I69

Range . . . . . . . . I7 I

Affinity . . . . . . 17 I

XI. Eucalyptus Risdoni, Hook., f.

Description . . . . . . . . 172

Notes supplementary to the description. . 172

Synonyms . . . . . . . . . 173

Notes on the Synonyms . . . . r73

Range . . . . . . . . . 176

Affinities . . . . . . . . 177

Explanation of plates . . . . . 179 


\section{DESCRIPTION.}

\section{E. amygdalina, Labill.}

THE following description is based upon Bentham (B.Fl., iii, 202), but by no means literally follows the classical work referred to :-

A tree, usually small or moderate-sized, but sometimes attaining a considerable height; the bark fibrous and persistent-not so fibrous as that of a "Stringybark," and of looser texture than that of a "Box," —of the character usually known in Australia as "Peppermint," since it was originally observed on trees at Port Jackson whose foliage emitted a peppermint odour when crushed. The fibrous bark occurs only on the trunk, or, at most, on the largest branches. The branches are usually quite smooth or ribbony.

Jurenile Foliage.-Opposite, narrow-lanceolate. Probably all forms have the twigs more or less rusty glandular; sometimes the leaves are in threes. (See Fig. 3, pl. 29.) The variation in width of the transit forms will be alluded to at $\%$. 163. The under side is often purple.

Hature Foliage.-From linear to broadly lanceolate, straight or falcate, mostly acuminate, and 2 to 4 in. long; when narrow rather thin, when broad thicker, the veins few and oblique, but often inconspicuous, the intramarginal one at a distance from the edge, or rarely near to it. This species varies in the size, shape, and texture of the leaves. The usual shape in New South Wales is lanceolate, or even broadly lanceolate, but the typical form is linear-lanceolate, or even linear, comparatively thick, and the veins very oblique at the base, not prominent. Sometimes the foliage is quite dense, in other cases it is sparse. The various forms have leaves which have a pleasing, yet strong (sometimes very strong), odour of peppermint, to which circumstance they owe their commonest vernacular name. The aroma is least evident in rar. nitida.

Buls clarate, often glandular and rough.

Calyx-tube turbinate, about 2 lines diameter, tapering into a pedicel often as long as itself.

Operenlam hemispherical, shorter than the calyx-tube; very obtuse, or slightly umbonate.

Peduncles axillary or lateral, terete or nearly so, with 4 to 8 , and even more, flowers.

Flowers.-Stamens under 2 lines long, inflected in the bud, all perfect; anthers small, with diverging, more or less confluent cells. Ovary flat-topped.

Fruit.-Subglobose-truncate, usually under 3 lines diameter, but larger in some varieties; slightly contracted at the orifice, the rim flat or slightly concave and rather broad; the capsule not at all, or only slightly, sunk, the valves flat or slightly protrurling.

Following is a general description of them as far as New South Wales is concemed:-They are of a pilular shape, though with some tendency to pear-shape. They are wide at the mouth and almost hemispherical, the rim thin and also thickish and well-defined. As compared with New South Wales forms the Tasmanian specimens have often more domed fruits, and the rim thicker and more conspicuous.

Bentham's "sub-globose truncate" applies to some of the forms. The tips of the valves are sometimes slightly exserted.

Timber.-Pale-coloured (nearly white) when newly cut, but drying to a pale brown. Often liable to gum-veins, which tend to form thin concentric rings. Of inferior durability and strength as a very general rule, but there are some apparently well-authenticated instances of the comparative durability. of this timber for posts and shingles, and other purposes which will be duly noted.

Hahitat. - Tasmania is the home of the type, but it is very abundant in Victoria and New South iVales, occurring in the colder districts of the last-named States. 


\section{Following is the original description of the species :-}

Eucalyptus operculo hemisphærico, mutico; capitulis lateralibus terminalibusque, solitariis; foliis lineari-lanceolatis.

Arbor mediocris altitudine, ramulis subteretibus. Folia lineari-lanceolata, utrinque acuta, subpetio lata, alterna, plurima acuminata, palmaria et amplius, juniora glauca. Flores vix pedicellati, capitulorum pedunculo communi subtereti. Stylus vix calycem superans; stigmate obtuso. Capsula subglobosa, inclusa, quadrilocularis. Alias ut supra.

Habitat.--In capite Van Diemen.

Obs. - Haec est fortasse Metrosideros salicifalia, cujus figuram descriptionemque fructus tantummodo invenies in Gaertn., Sem. 1, p. 171, tab. 34, fig. A.-(Labill., Nov. Holl., Pl. ii, 14, t. 154.)

The original specimen described by Labillardière therefore came from Tasmania (see Fig. 1, pl. 29). The following is Don's translation of the species description as given in DC. Prod. iii, 219 :-

Lid hemispherical, nearly mutic, shorter than the cup; peduncles axillary and lateral, nearly terete, length of the petioles; umbels $6-8$ flowered, nearly capitate; leaves linear lanceolate, attenuated at the base, and acuminately mucronate at the apex. Leaves 3 inches long and 3 lines broad; some unequal at the base and some equal. Petioles and peduncles, 3 lines long. Fruit globose, size of a grain of pepper.

The following particulars in regard to the oil of this species, and of allied forms, are quoted from Messrs. Baker and Smith's Research on the Eucalypts:-

\begin{tabular}{|c|c|c|c|c|c|c|}
\hline Species. & $\begin{array}{l}\text { Whence } \\
\text { collected } \\
\text { for oil. }\end{array}$ & $\begin{array}{l}\text { Specific } \\
\text { Gravity at } \\
150^{\circ} \mathrm{C} \text {. }\end{array}$ & $\begin{array}{l}\text { Specific } \\
\text { Rotation } \\
\qquad[a] \\
\quad \mathrm{D}\end{array}$ & $\begin{array}{l}\text { Saponifica- } \\
\text { tion } \\
\text { Number. }\end{array}$ & $\begin{array}{l}\text { Solubility } \\
\text { in } \\
\text { Alcohol. }\end{array}$ & Constituents found. \\
\hline amygdulinu & $\begin{array}{l}\text { Moss Vale } \\
\text { and Monga, } \\
\text { N.S.W. }\end{array}$ & $\begin{array}{l}0.9012 \\
\text { to } \\
0.905\end{array}$ & $\begin{array}{c}-11.37^{\circ} \\
\text { to } \\
-13.53^{\circ}\end{array}$ & $3 \cdot 76$ & $\begin{array}{c}1 \frac{1}{4} \text { vol. } 70 \% \\
\text { to } \\
2 \text { vols. } 70 \%\end{array}$ & $\begin{array}{l}\text { Eucalyptol, pinene, } \\
\text { phellandrene, pep- } \\
\text { permint ketone, } \\
\text { eudesmol, methyl, } \\
\text { ethyl, isobutyl, and } \\
\text { amyl alcohols. }\end{array}$ \\
\hline $\begin{array}{l}\text { radiata (non radiata } \\
\text { Sieb., but var. nu- } \\
\text { merosa, sp. or var. } \\
\text { nov.).* }\end{array}$ & $\begin{array}{l}\text { Wingello } \\
\text { and Monga, } \\
\text { N.S.W. }\end{array}$ & $\begin{array}{c}0 . \$ 695 \\
\text { to } \\
0.8747\end{array}$ & $\begin{array}{c}-74 \cdot 48^{\circ} \\
\text { to } \\
-89 \cdot 4^{\circ}\end{array}$ & $2 \cdot 8$ to 4.37 & Insoluble & $\begin{array}{l}\text { Phellandrene, } \\
\text { pinene, eucalyptol, } \\
\text { peppermint ketone. }\end{array}$ \\
\hline $\begin{array}{l}\text { vitrea, a suggested } \\
\text { hybrid, amygdalina } \\
\text { × coriacea. * }\end{array}$ & $\begin{array}{c}\text { Crookwell, } \\
\text { N.S.W. }\end{array}$ & 0.886 & $-33.92^{\circ}$ & $5 \cdot 4$ & 1 vol. $80 \%$ & $\begin{array}{l}\text { Phellandrene, euca- } \\
\text { lyptol, peppermint } \\
\text { ketone. }\end{array}$ \\
\hline
\end{tabular}




\section{SYNONYMS.}

'THIs is not a specially variable species, but it went early into cultivation in Europe, and for many years was abundantly despatched thereto. Many of the names were given to immature specimens, growing in pots; it is consequently one of the species richest in synonyms, and I do not suppose for a moment that I have ascertained the whole of them.

1. E. salicifolia, Cav. (Metrosideros salicifolia, Soland.)

2. E. angustifolia, R.Br.

3. E. tuberculata, Parm.

4. E. radiata, Sieber.

5. E. purpurascens, Link., var. petiolata, DC.

6. E. globularis,

7. E. glandulosa, Desf.

8. E. Lindleyana, DC.

9. E. longifolia, Lindl.

10. E. gracilis, Miq.

11. E. tenuiramis, Miq.

Var. numerosa, var. nov. (vel. E. numerosa, sp. nov.).

12. E. amygdalina, Labill., var. radiata, Benth. (partim).

13. E. calyculata, Link.

14. E. diversifolia, Otto.

15. E. elata, Dehnh.

16. E. elata, Giordano.

17. E. translucens, A. Cunn.

18. E. Andreana, Naudin.

Var. nitida, Benth.

19. E. nitida, Hook., f.

20. E. radiata, Hook., f. (non. Sieb.), var. 5.

21. E. ambigua, DC. (?) 


\section{NOTES ON THE SYNONYMS.}

1. E. salicifolia, Cav. Ic. iv, 24 (Metrosideros salicifolia, Solander), probably "Metrosideros salicifolia" $\alpha$ and $b$, Soland., MSS.

a. Calyx subglobosus (a) truncatus, edentulus. Semina parva; $(b)$ angulata, ferruginea. Embryo. . . (Gaertner, De Fructibus, I. 172, with tab. xxxiv.)

Fig. $3(\alpha)$ of this plate consists of two fruits, which may be $E$. amygdalina, Labill. (See also Labillardière's original description); 3 (b) consists of seeds. According to specimens in Herb. Vindob., labelled " Eucalyptus amygdalina, Labill., Metrosideros salicifolia, Gaertn., Ins, van Diemen, Herb. Bauer, Ferd. Bauer," the above is $E$. amygdalina, a view in which $I$ concur. The specimens are in leaf and fruit.

A plant in early bud from Tasmania, labelled "Eucalyptus salicifolia," in Fraser's handwriting, is in Herb. Oxon., and cannot be distinguished from No. 25, Gunn. It is E. amygdaline.

2. E. angustifolia, R.Br., No. 4,800 b. E. angustifolia, R.Br., MSS., Derwent ('Tasmania), from Herb. Brit. Mus.

3. E. tuberculata, Parm. DC. Prod. (No. 43) iii, 221. 'T'he Prodromus specimen is labelled "Jard. de Berlin, Mr. Otto, 1826," and consists of juvenile foliage.

4. E. radiata, Sieber.

(Sieb. plant exs. nov. holl. n. 425) operculo hemisphaerico mucronata capsulâ breviore, pedunculis axillaribus et lateralibus subangulatis petiolo subbrevioribus, floribus 15 -20 umbellatis breviter pedicellatis, foliis lineari-lanceolatis acuminatis, venis tenuissimis in nerrum margini parallelum confluentibus. In NovâHollandiâ. Fructus ghobosi 3 lin. diam. Petioli 4 lin. longi. Folia 4 poll. longa, 6-7 lin. lata (DC. Prod. iii, 218). De Candolle tigured the Prodromus specimen in DC. Mim. Myrt., t. 7.

Bentham (B.Fl. iii, 203), quoting the Prodromus and Mém. Myrt., names this plant E. amydalina, Labill., var. radiata. He, however, quotes Sieber's number as 475. A specimen of Sieber's No. 475 I received from the Botanical Museum, Berlin (labelled E. pauciflora, Sieb., by the way) is E. vadiata, Sieb., and probably De Candolle's quotation of 425 is a mere slip of the pen.

I have also an original specimen of Sieber's Fl. mixta, No 604 [there are, of course, two series, "plant exs." (plante exotice) and Fl. mixta], which is obviously similar to De Candolle's drawing of E. radiata, Sieb., Mém Myrt t. 7. I am, therefore, in a position to speak with authority as to the identification of E. radiata, Sieb. Under E. viminalis, Bentham (B.Fl, iii, 210) refers Sieber's 
Fl. mixta, 604, to E. viminalis; there has been some confusion of numbers here which I do not pretend to be able to unravel, and which is of no particular consequence.

E. radiata, Sieb., appears to be nothing more or less than a form of E. amygdalina very common in New South Wales, and I see nothing distinctive enough to warrant its being called a variety. The typical amygdatina from Tasmania, with its linear-lanceolate, often thickish, leaves, with hemispherical opereula and hemispherical, usually broad-rimmed, fruit, doubtless appeared to sieber to be sufficiently different from the New South Wales form. Sieber's type probably came from the bigher parts of the Blue Mountains ( $I$ have matched it completely from Wentworth Falls to Mount Victoria). It is also common in some northern localities. The specimens distributed by Sieber have fruits not dead ripe; when they are quite ripe the tips of the valves are slightly exserted.

Much confusion has gathered round E. radiata, Sieb.

Hooker ( $F l$. Tas.) attributed four forms to $E$. radiata which I will, later on, shorr to belong partly to E. Risdoni, Hook., f., var. elato, Benth., and partly to E. amygdalina, Labill.

Then Bentham (B.Fl. iii, 203) described a var. radiata of E. amygdalina which is a combination of $(a) E$.radiata, Sieb., of (b) Hooker's Tasmanian supposed forms of radiata, and of $(c)$ the "White Gum" of Bent's Basin and the Nepean River, N.S.W. (Woolls). The "White Gum" of Bent's Basin I will presently deal with under the name numerosa, var. or sp. nov.

\section{อ. E. purpurascens, Link.}

230. E. purpurascens. Fol. amplexicaulibus lanceolatis longe acutatis subtus glaucis. Hab. in Australia. Rami purpurascentes. Folia $4^{\prime}$ longa, 10" lata juniola subtus saltem nervis purpurascentia. (Link's Enumeratio, p. 31.)

E. purpurascens (Link, Enum. 2, p. 31), foliis oppositis amplexicaulibus lanceolatis longe acutis subtus glaucis. In Nova Hollandiâ. Rami et nervi foliorum purpurascentes. Folia 4 poll. longa 10 lin.

lata. Forsan varietates 2 sequentes sunt tantum ejusdem formæ ut in $E$. glauca diversissimæ. Flores ign.

Var. petiolata, foliis breviter petiolatis lineari lanceolatis acuminatis.-(DC. Prod. iii, 221.)

I have seen the original specimen in the Prodromus herbarium. It bears the label "E. purpurascens, Link, Enum., Jard. de Berlin, M. Otto, 1826," and again, "E. purpurascens, Link, var. petiolata, DC. (DC. Prodr., n. 42)." It is in juvenile foliage only, but Thave no doubt that it is referable to E.amygdalina. E. purpurascens, var. petiolaris, DC. is E. corymbosa, Sm.

A specimen of E. purpurascens, Link, in Herb. Vindob. is in the oppositeleaved stage, and is probably E. amygdalina, Labill. The under side of the young foliage of this species is often purple. 
The following, referred to E. purpurascens, Link, is doubtful:-

(766.) Eucalyptus purpurascens. E. textu Link, Enum. definita, q. 1, at bene convenit. Folia horizontalia cordata (quod jure semper basi tantum intelligitur; v. Fl. Port.) semiamplexicaulia tantum (ad Link, Enum.), at cum opposita sint, junctim sane amplexicaulia (quod tamen utrumque non plane idem arbitror), subrepanda, margine nervis que supra quoque purpurascentia; subtus sane glauca, et mihi albide, purpurascentique admisto. Margo tenuiter subrevolutus.-(Hoffmg. Verz. Pfl. Nachtr. 3, p. 36.)

\section{E. globularis, Hort., Ex. DC. Prod. iii, 219, under E. amygdalina.}

E. globularis, hortul. (?). Folia 3 poll. longa, 3 lin. lata, alia basi æqualia alia hine inæqualia. Pet. et ped. 3 lin. longi. Fructus globosus grani Piperis magn.

\section{E. glandulosa, Desf.}

Ramis tuberculosis; ramulis filiformibus ; foliis oppositis, connatis, lanceolatis, acuminatis. Folia glaberrima, uncias 3-5 longa, lineas 4 lata, in acumen longum attenuata. An E.tuberculata, DC., Prodr. (?.) (Desf., in Cat. Pl. Hort. Par. Ed. 3, 1829, p. 408.)

\section{See also :-}

Ramis tuberculosis, ranulis filiformibus, fol. oppositis connatis, lanceolatis acuminatis. Folia 4-5 uncias longa, 4 lin. lata. E. tuberculata (?) DC. Crescit .. . (?). (Walp. Repert. ii, 926.) There are specimens in Herb. Barbey-Boissier bearing the label "Eucalyptus glandulosa, Desf., Culta."

\section{E. Lindleyana, DC}

Operculo hemisphrico submutico, pedunculis teretiusculis flores $3-5$ umbellatas gerentibus, foliis lineari-lanceolatis, aliis petiolatis basi cuneatis subæqualibus aliis sessilibus basi obtusis. In Australasia (?). E. longifolia, Lindl. in Bot. Reg. t. 947. Phrasis ex icone, sed descriptio nulla edita ob fruticem in hortis mox post anthesin mortuum.-(DC. Prod. iii, 219.)

According to Bentham (B.Fl. iii, 202) this is referable to E. amygdalina, Labill.

An old specimen in the Vienna Herbarium (Collection Reichenbach, fil.), labelled with an old label, "Eucalyptus Lindleyana, DC. Prod. 3, 219. E. longifolia, Lindl. c." is E. amygdalina, var. numerosa.

\section{E. longifolia, Lindl, in Bot. Reg., t. 947. The brief description is :-}

E. longifolia; operculo hemisphærico submutico, foliis lineari-lanceolatis basi cuneatis subinæqualibus, umbellis paucifloris pedunculatis axillaribus.

Bentham refers it to $E$. amygdalina. I have seen it, and concur.

\section{E. gracilis, Miq. non F.v.M.}

Specimen No. 3 (from Tasmania, C. Stuart) attributed to the above species by Miq. in Ned. Kruidk. Arch. iv.

\section{E. tenuiramis, Miq.}

11. Eucalyptus tenuiramis, Miq. n. sp.: ramulis tenuibus gracilibus teretiusculis, foliis e basi attenuata subrequali lanceolatis vulgo subfalcatis, apiculo recto vel curvulo terminalis, subcoriaceis, punctatis, venis tenuibus adscendentibus tenere reticulatis utrinque cum costa subdistinctis, pedunculis 6-10 floris, floribus subsessilibus, calycis tubo obovato-conico striulato pruinoso, filamentis rubellis et flavis (in sicco) antheris didymis. 
Van Diemen's Land (Stuart, ‥ 11, p. 16).

Ramuli fusculi. Petioli tenues subsemipollicares. Folia 3-5, vulgo $4 \frac{1}{2}$ poll. longa, $4-7$ lin. lata, nunc glauco-pruinosa. Pedunculi subsemipollicares. Alabastra clavata. Calycis tubus fere 3 lin. longus.

(P. 129.) Species venis adscendentibus (p. 129) a plurimus diagnoscenda, Anne cum E. uncinata, Turez. Bull. Mosc. xxii, part ii, p. 23, comparanda (?).-(Ned. Kruidk. Arch. iv, 128, 1856.)

E. tenuiramis, Miq., is described in Ned. Kruidk. Arch. iv, 128 (185̄6) from Tasmanian specimens ("Stuart No. 11, p. 16," sic). I have examined the type specimen ("unicum in Miquel's handwriting") in Herb., Melb. E. tenuiramis, Miq., "Van Diemen's Land, C. Stuart." It has broadish leaves with thickened margins, is in flower, without buds or fruit. I cannot see any difference between this specimen and R. Gunn's No. 1,112 (see Fl. Tas.).

E. ligustrina, DC., surmised by Bentham (B.Fl. iii, 203) as probably amygdalina, is, in my opinion, a form of E. eugenoides, Sieb. It will be dealt with in due course.

\section{Variety numerosa, var. nov.}

(vel. E. numerosa, sp. nov.)

In allusion to the very large number of flowers in the umbel.

\section{E. amygdalina, Labill., var. radiata, Benth.}

In the Catalogue of Indigenous Woods of the southern districts of New South Wales, prepared by the late Sir William Macarthur for the Paris Exhibition, 1855, we have, under No. 109 :-

Eucalyptus radiata, (?) "Kayer-ro"" "River Gum of Camden." A small, quick-growing species, very elegant when in blossom; is found only on the immediate sandy banks of rivers; the wood of no value; the inner bark used for tying grafts, and other similar common purposes. Height, 30 to 50 feet; diameter, 12 to 18 inches.

The name was supplied by Kew, and it will be observed that it was doubtfully referred to $\mathbb{E}$. radiata.

In the Flora Australiensis, as I have already pointed out, Bentham included it with some other trees under his variety radiata of amygdalina.

It is the tree included by Mueller under E. amygdalina in "Eucalyptographia," where, quoting Howitt, he speaks of the "Wang-gnara" of Gippsland. Subsequently Howitt refers to the tree* in some detail.

It was figured and described by Deane and Maiden, $\dagger$ as var radiata, Benth.

The Rev. Dr. Woolls, Proc. Linn. Soc. N.S.W., v. 448, and on other occasions, protested against $E$. radiata, Sieb. (as he understood the species) being merged in

"The Eucalypts of Gippsland." Trans. Roy. Soc. V , Vol. ii, Pt. i, p. 86, and Plate 10, fig. 1-5.

+Proc. Lin. Soc, N.S.W., 1895, p. 606, Plate LVI. 
E. amygdalina, Labill. It will, however, remain an open question with some botanists as to whether this form is looked upon as a variety or as an independent species. It certainly is closely related to $E$. amygdalina, and different authors hold different views as to the amount of variation necessary to constitute a species. So that, as far as aboriginal and vernacular names are concerned, it is the "Kayer-ro" of Sir William Macarthur, the "White Gum" of Bent's Basin and the Nepean (Woolls. See B.Fl. iii, 203), and the "Wang-gnara" of Mr. Howitt. It goes under the names of "River White Gum," "Ribbon Gum," and also "Narrowleaved Peppermint." Its favourite habitat is on the sides of gullies, or on the steep banks of rivers, often some distance from the bed of the river or creek, but usually on a well-drained slope leading to a watercourse. It sometimes occurs on flats. It is often seen as a graceful sapling, but may attain the dignity of a large tree. In this State I have it up to 3 feet in diameter and more, with a height of 150 feet. It has rather sparse, drooping foliage, which gives it, at times, something of a willow-like aspect.

Bark.-It is nearly a White Gum when very young, but afterwards the bark of the upper part falls off in thin, long ribbons (hence the name "Ribbon Gum"), and the lower part of the trunk becomes covered, to a varying height, with fibrous bark of the character known to many as Peppermint bark. In its most marked form the bark at the butt is more rugged than that of amygdalina usually is. Sir William Macarthur spoke of the fibrous bark, and subsequently Mr. Howitt pointed out that the aborigines of Gippsland similarly used the baxk for tying and lashing, hence their name for the tree "Wang-gnara," which signifies "bark-string."

Seedling or sucker leaves.-The young stems have a rusty, glandular appearance, and the leaves are very narrow. I do not note any difference between them and the leaves of the normal species.

Iature leaves. - Thin; though usually narrow, up to 14 lines broad, often from four to 7 inches long. Although the leaves of this form are very thin, specimens from Bateman's Bay to Wagonga are especially thin. These specimens also have unusually narrow leaves.

Fruits. - Large numbers (commonly twenty or more; Mueller counted as many as forty-three in the umbel. See "Eucalyptographia" under amygda7ina. I have often counted them with forty (but I have not figured an umbel with so large a number for clearness sake) in an umbel, borne on rather long, often filiform pedicels. They have a very regular, umbellate appearance. Mostly pale-coloured when dry. Very uniform in size, 2 to $2 \frac{1}{2}$ lines (barely) in diameter, and pilular, or nearly pear-shaped. Sometimes they tend to close at the orifice. The rim varies in width. In some specimens it is comparatively broad, well-defined, and reddish.

Timber.-It is a white, fissile timber, rather tough when freshly cut, but afterwards of inferior strength. It is easily worked, but is not durable on exposure.

\section{SYNONYMS.}

13. E. calyculata, Herb. Link. (where described?).

A specimen in Herb. Berol. examined by me in that collection in 1900.

14. E. diversifolia, Otto (Hort. Berol.). A specimen in flower in Herb. Vindob. 
15. E. elata, Dehnh.

Specimen from "Hort. Neapel" (Herb. Vindob.) from Dehnhardt. "A giant of 100 feet high and 8 feet in circumference near the root". (Hort. Camaldul., Dehnhardt).

16. E. elata, Giordano.

A specimen in Herb. Barbey-Boissier bears the following label :- "Eucalyptus elata, mihi, in Cat. H. (hort.), Camuldensis, Giordano." A specimen labelled E. elata in herb. A. Braun, in herb., Berlin. There is a similar specimen in herb., Monac. (Munich), labelled "Aff: Eucal. radiata, Sieb. Eucalyptus elata, exsicc. Dr. Krumer, hort. Monac, 23rd Jan., 1849."

\section{E. translucens, A. Cunn., MSS.}

Specimens examined by me:- "River bank, County Argyle," Herb., Kew. (There is a similar specimen in Herb., Oxon., labelled "Eucalyptus translucens, Argyle"); also, Cowpasture River, $\frac{36}{1824}$ April, Herb., Kew. I have examined specimens similarly labelled in other herbaria.

\section{E. Andreana, Naudin,* Revue horticole (1890), p. 346.}

C'est probablement une des espèces auxquelles on a donné le nom d'E. amygdalina, mais il ne m'est pas possible de l'identifier à aucune d'entre elles. Elle existe dans plusieurs jardins de la région, notamment dans ceux de M. H. de Vilmorin et de M. Edouard André, au Golfe-Juan, qui en a été l'introducteur en France.

Cet Eucalyptus est vaguement biforme, en ce sens que les premières feuilles, à l'état juvénile, quoique opposées, ne sont pas tout à fait sessiles et qu'elles ressemblent à celles de l'âge adulte, étant comme elles longuement lancéolées. Ces dernières, un peu molles pour un Eucalyptus, sont souvent rapprochées deux par deux, un peu aiguës à la base, davantage au sommet, droites ou un peu arquées en faux, vertes, pendantes, longues en moyenne de 10 centimétres, sur une largeur de 1 à $1 \frac{1}{2}$.

L'inflorescence rappelle celle de l'E. amygdalina, étant, comme dans de dernier, composée d'ombelles axillaires un peu capituliformes et pluriflores, où le nombre des fleurs peut aller de 15 à 25 , peut-être quelquefois plus. Leur bouton est claviforme, atténué en pédicelle et terminé par un petit opercule hémisphérique, plus court que le tube du calyce, obtus ou terminé par un court mamelon. Le fruit, à peu près de la grosseur d' une graine de chènevis, est pyriforme-tronqué, et sa capsule, 3-4 loculaire et incluse, n'arrive pas tout à fait au bord du tube calycinal ou réceptacle.

$L ' E$. Andreana est un arbre élégant, surtout à l'époque de sa floraison, quand ses longs rameaux, grêles et pendants, ressemblent à autant de guirlandes de fleurs blanches. Nous ne le connaissons encore que par des exemplaires de 8 à 10 mètres, qui deviendront sans doute beaucoup plus grands avec les années.

Dans la planche de l'Eucalyptographia du baron Ferd. von Müller (fascicule V, No. 1), qui est -ensée représenter l'E. amygdalina, une partie des figures pourrait, à la rigueur, convenir à l'E. Andreana. mais celle qui en représente la forme juvénile ne me paraît pouvoir s'appliquer qu'à l'E. viminalis, ou à quelque autre espèce biforme à feuilles sessiles comme dans ce dernier.

* Perhaps identical with the species quoted in Index Kewensis (Durand's Supp.) as E. Andreanc (Carr), in Rév. Hortic. (1990), 346, fig. 104 et 105, but said to be from Tasmania. I have not seen the description. 


\section{Variety nitida, Benth.}

\section{E. nitida, Hook, f.:-}

Arbor mediocris, ramulis pendulis, foliis anguste lanceolatis longe acuminatis coriaceis nitidis vernicosis nervis divergentibus, pedunculis validis multifloris, floribus brevibus subsessilibus, calyce breviter clavato v. obconico, operculo brevi lato, capsulis sessilibus parvis subglobosis ore contracto $\mathrm{v}$. subdilatato, marginibus crassis planis angustive. (Tab. xxix.) (Gunn, 808.)

Hab.--Hobarton, Circular Head, Curre's River, east of Georgetown; A. Cunningham, Gunn.

I have great doubts as to the distinctness of this species, which I have at one time been inclined to refer to $E$ amygdalina, and at others to $E$. radiata (Risdoni, var. elatn, in part, J. H. M.), but from both of which it differs in very small sessile fruit, and very shining, coriaceous leaves. Gunn says that at the Currie's River it forms a bush only, 5 feet high; and that at Circular Head it grows 10-20 feet high, and appears mure of a shrub than a tree. It approaches $E$. stellulata, Sieber, in many points, but wants the three parallel nerves of that plant, and the large operculum.-(Hook., f., Fl. Tas., 1, 137, with plate.)

20. E. radiata, Hook., f. (non Sieb.), var. 5. Fl. Tas., i, 137.

5. Foliis angustis elongatis, capsulis parvis obconicis. Arbor elata, ad E. nitidam tendens.(Hook. f., loc. cit.).

A label by Hooker is "A large dense tree near the sea at Port Arthur," which also is a locality for his $E$. nitidus. The two are, in fact, identical.

Messrs. Baker and Smith (Research on the Eucalypts, p. 169), say-

It is now shown that its (E. amygdalina) leaves, timber, bark, fruits, chemical constituents, dc., differentiate it clearly and distinctly from E. nitida, Hook., f.,

but no evidence is furnished in support of this statement.

When reducing E. nitida to a variety of E. amygdalina, Bentham has a note:

Leaves broader and more rigid. Peduncles and pedicels shorter. Flowers rather longer. . . ( $E$. nitidn, Hook. f.). In the dried specimens this variety appears to pass into the variety elata of $\boldsymbol{E}$. Resdoni.--(B,Fl, iii, 203.)

Rodway (The Tasmanirn Flora, p. 56), defines var. nitida as-

Differing from small-statured individuals only in the leaves being broader and more rigid, running absolutely into the type.

There is no doubt that the species passes imperceptibly into var. nitida, which has thicker, broader leaves, broad, domed, red rim, fruits in heads; but all these points are variable. It is, indeed, not a strong variety; it is especially close to the shiny and coriaceous amygdalina so common near the coast in many parts of Tasmania.

21. E. ambigua, DC.:-

E. ambigua, operculo hemisphærico mucronulato cupuka breviore, pedunculis axillaribus compressis petioli longitudine, umbellis $8-9$ floris capitatis, foliis lanceolatis subcoriaceis basi eqqualiter attenuatis apice acuminato-mucronulatis. In Novâ Hollandiâ. Labillardière. Attinis E. ligustrine et amygdalina. Fructus subglobosus duplo major. Pet. et pedunc, 2-3 lin. longi. Folia 2-3 poll. longa 6-12 lin. lata rigidula venis lateralibus vix perspicuis.-(DC. Prod. iii, 219.) 
Bentham (B.Fl. iii, 203), thinks that-

E. ambigua, DC. Prod. iii, 219, from the diagnosis taken frow Labillardière's specimen, may perhaps be identical with $E$. amygdalina, Labill, var. nitida.

There is no specimen at Kew. Mueller says it-

May be a West Australian species, the somewhat leathery leaves, the compressed flower stalks, and the almost globular fruit not really pointing to $E$. anygdalina.-(Eucalyptographia, under $E_{\text {. amygdalina.) }}$

A specimen from the Prodromus herbarium, lent me by M. Casimir De Candolle, bears the following label:-

E. ambigua, DC. Eucalyptus obliqua? (Manu Labillardieri).

Nouv. Hollande, Labillardière (Manu DC, ei). Misit, 1808. Bentham.

I think it is probably $E$. amygdalina, tending to var. nitida, as suggested by

I have seen a specimen from Herb. Paris: "26. Eucalyptus ambigua, DC. Prod. iii, 219, ex Nova Hollandia. Specimen Billardieri comm. cl. Webb, Anno, 1840." This is E.amygdalina, var. nitida. I have also seen E. ambigua, Dehnhardt. Specimens in flower and early fruit from Dehnhardt, Hort. Camaldul. in Herb. Vindob. are Euc. amygdalina, var. numerosa. On the label Dehnhardt says the species resembles E. elata (amygdalina, var. numerosa), but is satisfied that they are different, and addressing (? Direetor of the Gardens at Vienna) adds, "Your superior botanical knowleảge will probably solve this puzzle."

I have seen a fourth cultivated specimen. It is ex. Herb. Lindley in Herb. Cant., and is labelled, "Eucalyptus ambigua," in Lindley's handwriting. It is in flower and early bud, and seems to be E. stricta, Sieb., the venation perhaps a little accentuated under cultivation. Leaves thick, lanceolate, veins very pronounced, opercula pointed, pedicels flattened, anthers reniform.

I think it may be accepted that E. ambigua, DC., is allied to E. amygdalina, Labill., var. nitida. It may, however, be E. stricta, Sieb.: another of the Renantheræ. Better material may be in existence.

Bentham's var. (?) hypericifolia (B.Fl. iii, 203), of amygdalina is, in my opinion, referable to $E$. Risdoni, var. elata. 


\section{RANGE.}

Tasmania is, of course, the home of the type. Labillardière figured his plant, and this should be borne in mind. The species is also found in Victoria, New South Wales, and in south-eastern South Australia.

Tasmania.

Gunn's No. 25 come from Point Effingham, "near Launceston, Distillery Creek, small tree." Specimens bearing the same number are also from New Norfolk. Two forms are under that name, one near var. nitida, and the other the ordinary thin-leaved amygdalina. We have here additional evidence of the impossibility of keeping the type and var. nitida apart. (See Fig. 2, plate 29.)

I have seen specimens also from Col. Paterson ex. Herb. Lambert in Herb. Cant.; also some collected by Dr. John Lhotsky. "No. 94, Voyage de l'Astrolabe et de la Zélée (M. le Guillou, 1811)," is E. amygdalina.

Much of the common Hobart amygdalina (e.g., Sandy Bay and Mount Wellington), has coriaceous leaves; so, indeed, have R. Brown's specimens of $E$. angustifolia from the Derwent. I have also collected it on the east coast. It is, indeed, found more or less all over Tasmania.

VICTORIA.

Mueller (Eucalyptographia) defines its range in Victoria as "from the southern and whole eastern humid districts, extending to the base of the Alps." Howitt states that it ascends to about 4,500 feet. Mr. Howitt has given much attention to the species, particularly in Gippsland, and following are two of his specimens; others will be referred to later:- $(a)$ Lilydale, with very small fruits, A. W. Howitt; (b) Sand-hills, near Stradbroke; rim very marked; the coastal form, inclining to be coriaceous; narrow leaves; near var. nitida. From a correspondent of Mr. Henry Deane I have received it as "Peppermint," from Darlimurla, South Gippsland. It has small fruits, and its leaves are very broad. This tree certainly shows affinity to $E$. regnans.

\section{South Australia.}

The late Prof. Tate says that a shrubby form is found in the Mount Gambier district. I have not seen it.

\section{NeW South WALES.}

In this State it extends from the Victorian to the Queensland border (Tenterfield), and I have no doubt that it will be found in Queensland, probably in the Stanthorpe district. Westerly it extends to the Jenolan Caves and the Capertee Valler. As a rule, it is found in the colder and more mountainous parts of the State. 
Southern Districts. - It occurs in the mountains from the Victorian border to the Braidwood district. Other specimens in the National Herbarium, Sydney, include:- "Peppermint," Braidwood (H. Deane); "Narrow-leaved Peppermint," near Goulburn, (H. Deane); Hilltop (J.H.M.). The following show affinity to var, numerosa:-Little River, Braidwood, and Araluen to Braidwood (J. S. Allan and J.H.M.) ; "White-topped Mountain Ash, inferior to Black-topped Mountain Ash," Kangaloon (J. L. Bruce).

Western Localities.-Blackheath, Mount Victoria, and the higher parts of the Blue Mountains generally. Walking over the Blue Mountains with Mr. R. H. Cambage, the first tree of this species we noticed is at the top of the big hill, Lawson to Wentworth Falls. Valves slightly exsert when fruits thoroughly ripe (J.H.M.). Capertee Valley (J.H.M. and J. L. Boorman). The most westerly locality known to me is Mullion Creek, Orange ( $R$. H. Cambage). See also var. nitida, p. 162.

Northern Localities.-The "Willow" of Wilson's Downfall is a form with smaller fruits.

"Messmate." Very abundant. Coming from the Bellinger River, first seen about Tyringham, and then at least as far as Wollomombi. Found on the very summit of the Round Mountain. At Bald Hills station, Mr. Walter Beauchamp showed me posts of this timber which had been down from ten to fifteen years, and which were still sound. This timber lasts even longer in damp ground. This is worthy of note, as E. amygdalina is not usually considered durable for the purpose stated.-(J. H. M., Agric. Gazette, N.S.W., 1894, p. 611.)

Yarrowitch to Tia, New England (J.H.M.); Moona Plains, Walcha, valves slightly exsert (A. R. Crawford). The northern specimens, as a rule, are closer to Sieber's $E$. radiata than to typical $E$. amygdalina.

Variety or species numerosa.--It appears to be confined to Victoria and New South Wales.

\section{VICTORIA.}

Boggy Creek and Tambo River, Gippsland, called "Wang-gnara" (A. W. Howitt); Darlimurla, S. Gippsland (correspondent of H. Deane). "Flourishes on poor flats; stunted in appearance."

\section{NEW SOUTH WALES.}

Found from south to north of this State. Some specific localities are given, for definiteness. Tantawanglo Mountain, (W. Baeuerlen); Eden (J.H.M.); Wyndham (A. W. Howitt); Deua River, Moruya (J.H.M.) ; Ryan's Creek, Monga (W. Baeuerlen); "Blackbutt," Narrabarba (J. S. Allan). "Easily worked, but worthless. Sometimes substituted for 'Mountain Gum' (E. goniocalyx) in the Braidwood district" (J. S. Allan); Runnymede, Nelligen (W. Baeuerlen); Currawang Creek (W. Baeuerlen; J.H.M.); Shoalhaven River, Badgery's Crossing to Nowra (W. Forsyth and A. A. Hamilton); Kangaroo Valley (J. L. Bruce); Marulan, Barber's Creek, and Wingello (H. J. Rumsey, W. Forsyth, J. L. Boorman, J.H.M.) ; 3 miles from Marulan; about 4 feet in diameter; called "White Top" or "Ribbon Gum" 
(A. Murphy) ; Nattai River, Burragorang (R. H. Cambage); Exeter (F. Jensen) ; Mittagong (J. L. Boorman and J.H.M.); Hilltop (J.H.M.) ; County of Camden (Macarthur); Mount Kembla (R. H. Cambage).

The above are all southerly localities. Westerly localities are the Nepean River (Woolls and others), and the most westerly point known to me is Mount Tomah (Jesse Gregson).

Northerly it appears to be rare. Mr. Baker (Proc. Linn. Soc. N.S.W., XXVII, 540, 1902) quotes Mr. Barwick as having found it at Putty, south of Singleton. He calls it E. radiata.

Var. nitida.-I have a specimen of Gunn's No. 808 (the only one mentioned by Hooker as typical). It is labelled "Circular Head, road to Forest, 10th December, 1836, and 21st January, 1837." Some specimens were labelled by Gunn " 808 (?)," although it is evident that they are typical, from the localities quoted by Hooker himself.

808 (?). Eucalyptus radiata ("radiata, var. 5," in Hook. f.'s handwriting). "I think this is the same as my original No. 808. At Currie's River it formed low bushes, about 5 feet high, but occasionally a few feet higher. It grew in the poor, sandy land near the sea."

Another label of Gunn's reads-

Currie's River, east of George-Town, 24/10/43.

(b) The label of another specimen reads$24: 10 / 43$

808 (?), from Currie's River, east of George-Town: a small tree, 5 feet high; on sandy land,

The following specimen is identical with that from Currie's River :Granite Hills, Cape Barren Island, low, shrubby tree.--(J. Milligan.)

1078 Gunn. "Risdon, river side, 10/10/40" (Hobart, of course) precisely matches the type, except that the leaves are narrower, which is of no importance, as the leaves vary if taken from the top of the tree or from the lower branches. I may observe that the form figured by Hooker (Fl. Tas., Pl. xxix) as E. nitida, varies a little from that of the specimens of Gunn's No. 808 that I have seen, but that is nothing to be surprised at. (a) "E.amygdalina, Swamp Gum, Tasmania, F. Abbott, 1878," in herb. Melb. in fruit only, and (b) "E. hremastoma, Deal Island, Bass' Straits, Exped. of Field. Nat. Club of Victoria, 1890," in fruit only. Both have coriaceous rather rigid leaves, and appear to be practically identical. They were originally labelled by Mueller as stated, and are in my opinion both very close to var. nitida. They are a little more pedicellate than the type.

Typical amygdalina has sometimes coriaceous leaves, but the shape is linearlanceolate, and the fruit more hemispherical than that of var. nitida. At the same time (e.g., at Deloraine, Tasmania), I have collected from the same tree some leaves which strictly match those of typical amygdulina, and some which would be typical for var. nitida. The fruits, however, belong to the normal species. 


\section{VICTORIA.}

"Peppermint," Hesket, near Mount Macedon, 2,000 feet (J. M. Griffiths), is identical with the "Swamp Gum" (Abbott), and Deal Island specimens. It is worthy of remark that this is from an inland locality.

\section{NeW South WaLES.}

In 1901 (Proc. Linn. Soc., N.S.W., p. 125), Mr. Deane and I described, under the name of $E$. hoemastoma, Sm. var. montana, a shrubby plant, only two or three feet high, from Mount Victoria, collected by myself. The bark of so small a shrub was no guide, and the blood-red rims decided us to place it with $E$. hemastoma, a pardonable error, as it obviously strongly resembles that species.

Since then, however, I have obtained typical E. amygdalina, var. nitida, and I find that these specimens closely resemble Gunn's No. 808, e.g., Currie's River, Tasmania. 'The pale brown fruits, with the dark red-brown rims, arrest attention. The only point in which I can distinguish the Mount Victoria specimens from those of Currie's River consists in the more obvious oil-glands of those from Mount Victoria, but this may be in a measure owing to the age (over 60 years) of the Tasmanian specimens. The similarity of the specimens is remarkable, when it is borne in mind that the Tasmanian specimens are mostly from the sea-coast, while Mount Victoria is an inland mountain locality. In a paper ${ }^{*}$ I have given very definite evidence of the absolute similarity of many Tasmanian and New South Wales plant forms, and this is an additional example.

I have specimens from the Jenolan Caves (W. F. Blakeley) which are the nearest approach I have yet seen in New South Wales to Hooker's figure of E. nitida, which, as already pointed out, varies somewhat from Gunn's 808 . From the south, e.g. Wingello (J. L. Boorman, Nov., 1899), I have specimens with fruits smaller than those of var. nitida, and with filiform pedicels like those of (although shorter than) var. numerosa. Also, from the south I have from Monga, near Moruya, on the coast (W. Baeuerlen, July, 1898), a remarkable form which resembles that of var. nitida a good deal. Some of its leaves are, however, exceptionally broad, and their shape and venation reminiscent of $E$. stellulata. Fruits with valves slightly exserted and more pedicellate than the type.

From Mount Wilson (Jesse Gregson and J.H.M.) I have obtained specimens with coarser fruits than those from Wingello, and more pedicellate. They come nearest to var. nitida.

Thus we have additional evidence of the evident impossibility of drawing a hard-and-fast line between the species and its varieties. 


\section{AFFINITIES.}

1. With $E$. Dives, Schauer (this will be referred to under $E$. dives).

2. With two trees which I look upon as hybrids of E. amygdalina and $E$. coriacea (pauciflora), I therefore write them E. vitellina x Naudin, and E. vitrea $\times$ R. T. Baker.

Naudin was of opinion that E. vitellina is a hybrid. I have seen specimens, and they are remarkably iike some specimens referred to E. vitrea. It would be a remarkable coincidence if the types of the two species were identical in every respect, for we must remember that the parent species are both variable, and their progeny may further vary according to the preponderating influence of a variable parent.

Euc. vitellina, Naudin, 2nd Mem. p. 65 (1891).

Arbre biforme, à tronc blanchâtre et lisse après la chûte de la vieille écorce, bien caractérisé par la gracilité de ses rameaux florifères, généralement pendants, et par l'étroitesse de son feuillage, d'une verdure vive, sans glaucescence. Je n'en connais jusqu'ici qu'un seul exemplaire vivant, dans de jardin de M. Nabonnand, au Golfe-Juan. C'est un jeune arbre de 8 à 9 mètres de hauteur (en 1889).

A l'état juvénile, qui ne paraît pas être le longue durée, les feuilles sunt opposées, sessiles, linéaires, aiguës, raides et luisantes, longues de 3 i 5 centimètres, sur une largeur de 22 à 3 millimètres. A l'état adulte, elles sont alternes, pétiolées, étroitement lancéolées, presque linéaires, longues de 8 à 12 centimètres, sur 4 a 5 millimètres de largeur. Les nervures secondaires, quoique obliques, sont rapprochées de la nervure médiane et dirigées dans le sens longitudinal du limbe, de manière à rappeler d'assez près la nervation des feuilles de $l^{3} E$. pauciflora.

Les ombelles, axillaires et pédonculées, contiennent communément de 9 à 13 fleurs, courtement pédicellées, dont les boutons claviformes et criblés de glandes oléifères portent un opereule déprimé, presque plat, surmonté d'un court mamelon. Le fruit, de la grosseur d'un pois, est pyriforme-tronqué, et ses bords dépassent quelque peu la capsule, le plus souvent quadriloculaire, qui y est incluse et dont les valves redressées à la maturité n'arrivent pas au niveau du pourtour de la capsule calycinale

L'E. vitellina a des analogies, d'une part avec l'E. panciflora, d'autre part avec l'E. amyydalina. On pourrait presque le considérer comme intermédiaire entre ces deux espéces.

The specimen of E. vitellina in my possession is nearest to "E.vitrea, Jenolan Caves, N.S.W., July, 1900 (W. F. Blakeley)," but with the leaves less thick in texture.

Eucalyptus vitrea. R. T. Baker, in Proc. Linn. Soc. N.S.W., 1900, p. 303. "White 'Top Messmate."

A tall tree, with a roughish bark, similar to E. amygdalina, Labill., the extremities of the branches being smooth.

Sucker leaves alternate or opposite, with a short petiole or sessile, ovate-lanceolate, acuminate, lateral veins diverging from below the middle of the midrib, prominent on both sides, intramarginal vein removed from the edge, not shining; under 6 inches long, $1 \frac{1}{2}$ inches broad. Mature leaves narrow lanceolate, about 6 inches long, and 6 to 9 lines wide, petiole short; shining on both sides, a dull green when 
fresh, but drying a light slate colour; lateral veins few and almost parallel to the midrib, two generally commencing at the base of the midrib and running the whole length of the leaf alnost parallel to the midrib. Oil-glands very numerous.

Peduncles axillary, short, 2-3 lines, bearing generally from 5-8 flowers. Buds from 21 to 4 lines long, operculum hemispherical, shortly acuminate. Ovary flat-topped. Anthers kidney-shaped, connective prominent.

Fruit hemispherical, about 3 lines in diametex; rim thick, red, slightly convex, shining; pedicel about 1 line long:

'Timber.-A hard, close-grained timber, full of shakes and gum-veins, and apparently of little economic value. It possesses none of the good qualities of $\mathbb{E}$. amygdalina, Labill., which is fissile, soft, and easily worked. The venation of the leaves resembles that of $E$. amygrlalina and $E$. coriacea, but more particularly the latter species. The immature fruits are difficult to distinguish from those of $E$. amygdalina, whilst the mature ones bear a strong likeness to those of $E$. coriacea. The bark is almost identical with that of $E$. amygialina, but the timber is quite distinct, resembling more closely that of $E$. dives, from which species, however, it differs in the shape and venation of both sucker and mature leaves, fruits, and constituents of the oil.

From $E$ coriacea it differs in the nature of its timber, bark, oil, and leaves. Summarised, this species has - (a) a bark similar to that of $E$. amygdalina; (b) timber similar to that of $\boldsymbol{E}$. dives; (c) leaves and venation similar to those of E. coriacea; $(d)$ fruits approaching in form to those of E. amygdalina: and (e) sucker leaves differing from those of any species above enumerated. It is most closely allied to $E$. coriacea and $E$. dives, but yet distinet from both (op. eit).

I had this form under observation for some years before Mr. Baker described it, and its puzzling affinities to more than one species attracted my attention as, indeed, they did that of Mr. Baker.

In Proc. Linn. Soc., N.S.W., 1901, p. 123, Mr. Deane and I wrote of it:-

E. fastigata, Deane and Maiden.-E. vitrea, Baker, is, in our opinion, a form of the above species. The type of $\boldsymbol{E}$. fastigata as figured (these proceedings, 1896, p. 809), has smaller fruits and the valves somewhat exserted, but the size of the fruits and the amount (or absence) of exsertion varies a good deal. We have specimens from the type locality of $E$. fastigata which precisely match $E$. vitrea.

Since the above was written, both Mr. Deane and I are of opinion that E. fastigate is simply a rough-barked form of E. regnans, so that the above remarks may be considered to apply to E. regnans. I am of opinion that the buds and fruits of the specimen of "Cut-tail" strongly resemble those of $\boldsymbol{E}$. vitrea, while the leaves are those of E. regnans.

Specimens of typical regnans from the Blacks' Spur, Victoria (H. Deane, Jan., 1900), locally known there as "Mountain Ash" and "Blackbutt," have fruits which are absolutely identical with those of vitrea.

Other specimens of regnans have fruits not domed and approaching those of vitrea.-Source of Teapot Creek, Gippsland (A. W. Howitt). Similar as regards fruits, but foliage dull.-Boggy Creek, Gippsland (A. W. Howitt). I can quote other specimens from Tasmania, Victoria, and New South Wales to illustrate this point.

$E$. vitrea is undoubtedly allied to $E$. dives, Schauer, as regards fruits, and to some extent as regards the leaves. The leaves of E. vitrea are usually shiny, 
whereas those of $E$. dives are usually dull, but those of the latter are sometimes quite as shiny as those of the former. Indeed, the Peppermint-trees of the Renanthere present many points of contract.

At Berrima (on the banks of the Wingecaribee, opposite the Rectory) is a Ribbony Gum with rough black bark up to the first fork. The rough bark is just like that of $E$. viminalis.

The habit of the tree is more erect as to foliage than that of normal coriacea close by. The timber is white, and is full of gum-veins like coriacea. The fruits are more hemispherical than the rest of the trees in the neighbourhood. In all my travels I have not previously seen an E. corincea a real ribbony gum as this is. $E$. coriacea is a species that does not present much evidence of variation as a rule, but I am inclined to think that this particular tree presents evidence of hybridisation. The other parent is probably E. amygdalina. It is remarkably like E. vitrea.

A specimen obtained from Wingello (A. Murphy, April, 1899), a locality where abundance of typical vitrea may be found, has smaller fruits, broader leaves than the type, more spreading veins, and the oil-dots are less prominent. The leaves also are less hooked at the tips, a marked coriacea character abundantly evident in the Berrima specimen. The Wingello specimen has, in my opinion, more of the amygdalina character than has the Berrima specimen. The Wingello specimen has an undoubtedly strong resemblance to $E$. dives,-e.g., Wallerawang, Tarana, and other places.

A specimen from Delegate River, N.S.W. (W. Baeuerlen) is very interesting. It was collected 13th April, 1889, and the collector's note was “E.pauciflora and E. stellulata hybrid." I afterwards placed the specimen under $E$. dives; but I think its proper place is with vitrea, although it is not typical. It shows the parentage of both amygdalina and coriacea. The fruits are smaller than those of typical vitrea. Some of the leaves are broad ( $5 \frac{1}{2} \times 2 \frac{1}{4}$ inches) and strongly reminiscent of $E$. coriacea.

"Hills near Mansfield, Victoria (Strathbogie)" (H. B. Williamson, No. 938). "From a tree of 30 or 40 feet, stem 1 foot in diameter; bole of the tree covered with persistent bark; upper stem and branches smooth; bark like large saplings of E. dives."

In sending the specimens (in 1900), Mr. Williamson makes the following observations, which are very interesting in connection with my view of the origin of E. vitrea:-

It is very scarce, and is always interspersed with No. 939 ( $\boldsymbol{E}$. coriacea, A. Cunn.-J.H.M.), and E. amygdalina. The flowers are very scanty, contemporary with those of No. 939, now a mass of bloom. $\boldsymbol{E}$. anygdatina now only shows occasional blooms.

The specimens are nearest to $E$. vitellina or $E$. vitrea, though with rather thinner leaves than the type. It must be borne in mind that variation also takes place in individuals extended over a large area. 
I have similar specimens (in fruit only) from a Stringybark forest 15 miles north-west of Mount Gambier, South Australia.

I have tested all the following points as regards E. vitrea,-viz., its sucker foliage (medium lanceolate, dull, even glaucous); mature foliage (thickish, shining, straight-veined, veins prominent, tips hooked); buds (operculum pointed, pale brown, shiny); fruits (pale brown, rim well-defined and reddish-brown, shape and size); bark (hard scaly, sub-fibrous, and smooth branches); timber and oil; and its characters are possessed in about equal proportions by E. coriacea and E. amygdalina.

I think I have produced sufficient evidence (and more will be forthcoming as soon as field botanists inquire with an open mind into the hybridisation question) to show that my suggestion as to the hybrid character of $E$. vitrea is a very reasonable one. That hybridisation occurs in the genus, and that there is much evidence of it, I consider to be absolutely proved.

Some illustrations of $E$. vitrea will be given in the next Part, which deals (inter alia) with E. regnans.

3. With E. regnans, F.v.M. This will be more conveniently gone into when $E$. regnans is reached. 


\title{
DESCRIPTION.
}

\author{
E. linearis, Dehnhardt.
}

THe following description has been drawn up by me:-

A slender, umbrageous, somewhat scrambling small tree of $20-30$ feet, usually with an absolutely smooth bark, hence called a "White Gum," sonetimes, however, slightly scaly at the butt.

It may be describerl as slender and graceful in all its parts.

Jurenile Foliage-Linear.

Mature Foliage.-Tinear to linear-lanceolate, say 3-4 inches long and 1-2 lines broad. Symmetrical, oradually tapering at the base into a petiole of say half an inch, and gradually at the apex into a point. Texture rather thick, consequently the main vein only, the midrib, can be readily seen.

Buds.- Umbels singly in the axils of the leaves, the common peduncle of about half an inch, the calyces tapering into short pedicels. Clavate in shape, and the operculum slightly pointed.

Flowers.-Renantherous.

Fruit. Usually from 5 to 10 in the umbel, the individual fruits almost sessile. Small, somewhat pear-shaped, slightly contracted at the orifice, rim well-defined and sloping inwards (sunk), valves well insert. Valves 3 or 4 in the specimens seen.

Timber.-White, and moderately fissile

Habitat.- This tree was originally described from trees raised from seed near Naples, Italy (hortus Camuldensis), lut it is helieved that the seed was originally obtained from trees growing on Mount Wellington, Hobart, Tasmania. It is not abundant, and is put to no special industrial employment.

Following is the original description by Dehnhardt:-

E. lamosissima. Ramulis viminalibus teretibusque lævibus; foliis alternis linearibus subfalcatis subcrenulatis rugosiusculis in petiolo decurrentibus apice uncinatis; cortici laevi punctato. Ramulis debilibus paniculatis. Folia uncias 3-4 longa, lineam 1 lata.

Species haec differt ab illis quae descriptae sunt in Catalogo Horti Parisiensis : phrases quibus utilitur cl. Desfontaines ejus Catalogi Auctor hic transcribo-_Catalogus plantarum horti Camuldensis, Ed. ii, 1832 , $\mathrm{p}, 20$.

Walpers gives the following :-

E. linearis, Dehnhardt, Rivista Napolitana, 1, 3, p. 173.-Operculo conico glandulifero; umbellis lateralib. 5-8 floris parvulis albidis; ramulis viminalib. teretibq. lævibq.; foll. alternis linearib. angustissimis subfalcatis rugosiusculis subcrenulatis, in petiolum decurrentib., apice uncinatis, cortice laevi punctato.Crescit in Nova Hollandia (Rep. Bot. Syst. ii., 154).

I received for study, from the Imperial Natural History Museum of Vienna, a type specimen of Dehnhardt's species, which is, however, in bud only. The orginal label in Dehnhardt's writing is in German, of which the following is a translation:- " I pray you read my description in the Catalogue. The tree is 40 
feet high, with a slender stem, and flowers the second time." The reference to the "Catalogue" is doubtless to the "Catalogus plantarum horti Camaldulensis," which contains the description of the species. The work in question was published at Naples, and the Hortus Camuldulensis * was a garden near that city. The first edition was published in 1829, and the second in 1832, and should be noted in case any claims for priority arise.

Dehnhardt's plant is, without doubt, a cultivated one, and bearing in mind the marked way in which seedling Eucalyptus plants differ from their parents, it is not likely to be absolutely identical with the Mount Wellington plant to which it has been referred. The idea becomes stronger with me that $E$. linearis, Dehnh., may prove to be a perfectly smooth-barked form of $E$. amygdalina, with unusually thin, linear leaves. If so, this form of E. amygdalina might be named var. linearis. $\dagger$

\section{SYNONYM.}

E. pulchella, Desf.

My researches in European herbaria in regard to this genus has brought to light another named species which seems to be con-specific with $E$. linearis. It is E. pulchella, Desfontaines.

The original work not being in any Australian library, I obtained a copy of the description from Kew. It is as follows :-

Eucalyptus pulchella, Desf. Ramulis filiformibus, foliis alternis, lineari-subulatis; floribus axillaribus, umbellatis, operculo convexo, mucrone obtuso, brevissimo. Ramuli filiformes, paniculati. Folia uncias 2 longa, lineam 1 lata, utrinque acuta. Petioli breves. Flores in umbellulas axillares dispositi. Pedunculus communis folio multoties brevior, 10-12 florus.-(Cat. Hort. Paris. Eid. 3, 408, 1829).

Dehnhardt contracts this description into :-

Eucalyptus pulchella. Ramulis filiformibus; foliis alternis lineari-subulatis. Ramulis filiformibus paniculatis. Folja uncias 2 longa, lineam 1 late-(Dehnh. Cat. Pl. Hort. Camald. Ed. 2, p. 20.)

Walpers' description, published in 1845, is also adapted from the original, and is as follows:-

Ramulis filiformib. foll. alternis limeari-subulatis, florib. axillarib. umbellatis; operculo convexo, mucrone obtuso brevissimo.-Crescit —_ ?"-(Repert iii., 927.) doubtful."

Bentham perhaps saw the species, but he pronounces it to be "very

See p. 58, Part II. of this work.

+ Note on Encalyptus linearis, Dehnhardt (a supposed Tasmanian species),-Maiden in Proc. Roy. Soc. Tas., 1902. 
I have recently received some specimens from the Vienna Herbarium labelled "E. pulchella, Hort. Kew." They are in bud, and appear to be identical with E. linearis, Dehnh. Undoubtedly the name pulchella was well bestowed, for the specimens have long, narrow, linear leaves, which are very graceful.*

I think my determination will be found to be correct, but in view of the paucity of the material and of the amount of doubt surrounding $E$. linearis, I hesitate to suppress $E$. linearis until further information is available.

1,079 Gunn, referred to $E$. amygdalina by Hooker, is a very narrow-leaved form, which in some herbaria bears the label "E. linearis, Cunn., environs of Hobart Town ; is one of Lhotsky's amygdalina vars."

I cannot find that Cunningham ever published a species of that name; the plant appears to be, however, identical with what goes under the name of $E$. linearis, Dehnh. A Kew label has "E. linearis, Hobart Town, 85/1819, A. Cunn."

Another specimen of Gunn's 1,079 is labelled "Peppermint Gum," and Backhouse calls it the "Mountain Peppermint," of Oyster Bay.

I have received cultivated specimens of what is either $E$. linearis, or a very narrow-leaved form of $E$. amygdalina, from California, under the name of $E$. amygdalina, var. angustifolia, Link, a variety name I am unable to trace. There is, however, in Link's Enumeratio ii, 30-

No. 227,E. angustifulia, Desfont. Par. Fol. subsessilia 2 ft. 6 in, lga., 2 in lata acutata attenuata, which may be E. linearis, Dehnh.

Specimens labelled "E. angustifolia, Desf., in herb. Berol (1900) are E. viminalis, Labill. I observe that Don (Gen. Syst. ii, 819) refers E. angustifolia, Desf. Link, to E. saligna."

I may mention that $E$. angustifolia, Desf., has also been quoted as E. angustifolia., Spreng., et Candolle and E. angustifolia, Link, Enum. ex Spreng. $\dagger$ There is, of course, an E. angustifolia, R.Br., which is E. amygdalina.

Then we have-

E. amygdalina, Labill., Nov. Holl., ii, p. 14. Tab. 154, DC. Prodr., 1.c. 219, n. 25. In Tasmaniæ sylvis, locis arenosis, Buffalo Range, N. H. Austr. (sic)-(Stuart, No. 18, Müller.) Arbor 50-60 ped., peppermint-gum tree incolarum, vere florens, foliis usque 4 poll. longis $\frac{1}{2}$ latis.

$\boldsymbol{\beta}$. folìs angustioribus ibidem (Stuart Herb., No. 8)-(Miq. Ned. Kruidk. Arch. iv, 124.)

Thus Miquel noticed the very narrow leaves (? of linearis, Dehnh.), but I do not know of a narrow-leaved form of amygdalina (or linearis), from Buffalo Range, Victorian Alps.

- Note on E. linearis, \&c. (op. cit.).

+ See "The Common Eucalyptus Flora of Tasmania and New South Wales."-Maiden, Proc. Austr. Assoc. Adv, Sçience, ix, 364, 
Rodway, in his Tasmanian Flora, p. 56, puts E. linearis, Dehnh., as a separate species and states:-

A small to medium-sized tree, bark smooth and white, or sometimes scaly on the lower portion of the stem. Leaves similar to those of $E$. amygdalina, only still narrower and the fruits smaller, slightly constricted, and the capsules usually slightly sunk. Very common, and although presenting a different appearance, hardly morphologically distinct from $E$. amygdalina.

To summarise, E. linearis, Dehnh., is a smooth-barked tree, and, in my opinion, in spite of the fact that there are connecting links between it and E. amygdalina, it will be convenient to retain it as a species, at all events for the present. We must look to Tasmanian botanists for a full investigation of it with reference to other forms. Mr. Rodway tells me it is not uncommon in Tasmania.

I must admit that I cannot always determine the species on herbarium material alone, and specimens collected by me from a White Gum, on Mount Wellington, have by no means narrow leaves. The bark is stripy; the leaves are strict, and inclined to be succulent. My own note, made in the field, is that they seem to have an odour of oil of geranium when crushed.* For a number of years a White Gum, referred to E. linearis grew (under cultivation) in the Government Domain, Melbourne, but it has recently died.

\section{RANGE.}

E. linearis is confined to Tasmania.

\section{AFFINITY.}

The closest affinity of $E$. linearis is, as has been abundantly indicated, to $E$. amygdalina.

"If this be confirmed, the evidence in favour of separating $E$. linearis from $E$. amygdalina would be, in the aggregate, sufficient. 


\title{
DESCRIPTION.
}

\author{
E. Risdoni, Hook., f.
}

THE following description has been based upon Bentham (B.Fl. iii, 203) though differing from it:-

A glaucous foliaged and beautiful tree of $20-30$ feet, the variety elata attaining a height of 50 feet and more. The bark smooth (hence known as a "Gum"), ashy grey, scaling in irregular patehes, the branches nore or less pendulous. The timber pale-coloured and rather fissile, but too small and inferior in quality to be of economic importance.

Jurenile Foliage.-Markedly cordate and connate.

Mature Foliage.-The juvenile foliage frequently persists and sometimes all, even on the flowering branches, remains opposite, ovate-cordate and more or less connate, or sometimes those of the latter shoots alternate, broadly lanceolate and falcate, rather thick with oblique veins, moderately conspicuous, the intramarginal one at a distance from the edge. In the variety plat? the cordate and connate foliage is absent or rare, except in the juvenile stage.

Buds. - Obovoid-clavate. Peduncles axillary or lateral, terete or angular, bearing each an umbel of 4 to 8 or even more. Calyx-tube very open, attaining 3 lines diameter. Operculum hemispherical, obtuse, shorter than the calyx-tube.

Hlowers. - Larger than those of $E$. amygdatina. Stamens nearly 3 lines long, inflected in the bud, all perfect; anther's with divergent confluent cells (i.e. Renantherous). Ovary flat-topped.

Fruit.-Subglobose-truncate, attaining 4 lines diameter', slightly contracted at the orifice, the rim rather sharp, sloping inwards (sunk), the valves flat or slightly protruding.

Habitat.-In its typical form it is confined to the Hobart district, but the variety elata has a wider range, though confined to Tasmania.

Following is the original description :-

Foliis oppositis ovato-cordatis acuminatis sessilibus $v$. basi lata connatis junioribus ramulis alabastrisque pulvereo-glaucescentibus, pedicellis axillaribus 6-10-floris, alabastris breviter clavatis, operculo depresso hemispherico umbone nullo, capsula breviter pedicellata obconica rotundata, ore paulo contracto margine plano latiusculo valvis inclusis.

Hab. Risdon, on the Derwent; Gunn. v. v.n. Arbor 20-pedalis, e basi ramosus, aspectu glauscescente, ramis patentibus divaricatis, ramulis gracilibus, cortice lævi. Folia $1 \frac{1}{2}-2$ uncialia, rigida, acuminata, latiora quam longa, obtusa cum mucrone. Pedunculi $\frac{1}{2}-\frac{3}{4}$ unciales. Alabastra $\frac{1}{4}-\frac{1}{3}$ unc. long. Capsulæ $\frac{1}{3}$ unc. longa, extus læres v. paulo rugosæ nitidæ.-(Hooker's Lond. Journ. Bot. vi, 477 (1847); Fl. Tas. i, 133 t. 24.)

Leaves.-0il.-Messrs. Schimmel \& Co., of Leipsic, report :-

Under the name of Eucalyptus Risdoni a pleasant and mild-smelling eucalyptus oil was introduced in 1874 in London. Sp. gr. $0.915-0.916 ;^{a} \mathrm{D}=-4^{\circ} 49^{\prime}$. It contained cineol and phellandrene.*

* Bericht, von S. \& Co., Apr. 1894, p. 29. 
Messrs. Baker and Smith (Research on the Eucalypts) give the followingi particulars of an oil from the same species:-

\begin{tabular}{c|c|c|c|c|c}
\hline Whence collected for Oil. & $\begin{array}{c}\text { Specific } \\
\text { Gravity } \\
\text { at } 15^{\circ} \mathrm{C}\end{array}$ & $\begin{array}{c}\text { Speciflc } \\
\text { Rotation, } \\
\text { [A]D. }\end{array}$ & $\begin{array}{c}\text { Saponifica } \\
\text { tion } \\
\text { Number. }\end{array}$ & $\begin{array}{c}\text { Solubility } \\
\text { in } \\
\text { Alcohol. }\end{array}$ & Constituents found. \\
\hline $\begin{array}{c}\text { Tasmania (specific locality } \\
\text { not given). }\end{array}$ & 0.9145 & -0.33 & 27.09 & $\begin{array}{c}1 \frac{1}{1} \text { vols. } \\
70 \%\end{array}$ & $\begin{array}{c}\text { Eucalyptol, phellandrene, } \\
\text { pinene, } \\
\text { peppermint }\end{array}$ \\
\hline
\end{tabular}

\section{SYNONYMS.}

1. E. hypericifolia, R.Br., also of Dum.-Cours.

2. E. amygdalina, Labill., var. hypericifolia, Benth.

3. E. perfoliata, Dumont, and of others.

t. E. connata, Dum.-Cours., also of Schauer. var. elata, Benth.

๖. E. radiata, Hook., f. (non Sieb.), partim.

\section{NOTES ON THE SYNONYMS.}

1. E. hypericifolia, R.Br.

This species is in Index Kewensis referred to as "ex Benth., B.Fl. iii, 203."

The reference is as follows:-

2. E. amygdalina, var. (?) hypericiolia, Benth.

Leaves of the fruiting branches all opposite, oblong-lanceolate, rounded or cordate at the base, and sessile or nearly so. Risdon Cove. R. Brown.

E. hypericifolia, R. Br. Herb.-The specimens are larger and good, but in fruit only. To this form may belong also some of the garden plants described from the foliage under the same name.-(B.Fl. iii, 203.)

In a letter to me Mr. Rodway speaks thus of var. hypericifolia:-

Fruit rather smaller than in var. nitida. These, with $E$. Risdoni and E. Risdoni, var, elata, form a quite uninterrupted series.

In his Tasmanian Flora he says:-

E. amygdalina, var. hypericifolia. Leaves rather broad, opposite and sessile. Fruit rather large, often pear-shaped. A very unstable form, approaching forms of E. Risdoni.

I cannot separate any specimens I have seen from E. Risdoni, or its var. elata. 
3. E. perfoliata, Dum.-Cours., described as follows, from leaf specimen's only, is "very doubtful."-(B.Fl. iii, 200.)

It may be convenient to draw attention to Dumont's imperfect descriptions at this place, especially as he says his plant is the E. hypericifolia of English gardens. With the aid of Kew I have been successful in obtaining Dumont's original description, which is instructive, as showing how Eucalypts were described in the early days. I have not been able to see the type:-

Eucalyptus hypericifotia, Dum.-Cours., Bot. Cult, ed. 2, vii, p. 279. E. à feuilles de millepertuis, E. hypericifolia, Hort. angl. Cette espèce ne me semble former qu'un arbrisseau. Ses rameaux sont très menus et n'ont guère, surtout vers leur sommet, que la grosseur d'un fil. Feuilles opposées, lancéolées, oblongues, pointues, très-entières, glabres, d'un beau vert en-dessus, un peu glauques en-dessous, de 4 centimètres de longueur, et de 4 à 5 millimètres de largeur. Lieu id [La Nouvelle-Hollande]. Toujours vert.

E. hypericifolia, Link, according to a specimen in the Prodromus herbarium is E. cneorifolia.

E. perfoliata, R.Br. (B.Fl. iii, 253), is a Northern Territory shrub. There is, however, E. perfoliata, R.Br. in Herb. Kew, which is E. Risdoni, Hook. f., E. perfoliata, Tausch, in the Vienna herbarium, ex Herb. Ferd. Bauer, is also E. Risdoni. The name perfoliata was loosely employed in regard to Eucalypts by the early botanists. (See Proc. Linn. Soc., N.S.W., 1901, 550.)

\section{E. connata, Dum.-Cours.}

E. à feuilles connées, $\mathbb{E}$. connata, Hort. angl. Tige droite, grisâtre, d'un rouge brun, ainsi que les rameaux dans leur jeunesse, cylindriques et glabres. Feuilles connées, presque perfoliées, ovales à leur base, oblongues, pointues, légèrement ondulées à leurs bords, très-entières, glabres, relevées en-dessous d'une nervure rouge et saillante, très-ponctuées de points transparens, longues d'un décimètre environ (4 pouces), larges de 16 a 17 millimètres (7 a 8 lignes). Lieu id [La Nouvelle-Hollande]. Toujours vert.-(Bot. Cult., ed. 2, vii, 280.)

Very doubtful (Benth.); E. diversifolia, Bonpl. (DC. Prod. iii, 220), with a query. E. connata, J. Schauer, from Tasmania, in Herb. Vienna, is E. Risdoni. If this species was described it would perhaps take priority of Hooker's name.

\section{Var. elata, Benth.}

A beantiful tree of the largest size, the bark of the trunk grey and deciduous, that of the extremities of the branches purplish-red or reddish-brown (Gunn). Leaves broadly lanceolate-faleate, 2 to 4 in. long rather thick, sometimes almost as in E. obtiqua. Flowers of E. Risdoni. Fruit pear-shaped, 4 lines diameter, with a broad convex rim-Lake St. Clair (Gunn). This variety in the dried specimens appears to connect $E$. amygdatina with $E$. obtiqua, but without doubt belongs to $E$. Risdoni, as observed by Oldfield, although the dried specimens were included by J. D. Hooker among the varieties of $E$. radiata, Sieb., now united to $\boldsymbol{E}$. amygdalina.-(B.Fl. iii, 203.)

See my notes on Gum-topped Stringybark, p. 177.

Var. elata is a drooping broad-leaved glaucous form, with broadish sucker eaves, common (Mr. Rodway states) in mudstone country in Tasmania, and one of 
the intervening forms between E. amygdalina and E. Riscloni. Has large domed fruits and coriaceous leaves, which are often glancous along the edges, giving them an unusual hoar-frost appearance.

Lanceolate leaves are common on the tops of branches of E. Risdoni, it being not an uncommon occurrence to find the sessile, almost cordate, leaves and the lanceolate leaves on the same branch. This was first drawn attention to by Bentham (B. Fl. iii, 203). Fig. 1, plate 32, shows three kinds of leaves taken by me from the same tree, including leares typical of $E$. Risdoni and its var. elata. Mr. Deane and I made a similar observation in regard to $E$. pulverulenta, leaves of the two shapes being found on the same twig. (See Proc. Linn. Soc., N.S.W., 1900, p. 110.)

5. E. radiata, Hook., f., non Sieb., var. 1-4 partim (Fl. Tas., i, 137).

Hooker's observations form an excellent example of the difficulties (especially great in the case of the older workers) in dealing with plants of the amygdalina group. In making up sets for distribution, the so-called varieties were not absolutely identical, being, in some cases, taken from different trees.

None of the specimens are the true $E$. radiata, Sieb., which I have not yet seen from Tasmania. Hooker (loc. cit.) attempted to define, and distributed, five varieties of $E$. radiata, Sieb., from Tasmania. Var. 5 is var. nitida of amygdalina, as I have already shown. I will show that vars. 1-4 are for the most part $E$. Risdoni, var. elato. Bentham (B.Fl. iii, 203) said, "one of the varieties is $E$. Risdoni, var. elata." The whole of Hooker's types of these forms have recently been placed at my disposal in quantity, so that I am able to speak with a tone of certainty I previously could not adopt. Hooker was doubtful himself of these forms. He said (loc. cit.) :-

A very common plant; as above characterised, it may perhaps include several species, and, amongst others, varieties of amygdatina. The forms I have enumerated are not all of them varieties in the correct sense of the term, but only states of one or more varieties, and, in some cases, of one individual, but it is quite impossible to unravel them. A small or lofty tree, with a straight trunk, sometimes with a smooth and sometimes a flaking or almost stringy bark. Branches noore or less weeping. Leaves usually shining, rather small, seldom 3 inches long, with one midrib, and very inconspicuous lateral veins, or none; narrow, sometimes very much so, though not so narrow as E. amygdalina usually has them. Flowers and capsules always pedicelled; the latter turbinate or obconic, rather large.

Following is Hooker's definition of E. radiata:-

Arbor mediocris, ramulis gracilibus sæpe pendulis, foliis anguste ellipticis lanceolatisve mediocribus vix nitidis 1-nerviis rectis falcatisve, pedunculis subelongatis multifloris, floribus pedicellatis, calyce obconico v. clavato, operculo brevi, capsula pedicellata. Variat insigniter :-

1. Foliis lineari-elongatis, fructibus latioribus quam longis subturbinatis, ore dilatato plano. Ad E. amygdalinam tendens (Gunn : 1,073, 1,077, 1,102).

1,073 is from "river-side, Risdon," and is E. amygdalina, Labill., aff. var. nitida, Benth.

1,077 is from "top of Grass-tree Hill," and is E. Risdoni, var. elata. 
1,102 is from "above Sassafras Valley, Hobart, 15 feet high, yellow bark, young leaves powdery, Novr.," and is E. Risdoni, var. elata.

2. Foliis elongatis lanceolatis, capsulis turbinatis longioribus quam latis, ore contracto (Gunn, 1,112).

No. 1,112 is "from Risdon, also from Grass-tree Hill, near Hobart." It is a broad-leaved form of E. amygdalina, tending to var. nitida. It is near Gunn's 1,073 (see var. 1), though with broader leaves for the most part, and also precisely matches E. tenuiramis, Miq. At the same time I have seen a specimen of var. 2, which is E. Risdoni, var. elata.

3. Foliis ovato-lanceolatis elliptico-lanceolatisve, capsulis majusculis turbinatis-Arbor elata ad E. giganteam tendens. River Derwent at Cluny, Mount Wellington, elev. 2,500 feet; Lake Echo, elev. 3,000 feet.

The specimens I have seen are in bud or early fruit. They are near var. 1, but more glaucous. Var. 3 belongs to that series connecting E. amygdalina, Labill., var. alpin., and E. Risdoni, var. elata, and different eucalyptologists would, from the material available, put them in one or the other, or both.

1. Foliis majoribus lanceolatis nitidis capsulis ut in forma 3.-Arbor mediocris ad. E. coriaceam tendens (Gunn: 1,100, 1,110).

No. 1,110 is from "foot of Mount Wellington," also "Hobart, Degraves." No. 1,100 is from "Grass-tree Hill, near Hobart." Both these are E. Risdoni, var. elata. For a sccond plant ( $\boldsymbol{E}$. obliqua, var. alpina) distributed under 1,100, see p. 178.

\section{RANGE.}

E. Risdoni and its variety are confined to Tasmania. I have examined the following types:-

(a) R. Gunn's No. 1,278, from Herb., Kew.

Small tree, growing in clusters on the side of a hill near Risdon, 10-20 ft. high, branched from the base (Oct. 1840, R. Gunn).

(b) 1,072, R. Gunn, Risdon, Hobart, 10/10/40.

Mr. T. Stephens says that he has never seen E. Risdoni grow on anything except on mudstone. Mr. Rodway says, "common on dry hills, Bellerive, Risdon, Muddy Plains, valley of South Esk," \&e.

The variety elata has far more extended range than that of the normal species; it is common on Mount Wellington, Hobart, and other specific localities have been incidentally referred to. 


\section{AFFINITIES.}

1. With E. coccifera, Hook., f.

The variety elata is very close to E. coccifera. It is often very difficult to separate them on herbarium specimens alone if ripe buds are not available, those of $E$. coccifera being more or less corrugated.

2. With E. amygdalina, Labill.

The affinity of $E$. amygdalina to $E$. Risdoni is undoubtedly close, the relationship being closest through the var. elata of the latter. E. Risdoni has broad sucker leaves, and on this character alone $I$ would retain it as a species separate from $E$. anygdalina.

The bark of $E$. Risdoni is smooth; that of E. amygdalina is always fibrous * on the butt; this is an important character.

In these days the determinations of Eucalypts by the older botanists are carefully criticised, in view of the extensive field knowledge of the genus we now possess, and which is becoming increasingly accurate, but the following remarks by Bentham (B.Fl. iii, 203) seem to be quite accurate:-

F. Mueller also unites $E$. Ris lon $i$ altogether" with $E$. amygdalina. J. D. Hooker and Oldfield, both of them from observations made on the spot, have assured me that the two are quite distinct, in habit as well as in the bark. The sessile opposite leaves occupy frequently the flowering branches of $\boldsymbol{E}$. Riston', and are only on the saplings and adventitious flowerless branches of $E$. amugdalina; they are, moreover, broad, frequently connate, and usually glaucous or nearly white in the former ; always, as far as known, narroworate or oblong-lanceolate in $\mathbb{E}$. amygdalina. When the leaves are alternate, they appear to be broader in E. Risdoni than in $E$. amygdalina, the pedicels thicker and more angular, the flowers and fruits largerdifferences, however, of degree only, to which our dried specimens do not admit of our fixing any precise limits, and in that state it is sometimes scarcely possible to decide to which species they should be referred.

3. With E. obliqua, L'Hérit.

I propose to inquire into the position of a "Gum-top Stringybark" $\uparrow$ called also, at least in New South Wales, "Mountain Ash."

The following botanical names for it are synonyms:-

]. Eucalyptus obliqua, L'Hérit, var. alpina. Maiden (Proc. Aust. Assoc. Adv. Science, Vol. ix, 369, foot-note.)

2. E. gigantea, Hook., f., Fl. Tas. as regards Plate xxviii ; also, as regards part of the text.

3. E. radiata, Hook., f., Fl. Tas. i, 137 (non. Sieb.), var. 4 (partim).

4. E. delegatensis, R. T. Baker, Proc. Linn. Soc., N.S.W., 1900, p. 305.

"Mr. Rodway writes to me:- "Many forms of undoubted E. amygdalina are smoth-barked from the butt." Nevertheless, in view of the uncertain position of $E$. linearis, I prefer to leave my remarks on the bark to stand for the present.

+ See Part II, p. 68 of this work.

F. 
The receipt of a large number of Gunn's specimens used by Hooker in the preparation of $\mathrm{Fl}$. Tas. has enabled me to clear up some hitherto doubtful points. colonorum."

E. gigantea, Hook., fil., Lond. Journ. Bot., vi, 479, is "Stringybark

E. gigantea is in Fl. Tas. i, 136, described in practically the same words, and it is called "Stringy-bark Gum." The specimens quoted are Gunn's 1,095, 1,104, $1,106,1,965,1,966$.

In Part II, p. 59 of this work, under E. obliqua, I have quoted Hook., f.'s remarks about Gunn's 1,095, from Lake St. Clair. 'The specimens labelled "1,095," which have been seen by me are, however, nearly typical obliqua from Lake St. Clair. It will be observed that Hook., f. looked upon these specimens as a variety of his $E$. gigantea.

Hooker says:- "In some varieties the young branches have a fine glaucous bloom upon them . . . . . Lake st. Clair." While Gunn's 1,095 from that locality is non-glaucous, some of Gunn's 1,100 collected by Hooker himself, from Marlborough (on the Upper Derwent, near Lake St. Clair), and which are E. radiata, Hook., f. (non Sieb.), No. 4 (partim), are glaucous, and are doubtless the specimens he had in his mind.

The loose branch of fruits of E. giganteus figured at Fig. 4, Plate 7, of Part II of this work were depicted from the same Kew herbarium sheet that contained the foliage specimens indicated, and are E. obliqua, var, alpina.

Gunn's 1,104 came from Black River, Circuiar Head, and is typical E. obliqua.

Gunn's 1,106 came from Sassafras Valley, and is typical E. obliqua.

Gunn's 1,965 and 1,966 came from Arthur's Lakes, and are my variety alpina of $E$. obliqua. In other words, they are $E$. radiata, Hook., f., No. 4 (partim). They are doubtless the originals of the drawing of Plate xxviii, of Hooker's Fl. Tas.

Of these four synonyms, therefore, $E$. gigantea, Hook., f., really belongs to E. obliqua, in spite of Hook., f, including two trees under that name in Fl. Tas.

E. radiuta, Hook., f., is founded on error, and the name should now be uropped.

It is a question whether the "Stringybark Gum " or "Mountain Ash" is a variety or a distinct species. Hooker, most Tasmanians whom I have consulted, and I look upon it as a form of E. obliqua; Mr. Baker considers it to be a distinct species (delegatensis). I am well acquainted with the tree in the field, have a very large series of specimens, and I have an open mind on the subject. It is, perhaps, a hybrid of $E$. obliqua and $E$. coriacea. The affinity of this form to $E$. Risdoni, Hook., f., var. elata, Benth., is undoubtedly close, and Hooker's confusion of specimens is readily accounted for. Indeed, at one time I held the view that 
E. Risdoni, its var. elata, and my E. obliqua, var. alpina (delegatensis), formed one grand trimorphic speeies. The strong, sweet odour of the trees of $E$. Risdoni, var. elata, in the forest very closely resembles that of $E$. obliqua, var. alpi. $a$. Some Gum-top Stringybarks are undoubtedly near typical E. obliqua. This form (alpina) of obliqua is found in alpine situations in 'I asmania, Victoria, and southern New South Wales. Following are some of the localities represented in the National Herbarium, Sydney :-

\section{Tasmania.}

"Gum-topped Stringybark," Lake Sorell (T. Stephens); Mount Wellington (Gunn), Nos. 1,965, 1,966, Arthur's Lakes; (Gunn), No. 1,100 (partim), Marlborough (in Gunn's Herbarium, but collected by J. D. Hooker); "Gum-top Stringybark," East Mount Field; Guildford Junction (R. H. Cambage); Parattah and Russell Falls River (T. Stephens).

TICTORTA.

Great Divide, western side; Dargo High Plains; Snowy Plains; Twelve-mile Creek (A. W. Howitt); "Messmate," Mount Mueller, near Mount Baw Baw (James Melvin); Mount St. Bernard (J.H.M.).

\section{New Sotth WALES.}

Delegate Mountain and Snowy Mountains (W. Baeuerlen); Eucumbene, near Kiandra, Yarrangobilly Caves (A. W. Howitt); Laurel Hill, Tumberumba (R. H. Cambage); Mount Kosciusko (J.H.M.).

\section{Explanation of Plates. PLATE 29.}

1a. Twig bearing buds; $1 b$, bud, just opening; $1 c$, flowers; $1 d$, fruits, all fac-similes of Labillardière's original drawing of $E$. amygdalina in Pl. Nov., Holl., t. 154. LN.B.-The fruit is not perfectly ripe.] 1e, anthers from flowers from Bellerive, Hobart, absolutely similar to those of the type.

2a. Twig, with buds and flowers, 26, fruits; of Gunn's No. 25. (See Hooker's Fl. I as.) It is absolutely identical with Labillardière's specimen. Gunn's No. 25 came from New Norfolk, but the form is common in Tasmania.

3. Juvenile foliage of $E$. amyydalina, from Hobart ( $L$. Rodway). Note that the young stem is glandular, and that the leaves are sometimes in threes

4a. Jurenile leaves; $4 b$, buds and mature leaves; $4 c$, fruits, from Blackheath, Blue Mountains, New South Wales, which absolutely match type specimens of $E$. radiata, sieb. (See p. 153.)

$5 a$. Juvenile leaves; $5 b$, buds; $5 c$, fruits, of a common New England form of $\boldsymbol{E}$. amygdalina. Very close to, if not identical with, E. radiata, Sieb. (See page 161.) Juvenile leaves broadish. (See No. 9.)

6a. Buds, with leaf; $6 b$, fruits, of typical E. radiatc, Sieb., drawn from Fl. Mixta, No. 604. The fruits are not perfectly ripe. The drawing (Mem. Myrt.), No. 2, pl. 30, shows the fruits of E. radiuta more pear-shaped than I have ever seen them, and nearer the shape of those of var. radiata.

7a. Juvenile foliage; $7 b$, mature leaf; 7c, fruits, from Wingello, New South Wales (J. L. Boorman). A form intermediate between var. numerosa and var. nitida. (See p. 163.)

Ba. Juvenile leaves; 8b, fruits, from Munendel Hill, Victoria (A. W. Howitt). E. amygdulina, with broadening juvenile leaves.

9. Juvenile leaves, Walhalla, $\forall$ ictoria (A. W. Howitt). E. amygdalina, with still broader juvenile leaves. 


\section{PLATE 30.}

E. amygdalina, Labill., var. numerosa, var. vel sp. nov. (and allies).

1a. Juvenile leaves; $1 b$, mature leaves; $1 c$, heads of buds; $1 d$, anthers; $1 e$, fruits of $E$. amygdalina, Labill., var. numerosa, Maiden, from Hilltop, near Mittagong, New South Wales. (See p. 155.)

2. Facsimite of part of drawing of DC, Mém. Myrt., t. 7. The original is a specimen of E. radiata, Sieb., quoted in the Prodomus as Pl. Exs., No. 425. Another specimen (Fl. Mixta, No. 604) is figured as No. 6 on Plate 29.

$3 a$. Leaf and $3 b$, fruits of $E$. amygdalina, with leaves broader than the type, and very small fruits. Lilydale, Victoria (A. W. Howitt).

4a. Leaf and $4 b$, fruits of a form of $E$. amygdalina, with small fruits, and especially broad leaves. Darlimurla, Victoria (H. Deane). This form undoubtedly shows affinity to var, numerosa.

$$
\text { E. lineuris, Dehnh. }
$$

5a. Twig of typical E. Tinenris, Dehnh. (Hort. Camald., in Herb. Vindob.); $5 b$, fruits from a cultivated tree (now dead) growing in the Domain, Melbourne.

\section{PLATE 31.}

E. amygdalina, Labill., var. nitidn, Benth. (and allies).

1a. Twig in flower ; $1 b$ and $1 c$, heads of fruit, all of " 808 (?) Gunn, Currie's River." [N.B.-The note of interrogation is in Gunn's handwriting, and is thus quoted by Hooker in Fl., Tas.] These specimens are typical for E. nitida, Hook., f.; and for Bentham's var. nitida. See p. 162).

2. Drawn from a specimen in W. H. Archer's herbarium, labelled " $E$. radiata, Hooker," var. 5. (See p. 162.) Tn this specimen the operculum is more conical than in typical nitida.

3a. Leaf ; $3 b$, buds ; $3 c$, fruits ; $3 d$, anthers; of Gunn's 1,078, from "Risdon, river-side ;" very near typical nitida.

4a. Leaf, with buds and flowers; $t b$, fruits, of var. nitida, from Mount Victoria, New South Wales. (J.H. M.) (See p. 163.)

$5 a$. Juvenile leaves; $5 b$, mature leaf; $5 c$, fruits, of a tree from Jenolan Caves, New South Wales (W. F. Blakeley); nearest to rar. nitida. (See p. 163.)

6a. Leaves; $6 b$, buds; $6 c$, fruits of a form from Monga, near Moruya (W. Baeuerlen); near var. nitida, but reminiscent of E. stellulata, Sieb. (See p. 163.)

\section{PLA'TE 32.}

1a. Twig of typical E. Risdoni, from Beltana, Hobart (quite close to Risdon Cove); 1b, front and back view of anthers; $1 c$, fruits; $1 d$ and $l e$, leaves taken from the same tree from which $1 a$ was taken! It will be observed that $1 d$ and le differ in no way from ordinary leaves of $\boldsymbol{E}$. Risdoni, var. elato. (See p. 175.)

2a. Twig, bearing flowers; $2 b$, twig, bearing fruits; $2 c$, pair of fruits, of $E$. Risdoni, Hook. $\mathbf{f}$, var. elata, Benth. ; 1,110, Gunn (partim). (See pp. 176, 178.)

$3 a, 3 b, 3 c$, leaves; $3 d$, flowers; $3 e, 3 f, 3 g$, fruits of $E$. obliqun, L Hérit, var. alpina, Maiden (E. deleyatensis, R. T. Baker), the "Gum-top Stringybark," 1,110, Gunn (partim). The fact that specimens of two Eucalypts, very similar in appearance, have been distributed as 1,100, Gunn, and an account of the confusion which has arisen in consequence, is related for the first time at p. 178 . 



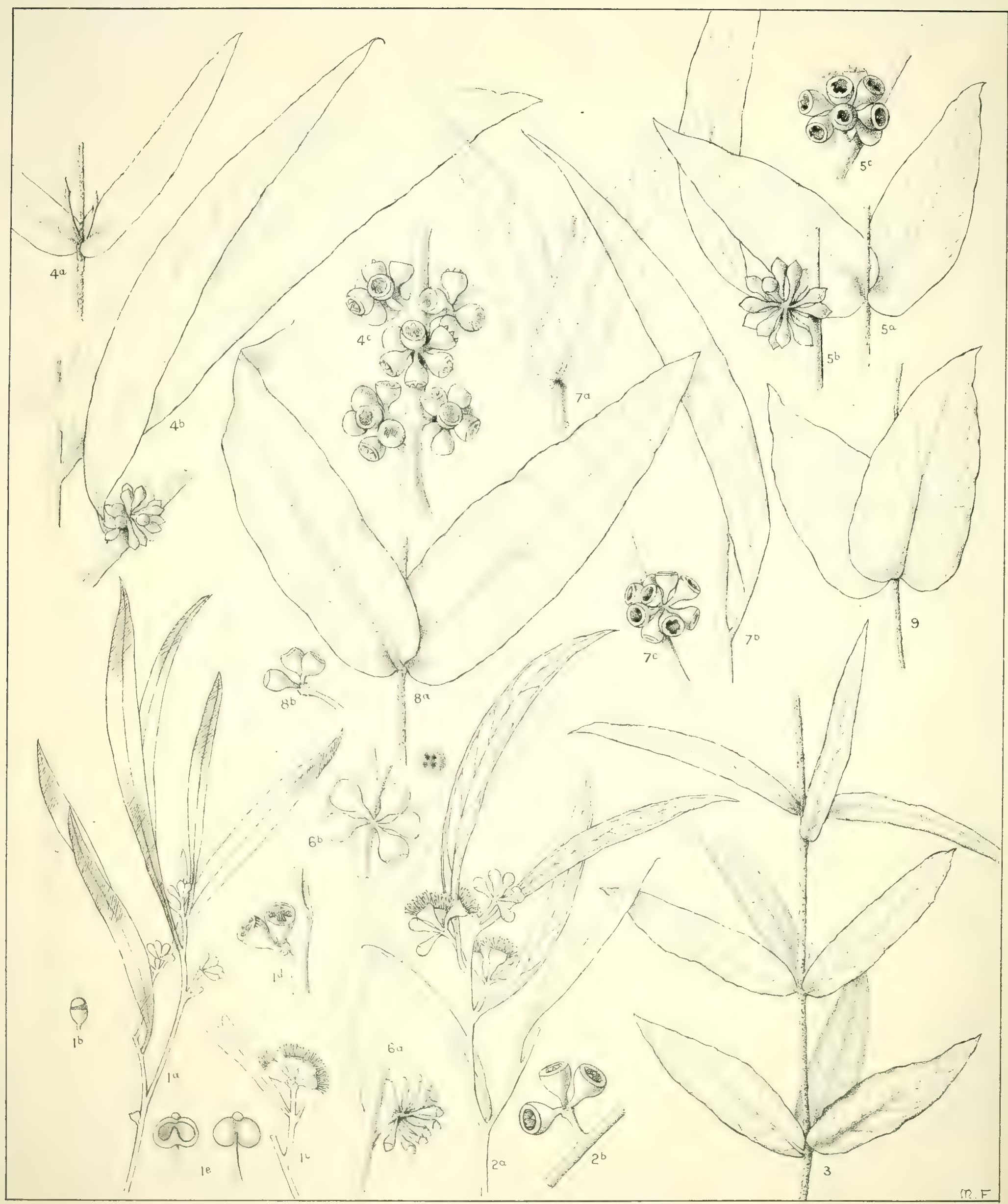





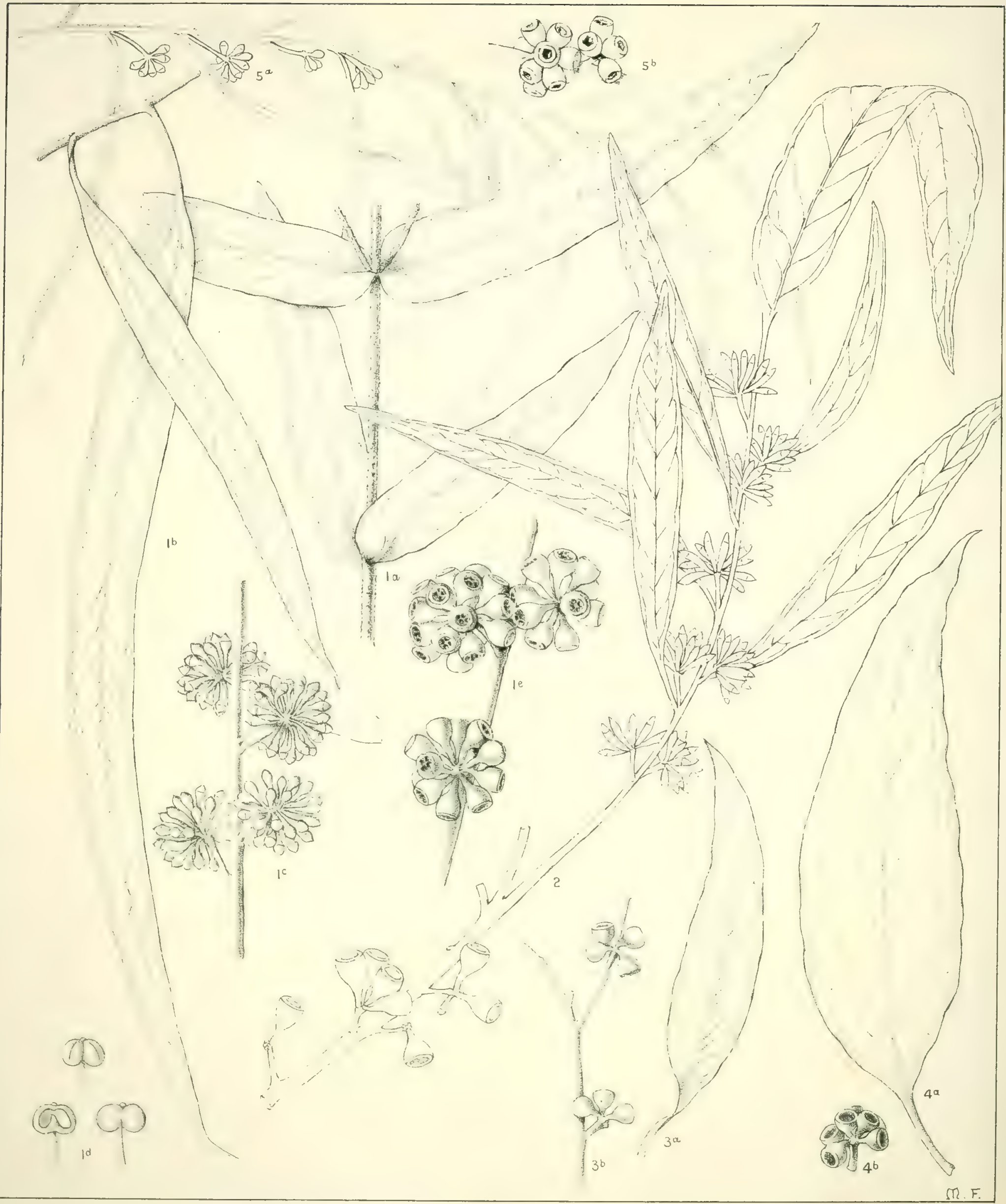

E. AMYGDALINA, Labill., var, numerosa, var. nov. (I); and allies.

E. LINEARIS, Dehnh. (5). 


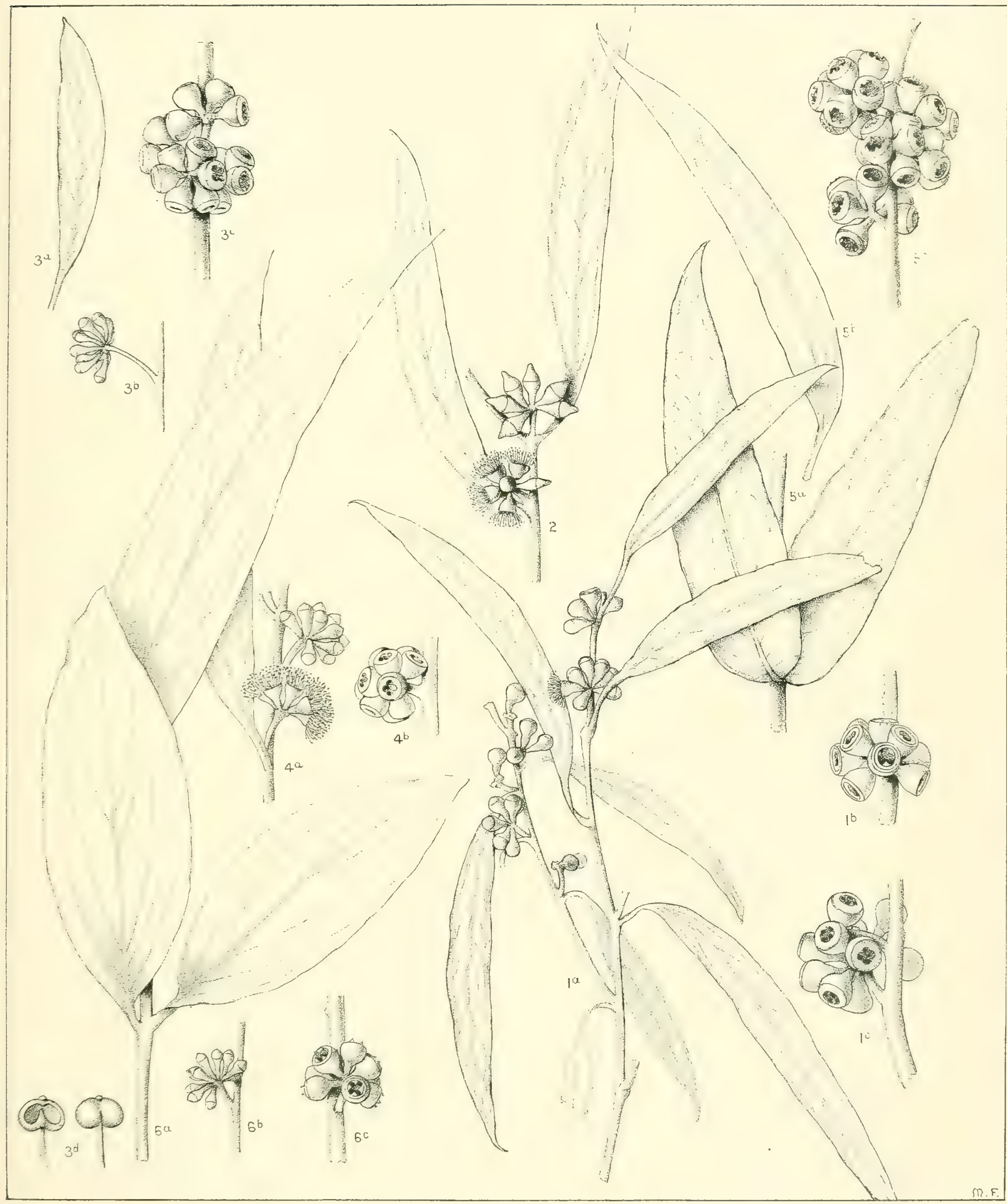

E. AMYGDALINA, Labill., var. nitida, Benth. (and allies). 



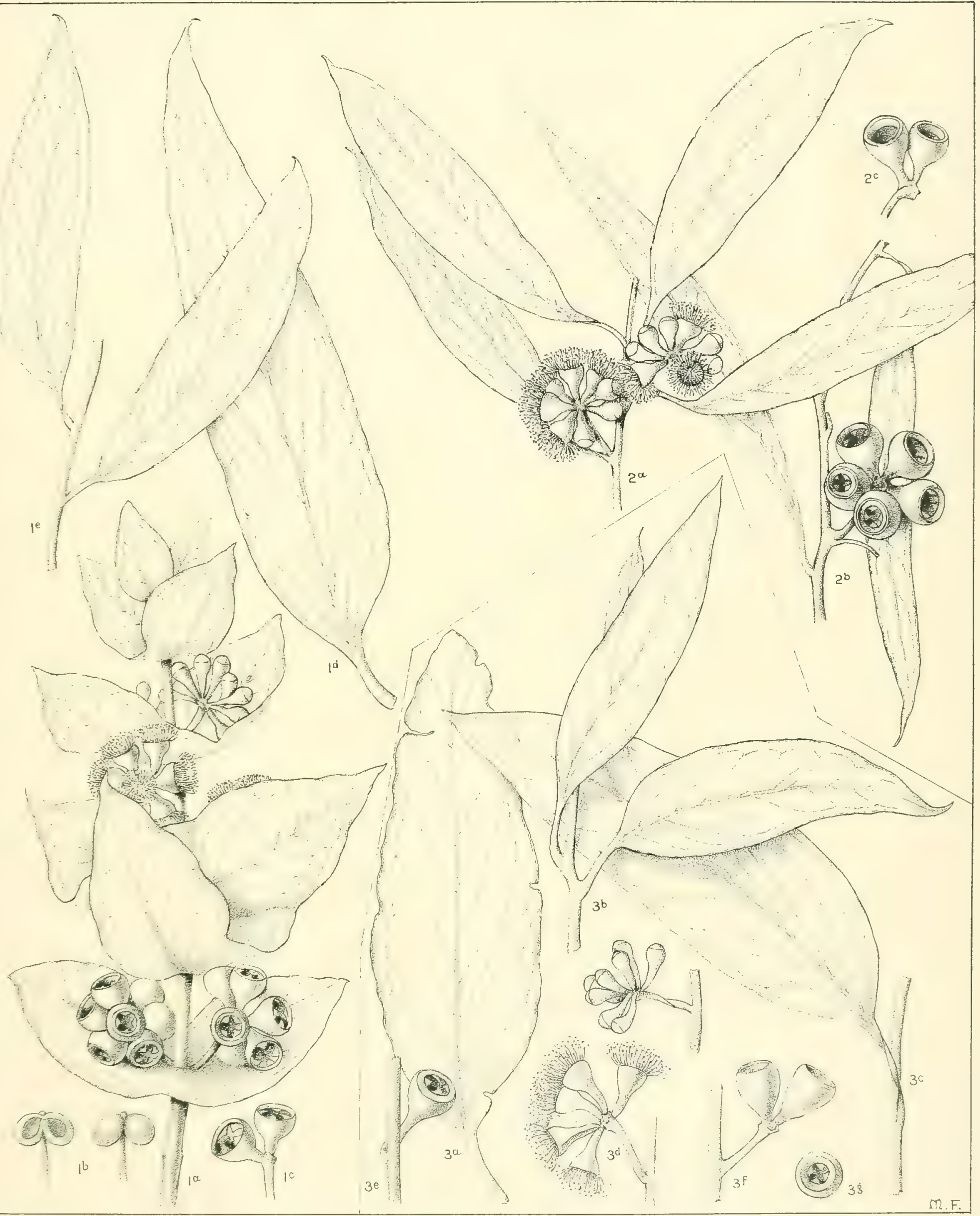

E. RISDONI, Hook., f. (I); E. RISDONI, Hook., f., var. elata, Benth. (2);

E. OBLIQUA, Labill, var, alpina, Maiden (3), for many years confused with (2). 



\section{A CRITICAL REVISION OF THE GENUS EUCALYPTUS}

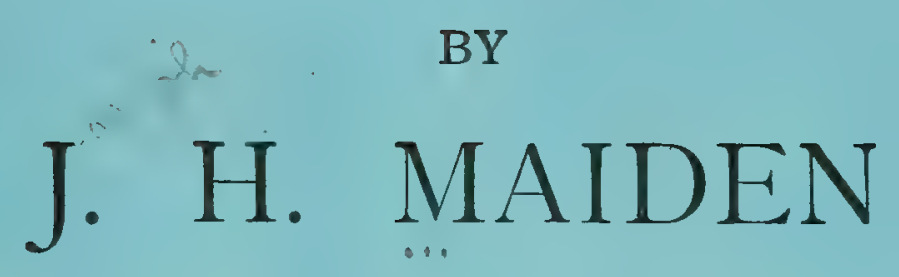

(Government Botanist of New South Wales and Director of the Botanic Gardens, Sydney).

\section{PART VII}

(WITH FOUR PLATES)

Price Two Shillings and Sixpence.

Published by Authority of

THE GOVERNMENT OF THE STATE OF NEW SOUTH WALES.

\section{Sųonten:}

WILLIAM APPLEGATE GULLICK, GOVERNMENT PRINTER.

1905. 



\title{
A Critical Revision of the genus Eucalyptus
}

\author{
BY \\ J. H. MAIDEN \\ (Government Botanist of New South Wales and Director of the Botanic Gardens, Sydney). \\ PART VII \\ (WITH FOUR PLATES). \\ "Ages are spent in collecting materials, ages more in separating and combining \\ them. Even when a system has been formed, there is still something to add, to alter, \\ or to reject. Every generation enjoys the use of a vast hoard bequeathed to it by \\ antiquity, and transmits that hoard, augmented by fresh aequisitions, to future ages. \\ In these pursuits, therefore, the first speculators lie under great disadvantages, and, \\ even when they fail, are entitled to praise." \\ Macaulay's "Essay on Milton."
}

PRICE TWO SHILLINGS AND SIXPENCE.

Published by Authority of

THE GOVERNMENT OF THE STATE OF NEW SOUTH WALES.

Sngoner:

WilliaM APPLEGATE GULLICK, GOVERNMENT PRINTER, PHILLIP-STREET.

* 54121 A $1 \overline{905 .}$ 

12.

EUCALYPTUS REGNANS

(F.v.M.).

13.

EUCALYPTUS VITELLINA

(Naudin),

AND
EUCALYPTUS VTTREA
(R. T. Baker).

\author{
14. \\ EUCALYPTUS DIVES
}

(Schauer).

\author{
15. \\ EUCALYPTUS ANDREWSI \\ (Maiden).
}

16.

EUCALYPTUS DIVERSIFOLIA (Bonpland). 


\section{Eucalyptus regnans, F.v.M.}

Description . . . . . . . . . 183

Notes supplementary to the description. . 183

Synonyms. . . . . . . . . . 184

Notes on the Synonyms . . . . 184

Range . . . . . . . . . . . 187

Affinities . . . . . . . . 188

XIII. Eucalyptus vitellina, Nandin, and Eucalyptus vitrea, R. T. Baker.

Description . • . • . . . • . . 189

XIV. Eucalyptus dives, Schauer.

Description . . . . . . . 190

Notes supplementary to the description. . 190

Synonyms . . . . . . . . . I9 I

Range. . . . . . . . . . . I9I

Affinities . . . . . . . 192

$X V$. Eucalyptus Andrewsi, Maiden.

Description . . . . . . . . . 194

Notes supplementary to the description. . 195

Synonyms . . . . . . . . . 195

Range. . . . . . . . . . . 195

Affinities . . . . . . . . 196

XVI. Eucalyptus diversifolia, Bonpland.

Description . . . . . . . . 197

Notes supplementary to the description. . 197

Synonyms . . . . . . . . . . 199

Notes on the Synonyms . . . . . 199

Range.

201

Affinities . . . . . . . . . 203

Explanation of plates . . . . . . . 204 


\title{
DESCRIPTION.
}

\author{
E. regnans, F.v.M.
}

Following is the original description of this species, as quoted by Mueller himself in his "Second Census of Australian Plants":-

Eucnlyptus amygdalina, Labill._ "In our sheltered, springy (containing water-springs-J.H.M.) forest glens, attaining not rarely a height of over 400 feet, there forming a smooth stem and broad leaves, producing also seedlings of a foliage different to the ordinary state of Eucalyptus amygdnlina as occurs in more open country. This species, or variety, which night be called Eucalyptus regnans, represents the loftiest tree in the British territory, and ranks next to the Sequoia Wellingtonin in size anywhere on the globe. The wood is fissile, well-adapted for shingles, rails, for house-building, for the keelson and planking of ships, and other purposes. Labillardière's name applies ill to any of the forms of this species. Seedlings raised on rather barren ground near Melbourne have shown the same amazing rapidity of growth as those of Euc. globulus, yet, like those of Euc. obliqua, they are not so easily satisfied with any soil." - Report of the Acclimatisation Society of Victoria (now Zoological and Arclimatisation Society); 7th report, 1870, p. 48.

The tree is later referred to :-

The very tall, whitish, straight columns of its stem (E. regnans) are developed in the valleys of mountain forests only; in lower regions the species dwindles down to a comparatively small tree [to which the more persistent layers of the outer bark give a very different appearance. In this state it passes as a peppermint-tree] among Victorian colonists, on account of the unusually large percentage of cajuput-like essential oil.-(Mueller, "Suggestions on the Maintenance, Creation and Enrichment of Forests." Small 8vo., p. 31, 1878).

Attention is invited to the words placed by me in brackets, in connection with what is stated in regard to E. fastigata, infra, p. 186. Then, again, we have:-

In sheltered, springy forest glens, attaining exceptionally to a height of over 400 feet, there forming a smooth stem and broad leaves, producing also seedlings of a foliage different to the ordinary state of E. amygdalina, as occurs in more open country, which has small narrow leaves and a rough brownish bark. The former species, or variety, which might be called Eucalyptus regnans, represents probably the loftiest tree on the globe--(Mueller, Select Extra-tropical Plants; N.S.W. Ed., 1881, p. 114).

In the Eucalyptographia, Mueller looked upon E. amygdalina as including $E$. regnans, and he does not appear to have formally described $E$. regnans before 1887-8. Following are his words :-

At last stupendously tall.

Bark. - Outside whitish and smooth, except at the stem base.

Leares.-Of rather thin texture, from elongate to broad-lanceolar, much unilaterally curved, shining on both sides, their secondary venules slightly spreading; oil-dots extremely numerous and pellucid.

Umbels.--Mostly solitary.

Flowers.-Small.

Lid (Operculum).-Hemispherical.

Anthers.- Minute, renate.

Fruit.-Quite small, generally semiovate, its border depressed or nearly flat; valves enclosed.

Leaves.-Of young seedlings opposite, sessile, cordate-roundish, whitish from waxy bloom.

"Giant-Gumtree" and "Spurious Blackbutt."-(Key to the System of Vict. Plants, i, 236.)

The species may be defined in the following words:-

A large tree, the largest indeed in Australia, though inferior in size to the "Redwood" (Sequoia sempervirens) and the "Big tree" (Sequoia Wellingtonia) of Western America (British Columbia and California). Trees about 300 feet high are known in Victoria, and huge in girth and straight in trunk they tower into the sky, affording little shade from their foliage because the scanty crown of leaves is so far removed from the earth. Some of the largest trees of New South Wales also belong to this species. 
Vernacular Names.-In its smoother-barked (Victorian) form it bears the name of "Mountain Ash," and even "White Gum," but it varies as to the amount of rough bark, and, indeed, its commonest name in Victoria is "Blackbutt." In New South Wales it is most usually called "Blackbutt" also, though in one district the name "Cut-tail" is in use.

Bark. - It has more or less of a sub-fibrous, dark-coloured bark on the butt and trunk. On the giant trees of Victoria there is often very little of this bark, but on others, in the same State, this bark runs further up the trunk and becomes more or less ribbony. In the same State, but more commonly in New South Wales, the whole of the trunk and part of the branches become covered. The smooth portion is white and smooth, and thus it follows that the same species may be either a White Gum or a Blackbutt.

Timber.-A timber can scarcely be more fissile than that of the straightest growing and largest of these trees. All trees of this species, however, possess this property of fissility in a marked degree. It is pale-coloured, and is extensively used for saw-mill purposes.

Juvenile Leaves. - "The young seedlings of this Eucalypt are at first like those of the typical amygdalina (this is hardly correct; they are never so narrow.-J.H.M.) but with somewhat broader, lanceolar, opposed leaves. These are soon replaced by broadly lanceolar, scattered, unequal-sided, pointed leaves, very like those of $E$. obliqua. The saplings so much resemble those of this Eucalypt in other respects that at first sight they might be confused." (A. W. Howitt, Eucalypts of Gippsland [Trans. Roy. Soc. Vict., ii, 87.]) Their shape is brought out in Plate 33, fig. 2. The leaf is undulate, and the margin is irregularly toothed.

Mature Leaves.-Lanceolate to broadly lanceolate, shining on both sides, usually thin in texture (but sometimes quite coriaceous), veins slightly spreading, oil-dots extremely numerous. Indeed, a common method of recognising $E$. regmans is to hold up a leaf to the light and to notice the fine oil-dots which cover its surface, but this character should be used with caution as the leaves of some other species possess it.

Buds. - The operculum hemispherical to conical, the pointed character heing more obvious in dried specimens.

Flowers. - The anthers reniform. While the umbels are mostly solitary, it is not unusual to find them in pairs, a character which is shared with some otber species of the Renantheræ, e.g., E. Andrewsi, Maiden.

Fruits.- The shape and size are alike variable. The calyx nearly hemispherical, but more usually gradually continued into the stalk, so as to take on a conoid shape. The pedicels not long, but the common petiole often an inch long. The rim prominent, usually more or less domed, and the valves usually exsert. The valves were originally described as enclosed, but this is not commonly the case in perfectly ripe fruits.

\section{SYNONYMS.}

1. E. amygdalina, Labill. var. regnans, F.v.M.

2. E. amygdalina, Labill. var. colossea, F.r.M.

3. E. inophloia, F.v.M.

4. E. fastigata, Deane and Maiden.

\section{NOTES ON THE SYNONYMS.}

1. E. amygdalina, Labill. var. regnans, F.v.M. Mueller wavered a good deal as to the specific rank of E. regnans, as has been pointed out, and distributed much material under the name quoted. 
2. E. amygdalina, Labill. var. colossea, F.v.M. E. regnans, F.v.M., bears the above name in Herb. Melb., and at one time Mueller distributed it under that name, but not so freely as under the name var. regnans. It is not to be confinsed with E. colossea, F.v.M., which is a synonym of E. diversicolor, F.v.M.

\section{E. inophloia, F.v.M.}

Mountain Ash (Eucalyptus inophloia or Mountain Ash) is so called from a fancied resemblance to the British timber of that name, and is employed by the coachmakers for bending into the form of shafts for light vehicles, for which it is well adapted. It bas not hitherto received the attention it deserves, being ordinarily used for splitting into palings for fencing and other inferior applications; it is much like the White Gum, and may be used for similar purposes.-(Intercol. Exhib. of Australasia, Melbourne, 1866-7; Official Record, 1867, p. 216.)

In the Official Report of the Victorian Exhibition of 1861 we have the entry, "E. inophloia, Mountain Ash, specific gravity of wood •642."

I cannot find a description of this species. The late Mr. J. G. Luehmann assured me that the "Mountain Ash" in question is E. regnans. I suggested it might have been $E$. obliqua, L'Hérit. var. alpina, Maiden.

\section{E. fastigata, Deane et Maiden. Following is the original description :-}

Introductory.- While dealing with the Stringybark group we draw attention to a tree which is very closely related to one of them, that is to all intents and purposes a Stringybark. We allude to the forest tree known as "Cut-tail" in the southern part of the Colony. It attains a height of 60-100 feet and more, and a diameter of at least 4 feet. Its affinities to other species will be dealt with under various headings, but we may point out that it strongly resembles $E$. obliqua in bark and wood, while the two species have very dissimilar buds and fruits. The only point of resemblance to $E$. amygdalina lies in the fruits, which are rather like those of our variety latifolia (E. dives, Schauer.-J.H.M.) figured in our former paper of this series.

We do not hesitate to say that "Cut-tail" cannot be included under any existing species, and therefore propose the name fastiyata for it, in allusion to the shape of the operculum and leaves.

Vernacular Names. - Several names are more or less in use in different places. The one most in use, where also the tree is best developed, is "Cut-tail," and inasmuch as this name is not applied to any other tree, so far as we are aware, we would suggest that all other English names be dropped as far as possible in favour of this. We bave made many inquiries as to the meaning of the term "Cut-tail" but without success, * and can only suggest that it has reference to the rough bark on the branches, which, in comparison with $E$. obliqua, which it so much resembles in general appearance, it is cut-tailed or curtailed.

Other names that have been mentioned to us for this tree are "Blackbutt," on the Nimbo Station, Braidwood-Cooma road, and, on the Tantawanglo Mountain, "Messmate"; "White-topped Messmate" and "Silver-top" at various places, and "Brown Barrel" at Queanbeyan.

Seedling or Sucker Leaves.-Ovate-lanceolate, early becoming oblique; scattered, in this respect very dissimilar to those of $E$. amygdalina, the leaves of which remain opposite until the tree has attained some size. The veining of the under side prominent. The twigs rusty tuberculate like $E$. amygdalina and some other species.

Leares of Mature Trees.-Lanceolate, and when fully grown narrow lanceolate. Often more or less ovate-lanceolate, and always more or less attenuate. They are rather coriaceous, smooth, and rather shining. They possess no odour of peppermint.

Buds. - The chief characteristic is the shortly acuminate operculum, which is much accentuated in dried specimens. In $E$. obliqua the operculum is blunt, and the whole bud club-shaped, very different to those of the species now under review. The anthers are partly folded in the bud.

- Mr. Baeuerlen (Proc. Lirn. Soc., N.S.W., 1899, 547) has explained that this name is an expert splitters' term. Eis paper should be referred to. 
Fruits.-The figure (Pl, Ixi, not reproduced.-J.H.M.) will make the shape clear. They are pearshaped, have a conical or domed rim, with the valves somewhat exserted. They are always three-celled as far as seen. Diameter of rim, $2 \frac{1}{2}$ to nearly 3 lines. Length from end of pedicel to rim, $2 \frac{1}{2}$ lines.

'The fruit differs from that of $E^{\prime}$. obliqua in being more or: less conical, while that of $E$. obliqua is subcylindrical. The latter species has no well-defined rim, and the valves are sunk, whereas in the tree now under consideration there is a prominent rim, while the valves are somewhat exserted. The fruits of $E$. obliqua are also larger than those of our species, and have shorter stalks. In the latter species, the peduncles are elongated over half an inch in fruit, and are distinctly pedicellate, about $1 \frac{1}{2}$ lines.

Bark. - It resembles closely that of $E$. obliqua, the principal difference between the two trees, in this respect, consisting in the fact that the tops and the branches of "Cut-tail "are smooth, while those of E. obliqua are the reverse.

Timber.--It has all the characteristics of the timber of E. obliquu, from which it is scarcely, or not at all, to be distinguished. At Montgomery's mill, on the Tantawanglo Mountain, near Cathcart, the two trees are considered of equal value, and the timbers of the two cut up and sold as one and the same.(Proc, Linn. Soc., N.S.W., 1896. p. 809.)

In my "Useful Native Plants of Australia" (1889) occurs the note :-

"Cut-tail" grows with a straight bole over 200 feet high, and with a diameter of 6 to 8 feet. Its wood is fissile in the highest degree, since it can be readily split almost to the thinness of paper. A sample of this timber from Haydon's Bog, near Delegate, cut in March, 1885, is in the Technological Museum. It is very straight in the grain (as might be expected), and very easy to work.

I have since examined other specimens, and find that, while the timber of some trees is not markedly fissile, E. fastigata may have timber as fissile as that of the Victorian tree.

Mr. Deane and I wrote (ib. 1899, p. 459):-

Our $E$. fastigata is a tree with a fibrous bark, not to be distinguished in this respect from $E$. obliqua, except in the smooth branchlets of the former. Mueller described his regnans as a smooth-barked tree; the fruit of our fastigata (from Mount Tantawanglo) is smaller than that of $\boldsymbol{E}^{\prime}$. regrans, and there are other differences, of more or less value, which caused us to look upon our tree as new to science.

We bave since studied the distribution of $E$. fastigato, and find that it is very widely diffused in New South Wales.

Contemplation of these specimens (for the most part collected by ourselves), and inspection of L. regnans as it grows in Victoria, incline us to the opinion that our $E$. fastigato may not be specifically different from E. regnans. Mueller's description of his species would require to be moditied in the specially important matter (in the case of a Eucalypt) of the bark, while the size of the fruit, and other minor matters in which the published descriptions of $E$. regnans and $E$. fastiguta do not agree, may not present insuperable obstacles to the fusion of the two species.

I have since continued to hear the Victorian and New South Wales trees under observation, and now state without hesitation that E. fastigata is but a form of $E$. regnans. I cannot even look upon it as a variety. Examination of Mueller's series of statements referring to the bark of E. regnans shows that he was alive to the fact that his species might be fibrous-barked. The smaller size of the fruit in fastigata is one not to be relied upon, as I find that those of normal regnans vary in. size. Mueller, indeed, insists on the small fruits of his regnans, and I have fruits quite as small as I have ever seen in fastigata. 


\section{RANGE.}

It is found in Tasmania, Victoria, and New South Wales.

\section{Tasmania.}

The late Mr. F. Abbott first drew attention to the fact that E. regnans grows in Tasmania, as the following passage in the "Eucalyptographia" (under $E$. amygdalina) bears witness:-

Huge stems, quite smooth and almost white . . . passes as one of the White Gum-tree: . . . according to Mr. F. Abbott it is this form which constitutes the "Swamp Gum-tree" in Tasmania, where already Sir William Denison placed early its huge dimensions on record.

Some specimens of "Swamp Gum" from Mr. Abbott are typical, or nearly typical, for $E$. amygdalina var. nitida.

But Mr. Abbott probably saw typical E. regnans in addition, and specimens collected by Mr. L. Rodway leave no room for doubt that the species occurs in Tasmania. Mr. Rodway says :- "Tree 70-80 feet; bark smooth, except at extreme base, where it is ribbony." His specimens are of nearly typical regnans. Identical specimens were sent me by Mr. H. E. Day, from Mount Wellington, from about the 1,000 feet level.

\section{VICTORIA.}

It occurs over a wide area in South and Western Gippsland, chiefly on the Mesozoic Carbonaceous formations, together with $E$. obliqua and $E$. glubulus, from the sea-level up to about 1,200 feet. It is also found in the mountains, as at Walhalla, 1,200 feet, and at Tucker Creek, Wentworth River, 2,500 feet.(Howitt, Trans. Roy. Soc., Vict., 1890-1.)

Some of the type specimens of E. regnans came from the Dandenong, and were marked by Mueller, "D. Boyle, 420 feet."

\section{NeW SoUth WALES.}

It occurs in most of the high mountainous districts of this State. Following re some localities represented in the National Herbarium, Sydney :-

Southern localities.-Tantawanglo Mountain, near Cathcart, Bombala district (H. Deane and J.H.M. type of E. fastigata); "Cut-tail," Delegate River (W. Baüerlen); Monga, near Braidwood (No. 2,108, W. Baüerlen) ; Braidwood district (Reidsdale, Irish Corner Mountain), with E. obliqua and E.goniocalyx (H. Deane); "Blackbutt," Queanbeyan (J. D. Francis) ; "Blackbutt," "Brown Barrel," "Messmate," head of Queanbeyan River, Nimbo Station, Cooma district (H. Deane); "Brown Barrel," Hoskinstown (S. Daniel); "Messmate," back of Vlladulla (Allan); under Table Mountain west of Milton, Macquarie Pass, ITest Albion Pass, "Messmate," bark rather stringy, going higher up than usual, generally to branches, with specially small fruits (R. H. Cambage); Mittagong (H. Deane). 
Western localities._- "Red Blackbutt," timber with straight grain, reddish in colour, stem decidedly rough, and black from the ground. Sunny Corner (J. I. Boorman); "Blackbutt," rough, soft bark, clean ribbony tips, a good timber, which is in demand for palings, leaves thick. Sunny Corner (No. 5, J. L. Boorman); "Blackbutt," Burraga (R. H. Cambage); "Blackbutt," 15 miles southerly from Oberon cross roads (R. H. Cambage); "Messmate," Tarana (A. Murphy) ; Jenolan Caves, with rather thick foliage (W. F. Blakeley); Mount Wilson, Mount Irvine, \&c., all have white tops (Jesse Gregson and J.H.M.); the giant tree at Mount 'lomah is of this species; diameter at ground, $17 \mathrm{ft} .6$ in.; 3 feet up, 16 feet 3 in.; height (estimated), 150 feet (J.H.M.) ; Hassan's Walls, Bowenfels (J.H.M.); at the foot of Govett's Leap, Blackheath ( $\mathrm{R} . \mathrm{H}$. Cambage).

Northern locality.-Yarrowitch, New England (J.H M.) These specimens absolutely match the type regnans, but the bark is rough. Most of the trees I observed are small, though a few are 3 feet in diameter. Some of the umbels have a double operculum. This New England record was made in 1898 (Proc. Aust. Ass. Auv. Science, vii, 539), and it remains to ascertain other northern localities, and to connect them with the western ones. The following specimen is probably one of such connecting localities: In general appearance resembles $E$. piperit", but seems of more sturdy and irregular growth; generally is branchy and hollow, and I should think of little value. On mountain tops, Upper Paterson and Allyn Rivers, \&c. (A. Rudder, May, 1890). The fruits with valves not exsert, and leaves rather coriaceous.

\section{AFFINITIES.}

1. With E. amygdalina, Labill.

This has been incidentally referred to. The seedlings and jurenile leaves (quite narrow in $E$. amygdalina) sharply separate the two species. The mature leaves also are usually broader. Turning to the fruits, those of E. amygdalina are usually hemispherical, and those of $\vec{E}$. regnans conoid. It is hoped that Plates 29 and 33 will make the principal differences between the two species clear, but there is no doubt there are transit forms.

2. E. vitellina, Naudin, and E. vitrea, R. T. Baker.

See p. 189. Note also the specimens, Delegate River (W. Baüerien) and Sunny Corner (No, 5, J. L. Boorman), placed under E. regnans. 


\section{DESCRIPTION.}

\section{E. vitellina, Naudin, and E. vitrea, R. T. Baker.}

SEE pages 150 and 164 of Part VI, where I have pretty fully explained my views as to these two species, which I look upon as natural hybrids of E. amygdalina and E. coriacea. It is not possible to clearly describe the forms without figures, hence the figures in Plate 34 and Plate 35 (5) have been prepared, which have been described under "Explanation of Plates."

Figures 3 and $3 b$ (Pl. 34) have been described as E. vitrea, since they come nearest to that species of any described New South Wales form; at the same time, there is no question that the plant represented comes nearer to the French-grown hybrid E. vitellina.

It seems to me that $E$. vitrea runs into $E$.regnans also, and figures 2,4 and 5 , Plate 34, are quoted in support of that assertion. This is one reason why the drawings of $E$. vitrea have been placed in juxtaposition to those of $E$. regnans. If it were possible for my readers to compare the actual specimens, they would see that the similarities are even closer (e.g., texture of leaves) than those brought out in the figures, and that they tend to show that there is abundant justification for my formerly expressed view that $E$. vitrea is but a form of $E$. fastigata (and therefore of $E$. regnans). The leaves of $E$. vitrea vary a good deal in the straightness or spreading character of the venation-showing affinity to $E$. coriacea on the one hand and to $E$. amygdalina and $E$. regnans on the other

The resemblance of $E$. vitrea to E. amygdalina, Labill. var. nitida, Benth., is worthy of notice.

Some localities of E. vitrea have already been given in Part VI; others have been given in the Explanation of Plates of the present Part. It also occurs at six miles on Hampton Road from Oberon (near Jenolan Caves). 


\title{
DESCRIPTION.
}

\author{
E. dives, Schauer.
}

Following is the original description :-

Schauer mss._Glaucescens : ramis ramulisq. rigidulis teretib.; foll. firmis oppositis alternisve ovatis petiolatis v. subsessilib., basi obliquis acuminatis, summo acumine breviter recurvo, margine incrassatis venosis subperforatis; umbellis subcapitatis multiftoris lateralib. axillaribq.; pedunculo semipollicari tereti. ; pedicellis cupulam obconicam subaequantib. et continuo in eandem accrescentib. ; operculo depresso subconvexo obtusissimo vix umbonato. - Folia 3-4 poll. longa, 1-2 poll. lata; cupula cum pedicello 3 lineas explens. In Nova Cambria australi interiori.-A. Cunn. Herb. no. 181:1822 (Walpers' Rep. ii, 926).

The type came from "Forest land north of Bathurst," where Allan Cunningham was in 1822.

Subsequently Bentham described it in 13.Fl. iii, 205, the fruit being unknown to him.

Mueller, in the "Eucalyptographia," alludes to it under E. amygdalina, and I believe that he always held the view that it was not separable from that species. I doubt if he ever saw juvenile foliage; I have not seen any that I know passed through his hands.

'The next account I find of it includes an account of the fruit :-

$E$. dives . occurs on the Blue Mountains, and the Mittagong Range. The . . seedvessel is globose-truncate, about two lines in diameter, four-celled, with a broad rim, and the capsule sunk, the valves scarcely protruding . . . the wood is not esteemed.-(Woolls Fl ra of Australia, p. 241. See also his Plants of New South Wales).

The tree is abundant on the Mittagong-Berrima Road, which Dr. Woolls used to travel, and I have some specimens collected by the reverend gentleman.

For a long time there remained a doubt as to the identity of the species, partly because it was looked upon as a shrub (or a small tree of 10 or 12 feet, a statement repeated by Dr. Woolls), and, meantime, Mr. Deane and I redescribed it under the name of E. amygdalina var. latifolia. (See Synonyms.)

Shortly afterwards I visited the Melbourne Herbarium, and found one of Dr. Woolls' specimens from Mittagong labelled $E$. amygdalina var. dives by Mueller. These precisely matched the Woollsian specimens in my possession, and $\mathrm{Mr}$. Deane and I published a note, announcing the rediscovery of $E$. dives, Schauer, Proc, Linn. Soc. N.S.W., 1899, 460. 
It may be described in the following words :-

A tree of medium size, but often flowering as a tall shrub.

Bark.-Rough, like a typical "Peppermint" with smooth limbs somewhat ribbony. (Mr. A Murphy, an experienced collector, says that, practically, he distinguishes this species from E. piperita by the yellowish upper limbs, those of piperita being white.)

Timber.-Pale-coloured, full of concentric gum (kino) veins. It would be difficult to get a sound $\log$ of any size, and it is an almost worthless timber.

Vernacular Names. - It is usually known as "Peppermint" throughout its range, and especially so in the Western districts. It is called "Blue Peppermint" at Rylstone; "Messmate" in the Southern districts generally.

Jurenile Leares.-Comparatively broad (sometimes so broad as to be nearly orbicular) ; stemclasping, more or less cordate at the base, and in some cases quite acuminate. The shape is brought out in the figure. Both juvenile and mature leaves reek with oil.

Mature Leaves.-Broadiy lanceolate, nearly symmetrical, usually rather thick. Venation spreading from the base. An important characteristic is the strongly marked venation. On drying, the principal veins stand out in relief against the vascular tissue. Often shining, a characteristic best brought out in fully mature leaves, but the foliage may be both dull and glaucous.

Up to 5 or 6 inches is a common length for the leaves, but they are barely 3 inches in some of the Bombala and Queanbeyan specimens; $4 \frac{1}{2}$ inches would appear to be an average length. Specimens up to nearly 2 inches in width are found in Mount Vincent specimens; $1 \frac{1}{2}$ inch is a common width; $1-1 \frac{1}{2}$ inch may be given as the average width.

Buds.-Operculum usually blunt, though not quite hemispherical. In dried specimens the opereulum more pointed. Buds often glaucous.

Flowers. - A profuse flowering species, with dense umbels of eight to twelve, and even more flowers. Anthers reniform, the cells divergent and confluent at the apex.

Fruits.-Sometimes nearly hemispherical with a greater or less tendency to pear-shape. The rim often domed or arched. The tips of the valves occasionally a little exserted. The rims (mouths) usually red, a characteristic often attributed to homastoma, and the fruit itself often pale-coloured; may be very shiny or glaucous.

\section{SYNONYMS.}

1. E. amygdalina, Labill. var. dives, F.v.M. (In Herb. Melb., as already alluded to.)

2. E. amygdalina, Labill, var. latifoli", Deane and Maiden, Proc. Linn. Soc., N.S.W., x, 609 (1895) with Plate lvii.

\section{RANGE.}

This species is confined to New South Wales and Victoria so far as is known at present.

\section{VICTORIA.}

It is only quite recently that it has been formally recorded from Victoria,* but some of the specimens, which were fragmentary, referred to in that paper, belong, in my opinion, to other species of the Renantheræe. $124(1901)$.

" "On the occurrence of Encculyptus dives, Schauer, in Victoria," by J. H. Maiden. -Vict. Naturatist, xviii, 
The following specimens in the National Herbarium belong to $E$. dives :Dargo and Wentworth River, Gippsland (A. W. Howitt), and by him ealled "Broadleaved amygdalina"; Mt. St. Bernard, 3,500 feet (J.H.M.) ; Wandong Ranges (C. Walter) ; Grampians (C. Walter); "N.E. district of Victoria" (H. B. Williamson, No. 930).

\section{NeW Sodth W ALes.}

It frequents much of the sterile rocky country of the colder parts of this State, both south and west, but its precise range remains to be determined. It has not been recorded from New lingland.

Southern localities.-Bombala and Cumberland Range (A. W. Howitt); near Delegate (J.H.M.); Jindabyne (J.H.M.); Yarrangobilly (W. Forsyth); "Messmate," Granite Hill, Tumbrumba (R. H. Cambage); Head of Tarcutta Creek, 8 miles from Tumberumba (Forest Ranger Mecham); "Messmate or Peppermint," ridgy country about Tumut (W. U. Nowland); Cockatoo, near Germanton (W. Forsyth); Queanbeyan (J. D. Francis); Bungendore (W. S. Camphell, A. W. Howitt); Bell's Creek, near Braidwood (J. S. Allan) ; Fagan's Creek (W. Baeuerlen); Barber's Creek (J.H.M.); Wingello, Berrima and Mittagong (J.H. U. and J. L. Boorman), where it is known as "Bastard Stringybark," "Bastard Messmate," or "Messmate."

Western localities. - This tree seems to rarely occur on the sandstone, but as soon as the granite occurs, P.g., near Bowenfels, it mak's its appearance plentifully. Mt. Victoria (R. H. Cambage and J.H.M., on Sandstone); Cox's River (R. H. Cambage and J.H.M.); Jenolan Caves (W. F. Blakeley); Wallerawang (H. Deane and J.H.M.); Tarana (A. Murphy); Capertee (J. L. Boorman and J.H.M.) ; Sunny Corner (J. L. Boorman); Oberon, Burraga, Trunkey, Rockley (R. H. Cambage); Orange (A. W. Howitt, R. H. Cambage).

"Blue Peppermint," Mt. Vincent, Mudgee district (R. T. Baker).

\section{AFFINITIES.}

1. E. amygdalina, Labill.

The two species have affinities apparent both to the forester and to the botanist.

Speaking of $E$. dives, Mr. W. U. Nowland, the Staff-Surveyor at Tumut, says:- "It is known to me as either a 'Messmate' or 'Peppermint,' according to locality. Some bushmen eall it by the former name, others by the latter, owing to it being very hard to distinguish it from another tree here ( $\boldsymbol{E}$. amygdalina), almost a fuc-simile, excepting in the shape of the leaf." 
If unaccompanied by sucker leaves, I doubt if $E$. dives can be sometimes distinguished from E. amygdalina. Mueller failed to distinguish the species, while admitting a certain amount of difference amounting to a variety.

Speaking generally, $E$. dives is more aromatic even than $E$. amygdalina. The odour is different, though difficult to describe. The foliage of the former species is usually broader and more glaucous than that of the latter. The fruit of $\boldsymbol{E}$. dives is usually larger; nevertheless, all these characters bave sometimes to be cautiously examined when herbarium specimens of mature foliage, buds, and fruits are alone available.

2. E. vitrea, R. T. Baker.

This tree, in bark, timber, and even fruits, resembles that of $E$. dives a good deal. The matter has been alluded to at page 155, Part VI. 


\section{DESCRIPTION.}

\section{E. Andrewsi, Maiden.}

\section{This species was described in a paper* from which most of the particulars} now given have been drawn.

A tall tree, on an average, say 80 feet in height, with a stem diameter of $2-3$ feet. "On the Bulldog Hill, 3,000 feet (between the Timbarra and Clarence Rivers), it attains a diameter of at least 8 feet, and the height of large trees is most likely from 150 to 180 feet. Here it consorts with true Blackbutts (E. pilularis) and Forest Oaks (Casuarina torulosa) which even at times rise 100 feet, and 50 or 60 feet without a branch."-(E. C. Andrews.)

Writing from Drake to Mr. Cambage, Mr. Andrews says:- "One tree we measured 20 feet in circumference, about 80 feet to 100 feet to first limb, and from 150 feet to 180 feet high (guess). Another: 23 feet in circumference, 170 feet high. (3) Another we measured $25 \mathrm{ft} .6 \mathrm{in}$. round butt (4 feet above ground). Blackbutt-top but about 150 feet high then. I suppose there were from 50 to 100 from 18 feet to 20 feet and 21 feet in circunference."

Juvenile leaves. Rather large and soon becoming alternate, glaucous. The youngest foliage availahle to me is elliptical, and about 4 inches long by half the width, with petioles of $\frac{1}{2}$-inch. "Seedlings have erect habit, with fairly large leaves; pale in colour." - $(\mathbf{R} . \mathrm{H}$. Cambage.)

Mature leaves. Broadly lanceolate, sometimes falcate, but apparently usually symmetrical. Dull on both sides and even glaucous, $\uparrow$ but ultimately glabrous and even shining; equally green on both sides, venation spreading from the base. Usually under 6 inches long and about 1 inch wide. Of a distinct peppermint odour.

Buds.-Clavate, the operculum sometimes slightly umbonate. A free flowerer, the anthers reniform.

Fruits. Nearly hemispherical, about 4 -inch in diameter; with a flat thick rim, tips of the valves flush with the mouth; peduncle thin; angular, $\frac{1}{2}-\frac{3}{4}$ inch long, pedicels about $\frac{1}{5}-$ inch in length. Fruits abundantly produced, usually six to nine in the head. The fruits remind one of those of $E$. hamastoma var. micrantha.

Bark.--Has "Peppermint" bark on the trunk and large branches; only the ultimate branches smooth. Twigs red (claret-coloured), often glaucous, usually round, apparently rarely angular.

Timber.-Pale-coloured, comparatively light in weight, and very fissile, containing a few kino veins. So similar in appearance to that of $E$. piperita, Sm., that I am at present unable to indicate any difference. "Split for palings" (R. H. Cambage). "Timber like E. acmenoides, but not wavy like it; more like E. piperita timber" (A. Murphy). "Timber seemingly preferred to all others for fencing, building, etc." (J. L. Boorman). [In this connection it may be pointed ont that the value of a timber is comparative; the best timber of a district may be inferior to that of another district.]

Known locally as "Blackbutt," less Erequently as "Peppermint," and "Messmate." It is the "Blackbutt" of Mr. W. Christie's paper, ł and his "Specimen No. 11" (p. 35) has been preserved. Known all over Now England as "Blackbutt." At Oban it is called "Bastard Stringybark," and at Emmaville "Messmate" (E. C. Andrews).

" "On four new species of Eucalyptus;" by J. H. Maiden.-Proc. Linn. Soc. N.S. W., pp. 472-5 (1904).

+ Glaucousness often varies a good deal with the season of the year; e.g., specimens received by me in October last were entixely dull or glaucous, others received in June of the present year are slightly shining.

+ "The forest vegetation of Central and Northern New England in connection with geological influences."-Journ. and Proc. Roy. Soc., N.S.W., xi, 21, 18\%. 
This species was first prominently brought under my notice by $\mathrm{Mr}$. $\mathrm{k}$. H. Cambage in October, 1903. That gentleman collected it, and made cxtensive notes concerning it. It is named in honour of srnest Clayton Andrews, B.A., Greological Surveyor, Department of Mines, New South Wales, who has been giving attention to the flora of New England, particnlarly as regards the vegetation on various ge slogical formations, and who has made special inquiries in regard to the tree that is called by his name.

\section{SYNONYM.}

E. Sieberiana, F.v.M. var. Oxleyensis, Deane and Maiden (Proc. Linn. Soc., N.S.W., 1899, 79t, where it is fully described).

The specimens referred to as E. Sieberiana, F.v.M. var. Oxleyensis, Deane and Maiden, loc. cit., for the most part belong, in my opinion, to $E$. Andrewsi. They have smaller fruits, usually more pyriform than the type, but in view of the fact that the fruits of trpical $E$. Andrewsi vary more than ordinarily as ripening proceeds, it is premature to define varieties of $E$. Andrewsi at present.

\section{RANGE.}

Confined to the colder parts of northern New South Wales and southern Queensland, so far as is known at present.

Plentiful in many parts of New England, N S.W. The species seems to attain its greatest size on the eastern slopes and New England. Plentiful on belts of porphyritic felsite (R. H. Cambage).

"Grows generally on granitic soils, but it frequently occurs on the junction of basaltic soils with those of poorer formation"-(W. Christie.)

North and east of Tingha (about 2,700 feet above sea-level), and on the roads to Inverell and Guyra (R. H. Cambage, J H.M.) ; Howell (J. L. Boorman, J.H.M.); Wallangarra; Boonoo Boonoo; (J. L. Boorman). "Following are New England localities: Wilson's Downfall, Undercliffe, Great Dividing Range west of Bolivia and Deepwater. From the 10 to 25 mile pegs along the Glen Innes-Grafton Road. Along the Glen Innes-Glen Elgin track, Kingsgate, Oban, Tingha, Drake, Glen Innes to Inverell Road, \&c., \&c. Broadly it selects the high rocky table-lands of New England, especially the eastern edge (if rocky and poor soil like granite), and also the large mesas which extend easterly of the mesas proper, as, for example, that large block of high land 50 miles in length between the Rocky (Timbarra) and Clarence Rivers." - (E. C. Andrews.) 
Mr. Andrews has found it at the head of the Manning River.

Stanthorpe, Queensland (A. Murphy). Mr. J. L. Boorman afterwards sent it from Stanthorpe under the names " Blackbutt," "Messmate," "Woolly Butt."

The following specimens belong, in my opinion, to $E$. Andrewsi:- The "Peppermint" of Maiden's Dorrigo Report (Agric. Gaz., N.S.W., 1894, p. 6]2) ; summit of Mt. Seaview and adjacent mountains (Agric. Gaz., 1898, p.585); Tenterfield District; "White Limb" of Glen Innes (Dist. Forester Stopford) ; " Yeppermint," Cobark, on high ground (A. Rudder); Upper Williams River (A. Rudder). " Moore's Reef on top of hill going to the Hole (Upper Barrington River). Tree in general appearance much like E. piperita. Height about 120 feet, diameter about 3 feet, with spreading and irregular smooth upper branches to size man's leg. Soil stony with blackish mould. 11/10/93."-(A. Rudder).

\section{AFFINITIES.}

1. This species in habit, bark, and timber comes close to E.piperita. Its juvenile leaves, buds, and fruits are, however, very different. The fruits are never constricted at the orifice.

2. It is also closely allied to $E$. dives, but it has not the characteristic stemclasping juvenile foliage of the latter, from which it differs in other respects, e.g., in the flat-topped and even sunk fruits, the slender pedicels with the more clavate slender buds and the more tapering bases of the fruit. Its foliage is also much less aromatic than that of $E$. dires.

3. E. regnans, F.v.ir.

The Cobark and Upper Williams River specimens were referred by Deane and Maiden (Proc. Linn. Soc. N.S.W., xxvi, 123, 1901) to E. fastigata (pyriform series). Lndoubtedly $E$. Andrewsi shows some affinity to E. regnans, F.v.M. (which includes E. fustigata).

4. E. Sieberiana, F.v.M.

The affinity of these two species is indicated by the fact that before E. Andrewsi was recognised as a distinct species it was looked upon as a variety of $E$. Sieberiana. The fruits are smaller and the bark more fibrous than those of the typical trees of E. Sieberiana.

5. E. hamastoma, Sm.

Undoubtedly the fruits, particularly when red-rimmed, resemble those of $E$. hemastoma a good deal. The mature foliage also is not dissimilar. E. hremastoma is, however, a "White Gum," with a totally different timber.

The fact is that specimens of $E$. Andrewsi have long been known, but they have, from time to time, been referred to other species, thus indicating affinities more or less strong. 


\section{DESCRIPTION.}

\section{E. diversifolia, Bonpland.}

\section{Following is the description taken from Bonpland's rare work :-}

Eucalyptus diversifotia.-Eucalyptus: foliis glaucis, falcato-lanceolatis, apice mucronatis, ad basim aequaliter angustatis : umbellis axillaribus : operculo conico mutico: capsula turbinata, operculo cruciformi clausa.

Habitat in Nova Hollandia.

Arbre toujours vert, de vingt pieds ( 7 mètres) de hauteur; trone droit, cylindrique, de quatre à cinq pouces (12 centimètres) de diamètre, recouvert d'une écorce grisâtre presque lisse.

Rameaux alternes, ouverts, un peu tortueux, cylindriques.

Feuilles alternes, glauques, persistantes, de forme et de longueur différentes, longues de deux à quatre pouces ( 15 à 16 centimètres) sur cinq à huit lignes (10 à 18 millimètres) de largeur ; droites ou courbées en faucille, légèrement coriaces, ponctuées, comme charnues et rougeâtres sur les bords, aiguës à la base, terminées au sommet par une pointe molle plus ou moins alongée. Dans les jeunes pieds, les feuilles inférieures sont opposées, sessiles, ovales, lanceolées, ou oblongues.

Pétioles longs de six lignes (12 millimètres), rougeâtres, garnis de petits tubercules, sillonnés en-dedans, convexes en-dehors.

Fleurs d'un blanc pur, disposées en ombelle, et situées dans les aisselles des feuilles.

Pédicelle droit, beacoup plus court que les feuilles, portant ordinairement six ou neuf fleurs presque sessiles.

Calica supère, demi-sphérique, persistant, fermé par une coiffe en forme de cône, qui tombe lors du développement des étamines.

Corolle: il n'y en a pas.

Etamines nombreuses, insérées au bord intérieur du calice: filets blanc, droits, plus longs que le calice: anthères biloculaires, ovales, fixées par le milieu : poussière jaune.

Pistil: ovaire infère : style droit plus court que les étamines: stigmate aigu.

Fruit: capsule turbinée, entièrement recouverte par le calice devenu très-épais : fermée, par un opercule en forme de croix, composé de quatre ou huit pièces fortement unies ensemble : divisée jusque vers son milieu en quatre valves, et intérieurement en quatre loges.

Graines nombreuses, très-dures, de formes différentes, attachées à un réceptacle commun placé au centre de la capsule.

\section{Observations.}

Le genre Eucalyptus a été établi par l'Héritier, et le caractère générique donné par cet auteur a été adopté par tous les botanistes. L'examen que j'ai fait de l'Eucalyptus diversifolia, qui est la seule espèce que j'aie vue en fleur, me porte à croire que le caractère de ce genre doit être réformé. Il faut espérer que M. Robert Brown, qui a vu un grand nombre d'espèces vivantes, fera ce travail dans le second volume de son Flora Novae Hollandiae, que tous les botanistes attendent avec impatience.

Nours connoissons à peu près vingt-quatre espèces d’Eucalyptus, déscrites dans les divers auteurs; mais il en existe un bien plus grand nombre, soit dans nos jardins, soit dans nos herbiers. L'herbier seul du Muséum en possède plus de quinze espèces nouvelles.

L' Eucalyptus diversifolia est dû à l'expédition du capitaine Baudin, qui en a apporté les graines de la Nouvelle-Hollande. Il est curieux d'observer que les naturalistes qui composoient cette expédition n'ont pas apporté cette plante dans leurs herbiers, et que la majeure partie des espèces de ce genre que nous cultivons, sont nouvelles, et ne se trouvent même pas dans les herbiers.

Ce qui ne porte à croire que le caractère générique des Eucalyptus doit être réformé, c'est que sur celui que je viens de décrire, la capsule est fermée par un opercule cruciforme, composé de quatre ou huit pièces étroitement soudées. Cet opercule tombe à l'epoque de la maturité des graines, et indique le temps précis de leur récolte. Il est probable que cette partie dont aucun botaniste n'a parlé, existe dans plusieurs autres espèces du même genre. 
Les feuilles dans les jeunes plantes de cet Eucalyptus, de même que dans plusieurs autres espèces du même genre qui se cultivrnt à Malmaison, sont opposées, et affectent une forme entièrement différente de celle des mêmes individus plus arancés dans leur végétation.

Les Eucalyptus offrent une nouvelle richesse au midi de l'Empire. M. Martin, savant estimable, directeur du jardin botanique de Toulon, a mis depuis plusieurs années, en pleine terre, un petit pied d'Eucalyptus qu'il avoit reçu de Malmaison. Cette plante, que j'ai vue dans l'été de 1813, avoit acquis plus de vingt pieds de hauteur, et étoit, pour la première fois, couverte de fruits bien nourris. Cette seule expérience prouve que les Eucalyptus pelivent croître avec l'olivier, les grenadiers, les citroniers, et d'autres arbres utiles de nos provinces méridionales.

L'Eucalyptus cultivé par M. Martin nous paroît être le même que l'Euchlyptus dícersifolia. Les petites différences que j'observe entre l'échantillon de cette plante, que j'ai cueilli à Toulon, et les pieds que je cultive à Malmaison, semblent être produites par le changement de culture ou par le climate. (Descr. Pl. Jarl. Mulmaison, 35, 1813.) See also DC. Prod. iii, 220; "Mém sur les Eucalyptus introduits dans la réuion Méditerranéenne," par. C. Naudin (trnales des Scinnces Noturelles, 6e Série Bot., t. xvi (No. 6), p. 413 (1883); "Description et emplıi des Eucalyptus introduits en Europe, principalement en France et en Algérï." C. Naudin. Antibes 1891, p. 50.

It is described by Bentham (B.Fl. iii, 206), and I proceed to amplify his description :-

Usually a tall, Mallee-like shrub, with smooth, ribbony bark, but stated to occasionally attain tree size.

L.enves. - Oblong or lancenlate, acute or acuminate, mostly under 3 inches and often nearly straight, very thick and rigid, scarcely showing the oblique veins.

Peduncles.-Axillary or lateral, short, terete or angular, each bearing 3 to 8 rather large flowers on very short pedicels.

Calyx-tube.-Short and open, above 2 lines diameter.

Operculum.--Conical, somerimes quire rostrate.

Stamens.-At least 3 lines long; anthrs renifurm, with diverging confluent cells (see below).

Fruit.-The fruit displays great variation in size, shape, and sculp ure. It is often warted. It is subcylindrical or conoid to wearly globular, from scarcely more than $\frac{1}{4}$-inch $t, \frac{5}{8}$-inch in diameter. The fruit som-times, but not always, contracted at the orifice, the rim broad, usually convex (sometimes horizontal) and always prominent, the valves sunk or slightly protruding.

The prominence of the rim varies a good deal, that of Drummond's No 64 (Benthain's E. pachylomn) being quite domed. A specimen from Stirling Range. West Australia, has an even broader rim, even broader than the calyx, the fruit being markedly globular. Tue rim often has a well-marked gruove, sometimes two.

It is again described (as $E$. santalifulia) and also figured by Mueller in "Eucalyptographia." In this work he states that:-

The cardinal charactcristic of $E$. santalifolia rests in the position of the stamens before their expansion; then through a simple turn the lower portion of the filuments remains drcumbrnt, whereas the upper part becomes erect, but in no way the filament; are reduplicated. Such peculiar eurvature of the stamens, while in bud, is not known to exist in any other species of Eucalyptus, although an approach to such a staminal astivation is offered by $E$. Planchoniana. All other species, in which the stamens are not distinctly doubled lack in their early state, namely $E$. gomphocephala, $E$. Oldfieldii, E. sidurophloia, $E$. treticurnis, $E$. salmonophloin, as well as $E$. cornura and its allies, have the filaments in bud either straight or turned differently to those of $E$. santalifulia.

The section of the bud at Fig. 2 of the illustration is somewhat diagrammatic, but it essentially represents the position of the stamens before expansion in fresh Victorian specimens, for example. I am not in a position, without further investigation, to say whether this arrangement of the unexpanded stamens is "the cardinal characteristic" of the species, which would involve examination of an enormous amount of material. 


\section{SYNONYMS.}

1. E. santalifolia, F.v.M.

2. E. dumosa, Benth. non A. Cunn.

3. E. cneorifolia, DC. (partim) (?).

4. E. connata, Dum.-Cours.

5. E. santalifolia, F.v.M., var. firma, Miq.

6. E. firma, F.v.M. herb. ex Miq.

7. E. cuspidata, Tausch.

8. E. viminalis, Labill., var. diversifolia, Benth.

9. E. pachyloma, Benth.

\section{NOTES ON THE SYNONYMS.}

\section{E. santalifolia, F.v.M.}

Following is the original description :-

Fruticose ; leaves alternate, coriaceous, glaucescent, opaque, oblong-lancenlate, hooked-acuminate, a little oblique, thinly veined, hardly rotted; umbels axillary and terminal, pedunculate, e pitate; lid depressed-conical or heinispherical; tube of the calyx obconical, bell shaped, nearly three times longer than the lid; fruit not contracted at the top; valves of the capsule enclosed. i, 35, 1555.)

In th: Mallee scrub on the Murray River, on St. Vineənt's and Spencer's Gulfs.—(Trans. Vict. Inst.,

Then comes Miquel's description of Mueller's specimens in the following year :-

21. Eucalyptus santalifulia, Ferd. Müll. : subarborescens, ramulis angulatis junioribus viridulis, foliis anguste lanceolatis acumine recurvo terminaris crasse coriaceis glaucis, venis erectopatulis numerosis fere obte tis, yedunculis axillaribus 3-5 floris, floribus sessilibus, calycis tubo ovoideo-obconico, operculo brevi hemisphaerico subapiculato, antheris subglobosis.

Tanuario et Febr. florens. Crescit trans rivum Salts-creek (Dr. Behr.). Marble-range, Port Lincoln.-(F. Müll.). Miq. in Ned. Kruidk. Arck., iv, 133, 1856.

\section{E. dumosa, Benth. non. A. Cunn.}

According to Bentham (B.Fl. iii, 230), Miquel's plant is E. dumosa, A. Cunn.: but Mueller ("Eucalyptographia") is not of that opinion.

Bentham further states :-

"The large fruited specimens, originally sent by F. Mueller and described by Miquel as E. santalifulia, belong to a distinct species of the Renantheræ, for which I have retained the name,"(B.Fl. iii, 217, under $E$. cneorifolia.) 
I am not able to reconcile Bentham's two statements. Perhaps, as regards one of the plants referred to by him, he is referring to plants of the incrassato series (e.g., var. conglobata, see p. 100, Part IV) which grow in the same localities as $E$. diversifolia and, in the absence of fruits, are sometimes not very dissimilar to $E$. diversifolia. Under $E$. dumosa Bentham does not quote the particular specimens seen by Miquel, and Bentham's observations can only be cleared up by reference to his specimens.

3. E. cneorifolia, DC. (partim) (?)

(E. santalifolia, F.v.M., in Trans. Vict. Inst., 35, partly, according to Benthar, B.Fl. iii, 217.) This requires to be cleared up. Alluded to under (2).

4. E. connata, Dum.-Cours (Bot. Cult. Ed.ii, vii, 280). See DC. Prod. iii, 220.

5. E. santalifolia, var. firma, Benth. non. Miq. in Ned. Kruidk. Arch., iv, 133, according to Bentham (B.Fl. iii, 206).

From Miquel's description, which follows, it will be seen that he did not name the variety, an authentic specimen of which I have not seen.

Following are Miquel's words :-

Forma venis magis distinctis subadscendentibus. E. firma, Herb. Müll., Nova Holl., austr.

Frutex fere arboreus E. strictae cognatus, teste cl. Müller in Herb. Behr. E sessiliflorae nomine obvia. Folia $2 \frac{1}{2}$-vix 3 poll. longa, $3-4$ lin. lata. Pedunculi 1-3 lin. longi. Capsula 4-locularis (Miq. in Ned. Kruidk. Arch.iv, 133, 1856, under E. santalifolin, F.v.M.).

6. E. firma, F.v.M., herb. ex. Miq., as quoted under (5).

7. E. cuspidata, Tausch.

Herb. Bauer. Ferd. Bauer, in Herb. Vindob. is Euc. diversifolia, Bonpl., and was probably obtained from Kangaroo Island or mainland of South Australia.

8. E. viminalis, Labill., var. diversifolia, Benth. (B.Fl. iii, 240).

Bentham says :-

E. viminalis varies very much in the size and number of flowers, and the shape of the operculum. In the original Tasmanian form, common also in Victoria, the peduncles are mostly 3-flowered, although occasionally many-flowered specimens occur. In the South Australian E. diversifolia the flowers are rather numerous in the umbel, and the fruit large. fruit.

I have seen Bentham's specimens, which are E. diversifolia, in immature

\section{E. pachyloma, Benth.}

A shrub of 5 feet (Maxwell).

Leaves.-Mostly lanceolate or linear-lanceolate, acuminate, under 3 inches long, thick and rigid, the very oblique veins scarcely conspicuous, the intramarginal one at a distance from the edge.

Peduncles.-Axillary or lateral, short and thick, terete or slightly angular, each with two to four rather large flowers.

Calyx-tube.-Broadly turbinate or almost hemispherical, about 4 lines diameter, smooth and tapering into the very short, thick pedicel. 
Stamens.-Pa e-coloured, $\frac{1}{2}$ inch long or more, slender and inflected in the bud; anthers ovate, with distinct parallel cells.

Disc.-Concare.

Fruit.-Sessile, depressed-globose, 7 to 8 lines diameter, with the very thick, broad, convex and raised rim of $E$. Oldfieldii, but without any depressed centre, the capsule not sunk, and the small valres protruding as in $E$. rostrata

W. Australia, Drummond, 4th, Coll. No. 64; sand plains, Kalgan River, ollfield; valleys of the Stirling Range, Maxioll. (B.Fl, iii, 237.)

E. santalifolia, F.v.M., var. (?) Baxteri, Benth. (B.Fl. iii, 207). (E. Baxtevi, R.Br., Herb.), is E. capitellata, Sm., and will be dealt with in the next Part.

\section{RANGE.}

Bonpland states that the seed of his species came from Captain Baudin's Expedition, "qui en a apporté les graines de la Nouvelle-Hollande." Bentham says the seed came from Kangaroo Island. Besides this South Australian locality (it is also found on the mainland of South Australia), it also occurs in Western Australia, and recently I have recorded it from Victoria also.* It is both a coastal and a desert species; indeed, in South and Western Australia the desert flora comes to the coast. The type of E. santalifolia came from the Mallee scrub on the Murray River.

Mueller gives the following localities:-_" In sandy desert country, as also in scrubby valleys or on arid ridges near King George's Sound (Drummond); on the Williams River (Webb); near the Kalgan River (Oldfield); at the base of the Stirling Ranges (F.v.M.) ; at Venus Bay (Clode) ; in various localities near Spencer's Gulf (Wilhelmi); in the vicinity of Lake Albert (Irvine); on Kangaroo Island (Waterhouse) . . . Prof. Ralph Tate noticed that $E$. santalifolia, together with . . . E. cneorifolia, DC., constitutes the predominant serubs of Kangaroo Island, that the bark is smooth and separates in long and thin shreds, that the species is found chiefly on ancient shell-beaches with fresh water below, and that it does not attain a height above 20 feet." - ("Eucaly ptographia," under E. santalifolia.)

\section{South Australia.}

Following are some Kangaroo Island specimens in the National Herbarium, Sydney :-

1. "Eucalyptus, South Coast, Bays 9, 10," in R. Brown's handwriting. Coll. 1802-5. No. 4,743 of J. J. Bennett's distribution from the British Museum, 1876, labelled "E. obliqua (?)."

\footnotetext{
- Vict. Nat., xxi, 116 (1904).
} 

Coast."

2. No. 4,744 (of J.J. Bennett). Collected by R. Brown, 1802-5, "South

Both specimens with not perfectly ripe fruit.

3. A specimen from Herb. Paris, the original of which, with contemporary handwriting, "Envoyé à M. Brown, N. Holl. Côté Occidentale, " Ile des Kanguroos."

4. Waterhouse.

5. Tate.

Also from Guichen Bay (? collector), labelled $E$. viminalis, var. diversifolia, by Bentham.

"With a fruiting specimen, obtained from Guichen Bay, and to all appearance belonging to $E$. santalifulia, a note is given that there the tree rises to 60 feet, such tallness being probably of exceptional occurrence."-( "Eucalyptographia," under E. santalifolia.) Mueller does not give the name of the collector, and the size of the species is worthy of further investigation.

Port Lincoln (W. Gill).

A white Mallee, 90-Mile Desert, S.A. (R. H. Cambage), with sub-cylindrical flat-topped fruits, smaller than the Victorian ones. "A glaucous Mallee up to 12 feet high. Smooth gum bark with ribbons." same locality (R. H. Cambage). With smaller fruits than usual. Rim somewhat domed.

\section{VICTORIA.}

Cape Nelson, near Portland, "restricted to a small area. Flourishing on the old sand-dunes where they occur about one mile from the coast, and have sole possession of the area where they occur, though E. obliqua, E. amygdalina, and $E$. viminalis occur in places a little further inland, and also along the coast." (A. E. Kitson in litt.) These specimens have the largest fruits ( $\frac{5}{8}$ inch in diameter) I have seen in this species.

\section{Western Australia.}

Drummond's No. 64; Stirling Range (Mueller); west from Yetemerup, $\mathbf{N}$. side of Stirling Range (A. Morrison), with fruits not much larger than thos of Mr. Cambage; King George's Sound (? Webb).

- This label is interesting because of the use of the words "Côté Occidentale" in this way. Strictly speaking, Côté Occidentale begins at Cape Leenwin, but I have been more than once perplexed with the use of the term in old labels when there is strong reason to suppose that the specimens were obtained from Kangaroo Island, or from the coast of South Australia, or from the coast of West Australia east of the Leeuwin. 


\section{AFFINITIES.}

1. E. capitellata, Sm., and E. macrorrhyneha, F.v.M.

In "Eucalyptographia" (under E. santclifolia) Mueller has drawn attention to the resemblance of the fruits of $E$. santalifolia (diversifolia) to the species named. The resemblance is there, more particularly between the fruits with the dome-shape and those of $E$. macrorrhyncha. Mueller also deals at greater length with the relations to E. capitellata. I propose to deal with these affinities when treating of E. capitellata and E. macrorrhyncha.

\section{E. Planchoniana, F.r.M.}

The buds and coarse fruits of this species somewhat resemble those of the large fruited (Victorian) form of $E$. diversifolia, but the valves of $E$. Planchoniana are more sunk, and the leaves usually thinner and larger.

3. E. coccifera, Hook., f.

The foliage and the immature fruits of the two species resemble each other somewhat.

4. E. strieta, Sieb.

Miquel, in drawing attention to the affinity of the form (var.? firma, see p. 200) of $E$. santalifolia to $E$. stricta, indicates the affinity of the two species. Certainly the leaves are remarkably similar," but the buds of E. stricta are more clavate, and the fruits smaller and more constricted at the orifice.

\section{E. obliqua, L'Hérit.}

A. "S. A., Hills, near Guichen Bay, Marble Range and Venus Bay, F. Mueller," -(Herb. F. Mueller and Herb. Sonder.) "This is now reduced by F. Mueller to a form of obliqua."-(Bentham, B.Fl. iii, 206, under E. santalifolia.)

B. Specimens labelled "Eucalyptus fabrorum, Schldt., Port Lincoln scrub, legit Carl Wilhemi, exam. Dr. Ferd. Mueller," in Herb. Vindob, are E. diversifolia, Bonpl.

Different specimens attributed to E. fabrorum, Schlecht., seen by me, are referable to E. obliqua, L'Hérit. (see p. 60, Part II), and also to E. pilularis, Sm., var. Muelleriana, Maiden (see p. 4.0, Part I), and, perhaps, even to the Victorian and South Australian form of $E$. capitellata, Sm. More field work requires to be done in South Australia and western Victoria to define the relations between $E$. diversifolia, Bonpl., and the other species named, 


\title{
Explanation of Plates.
}

\author{
PLATE 33. \\ E. regnans, F.v.M.
}

1. Leaves with flowers; $1 a$, leaf with fruits ( 1 and $1 a$ from the same twig); $1 b$, buds ; $1 c$, fruits of type, from the Dandenong, Victoria (D. Boyle). Note that the fruits on la are immature and resemble those of $E$. amygdatina a good deal.

NoтE.-It was for some time considered that $E$. regnans was confined to Victoria, and E. fastigata to New South Wales.

2. Seedling of $E$. regnans, from Mirboo North, Victoria (A. W. Howitt). I have a seedling of the same size of $E$. fastigata from Tantawanglo Mountain, New South Wales (H. Deane and J.H.M.), which is a fac-simile of this. I cannot, indeed, tell them apart. $2 \alpha$, juvenile leaf Mirboo North (A. W. Howitt).

3. Leaves in intermediate stage of "Cut-tail," $E$. fastigata, Tantawanglo Mountain (H. Deane and J.H.M.).

4. Fruits, old and nearly Hat-topped. Blacks'Spur, Victoria (H. Deane).

5. Fruits, not domed. Walhalla, Vic. (A. W. Howitt). Note that these fruits, in everything but size, resemble those of $E$. numerosa, Maiden. The Walhalla fruit precisely match those of some specimens received from Tasmania (L. Rodway).

(i. Leaf; $6 a$, fruits (nearly flat-topped) of $E$. fastigata. Nimbo Station, New South Wales, No. 430 (H. Deane).

7. Leaf of large size. Sunny Corner, New South Wales (J. L. Boorman).

8. Unusually small fruits. West Albion Park, New South Wales (R. H. Cambage).

9. Fruits. Mittagong, New South Wales (H. Deane).

10. Leaf; $10 a$, fruits. Mt. Wellington, Tasmania (L. Rodway and H. E. Day).

[The twig with pear-shaped fruits, to the left of the plate of E. amygdalina ("Eucalyptographia"), represents $E$. regnans. The fruits are scarcely ripe.]

\section{PLA'TE 34. \\ E. vitrea, R, T. Baker.}

1. Pair of juvenile leaves; $1 a$, leaf in the intermediate stage; $1 b$, mature leaf; $1 c$, buds; $1 d$, fruits. Wingello, New South Wales (J. H. Maiden and J. L. Boorman). They are precisely similar to type specimens from Sutton Forest, a few miles away (R. T. Baker).

2. Leaves and buds showing two umbrls (this is common enough in $\boldsymbol{E}$. regnans); $2 a$, fruits, from another tree at Wingello. This tree often grows on low-lying rather sour land, or on land liable to floods.

3. Leaves; $3 a$, buds; $3 b$, fruits. Following is the Collector's note:-No. 452. "The bark of this tree resembles that of $E$. amygdalina, the branches being much whiter, while the leaves and capsules are much the same as those of E. fastigata." Jenolan Caves (W. F. Blakeley).

The foliage is pale-coloured and shiny, and most of it is very narrow, thick, with venation faintly visible on one side of the leaf. The fruits are not perfectly ripe, and hence the rim exhibits a sunken appearance in some of the specimens. (Compare Pl. 35, fig. 5b.)

1. Intermediate leaf; $4 a$, buds and mature leaf; $4 b$, fruits. Delegate River (W. Baeuerlen). Shows transit to $E$. regnans.

5. Leaf; $5 a$, buds: $5 b$, fruits. Upper Yarra, Victoria(C. Walter). Another remarkable form intermediate between $E$. vitrea and $E$.regnans. In 4 and 5 we have the broad-leaved or regnans character. Some botanists, with reason, look upon this as a form of $E$. eugenioides, Sieb : and I will deal with this view in the next Part. 


\section{PLATE 3\%.}

E. dives, Schauer.

1. Jurenile leaves. Cockatoo, near Germanton, New South Wales (W. Forsyth).

2. Flowering twig; $2 a$, buds; $2 b$, fruits. "Messmate." Head of Tarcutta Creek, 8 miles from Tumherumba, New South Wales (Forest Ranger Mecham).

3. Fruits. Tareutta (W. Forsyth).

4. Fruits, showing slightly exserted valves, Queanbeyan (H. Deane).

$$
\text { E. vitellina, Naudin. }
$$

๖. Flowering twig; $5 a$, anthers; $5 b$, leaves and immature fruit; $5 c$, leaf. All of $\boldsymbol{E}$. vitellina, Naudin. Jardin Nabonnand au Golfe Juan, Southern France,

\section{PLATE 36.}

E. Andrewsi, Maiden.

1. Pair of jurenile leaves. Tingha, New South Wales (R. H. Cambage).

2. Large coarse leaf in the intermediate stage (i.e., between the juvenile and mature stages), Drake, New South Wales (E. C. Andrews).

3. Buds; 3a, flowering specimen of the "Blackbutt" or "Peppermint" of New England (E. C. Andrews); $3 b$, anthers from the same specimen.

4. Fruits. Tingha (R. H. Cambage).

\section{E. diversifolia, Bonpland.}

5. Pair of juvenile leaves copied from Bessa's drawing in Bonpland's "Description des plantes rares à Malmaison," t. 13 (copied by Miss M. Smith, Kew).

6. Leaf; $6 a$, two clusters of buds; $6 b$, anthers; $6 c$, immature fruits ; $6 d$, ripe fruits, from Portland Bay Victoria (Mr. Adams, through A. E. Kitson).

7. Leaf; $7 a$ and $7 b$, fruits, from Kangaroo Island, South Australia (R. Tate).

8 , and $8 a$, two pairs of juvenile leaves; $8 b$, twig with fruits; $8 c$, fruit, from Port Lincoln, South Australia (W. Gill).

9. Twig with fruit; $9 a$, a second twig with fruit; $9 b$, a fruit; all of Drummond's Western Australian 4th Collection No. 64, the type of E. pachyloma, Benth.

10. Leaf; $10 a$, pair of fruits; $10 b$, fruit of "E. pachyloma, Benth." from Stirling Range, Western Australia

11. Leaf and fruits from west of Yetemerup, north side of Stirling Range (A. Morrison). 



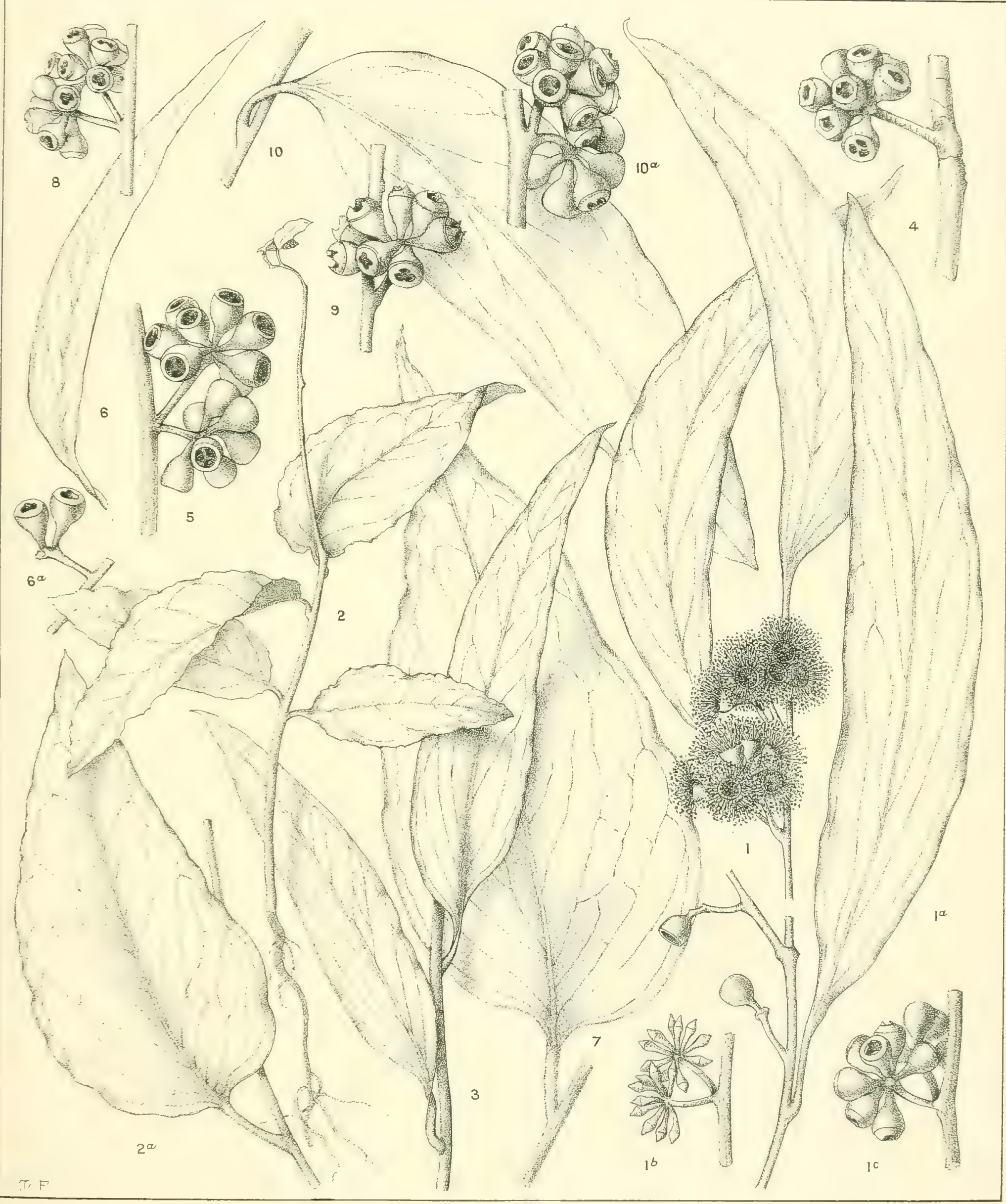

EUCALYPTUS REGNANS, F.v.M.

(which includes E. fastigata, Deane and Maiden). 



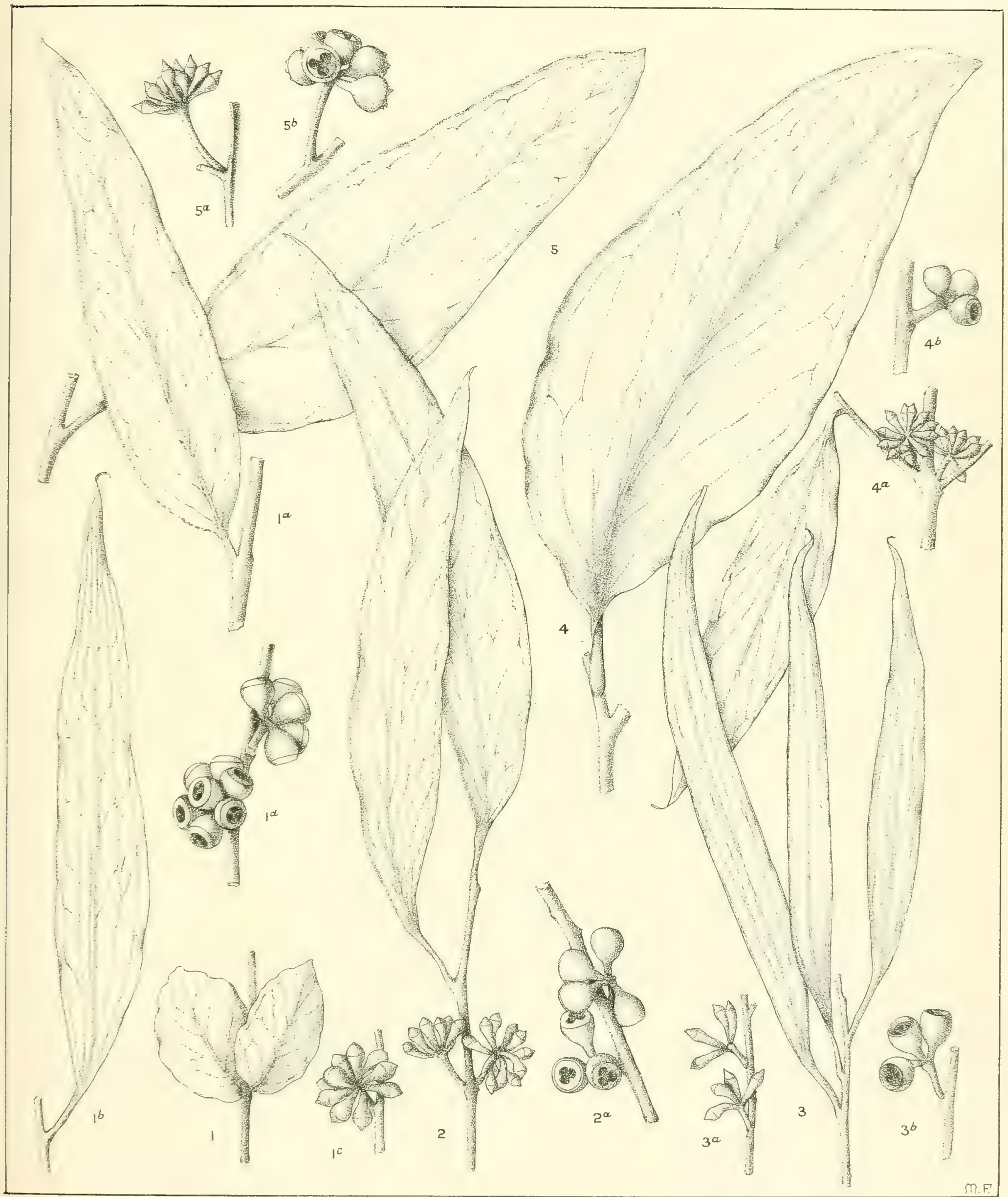

EUCALYPTUS VITREA, R. T. Baker (1-2).

3, an aberrant form; 4-5, forms intermediate between $E$. vitrea, R. T. Baker, and E. regnans, F.v.M. 



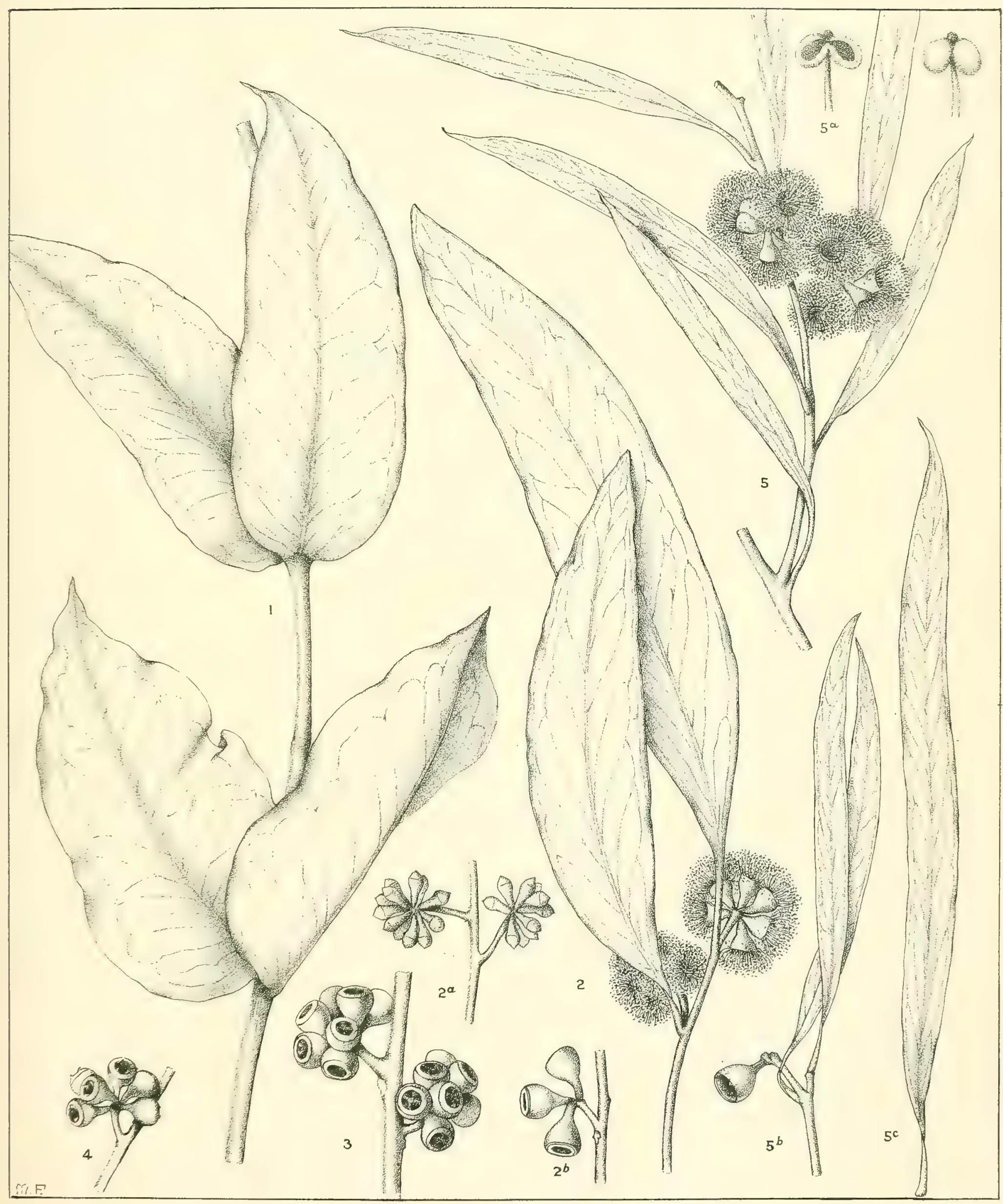

EUCALYPTUS DIVES, Schauer (1-4).

E. VITELLINA, Naudin (5). 



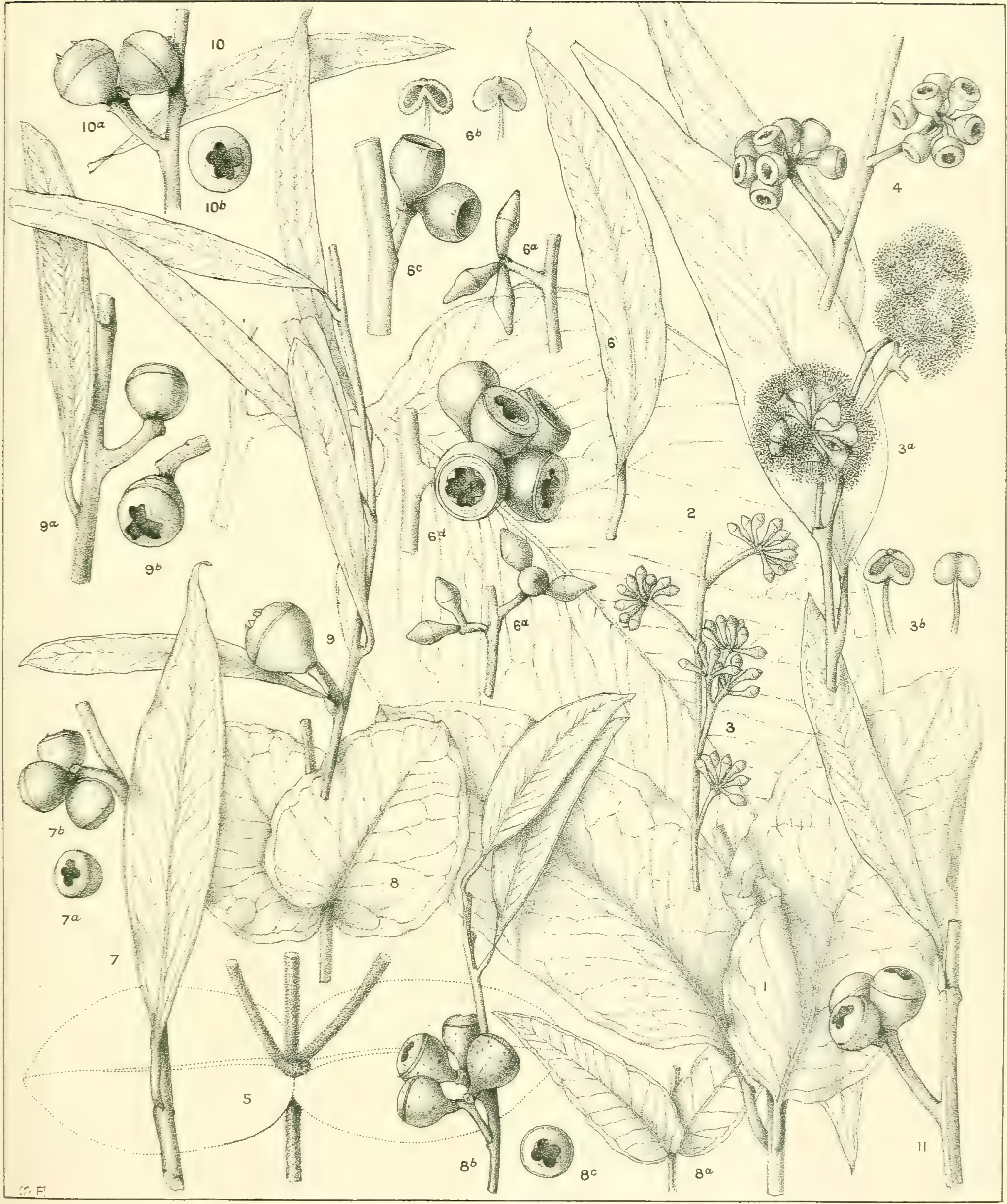

EUCALYPTUS ANDREWSI, Maiden (1-4);

E. DIVERSIFOLIA, Bonpland (5-11). 



\section{A CRITICAL REVISION OF THE GENUS EUCALYPTUS}

BY

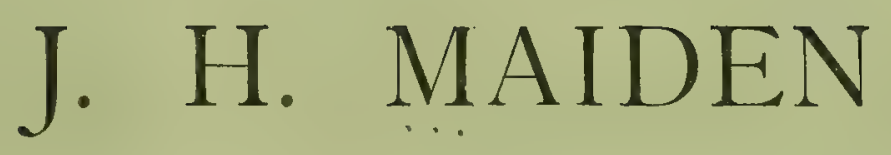

(Government Botanist of New South Wales and Director of the Botanic Gardens, Sydney).

\section{PART VIII}

(WITH FOUR PLATES)

Price Two Shillings and Sixpence.

Pubiished by Authority of

THE GOVERNMENT OF THE STATE OF NEW SOUTH WALES.

Znounte :

WILLIAM APPLEGATE GULLICK, GOVERNMENT PRINTER.

1907. 



\title{
A Critical Revision of the genus Eucalyptus
}

BY

\author{
J. H. MAIDEN
}

(Government Botanist of New South Wales and Director of the Botanic Gardens, Sydney).

\section{PART VIII}

(IVITH FOUR PLATES).

"Ages are spent in collecting materials, ages more in separating and combining them. Even when a system has been formed, there is still something to add, to alter, or to reject. Every generation enjoys the use of a vast hoard bequeathed to it by antiquity, and transmits that hoard, augmented by fresh acquisitions, to future ages. In these pursuits, therefore, the first speculators lie under great disadvantages, and, even when they fail, are entitled to praise."

Macaulay's "Egsay on Milton."

PRICE TWO SHILLINGS AND SIXPENCE.

Pullished by Authority of

THE GOVERNMENT OF THE STATE OF NEW SOUTH WALES.

Surneg:

William APPlegate Gullick, Government PRinter, Phillip-STreet.

$\begin{array}{lll}* & 190881 \text { A } & 1907 .\end{array}$ 
17.

EUCALYPTUS CAPITELLATA

(Smith).

18.

EUCALYPTUS MUELLERIANA

(Howitt).

19.

EUCALYPTUS MACRORRHYNCHA

(F. v. Mueller).

20.

EUCALYPTUS EUGENIOIDES

(Sieber).

21.

EUCALYPTUS MARGINATA

(Smith).

\title{
22.
}

EUCALYPTUS BUPRESTIUM (F. v. Mueller).

\author{
23. \\ EUCALYPTUS SEPULCRALIS \\ (F. v. Mueller).
}


XVII. Eucalyptus capitellata, Sm. P rac..

Description . . . . . . . . 21 I

Synonyms . . . . . . . . . . 212

Range. . . . . . . . . . . . 2 It

Affinities . . . . . . . . 218

XVIII. Eucalyptus Muelleriana, Howitt.

Variation in this and other Stringybarks . . . 2 ig

Affinities (E. Wilkinsoniana, R. T. Baker, and E. nigra, R. T.

Baker, are here considered)

XIX. Eucalyptus maerorrhyneha, F. v. Mueller.

Description . . . . . . . . 225

Synonyms . . . . . . . . . . . . 26

Range. . . . . . . . . . . . 227

Affinities . . . . . . . . . . . 230

XX. Eucalyptus eugenioides, Sieber.

Description

Synonyms. . . . . . . . . . . 233

Range. . . . . . . . . . . . 235

Affinities . . . . . . . . . . 239

XXI. Eucalyptus marginata, Smith.

Synonyms.

XXII. Eucalyptus buprestium, F. v. Mueller. $\quad 243$

XXIII. Eucalyptus sepuleralis, F. v. Mueller.

$24+$

The limitations of morphology, and record of oil constituents considered in regard to the determination of species of Eucalyptus . . . . . . $24 t$

IExplanation of plates 


\section{PRELIMINARY NOTE.}

ThIs Part mainly deals with the Stringybarks, which are recognised by every systematic botanist as being specially difficult. They afford an admirable instance of the protean character of Eucalyptus. No character in this group, at least, be it juvenile or mature leaves, flowers, fruit, bark, timber, can be relied upon as absolute. One must adhere to the type as closely as possible, and, as regards aberrant forms, indicate their affinities.

I do not wish to repeat myself at this place, and would refer my readers to my remarks on individual specimens in regard to aberrant forms. Eucalyptus trees vary according to the geological formations on which they are grown, and to the climate, apart from their innate tendency to vary. Then hybridisation plays an important part, though largely unrecognised by botanists even yet. I have dealt with these aspects of the subject at some length at p. 243 . 


\title{
DESCRIPTION.
}

\author{
E. capitellata, Sm.
}

E. capitellata, Sm., was described by J. E. Smith, not quite satisfactorily (as was also the case with so many of the early species of this difficult genus), in White's Toyage to N. S. Wales, 216 (1790).

Then we have :-

Eucalyptus capitellata, opereulo conico calyceque anguloso subancipiti, capitulis lateralibus pedunculatis solitariis.

Lid conical, and, as well as the calyx, angular, and somewhat two-edged. Heads of flower's lateral, solitary, on flower stalks.

The leaves are ovate-lanceolate, firm, astringent, but not very aromatic. We have seen no other species in which the flowers stand in little dense heads, each flower not being pedicellated so as to form an umbel. The lid is about as long as the calyx. Flower-stalk compressed, always solitary and simple.

The fruit of this species, standing on part of a branch whose leaves are fallen off, is figured in Mr. White's "Voyage," p. 226, along with the leaves of the next species (E. piperito, Sm., J.H.M.).-("A Specimen of the Botany of New Holland," p. 42, 1793).*

The description was made from plants procured in the neighbourhood of Sydney, and White's figure of the fruits of E. capitellate is sufficiently good to prevent it being confused with those of any other species. Smith again described it in Trans. Linn. Soc. iii, 285 (1797). See also Wendl. Coll. 36; it is described more fully by Bentham, B.Fl. iii, 206, also by Mueller (Eucalyptographia).

There is no doubt that the type is that form of E. capitellata, Sm., which grows close to the shores of Port Jackson and its estuaries, and the rivers immediately north and south of Port Jackson. See figs. 1-6, pl. 37.

It may be described in the following words :-

A tree of medium size, often, in exposed situations, e.g., near the coast, dwarfed and gnarled.

Bark.- Often very thick and fibrous, a typical Stringybark, the rough bark sometimes extending to all but the smallest branches. Sometimes the trees have a thinner, more sub-fibrous bark, with the upper portion of the trunk and limbs smooth. Notes on the bark will be given when speaking of particular specimens.

Timber.-Brown when fresh, drying to a paler colour. A good timber for splitting and hence much used for posts, rails, buildings (formerly for shingles), and fuel. It is tough, strong, and durable.

Vernacular Names.-As a very general rule this tree is known merely as Stringybark. "Red Stringybark" is a name sometimes applied to this species in this State, in allusion to the darker colour of the wood as compared with that of $E$. eugenioides. It also goes under the name of "Broad-leaved Stringybark." It is the "Mountain Stringybark" of Victoria (A. W. Howitt). J. E. Smith, op. cit. called it (following White) "Brown Gum-tree." Messrs. Baker and Smith have suggested the name "Brown Stringybark" for this species.

Aboriginal Names.- "Yangoora" is a name given to E. capitellata and E. macrorrhyncha indiscrininately by the Gippsland aborigines, according to Howitt. The late Sir William Macarthur informed me that "Dthah-D thaang" was the name given to E. capitellata by the blacks of the Illawarra district, and "Ngneureung" by those of the Brisbane Water district, while "Bour-rougne" was the name given by those of the Camden district (perhaps, however, to one of the forms intermediate between E. eugenioides and capitellata).

- The correct date of this work cannot be earlier than 1794, since at p. 36 it takes cognizance of a plant which flowered in April of that year. 
Juvenile Foliage.-For an account of it in its earliest stages, see pages 216 and 217 . In this stage I am unable to separate the leaves from those of undoubted $E$. macrorrlyncha; but when growing in exposed marine situations they take on a form which I now proceed to describe, and which I believe to be quite characteristic of the species.

Thick in texture, nearly orbicular, almost sessile, with a cordate base. Emarginate, or with a slight apex or none; margin sinuate or slightly crenate, besprinkled copiously with stellate hairs on the under side, the twig abundantly so; shining on the upper side.

The intermediate leaves scarcely changed in shape, but very coriaceous, and shining on both sides.

Mature Leaves. - They are very coriaceous, cven when grown at a considerable distance from the sea. The leaves usually larger and coarser than those of two other Stringybarks ( $E$. macrorrhyncha and $\boldsymbol{E}$. eugenioides) ever are, and often very oblique, but not always so. The foliage may be described as "coarse" in its typical form.

Shining; equally green on both sides; venation spreading.

Buds.--The buds and peduncles are generally somewhat thick and angular or flattened, and contrast with the neatness of shape of those of $E$. eugenioides and E. macromprncha.* Commonly found with a double operculum.

Flowers.- The filaments of the anthers sometimes dry dark.

Fruits.-In consequence of the fruits being sessile, or nearly so, and crowded into heads, these assume a polygonal shape at the base, as if they had been pressed together when in a plastic condition. With this exception, the fruits have the form of a very much compressed spheroid, the horizontal diameter of which is from one and a half times to twice the depth. The fruit is swollen out below the rim, which is sometimes very well defined, and of a red or brown coluur. The fruit is sometimes truncate, but more frequently the rim is dome-shaped. There is great variability in the amount of exsertion of the valves. The fruit may be perfectly ripe without exserted valves, but a twig from the same tree may have them exserted.

\section{SYNONYMS.}

1. E. congesta, R.Br.

2. E. capitellata, Sm. var. (?) latifolia, Benth.

3. E. Baxteri, R.Br., and therefore E. santalifolia, F.v.M., var. (?) Baxteri, Benth.

\section{NOTES ON THE SYNONYMS.}

\section{E. congesta, R.Br., Port Jackson, 1804 (R. Brown, Iter Australiense, 1802-5,} distributed by J. J. Bennett, 1876, under No. 4,727). Named and so labelled, "Eucalyptus congesta," by Brown, but I am not aware that the name has been published.

\section{E. capitellata, Sm. var. (?) latifolia, Benth.†}

Leaves short, obliquely ovate, very thick and much more straight, the bark deciduous (Robertson). Fictoria. Heath, near Portland, Robertson. Possibly a sessile-flowered form of E. santalifolia, but the form of the calyx is more that of $E$. capitellata, and quite different from that of $E$. santalifolia, rar. Baxteri.--(B.Fl. iii, 206).

* In B.Fl. iii, 190, Bentham says of L. capitilluta, "operculum very obtuse" ; and of E. macror rhyncha, "acuminato or conical." A specimen of Eucalyptus capitellata from N. Holland, Dr. Smith, ex-herb. Lambert, in Herb. Cant., is interesting as one of the very few specimens of this species known to have passed through Dr. (Sir J. E.) Smith's hands. Strange to say, the only two opercula are pointed, although the specimen undoubtedly belongs to $\mathrm{E}$. capitellata, Sm.

+ See also "Two synonyms of Encalyptus capitellata, Sm." by J. H. Maiden, Journ. Bot., 1906, p. 233. 
The following specimens are in the National Herbarium, Sydney :-

(a) "Heath near Portland Bay, 20th March, 1842 (J. G. Robertson)," twigs bearing fruit.

(b) "Heath, 10 miles west of Roseneath, Glenelg River. Stringybark. Bark not deciduous, timber white, from 10 to 30 feet high, 21st January, 1844" (J. G. Robertson, No. 493) ; twigs bearing buds.

(c) "Heath, Steepbank Rivulet, growing at foot of 498 , and supposed to be young of it, 12th June, 1843 " (J. G. Robertson, No. 500); juvenile foliage.

They are all E. capitellata, Sm., not differing sufficiently from the type to be called a variety. They are very close to the Port Jackson specimens, and certainly not broader leaved.

\section{E. Baxteri, R.Br. (?)}

E. santalifulia, F.T.M., var. (?) Baxteri. Leaves ovate, or ovate-oblong, obtuse, usually very oblique, under 3 in. long, rery thick, with oblique, scarcely conspicuous reins. Penduncles thick and angular, mostly very short. Flowers closely sessile in a dense head. Calyx-tube nearly 3 lines diameter, and shorter than broail. Operculum thick and hemispherical, the buds nearly globular. Ovary flattopped. R. Baxteri, R.Br. Herb. S. Coast, probably Kangaroo Island, Baxter (Herb. R.Br.). The heads of the flowers are very much like those of $E$. dumosa, var. conglobata, but the opereulum, and especially the anthers, are quite different. Fruit not seen.-(B.Fl. iii, 207.)

I wrote to Mr. James Britten, Department of Botany, British Museum, who kindly allowed Miss M. Smith, of Kew, to make drawings of two sheets of specimens in the herbarium under his charge. Both are twigs in flower and plump bud. One specimen bears the labels, "Eucalyptus, Mr. Wm. Baxter, received 1828; probably South Coast, perhaps Kangeroo (Brown in 1825 spelt Kangaroo thus) Island, or possibly V. D. Land" (R. Brown).

"E. Baxteri, R.Br., perhaps a var. of capitellata" (Bentham).

"Eucalyptus santalifolia, F.M., var. Baxteri, Benth. Fl. Austral. iii, p. 207."

The second specimen is labelled "Eucalyptus, Mr. Wm. Baxter, receired 1828, E. santalifolia, F. Muell., var. Baxteri, Benth. Fl. Austral. iii, p. 207."

Mr. Britten sent me a fragment of the type, and wrote: "I cannot make out where Bentham found the name E. Baxteri, Br., which he puts on the sheet. The plant is not described in Brown's MSS."

The following specimens in the National Herbarium, Sydney, precisely match the above :-

(a) "Major Mitchell's Heath, near Portland, 20th March, 1842. Supposed 497 of J. G. R." (J. G. Robertson, No. 503.)

(b) "Five miles from Portland, on road to Bridgewater Bay. Shrub 6-10 feet high. 5th February, 1844." (J. G. Robertson, No. 497.)

Both these specimens are in flower and early fruit; No. 503 is in ripe fruit also. Both are E. capitella'a, Sm. Some of the leaves of the Portland Bay specimens resemble those of some Victorian and South Australian specimens of 
E. Muelleriana, Howitt (E. pilularis, Sm., var. Muelleriana, Maiden), but the buds and fruit are different, the buds especially so. In a word, Robertson's 497, 498, 500,503 are conspecific, in spite of the fact that under var. (?) latifolia Bentham draws attention to a certain difference in the shape of the calyx.

Bentham's inclusion of Baxter's specimens under E. santalifolia, F.v.M. (E. diversifolia, Bonpl.), is a mistake. E. diversifolia has uniformly narrower leaves, not to mention other points. At the same time, the geographical limits of $\boldsymbol{E}$. capitellata, Sm., E. diversifolia, Bonpl., and E. Muelleriana, Howitt, unite near the Victorian-South Australian boundary, and botanists would do well to be on their guard not to commit the very pardonable error of confusing them with imperfect material. Portland Bay is on the south coast, 230 miles west of Melbourne, and about the same distance east of Adelaide.

I have recently received the same form from Portland (Mr. Adams, through Mr. A. E. Kitson), also specimens from Dagholm, also in Victoria (A. W. Howitt).

\section{RANGE.}

THis species is confined to New South Wales, Victoria, and South Australia.

\section{New South Wales.}

It has already been stated that the type came from Port Jackson. Around Sydney it appears to be almost (perhaps entirely) confined to the sandstone.

Northern Districts. - The following coastal specimens are strictly typical :Morriset (A. Murphy). "Bark deeply furrowed, timber good." "This species has always yellow inner bark," Wyee (A. Murphy); Wallsend (W. W. Froggatt); Port Stephens district (A. Rudder).

The following northern specimens depart more or less from the type:-Smallfruited and therefore small-budded form, Booral district, 29th October, 1895 (A. Rudder). The small fruits and pointed buds depart from the type. Some botanists may look upon it as a var. of $E$. eugenioides with very exsert valves. See fig. 9, pl. 38. "Stringybark, Lawrence, Clarence River district." (J. V. de Coque.)

The most northerly locality from which we have it is the Round Mountain, Guy Fawkes Range, 4,250 feet above the sea, and about 50 miles east of Armidale, on the Grafton road. (J.H.M.) Buds as compressed as it is possible for them to be. Fruits large and hemispherical. From the material available there may be room for opinion as to whether this is $E$. capitellata or E. macrorrhyncha, but the buds, at least, incline me to the view that it is E. capitellata.

(a) Near Apsley Falls, Walcha, No. 1,217, R. H. Cambage (E. C. Andrews) is identical with the preceding. 
(b) Fourteen miles east of Deepwater at 4,000 feet, No. 1,219, Cambage (E. C. Andrews). In intermediate foliage only, but doubtless identical with the preceding.

(c) Near Swamp Oak, Walcha, No. 1,218, Cambage (E. C. Andrews) has a very short pedicel and is one of the specimens which show how difficult, and perhaps impossible, it is to say what line of demarcation there is between E. capitellata and E. macrorrhyncha.

Southern Localities.-E. capitellata in its strictly typical form is found for a considerable distance along the coast. The following trees a few miles inland arc somewhat aberrant. For a southern tree (Clyde Mountain) see also p. $217 \mathrm{infra}$.

Bowral to Wombeyan (J.H.M. and R.H. Cumbage); Tellowish tip-cat buds, normal juvenile foliage.

At Hilltop, near Mittagong, N.S.W., there is a variety locally known as "Blue-leaf Stringybark." It is so called because the leaves, especially in the sunlight, are observed to have a bluish cast, and this bluish appearance (especially noticeable in the young leares) is largely retained on drying for the herbarium. The tops of the trees can be readily noticed amongst the other foliage from a neighbouring eminence. The fruits are in sphcrical clusters, and I mrote (Agric. Gaz., N.S.WV., vii, 268, May, 1896) that if it were desirable to distinguish this tree as a variety of eugenivides, the name agglomerata would be rery suitable. (See also Deane and Maiden, Proc. Limn. Soc., 1896, p. 808.) See fig. 6, pl. 35.

I look upon this ns one of the forms intermediate between E.ergenioides and $E$. capitellatu. On account of the jurenile leares, and of the fruits, I believe it to be nearer the latter than the former. The silvery or bluish cast of some Eucalyptus trees as they grow in the forest merits further inquiry. It is probable that several species present this appearance, perhaps at some seasons, and in some localities more than others. I have noticed typical L' eugenioides in the Blue Mountains, with a "silver top."

The fruits of the tree now under notice precisely resemble those of Nye's Hill, Wingello: 8/99 (J. L. Boorman).

The juvenile leaves precisely match those from Mt. Spiraby, near Tenterfield (J.H.M.). They also precisely match those of what may be termed the Blue Trountains form of E. capitellata (infra, p. 216).

Other evidence as to connecting links between $E$. capitellata and $E$. exgenioides will be found under the latter species, see p. 238. Here I show that there are specimens which, as regards their fruits, should come under E. engenioides, but their jurenile foliage is broad enough for $E$. capitell tat .

"White Stringybark." - Tall trees, white bark, good timber, leaves bluish tint, ensily distiuguished from "red" in the bush by the more robust gromth. Nye's Hill, Wingello, 8/99 (J. L. Boorman). Tho fruits are as small as those of $\mathbb{E}$. engenioides, but compressad like those of $E$. capitellata. They precisely resemble 
those of the Hill-top Blue-leat Stringybark, just referred to. The "bluish tint" of the leaves is also similar. Buds stellate, and strongly resemble those of E. eugenioides when young; coarse and angular like those of $E$. capitellata when more mature.

The following two specimens are instructive :-

(a) Berrima, September, 1901 (J.H.M. and J. L. Boorman).-Here we have fruits very similar to those of $E$. capitellata from Wingello, 8/99 (J. L. Boorman), and if not identical with them then intermediate between $E$. eugenioides and E. capitellata.

(b) Then we have a second series of specimens from Berrima, 9/01 (J.H.M. and J. L. Boorman), with the buds eugenioides-like and with the fruit hemispherical and capitellate. Figures will explain these two forms, which seem to be intermediate between eugenioides and capitellata. I place (a) with E. capitellata and (b) with E. engenioides. (See fig. 7, pl. 3S.)

Western Localities.- I now turn to a form which may provisionally be referred to as the Blue Mountains form of the species, because it is so readily studied there, but it also occurs coastwards and southwards.

The following account was prepared by Mr. R. H. Cambage and myself (only an unimportant addition has been made) :-

We now draw attention to a liucalypt from the Blue Mountains, which has almost invariably gone under the name of $E$. capilellata, Sm, but which is worthy of special remark.

Bark. - Not a perfect Stringybark, as compared, e.g., with macrorryncha, which is more fibrous. The more fibrous bark is yellowish; close to the wood it is white. Has clean limbs, at times slightly ribbony.

Reference to the bark being not a typical Stringybark is boine out by the Mount Wilson name, which is Messmate. Mr. H. Dcane, at Blackheath, some years ago, called it a Pepperwint bark, and suggested hybridism.

On a specimen from Jenolan Caves, the collector (W. F. Blakely) has a note, "Bark on the lower portion of the stem light reddish-brown in colour, resembling Stringybark; upper portion, grey; branches, yellowish-green."

Timber.-Brownish.

Juvenile Leaves.-The margins undulate, and with a reddish rim when fresh. The leaves roughish, particularly on the lower side, owing to the presence of stellate hairs which are also on the edges of the leaves and on the twigs.

In the intermediate stage they are Eugenia-like and shining on both sides, only very slightly darker on the upper side.

The branches are brittle and appear to be much less fibrous than those of E. engenioides in the vicinity.

Matnre Leaves.-Resemble those of typical E. capitellata.

Buds.--Clavate. Mount Wilson specimens, and others from the higher parts of the Blue Mountains, show the buds rugose, after the fashion, though not so well marked, as some from Victoria.

Flowers.-Anthers reniform.

Fruits.-Packed in a dense head; uften white dotted. In the ripe fruits ralves well exsert, rather more so than in E. macrorrynncha. Indeed, the Rev. Dr. Woolls labelled the Mount Wilson specimens $E$. macrorrhyncha.

In that species, however, the rim remains domed in mature fruits, while in this Blue Mountains form of $E$. capitellata the rim is turned outwards till it becomes almost a contiauation of the calyx.

* Proc. Linn. Soc. N.S. W., 1905, p. 193. 
Habitat.- We have collected this form from Woodford to Cox's River (Bowenfels) and the Jenolan Cares, and also at Mount Wilson. Further localities to connect with the coast will be looked for. The most westerly locality from which it has been obtained is Mudgee, where it is called "Silvertop" (which points to a bluish cast) according to Mr. R. T. Baker, who collected it; also Corricudgy Mount, R. T. Baker, October, 1897. July, 1890 .

We hare the same form on the Clyde Mountain (southern mountain ranges), No. 31, W. Baeuerlen,

In the Outer Domain, Sydney, we have an interesting tree, which is au naturel, and which attracts attention from the fact that it is more "bark-bound" than the majority of $E$. capitellata trees around Port Jackson, that is to say, the bark, though fibrous in texture, is thinner, denser, and nore elosely appressed to the trunk.

The jurenile leares and the intermediate leaves depart frow the type, being narrower, more lanceolate, and more closely resemble those of the Blue Mountains form just referred to.

Incidentally, it may be remarked that the orbicular suckers of $E$. capitellata from type localities (Port Jackson) would appear to be a product of an exposed situation. All the forms of $E$. capitellata appear to have more or less lanceolate juvenile leaves in their earliest stage.

Seedlings raised from typical capitellal a trees early take on a lanceolar shape with entire margins. This is succeeded by an undulate margin, with stellate hairs on the leaves and on the irregularly-toothed margin and twigs. These display a complete similarity to those of the Blue Mountains, and it seems impossible to assume that they do not belong to the same species. It would appear impossible to seize on characters even to make a well-defined variety.

Both of us have independently grown seedlings from Port Jackson and Port Hacking seed, and we cannot see any difference between the seedlings and those of the Blue Mountains trees.

\section{VICTORIA.}

There are two coastal forms of $E$. capitellata, as might be expected from the extensive geographical range of the species-the New South Wales, and the Victorian-South Australian.

Ilowitt states in his "Eucalypts of Gippsland" that he has not seen it growing there at a less elevation than 500 feet, and that it cannot, therefore, strictly speaking, be called one of the littoral species. In New South Wales, and also near the Victorian-South Australian border, it, however, often grows quite close to the sea.

$\mathrm{Mr}$. Howitt writes privately-"E. capitellata grows to a large size in the mountain districts, for instance, Moondarra, Wandin Yallock, and elsewhere in the Yarra watershed. In the western district the tree has usually a dwarfed habit."

See also my observations on the Victorian specimens referred to E. capitellata, var. (?) latifolia and E. Baxteri, supra, p. 213.

Form with rugose buds. - I now place together some further plants of this species with more or less rugose buds. I have already drawn attention to the subject, ${ }^{*}$ and think that this tuberculate appearance will be found to be somewhat common now that attention has been invited to it. The specimens from Mount Lofty, South Australia (M. Koch) may be compared.

I do not name this rugose-budded form as a variety, but, in view of the difficulty of "breaking down" such a widely-diffused and rariable species as E. capitellata, it seems well to point out any prominent characters, to aid in classification. 
Grampians, 2,000 feet, Victoria (H. B. Williamson). These specimens, as regards the broad leaves and fruits, are very similar to the coastal Victorian form, but the buds (both calyx and opereulum) are markedly rugose. Specimens also from the Grampians (C. Walter) have narrower leaves (nearer the type). The fruits are more pear-shaped, but there were only three in the umbel, and they are not much compressed. The specimens do not really differ from the preceding.

Darlimurla, S. Gippsland (H. Deane). The leaves and fruits typical (fruits slightly pedicellate), but the buds rugose. Fruits a little small.

All these specimens are practically alike. They are all $E$. capitellata, Sm.

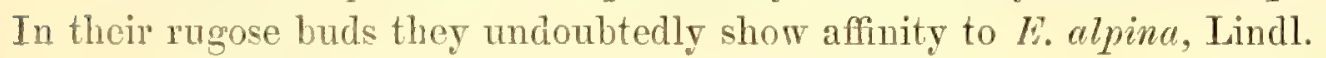

\section{South Australia.}

Sandy rises covered with fern undergrowth, Narracoorte (W. Gill). Clavate, scarcely angular buds, with domed fruits, valves well exsert.

Mount Lofty, South Australia (R. H. Cambage, 20th March, 1901, also W. Gill). Short, broadish leaves, ovoid, shiny, slightly tuberculate buds, almost sessile, squat, conoid to hemispherical domed fruits. See fig. 11, pl. 37.

Stringybark, Mount Lofty Ranges (Max Koch, September, 1902). The figures (fig. 1, pl. is) show the remarkable variation in the shape of the fruits in this tree. Buds rather small, some with conical operculum, and some with clavate shape of buds; many of them slightly rugose. I doubt if the Mount Lofty specimens can be separated from those labelled "Eucalyptus fabrorum, Schlechtendal. In montibus steriorilibus elatis, November, 1848. Dr. Mueller" (probably Mount Lofty, South Australia); see this Work, Part i, p. 40; Cf. also Part ii, p. 60.

\section{AFFINITIES.}

1. E. eugenioides, Sieb. See under E. eugenioides, p. 239.

2. E. Muelleriana, Howitt. See under E. Muelleriana, p. 224.

3. E. macrorrhyncha, F.v.M. See under E. macrorrhyncha, p. 230.

4. E. santalifolia, F.v.M.

$E$. santalifolia agrees with $E$. capitellala in the almost total absence of flower-stalklets, but it attains not the size of a large tree, the leaves are smaller, more rigid, of a lighter green, less conspicuously veined, and not remarkably inequilateral, the flowers are generally less numerous on each stalk, the calyces are larger, with wider tube and longer lid, the stamens not inflexed before expansion, the anthers more cordate than renate, and the fruits usually smaller, not to speak of the seedlings of the two species, those of $E$. capitellata, according to specimens transmitted by the Rer. Dr. Woolls, being star-hairy and producing leares narrow-lanceolar (sic, J.H.M.) though rounded at the base also.-(Eucalyptographia, under $E$. santalifolia).

T have already dealt with the affinity of these two species; see p. 213.

5. E. alpina, Lindl. I have made some observations on the affinities of these two species, Proc. Limn. Soc. N.S.W., 1904, p. 766. 


\section{DESCRIPTION. \\ E. Muelleriana, Howitt.}

(For Description, Synonomy, Range, \&c., see Part I, as E. pilularis, var. Muelleriana.)

Is dealing with the Stringybarks, I have been vainly looking for characters which will differentiate all forms. For example, I have ondeavoured to separate them by the seedling or juvenile leaves (width, and the presence or absence of stellate hairs). But I find that these characters, like all others in Eucalypts, vary. The state of ripeness of the fruits counts for much, the state of being capitate counts for little in classification. The jurenile leaves of Stringybarks (viz., E. capitellata, macrorrhyncha, eugenioides, Muelleriana) appear to be beset with hairs, more or less,-Muelleriana, perhaps, least of all. Those of E. eugenioides are usually narrowest. Those of E. capitellata and E. macrorrhyncha are broader, though the latter are usually narrower than the former. Those of $E$. Muelleriana vary much in width, and are sometimes very narrow. "The extremely shiny upper surface" of the leaves of this species (Howitt) characteristic of the type, unfortunately for purposes of classification, breaks down in some of its forms.

An instructive series of specimens was collected by Mr. A. W. Howitt,(a) Armidale, New South Wales, with narrow juvenile foliage; (b) between Chandler and Styx Rivers: "Up to 50 feet, bark stringy to smaller limbs and branches." This has juvenile foliage of intermediate width. (c) Styx River and Armidale: "A Stringybark tree, tall, up to 60 or 70 feet." The opposed juvenile leares up to one inch and a half wide; (a), (b), (c) belong to the same species; the transition between them is evident.

I have received from Mr. A. W. Howitt seedlings and other juvenile foliage of his typical E. Muelleriana, from Long Cutting, Tambo River, Victoria. The seedling leaves are half an inch in diameter, while the jurenile leaves, still in the opposite stage, are an inch and a quarter broad, with the stellate hairs so common in the Stringybarks. I cannot point out any differences between these jurenile leaves and those of the New South Wales (a), (b), (c) just referred to. The leaves of (a) are as narrow as those of E. eugenioides, while those of (c) are broader than those of E. Muelleriana were formerly supposed to be. Examining them from all points, I am of opinion that different botanists may look upon them as belonging to $E$. eugenioides, or to a small-fruited form of $E$. Muelleriana.

E. Muelleriana appears to have a number of associated forms closely related to it, and, for that and other reasons, I think it is better to look upon it as a species, and not as a variety. I, therefore, modify my views as to the rank of $E$. Muelleriana, as expressed in Part I of this work. 
The fruits of typical $E$. Muelleriana are, on the average, about half an inch in diameter. It might be desirable to give the small-fruited forms (i.e., those about a quarter of an inch in diameter, or rather more) a name, for it is they which show transit to and are confused with E. eugenioides. It might be desirable to renew the variety name minor which was applied to forms of E. lavopinea by Mr. Baker, but, as regard̆s myself, I must say that I am unable to define the small-fruited forms as distinct from $E$. eugenioides. They are simply portions of a curve.

E. Muelleriana is known as "Yellow Stringybark," from the yellowness of the inner bark, which yellowness also often exhibits itself as a stain more or less marked throughout the wood. At one time I hoped that this yellowness (where evidence of its presence is available) might be a useful diagnostic character. It is certainly useful sometimes, but it breaks down in that it is observable in E. eugenioides and other species. The presence of this colouring matter in various treos is worthy of investigation by the chemist, as it may be of some aid to diagnosis not clearly understood at present. I have spoken of the yellow colour being present in species other than Muelleriana; I now give an instance of its absence from Muclleriana. "Pale Stringybark," Mt. Lofty, S.A. (R. H. Cambage, 20th March, 1901); also, same locality (Walter Gill, Nov., 1901). Mr. Gill adds the note "The inner bark has none of the bright yellow colour of the Wingello, New South Wales, trees you and I felled in March." The Wingello trees are typical Muelleriana. Sce Part I, p. 40.

The Mt. Lofty specimens have duller buds and fruits, shape of fruits somewhat pear-shaped, rim well defined, reddish-brown, slightly domed, tips of valves slightly exsert. The fruits are reminiscent of those of some South Australian specimens of $E$. diversifolia, Bonpl.

\section{AFFINITIES.}

1. E. pilularis, Sm.

Its affinity to E. pilularis, Sm., I have abundantly made clear in Part I of this work. I sometimes cannot separate them on herbarium specimens. $\boldsymbol{E}$. semicorticata, F.v.M., Brisbane River (received by me from Kew), has the pointed buds of E. pilularis, and the fruits of E. Muelleriana. I can only repeat that E. Muelleriana cannot be separated by hard Jines from E. pilularis.

2. E. eugenioides, Sieb.

I do not know on what character-juvenile foliage, mature foliage, buds, fruits, bark, timber, E. Muelleriana (in its small-fruited forms) can be absolutely separated from E. engenioides, Sieb. I have already touched on this point, both under E. eugenioides and in my preliminary remarks under E. Muelleriana. That being so, I camnot find fanlt with a botanist who does not see ere to eye with me in 
regard to the placing of this and that intermediate specimen in one species or the other. This is inconvenient, but the convenience of taxonomists has to give way to the grand law of variation.

I look upon E. Tilkinsoniana, R. T. Baker, and E. nigra, R. T. Baker, as being inseparable from $E$. eugenioides on the one hand and from E. Muelleriana on the other,"* and I have made careful investigations in the forest.

E. Wilkinsoniana, R. T. Baker, Proc. Limn. Soc. N.S.W. 'xxv, 678 (1900). Syn. according to Mr. Baker. E. hremastoma, $\dagger$ Sm. var. (Mueller in Eucalyptographia Dec. 2) ; E. lceropinea, var. minor, Baker.

The affinity of E. Wilkinsoniana with $E$. Muelleriana is an inference already made by Mr. Baker, partly on oil determination, but made by me on morphological grounds. Mr. Baker's original view was that this tree is a small-fruited form of E. Muelleriana (his levopinea) and I think that that view has much to support it. It, however, ignores the obvious relation to E. eugenioides.

The type of E. Wilkinsoniana came from Marulan, also Barber's Creek (H.J.Rumsey). Specimens were sent to me also from the Glenrock paddocks, Barber's Creek, by H. J. Rumsey. Type specimens also from Sutton Forest (R. T. Baker). All these localities are very familiar to me, and the tree was collected by me long before it was described. Specimens from Burragorang (R. T. Cambage) and many other localities also match the type.

The fruits vary a good deal. See the remarkable differences of the forms of two heads of fruits from the same branch at Barber's Creek (H. J. Rumsey, the original collector of the type specimens). See fig. 17, pl. 38.

Mr. Baker's statement in his description of E. Wilkinsoniana that $E$. lavopinea never has a red rim appears to be founded on a misapprehension.

An extreme form of the fruits (from Sutton Forest) is that shown in the figure of $E$. Wilkinsoniana (Pl. 38, fig. 18). I have precisely the same form from 1 mile south-west of Parramatta, Wianamatta Shale formation (R. H. Cambage). Sometimes (e.g., same place and collector) the fruits are more constricted at the orifice, showing transit to E. pilularis. This shape of fruit is common enough in typical Muelleriana, whose fruits are, however, larger. Following is the same form.

E. pilularis, Sm., Gladesville, Sydney (H. Deane, May, 1886 ; J. L. Boorman, Dec., 1898) normal apparently in every other respect except that the size and shape of the fruits very elosely approximate that of $E$. Wilkinsoniand figured at pl. 38, fig. 18.

The fruits of E. levopinea, R. T. Baker, from Gulf Road, Rylstone (R. T. Baker) display such variation in size and shape as to have caused differences of views as to the species. For example, in Proc. Linn. Soc. N.S.W., 1896, 803,

- See note in Proc. Linn. Soc. N.S.W., 1905, p. 509.

tThe statement that $\mathbb{E}$. hamastoma, var. is a synonym of $\mathbb{E}$. Wilkinsoniana, is founcled on a misapprehension. See Proc. Linn. Soc., N.S.W. 1904, p. 760. The original specimen is E. Sieberiana, F,v.M. 
and 813, Mr. Deane and I referred some of them to an abnormal form of $E$. macrorrhyncha, between it and capitellata. That they are identical with $E$. Muelleriana, Howitt, has since been shown, but I would point out the resemblance in shape to those of some fruits of $E$. Wilkinsoniana.

The white-dotted appearance of the fruits common in E. Muelleriana is common on those of other Stringybarks, e.g., E. eugenioides and $E$. Wilkinsoniana and E. nigra.

The granular or roughened appearance of the rim which is specially common in $E$. Muelleriana is seen also in E. Wilkinsoniana, E. macrorrhyncha (e.g., Barber's Creek), and other forms.

The pale-coloured shiny buds of E. Muelleriana are seen also in $E$. Milkinsoniana.

The depressed hemispherical fruit seen in E. Wilkinsoniana is common in northern E. Muelleriana and E. engenioides.

Many other specimens (some are figured, e.g., 17 and 18, pl. 38) could be cited, showing that $E$. Wilkinsoniana cannot be considered a species apart from E. Muelleriana.

Let us now consider E. nigra, R. T. Baker, Proc. Linn. Soc. N.S.W., xxv, 689 (1900).

The type specimens of E. nigra, R. T. Baker, have usually thin rims to the fruit, and the tips of the valves barely protrude. They appear to be precisely matched by Kanimbla Valley (A. II. S. Lucas, March, 1900 ; J.H.M., February, 1901), a typical Stringybark (with yellow inner bark), and from the same tree I collected the broad-rimmed fruits of E. Muelleriana (see fig. 14, pl. 38). In other words, the fruits of E. nigra are not always thin-rimmed, varying, in this respect, in the same tree.

The lexves, buds, flowers, and fruits show that E. nigra cannot be separated from those of $E$. Muelleriana, although I have made earnest endeavours, extending over a long period, to separate them. The type-specimens come from Ballina, Richmond River, and Canterbury, Sychey.

E. nigra is, in my view, one of the forms which form part of the series between $E$. eugenioides and E. Muelleriana, and we have here but another instance of the protean forms of the Stringybarks.

I believe that Mr. Baker's E. nigra even extends to Victoria, and that the specimen, Upper Yarra, October, 1689 (C. Walter), looked upon by me as a remarkable form showing transit betwcen E. regnans, F.v.M., and E. vitrea, R. T. Baker (see Part VII, fig. 5, pl. 34), may be looked upon as a form of 
E. Muelleriana (or of E. eugenioides, Sieb., as Messrs. Luehmann and Walter imagined it to be). In Eucalypts which are aberrant (and this remark applies more or less to other genera) it is often the case that they may be referred to more than one species, according to the point of view.*

As to the reputed inferior quality of the timber of $E$. nigra as compared with $E$. eugenioides, I have some timber of the former which seems as good as any of the latter; indeed, I cannot tell any difference between the two. I would suggest that the reputed inferiority of $E$. nigra timber is owing to local causes.

In northern New South Wales (e.g., "Stringybark," Acacia Creek, Macpherson Range, W. Dunn (No. 72), and "Woolly-butt," Armidale district, H. A. Perrott) we have Stringybarks with broader juvenile leaves than those of typical Muelleriana, the fruit smaller, and sometimes a little angled. The jurenile leaves appear to be quite identical with specimens from Eden, in the extreme southeast of New South Wales, collected by Howitt, and referred to E. engenioides.

The tree also occurs in southern Queensland, e.g., Stanthorpe (A. Murphy), "the common Stringybark of the district, runs out near Warwick."

In one point at least (the angularity of the fruit) this last specimen shows some affinity to the pear-shaped fruited series which connects $E$. macrorrhyncha and E. Muelleriana (see p. 229).

The leaves, buds, and some of the fruits precisely match Mr. Baker's E. nigra, and I cannot separate them from the small-fruited form of E. Muolleviana, on the one hand, nor from E. eugenioides on the other. I think their proper place is transit between E. Muelleriana and E. eugenioides. These northern specimens connect with those from the (a), (b), (c) from the Armidale district, already referred to (p. 219).

Mr. Baker also records E. nigra from Cook's River, Sydney. I am of opinion that these specimens are referable to $E$.eugenioides, the size and shape of whose fruits is very variable in the Sydney as well as in other districts.

These difficulties of nomenclature and hesitancy to attribute some forms definitely to one species to the exclusion of others arises from the realisation, which presents itself to a philosophic mind, that in nature we have an infinite gradation of forms - a fact which is increasingly brought home to us as our knowledge of them increases. A knowledge of the oil-contents of the cells of the leaves is a contribution to such knowledge; but we must be on our guard that we do not allow ourselves to be unduly influenced by this, but should balance it fairly with evidence obtained in other lines of investigation.

- "Two species may in their typical forms be very unlike, yet exhibit such affinity that they are more or less connected by frequent intermediates, hybrids, or atavistic forms." ("The generic concept in the classification of the flowering plants."-B. L. Rolinson in "Science," n.s. xxiii, p. 83.) 
3. E. capitellata, Sm.

I have shown, in dcaling with Victorian and South Australian specimens (p. 213), how difficult it sometimes is to separate E. Muclleriana from E. capitellata. Typical suckers of E. capilellate may be different enough. The test as to the coriaceous character of the leaves breaks down, e.g., I have very coriaccous leaves of typical E. Muelleriana from Wingello, N.S.W., while west and north coriaccous leaves of E. Inelleviana are particularly abundant. That IF. Muelleriana and E. capitellata run into each other I have no doubt.

4. E. macrorrhyncha, F.v.M.

Turning to observations under E. macrorshyncha, I am simply unable to separate E. Muelleriana and E. macrorriyncha in some northern New South Wales and southern Queensland forms. The figures (10-13, pl. 38) will explain my meaning. Some of the northern forms may be looked upon by some botanists as referable to $E$. capitellata; indeed, I cannot say in what important character they differ from the Vietorian-South Australian spccimens referred to under E. capilellata.

The following notes on E. MIuelleviana seedlings refer to the type plants in Victoria. I have already pointed out, horrever, that the seedling leaves vary :-

In $E$. macrorrhyncha the scedlings are also more or less beset with tufts of hairs, giving the stems a rough appearance, but in a less degrce than the last-named species ( $E$. capitellata). The leares, at first opposed, are lanccolar in form, and slightly shiny. The secdlings of $E$. Muelleriana are as characteristic as those of any other species known to me. The stem and stalklets are slightly tufted with hairs, or are even smooth; the leaves rather long, lanceolar, pointed, and opposed throughout, even in seedlings of a foot or more in height, while their extremely shiny upper surfac: distinguishes this form from all the other species of this group [my italies, J.H.M.], being more marked even than in E. obliqua, from which the persistent opposition of the leaves readily distinguishes it.-(Howitt, Trans. Roy. Soc. Frict., vol. 2, pp. 92-3.) 


\section{DESCRIPTION.}

\section{E. macrorrhyncha, F.v.M.}

Mueller (Census, \&c.) quotes "First Generai Report of the Government Botanist of Victoria, 1853," as the authority for this nnme. It is there spelt as I have given it. The species was not, however, described until Vol. iii of the "Flora Australiensis" (1866). See B.Fl. iii, 207, and Mueller's "Eucalyptographia."

This, in its typical form, is a very easily recognised species. The buds are, when fully developed, large, rhomboidal in longitudinal section, with pointed operculum, and the pedicels are long, so that the flowers and fruits form loose heads.

Vernacular Names. - It is usually known as "Stringybark" mere'y, but by comparison with F. engenioides as "Red Stringybark." According to Howitt, it is known as "Mountain Stringybark" in Gippsland, a name to which in this State the other Stringybarks have also some claim. It is the common Stringybark of the north-eastern districts of Victoria, and appears to be quite absent from the coast districts of New South Wales.

Jurenile Foliage (figured in the Eucalyptographia).-The leaves may be described as follows:Ellipticul, margins undulate and irregularly toothed. Small tufts of hairs along the margin. The twigs, midribs and veins, and even the soft tissue more or less basprinkled with stellate hairs, the twigs abundantly so.

Mature Loaves.-Usually 4 to 6 inches long and 1 to $1 \frac{1}{4}$ inches wide. Rather coriaceous, equally green on both sides. Venation spreading, prominent, particularly the midrib. Intra-marginal vein at some distance from the edge. Twigs and leaf-stalks angular.

Bud. - These are strongly padicellate, and the ejge of the calyx tubs forms a prominent ring, while the operculum is often curved; asuminate and often lengthened out into a point. In the matter of shape one cannot help likening them to those of $E$. rostratx, which, however, are small in comparison.

The buds are usually more or less angular, and in the typical form are very angular. In extreme forms the angularity disappears.

Fruits.-These vary somewhat in shape and size, but, owing to the long pedicels, the prominent edge to the rim, and the domed top, they can usually be recognised.

They vary as to amount of doming, so that eventually, in some specimens, the rim is obliterated. Valves well exsert.

The diameter of typical fruits is not much more than $\frac{9}{8}$ inch at its greatest (rim) width.

A particularly large-fruited form has been collected by Mr. R. T. Baker in the Rylstone district, where trees with fruits of ordinary size are also found. Large fruits (not so lirge as the Rylstone ones) are also found with the ordinary ones at Howell (J.H.M.).

Timber.-This seems in every respect to resemble that of $E$. capitellata. It is the cummon Gold-fields Stringybark, and its timber is brown, 


\section{SYNONYMS.}

1. Var. (?) brachycorys, Benth.

2. E. scyphoidea, Naudin.

\section{NOTES ON THE SYNONYMS.}

Var. (\$) brachycorys, Benth.

Opcreulum short and obtuse. Fruit of E. macrorrhyncha. Expanded flowers not seen, and therefore affinities uncertain. New England, N.S.W., Stringybark, C. Stuart -B. Fl. iii, 207.

The variety brachycorys, mentioned by Bentham, seems transferable to $E$. capitellata, unless, indeed, it should prove distinct from both, when as a species it could be kept apart under the above designation.-(Mueller, Eucalyptographia, under E. macrorrhyncha.)

The variety brachycorys, doubtfully referred by Bentham to E. macrorrhyncha from New England (near Timbarra) at elevations about 2,000 feet, may possibly be a form of $E$. capitellatc, with which it shares the blunt lid, though the calyces are attenuated into distinct and slender stalklets; but the bark of this tree, though stringy, is said to be separating in patches, and, curiously enough, the tree is locally called Spotted Gum tree.* The fruits are rather more depressed. Expanded flowers remained unknown.(Eucalyptographia, under E. capitellata.)

I have seen Stuart's specimens, and they have thick leaves, with well-marked venation. Buds rounded, shining. Fruits sharply rimmed and grooved. Fig. 14, pl. 39, makes this form clear.

I cannot agree that it is a variety, and Bentham was himself doubtful on that point. It is an unstable form and it touches the normal form and adjacent species in various ways. It is especially common in the Northern Districts.

The sharpness of the rim, which seems to be the most pronounced character, appears to be accidental, and to be less accentuated as ripening of the fruit proceeds. It is seen in specimens from widely different localities, e.g., Cootamundra to Grenfell (A. Osborne); Borenore (H. Deane); Canoblas, Orange (A. W. Howitt); Capertee and Sunny Corner (J.H.M. and J. L. Boorman); Emmaville (E. C. Andrews).

2. E. scyphoidea, Naudin.

I do not know where it was described.

Copy of a label, in Herb. Mus. Paris, in M. Naudin's handwriting :-

Eucalyptus scyphoidea, Ndn. Species nova. Trouvé dans le jardin Nabonnand au Golfe Juan. Arbre unique dans le pays. Villa Thuret, 1899. Ch. Ndn."-(Maiden, Proc. Linn. Soc. N.S.W., 1903.)

It is a form of E. macromhyncha, commonest in the Northern Districts, which, with var. (?) brachycorys, is simply indistinguishable from the normal species. It has buds nearly normal, while the fruit tends to the spherical shape that is common in many specimens of this species, as will be readily seen from examination of the figures.

* I do not know the authority for this statement. Charles Stuart's note on a New England specimen (Herb. Melb.) is "A mountain species. Bark separatiog in fibress like the Vạn Diemen's Land E. gigantea $(E$, obliqua)," I have seen the tree in the forest. 


\section{RANGE.}

E. macror hyncha is found in Victoria (where the type came from), South Australia, New South Wales, and southern Queensland.

\section{VICTORIA.}

As regards its range in Gippsland, Mr. A. W. Howitt states, "It commences at Glen Maggie, on the dry Silurian ridges, extends all along the stony ranges flanking the valley, and reaches an altitude of about 3,000 feet on the track leading up from the Wellington to the Snowy Plains."

Mueller gives its range "On comparatively sterile ridges and ranges, chiefly of the Silurian formation, widely and often gregariously distributed through much of the wooded country of Victoria, for instance towards the Upper Yarra and in the Dandenong Ranges; thence to the mountains of Gippsland easterly, to the Mitta Mitta and Hume River northerly, the Aroca and the Pyrenees westerly, and towards Cape Otway southerly in our colony." - (Eucalyptographia, under E. macrorrhyncha.)

Following are aberrant forms. Small, glaucous, pointed buds like those of E. eugenioides. Oil-glands of leaves prominent. Fruits typical macrorrhyncha. Buchan, North Gippsland (A. W. Howitt).

A closely-allied form from Stawell (A. W. Howitt) has the buds glabrous and even shining. The fruits are less typical than those of the preceding specimen, being closer to capitellata.

\section{South Australia.}

In South Australia E. macrorrhyncha is confined to the Adelaide district, according to the late Prof. Tate.

\section{New South WaLes.}

In this State it is found along the Dividing Range and Table Land from south to north. It goes down the western slopes, and on the spurs of the main range, and on the isolated ranges some distance into the interior. The most westerly localities actually recorded are the Harvey and Warrumbungle Ranges.

Southern Localities.-Quiedong, near Bombala (W. Baeuerlen); Bombala to Delegate (J.H.M.) ; 'lantawanglo Mountain, Catheart, Montgomery's Mill (H. Deane); Gungahleen (Goldsbrough, Mort, \& Co.), with thick, short leaves and strongly marked venation; Tumut (W. W. Froggatt); Gundagai (H. Deane); Barber's Creek (H. J. Rumsey), with swollen, insect-punctured buds as already figured in I. stellulata. Bowral to Wombeyan Caves, 1 mile east (J.H.M. and R. H. Cambage) with narrowish, lanceolate suckers, not quite at the youngest stage. 
Fruits with very sharp rim; little doming, or a concavity rather than a convexity, Cootamundra to Grenfell (Dist. Forester Arthur Osborne); Weddin, near Young, normal (J.H.M.)

Borenore, near Forbes (H. Deane) with fruits similar to those from Cootamundra, \&c., and which resemble those of var. (?) brachycorys.

Westem Localities.-Hassan's Walls, Bowenfels (J.H.M.); Capertee and Sunny Corner, with remarkably angular rim to fruits (J.H.M. and J. L. Boorman). These specimens, as far as leaves and fruits are concerned, are close to var. (?) brachycorys, but the buds are those of the New England form. the type.

Rylstone (R. T. Baker); Mudgee (W. Woolls). Fruits rather smaller than

A coarse grandiflora form with the fruits $\frac{5}{8}$ inch in diameter, the rim very prominent and urceolate in shape, was collected by R. T. Baker at Mt. Vincent, also at Rylstone. (Fig. 19, pl. 39.)

Perth, found only in the Ranges around Apsley; small stunted trees used for props in the mines adjacent (J. L. Boorman).

"Red Stringybark," buds swollen like those of E. stellulata, Canoblas, Orange; ditto (A. W. Howitt), with rim of fruit as sharp as seen in var. (:) brachycorys, Ophir, Orange (R. H. Cambage); Wellington (A. Murphy).

Near top of Mt. Bulaway, Warrumbungle Ranges, at 3,000 feet (W. Forsyth). The angularity of the rim in these fruits is nearly obliterated, and the pedicels are very short. The opereula are pointed, but far less sharp than those of normal macrorrhynchx usually are. That this tree is a strong connecting link between E. capitellata and E. macrorrhyncha is unquestionable. A form with normal fruits is also found in the Warrumbungle Ranges (W. Forsyth).

Minore, near Dubbo, perhaps the most westerly locality in this herbarium (J. L. Boorman). Juds less angular than the type.

Harvey Range, near Dubbo (J. L. Boorman). Small crooked trees of 15-20 feet. Leares rery thick and shiny, and with veins well marked. In some trees the fruits hemispherical and much resembling those of var. (?) brachycorys. In others, the fruits hardly to be distinguished from those of E. tereticornis, Sm.

The Meadows, Dubbo district; used for fencing-posts and charcoal ( $\Lambda$ ssistant Forester A. R. Samuels). The buds remarkably like those of E. rostrata, so much so, that a word of caution is necessary. This is not an unusual thing in Western forms, but the anthers and the venation of the leaves are very different.

Northern Localilies.-But it is as we travel north, farthest away from the home of the type, that the aberrant forms become most plentiful. The doming of the rim is usually a very good guide in this species, but sometimes this character is not well defined, and the rim must then bo interpreted with caution. 
On New Fngland the tendency of the leaves is to become smaller and more coriaceous, and the buds to become less to more angular* than the type, the operculum shorter and the fruit more pear-shaped. The rim is not sharp, and the domed portion is narrow. At the same time there are considerable differences in the shapes and sizes of the fruits in these northern forms as the figures will show. Following are some specimens in the National Herbarium :-

Tingha, on granite, fruits nearly spherical, more or less glaucous, buds approaching normal (No. 962, R. H. Cambage).

Tingha, jurenile foliage narrorrer or more lanceolate than the type, but not invariably so. Stellate hairs, marginal characters as before. Intermediate foliage very broad and coarse (like the Stanthorpe, Q., specimen figured at fig. 18, pl. 39). Buds compressed (J. I. Boorman). Mr. Boorman and I have collected fruits at Tingha in heads, with valves as exsert as it is possible for them to be.

At Howell, near Tingha, Mr. Boorman and I collected a grandifora form of this species, also specimens similar to the Tingha ones, and also fruits inclining to be pear-shaped, as referred to elsewhere when discussing this species.

Mount Seariew (J.H.M.). Bluff River, near Tenterfield; also Glen Innes (H. Deane) are obviously similar to var. brachycorys, but the rim is less rounded.

A second Bluff River specimen (H. Deane) is more glaucous and angular in all its parts, with larger fruits. I cannot distinguish it from Boorman's Tingha specimens, except, perhaps, in the more pronounced grooving of the rim.

Tent Hill, west of Deepwater (E. C. Andrews). In fruit only, which is depressed, tending to be hemispherical and the rim not sharp.

Emmaville. Buds very compressed (J. L. Boorman). From same locality (E. C. Andrews), but with shiny, scarcely angular buds, and angular, flat, broadrimmed fruits like var. (?) brachycorys. This angular rim appears to be less marked in fully ripe fruits. Stanthorpe, Queensland (F. M. Bailey).

The following specimens show some affinity to Muelleriana, and may be reported upon separately as a matter of convenience.

(a) Nundle, Liverpool Range (J. L. Boorman). Fruits pear-shaped, whitedotted, buds not angular, opercula conical. (See fig. 11, pl. 38.)

(b) Allied to the above, but buds and fruits smaller and paler, and the angular rim of the latter almost absent. Attunga, 12 miles N.W. of Tamworth, growing on hill of serpentine formation ( $R$. H. Cambage). (See fig. 12, pl. 38.)

(c) "Red Stringybark," Walcha District (A. R. Crawford), with fruits inclining to pear-shape. (See fig. 10, pl. 88.)

In the more exposed situations the mutual compression causes the buds to be bluntly angular and compressed just like $E$. cerpitellata of the coast. 
(d) Hartley's Mill, Glen Innes (H. Deane). This is a very interesting specimen, of which leares and fruits (not quite ripe) are alone available. It was referred doubtfully to E. eugenioides by Deane and Miaiden, in Proc. Linn. Soc. N.S.W., 1896, 805. (See fig. 13, pl. 38.)

It is, I think, a transit form between $E$. macrorrhyncha and $E$. Muelleriana. It can be looked upon as an extreme form of the pearshaped fruited macrorrhyncha specimens just referred to. The figure will explain it, and I will only add that I have not noticed the grooving of the rim, which is clear in this form, other than in E. macrorrhyncha.

(e) Warialda (J. L. Boorman), and the trees also examined by me. Apparently rare in the district. Occurs on the Inverell-road, near the dry creek with a bridge, under 2 miles from the township. The timber is warm brown. The suckers (some of them) nearly as narrow, perhaps quite as narrow, as ever seen in E. eugenioides. (See fig. 21, pl. 39.)

The fruits are quite small, and there is almost an entire absence of angularity of the rim. Occasionally angularity is observed. This form is obviously similar to $(d)$, and it is an extreme form of E. macrorrhyncha.

\section{AFFINITIES.}

1. E. capitellata, Sm.

In specific botanical affinity $E$. macrorrhyncha stands nearest to $E$. capitellata; leaves and fruits of both are the same; but the flowers of the latter are always sessile, or nearly so, and thus crowded into heads as the species-name signifies, besides being usually smaller; the lid of $E$, capitellata is hemispheric, without any prominent point, and shorter in proportion to the tube, the latter being also more angular, and downward less attenuated.--(Eucalyptographia, Mueller, under E. macrorrhyncha.)

That E. capitellata and E. macrorrhyncha possess points of resemblance is apparent to the most superficial observer. A comparison of the two may be roughly tabulated as follows:-E. capitellata-Operculum obtuse. Flowers and fruits sessile, or nearly so. Fruit expanded below the rim.

E. macrorrhyncha.-Operculum acuminate, or conical. Flowers and fruits strongly pedicellate; calyx border prominent.

But these characters are not absolute, and oniy belong to the types, considerable variation occurring in some specimens.

I cannot separate E. capitellata and E. macrorrhyncha on juvenile leaves, and agree with Mueller's dictum, "leaves and fruits of both are the same" ; their limits are simply indefinable. 
2. E. Muelleriana, Howitt.

I have already spoken strongly as to the affinity of these two species. Contemplation of figures 10-13, plate 38, will illustrate the transit between them. This transit appears to be most marked in northern New South Wales and southern Queensland specimens. The colours of the timbers of the two species do not help one much in these transit forms. The colour of the timbers referred to is a warm brown, while that of $E$. macrorrhyncha in its typical form is rather darker, while that of $E$. Muelleriana is paler.

But as one gets away from the type localitics of species, the colour of the timber varies within limits. Indeed timbers, like other products of plants, cannot always be placed in one species without a qualifying statement that it would be legitimate to look upon them as forms of another. I regret, as a systematist, to have to say this, but it is a necessary corollary of the grand law of variation amongst plants, often evident, but more frequently not so evident to the limited experience and knowledge of man.

\section{E. diversifolia, Bonpl.}

E. santalifolia, F.v.M. (E. diversifolia, Bonpl, J.H.M.), from the limestone ridges of Guichen Bay, and thence westward to Venus Bay beyond Spencer's Gulf, differs in smaller and less oblique leaves, with more concealed veins, and anthers rather cordate than kidney-shaped, but the fruits are again the same, unless the valves are smaller. Possibly it may prove a variety; it flowers already in a shrubby state. I have not seen the lid of its calyx.-(Eucalyplographia, Mueller, under E. macrorrhyncha.)

The affinity is, however, not very close, as references to the figures and text in Part VII will show. 


\section{DESCRIPTION.}

\section{E. eugenioides, Sieb.}

\section{Sreber's definition of $\boldsymbol{E}$. eugenioides is as follows:-}

E. opereulo mucronulato, umbellis lateralibus racemosis, ramulis teretibus, foliis inæequaliter oblongolanceolatis (Sprengel's Curce Posteriores, iv, 195), a description which would lave rendered it impossible to state what species was meant, had not a specimen, named by Sieber, been in existence.

It is also described in Mueller's "Eucalyptographia." The species may be described as follows:-

Vernacular Names.-It is usually known simply as "Stringybark." It is often known as "White Stringybark" in this State and also in Victoria (A. W. Howitt), but the timber is often reddish, and hence it bears the name of "Red Stringybark" also. In those cases E. capitellata from the same district usually bears the name of "White Stringybark!"

Juvenile Foliage.-Specimens of the type (Sieber's No. 479) are just-only just-past the opposite stage. They are lanceolate, under $\frac{3}{4}$ inch wide at the outside, and up to $2 \frac{1}{2}$ inches long. Venation strongly marked. Leaves undulate and young shoots warty. (See fig. 2, pl. 40.)

Mueller has figured* the jurenile foliage of the species in the Eucalyptographia, and I accept it as certainly belonging to the species, although the figure would have had enhanced value had the locality of the specimen been given.

Mature Leaves.- These are generally much thinner and more delicate in lexture than those of $E$. capitellata and $E$. macrorrhyncha; the leaves are sometimes very shing and much thicker than others. They are also of a richer green, more shapely, graceful and Lugenia-like, a circumstance which led to the adoption probably of the specific name.

Buds. - The buds are clustered and often very much crowded into heads, by which the inflorescence assumes a very marked character. They always have pointed opercula, but rarely angular, as in E. capilellata, the points being sometimes so marked as to approach those of E. macrorrhyncha, but they are then fuller on the top, and do not show such a prominent edge at the base of the operculum. Sometimes, e.g., Syclney to Blue Mountains, they are arranged in a stellate manner.

Fruits.- Sieber having distributed no fruits with his type, I attach the following description of fruits from trees in the Sydney district, which have jurenile and mature leaves, and flowers practically identical with the type:-

They are nearly hemispherical, with the valves slightly exsert; but nearly globular fruits with the valves sunk, and the orifice constricted, may be taken off the same tree. Occasionally the fruit is quite flat-topped. The rim is often red, as red as those of E. hamastoma ever are. They are slightly pedicellate, often crowded into inore or less globular heads, but rarely compressed like those of $E$. capitellata.

Timber.- When fieshly cut usually dark brown, but drying to a pale warm brown and even whiter. In some districts, however, the timber is distinctly red, even redder than the local $\boldsymbol{E}$. capitellata timbere.

- Mleller's figure shows a leaf longer than broad; in $E$. capilellata we have a distinctly broad leaf. In some forms referable to $E$. extgenioules we have a very narrow leaf. I have no hesitation in saying that a narrow juvenile leaf is the standard or type for $E$. engenioides (but see also fig. $10 a, \mathrm{pl} .40$ ), and a broadish one for $E^{*}$. capitellata. The difficulty, of course, begins with the intermediate forms. In many cases one cannot state whether the juvenile foliage is narrow or broad, and evidence furnished by other characters is, in some ceses, difficult to interpret. 


\section{SYNONYMS.}

1. E. scabra, Dum-Cours.

2. E. penicillata, Hort.

3. E. acervula, Sieb.

4. E. oblonga, DO.

5. E. undulata (?), Tausch.

Variety nana, Deane and Maiden.

6. E. oleifolia, A. Cunn. (probably).

7. E. ligustrina, DC.

Note on E. salicifolia, Cav.

\section{E. scabra, Dum-Cours.}

Following is the original description :-

E. à feuilles rudes, $\boldsymbol{E}$. scabra, Hort. Angl.-Cette espèce me paroit être une des plus belles de ce genre, du moins relativement à son feuillage. Ses feuilles sont ovales, très entières, terminées par" une pointe particulière, relevées en-dessous de nervures parallèles qui s'arrondissent, en s' anastomosant à une ligne environ des bords, fermes, un peu rudes au toucher, d'un beau vert, longues de 9 centimètres (3 pouces et demi), larges de 5 cent. et demi (2 poures). Lieu id. Toujours vert. Cult. Orangerie. Celle des autres espèces et des plantes de la Nourelle-Hollande.

De toutes les espèces de ce genre, il $n$ 'y a que celles qui sont nommées $E$. resinifera et obliqur qui aient encore Heuri en France et en Angleterre.-(Dum-Cours. Bot. Cult. ed. 2, vol. 7, p. 279, 280).

We then find Sieber's No. 479 (the type of E. eugenioides) placed under the same name, in the following words :-

E. scalra (Dum-Cours, bot. cult. 7, p. 280) operculo subconico cupulâ paulo breviore, pedunculis axillaribus angulato-compressis petiolo requalibus aut longioribus, floribus capitatis, foliis lanceolatis basi inæqualibus ramorum sterilium crispis, fertilium planis, saepe novellis cum ramis velutinis. In NovâHollandiâ. E. eugenioides, Sieb. ! plant. cxs.nov.-holl., n. 479.--(DC. Prod. iii, 218.)

Specimens referred to, Sieber's No. 479, and named E. scabra, Dum-Cours, are precisely matched by many specimens in the National Herbarium, Sydney, e.g., Wyee (A. Murphy).

\section{E. penicillata, Hort.}

E. penicillatu, hortul. Ramuli et folia pilos breves fasciculatim congestos gerunt, demum glabra evadunt, interdum glabra nascuntur. Petioli 4 lin. longi. Folia basi inæqualia orali-aut oblongolanceolata acuminata. Pedunculi in specim. Sieberiano petiolo xquales $4-5$ flori, in specim. culto Noissettiano petiolo duplo longiores 15 -20 flori (given as a synonym of E. scabra in DC. I'roct. iii, 218).

3. E. acervula, Sieb. (Sieb. plant. exs. nov.-holl., n. 469).

Operculo conico capsulæ longitudine, pedunculis lateralibus petiolo brevioribus pedicellisque ancipitibus, foliis ovato--]anceolatis hasi hinc valde excisa obliquis apice acuminatis. In Nova-Ho!landia. Folii petiolus 3-7 lin. longus, lamina 4-5 poll. longa pollicem lata. Pedunculi 4 lin. longi ommes in ramis infra folio orti. Umbellæ 5-10 flore. Florum alabastra 3 lin. longa.-(DC. Prod. iii, 217.)

All the specimens of Sieber's No. 469 that I have seen are in mature foliage and bud. I cannot separate them from Sieber's No. 479; in fact, they might have been taken from the same tree.

“31. Encalyptus acervula, Sieb.-DC. 1.c. 217, n. 10, Mém. Myrtac. Folia in supp. paullo latiora. Swampy plains towards the Plenty-range (F. Müller)" (Miquel in Ned. Kruidk. Arch. iv, 137, 1856). I have not seen this Victorian specimen. 


\section{E. oblonga, DC.}

Following is the original description :-

$E$. oblonga, operculo conico cupulæ longitudine, pedunculis lateralibus et axillaribus petioli longitudine compressis, umbellis 8-12 floris, foliis oblongis basi inaqualibus attenuatis apice mucronatis coriaceis aveniis.

In Novâ-Hollandiâ. Sieb. ! plant exs. nov.-holl. n. 583. Alabastra oblonga utrinque attenuata ad apicem pedunculi subsessilia et eo paulo breviora. Folia 3-4 poll. longa, 9 lin. lata.-(DC. Prod. iii, 217.)

This is in leaf and young bud only. Some of the leaves are oblong; they are mucronate, shiny, very coriaceous, so that the venation cannot readily be seen. The buds are shiny, operculum pointed, calyx tapering into the short pedicel, making the bud symmetrical and of the shape of a "tip-cat." I refer it, without doubt, to a form of E. engenioides common on the Blue Mountains. I match it absolutely with specimens from Lawson (J. H. Camfield); Jenolan Caves (W. F. Blakely); and Mudgee (C. Marriott).

5. E. undulata, Herb. Vindob. (? Tausch., but label partly defaced) is a seedling or sucker branch of $E$. eugenioides, Sieb.

Var. nana, Deane and Maiden.

Figured and described in Proc. Linn. Soc. N.S.W., 1893, p. 799.

This is a shrub of 5 or 6 feet, forming a dense shrubby grow th at Wentworth Falls, Blue Mountains, N.S.W. It has the stellate hairs (juvenile foliage) of the rest of the Stringybarks.

6. E. oleifolia, A. Cunn.

In his MSS. Journal I find the following entries:-

(a) At page 6: "Blackheath, 5th October, 1822, operculo hemispherico foliis (parvis) ellipticis ovali-lanceolatisve mucronatis acutiplanis, umbellis axillaribus pedicellatis 9-10 floris. A low shrub 2 feet high."

(b) "A low shrub 1-2 feet high, verge of Regent's Glen." This is probably also E. eugenioides, var. nana.

Mr. R. H. Cambage has also collected it on a sandstone plateau about 1,700 feet high at West Dapto. His note is: "Dwarf Stringybark, growing somewhat as a Mallee. Height, 2 feet 9 inches."

7. E. ligustrina, DC.

Operculo hemisphærico mucronato cupulâ breviore, pedunculis axillaribus compressis petioli longitudine, floribus 6-8 sub-capitatis, foliis lineari-lanceolatis basi valde inæqualibus attenuatis apice acuminatis. In Novâ-Hollandiâ. Sieb. (?) plant, exs, nov.-holl. n.617. Folia 2 poll. longa 4-5 lin. lata. Petioli et pedunculi 3-4 lin. longi. An E. salicifolia, Cav, Ic. 4 n. 376 (?).-(DC. Prod. iii, 219.)

All the specimens of Sieber's No. 617 that I have seen are in bud only, but they precisely match E. eugenioides, var. nana.

\section{Tote on E. salicifolia, Cav.}

A specimen of Sieber's No. 617 in Herb. Vindob. (ex. Coll. Reichenbach, fil.) in old handwriting bears the label, "E. ligustrina, DC. Prod. iii, p. 219, n. 24. E. salicifolia, Cav. ic. iv, p. 21, No. 376! " with the words, "Spont. N. Holl. Sieb. 617," in a later handwriting. It is E. eugenioides, Sieb., var. nana. 
At p. 152, Part VI, of this work this species is referred to $E$. amygdalina, and the determination of Sieber's No. 617 as E. salicifolia is, I believe, wrong. I give the original description of E. salicifolia, as Cavanilles' work is not in New South Wales:breviore.

" 376 . Eucalyptus foliis lanceolatis, nervo dorsali inæqualiter partis, altera parte versus basim

"Haec species a reliquis distinguitur foliis altera parte versus basim breviori ut in Begonia et aliis plantis: nervuli sunt etiam adscendentes : umbellæ 7-10 floræ, axillares."-(Cav. Icones, iv, p. 24.)

See also Metrosideros salicifolia (Gaertn. Sem. i. p. 171, t. 34; Lamarck Illustr. t. 421, f. 4). Specimens (so named) have also been recorded from "Bay of Islets, Cape Grafton, Endeavour's River, Point Lookout, Possession Island," as collected by Sir Joseph Banks, but I have not seen them. For geographical reasons they could not be $E$. amygdalina, and it is very improbable that they are $E$. eugenioides. See also Dryander's "Chloris" (Ann. Bot. ii, 524, 1806).

\section{RANGE.}

IT appears to be confined to eastern Victoria, New South Wales, from south to north, on the Dividing Range and its spurs, and east of them, and to southern Queensland.

\section{VICTORIA.}

The Victorian forms (often referred to in the writings of Victorian botanists as $E$. piperita), as a rule have fruits which are more or less pilular, i.e., with sunk valves, thus approaching $E$. piperita, but the fruits appear to be never uiceolate, as in that species.

Some of them, e.g., Eureka Hill, Tinker Creek, Gippsland; Drouin West; also Osler's Creek (A. W. Howitt), have jurenile leaves which vary from narrow to broadish.

Mr. (now Dr.) A. W. Howitt wrote to me, "The White Stringybark forms forests in Gippsland, for instance at Toongabbie, between Stratford and Bairnsdale, Bairnsdale and Buchan at the Lakes Entrance, in Croajingolong. It also occurs throughout the mountainous districts. It grows to a good size, is free from gumveins, and is a useful timber. Its western limits are probably Traralgon and Woodside."

Following are Victorian specimens in the National Herbarium, Sydner, collected by Dr. Howitt.

Macalister River.-Fruits in heads, orifice small; source of Wild Horse Creek, 3,000 ft.; Drouin West; Stockyard (the river banks); Agnes Bridge, very long opercula; "Yellow Stringybark," Stony Creek, Nicholson River, Bairnsdale; the suckers intermediate in character.

"A Stringybark growing in the clayey flats (post-Pliocene?) at Toongabbie, near the foot of the hills. From a moderately large tree, say $100 \mathrm{ft}$. 'Yangoura' of the blacks" (A. W. Howitt).

A specimen from Blackburn, near Melbourne (C. Walter) has the valves of the fruits slightly exsert. 


\section{New South Wales.}

Southern Localities.-Twofold Bay (J.H.M.), Wyndham and Bembooka (A. W. Howitt); Conjola, near Milton, with very long opercula (W. Heron) ; south of Nowra, from Jervis Bay (J.H.M.); Shoalhaven River, also Diggers' Creek (W. Forsyth and A. A. Hamilton), with filiform pedicels; Kangaloon (J. L. Bruce); Barber's Creek (H. J. Rumsey); Wingello (J. L. Boorman), medium trees, detected by short leaves and absence of glaucous tint. "Red Stringybark," in contradistinction to "White Stringybark" (E. cupitellata), a reversal of this nomenclature being more common in other parts of New South Wales. A second collector (A. Murphy) confirms Mr. Boorman's report of the local nomenclature.

Berrima (see notes under E. capitellata).

The Peaks, Burragorang (R. H. Cambage), Kangaroo Valley and Bowral to Bullio (J.H.M. and R. H. Cambage). These specimens are indistinguishable from Sieber's type of E. acervula, No. 469, but are eugenioides, showing transit to one of the forms included by Mr. Baker in his Wilkinsoniana.

Hilltop, with specially marked white-dotted fruits and elongated opercula

Sydney district, common on the Wianamatta shale, but also found on sandstone. Following are some Sydney district localities:-Homebush (J.H.M.); Concord Park (R. H. Cambage); Bankstown and Cabramatta (J. L. Boorman); Hurstville (R, H. Cambage), the valves sunk; La Perouse (W. W. Froggatt); Peat's Road (H. Deane); Newport (R. H. Cambage).

Some trees found by J.J. Fleteher at Gladesville, photographed by R. H. Cambage, and examined by all three of us, have a flaky bark (somewhat like $E$. resinifera), than that of a true Stringybark; probably showing hybridism.

Western Localities.-To the foot of the Blue Mountains from Sydney, it is rather common. It is the commonest Stringybark on the Blue Mountains, occurring all over the range, and at all heights. Compared with the other rather common Blue Mountain Stringybark (E. capitellata), the timber is redder (!) The jurenile foliage is narrower, and not glaucous, like that of $E$. capitellata. The fruits of $E$. engenioides on the Blue Mountains are not often exsert; instances to the contrary are Springwood (H. Deane); Mount Wilson (Jesse Gregson), with inner bark very yellow.

Jenolan Caves (W. F. Blakely). Collector's note:- "The bark of these trees is of a light reddish colour on the inside; the outside is of a dirty grey colour, or weather-beaten, and is very ridgy ; the ridges run out to nothing as they approach the top of the tree. The bark is of the same colour from the bottom to the topmost branch, and is of a rather rough nature."

At Capertee (J. L. Boorman) and Mudgee (Dist. Forester C. Marriott) it is known as "White Stringybark." 
E. engenioides does not appear to go further west than Jenolan Cares and Mudgee.

"Bastard Stringybark" (Penrith : J. L. Boorman, January, 1900). I desire to invite attention to an interesting form of this species. The fruits are smaller than is usual and nearly globular. They are on nearly filiform pedicels of about 2 lines; the common peduncle is twice that length, and more. The bark is harder and denser (less stringy) than those of the normal species-more "bark bound"; a character also noted under E. capitellata. Perhaps hybridism is indicated in this case. The plant is indubitably E. eugenioides, though, from examination of the fruits alone, it might reasonably be supposed to be $E$. hamastoma, var. micrantha.

Northern Localities.-Nost of the northern specimens have the rims red and prominent, and the valves slightly exsert.

"Good timber, cut for sleepers. Yellow inner bark, between the rough and the inner bark; the fibrous portion very tough." W Wee (A Murphy). The fruits are slightly constrieted, and in hends; the filaments turn brownish-red on drying.

Stringybark, free splitting; bark between sap and outside yellow. St. Aiban's district, Hawkesbury River (A. Murphy). Transit to E. Muelleriana.

Wallsend (W. W. Froggatt).-Fruits rather small, rim red and conspicuous, valves slightly exsert, leaves broadish (?); Booral (A. Rudder, No. 4); Wallsend (J. L. Boorman); Booral (A. Rudder, A. 29).

"Stringybark, height about $60 \mathrm{ft}$., diam. $18 \mathrm{in.,} \mathrm{mould} \mathrm{over} \mathrm{shale,"} \mathrm{near}$ Underbank, Upper Williams River (A. Rudder, G. 10).

Pokolbin, No, 1,486, R. H. Cambage. Near to E. Wilkinsoniana, R. T. Baker.

Stewart's Brook.-Rim of fruit red and pronounced (J.H.M.); Moggrani Mountain, Gloucester (J.H.M.); Upper Hastings River; cutting near Yeldham's. Fruits slightly exsert and rim pronounced (J.H.M.); Macleay River (Forester. W. Macdonald).

Yurrurundi (J.H.M. and J. L. Boorman). Valves slightly exsert; rim broadish, hemispherical, slightly depressed, with short filiform pedicels, connecting with the "Bastard Stringybark" of Penrith.

Collaroy (J.H.M. and J. L. Boorman), showing white dots and a slight ribbing of the fruits.

Near Cemetery, Tingha (R. H. Cambage); with fruits a little more subcylindrical and perhaps a little more domed than the type. Specimens from the same locality with nearly pilular fruits and very narrow jurenile foliage.

Near 11-mile post, Inverell to Tingha (R. H. Cambage). Form with even narrower leaves than the type. 
Tingha to Guyra, 19 miles from the latter place (J.H.M. and J. L. Boorman). Juvenile leaves intermediate. Mature leaves broadish. Fruits (from same tree) flat-rimmed, domed; valves exsert and sunk; hemispherical and inclined to be sub-cylindrical.

I place this specimen under $E$. eugenioides, and it certainly seems to form a connecting link between the Tingha specimeus and the supposed hybrid which follows.

Between Tingha and Guyra, 19 miles from the latter (J. L. Boorman). "Stringybark," medium-sized trees growing in swampy ground in company with that of E. stellulata and E. nova-anglica. An interesting form; leaves broad, thickish. None of the fruits with exserted valves, which is unusual in northern specimens. I am of opinion that here we have a hybrid between E.eugenioides and E. stellulata.

Fruits in heads, slightly constricted, valves sunk. Tent Hill (E. C. Andrews).

Small fruits in heads, valves not exsert, Styx River (A. W. Howitt). I have other specimens from the same locality showing close affinity to E. Muelleriana.

Walcha (J. F. Campbell). Fruits rather exsert, and rim inclined to be domed. Shows affinity to E. macrorrhyncha. Ascending New England from Port Macquarie, this species was first observed about Yarrowiteh. Thence it was not uncommon in the Tia district, where it is known as "Red Stringybark," and used for timbering the mines at Tia, and also locally for flooring-boards. This species shows a double operculum (J.H.M.).

Tenterfield to Sandy Flat (J.H.M.) - Fruits very similar to those of Sydney, e.g., Concord Park (believed to be typical), hemispherical, and somewhat exserted valves. Buds very compressed, almost like capitellata. I figured this (Plate 4, Part I) as E. Muelleriana, and I now put it under $E$. cugenioides with doubt. It certainly is a transit form.

Drake to Richmond River (A. Hagman); Drake (E. C. Andrews), with rim of fruit rather sharp and valves exsert (transit to E. Muelleriana).

Foot of Mt. Lindsay (W. Forsyth); Moonambah, Richmond River (W. Baeuerlen); valves slightly exsert.

\section{QUEensland.}

Nerang, near Tweed Heads (F. M. Bailey). Small fruits with sharp rim, valves lather prominent.

"Stringybark." Yellow inner bark. See fig. 16, pl. 38, Stanthorpe (J. L. Boorman). A eugenioides-Muelleriana form.

"Yellow Stringybark," Landsborough, North Coast Railway (P. MacMahon). A pale-coloured timber, with stains of bright yellow running through it. 


\section{AFFINITIES.}

1. E. capitellata, Sm.

There is no sharp line of demarcation between E.eugenioides and E.capitellata, intermediate forms occurring between them in regard to buds, fruit, leaves, and even timber.

Some fruits show a tendency to E. capitellata in having fruits larger and more "squatty" or compressed than those of E. eugenioides. But the valves of the fruits are not so exserted, nor are the buds so flat and angular as those of E. capitellata usually are. The buds are, in fact, those of E. eugenioides.

$E$. eugenioides displays a tendency to form globular masses of closely-packed sessile fruits, after the manner of $E$. capitellata. These globular masses present such a different appearance to the ordinary form of E. eugenioides that they may, at first sight, be reasonably supposed to form a variety, but we have many gradations between them and the ordinary form.

The state of being capilate is by no means confined to E. capitellata, and seems to me induced by exuberance of floriferousness. For example, at Newport, near Sydney, where $E$. eugenioides was flowering as freely as I have ever seen it, and covered with honey-seeking insects, on the same twig we find dense heads of fruits and more open heads with distinctly pedicellate fruits. There we have also the roughened rim and the white-dotted fruits.

To recapitulate somewhat, we have :-

$E$. eugenioides fruits may be sessile; they may be compressed; they may precisely resemble those of E. capitellata in shape, as regards the sunk valved forms. The valves are rarely, if ever, so exsert as in some forms of capitellata.

In E. eugenioides the buds are smaller; occasionally slightly angled, but never to the extent that those of capitellata are (with the possible exceptions referred to, e.g., young buds of Berrima and Wingello, pp. 215, 216). often are.

Sometimes they, like the leaves, are shining like those of E. capitellata

The jurenile leares may be broadish as in Figure $\mathrm{v}$ in Howitt, Trans. Roy. Soc. Vict., 1890-1, vol. 2, pl. 14, fig. 4. With these I place specimens collected in Gippsland (Toongabbie, Bruthen, Eureka Hill, Tinker Creek), by A. W. Howitt. A figure of one of Mr. Howitt's natural seedlings has just been alluded to, and fig. 1 of the same plate, considered by Mr. Howitt to be E. piperita, is the same form.

Such specimens as these (and other instances have been referred to by me) show that there are intermediate stages between $E$. eugenioides and E. capitellata, and that the evidence of seedlings, at one time believed to be infallible, breaks down. At the same time, juvenile foliage (whether of seedlings or suckers) is most valuable: Yet here we have additional evidence pointing to the conclusion that every character in Eucalyptus is unstable. 
2. E. macrorrhyncha, F.y.M. (See E. macrorrhyncha.)

3. E. Muelleriana, Howitt. (See E. Muelleriana.)

4. E. piperita, Sm.

In the "Flora Australiensis" E. cugenioides is reduced to a variety of E. piperita, but it has since been shown to be an undoubtedly good species, its affinities being more with E. capitellata than with E. piperita. From the latter it is easily distinguished in the living state by the strong fibrous character of the bark which extends to the small branches, the other species having a bark of the texture of $E$. amygdalina, and being only half-barked in general like $E$. pilularis. The fruits of $E$. piperita are more contracted at the top with a thin rim, whereas those of $E$. eugenioides have a well-marked rim, sometimes flat, but generally raised. The juvenile foliage and timber are also very different.

Following are the reports on the Stringybark oils dealt with in this Part, taken from Messrs. Baker and Smith's "Research on the Eucalypts." Each form was only subjected to one or at most two distillations:-

\begin{tabular}{|c|c|c|c|c|c|c|}
\hline Species. & $\begin{array}{l}\text { Whence } \\
\text { obtained. }\end{array}$ & $\begin{array}{l}\text { Specific } \\
\text { Gravity at } \\
15^{\circ} \mathrm{C} .\end{array}$ & $\begin{array}{l}\text { Specific } \\
\text { Rotation } \\
{[a]} \\
D\end{array}$ & $\begin{array}{l}\text { Saponifica- } \\
\text { tion } \\
\text { Number. }\end{array}$ & $\begin{array}{l}\text { Solubility } \\
\text { in } \\
\text { Alcohol. }\end{array}$ & Constituents found. \\
\hline capitellata, Sm. ... & $\begin{array}{l}\text { Canterbuxy, } \\
\text { Sydney, } \\
\text { N.S.W. }\end{array}$ & 0.9175 & $+4 \cdot 8^{\circ}$ & $4 \cdot 27$ & $1 \mathrm{vol} .80 \%$ & $\begin{array}{c}\text { Eucalyptol, pinene, } \\
\text { phellandrene,* } \\
\text { sesquiterpene. }\end{array}$ \\
\hline $\begin{array}{l}\text { Muelleriana, Howitt } \\
\text { (as E. lavopinen, } \\
\text { R. T. Baker). }\end{array}$ & $\begin{array}{l}\text { Rylstone, } \\
\text { N.S.W. }\end{array}$ & 0.8755 & $\begin{array}{l}-46.74^{\circ} \\
\text { (first frac- } \\
\text { tion). }\end{array}$ & $7 \cdot 0$ & Insoluble & $\begin{array}{l}\text { Pinene (lrevo-rota- } \\
\text { tory). }\end{array}$ \\
\hline $\begin{array}{l}\text { Do. (as E. (lexiropinea, } \\
\text { R. T. Baker). }\end{array}$ & $\begin{array}{l}\text { Barber's } \\
\text { Creek and } \\
\text { Currawang } \\
\text { Creek, } \\
\text { N.S.W. }\end{array}$ & $\begin{array}{c}0.8758 \\
\text { to } \\
0.8778\end{array}$ & $\begin{array}{l}+38 \cdot 18^{\circ} \\
\text { to } \\
+39.59^{\circ}\end{array}$ & $22 \cdot 9$ & Insoluble & Pinene, esters. \\
\hline $\begin{array}{l}\text { Wilkinsoniana, R.T. } \\
\text { Baker. }\end{array}$ & $\begin{array}{l}\text { Barber's } \\
\text { Creek, } \\
\text { N.S.W. }\end{array}$ & $0 \cdot 89 \div 4$ & $-23 \cdot 9^{\circ}$ & $5 \cdot 0$ & Insoluble & $\begin{array}{l}\text { Pinene (lævo-rota- } \\
\text { tory), eucalyptol. }\end{array}$ \\
\hline nigra, R. T. Baker... & $\begin{array}{l}\text { Woodburn, } \\
\text { N.S.W. }\end{array}$ & 0.87 .14 & $-38 \cdot 88^{\circ}$ & $7 \cdot 2$ & Insoluble & $\begin{array}{l}\text { Phellandrene, } \\
\text { eucalyptol. }\end{array}$ \\
\hline $\begin{array}{l}\text { macrorrhyncha, } \\
\text { F.v.M. }\end{array}$ & $\begin{array}{l}\text { Rylstone } \\
\text { district, } \\
\text { N.S.W. }\end{array}$ & 0.9290 & $\begin{array}{l}-1 \cdot 11^{\circ} \\
\text { (first frac- } \\
\text { tion). } \\
\end{array}$ & $8 \cdot 36$ & $\begin{array}{c}1 \frac{3}{4} \text { vols. } \\
70 \%\end{array}$ & $\begin{array}{l}\text { Eucalyptol, phellan- } \\
\text { drene, eudesmol, } \\
\text { pinene. }\end{array}$ \\
\hline eugenioides, Sieb. ... & $\begin{array}{l}\text { Canterbury, } \\
\text { Sydnes, } \\
\text { N.S.WV. }\end{array}$ & $\begin{array}{c}0.9122 \\
\text { to } \\
0.9132\end{array}$ & $\begin{array}{c}+3 \cdot 74^{\circ} \\
\text { to } \\
+5 \cdot 246^{\circ}\end{array}$ & 6.89 & $\begin{array}{l}1 \text { vol. } 80 \% \\
\text { but solu- } \\
\text { bility in- } \\
\text { creases on } \\
\text { keeping. }\end{array}$ & $\begin{array}{l}\text { Pinene, eucalyptol, } \\
\text { sesquiterpene. }\end{array}$ \\
\hline
\end{tabular}

On these figures, E. capitellata and E. Eugenioides are very closely related. I invite attention to the relationships of the other species on the figures given; they can be discussed in a chemical or pharmaceutical journal.

* This terpene (phellandrene) alters much, occurring in small quantities in many Eucalyptus oils at certain seasons of the year, while at other times it is abseat (H. G. Smith). 


\section{DESCRIPTION. \\ E. marginata, Sm.}

Trans. Limn. Soc. vi, 302 (1802). B.Fl. iii, 209.

FIGURED and described in "Eucalyptographia." See also Diels and Pritzel, Engler's Jahrb., 1904, p. 439.

A full account of its economic uses will be found in Maiden's "Useful Native Plants of Australia" (1889).

Following is the original description :-

Marginata, operculo conico magnitudine calycis, umbellis lateralibus, foliis ovatis margine incrassatis. E. marginata, Donn. Herb. Cant. ed. 2. 101 (?)

Ir. Aiton favoured me with specimens of this plant three years ago from Kew Gardens. The seeds were brought from Port Jackson. Its leaves agree very much in form with those of E. robusta (next to which it ought to be placed), but the foot-stalks are shorter, veins more prominent, and the margin more thickened, somewhat cartilaginous, and reddish. The umbels are solitary, axillary, and simple. Flowers scarcely one-third the size of the robusta, and their covers are neither broader than the calys, nor longer; neither are they contracted in the middle. The flowers much resemble those of my E. pitularis, but the leares are totally different.

Aiton, Hortus Kewensis, iii, 192, calls it "Thick-edged Eucalyptus," and stated that it was introduced to Kew, in 1794, by seeds obtained from Archibald Menzies, Esq.

Menzies was with Captain Vancouver, who visited South-western Australia, and discovered King George's Sound in 1791. No othei portion of Australia was risited by the expedition, and Smith's statement that the seeds came from Port Jackson is probably a mere slip of the pen or a misunderstanding of what Aiton told him. The matter is also discussed by Mueller (Eucalyptographia) under E. marginata, and there is no donbt that E. marginala, Sm., is the West Australian Jarrah.

\section{SYNONYMS.}

1. E. pedicellata, R.Br. MSS. or "Archl. Menzies"-perhaps as collector only-in Herb. Brit. Museum.

2. E. floribunda, Hügel, Enum. Pl. Hïgel, p. 49 (1837).

Type from "Swan River."

3. E. hypoleuca, Schauer in Lehmann's Pl. Preiss. No. 131 (1814). Preiss. No. 226.

The type came from Wuljenup, district of Plantagenet. 
4. E. Mahogani, F.v.M. Fragm. ii, 41 (1860).

Kalgan River, Oldfield. Leaves rather thick.

I have examined types of all of the above.

Drummond's 85 (5th Coll. ?) has rather broad leaves and is in flower only.

Diummond's 185 (5th) "Swan River to Cape Riche" has small leaves, shiny and coriaceous.

The original pronunciation of the well-known name "Jarrah" is "Yarrah."

Mueller quotes Augustus Gregory as giving "Jerrile" as the aboriginal name; Dr. A. Morrison gives another, viz., "Maalock." Two other species have been sent to me from Western Australia under the latter name.

The thickened margin of the leaf affords a useful diagnostic character, but it is not an infallible guide.

'The seedling leaves are remarkable and have not been previously described. Mr. A. G. Hamilton collected the specimen figured (fig. 1, pl. 40) at Woodlupin Creek, W.A.

The cotyledon leaves are nearly reniform, and when dried are $1 \frac{1}{2}$ inch in greatest width; width of the lamina from the attachment of the petiole continued until the margin of the lamina is reached is 1 inch; length of petiole $\frac{7}{8}$ inch. The cotyledon-leaves and intermediate leaves are glandular-hairy with reddish hairs, lanceolate, and the base of the lamina comes below the point of attachment of the petiole to the lamina.

One of the best known of Australian timber-trees, partly because it is more gregarious than those of most other species of the Australian States. It is a very valuable asset of the Western State, and one of which she can reasonably be very proud.

The bark is rough, not a true Stringybark, but while fibrous it is flaky, furrowed, and somewhat dense in texture.

It is a species with a wide range in Western Australia, and I have nothing to ald to the range indicated in "Eucalyptographia." 


\title{
DESCRIPTION.
}

\author{
E. buprestium, F.v.M.
}

Fragm. iii, 57.

Described in B.Fl. iii, 205, and described and figured in "Eucalyptographia." See also a note by Diels and Pritzel, Engler's Jahrb. 1904, p. 437.

A Western Australian shrub of 8 or 10 feet, named from specimens originally collected by G. Maxwell, south of Kojoneerup, near Helen's Peak and near Salt River and Pallinup River. It is also Drummond's 3rd Coll. Suppl. No. 12.

It has been collected at Stirling's Range by several collectors.

Mueller gives "near Arrowsmith River," so that we have for its habitat the coastal belt from, say, Beaufort Inlet on the south, to the Arrowsmith River on the west coast.

As regards buds, the colour (warm brown) and the shape remind one a good deal of those of E. Baileyana, F.v.M.

The leaves are not dissimilar to those of the smaller ones of those of E. Todtiana, F.v.M., while some of the fruits of the two species are not dissimilar in size and shape, although those of $E$. Todtiana have usually broader rims.

$E$. buprestium is a species of which but few field-notes are available. When it has been examined more carefully and juvenile leaves are seen, we shall be able to speak more definitely of its affinities. 


\section{DESCRIPTION. \\ E. sepuleralis, F.v.M.}

In Dec. viii "Eucalyptographia" (1882).

I HAVE no specimens other than a portion of the type, and have nothing to add to the description as given in "Eucalyptographia."

But I would point out that the precise position of this species is still unknown, and will remain so until seedlings are raised. I trust, therefore, that seeds will soon be again available.

Mueller places it next to $E$. buprestium while drawing attention to the anthers, which are indeed one of the connecting links between the Renantheræ and the Parallelantheræ. I would suggest that the true affinity may be with $E$. erythronema, Turcz., from which it is sharply separated by the fruits; but leaves, anthers, and even buds show resemblance.

Work to show the affinities of the species of this extensive and perplexing genus is much desired. At present many of the species have been described without due reference (often data were not available) to their congeners.

\section{The limitations of Morphology and record of Oil-constituents considered in regard to the determination of species of Encalyptus.}

I THINк I have fairly shown that the present group of species, the Stringybarks, exhibits variation in a most marked degree. It is, therefore, opportune to again* deal with the subject of variation in the genus. Darwin has uttered the dictum that species of the larger genera in any country vary more than the species of the smaller genera. $\dagger$ Experience with the large genus Eucalyptus certainly bears out the truth of this dictum. Hooker's paper \$ may be profitably studied in this connection.

Variation can be studied from three standpoints:

1, Selection;

2, Hybridisation, or crossing;

3, Mutation;

and all of them, in my view, are operative in the genus Eucalyptus, accounting in varying degree for the innumerable variations so far observed.

"Sec, for example, "Is Eucalyptus variable?" Proc. Roy. Soc. N.S. W., xxxvi, 315.

+Origin of Species, chapter ii.

¥ "On the General Phenomena of Yariation in the Vegetable Kingdom." Introduetory essay to Flora of Tasmania, $\mathrm{V}$ 
Selection.-This is Darwin's expression for what Herbert Spencer has termed the "survival of the fittest." This selection can be aided by man, but most of the variations already noted in the genus refer to naturally-grown forms.

Darwin's view was that of all the eauses which induce variability, excess of food is probably the most powerful.*

Hybridisation is a term implying the breeding together of members of different species. The word is derived from the Latin for a mongrel. In other words, two different species must be concerned. The word "crossing" is sometimes taken to imply "the mingling of strains within a species"; but, in view of the unequal relations of varieties and species as often defined, it seems convenient to take hybridisation and crossing together, at all events for our present purpose.

I have dealt with hybridisation as regards Eucalyptus in various publications, $\uparrow$ and need not repeat the facts and inferences at this place.

Mutation or Saltation is the term applied to sudden changes of characters for which no immediate cause is apparent. The phenomena were first largely investigated and brought under notice by Hugo de Vries, of Amsterdam.

The resultant plants or sports are not hybrids, and are produced as the effect of various circumstances which disturb the conditions of a plant. The tendency to alteration is latent in the plant, and stimuli not always clear to us are sufficient to bring out these mutation-forms.

When we speak of the natural or innate tendency of a plant to differ from the remainder of the plants of similar origin, we often refer to mutation-forms.

\section{Tariation in plants induced by environment.}

Let me quote some references by eminent botanists to this subject:-

1. Pseudo-species of Botanists.-Dr. D. Mariano de la Paz Graells . . . adds the following remarks upon some of the many so-called species, which he shows are only modifications due to environment. Thus, of Pyrethrum sulphureum and Dianthus brachyanthus, he writes:-

The polymorphism which these plants acquire at different elevations has given rise to the formation of distinct species, i.e., admitted as such by botanists of note. Studying the original division of $P$. pulverulentum, of Lagasca, and of $P$. sulphureum, of Boissier and Renter, Willkom has united them into one single species, which he has called in his Prodromus Flora Hispanica, P. Hispanicum. In this, he recognises two well-defined gToups, the "pinnatifid" and "laciniate" types, placing in the first group $P$. pulverulentum of Lagasca, and the $P$. radicans of Cavanilles; and in the second, $P$. sulphureum, Boiss. et Rent, which Asio had named Chrysanthemum Aragonense, and C. Bocconi or P. Bocconi, Wal. $P$. versicolor, Willkom; which turns out to be the $P$. sulphureum, var. $P$. alpinum, Boiss. et Rent.

* See "Of the Causes of Variability," chapter xxil of Darwin's Auimals and Plants under Domestication, a most interesting and valuable chapter.

$+e . g .$, "On Hybridisation in the genus Fucalyptus," report vol. $\mathrm{x}$, Aust. Assoc. Adv. Science (Dunedin meeting, Jandary, 1904). This paper contains several bibliographical references.

This work, e.g., V, 140 ; VI, 164; Forest Flora of Nev South Wales; Proc. Linnean Soc. N.S. W., especially 1905, p. 492 ; Victorian Naturalist, xxi, 114, 116.

See also Maiden and Cambage, Proc. Linn. Sac. N.S.W., 1905, p. 199.

+ Compare my Donedin paper (already cited), p. 297 ; also wy paper, "The Variability of Eucalyptus under Cultivation," Proc. Linn. Soc, N.S.W., 1904, p. 887. 
The same thing has happened with Dianthus brachyanthus, Boiss. et Rent., which Xatar and Maill took to be $D$. attenualus, Benth., in the Pyrenees, and Koch for D.virgineus; such mistakes being due to the modifications produced by varying elevations. In some cases the very same organs become atrophied or disappear, while in others they become much more developed than usual.*

2. The especially characteristic features of alpine plants, as compared with similar or allied plants growing at lower levels, are a dwarfing in size and compactness of growth, sometimes giving rise to a moss-like appearance; a more intense green colour in the leaves, and greater brilliancy and size in the flowers; an increased hairiness of the leaves, and occasionally a certain degree of fleshiness of the tissues. $\dagger$ Now, by growing lowland plants at high altitudes, Bonnier, $\ddagger$ Flahault, $\S$ and others have shown that such characters as these may be rapidly acquired. For instance, Bonnier made observations on Teucrium Scorodonia for no less than eight years, and he found that this plant, when sown at a high situation in the Pyrenees, produced very short aërial stems, with more hairy and darker green leaves, and more compact inflorescence. On the other hand, seeds gathered from plants growing at high altitudes, and sown in Paris, after three years produced elongated stems, with less hairy and brighter green leaves, or plants very similar to those from seeds obtained in the neighbourhood of Paris.||

3. Existing floras exhibit only one moment in the bistory of the earth's vegetation. A transformation which is sometimes rapid, sometimes slow, but always continuous, is wrought by the reciprocal action of the innate variability of plants, and of the variability of the external factors. I

\section{And again :-}

4. There are, further, some species-and this fact is as important to the systematist as to the physiologist-which adapt themselves to the varying conditions of humidity so completely that their extreme forms appear to belong to different species, but thest by a change in the supply of moisture may pass over into one another,**

5. Every plant . . . occupies its place in the order of nature by the action of two forcesthe inherent constitutional life-force with all its acquired habits, the sum of which is heredity; and the numerous complicated external forces or environment. To guide the interaction of these two forces . . . is, and must be, the sole object of the breeder, whether of plants or animals. $\dagger \dagger$

6. The combination and interaction of these innumerable forces embraced in heredity and environ. ment, have given us all our bewildering species and varieties, none of which ever did or ever will remain constant. + t

7. Bringing a species into a new environment disturbs its fixity. Rich soil especially gives rise to variations in growth which seems to be new, and by repetition become inherently fixed. Sometimes ancestral states are brought about by good soil; sometimes (perhaps oftener), also by starvation; new variations oftenest by rich soil and general prosperity.S\$

\section{Tariation is going on now.}

Authors sometimes argue in a circle when they state that important organs never vary; for these same authors practically rank that character as important (as some few naturalists have honestly confessed) which does not vary; and, under this point of view, no instance of an important part varying will ever be found; but under any other point of view many instances assuredly can be given.||f|

\section{And again :-}

I will add another remark: Naturalists continually assert that no important organ varies; but in saying this they unconsciously argue in a vicious circle; for if an organ, let it be what it may, is highly variable, it is regarded as unimportant, and under a systematic point of view this is quite correct. But as long as constancy is thus taken as a criterion of importance, it will, indeed, be long before an important organ can be shown to be inconstant. 99

- Origin of Plant Structures. Henslow, 112.

† Compare, also, in this connection, my $A$ second contribution towards a Flora of Mt. Kosciusko, Agric. Gazetle, $N . S . W .$, Oct., 1899 .

$\ddagger$ Ann. Sci. Nat. Bot., vii série, xx, p. 217, 1894 .

$\S A n n . S c i$. Nat. Bot., p. 159, 1879, and Rev. Gén. de Bot., ii, p. 513, 1891. I| Variation in Animals and Plants. H. M. Vernon, p. 311. II Plant Geography. Sehimper, p. v. - Ib. p. 3. H Hundamental Principles of Plant Breeding. L. Burbank, p. i. $\quad+\ddagger 1 b$. p. 3. \$\$ Some experiments of Luther Burbank. D. S. Jordan, p. 205. IIII Origin of Species. Darwin, p. 46. शाT Animals and Plants under Domestication. Darwin, vol, i, p. 359. 


\section{Reputed constancy of characters in Eucalyptus.}

The following statements have been made :-

1. "Comparative constancy of specific characters of Eucalyptus species but it is indiridual species that we maintain show a comparative constancy of specific characters throughout their known geographical distribution." (Messrs. Baker and Smith.)

And again :-

2. "The reputed or supposed great variation of individual Eucalyptus species has probably arisen by the attempts of botanists to found species on morphological characters alone." (The italics are not mine.)

Two points are involved in this statement:

(a) The reputed invariability (or in other words, the "comparative constancy") of species of Eucalyptus;

(b) The founding of species on morphological characters alone.

Real genetic relationships take cognisance of all the characters.

Some of the items in regard to which I always endeavour to obtain informa. tion as regards any particular species of Eucalyptus are as follows :-

Shape of juvenile leaves; venation and mature leaves; principal constituents of oil ; anthers; fruit; bark; timber; kino; habit; any other character.

I attach great importance to studying the trees in the field. In this way habitat, habit, size, bark, timber, can best be studied.

In these researches I may be pardoned for saying that I have travelled more or less in every State of the Commonwealth, covering thousands of miles on foot in pursuit of this study alone, in contradistinction to mere herbarium work.

This is one way of learning what are "natural" species, and affinities and dissimilarities can be largely learned in this way. I have, indeed, inaugurated on a comprehensive scale the study of genetic relationships in Eucalypts, and have always deprecated the study of this genus from herbarium specimens or "morphological characters alone."

The extracts from the writings of eminent botanists are pertinent in this connection :-

1. It is clear that at present the question (relation of plants to one another) is very far from settled; indeed, hardly more than a beginning has been made in the establishment of a system which can be said to represent real genetic relationships.*

2. Rather there is an increasing tendency to the view that the solution of plantaffinities, as Linnæus long ago affirmed, must be sought in a comparative study of all the characters. $\uparrow$

3. The idea that morphology has nothing to do with the function of organs has been acquired entirely because the fact has been overlooked that the transformations seen in organs are conditioned by a change of function. Their functions, therefore, have been treated as subordinate in determining the characters of organs; external relations alone have been taken as the chief points for consideration. But the relationships of mere form are by no means the permanent ones in 'the tide of phenomena.' They also change. The determination of this change, that is to say, of the alterations which have taken place, and are believed to take place in the formation of organs of a natural group, is one of the weightiest tasks of organography. If we separate function from form we are at once led into altogether unfruitful speculations.+

* D. H. Campbell, Evolution of Plants, p. 13 .

† A. B. Rendle, The Classification of Flowering Plants, i, p. 28.

\$ Organography of Plants. Goebel. Part i, p. 12. 
I repudiate any suggestion that the taxonomic evidence afforded by the morphology of plants can be intelligently studied except in connection with such physiological evidence as may be available.

\section{At the same time, the classifactory characters must be mainly morphological.}

"But in his clear definition of the principles which must guide the worker who is seeking a true natural system, De Candolle did work of far greater value. He pointed out that characters which are of the utmost importance to the life-functions of the plant are useless from a systematic point of view. In a word, it is to morplology, and not to physiology, that we must look for aid in establishing relationships."

\section{Oil an accessory or adaptive character.}

The essential oils are accessory substances, and, may I repeat it, variable like everything clse connected with Eucalyptus.

1. The chemical qualities, odours, and tissues of plants are often modified by a change which seems to us slight. The Hemlock is said not to yield conicine in Scotland. The root of the $\boldsymbol{A}$ conitum napellus becomes inuocuous in frigid climates. The medicinal properties of the Digitalis are easily affected by culture. The Rhubarb flourishes in England, but does not produce the medicinal substance which makes the plant so valuable in Chinese Tartary. As the Pistacia lentiscus grows abundantly in the south of France, the climate must suit it, but it yields no mastic. The Laurus sassafias in Europe loses the odour proper to it in North America. Many similar facts could be given, and they are remarkable because it might have been thought that definite chemical compounds would have been little liable to change either in quality or quantity. $f$

2. Just as the presence and quantity of opium, hasheesh, aconitine, \&c., secreted by plants, vary greatly with the climate, so it is reasonable, in the absence of strict investigations, to assume that these oils are in an excess through the intense heat, and other conditions of the climate of deserts. :

3. Interesting as is this correlation of morphology and constituents in the Eucalyptus species, it may be pointed out that a knowledge of the constituents of a plant is never likely to play such an important part in systematic botany as the authors appear to believe, since there are already known numerous instances of plants which, grown under different climatic conditions, show no morphological change, yet exhibit remarkable variation in constituents, and, on the other hand, plants which are not at all closely related frequently contain the same colouring matters, alkaloids, etc., so that the necessary specific constancy of constituents, which alone would make such criteria useful, is wanting. The authors lay stress on observations made by them as to the absence of marked variation in the composition of oils yielded by the same Eucalyptus species grown in different districts of Australia; but the evidence of constancy in this respect would be greatly strengthened if it could be shown to hold for the same species outside Australia. For an investigation of its kind ample material now exists in foreign plantations.\$

The cases of the Peppermint and Lavender, both plants yielding essential oils, are notorious. Science has not yet established a connection between morphological characters and oil-yields in these cases.

It is only necessary to consult any good work on essential oils, say Die etherischen Oele, E. Gildemeister and Fr. Hoffmann (Julius Springer, Berlin), of which the authorised translation is The Tolatile Oils, by Edward Kremers (Pharm. Review Co., Milwaukee, U.S.A.), and especially Schimmel's Semi-annual Reports

- Rendle's Flowering Plants, vol. i, p. 12. Page 16 of this work may also be referred to.

† Animals and Plants under Domestivation. Darwin, vol. ii, p. 274.

* Origin of Plant-structures. Henslow, p. 82 .

$\$$ Review on "A Research on the Eucalypts, especially in regard to their Essential Oils" (Baker and Smith), by Dr. T. A. Henry, in "Nature," vol. 67, April 2nd, 1903, p. 525. 
(Berichte) to be satisfied that the chemical composition and physical properties of essential oils of ascertained botanical origin often vary considerably for the same species.

Oil determinations are usually difficult to apply for purposes of diagnosis. Similarly, in Radlköfer's Monograph of the Sapindaceæ, I find it difficult to accept such characters for the genera as, "fruit contains saponine; fruit without saponine."

In Eucalyptus in a given species there is variation in regard to the constituents of the oil. For example, as regards E. Wilkinsoniana, P. T. Baker:

At many different times of the year the oil contains small quantitios of Eucalyptol; at other times, however, some phellandrene; it contains, moreover, a small amount of ester.

It is an invidious task to be the judge as to the amount of chemical variation which will be admitted as evidence of the ralidity of a botanical species.

E. rostrata, Schlecht, var. borealis, Baker and Smith, and E. lavopinea, R. T. Baker, var. minor, R. T. Baker (E. Wilkinsoniana, R. T. Baker) have been founded "on chemical evidence alone," or mainly. I do not say that morphological evidence will not be forthcoming to justify this nomenclature, but it is not available yet, and it has been specially sought for. There are two ways of looking at this matter; one way is to endeavour to ascertain the position of a plant by morphological methods, and then to ascertain if the evidence supplied by physiology supports the view arrived at; or physiological evidence (e.g., based on examination of essential oil) may first be examined, and the morphological facts then brought under review.

\section{Is the oil character the one invariable?}

In a case such as the Stringybarks (to choose one group out of many) where there is an infinite gradation of forms, the result of environment, hybridisation, and perhaps other causes, the suggestion that in the oil there is a master-key to the limitation of species seems to be based on a shifting foundation.

The suggestion that we have at length discovered a kind of philosopher's stone is indeed alluring; that in all the manifold changes of Eucalyptus that we have at length obtained a test by which we can diagnose a species is tempting, but the test will only be found to be general in application, like those applied to the timbers.

As to the variation in timber in the genus, that is the experience of any man who has much to do with it. I do not wish to quote the views of the bush-worker, who is often ignorant and empirical; at the same time, many of them are very shrewd. The timber-inspector and the timber-merchant, who have broader views, however, both share this view.

The composition of the oil is not the only character other than that usually employed to aid the botanist in the diagnosis of Eucalypts. For example, I restored E. exserta, F.v.M., to specific rank, following up a clue given to me by the timber. 
That there are limitations in regard to the interpretation of morphological characters for the purposes of taxonomic research, I at once admit. Following is a very good example of such searching after the light:-

"As soon as three Orchidean forms (Monochanthus, Myanthus, and Catasetum) which had previously been ranked as three distinct genera, were known to be sometimes produced on the same spike, they were immediately included as a single species." *

A botanist often has to work on incomplete material, and to unduly disinter the mistakes of morphologists, some of which (as regards Eucalyptus) have been made before the era of exhaustive field investigations on the genus inaugurated by myself, would be as unnecessary as to point out the mistakes of scientific discoverers in any other branch of science, who, by their work, have paved the way to research on higher planes.

\section{Variation in oil.}

The variation in oil constituents within the same species has already been referred to. To consider another aspect of the question, a man, when he makes a distillation, which costs much trouble and expense (which is certainly the ease with Eucalyptus oil) is apt to stereotype its results; whereas, if he could make a hundred times as many distillations he could take a broader view of the variability of the oils.

Thousands of distillations require to be made before oil results can be based on material as varied as that on which the systematists referred to as "morphologists" base their conclusions.

The distillations of Eucalyptus oils from material of authenticated botanical origin, were inaugurated by me with the view (inter alia) of obtaining authentic Eucalyptus oils for therapeutic and other purposes, and also of ascertaining to what extent the oils could be used as aids in the diagnosis of species.

Researches on Eucalyptus oils may, however, be employed for two ends :-

1. Acquiescence in the naming of existing species (e.g., E. saligna and E. botryoides).

2. For the naming of new species.

As regards (1) if the premises be wrong,-if it should prove that $E$. saligna and $E$. botryoides are identical species, what becomes of the statement that the oils show them to be distinct?

If the answer be that there is some innate principle in these two trees that morphology does not reveal, then we require very strong evidence that the alleged oil differences are real and not apparent. But I have already touched upon this point.

It seems to me that an important difference between the morphological and the oil-system determination is this :-

In morphology you have a fixed standard termed the type.

In oils you have no fixed standard, the oil-constituents being variable within limits not yet determined and perhaps indeterminable. 
This brings one to ask:-What variation in amount of a constituent, or what constituent must be present or absent in any particular case to constitute a valid species ?

\section{Classification on oils alone associates dissimilar species.}

We should reflect when we find it stated that the oils from $E$. bicolor, A. Cunn., are similar to those attributed to "E. bicolor," and which are really the product of $E$. Bosistoana, F.v.M. If this should be founded on fact, then it proves that species with different genetic relationships resemble each other in oil-constituents.

The classification based on oils alone places certain species and their varieties in different groups, e.g.-
E. sideroxylon, A. Cunn.
E. Stuartiana, F.v.M.
E. tereticornis, Sm.
E. rostrata, Schlecht.

It also brings together species which perhaps every other classification shows us do not exhibit close affinity. Instances of this can be quoted at any time.

To sum up, I think that characters based on the essential oils are subject to variation. They do not escape the interacting laws of change any more than morphological characters do.

\section{Explanation of Plates (37-40).}

\section{PLATE 37.}

E. capitellata, Sm.

1. Fruits (misplaced by White) of $E$. capitellata in White's "Voyage," 1790, p. 226, of the "Peppermint Tree."

2a. Leaf; 2b, pointed operculum and flowers of a specimen from Dr. (J. E.) Smith, ex herb. Lambert in herb. Cant. Piece of the type of the species.

3a. Leaf; $3 b$, buds, of R. Brown's E. congesta from Port Jackson.

4a. Pair of juvenile leares; $4 b$, pair of leaves in the alternate stage, showing the orbicular shape. From Middle Harbour, Port Jackson.

5a. Buds; 55 , anthers; $5 c$, fruits, from Oatley, George's River, a few miles south of Port Jackson.

6a. Leaf; $6 b$, buds; $6 c$ and $6 d$, fruits. All from the same tree, North Shore, Port Jackson. Note the variation in the amount of exsertion of the valves, and the similarity of $6 d$ to 1.

[N.B.-All the above are practically identical.]

7a. Buds; $7 b$, fruits, from Guy Fawkes, New England.

8a. Juvenile leaves in the alternate stage; $8 b$, mature leaf; $8 c$, buds; $8 d$, fruits of E. capitellatn, var. (?) latifolia, Benth. (B.Fl. iii, 206). Portland, Vic., J. G. Robertson, 1842.

9a. Leaf; 9b, buds; 9c, fruits of E. santalifolia var. Baxleri, Benth. Portland, Vic., J. G. Robertson, 1842. 10a, Leaf, with buds attached; 10b, fruits of E. capitellata, Portland, Vic. Mr. Adams, through A. E. Kitson, 1901.

11a. Leaf and buds; 11b, fruits. Sandy rises, Narracoorte, South Australia (W. Gill, 5/01).

12a. Leaf; 12b, rugose buds, simulating E. alpina; 12c, fruits, Grampians, Victoria, 2,000 feet. (H. B. Williamson.) 


\section{PLATE 38.}

\section{E. capitellata (left hand of Plate, Nos. 1 to 9).}

1a. Buds, with rugged operculum; $1 b, 1 c, 1 d, 1 e, 1 f$, fruits, all gathered from the same tree at Mt. Lofly, near Adelaide (Max Koch). Displaying a considerable amount of variation in exsertion of valves.

2a. Pair of seedling leaves; $2 b$, buds ; $2 c$, fruits from Osler's Creek, Gippsland, Victoria (A. W. Howitt). A seedling from the same tree was figured by Howitt at fig. 2, pl. 14, Trans. Roy. Soc. Vict., 1890-1. Mature leaves broadish. Specimens collected by Howitt at Wandin Yallock, and King Parrot Creek are identical.

3a. Juvenile leaves; $3 b$, buds; $3 c$, fruits, Blackheath, New South Wales (J.H.M. and R. H. Cambage), of the Blue Mountains form described at p. 216.

4a. Juvenile or intermediate leaves; $4 b$, buds; $4 c$, fruits, of the form from the Outer Domain, Sydney, described at p. 217.

5. Leaf, buds and early fruits of the " $E$. dumosa" (Benth. non A. Cunn.) Blue Mountains, New South Wales (Backhouse), B.Fl. iii, 230. It is a twig of $E$. capitellata with small leaves, such as is common enough. [The venation in the small leaves of the specimen resembles that of $E$. incrassata, var. dumosa a good deal.]

6a. Juvenile leaves; $6 b$, fruits of the "Blue-leaf Stringybark" described at p. 215. Hill Top, New South Wales (J.H.M.).

$7 a$. Buds ; $7 b$, fruits of the E. eugenioides transit to $E$. capilellata, described at p. 216. Berrima, New South Wales, 9,01 (J.H.M. and J. L. Boorman).

$8 a$ and $8 b$, buds; $8 c$. fruits. Wingello, New South Wales, $8 / 99$ (J.H.M. and J. L. Boorman). $8 a$ and $8 b$ are from the same twig! $8 a$ is typical for capitellata, while $8 b$ would readily be pronounced eugenioides. I look upon this as small-fruited capitellata, and it is discussed at p. 215.

9a. Buds; 9b, small fruits, with well exserted valves. Booral, New South Wales (A. Rudder). I look upon this as a small-fruited form of $E$. capitellata, and it is described at p. 214.

\section{E. Muelleriana and allies (Nos, 10 to 18 ).}

10a. Buds and flowers; 10b, fruits. "Red Stringybark." Walcha, New South Wales (A. R. Crawford).

11a. Buds and flowers; $11 b$, fruits. Nundle, New South Wales (J. L. Boorman).

12a. Leaf; 12b, buds (yellow); 12c, fruits. Attunga, 12 miles north-west of Tamworth, New South Wales (R. H. Cambage).

13. Fruits. Harding's Mill, near Glen Innes, New South Wales (H. Deane).

10-13. Are all from the northern table-land. The fruits are all nore or less pear-shaped. 11 is more conoid than the rest. 13 is not fully ripe. They are obviously closely-allied forms, and I have no doubt that they are transit forms between $\boldsymbol{E}$. macrorrhyncha and $\boldsymbol{E}$. Muelleriana. I place them with the former species for the reasons stated at p. 229 ; but I think it is useful to contemplate their aftinity with the latter.

14a. Buds; $14 b$ and $14 c$, fruits, all obtained from the same tree. Kanimbla Valley, Lowther Road, New South Wales (A. H. S. Lucas and J.H.M.) Note the narrow rims of $14 b$, which resemble those of $E$. nigra, R. T. Baker. The rims of $14 c$ are much broader. I think the plant is a small-fruited form of $E$. Muellerinna, but other botanists may place it under $E$. eugenioides.

15a. Buds; $15 b$, fruits of type of E. nigra, R. T. Baker. Woodburn, Richmond River (W. Baeuerlen). Compare $15 b$ and $14 b$. I look upon E. nigra as a transit form between E. Muelleriana and E. engenioides.

16a. Leaf in the intermediate stage; $16 b$, mature leaf; $16 c$, buds, inclined to be angular; $16 d$, fruits. Stanthorpe, Queensland. "The common Stringybark of the district" (A. Murphy). I look upon this as a small-fruited form of $E$. Muelleriana, showing transit to $E$. eugenioides.

17a. Buds; $17 b, 17 c, 17 d$, fruits taken from the same tree of type of $E$. Wilkinsoniana, R. T. Baker. (E. lovopinea, R.T.B., var. minor.) Glenrock Paddocks, Barber's Creek, New South Wales (H. J. Rumsey).

18a. Buds; 18b, fruits of co-type of E. Wilkinsoniana. Sutton Forest, New South Wales (R. T. Baker). The fruits of $18 b$, with flat rim, are closest to the form shown in $17 b$, and not a stable form. I look upon $E$. Wilkinsoniana as a small-fruited form of. E. Muelleriana, undoubtedly showing transit to $\boldsymbol{E}$. eugenioides. 


\title{
PLATE 39.
}

\author{
E. eugenioides, Sieb. (1-2).
}

$1 a$ and 1b. Juvenile foliage. Armidale (A. W. Howitt). [Note that $1 a$ and $1 b$ are still in the strictly opposite stage, and that they still retain their stellate hairs, yet the difference in the width is remarkable.] $1 c$, buds, inclined to be angular; $1 d$, fruits. For comment on these specimens see pp. 219 and 223 .

$2 a$, Jurenile leares; $2 b$, juvenile leares a stage further, yet not beyond the stellate hairs stage; $2 c$, buds, slightly angular, but in a less adranced stage than $1 c ; 2 d$, fruits, flat-topped. Stanthorpe, Queensland (J. L. Boorman).

[There is no doubt that the Armidale and Stantborpe specimens belong to the same form. I look upon it as E. eugenioides, showing transit to a small-fruited form of E. Muelleriana, and the matter is discussed at p. 219.]

$$
\text { E. macrowhyncha, F.v.M. (3-21). }
$$

3a. Leaf; $3 b$, buds; $3 c$, fruits. Chiltern, Victoria. Seen and named by Mueller.

4. Fruits. Maryborough, Victoria (J. Blackburne).

כa. Leaf; 55 , buds; $5 c$, fruit, Buchan, N. Gippsland (A. W. Howitt). The fruit is nearly typical, but the buds are nearer those of $E$. eugenioides.

$6 x$ and 63 . Two juvenile leaves still in the opposite stage; $6 c$, leaf fron the same place, showing the tufts of stellate hairs on the margin; $6 d$, leaf (same locality), with the hairs enlarged, showing their relative abundance; 6e, fruits; all between Bombala and Delegate, New South Wales (J.H.M.).

7. Buds. Weddin, near Grenfell, New South Wales (J.H.Mr.).

8. Fruits. Hassan's Walls, Bowenfels, New South Wales (J.H.M.).

9a. Buds; 9b, fruits. Wellington, Nerr South Wales (A. Murphy).

10. Fruits. Warrumbungle Ranges, New South Wales (W. Forsyth).

11a. Buds; 11b, large fruits; 11c, seedling raised from the seeds of 11b. Near top of Mount Bulaway, Warrumbungle Ranges, Netw South Wales (W. Forsyth). For notes on these specimens see p. 228.

12a, 12b. Two pairs of juvenile leaves; 12c, buds (capitellata-like); 12d, fruits. Tingha, New South Wales (J. L. Boorman).

13a. Buds, angular, capitellata-like; 13b, fruits. Emmaville, New South Wales (J. L. Boorman).

14a. Buds; 14b, fruits of var. (?) brachycorys, Benth. (Type). New England, New South Wales (C. Stuart).

15. Fruits, with remarkably angular rim. Capertee, New South Wales (J.H.M. and J. L. Boorman).

16. Fruits. Borenore, New South Wales (H. Deane).

17. Fruits. Cootamundra to Grenfell, New South Wales (A. Osborne). Nos. 16-17 closely resemble those of var. brachycorys.

18a. Buds; 18b, fruits, very broad-rimmed, and scarcely angular. Stanthorpe, Queensland (F. M. Bailey).

19a. Buds; $19 b$ and $16 c$, fruits of a grandiflora form. Rylstone, New South Wales (R. T. Baker). Compare this with 15.

20a. Bads; 20b, fruit of E. scyphoidea, Naudin-the type. See p. 226.

$21 a, 21 b$ (at foot of plate). Two pairs of juvenile leaves. Warialda (J. L. Boorman). This is the form of E. macrorrhyncha described at p. 230. It will be observed that these leaves are as narrow as those of $E$. eugenioides ever are. If they were alone, surely they would be referred to E. ergenioides, This form must be studied in conjunction with figs, 10-13 of Plate 38. 


\title{
PLATE 40.
}

\author{
E. eugenioides, Sieb. (except No. 1).
}

1a. Cotyledon leaf; $1 b$, juvenile leaf of $\boldsymbol{E}$. marginatx. Woodlupin Creek, Western Australia (A. G. Hamilton).

2a. Juvenile leaves, just past the strictly opposite stage; $2 b$, mature leaf; $2 c$, anthers, of Sieber's No. 479, type of $E$. eugenioides.

3a. Ripe buds and opening flowers; $3 b$, fruits, with slightly exserted valves, from Homebush, Sydney (J H.M. and R. H. Cambage). The juvenile and mature leaves and flowers are strictly identical with Sieber's No. 479.

4a. Juvenile leaves (note the stellate hairs) in the strictly opposite stage; $4 b$, juvenile leaves a stage further; $4 c$, buds; $4 d$ and $4 e$, fruits taken from the same twig. Blackheath, New South Wales (J.H.M. and R. H. Cambage). The foliage, juvenile and mature, of this tree cannot be distinguished from Sieber's No. 479.

5a. Mature leaf; $5 b$, buds; $5 c$, fruits of Sieber's No. 469, type of his $E$. acervula.

6. Mature leaves and buds of Sieber's No. 583, type of $E$. oblonga, DC. There is a loose fruit attached to this specimen, but I refrain from figuring it because it is detached.

7. Fruits of "White Stringybark," Mudgee district (C. Marriott). Herbarium specimens of this Stringybark are identical with Sieber's No. 583. The fruits I have figured (7) are identical with the detached fruit referred to (6).

$8 a$, Mature leaf (rather broad); $8 b$, buds; $8 c$, fruits (rather large). Hurstville, near Sydney (J. H. Camfield).

9a, Buds; 9b, fruits. Hilltop, New South Wales (J.H.M.). Note the long opercula.

$10 a$, Juvenile leaves; $10 b$, buds ; $10 c$, fruits. Eden, south-east New South Wales (near Victorian border) (A. W. Howitt). Note the breadth of these juvenile leaves as compared with $4 a$, which are near the type. There is, indeed, much variation in the juvenile foliage of $E$. eugenioides.

[Comparing $10 a$ with $4 a$ (Plate 37), we see how different the juvenile foliage is from that of typical $E$. capitellata. But if we also compare $10 a$ with the juvenile foliage of that form of $L$. capitellata depicted at $2 a$ (Plate 38 ), we see how careful we must be not to determine $E$. eugenioides or $E$. capitelluta on juvenile foliage alone. Reference to $2 b$ and 20 (Plate 38) shows that the closer affinity of the plant in question ( $2 a$ of pl. 38) is with $E$. capitellata rather than with $E$. eugenioides.]

11a, Remarkably slender buds; 11b, remarkably small fruits. Walhalla, Gippsland, Victoria (A. W. Howitt).

$12 a$, Very slender buds; 12b, fruits, of the "Yangoura," of the Victorian aborigines (A. W. Howitt). See p. 234.

13a, Long, large buds; 13b, large pedicellate fruits. Agnes Bridge, Victoria (A. W. Howitt).

$14 a$, Juvenile leaf [note its great breadth]; 14b, buds; 14c, small fruits. Wingello, New South Wales (J. L. Boorman).

'15a, Juvenile leaf; 15b, buds; 15c, fruits, showing faint ribbing. Wyee, New South Wales (A. Murphy).

16a, Buds; 16b, fruits, slightly domed, and with exserted valves. Foot of Mt. Lindsay, New South Wales (W. Forsyth).

$17 a$, Rather narrow leaf; 17b, fruits with exserted valves. Near 11 -mile post, Inverell to Tingha (R. H. Cambage). See p. 236.

$18 a$, Juvenile leaves, past the opposite stage [note their great width]; 18b, buds; $18 c$ and $18 d$, fruits, varying in size, exsertion of valves, and width of rim. All from Walcha district (J.H.M. and J. F. Campbell).

19, Fruits, with well exserted valves. Drake, New South Wales (E. C. Andrews).

20, Fruits, with sunk valves. Drake, New South Wales (A. Hagman).

$21 a$, Buds, inclining to be angular; 21b, shallow fruits. Lawrence, Clarence River, New South Wales (J. V. de Coque).

$22 a$, Buds: 22b, fruits, with valves well exserted. Murrurundi (J.H.M. and J. L. Boorman). 


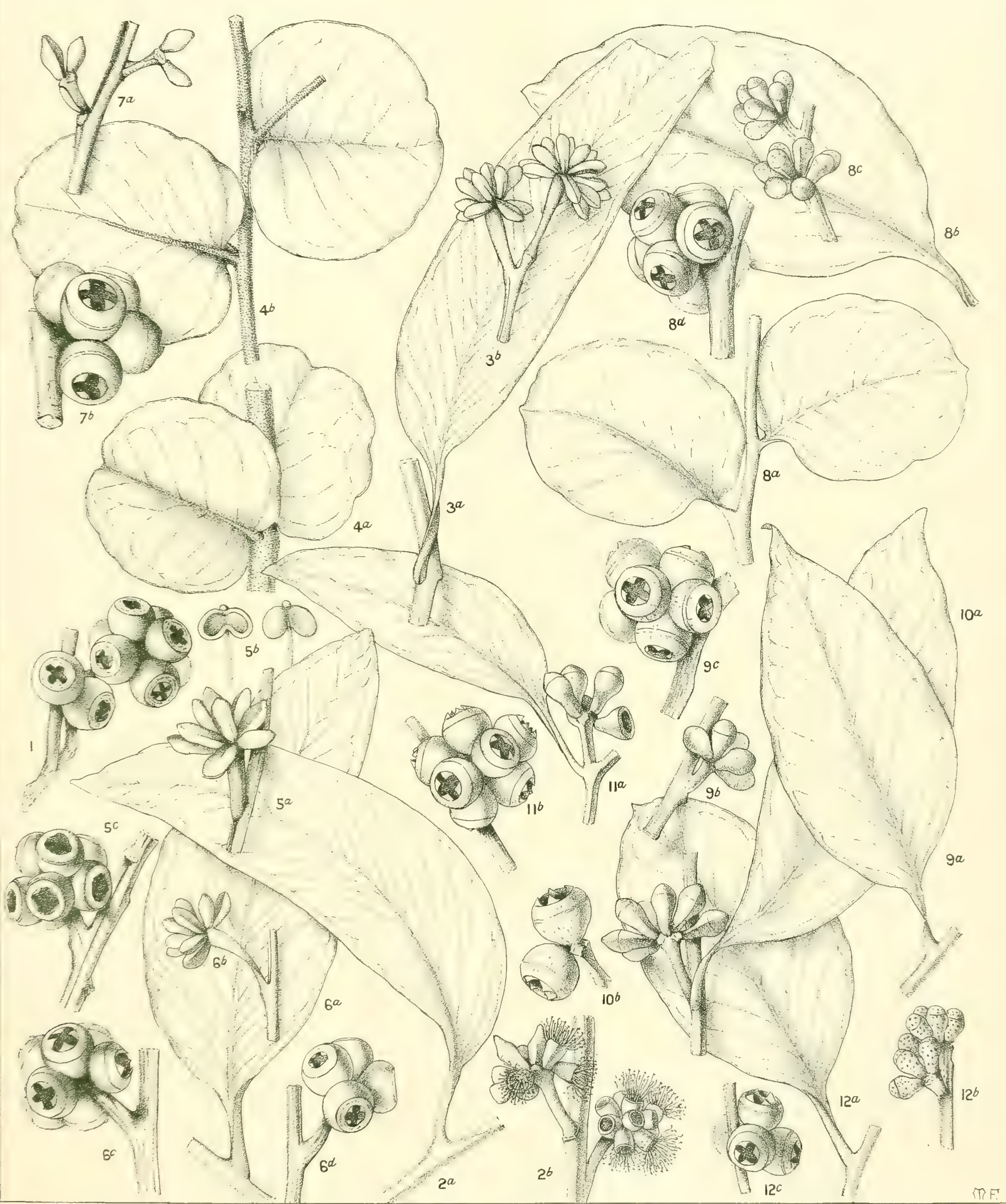





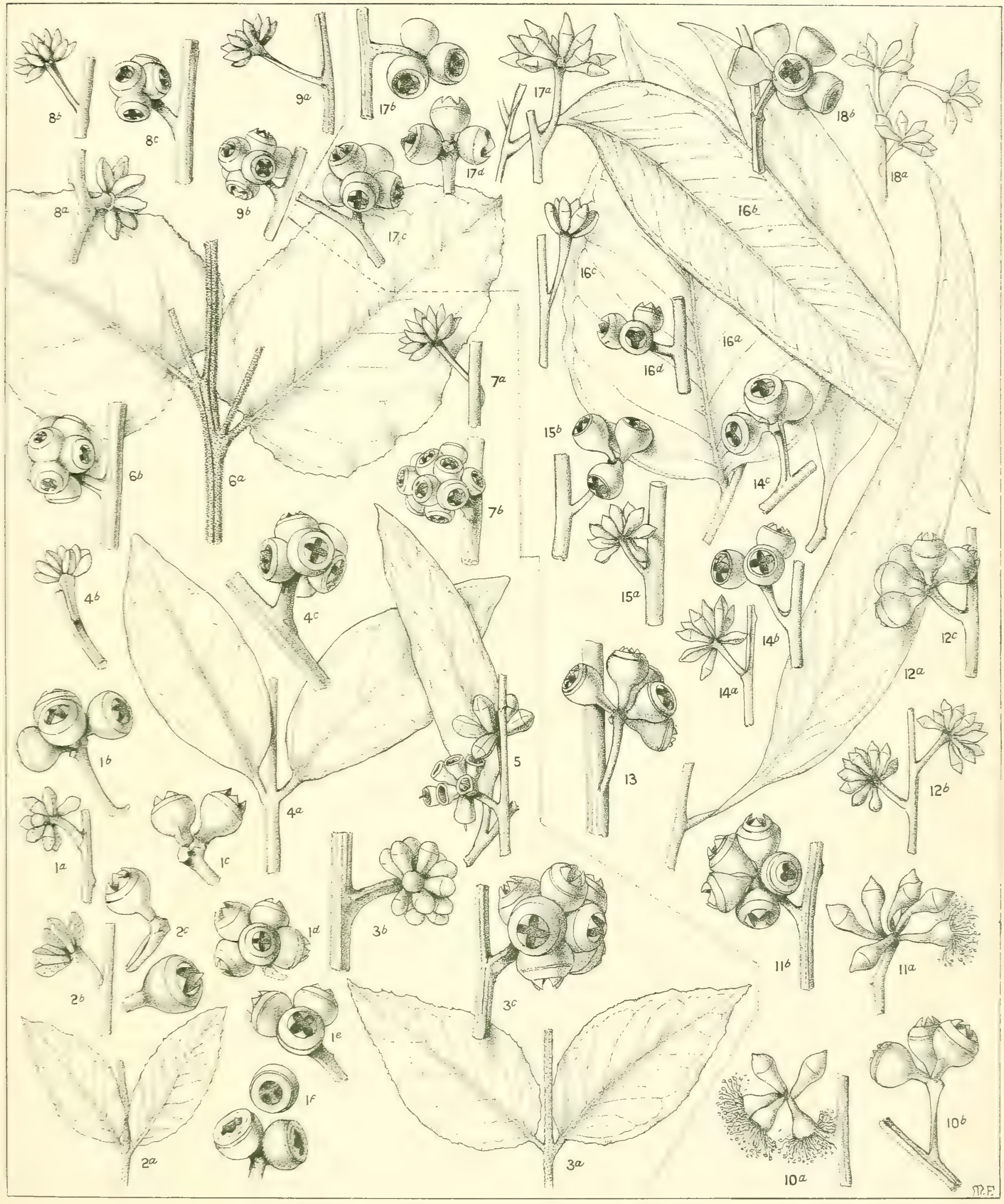

EUCALYPTUS CAPITELLATA, SM. (1-9).

E. MUELLERIANA, HOWITT, AND ALLIES (10-18). 



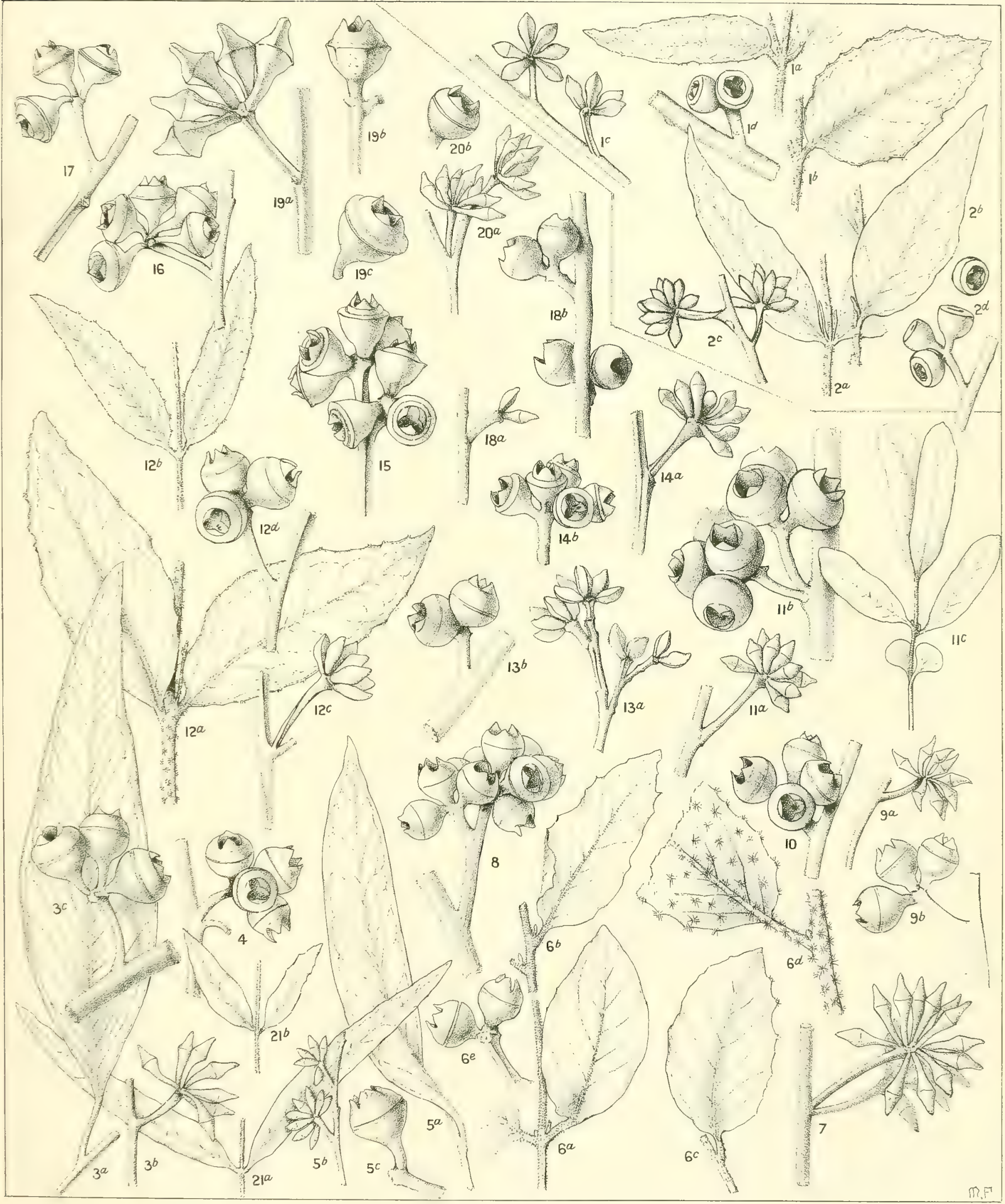

EUCALYPTUS MACRORRHYNCHA, F.v.M. (3-21). 



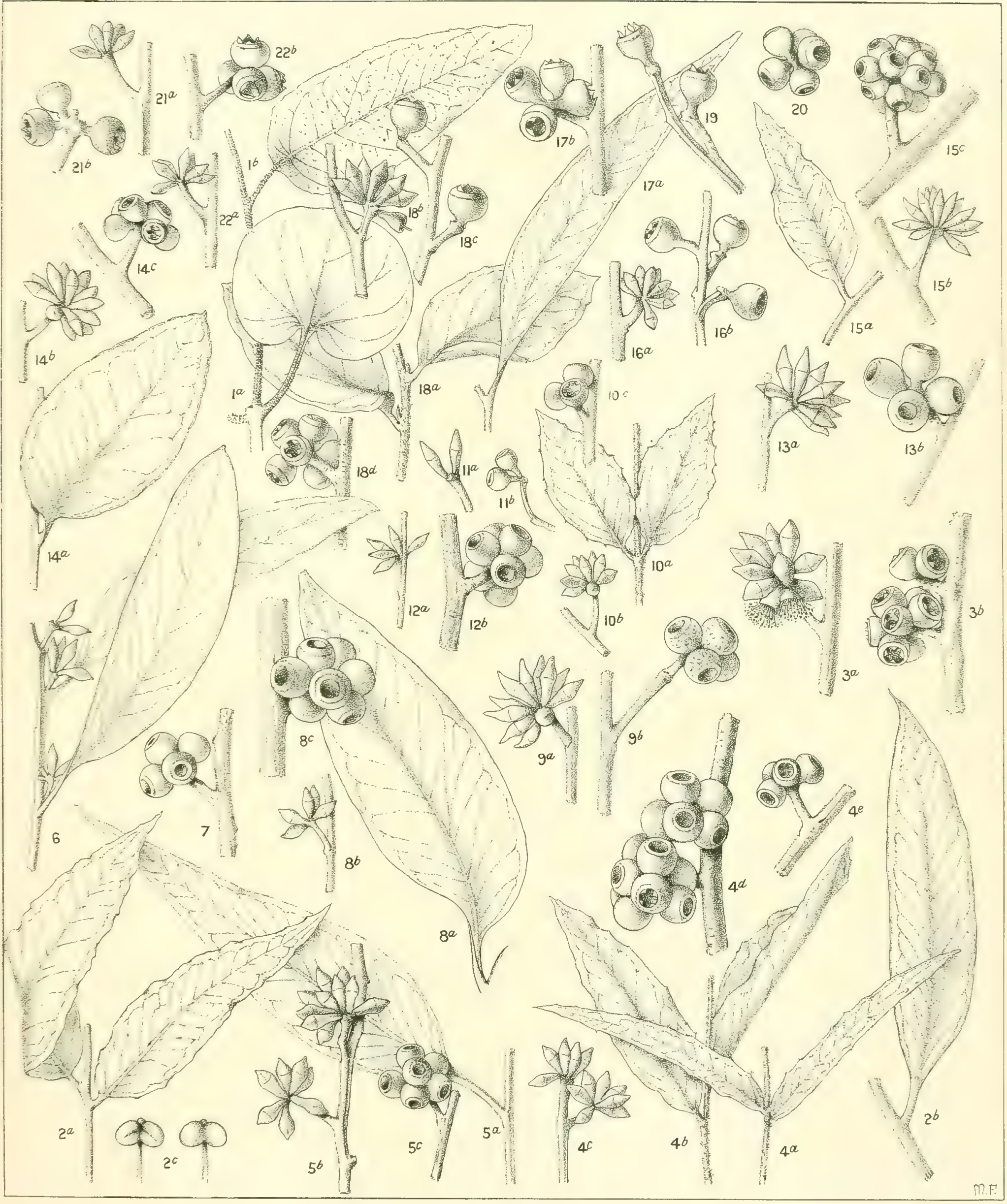

EUCALYPTUS EUGENIOIDES, SIEB.

(with the exception of 1 , which is $E$. marginata, Sm.) 



\section{A CRITICAL REVISION OF THE}

GENUS EUCALYPTUS

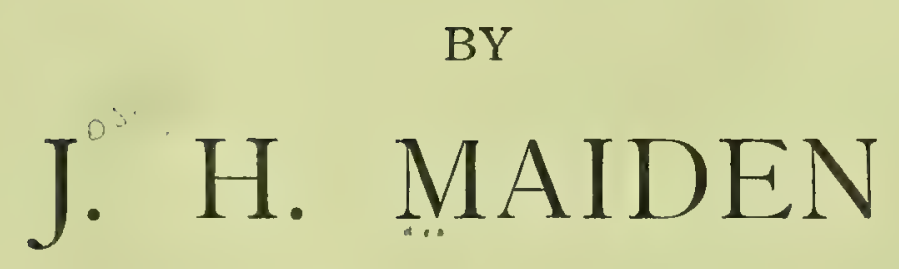

(Government Botanist of New South Wales and Director of the Botanic Gardens, Sydney).

\section{PART IX}

(WITH FOUR PLATES)

Price Two Shillings and Sixpence.

Published by Authority of

THE GOVERNMENT OF THE STATE OF NEW SOUTH WALES.

Sunouren:

WILLIAM APPLEGATE GULLICK, GOVERNMENT PRINTER.

1907. 



\title{
A Critical Revision of the Genus Eucalyptus
}

BY

\author{
J. H. MAIDEN
}

(Gorernment Botanist of Nery South Wales and Director of the Botanic Gardens, Sydney).

\section{PART IX}

(WITII FOUR I'LATES).

"Ages are spent in collecting materials, ages more in separating and combining them. Even when a system has been formed, there is still something to add, to alter, or to reject. Every generation enjoys the use of a vast hoard bequeathed to it by antiquity, and transmits that hoard, augmented by fresh acquisitions, to future ages. In these pursuits, therefore, the first speculators lie under great disadvantages, and, even when they fuil, are entitled to praise."

Macaulay's "Essay on Milton."

\section{PRICE TWO SHILUINGS AND SIXPENCE.}

\section{Singrey :}

WiLIIAM APPLEGITE GULICK, GOVERNMENT PRINTER, PHILLIP-STREET,
$* 2136$
$A$
1907. 

XXIV. Eucalyptus alpina, Lindley.

Description

PAGE.

Notes supplementary to the description . . 259

Range.

Affinities

XXV. Eucalyptus microcorys, F. v. Mueller.

Description . . . . . . . . . 261

Notes suppiementary to the description. , 261

Range. . . . . . . . . . . 26 I

Affinities . . . . . . . . . 262

\section{Eucalyptus acmenioides, Schauer.}

Description . . . . . . . . . . 263

Notes supplementary to the description. . $26_{3}$

Synonyms. . . . . . . , . . . $=63$

Range. . . . . . . . . . . . 265

\section{Eucalyptus umbra, R. T. Baker.}

Description . . . . . . . . . 269

Notes supplementary to the description. . 269

Is it a variety of $E$. acmenioides? . . . . 269

Range

Affinities

XXVIII. Eucalyptus virgata, Sieber.

The name Eucalyptus rigida . . . . . . . 273

E. virgata, Sieb., and E. stricta, Sieb. . . • . . 275

Description . . . . . . : • . . 275

The varieties considered . . . . . 276

The confusion between $E$. stricta, Sieb., and $E$. cneorifolia, DC. . . . . . . . 279

Range

Affinities . . . . . . . . . . 284 
XXIX. Eucalyptus apiculata, Baker and Smith.

Description History of the species . . . . . . . . 285 Synonyms . . . . . . . . . . . 286 Affinity . . . . . . . . . . 286

XXX. Eucalyptus Luehmanniana, F. v. Mueller. Description . . . . . . . . 287

Notes supplementary to the description . . 287 Synonyms . . . . . . . . . 288 Range . . . . . . . . . 290 Affinities . . . . . . . 290

XXXI. Eucalyptus Planchoniana; F. v. Mueller.

Description . . . . . . . . 291

Affinity . . . . . . . 29 I

İxplanation of plates . . . . . . . 29 I 


\section{DESCRIPTION.}

\section{Eucalyptus alpina, Lind1.}

LINDLEY's original description says:-

Ramulis brevibus rigidis angulatis, foliis alternis petiolatis ovato-oblongis viscosis basi obliquis, umbellis axillaribus paucifloris petiolis brevioribus, operculo hemisphærico verrucoso inæquali tubo calycis turbinato verrucoso breviore. (Mitchell's “Three Expeditions," ii, 175.)

Mitchell himself simply says:-

Near the highest parts of the plateau I found a new species of Eucalyptus, with short, broad, viscid leaves and rough-warted branches.

It is described by Bentham, B.Fl. iii, 225, and by Mueller in the "Eucalyptographia," where it is also figured.

\section{Notes supplementary to the deseription.}

Leaves usually broader and thicker than those of E. capitellata, Sm., though the latter is sometimes very similar to $E$. alpina in this respect.

Buds.-The buds are as rugose as possible. While in most specimens the rugosity is irregular, in others it is more or less disposed in parallel ridges. Rugosity of the buds is also seen in E: capitellata (see p. 217, Part VIII of this work). Thus we have it in a marked manner in specimens from the Grampians, Victoria, 2,000 feet (H. B. Williamson). Specimens from this locality, cultivated in South Africa, lose much of their rugosity. Specimens showing less rugosity are Darlimurla, South Gippsland (H. Deane); and also tops of the Blue Mountains, N.S.W., and other high elevations.

Anthers.--Let us examine some anthers:-(1) Eucalyptus capitellata, Sm. (typical), from Kogarah, Sydney: anther cells divergent, rather broader than long, opening in slits. (2) E. capitellata, Sm., from Grampians, 2,000 feet, Victoria (H. B. Williamson, Jan., 1901): anther cells divergent, hardly broader than long, opening in slits. (3) E. alpina, Lindl., from Grampians, Victoria (C. Walter, Deé., 1887): anther cells parallel, decidedly longer than broad, opening in parallel slits.

The structure of the anthers is the same in the three specimens, i.e, two cells opening in longitudinal slits, and attached to the filament near the top. In No. 3 the cells are long and parallel; in No. 2 they are shor:er and more spreading; and in No. 1 still more spreading. We have, indeed, a continuous series. I have tried to accentuate the differences between the anthers of E. capitellata and E. alpina, but feel that they run into each other.

Fruit (of alpina) very variable, both as regards size, shape, and sculpture. Those figured in the "Eucalyptographia" may be taken as one pattern. Then I have specimens from Mount Abrupt $(\mathrm{H}$. B. Williamson), almost 1 inch in diameter! valves 7 , the calyx hardly rugose, the rim broadish and truncate (horizontal). A second specimen from Mount Zero (D'Alton) has the fruits $\frac{5}{8}$ inch in diameter, valves 5, the calyx very warted, the rim domed, and the valves as exserted as possible. A third specimen exhibits minor differences.

I have seen two of Lindley's type-specimens of $E$. alpina :-

(a) "No. 243. Summit of Mt. William, Major Mitchell's Expedition, 1836," with the addition in Lindley's handwriting "Eucalyptus alpina, m" [mibi]. In bud only. Herb. Cant. ex herb. Lindley.

(b) "No. 243 of Major Mitchell's Expedition, Eucalyptus alpina. Interior of New South Wales." [Victoria had not then been separated.-J.H.M.] In fruit only. Herb. Cant. ex herb. Lemann. 
These specimens have rugose buds, but comparatively small, nearly smooth fruits. They are very close to the specimens of $E$. capitellata already referred to as Grampians (H. B. Williamson).

Although the specimens from the top of Mount William are intended to be the type, the specimens distributed have included some specimens of plants that cannot be saparated from $E$. capitellata, Sm.

(The above notes are mainly those I published in Proc. Linn. Soc. N.S.W., 1904, pp. 766-8.)

\section{RANGE.}

CoNFINED to the highest parts of the Grampians (Victoria). Its range is wider than that stated in the "Eucalyptographia." Mr. H. B. Williamson, of Penshurst, Victoria, obligingly gave me the following statement:-

"Mt. Abrupt is the most southern peak of the Grampians and Mt. Zero the most northern, the former being nearly 20 miles south of Mt. William and the latter about the same distance north. Victoria Range is a parallel range west of the Serra Range, in which Mt. Abrupt is. The plant probably occurs on peaks between those three peaks, so its range could be stated 'on peaks along the whole of the Mt. William and Serra Ranges, 40 miles."

\section{AFFINITIES.}

Bentham ("Flora Australiensis") places E. alpina between E. globulus and E. cosmophylla. Mueller ("Census") places it between E. Preissiana and E. globulus and near E. cosmophylla.

The determ nation of affinities of species of Eucalyptus is, however, very complex, and can only be ascertained by judicial consideration of a number of factors, e.g., shape of juvenile leaves, shape and venation of the mature leaves, principal constituents of oil, anthers, fruit, bark, timber, kino, habit, \&c., and not one or two of them solely. But I think I have shown that the relations of E. alpina, Lindl., and E. capitellata, Sm., are very close; and doubtless additional evidence will be forthcoming as to juvenile foliage, oil, timber, \&c. My observations as to the transition forms of anthers may cause botanists to give more attention to this aspect of variation.

Both $E$. alpina and $E$. capitellata are Stringybarks. I am strongly inclined to make alpina a variety of capitellata, but keep them distinct as a matter of convenience for the present.

Since the above was written the following statement has appeared:-

On the top of Mt. William a few trees of Eucalyptus alpina were in flower. The local residents take this stunted Eucalypt to be the dwarfed forin of the Stringybark, E. cxpitellata, so common on all the lower parts of the rangez. It is said to exist in many other places as well, on the Redman, which can be seen over the valley, rising to nearly the same height as Mt. William, and as far south as Mt. Abrupt, near Dunkeld. (A. G. Campbell in "The Plants of the Grampians," in Vict. Naturalist, July, 1907.) 


\section{DESCRIPTION.}

\section{E. mierocorys, F.V.M.}

T'нгs species was originally described in Latin in Mueller's Fragmenta, ii, 50 (1860). It is well described in Bentham's Flora Australiensis, ii, 212. It was subsequently described and figured in Mueller's "Eucalyptographia."

\section{Notes supplementary to the description.}

Ternacular names.-The name of Tallow-wood is universal in New South Wales because of the greasy texture of the wood, which leads to its selection for ball-room flooring, for example. In Queensland, however, it also goes by the names of Turpentine and Peppermint, owing to the oil in its leaves; these names are applied to other trees in New South Wales.

Size.-This is a very large tree, one of the bulkiest of Australian trees. Trees 10 feet in diam 3ter at 3 feet from the ground are not rare in the Manning River district, N.S.W.

Seedlings.-Cotyledon leaves purplish underneath.

Jurenile foliage.-Pale underneath and thin. As growth proceed, the paleness disappears. With this exception this species is one in which the juvenile foliage does not very markedly differ from that of the mature foliage.

Timber.-One of the best known of New South Wales timbers; considered to be the most valuable after Ironbark. Being so valuable from an economic point of view, it will be dealt with at length in an early Part of my "Forest Flora of New South Wales."

Bark.-Sub-fibrous, of loose and even woolly texture. In colour it is of a sort of brick or rusty red, and is persistent even to the smallest branches. It is often of a corrugated apnearance, particularly in old trees.

\section{RANGE.}

IT is confined to eastern New South Wales and Queensland, being found more or less plentifully over an extensive area, usually on good soil.

The most southerly locality known to me is Cooranbong, between Newcastle and Gosford, New South Wales; its northern limit in Queensland is unknown to me. It goes at least as far as Cleveland Bay in lat. $19^{\circ} \mathrm{S}$.

Westerly in New South Wales I have it from the Styx River, Armidale district (A. W. Howitt), and Acacia Creek, Macpherson Range (W. Dunn); its range is worthy of further investigation. 


\section{AFFINITIES.}

1. With E. acmenioides, Schauer.

This species appears to stand by itself amongst the Renantheræ to a greater extent than any other members of that group. In other words, it is one of the best defined of the group. The species closest to it appears to be $E$. acmenioides, Schauer. The anthers of the two species appear to be identical, and the bark and timber have much in common. The kino of $E$. microcorys is sharply different from it. The oils of the two species are, however, placed by Smith* in different sections.

2. With E. pilularis, Sm.

This is indicated in the unusual character of marked pale underside of the juvenile foliage.

- Proc, Rry. Soc., N.S.W., xxxix, 45 and 47. 


\section{DESCRIPTION.}

\section{E. acmenioides, Schater.}

Followlik is the original description:-

Arborea : ramulis rigidulis teretib.; foll. chartaceis oblongo-lanceolatis, basi valde obliqua in petiolum attenuatis longe acuminatis cuspidatis, margine revolutis, supra nitidis, punctis creberrimis perforatis; pedunculis multifloris ancipitib. petiolum aequantib., infimis axillarib., cæteris in paniculam terminalem dispositis; pedicellis acutangulis cupula duplo longiorib.; operculo coriaceo conico acuminato cupula exangulata paullo breviori.-Foliorum lamina 3-4 uncias longa, 9-12 lin. lata, petiolus semipollicaris, operculum sesquilineam altum.-Affinis E. persicifolice, Lodd. quae colonis. " Black-butted Gum " audit.In sylvis Noræ Cambriæ australis.-A. Cunn. Walp. Rep. (Supplementum primum), ii, 924 (1843).

It is not described in the Flora Australiensis, since Bentham doubtfully made it a variet? (? var. acmenioides) of E. pitularis, Sm. It is figured and described in Mueller's Eucalyptographia.

\section{Notes supplementary to the description.}

Ternacular names.- " White Mahogany," but often erroneously called "Stringybark," because of the similarity in appearance of this species (particularly when young) to Stringybark.

Bark.-Fibrous, not unlike Stringybark in smallish trees; but more like Tallow-wood bark ( $E$. microcorys) in large trees. The branches are corered as well as the trunk. I would draw attention to the rarity of kino in this species.

I do not doubt that a good deal of country reported to be Stringybark is really White Mahogany of one form or another. Both trees like the same situations-well drained, sterile hills and mountain sides

Timber.-Pale-coloured, dense, and of high specific gravity.

Jurenile leares.-The first leares are opposite and not oblique, but symmetrical, broadly orate, lanceolate and with pale underside. As the plant grows older they become alternate and are acuminate.

Mature leares.-In the mature leares there is a tendency to crenulate margins, and some show a considerable resemblance in outline to that of a peach. The leaves are less oblique than in most Eucalypts, and the veins, unlike most Renanthero, are parallel, making a considerable angle with the midrib, and are thus very distinct from those of $E$. eugenioides. The axes are angular; leares pale underneath. The pale colour of the underside of the leaf is accentuated in drying, particularly if it has been collected damp, the upper surface often drying quite dark.

Fruit.- It is not altogether unlike that of $E$. eugenioides, but is flat at the top, with a thin rimin the normal form.

\section{SYNONYMS.}

1. E. triantha, Link. (not absolutely settled, in my mind, but very probable).

2. E. carnea, R. T. Baker. E. umbra, R. T. Baker, certainly requires further investigation. The matter is gone into below. 
1. E. triantha, Link. Following is the original description:-

222. E. triantha. Fol. oblongis basi inaequalibus subattenuatis acuminatis subfalcatis, pedunculis axillaribus trifloris, floribus sessilibus.

Hab. in Australia. Glaberrima uti reliquae. Fol. petiolo 5-6" longo. lamina 3 longa 10" lata non punctata, subtus nervis parallelis omnibus ante marginem connexis. Ped 6" longi. Oferculum ? (Link. in Enumeratio plantarum horti rejii botanici Berolensis, ii, 30, 1822).

Bentham (B.Fl. iii, 200) rejects the name triantha on the ground that the plant is too imperfectly described.

Mueller (Eucalyptographia) rejects the name triantha on the ground that it is unsuitable, the three-flowered form being an exception. Such a reason is not valid. However, in his Second Census, he suppresses acmenioides and adopts the name triantha.

I have only seen that fragment of the type of $E$. triantha which I have figured in Plate 42. As I am not absolutely certain of the identity of $E$. acmenioides and E. triantha, I prefer not to adopt E. triantha at present. The name is 21 years older than $E$. acmenioides, and I shall not hesitate to restore $E$. triantha if, in my opinion, additional evidence warrants it.

In communicating to me a portion of the type of E. triantha, the Director of the Royal Botanic Garden of Berlin informed me that no specific locality was given by the collector.

2. E. carnea, R. T. Baker.

Described in Proc. Linn. Soc. N.S.W., xxxi, 303 (1906).

The abstract of the description furnished by the author is as follows:-

"E. carnea is a typical forest Stringybark, with a pinkish or flesh-coloured, hard, durable timber. The mature fruits differ very little in shape and size from those of $E$. acmenioides, Schau., but otherwise these two species can be differentiated by their leaves, timber, and oil. This latter constituent is of some chemical and industrial importance, as it contains, besides a dextro-rotatory pinene and eucalyptol, an acetic acid ester. Only a small quantity of free acetic acid was found in the crude oil, but the ester split off acid on distilling the oil under atmospheric pressure. Systematically the species should be placed with the Stringybarks, and in sequence with $E$. nigra, R.T.B., and $E$. acmenioides, Sch."

The author points out that he had previously confused it with E. umbra (q.v.). Mr. Baker's description is accompanied by a plate, and figure 8, Plate 42 of the present work depicts the plant.

Mr. Baker only records it from the Richmond River, N.S.W., and draws attention to the pink colour of the timber, which is stated to be of diagnostic value.

It seems to me that this tree cannot be separated from $E$. acmenioides.

Both E. carnea and E. acmenioides have pale underside leaves, much more evident in the case of the latter. Both lose it more or less with very old leaves.

As to the dimensions of the juvenile foliage, I have Mr. Baker's type before me, and A. Murphy's "White Mahogany, from the low flat country, Woy Woy" (the tree 
that we always look upon as typical for $E$. acmenioides), has juvenile leaves which are a facsimile of them. Both have pink veins. The fruits of $E$. carnea are identical with those of $E$. acmenioides obtained from many localities.

The ideas that I formerly held that broad juvenile leaves, coarse thick foliage, and broad-rimmed fruits specially separate $E$. umbra from $E$. acmenioides have weakened with additional investigation, and I incline to the opinion that $E$. carnea is one of the transit forms, and that it is even very doubtful whether $E$. umbra can be defined as a species distinct from $E$. acmenioides.

Some of the specimens in the National Herbarium, Sydney, on which these views are based, will be found recapitulated under $E$. acmenioides at page 267.

E. carnea.

Holding these views, I propose the name variety carnea of $E$. acmenioides for

\section{RANGE.}

As will be observed, the type came from "New South Wales forests."

It is confined to eastern New South Wales and Queensland. Its southernmost locality known to me is the Port Jackson district; its most northern is Rockhampton, Queensland, occurring in coastal districts and table-lands. Westerly I have it from Drake, near Tenterfield, but its range is worthy of further investigation.

I think it will be a matter of practical convenience, in view of the uncertain limitations of $E$. acmenioides, $E$. carnea, and $E$. umbra, to give notes on certain specimens, beginning with the most southerly ones, and working northerly in geographical order.

The salient points of $E$. acmenioides may be borne in mind as follows :-

Leaves thin, with crenulate margins, paler on the underside.

Opercula of plump buds hemispherical and pointed.

Fruit small, say $2.5 \mathrm{~cm}$. in diameter, tending to be spherical, or truncate-spherical, sometimes very slightly urceolate, thin rim, with rather long, filiform pedicels not gradually broadening into the base of the fruit.

\section{New South Wales.}

Port Jackson District.-Brush Farm, Ryde; in plump bud and flower (T. S. Burnell); style persistent, Ryde (H. Deane); Field of Mars Common (H. Deane); leaves a little thicker and coarser, Baulkham Hills (W. Woolls); also Parramatta (H. Deane).

Port Jackson to Hunter River.-Kincumber (W. R. Stacy); fruits nearly hemispherical, juvenile foliage like E. carnea; "From the low flat country," Woy Woy (A. Murphy).

Hunter to Manning Rivers.-Moy's Flat, also Myall Lake (A. Rudder); Gloucester Buckets (J.H.M.). 
Manning to Tweed Rivers.-Port Macquarie (G. R. Brown, No. 508); "Peppermint," very small pilular fruits, Macleay River (W. MacDonald); Mount Sea View, Upper Hastings River, the fruits small, hemispherical, rim a little broad (J.H.M.); in gullies and on ridgy inclines, Woolgoolga (E. H. F. Swain); fruit small, Drake (E. C. Andrews); Murwillumbah (R. A. Campbell).

Mr. E. C. Andrews says that it is widely distributed on the eastern slopes of New England.

Most of the above collectors call the tree "White Mahogany." Both Mr. Swain and Mr. Campbell call it "Messmate," as well as "White Mahogany."

\section{QUEensLand.}

I very carefully examined this tree in the Brisbane district, where it is plentiful, and also collected many specimens. The juvenile foliage is stem clasping, and varies a good deal in width. Fruits small and dainty, nearly spherícal.

"Stringybark," Waterworks, Brisbane (J. L. Boorman).

"Prope Brisbane River" (Amalia Dietrich, 1863-5). This specimen, from the Godeffroy Museum, Hamburg, was examined by Bentham, and bears the label in his handwriting, "Eucalyptus marginata, Sm." It was presented to me by the Vienna Herbarium.

"Gum-tree of the Brisbane" (Leichhardt). "E. crebros aff." (Bentham's note). Placed by Bentham with E. crebra (B.Fl. iii, 221). A fragment was communicated to me from the Melbourne Herbarium, and a much larger specimen entrusted to me by Kew for examination: The leaves are remarkably narrow, very dark-coloured on the upper surface, the margin a little recurved, the fruits remarkably small, nearly spherical, and the tips of the valves faintly exserted.

. It was quite reasonable to refer this twig to $E$. crebra, for the leaves are of the shape and size so common in the species, but the venation is different, and $E$. crebra leaves have no pale underside. The venation is also a little different, and the fruits, while resembling those of $E$. crebra, are not the same.

It is well known that the leaves of Eucalypts become smaller as the top of the tree is reached, and the narrowness of the leaves, which has caused. so much difficulty, is, in my opinion, explained in this way.

"Stringybark," Rockhampton (A. Murphy). Pale underside, but not so much marked as in many southern specimens. Thin-rimmed fruits, becoming slightly urceolate.

\section{Var. calnea, var. nov.}

The carnea form, i.e., the thick-leaved form of $E$. acmenioides, appears to exist over about the same geographical range as $E$. acmenioides. In Mr. Baker's original description, the Lower Richmond River, N.S.W., was alone quoted. 
The following specimens are more or less referable to this variety :-

Broken Bay to Hunter River.-A dense mass of fruits, foliage coarse and thick. Fruits thin-rimmed, and varying from fig. 1c, plate 42, to nearly hemispherical, and a broader brim, Wyong (J. L. Boorman). Specimens exactly similar, except that the fruits are not borne in such profusion. Juvenile foliage very thin, Tuggerah (J. L. Boorman). These two specimens have the fruits of $E$. acmenioides and the leaves of E. umbra or carnea.

"Messmate," figured at fig. 6, plate 42. I have accentuated the points in this specimen, but am satisfied it is not really dissimilar to the Wyong and Tuggerah specimens. Awaba (J. L. Boorman). Specimens from Waratah, Newcastle (Jesse Gregson) are similar.

Wyee (A. Murphy), rim of fruit very narrow, yet closer to the umbra type.

Hunter to Manning Rivers.-The following specimens are of interest in that they were collected by the late Forester Augustus Rudder, with whom I had many conversations and much correspondence with the view of finding out if we could really make another species out of the trees called "White Mahogany," and included by the Rev. Dr. Woolls and Baron von Mueller, amongst others, under E. acmenioides.

(a) Seven miles from Raymond Terrace, on the Booral Road; alluvial, 19/2/93. Thick foliage, fruits more pear-shaped than usual, thin rim. I call this thickleaved acmenioides, but I cannot separate it from carnea.

(b) Broad foliage, buds much resembling fig. 4a, plate 42, fruits like fig. 1c. Near Dungog, ordinary forest clayey subsoil; shale, 6/9/91. Thick-leaved acmenioides inseparable from carnea, in my view.

(c) Very broad, coarse foliage. Small fruits, somewhat like fig. 1c, plate 42; thought by Mr. Rudder to be E. piperita. Near Cooloongoolook; clay soil, $24 / 7 / 91$. Same as $(b)$ in my opinion.

The following specimens from the same district were collected by myself:-

(d) Stroud. Fruits much like $(a)$, not so ripe, and scarcely so pear-shaped. This specimen has the fruits (some of them) a little broadish, and shows that carnea and umbra run into each other. I name it the same as $(a)$.

(e) Tinonee. Fruits pear-shaped like (a), but smaller. Fruits of acmenioides, thick foliage of carnea or umbra as one chooses to say.

Hastings to Richmond Rivers.-No. 129, "White Mahogany." Forester G. R. Brown, Port Macquarie. In flower only, style persistent. Thick, rather coarse foliage, buds and leaves a good deal like fig. $4 a$, plate 42 . I call it thick-leaved acmenioides.

Port Macquarie to Kempsey (J.H.M.).-Foliage thick, fruits of normal acmenioides. Inseparable from carnea.

Now we come to two type-specimens of $E$. carnea, viz.:-Woodburn, Richmond River (W. Baeuerlen) and Wardell, Lismore (W. Baeuerlen). 
Some of the fruits of the Woodburn specimen have the rim broadening a little, like the Stroud specimens. The Wardell specimens have all of them thin rims, but thin-rimmed fruits of this kind are with broader-rimmed fruits on the same tree and on the same twig. I call both of these specimens thick-leaved acmenioides.

\section{QueEnsland.}

Nerang (F. M. Bailey). Typical acmenioides fruits, thick leaves like carnea.

Ithaca Creek (F. M. Bailey). Rim just a little broadish and tips of valves faintly exserted, but fruits not quite ripe. Leaves thickish. This specimen seems to be from a windfall; perhaps that accounts for the absence of the pale underside of the leaves. It is very close to typical acmenioides.

"Yellow Stringybark: good for fencing, palings, \&c." Maryborough (W. H. Williams). Thick leaves, fruit with thin rims and very slightly urceolate. I call this thick-leaved acmenioides.

Black Downs Table-land, 100 miles west of Rockhampton, at an elevation of 2,400 feet (P. MacMahon, No. 8). Thick leaves, pear-shaped fruits ; is perhaps thickleaved acmenioides.

"Stringybark tree of Rockingham Bay" (J. Dallachy, ex herb. Melb.). Leaves thickish, not paler on the underside (perhaps because of the age of the specimen-40 years). Fruits thin-rimmed, more urceolate, and with the valves more exsert than in any specimen of $E$. acmenioides I have ever seen. That this is really identical with Murphy's Rockhampton specimens I do not think that anyone who has compared them will doubt, but I must keep them apart, because these particular specimens have thickish leaves, and I cannot detect the pale underside. 


\section{DESCRIPTION.}

\section{E. umbra, R. T. Baker.}

The original description will be found in Proc. Linn. Soc. N.S.W., xxv, 687 (1900). This is modified to some extent by the describer, op. cit. xxxi, p. 304 (under $E$. carnea):

See figures 10-12, Plate 41, of the present work. .

\section{Notes supplementary to the description.}

In the original description of this species (p. 687) Mr. Baker described the sucker leaves (juvenile leaves) as "thin." Op. cit. xxix, 758, in endeavouring to accentuate the differences between $E$. acmenioides and $E$. umbra, I corrected this, stating that they were thick. I have since got them both thick and thin, and no doubt thinness is the proper character, thickness being induced by climatic exposure.

E. umbra is a species which Mueller and other botanists considered to be a coarse form of E. acmenioides. Mr. Deane and I (Proc. Linn. Soc., N.S.W. xxiii, 789) explained that view. E. umbra is (b) the "stout and coarse" form. Op. cit. xxix, 758 (1904) I have tried to accentuate the differences between $E$. acmenioides and $E$. umbra in the following words:-

"These species may be at once separated if sucker-leaves be available. Those of $E$. asmonioides are thin and Eugenia Smithii- (Acmena-) like, while those of $E$. umbra are thick, broad, and coarso, much thicker and coarser than those of $E$. acmenioides. They are indeed as thick and coarse as those of $E$. capitellata ever arc. The statement in the original description of $E$. umbra, that the sucker-leaves are 'thin,' must be modified."

And again (p. 759)-

"Usually the flat-rimmed fruit is accompanied by thick foliage, indicating umbra. But sometimes this coarse foliage accompanies thin-rimmed fruits which one has hitherto assigned to $E$. acmenioides without hesitation. Such, for example, is the 'Messmate' of Awaba, which grows on foot-hills, moist places, not swamps. These specimens certainly show a transit between $E$. umbra and $E$. acmenioides, and in the present state of our knowledge I doubt if we can always separate the two species in the absence of juvenile foliage."

I have since tried to work out the differences in bark and timber, but have failed so far to obtain characters which I can rely upon.

For Mr. Baker's observations on this point, see op. cit. xxv, 688. He states that it is "altogether a much inferior timber to $E$. acmenioides." We want further information on this point.

Some observers consider the differences between $E$. acmenioides and $E$. umbra a matter of soil. Mr. Andrew Murphy, seed-collector, who has collected Eucalyptus səed for me by the hundredweight, wrote me, "I am not clear about the "thick rim White Mahogany.' It seems to me that ordinary White Mahogany takes that form when near the sea-coast on mountain-tops." 
The salient points of $E$. umbra may be borne in mind as follows :-

Leaves thickish, with margins not so crenulate as in $E$. acmenioides, or absent. Not usually paler on the underside, except in juvenile foliage.

[In my view, thinness of foliage and paleness of the underside of the leaves are characters developed in comparatively sheltered localities. Mr. Baker (op. cit. xxv, 688) quotes Mr. Baeuerlen as stating that $E$. acmenioides penetrates only into the rich scrub, while E. umbra is found in the poorer forest country. I have dealt with the differences of habitat of the two forms in xxix, 758.]

Buds more angular than thosc of $E$. acmenioides.

Fruit, five lines in diameter, whrn mature (R. T. Baker), more hemispherical than spherical, rim broadish, sometimes very broad, and often domed. The pedicels usually coarser than those of $E$. acmenioides, and the plant altogether coarser.

Mr. Baker calls his E. umbra "Stringybark," and that is a name very widely applied to E. acmenioides. Both are called "White Mahogany."

The differences between. Mr. Baker's species umbra and carnea and acmenioides, Schauer, are thus indicated by Mr. Baker (Proc. Linn. Soc. N.S.W., xxxi, 305).

E. carnea. "The abnormal leaves (a term newly coined by Mr. Baker in lieu of "juvenile foliage), venation, and texture differ in shape from those of $\boldsymbol{E}$. umbra.

"Fruits can scarcely on a first inspection, if at all, be distinguished from E. acmenioides. . . . . Valves and inner $\operatorname{rim}$ (of $E$. acmenioides) always deeper sunk than in $E$. carnea. The leaves of these two trees, though having much the same venation, are decidedly different, especially in their texture, shape, and colour. Those of $E$. acmenioides arc thin, whilst those of $E$. carnea are thick, and the abnormal leaves of each are quite different, and sharply divide the species."

My specimens show that there is transition in thickness of leaves between $E$. acmenioides and E. carnea, while the shapes of the "abnormal" leaves of the two species are not as sharply different as was at one time believed to be the case.

Mr. Baker places $E$. carnea next to $E$. nigra ("its nearest congener is $E$. nigra in a ligneous classification, otherwise it differs from it in the shape of its "fruits, leaves, and oil-contents"), and also says, "In a systematic series it might be placed between E. acmenioides and E. nigra." He adds that in E. carnea the timber is tinged with pink.

I have done my best to accentuate the differences between $E$. acmenioides and $E$. umbra, and some differences that I thought to be very important have since been shown to be less definite. I have endeavoured to retain the name $E$. umbra, but I think that it is very probable that further investigation may show that it is really a climatic and soil form of $E$. acmenioides, a view universally held until Mr. Baker described umbra in 1900. 


\section{RANGE.}

Neither $E$. umbra nor $E$. acmenioides has been found south of the Port Jackson district so far. In Proc. Linn. Soc. N.S.W., xxv, 687, Mr. Cambage is quoted as having found E. umbra at Milton. That gentleman informs me that the Milton tree is the species afterwards named $E$. Consideniana by me.

I have no typical umbra further north than Wyee (and even that is doubtful), so that this form may be looked upon as a very local one, simply occurring between Port Jackson and the Hunter. Mr. Baker (Proc. Linn. Soc. N.S.W., xxv, 687) quotes Wardell, Dundoon (Dunoon), and Tumbulgum; Peat's Ferry, Cowan Creek, Eas'wood, and Military Road (Sydney); Tinonee, Gosford, and Milton. Op. cit. xxxi, 304, the Wardell and Dunoon specimens have been referred to $E$. carnea by Mr. Baker, and in view of my notes on specimens, perhaps some other reputed umbra specimens should be transferred to carnea, so that the range of both forms requires revision.

\section{New South WALES.}

Port Jackson District.-The type comes from Spit Road, Mosman's, Sydney. It is common about Middle Harbour. A specimen from south side of Spit, Middle Harbour. (J. H. Camfield, July, 1897), has juvenile foliage indistinguishable by me from that of E. acmenioides.

Broken Bay District.-(Broken Bay is the mouth of the Hawkesbury, and is an estuary between Port Jackson and the Hunter River).

Near Peat's Ferry (H. Deane). The fruits and leaves are typical for umbra, but the buds equally those of typical acmenioides.

Newport (R. H. Cambage). Some of the juvenile leaves very broad, but all rather thin, and paler on the underside. Mr. Cambage and I found it fruiting as a dense scrub of 3-4 feet high on the summit of First Point, Kincumber.

"Stringybark. A large tree, bark not furrowed, outside very fibrous." Woy Woy (A. Murphy, 8/98); "White Mahogany, mountain variety." Woy Woy (A. Murphy, 9/04); Gosford (John Martin).

\section{AFFINITIES.}

As I am uncertain as to the specific differences of $E$. acmenioides and $E$. umbra, it will be convenient to deal with their affinities under one head.

1. With E. pilularis, Sm.

Bentham (B.FI. iii, 208) doubtfully made this a variety (? var. acmenioides) of E. pilularis, stating that it sometimes seems to pass into the typical E. pitu'aris, 
Mueller (Eucalyptographia) rightly restored the specific rank of the White Mahogany, although previously (under E. pilularis) he had expressed some doubt as to whether $E$. acmenioides and E. pilularis are really distinct. But the fruits, the bark, and the character of the timber separate the species very readily. Mueller states that the small capsules figured on the left hand of the $E$. pilularis plate in the "Eucalyptographia" are $E$, acmenioides. It may be so, but the figure is poor.

A form from Parramatta has fruits which might very readily be casually taken for $E$. pilularis. They differ from those of normal E. pilularis in being smaller, the rim not defined, and the valves approaching the orifice.

The affinity is also indicated in the tendency to the thickening of the rim in E. pilularis and in the frequent coarseness of its foliage, particularly noticeable in maritime situations. This more particularly applies to $E$. umbra.

E. pilularis and E. acmenioides have juvenile foliage with pale under-surface.

The affinity of the two species was observed by Schauer in describing $E$. acmenioides, when he compared it with $E$. persicifolia, Lodd., (a synonym of E. pilularis, Sm.).

- With E. microcorys, F.v.M.

Timber and foliage a good deal resemble those of $E$. microcorys. This more particularly refers to the typical form of $E$. acmenioides, which appears to be the form closest, of all Eucalypts, to E. microcorys.

3. With E. piperita, Sm.

In the thin, pale-underside juvenile leaves; in the mature leaves it resembles those of var. carnea, while both piperita and acmenioides have a tendency (greater in the former species) to urceolate fruits. The rim of the fruit is thin in both species.

4. With E. ellgenioides, Sieb.

I have already expressed the view that Mr. Baker's E. nigra is a form of $E$. eugenioides. I still think it is closer to that form than to E. acmenioides, although it is evident that the true Stringybarks, the Blackbutt (E. pilularis), and the White Mahogany (E. acmenioides) are closely related. Mr. Baker considers his carnea to be closest to his nigra. For an account of E. nigra, see Part VIII of this work, page 222.

5. With E. Bosistoana, F.v.M.

Fruiting twigs of E. umbra may not unreasonably be mistaken for E. Bosistoana, F.v.M. The valves of the latter are more numerous than is the case with $E$. acmenioides; the valves of $E$. Bosistoana also are usually a little exserted. E. Bosistoana belongs to the Box Group, so that the two trees could not readily be confused in the forest.

6. With E. melliodora, A. Cunn.

I have seen a form, with brown shining fruits, which present a good deal of resemblance in outline to some fruits of E. melliodora. This is worthy of notice, though the two species are otherwise very dissimilar. 


\section{E. virgata, Sieb.}

In Sprengel's Cur. Post., 195 (1827).

I DESIRE to bring the following names under review:-

E. rigida, Hoffmannsegg (Verz. Pf!. Nachtr. ii, 114, 1826).

E. virgata Sieb. (in Sprengel's Cur. Post., 195, 1827).

E. stricta, Sieb. (in Sprengel's Cur. Post., 195, 1827).

E. ambigua, DC. (Prod. iii, 219, 1828).

E. obtusiflora, DC. (Prod. iii, 220, 1828).

E. fraxinoides, Deane and Maiden (Proc. Limn. Soc. N.S.W., 1898).

All these plants form a series with narrow* suckers. Compare E. Luehmanniana.

I will bring forward evidence to establish the following nomenclature:-

E. virgata, Sieb.

1. Var. obtusiflora, Maiden.

Syn. (a) E. obtusiftora, DC.

(b) E. rigida, R.Br.

(c) E. rigida, Sieb. (E. rigida, Hoffmg, is indeterminable).

(d) E. piperita, Sm., var. pauciflora, DC., in Prod. iii, 219.

2. Var. stricta, Maiden.

Syn. (a) E. stricta, Sieb.

(b) E. ambigua, DC.

3. Var. fraxinoides, Maiden.

Syn. E. fraxinoides, Deane and Maiden.

4. Var. triflora, Maiden.

\section{- The name Eucalyptus rigida.}

E. rigida was the name originally given by Robert Brown (in 1800-5) to specimens gathered by him on the South Head road (part of Sydney). I have seen these specimens in the British Museum, and in other herbaria.

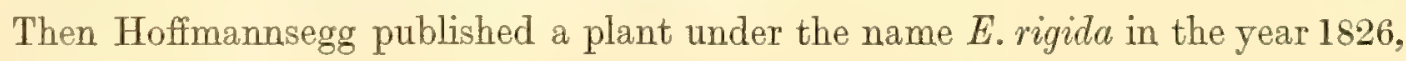
in the following words:-

(432) Eucalyptus rigida. E. caule ramisque teretibus, foliis rigidis duris, infimis sessilibus oppositis ovatis subcordatis obtusis, superioribus sensim petiolatis sparsis lanceolatis acutis subapiculatis. . . . .

$\mathrm{Hab}$. in Austral.

* I have already uttered the dictum that everything is variable in Eucalyptus. Taken as a general statement, it is perfectly true that plants of the virgata series have narrow suckers. But we may have suckers so broad that it becomes difficult to separate them, on this ground, from Luehmanniana, e.g., certain specimens of $E$. virgata, var. obtusiflora, from South Head, Port Jackson (R. H. Cambage).

In the present Purt $\mathrm{I}$ have already referred to the variation in width of suckers of E. acmenioides. 
Folia supra modum inflexibilia, valde polymorpha. Nam praeter basale quoddam, monstrositate forte, breve, transverse ovatum, in pedunculum angustatum, infima to $2^{\prime} 4^{\prime \prime} \lg ., ~ \triangleleft 1^{\prime}$ lt., sequentia $3^{\prime}$ lg., $1^{\prime}$ It., ideoque oblongar, superiora, in caule $2^{\prime} 6^{\prime \prime}$ lg., $8^{\prime \prime}$ lt., in ramo inferius oblongo-lanceolatum, superius oblongo-ovatum obtusum, etc. (Verz. Pf. Nachtr., ii, 114.)

The description in DC. Prod. iii, 221, is:-

Foliis rigidis duris, infimis sessilibus oppositis ovatis subcordatis obtusis, superioribus petiolatis, sparsis lanceolatis acutis subapiculatis, caule ramisque teretibus. In Novâ-Hollandiâ. Flores fructusque ign. An eadem ac $\boldsymbol{E}$. diversifolia.

Mueller ("Eucalyptographia" under E. pulverulenta) says:-_"E. rigida of Count Hoffmannsegg's Verzeichniss der Pflanzen-Kulturen, 114 (1826), is probably referable to E. pulverulenta." This is but a surmise, and there are no specimens in the Melbourne Herbarium to back up such an opinion. The word "rigidis" does not specially apply t) E. pulverulenta, while the words "sessilibus oppositis ovatis subcordatis obtusis" apply to that and other species with more or less correctness.

There are specimens in Herb. Vindob. bearing the following label:-_"Eucalyptus rigida, Hoffmannsegg, Nov. Holl. Ferd. Bauer, Hb. Bauer," which are identical with Brown's South Head road plant, which again is identical with Sieber's No. 473 (E. rigida, Sieb.) $=E$. obtusiflor $a, \mathrm{DC}$.

E. rigida, Sieb., Pl. Exs. (Sieber's No. 473), from Port Jackson, is E. obtusiflora, DC., according to Bentham (B.Fl. iii, 205). I have specimens of the type, and concur.

"To $E$. stricta belongs furthormore E. rigida of Sicber's collections No. 473, although united by Bentham with $E$. obtusiflora, but the latter, according to leaves from the original specimen kept at Geneva and forwarded to me by M. Alphonse de Candollo, proves it completely distinct from E. rigida." (Mueller, in Eucalyptographia under E. stellulata.)

I have already stated that I have specimens of Sieber's No. 473 (with the original labels still adherent), which is the plant referred to by De Candolle in the Prodromus, and it is a common Sydney plant known to every Sydney botanist.

Sieber's No. 473 (E. rigida, Sieb.) is the plant we have recognised for many years as $E$. obtusiflora, DC, and I venture to say that the drawing in Mém. Myrt., Pl. 10 (E. obtusiflora, DC.), is a good drawing.

Mueller also labelled stricta var. angustifolia, E. rigida. This is E. apiculata, Baker and Smith, and is a different plant. I think, therefore, Brown's name must be dropped. To what extent he circulated it in herbaria I do not know.

Hoffmannsegg's name must be abandoned because of its uncertainty, while Sieber"s name rigida can only claim the date 1828, the year of publication of DC. Prod. iii. 


\section{E. virgata, Sieb., and E. stricta, Sieb.}

THE original description of E. virgata, Sieb. (in Sprengel's Cur. Post., 195, 1827), is as follows:-

E. opereulo conico pedunculis 3-floris incrassatis compressis rugosis erectiusculis folis lanceolatis acuminatis coriaceis subvenosis glabris.

This was expanded by De Candolle (Prod. iii, 217) into the following words:-

Operculo conico cupulæ longitudine, pedunculis axillaribus lateralibus petiolo vix longioribus pedicellisque ancipitibus, foliis oblongo-linearibus utrinque acuminatus crassiusculis coriaceis subaveniis. Folii petiolus 4 lin. longus, lamina 4-6 poll. longa 6-9 lin. lata. Umbelle 5-6-floræ. Margo folii crassiusculus.

E. virgata is redescribed by Bentham (B.Fl. iii, 202). . . . .

Chiefly from Oldfield's, Woolls's, and F. Muellor's specimens. Sirbar's appear to be the same, but they are only in young bud, and, therefore, uncertain. It differs from both $E$. coriacea and $E$. obliqua in the outer stamens bearing only abortive anthers, and in that respect approaches $E$. homastoma, from which it differs as well in foliage and in fruit, as in these imperfect stamens being much fewer and rarely, if ever, quite without anthers.

The E. virgata of B.Fl. iii, 202, confuses E. virgata, Sieb., with the "Mountain Ash," afterwards defined as E. Sieberiana, F.v.M. Mueller, in the "Eucalyptographia" perpetuated a similar mistake, in a reverse direction, at the time he defined the common "Mountain Ash" with rugged bark as a new species, E. Sieberiana (it is certainly a good species), but confusing it with $E$. virgata, Sieb. Typical E. virgata, Sieb., is usually a tall shrub, as its name denotes, while E. Sieberiana, F.v.M., is usually a forest tree.

Previously, however (in 1880), the species was regarded by Mueller, in the same work (Eucalyptographia), as a synonym of $E$. Sieberiana (Decade 2).

E. virgata was in 1884 considered by Mueller (Decade 10, Eucalyptographia) as a form of $E$. stricta.

E. virgata as a specific name was ignored by Mueller until the publication of the 2nd Census in 1889 .

Then we have Luehmann's view:-

$E$. virgata.-Although I believe that Mueller was correct in including this as a variety in $E$. stricta, yet I have kept it apart as the appearance of the extreme forms is so very different. (Trans. Aust. Assoc. Adv. Science, 1898, p. 529.)

In the Eucalyptographia (Decade 10) under E. stricta, Mueller includes E. virgata and $E$. Luehmanniana, but not E. obtusiflora.

At one time Mueller used to label specimens of our common obtusiflora " $E$. obtusiflora, Benth. non DC.; E. stricta, Sieb. var."

Mueller, Luehmann, and I all agree that E. virgata and E. stricta are conspecific. If anyone will examine my large series of specimens, and also contemplate the plants in the field, I fail to see how he can keep them under two species names. It becomes a matter for consideration as to whether virgata or stricta is the older one. 
In Sieber's Cur. Post. they are described on the same page, and virgata is put before stricta only for the reason that, in a former portion of his work, virgata, in his opinion, comes "post No. 11 " (capitellata, Sm.), and stricta comes "post No. 14" (pulverulenta, Ker.).

But, because on the same page, virgata is described in the paragraph immediately preceding stricta, virgata is technically the older name, ${ }^{*}$ and, if one of these two is to go, stricta must be suppressed. So that if I prove that E. virgata and E. stricta are conspecific, the latter name must give way to the former.

The description of $E$. virgata, as given at page 85, Part xxv, of my "Forest Flora of New South Wales," may be repeated here:-

An erect shrub or small tree, smooth, or with a little ribbony bark, and pale-coloured wood.

Juvenile leaves.-Glaucous, lanceolate or narrow-elliptical.

Mature leaves.-Slightly falcate, lanceolate, tapering to a fine point, 3 to 6 inches (commonly 4 inches) long, with a twisted petiole of half an inch. Texture thick, very coriaceous, equally green and shining on both sides, the midrib and primary veins often strongly marked. Intramarginal vein not far removed from the edge.

Buds. - Angular, operculum pointed, calyx gradually tapering into a flattened peduncle.

Flowers.-Usually six to ten in the head, the former being a common number. Anthers reniform.

Fruits $\uparrow$.- Sub-cylindrical, about $\frac{3}{8}$ inch in diameter, and about $\frac{5}{8}$ inch in length, to the commencement of the short petiole. Rim broadish, flat-topped, or slightly sunk.

1. Var. obtusiflora, Maiden (E. obtusiflora, DC.).

E. obtusiflora, DC., was first described in Prod. iii, 220, in the following words:-

Operculo hemisphærico obtusissimo cupulâ obovatâ breviore, pedunculis subangulatis axillaribus petioli longitudine, floribus 4-5 capitatis foliis lanceolatis mucronatis basi aequaliter attenuatis coriaceocrassiusculis. In Novâ Hollandiâ ad oram orientalem. Priori valdè affinis et forsan varietas. Differt floribus majoribus, calyce potius obovata quàm turbinato, operculo obtusiore, foliis latioribus. Mucro folii ut in priore crassiusculus deciduus.

Although A. P. De Candolle, in that work, does not specifically mention the number of Sieber's Pl. Exs. referred to, his posthumous work (Mémoire sur la Famille des Myrtacées, Genève, 1842) gives a figure of the plant, which places its identity beyond question.

An original specimen of Sieber's No. 473, in Herb. Barbey Boissier, bears the MS. label:-_Eucalyptus piperita, Sm., De la nouvelle Hollande, M. Sieber, 1825."

A second specimen in the same herbarium (without an original label) bears the label:-“"No. 472, Eucalyptus stricta, Sieber, N. Holl."

* "Of names published in the same work and at the same time, those having precedence of position are to be regarded as having priority." (Canon 13 of the Code of Botanical Nomenclature proposed by the Nomenclature Commission of the Botanical Club of the American Association for the Advancement of Science.) See Bulletin of the Torrey Botanical $C l u b$, xxxi, 254 (1904). The canon was apparently ignored by the Vienna International Congress on Botanical Nomenclature, 1905.

+ Although fruits were not preserved with the types of either $E$. virgata or $E$. obtusiflora, there is no doubt that most of the fruits of the pointed operculum series (virgata) are more sub-cylindrical than those of the hemispherical or blunt operculum series (obtusiflora), but nearly hemispherical fruits are found on plants of virgata, while sub-cylindrical fruits are found on plants of obtusifora. 
These specimens are identical, have blunt buds, and in every respect are E. obtusiflora, DC.

I have described variety obtusiflora at page 85, Part xxv, of my "Forest Flora of New South Wales," in the following words:-

An erect shrub or small tree, smooth, or with a little ribbony bark, and pale-coloured wood.

Juvenite leaves.-Broadly lanceolate, somewhat similar in shape to the adult leaves, only larger. Approximate dimensions -4 to $f$ inches long by 1 inch broad.

Mature leaves.-Rigid, very coriaceous, ovate-lanceolate, slightly oblique, leaves sometimes blunt, sometimes hooked; rarely 1 inch wide (usually $\frac{3}{4}$ ) and up to 4 inches or a little more long. The venation marked.* Colour of leaf pale or yellowish-green, often glossy, and the margin often reddish. The intramarginal vein some distance from the margin. The transverse veins starting out at a fairly uniform angle to the midrib. As Bentham puts it (B.Fl, iii, 189): "Leaf veins not close, often very oblique, but all inserted along the midrib."

Buds clavate and umbonate, even-pointed.† Some specimens from Botany and National Park have the operculum hemispherical, apparently without sign of umbo. This form frequently shows the double operculum.

Flowers.-The peduncles somewhat angular; calyx-tube short and broad (Bentham), but this is not a constant character.

Fruits. - 4- to 5-celled, flat-topped, wrinkled, brown and shiny, like E. Luehmanniana, but smaller. Some specimens from Loftus have slightly urceolate 4-celled fruits, which have thin rims, and are depressed.*

\section{Var. stricta, Maiden (E. stricta, Sieb.).}

The original description of E. stricta, Sieb. (in Sprengel's Cur. Post., 195, 1827), is as follows:punctatis.

E. operculo submutico pedunculis lateralibus 2-floris foliis linearibus acutis coriaceis glabris sub-

See also De Candolle's figure in Mém. Myrt. t. 8 ("the anthers incorrect," Bentham). The type is Sieber's Pl. Exs. No. 472, and it is more fully described in DC. Prod. iii, 218.

I have described this variety at page 86, Part xxv, of my "Forest Flora of New South Wales," in the following words:-

This is the Scrubby Gum of the Blue Mountains, a dwarf gum, very abundant on the higher parts of the Blue Mountains and other elevated parts of the State, where it often forms an almost impenetrable scrub. On the bleakest parts of our ranges, up to between 4,000 and 5,000 feet, this dwarf gum luxuriates. It is often looked upon as mallee, but it is not one of the true mallee species of the drier parts of this and other States, which have thickened root stocks. It is strict (erect) in its habit; hence the specific name.

It is toc small for timber. Height from 6 to 15 feet, with bark falling off in strips, leaving smooth stems and timber pale-coloured.

Juvenite leaves.-Lanceolate, erect, equally green (bright or sap-green) on both sides. The oil-dots on the juvenile foliage are well marked. The young twigs are reddish, with tubercles of a darker colour.

* This is especially the case where the trees grow close to the coast.

+ It is quite impossible to take the bluntness of the buds (on which the species name was given) as a character. The trangition in this and other respects to typical $E$. virgata, Sieb., is perfect.

¥ Some fruits from Botany are almost hemispherical and 5-celled; they are apparently a connecting link with $E$. stricta. I am of opinion that it is not possible to discriminate between some forms of stricta and obtusiflora without fruits. 
Mature leaves.-Rigid, very coriaceous, varying from narrow-linear to ovate-lanceolate. Usually . hooked at the apex. Often glossy.

Buds.--Operculum very short, nearly hemispherical, surmounted by a point (umbonate), often red in fresh specimens. Much shorter than the calyx-tube. Bentham speaks of the buds as ovoid. This is hardly true as a general rule. They are clavate, and often yellowish, especially the opereulum.*

Flowers. - The stamens are folded in the bud, and the anthers are all fertile and renantherous. The peduncles flattened or angular. Each with 4 to 8 (Bentham), or 5 or 6 (De Candolle), shortly pedicellate small flowers. Calyx-tube not 2 lines in diameter, tapering.

Fruits.-Globose-truncate, smooth, often glossy, up to 5 lines broad and 6 deep, but varying in size, contracted at the orifice, i.e., slightly urceolate, the rim narrow or thin, the capsule sunk, and the valves not protruding. Usually the valves are very much sunk, but occasionally (e.g., at Wentworth Falls) the tips of the valves are flush with the top of the capjule.

The capsule is usually sunk in Blue Mountains specimens, the edge of the capsule (rim) being thin and gradually sloping into the orifice.

In this variety we have:-

1. The Mallee form.

2. The arboreal form. Distinct looking enough, in extreme forms, but they run into one another, and certainly cannot be separated in herbarium specimens.

The arboreal form, besides its size, has broader leaves, and is larger generally.

At page 159, Part VI, of this work, I refer to "6 fourth cultivated specimen " (of E. ambigua, DC.), there doubtfully attributed to $E$. stricta, Sieb. Ft is remarkably like the arboreal form of E. stricta just referred to, and depicted at fig. 17, Plate 43.

3. Var. fraxinoides, Maiden (Syn. E. fraxinoides, Deane and Maiden).

See page 87, Part xxv, of my "Forest Flora of New South Wales."

A tall tree.

Bark.-Smooth-barked, the outer layer falling off in ribbons; the bark blotched, reminding one somewhat of a Spotted Gum (E. maculata) as regards its blotches, and $E$. viminalis (Ribbon Gum) as regards the stripping of the outer bark.

Timber.-Pale-coloured, light in weight and colour, fissile.

Juvenile leaves.-Only seen in the alternate stage, varying from bluntly lanceolate to almost linearlanceolate; slightly falcate; twigs very glaucous.

Buds.-Ovoid when young; as growth proceeds the operculum more or less pointed at the top, and thus assuming a somewhat conical shape; up to seven or eight in the umbel.

Flowers.-Peduncles flattened; stamens inflexed in bud; the anthers reniform.

Fruit.-Shining, nearly globular; usually $\frac{7}{1.6}$ inch in diamster, or a little less; urcalate in young fruit, the neck being almost lost in the matuse fruit. The rim sharp. The valves usually five, and very depressed.

Range.-On high mountain ranges of the extreme southern part of New South Wales (Tantawanglo Mountain, near Catheart).

The affinity of this variety is closest with var. stricta: It differs from the latter in being a large tree, in the shape of the fruits, and in the venation of the leaves.

* Bentham notes that the operculum is not longer than the calyx-tube. It is usually very much shorter. It noay be remarked that in regard to the general shape of the operculum with its umbo, this species bears resemblance to var, gbtusiflora, 
The fruits are sometimes not very dissimilar in shape to those of $E$. maculata and the small form of $E$. corymbosa, but the White Ash has no real affinity with either species, as it belongs to a different group entirely.

\section{Var. triftora, Maiden.}

I have described this variety at page 87 , Part xxv, of my "Forest Flora of New South Wales."

It was originally referred to by Mr. Deane and myself under E. stricta, in Proc. Linn. Soc. N.S.W., 1900, page 108. We received it from Mr. R. H. Cambage from top of Pigeon House Mountain (2,360 feet), near Milton. It is a small tree, a "White Ash."

Mr. Cambage's note is - "Bark dark, rough at base, then tones off; lower part only a little rough. Not even as rugged as E. pilularis."

Fruits nearly sessile, and in threes, hence the name proposed for this variety. Fruits nearly hemispherical, with a slight tendency to be urceolate.

The fruits of the arboreal form of stricta from Blackheath are also sessile, and are akin to this form. It would be desirable to ascertain, over large areas of country, to what extent the arboreal form of var. stricta has sessile fruits in threes.

Speaking generally, the coastal forms of $E$. virgata are the typical one and its variety obtusiflora, while the mountain forms are those of var. stricta (dwarf or arboreal).

At first sight $E$. virgata, Sieb., with its broad, flat horizontal fruit rim, E. obtusiflora, DC., with its blunt operculum, and E. stricta, DC., with its sunk fruit rim and somewhat urceolate-shaped fruit, are distinct enough in appearance, but when one examines a large series it is evident that we have no constant character to separate them.

Some specimens, e.g., from the Southern Mountain ranges and South Coast, will not fall under any of the above typical forms. I find myself at different times arranging specimens from the same district, and possibly from the same tree, under the three species or varieties referred to, with good reason in each case.

Specimens from Sugarloaf Mountain, near Braidwood, for example, would certainly be placed under var. stricta if they stood alone, but the fruits in the broadish rim of some of them show transit to $E$. virgata (typical).

From many other localities instances of the unstable character of the forms of this protean species could be cited.

\section{The confusion between E. stricta, Sicb., and E. cueorifolia, DC:}

I have carefully examined many flowering specimens of $E$. virgata, and its varieties obtusiflora and stricta, and all have reniform anthers. The anther of $E$. stricta, as figured in the "Eucalyptographia" (E. stricta plate, No. 5), is also reniform, and is doubtless correct. 

is:-

But Bentham's description (B.Fl. iii, 217) of the stamens of E. stricta, Sieb.,

Stamens not above 2 lines long, inflected in the bud; anthers very small and globular, with distinct parallel cells, opening at first in round pores, which extend into oblong slits.

Such anthers, partly as Bentham describes (i.e., parallel cells), are figured in Pl. 8, Mém. Myrt., DC., but Bentham says, "Anthers incorrect."

Luehmann says:- "The typical stricta of Sieber. Well described in "Eucalyptographia' with reniform anthers, Bentham (B.Fl. iii, 217) apparently had a mixture of two species before him, describing the fruit of $E$. stricta, but the anthers of another species."-(Proc. Aust. Assoc. Adv. Science, 1898, p. 528.)

I feel satisfied that all that is wrong in Plate 8 is the two enlarged anthers, and that the remainder of the plate may be accepted as true to its label_._" Eucalyptus stricta, Sieb."

I repeat (having seen Sieber's type of $E$. stricta) that both Bentham's description of the anthers as globular and De Candolle's figure of them as parallel-celled, are wrong, and that Sieber's plant belongs to the Renantheræ.

Speaking of the synonymy of $E$. oleosa, F.v.M., Mueller says:-

"E. cneorifolia, DC. Prod. iii, 220, and B.Fl. iii, 217, "so far as the plant with rough calyx (see De Candolle's plate 9.-J.H.M.) and kidney-shaped anthers from the mountains of New South Walcs (E. stricta, Sieb.-J.H.M.) united with it by De Candolle, and of which he gave a figure in his Mémoire sur la famille des Myrtacées pl. 9," is concerned " (Eucalyptographia, under $\boldsymbol{E}$. oleosa).

He carries out the same view when he labels a Blue Mountain specimen:- " $E$. stricta, Sieb.: E. cneorifolia, DC., Mem. et partim prod." (perhaps referring to the fruits). He puts a similar label on an $E$. apiculata specimen.

Mueller's view, and I had it from his own mouth and from that of Luehmann, may be also expressed in this way:-

The E. stricta, Benth., non Sieb. = E. cneorifolia, DC. (as depicted in Plate 9), which cneorifolia perhaps $=$ oleosa. Such a plant is not found on the Blue Mountains of New South Wales.

Mueller's view is the result of pushing the figures of parallel anthers in De Candolle's Plate 8 (E. stricta, Sieb.) to their logical conclusion, and also contemplating the rather poor figure 9 (of $E$. cneorifolia, where the fruits more closely resemble stricta than oneorifolia). I do not think it is necessary to take $E$. oleosa into consideration, and trust that the identity of $E$. stricta, Sieb., is perfectly clear.

I shall refer to the unfortunate confusion of E. stricta and E. cneorifolia again when I come to the latter species, since through the kindness of M. Casimir De Candolle I am in a position to speak with authority as to the plants confused under E. cneorifolia, DC. 


\section{RANGE.}

A typical form. Sieber's No. 467, Fl. Nov. Holl. Sieber's specimen came frcm Port Jackson or Blue Mountains, according to Bentham (B.Fl. iii, 202). Specinen received. from Berlin Herbarium.

Following are notes on three trees from the Spit, Middle Harbour, Port Jackson. They were all gathered within a few yards of each other, are all the same, and all similar to the type.

(a) 15 feet high. Angular twigs, pale-coloured foliage, the leaves falcate and hooked, 2 to $3 \frac{1}{2}$ inches, or rarely 4 inches, long. Pointed yellowish operculum. Fruits 5-celled, over $\frac{1}{2}$ inch long, by about $\frac{5}{16}$ across, and pale-coloured. They have a long, broad, common peduncle, and the calyx is elongated and continuous with the pedicel.

(b) Operculum pointed. Fruits 5-celled, flat-topped or a little domed, and barely half an inch long. The common peduncle elongated, and much flattened upward.

(c) Operculum pointed. Fruits half an inch long, flat-topped, but sunk, angled, in addition to a certain amount of longitudinal folding, the result of shrivelling, common to both var. obtusiflora and E. Luehmanniana. Leaves very shiny, thick, and with strongly-marked venation.

Bulli (W. Kirton), from Baron von Mueller.

All the above are from Port Jackson and a few miles to the south, likewise on the coast, and all are quite typical. It is, however, admixed with the blunt operculum form throughout its entire range.

Then compare the following specimens from localities further south:-

(1) Jervis Bay.-Leaves with strongly-marked veins; in this respect, and as regards size, precisely like var. obtusiflora. Operculum between that of $E$. virgata and var. obtusiflora. Fruit with thin rim, well sunk, and closely resembling that of E. stricta.

(N.B.-Buds of var. stricta usually closely resemble those of var. obtusiflora.)

(2) Conjola, near Mitton.-Strongly resembling the preceding, but the buds more nearly resembling those of var. obtusiflora; and as regarc's the fruits, some of them with a broader brim, showing characters of both $E$. virg:ata and var. stricta.

1. Var. obtusiftora (Sieber's No, 473, Fl. Nov. Holl.).

In its typical form confined to the coast, and apparently at no great distance from Port Jackson. It seems unnecessary to repeat a number of localities. 
Following is a connecting link with var. stricta :-

A small tree from Middle Harbour, Sydney, about 9 feet high, with a white-grey s nooth bark, the old bark leaving the tree in long, dark-coloured shreds. Buds clavate, and with double operculum. Fruits about $\frac{3}{3}$ inch long, of the shape of those of var. stricta, but with a thicker rim, and less sunk, 4-celled. The leaves linear-lanceolate, 5 inches by $\frac{1}{2}$ inch.

Var. obtusiflora is so similar to var. stricta that some botanists habitually label it $E$. stricta, looking upon it as the coastal form of that species (or variety).

\section{Var. stricta (Sieber's No. 472, Fl. Nov. Holl.).}

Occurs in the Blue Mountains, and the Braidwood and Moruya districts and intermediate localities. It cannot be stated that the true E. stricta is found in the Port Jackson district, as recorded by Bentham.

Very abundant on the Blue Mountain Range; it seems superfluous to give a list of localities. Mr. Cambage and I gave the following note on walking over the Blue Mountains:-

"Our first specimen was observed just past Faulconbridge Station, and was 9 inches in diameter, with a height of 20 feet. It is worthy of remark that the young leaves contain caoutchouc. In favourable localities this species, usually a shrubby plant, grows taller, with fewer flowers and coarser foliage. The coarseness of the species appears to be a matter of good soil and shelter."-(Proc. Linn. Soc. N.S.W., 1905, p. 196.)

Following is an aberrant specimen:- "Mountain Ash," Molong (W. S. Campbell). The fruits are more hemispherical and smaller than those of var. stricta usually are, but it seems to be an extreme form of that species. Molong is the most westerly locality yet recorded for it. Its fruits are not very dissimilar to those of the Pigeon House Mountain specimens (var. triflora), while its leaves are broad, like those of some of the aberrant forms from the south. Specimens such as these show a tendency towards E. Sieberiana.

All the above are western localities. Going south we have Sugar Loaf Mountain, Braidwood (W. Baeuerlen); top of Table Mountain, west of Milton, 4-7 feet high (R. H. Cambage); top of mountain (1,700 feet) near West Dapto (R. H. Cambage).

Let us now deal with the arboreal form of var. stricta (we cannot call it a variety).

See the Faulconbridge specimen already alluded to. Common in good soil and sheltered situations in the Blue Mountains generally.

Going south, we have "Trees up to 40 feet high. Scaly bark at base, whitish and smooth on upper part of trunk. Suckers up to 2 inches broad."* West Albion

* See note at foot of page 273. All the varieties tend to vary as regards the width of the jurenile foliage, but the general character of var. stricta is narrowness. 
Park, near Macquarie Pass (R. H. Cambage). Trunk 2 feet in diameter, growing just under edge of cliff (i.e., where there is accumulation of better soil, and some shelter), Bong Bong Pass, West Dapto (R. H. Cambage). In addition to the fairly large trees of this form in the Blue Mountains, I have observed them in the vicinity of the Fitzroy Falls, near Moss Vale, and in other places.

Following is a tree at Blackheath, N.S.W., which may be studied in this connection. It is about 25 feet in height and is 16 inches in diameter at 2 feet from the ground. It is very fully described as " $\mathrm{A}$ " in Proc. Linn. Soc. N.S.W., 1905, p. 199, by Mr. Cambage and myself, and we look upon it as a hybrid, of which E. stricta or var. stricta is a parent.

Another reputed stricta hybrid is designated as "C" by Mr. Cambage and myself in the paper just quoted. It is smaller than "A." A form closely allied to this has been collected by Mr. H. Deane at the Wolgan (table-land), near Clarence Siding, Blue Mountains. For the present we must content ourselves with collecting and making further observations, as it does not appear desirable, at all events at present, to name these aberrant forms.

But we have not finished with the anomalous forms of var. stricta.

Mr. Henry Deane has collected a plant from the summit of the Barren Mountain, on the range dividing the Bellinger and Clarence waters, 45 miles from the coast, and 4,500 feet above the level of the sea. This locality is very interesting for a variety of $E$. virgata. If flowering twigs were alone examined it would be called var. stricta, but the fruits are different. They are smaller, less urceolate, and with thicker rims, and in shape intermediate between var. stricta and E. virgata.

The leaves are entire, but if they be held up to the light, it will be observed that the soft tissue of which they are composed is serrulate; the cuticle does not follow the minute indentations, but forms an entire margin. The same thing is noted, in a lesser degree, in normal var. stricta, and also in E. apiculata.

The plant closest to it, in my opinion, is that designated as " B" by Mr. Cambage and myself, in the paper already cited. It is fully described there, and comes from Blackheath, a locality we have specially examined for anomalous forms of var. stricta.

\section{Var. fraxinoides.}

I only know of the type locality, Tantawanglo Mountain, Monaro, where it was collected by Mr. H. Deane and myself.

4. Var. triflora.

I only know of the type locality, Pigeon House Mountain, South Coast, N.S.W. (R. H. Cambage).

We want specimens of these two varieties collected from various localities. 


\section{AFFINITIES.}

1. With E. Luehmanniana, F.v.M.

This will be brought out in the present Part.

2. With E. apiculata, R. T. Baker and H. G. Smith.

The relations between these two species are of the closest character. E. apiculata may be br:efly described as a narrow-leaved form of $E$. virgata, var. stricta.

3. With E. Sieberiana, F.v.M.

The confusion which has existed between these two species (typical virgata and Sieberiana) has already been referred to under page 275. There is no doubt that herbarium specimens of the two species may sometimes be confused. As a rule, however, if fruits be available, the smaller and narrower fruits of $E$. Sieberiana are a ready guide. The affinity will be dealt with more fully when $E$. Sieberiana is reached.

4. With E. heemastoma, Sm.

Where $E$. virgata (typical form) is intermixed, as in the Port Jackson district, with $E$. hemastoma of about the same height (dwarf scrubby trees or saplings), the resemblance between them is not inconsiderable, and should be kept in view. 


\section{DESCRIPTION.}

\section{E. apiculata, R. T. Baker and H. G. Smith.}

Described in "Research on the Eucalypts," p. 198 (1902). Referred to, by name, without botanical description, in Proc. Roy. Soc. N.S.W., xxxv, 122 (1901). Following is the description:-

A shrub 6 to 8 feet high.

Leaves narrow, lanceolate, with a pronounced recurved point, erect, thinly coriaceous, shining, 4 inches to 5 inches long, potiole about 2 lines long.

Veuntion quite hidden beneath the cuticle, which, when removed, shows the lateral veins to be oblique and spreading, and identical in disposition with those of $E$. dives, Schau., and others of the "Peppermint" group of Eucalypts. umbel.

Peduncles axillary, about 5 lines long, terete or slightly flattened, with five to seven flowers in the

Calyx hemispherical.

Operculum hemispherical, shortly acuminate, 3 lines in diameter.

Orary flat-topped.

Stamens all fertile; anthers parallel, opening with longitudinal slits, connective projecting very prominently above the anthers.

Fruits might be described as hemispherical or pilular, but contracted at the rim, which is either countersunk or flat, 3 to 4 lines in diameter.

Habitat.-Berrima (J. J. Fletcher et R.T.B.); Mittagong (J. J. Hook), New South Wales.

Remarks.-This tree, both in the field and in herbarium material, has so much the facies of $E$. stricta, Sieb., that it was considered by us at first, and without any hesitation, as identical with that species. "The differences, however, in the constituents of their respective oils-differences such as could not be due to soil or climate, as both Eucalypts occur on the Hawkesbury Sandstone formation, and at the same altitude -caused us to make a further search for morphological characters, such as the oil constituents seemed to indicate. The presence of the peppermint constituent in this species also led us to look for a venation similar to that of $\boldsymbol{E}$. dives, Schau., and others containing this particular property, and such was found when the cuticle of the leaf was removed. By a similar treatment, the leaf of $E$. stricta was found to have a venation corresponding to E. Bridgesiana, R.T.B., and others of the best eucalyptol-yielding eucalypts. It is, therefore, upon the presence of these characters and oil constituents that the two species, $E$. stricta, Sieb., and E. apiculata, are separated (op. cit. p. 198).

The history of this species is, so far as I know it, as follows:-

(1) On a label, in the collector's handwriting, we have:- " $6 \mathrm{ft}$. densely covered with white blossom; many stemmed. High ridges above Berrima River, December" (L. Atkinson). This is Miss Louisa Atkinson, the well-known authoress, afterwards Mrs. Calvert. Mueller distributed Mrs. Calvert's specimens with the label "Eucalyptus rigida, Sieber (E. stricta, Sieb., var. angustifolia)." This was in the sixties.

(2) Another specimen, bearing in Rev. Dr. Woolls' handwriting the label "E. stricta, a scrubby species growing near Berrima, \&c.," was endorsed by Mueller; 
"Renanthereæ! E. cneorifolia, DC. Mém and partim Prodr." This is, of course, an allusion to the confusion between $E$. stricta and $E$. cneorifol a, with which I have dealt at page 280, Mueller being at the time under the impression (following Bentham) that the anthers of $E$. stricta were not reniform.

(3) Another specimen, which came through Dr. Woolls' hands, was labelled by him: "This specimen came from the (Berrima) coal-mine property, about 4 miles from Berrima" (J. Atkinson). "He calls it "Boree."

(4) Besides the label already quoted ( $E$. cneorifolia), I have seen specimens from Berrima labelled as follows by Mueller:- "Eucalyptus rigida, Sieber (E. stricta, Sieb. var. angustifolia)." I have already shown that Sieber's $E$. rigida $=E$. obtusiflora, DC.

(5) It was placed by Mueller under E. stricta ("Eucalyptographia"), and it is the narrow-leaved twig figured at the right-hand of the plate depicting that species. In the text he refers to it as "linear," and as collected at "Berrima (Mrs. Calvert) - . Leaves sometimes reduced to a width of 2 or 3 lines."

(6) It was subsequently described by Mr. Deane and myself as E. stricta, var. rigida, in Proc. Linn. Soc. N.S.W., xxii, 710 (1897), with a figure (fig. 18 of Plate xxxi).

(7) Then Messrs. Baker and Smith described it in 1902 as E. apiculata, as shown.

Looking at the analyses of the few specimens of oils of apiculata and the virgata series quoted by these gentlemen, I am not satisfied that E. apiculata can be granted specific rank on account of its oil, but think that the evidence of the juvenile foliage warrants the recognition of $E$. apiculata as distinct. I have never been fortunate enough to find the juvenile foliage in the opposite stage on the occasion of my visits to the habitat of the plant, but think that the early leaves as shown at $3 b$, Plate 44, are sufficiently different from those of $E$. virgata, var. stricta, to justify the species.

\section{SYNONYMS.}

1. E. microphylla, A. Cunn. (partim).

2. E. Cunninghamii, G. Don (partim).

3. E. Cunninghamii, Sweet. See page 130, Part V, of this work. The E. stellulata, var. angustifolia, there referred to, was subsequently described as E. Moorei, Maiden and Cambage.

4. E. stricta, Sieb., var. rigida, Deane and Maiden, in Proc. Linn. Soc. N.S.W., $\mathrm{xx} i \mathrm{i}, 710$ (1897).

\section{AFFINITY.}

It is very closely related to $E$. virgata, Sieb., var. stricta, Maiden. 


\section{DESCRIPTION. \\ XXX. E. Luehmanniana, F.v.M.}

Fragur. xI, 38 (Fasciculus Lxxxix, Nov., 1878). This is in Latin. It may be redescribed in the following words:-

A straggling, tall shrub or small tree, rarely exceeding a height of 15 to 20 feet, or a stem-diameter of 3 inches. The stem smooth and the timber pale-coloured.

This species is glaucous, even nearly white. At the same time it imperceptibly passes into a nonglaucous form. The branchlets are angular, and the species is coarse,-peduncles, fruit3, leaves, \&z., boing alike large.

Jurenile leares,-Coarse, up to 7 inches long by 4 inches wide. The resemblance to those of E. hamastoma is striking.

Mature leares. - Distinctly falcate, up to 8 inches by $1 \frac{1}{2}$ inches. Coriacenus; edges thickened; marginal vein usually at a little distance from the edge.

Peduncles.-Very much flattened. I have specimens which spread out upwards, so much that they are $\frac{1}{2}$ inch wide at the place of attacliment of the inflorescence. Top of peduncle quite broad and fleshy, in which the pedicels are articulate.

Buds.-Angular, pointed.

Caljx-tube. -The calyx often tapers into a widely expanded lobs, which is articulate on a broadtopped common peduncle; usually seven flowers in a head.

Operculum.-Double operculum or large calyptra-like bracts enveloping the whole head of flowerbuds, and only thrown off when the individual flower-buds are nearly ready to throw off their own opercula.

Fruit.-Often pale brownish and glossy, 5-celled, corrugated-partly due to drying; the rim slightly projecting.

\section{Notes supplementary to the description.}

Specimens from the north of Port Jackson (between this estuary and the Hawkesbury River) appear to differ from the type only in the following particulars:-

(1) They are glabrous.

(2) The calyx-tube is more elongated, and the stalk of the fruit thinner.

The most obvious difference is the almost entire absence of glaucousness; no other difference is obvious or constant.

Plants from the Spit (Middle Harbour, Sydney) have the buds quite pointed, and long, with non-glaucous leaves. This is a form which would be separated from $E$. virgata with greater or less reluctance, according to the elasticity of view held in regard to the definition, of that species. 


\section{SYNONYMS.}

1. E. siricta, Sieb., var. Luehmanniana, F.v.M.

2. E. virgata, Sieb., var. Luehmanniana, F.v.M.

3. E. rigida, Sieb., var. Luehmanniana, F.v.M.

var. altior, Deane and Maiden.

4. E. oreades, R. T. Baker.

5. E. virgata, Sieb., var. altior, Deane and Maiden.

1. E. stricta, Sieb., var. Luehmanniana, F.v.M.

The species name Luehmanniana was suppressed by the author in his Census (1st Edition, 1882), but not before he had included it under.E. stricta (Eucalyptographia). $\mathrm{He}$ is not as clear as he might be on the subject, but he speaks of $E$. virgata as "a form" . . . (of E. stricta), and a little further on of "The variety Luehmanniana - . " (of virgata, and consequently of stricta). In the 2nd Edition (1889) of the Census it appears (by reference) under $E$. virgata, Sieb., which species itself had been suppressed in the 1st Edition of the work.

2. E. virgata, Sieb., var. Luehmanniana, F.v.M.

Mueller distributed a good deal of this plant under the above name. He refers to it in "Eucalyptographia" (under E. stricta) in the following words:- "But the real $E$. virgata does undergo a development in another direction, enlarging to that startling state, which was distinguished as E. Luehmanniana . . ."

3. E. rigida, Sieb., var. Luehmanniana, F.v.M.

(in "Eucalyptographia" under E. Planchoniana).

\section{Var. altior, Deane and Maiden.}

Following is the original description of the variety:-

A tree which may be described as a form of E. Luehmanniana, with fruits and all other parts comparatively small. The following notes will render the resemblances and differences clear:-

Immature folinge, inflorescence and fruits, also twigs, all glausous.

General remarks. - A tree of 60 or 70 feet, with a trunk diameter up to 2 feet. It will be observed that the tree is far larger than that of $E$. Luehmanniana, a circumstance which we record in the name altior.

Bark.-Smooth, with some bark near the butt, falling off in ribbons. A "White Gum."

'Timber.-Pale-coloured.

Seedling leaves.-Young seedlings remind one of those of $E$. Sieberiana a good deal. They are medium lanceolate, bluish-green, equally green on both sides. Decussate at first, after two or three pairs they lose their horizontal charaeter. At length they are more or less undulate and pendulous (Maiden and Cambage, Proc. Linn. Scc. N.S.W., 1905, 196). 
Mature leaves.-Very similar to those of E. Luehmanniana, with, perhaps, the following differences:-The leaves are thinner, the petioles less flat, and there is a greater tendency in the lower leaves for the veins to procced right from the base of the leaf. Rarely longcr than $4 \frac{1}{2}$ inches or broader than 1 inch.

Peduncles.-Very much flattened, in proportion to the sizo of the fiuits, perhaps as much so as is the case in the nomal specios.

Calyx-tube. - Similar to the normal species, though less angular. Usually seven flowers in a head.

Operculum.-Proportionately smaller, also less pointcd. Palc-coloured operculum like some of the slightly-pointed opcreulum caast-forms of obtusiflora.

Fruits.-Flat-topped; when not fully ripe quite glaucous, with the exception of the rim which is red, contrasting strongly with the remainder of the fiait, which is smoother than that of the normal species. Pale brown and shining when fully ripe; from nearly hemispherical to subconical, the edge of the rim sharp, and 5-celled. f: vit, $\frac{1}{S}$ inch.

Dimensions. - Greatest length and greatest breadth of fruit about $\frac{7}{16}$ inch. Width of rim in mature

Range. - In the taluses of the sandstone cliffs about Mount Wilson. (Deane and Maiden in Proc. Linn. Soc. N.S.W., 1897.)

\section{Notes supplementary to the description.}

It is not only found at Mount Wilson, but at Mount Victoria and other elevated parts of the Blue Mountains. It is a typical ribbony gum, the ribbons being 8 or 10 feet long and even more, broad and tough. We think it very probable the species has been sometimes noted as $E$. viminalis, judging from its appearance as a ribbony gum, but it is a handsomer and more erect species than E. viminalis. It is a tall tree, very straight, 60-100 fee high, and even more. It has absolutely clean, shiny stems except at the butt, say for 8 or 10 feet, where it is more or less fibrous. At Mount Wilson. it is associated with $E$. goniocalyx, and at Mount Victoria with the same species to a less extent. It has reddish twigs, and slightly glaucous leaves rich in oil. . . .

The Blue Mountains tree is known and cut commercially as "Mountain Ash." This is, of course, the ordinary name of E. Sieberiana, F.v.M. The timbers of the two treès are not dissimilar, neither are the immature fruits (Deane and Maiden, loc. cit.). At Mount Irvine it is known as "Yellow Gum."

The large calyptra-like bracts on the umbels of buds, so obvious in the normal form, are very marked in the variety also. Both type and variety have specially fragrant leaves.

\section{SYNONYMS.}

4. E. oreades, R. T. Baker, Proc. Linn. Soc. N.S.W., xxiv, 596 (1899). Figured with unripe fruits.

5. E. virgata, Sieb., var. altior, Deane and Maiden, (Proc. Linn. Soc. N.S.W., . 1901, 124.) 


\section{RANGE.}

THe typical form is restricted, so far, as is known at present, to the neighbourhood of Port Jackson and of the National Park (a few miles to the south). The most northerly locality known to me is Berowra (R. H. Cambage).

\section{Variety altior.}

Found in the valleys or on the taluses of the hills of the Blue Mountain Range, from Springwood higher. Also at Mount Warning, near the Queensland border, at an altitude of over 3,000 feet (W. Forsyth). A tree there of 30-40 feet. So far, I do not know any connecting localities; these should be looked for.

\section{AFFINITIES.}

Compared with $E$. virgata and its forms, E. Luehmanniana has broad juvenile foliage. This has enabled me to submit a scheme for the separation of the two species. At the same time the two species are closely related and have more than one point of c'ose approach, if not of actual contact. E. virgata (the typical form), for example, is very close to $E$. Luehmanniana, and the synonymy of the two species shows how different botanists have been impressed with the closeness of the relations between them. Nevertheless, in my view, there is a distinct line of cleavage between them.

1. With E. virgata, Sieb., var. fraxinoides, Maiden.

This tree resembles var. fraxinoides somewhat in general appearance (except as regards the occasional blotchiness of its bark), in timber, buds, and inflorescence, but the fruits are very different.

2. With E. Sieberiana, F.v.M.

This variety has a good deal of affinity with E. Sieberiana. This is shown in the seedlings, and, to a less extent, in the fruits and timber. The bark (hard and dark in the case of $E$. Sieberiana) would prevent the two trees, when of any size, from being confused with each other.

3. With E. obliqua, L'Hér.

These two trees have a good deal in common. The bark of E. ofliqua is, however, fibrous, and its fruits different in shape. 


\title{
DESCRIPTION.
}

\section{E. Planchoniana, F.v.M.}

Fragm. xi, 43 (November, 1878). It is described in English in the "Eucalyptographia," where there is a figure. In my view this drawing can be improved, and so I caused a drawing to be made for Part xxiv of my "Forest Flora of New South Wales." That Part contains some of my notes on the species, and I have but little to add.

The affinity of E. Planchoniana to E. virgata is unquestionable. It might even be looked upon by some botanists as a very large-fruited form of that species. I do not see any difference in the timbers of the two species. At the same time I do not propose to suppress E. Planchoniana. As a young tree, the marked purplish cast of its foliage gives it an ornamental appearance.

\section{Explanation of Plates (41-44).}

\author{
PLATE 41. \\ E. alpina, Lindl.
}

1a. Twig with buds; 1b, twig with fruits; 1c, single fruit of type specimens, viz., No. 243 of Major Mitchell's Expedition, 1836, "Summit of Mount William," Grampians. Note how much smaller and less tuberculate the fruits are than in most specimens attributed to $E$. alpina.

2a. Flowers (past maturity); 2b, front and back view of anther ( $\mathrm{I}$ cannot see any difference between the anthers of $E$. alpina and $E$. capitellata); 2c, fruits (note their tuberculate character). All from the Grampians, Victoria. (C. Walter.)

3. A single oblique leaf from the Grampians.

4a. Buds; 4b, fruits, from Mount Zero, Grampians. (St. Eloy D’Alton.)

5a. Leaf; 5b, fruit (note its large size and smoothness). Mount Abrupt. (H. B. Williamson.)

$$
\text { E. microcorys, F.v.M. }
$$

6. Juvenile leaves, still in the opposite stage. Armidale, N.S.W. (A. W. Howitt.)

7. Broadish leaf, in the intermediate stage. Mullumbimby, N.S.W. (W. Baeuerlen.)

8a, 8b. Mature leaves; 8c, fruits. Grafton to Coff's Harbour, N.S.W. (J.H.M. and J. L. Boorman.)

9a. Buds; 9b, front, and 9c, back view of anther. Woolgoolga, N.S.W. (E. H. F. Swain.)

[Tab. xxxiv, $3 a$ (bis) of Vol. I of Gaertner's "De fructibus et seminibus plantarum" may ke E. microcorys.]

$$
\text { E. umbra, R. T. Baker. }
$$

10. Sucker leaf, one of two strictly opposite and sessile. Newport, N.S.W. (R. H. Cambage.)

11a. Mature leaf; 11b, buds; 11e, fruits of typa. Spit Road, Mosman's Bay, Sydney. (R. T. Baker.)

12. Fruitz, very small, from Peat's Ferry. (H. Deane.) From the same tree are fruits of the normal size. 


\title{
PLATE 42.
}

\author{
E. acmenioides, Schauer.
}

$1 a$ and $1 b$. Juvenile leaves, still in the opposite stage; $1 c$, fruits, from Brisbane, Queensland. (J.H.M.)

2. Fruits from Kincumber, N.S.W.; larger than the preceding. (W. R. Stacey.)

$3 a$. Leaf; $3 b$, ripe buds, just losing opercula, of the type specimen of $E$. triantha, Link., from the Botanical Museum, Berlin (per favour of Dr. L. Diels).

4a. Twig with buds (note the sinuate margin of the leaf, which is charactcristic of the species); $4 b$, front and back view of anther; 4c, fruits (larger than Nos. 1 and 2). Booral district, N.S.W. (A. Rudder.)

5a. Leaf (rather broad); 5b, fruits; from Rockhampton, central coastal Queensland. (A. Murphy.)

6a. Very thick leaf, with wavy margin; $6 b$, buds; $6 c$, fruits of a White Mahogany from Awaba (between Gosford and Newcastle), N.S.W. (J. L. Boorman.) I look upon this as showing transit between E. umbra and $E$, acmenioides.

$7 a$ and $7 b$. Juvenile leaves, still in the opposite stage; $7 c$, mature leaf, with wavy margin; $7 d$, very young buds; 7e, fruits, from a "White Mahogany" tree, Woy Woy, N.S.W. (A. Murphy.) I cannot resist the inference that this tree is intermediate in character between $E$. umbra and $E$. acmenioides. Both 6 and 7 are coarser than $E$. acmenioides, and the leaves and fruit approach those of $E$. umbra.

8a. Juvenile leaves; $8 b$, fruits of a tree from Woodburn, Richmond River, N.S.W. (W. Baeuerlen), which Mr. R. T. Baker has, since the drawing was made, described as a new species, under the name of $\boldsymbol{E}$. carnea. I look upon it as an intermediate form between $\boldsymbol{E}$. umbra and $\boldsymbol{E}$. acmenioides.

\section{PLATE 43.}

$$
\text { E. virgata, Sieb. }
$$

1. Twig, with buds, drawn from Sieber's type of $E$. virgata (No. 467, Fl. Novæ Holl.). Leaves very thick, and scarcely showing venation.

2a. Juvenile leaves, just past the opposite stage; $2 b$, mature leaf; $2 c$, buds; $2 d$, fruits. North side of the Spit, Middle Harbour, Port Jackson. (J. H. Camfield.) The specimens match the type very closely; I have some that quite match it.

$$
\text { var. obtusiflora. }
$$

3. Portion of drawing of type of E. obtusiflora, DC. (Pl. 10 Mém. Fam. Myrt. t. 10, par A. P. De Candolle.)

$4 a$. Leaf; $4 b$, front and back view of anther; $4 c$, buds; all drawn from a typa specimen of Sieber's No. 473 , the number figured by De Candolle in the drawing just quoted. This form is specially abundant near South Head, Port Jackson.

5. Perfectly ripe fruits of $E$. obtusiflora, DC, from Vaucluse to Bondi, Sydney. (J.H.M.) Note the broad, flat rims.

6. Fruits. La Perouse Road, Botany. (J. H. Camfield.) Typical obtusiflore. Fruits rather hemispherical and with sunk rims. Other fruits from this area precisely match (5).

7. Juvenile leaf, still in opposite stage. National Park. (J. H. Camfield.)

N.B.-I camot say in what way these leaves differ from those of the arboreal form of Blackheath, N.S.W. (See fig. 17a, Plate 43.)

$8 a$. Juvenile leaves, in opposite stage; $8 b$, buds; $8 c$, two views of a fruit, showing warty protuberances; $8 d$, fruit showing a tendency to be urceolate. North side of Suspension Bridge, Middle Harbour, Port Jackson. (J. H. Camfield.)

N.B.-All these specimens from the same shrub!

This is a coastal locality, and yet the juvenile leaves and fruits ( $8 d$ ) would be at once named stricta if found on the Blue Mountains. 
9. Fruits. National Park, near Sydney. (J. H. Camfield.) These fruits are from a coastal locality, and the shrubs are named obtusiflora without hesitation, but the fruits are strikingly reminiscent of stricta.

10. Fruits. Jervis Bay. (J.H.M.) These fruits are not quite ripe, and are shrivelled. Buds pointed (like virgata); thin rims to fruits. They certainly connect virgata and obtusifora.

11a. Buds; 11b, fruits; 11c, fruit. Conjola, near Milton (almost the most southerly recorded locality for N.S.W.) (W. Heron.) These specimens were all taken from the same shrub! The pointed buds show transit to virgata; the fruits (11b) are nearly typical obtusiflora (5), yet they are slightly urceolate, liko stricta. The fruits (11e) show, Jike (6), that we can have thin rims in obtusiftora.

$$
\text { var. stricta. }
$$

12. Portion of drawing of E. stricta, Sieb., taken from Pl. 8 of Mém. Fam. Myrt. par A. P. De Candolle.

13a. Twig bearing buds; 13b, fruits; drawing from a specimen of Sieber's type of $E$. stricta (No. 472).

14. Fruits. Lawson, Blue Mountains, N.S.W. (J. H. Camfield.) These are the fruits which are as small as or even smaller than the type. (See 13b.)

15. Fruits. Jenolan Caves, N.S.W. (W. F. Blakely.) These are drawn to show that the fruits of E. stricta may be much larger than those of the type.

Arboreal forms of var. stricta.

16a. Leaf; 16b, fruits. "Mountain Ash," Molong, N.S.W. (W. S. Campbell.) This appears to be an arboreal form allied to $E$. stricta, with larger leaves and more hemispherical fruits.

17x. Juvenile leaves (note how broad they are); 176 , juvenile leaves (note how narrow they are, but from the same plant as $17 a)$; 170 , buds; $17 d$, fruits. All from the same clump of trees at Blackheath, N.S.W. (R. H. Cambage and J.H.M.) These trees are of considerable size, and are in good soil and in a sheltered situation. We traced all stages, from the scrubby growths on poor soil and exposed situations to the larger growths with better soil, \& $c^{2}$. The inflorescence is sessile, but the pedicel varies in various forms.

\section{PLATE 44.}

var. fraxinoides.

1a. Leaf; $1 b$, buds; $1 c$, fruits; $1 d$, fruits. All from the type of $E$. fraxinoides, Deane and Maiden, and collected by the describers at Tantawanglo Mountain, N.S.W. $1 d$ shows unmistakable affinity to var. stricta.

$$
\text { var. triftora. }
$$

2a. Leaf; 2b, fruits. A "White Ash," top of Pigeon House Mountain, South Coast, N.S.W. (R. H. Cambage.) A remarkable and interesting form of this variable species. (See p. 279.) The fruits are nearly spherical, and in threes. The common peduncle of the three fruits has been shown too prominently in the drawing.

$$
\text { E. apiculata, Baker and Smith. }
$$

3a. Juvenile leaves; $3 b$, leaves in the intermediate and mature stage; $3 c$, anther, front and back; $3 d$, fruits. Near Berrima Coal-mine, N.S.W. (J.H.M. and J. L. Boorman.)

$$
\text { E. virguta, Sieb., var. stricta, Maiden (arboreal form). }
$$

4a. Leaf; 4b, buds; 4c, fruits. Faulconbridge, Blue Mountains, N.S.W. (R. H. Cambage and J.H.M.)

5a. Leaf; $5 b$, buds; $5 c$, fruits. West Albion Park, near Macquarie Pass, N.S.W. (R. H. Cambage.)

Nos. 4 and 5 are trees. They are arboreal forms of var. stricta. They resemble each other, and especially No. 17, Plate 43.

Var. stricta, although usually a shrub, becomes a medium-sized tree when the conditions are favourable. 


\section{E. Luehmanniana, F.v.M.}

$6 a$. Juvenile leaves; $6 b$, portion of stalk enlarged, showing glands; $6 c$ and $6 d$, leaves in the intermediate stage; $6 e$, mature leaf; $6 f$, broad peduncle and bract (double operculum) covering buds; $6 g$, broad peduncle and young buds; $6 h$, a stage more developed than $6 g ; 6 k$ and $6 l$, fruits. All of E. Luehmanniana, National Park, Sydney, practically a type locality, except $6 h, 6 k$, which are from the Spit, Middle Harbour, Sydney.

var. altior, Deane and Maiden.

As to the leaves, I cannot ascertain in what way they differ from those of the normal form. Speaking generally, perhaps the coarse intermediate foliage is more common in the normal form (perhaps more obvious because it is dwarf) than in the variety. But neither in the juvenile foliage nor in the mature foliage could any difference be seen, and so the expense of separate drawings was not undertaken.

$7 a$, 76 . Fruits from Mount Wilson (J.H.M.); $7 c$, biact; $7 d$, buds, Blackheath (J.H.M.); $7 e$, broadening petiole and bract, Mount Warning (W. Forsyth); 7f, fruits from type of E. oreades, R. T. Baker, Adelina Falls, Lawson (R. T. Baker). The fruit is immature and rim much sunk. $7 g$, fruits, Mount Wilson (J.H.M.) The fruits are still immature, but riner than $7 f$.

Syciney : William Applegate Gullick, Gorernment Printer. $-100 \%$ 


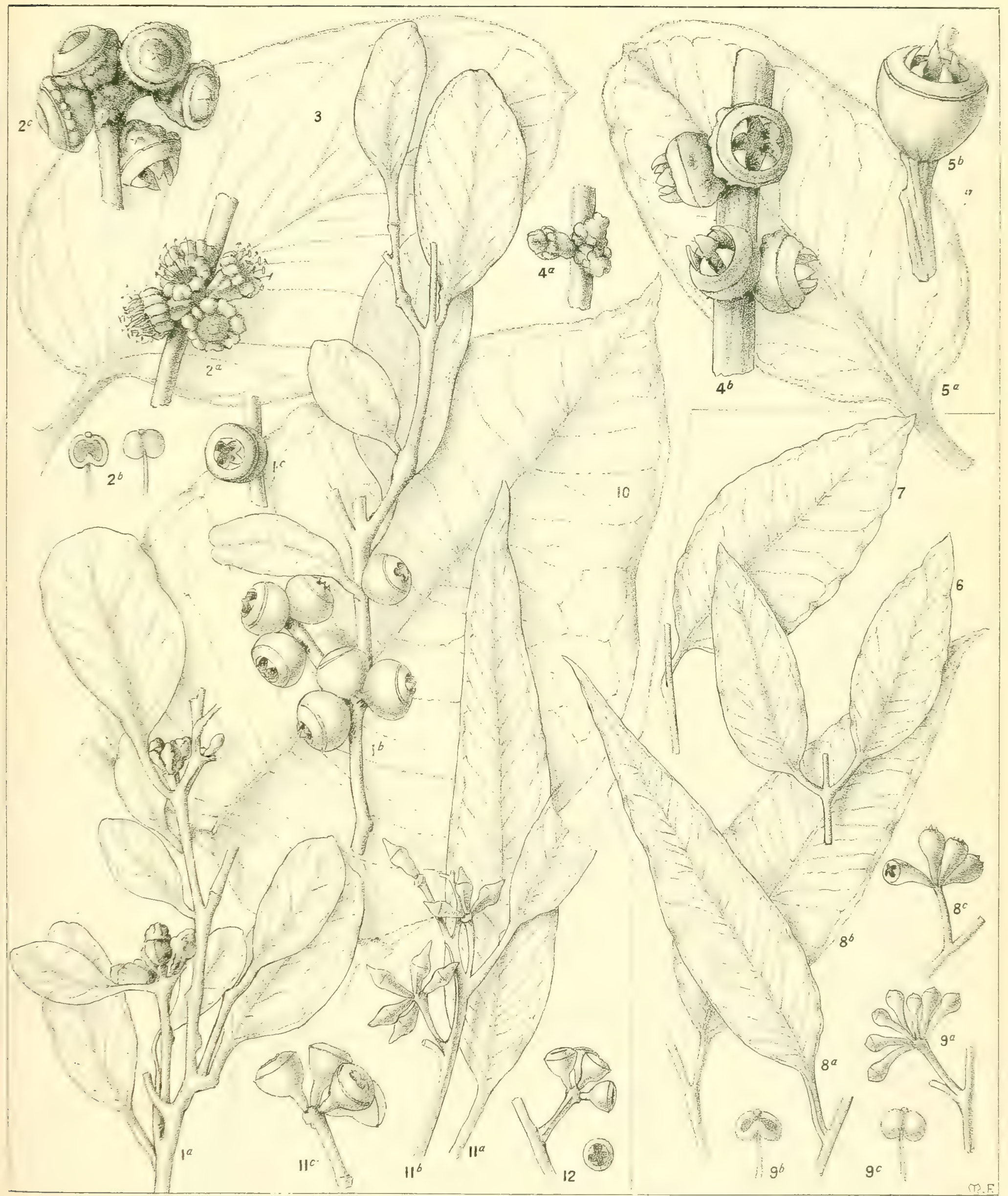





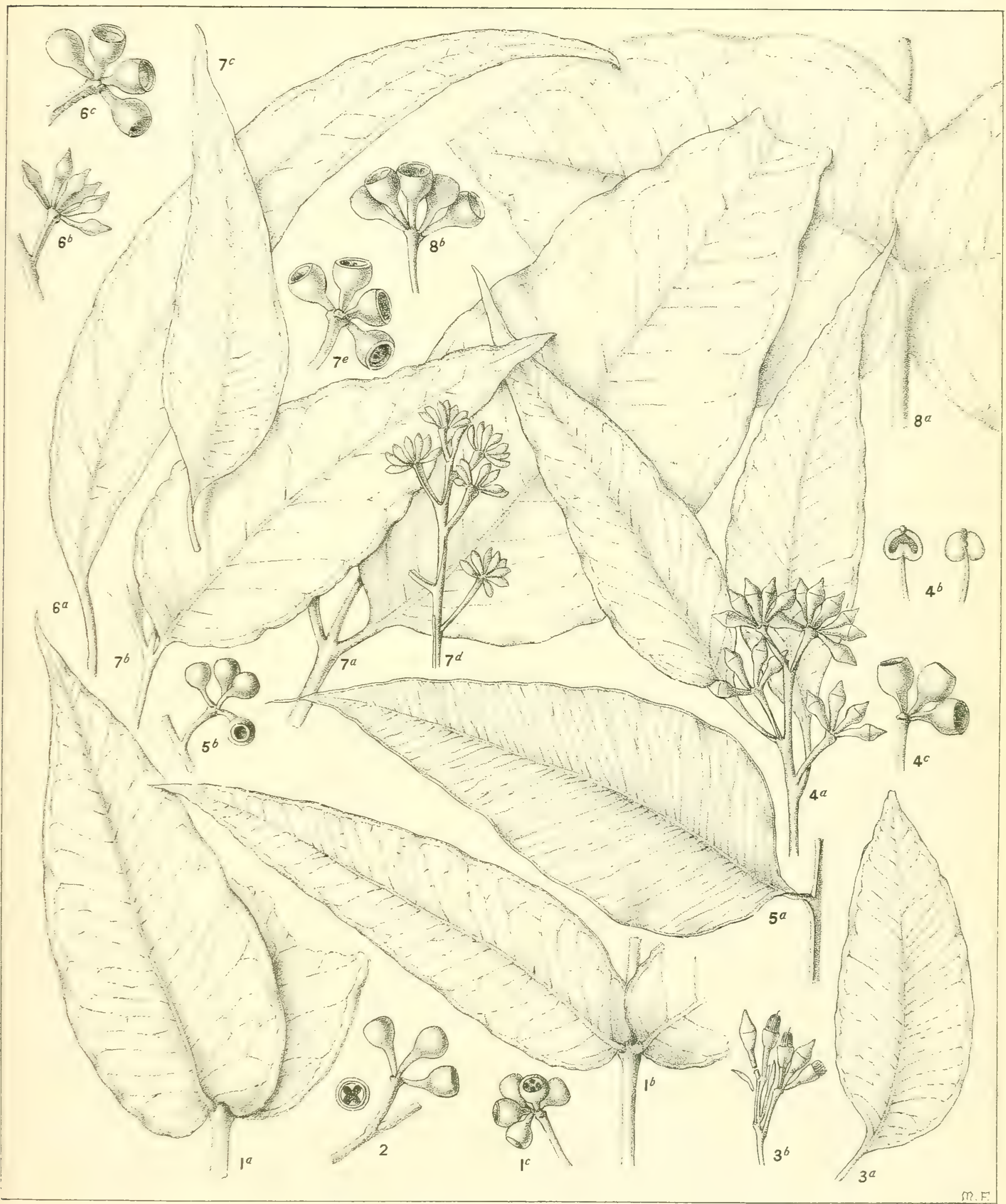





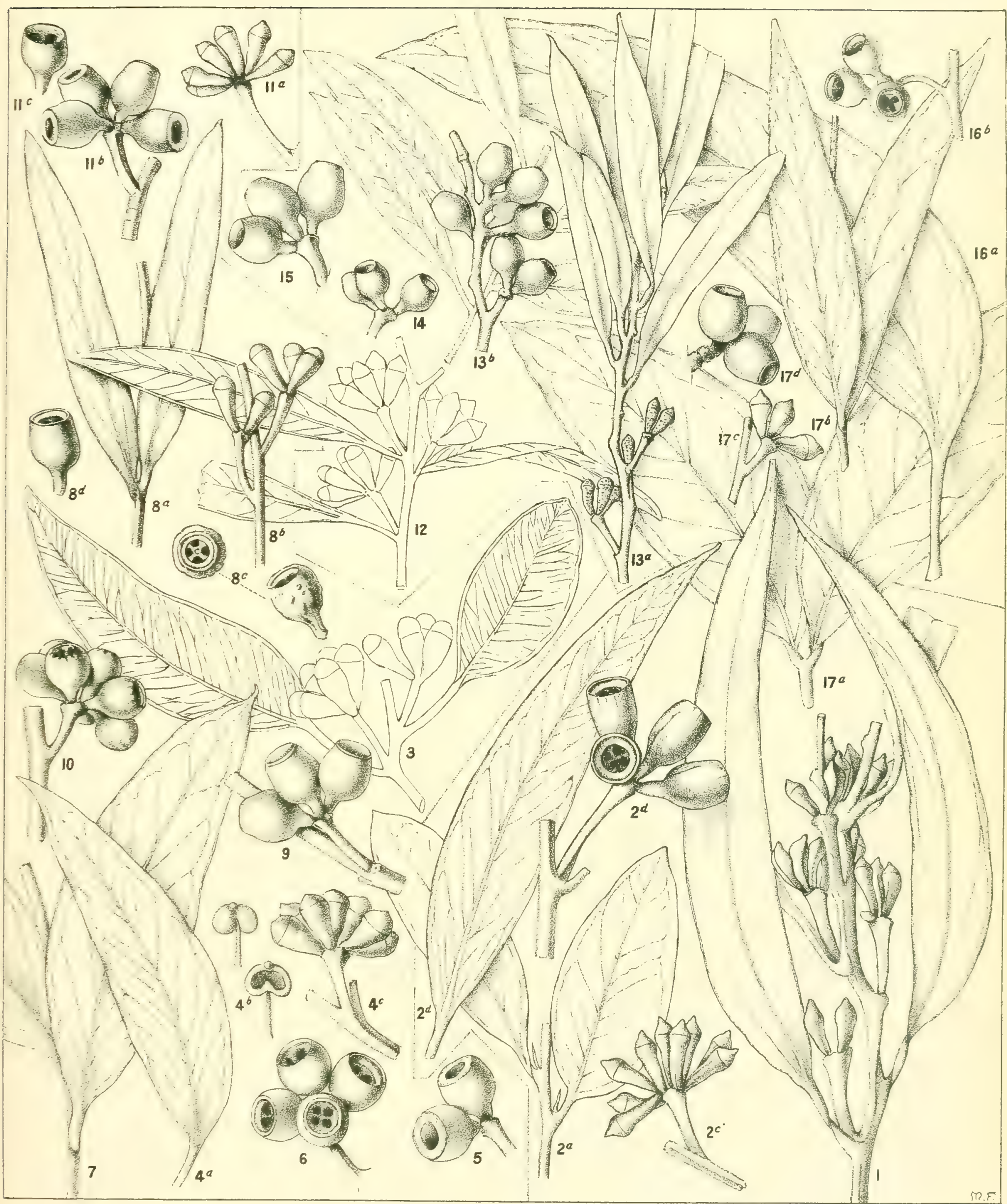





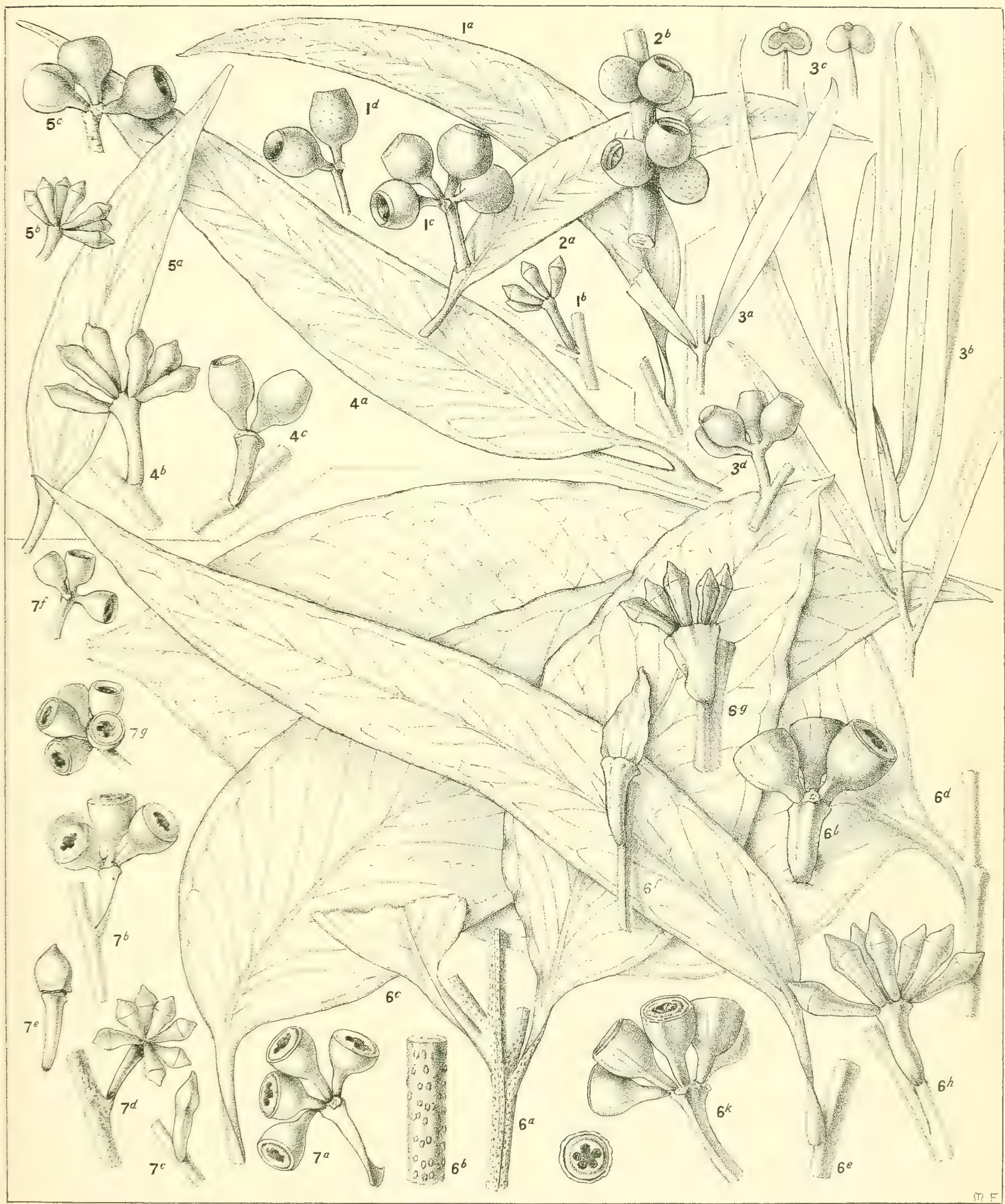

E. LUEHMANNIANA, F.v.M. (5-7.)

(Nos. 1-5 are forms allied to E. virgata, var. stricta). 



\section{A CRITICAL REVISION OF THE GENUS EUCALYPTUS}

\section{BY \\ J. H. MAIDEN}

(Government Botanist of New South Wales and Director of the Botanic Gardens, Sydney).

\section{PART X}

(WITH FOUR PLATES)

Price Two Shillings and Sixpence.

Published by Authority of

THE 'GOVERNMENT OF THE STATE OF NEW SOUTH WALES.

Syconen:

WILLIAM APPLEGATE GULLICK, GOVERNMENT PRINTER.

$\overline{1908 .}$ 



\title{
A Critical Revision of the genus Eucalyptus
}

BY

\author{
J. H. MAIDEN
}

(Government Botanist of New South Wales and Director of the Botanic Gardens, Sydney).

\section{PART X \\ (WITH FOUR PLATES).}

" Ages are spent in collecting materials, ages more in separating and combining them. Even when a system has been formed, there is still something to add, to alter, or to reject. Every generation enjoys the use of a vast hoard bequeathed to it by antiquity, and transmits that hoard, augmented by fresh acquisitions, to future ages. In these pursuits, therefore, the first speculators lie under great disadvantages, and, even when they fail, are entitled to praise."

Macaulay"s "Essay on Milton."

PRICE TWO SHILLINGS AND SIXPENCE.

Pullished by Authority of

THE GOVERNMENT OF THE STATE OF NEW SOUTH WALES.

Sugunev :

William APPLEGATE GULlick, GOVERNMENT PRINTER, PHILLIP-STREET.

$\$ 25380 \quad$ A

1908. 



\section{Eucalyptus piperita, Smith.}

Description

PAGE.

Synonym .

Notes supplementary to the description. . 300

Range.

Affinities

XXXIII. Eucalyptus Sieberiana, F. v. Mueller.

Description

Notes supplementary to the description. . 306

Synonyms

301

Range.

Affinities

\section{Eucalyptus Consideneana, Maiden.}

Description

Notes supplementary to the description. . 312

Range.

Affinities

XXXV. Eucalyptus hocmastoma, Smith.

Description

The type fopm . 317

The type form . . . . . . . . 317

Varieties . . . . . . . 318

Synonyms :

Range

Affinities

XXXVI. Eucalyptus siderophloia, Bentham.

Description

Notes supplementary to the description . . 324

Varieties

Synonyms.

Note on E. persicifolia, DC.

Range

Affinities 


\section{Eucalyptus Boormani, Deane and Maiden.}

Description

Notes supplementary to the description . . 330

Range

Affinities

XXXVIII. Eucalyptus leptophleba, F. v. Mueller.

Description

Notes supplementary to the description . . 332

Synonym .

Range

Affinities

XXXIX. Eucalyptus Behriana, F. v. Mueller.

Description

Notes supplementary to the description . . 335

Synonym

Range

Affinities

336

Affinities

XL. Eucalyptus populifolia, Hooker.

Description . . . . . . . . . 339

Notes supplementary to the description . . 339

Synonyms.

339

Range

Affinities

Doubtful Species: Eucalyptus Bowmani, F. v. Mueller.

Description . . . . . . . . . 344

Range

Notes supplementary to the description . 344

Affinities

Explanation of Plates. 


\section{DESCRIPTION. \\ XXXII. Eucalyptus piperita, Sm.}

Followtrg is the original description :-

E. piperita, operculo hemisphrico nucronulato, umbellis lateralibus subpaniculatis solitariisve; pedunculis compressis, ramulis angulatis.

Lid hemispherical, with a little point. Umbels lateral, somewhat paniculated, or solitany; flower stalks compressed; young branches angular.-Syn. E. piperita, White's Voy. p. 226, figure of the leaves only.

A fine essential oil, much like that of Peppermint, is obtained from this species, and every part of the dried plant exhales the same odour when rubbed. We are now convinced this is distinct from the following ( $E$. obliqua), having compared the flowers of both. At the same time we have observed the minute white spots on the leaves (White's Voy., 228) in R. piperita, as well as in the other.-("Zoology and Botany of New Holland," by G. Shaw and J. E. Smith, 1793, Vol. i, p. 42.)

Some confusion which has gathered around this species and E. capitellata described by Smith at the same time, is explained at p. 211, part VIII, of this work.

Smith again described the plant in Trans. Linn. Soc., iii, 286 (1797).

I have examined the following early specimens, and they are all $E$. piperita:-

(a) "Eucalyptus, Governor Phillip, New South Wales, ex herb. Lambert." Herb. Cant. ex herb. Lemann.

(b) "Eucalyptus piperita, N. Holland, Dr. Smith, ex herb. Lambert." Herb. Cant. ex herb. Lemann. Apparently a co-type.

(c) No. 4,725 of Robert Brown's specimens (1802-0) distributed by the late Mr. J. J. Bennett.

(d) "Eucalyptus closely allied to E. paniculata, Sm., Port Jackson, A.C." Herb. Cant. ex herb. Lindl. Iabel in Allan Cunningham's handwriting.

Then we have-

"221. E. piperita, Smith. W., sp. (Willdenow's) 2.978. Hab. in Australia, Fol. 3' lg. 1' lt. parum acutata basi subovata." (Link's Enumeratio.)

We have also Hoffmannsegg-

"431. Eucalyptus piperita. In Link Enum. folia . . . basi subovata dicuntur, itidenque in E. media, mucronata, et reticulata. In Flor. Port. autem constitutum est, ovatum esse id, cujus latitudo plus quam dimidium sit longitudinis. Tune hic terminus basin respicere nequit. Forte cl. Aut. sententiam ibi pronunciatam mutavit; equidem ei semper, utpote utilem expertus, fideliter adhæreo." (Verz. Pfl. Vachtr. 2, p. 114.)

E. piperita was first fully described in English by Bentham, in B.Fl. iii, 297. Mueller described it and figured it in his "Eucalyptographia," but his figure is very unsatisfactory, and his description shows that he has confused it somewhat with $E$. eugenioides, Sm.-like E. piperita, a common Sydney species.

The fruits depicted are intermediate between those of $E$. piperita and $E$. pilularis or $E$. eugenioides; they are far from being typical. Mueller states ("Eucalyptographia," under piperita) that the seedling or juvenile foliage there 
depicted belongs to $E$. eugenioides. It is certainly not typical eugenioides, but rather capitellata or macrorrhyncha. See figures in Part VIII. The juvenile foliage of E. piperita is always glabrous.

The species may be described as follows :-

Vernacular names.-"Peppermint" is its usual name about Port Jackson and in some other districts. It goes by the name of "Messmate" in some other parts of the State. It has been called "Almond-leaved Stringybark" and sometimes "White Stringybark." Through confusion with E. pilularis (to which it is often not dissimilar in general appeurance) it is sometimes known as "Blackbutt," but such names as Stringybark and Blackbutt as applied to this species should be discouraged.

Bark.- Sub-fibrous on the trunk, with smooth branches. In mountainous districts it is often decidely a ribbony Gum.

Timber.-Pale-coloured, with gum-veins, deficient in strength and durability, and only used in default of better timber.

Seedling leaves. - The seedlings are cordate at the base; stem-clasping, blunt, or with a short, sliarp apex. They are arranged decussately and horizontally; hardly glaucous; paler on the underside. Venation well marked. They have a strong peppermint perfume.

Mature leaves. - Very oblique, more or less falcate and acuminate. In the Flora Australiensis it is stated that the leaves are rarely above 1 inch long, but this appears to be a mere typographical error, as specimens with far longer leaves which were examined by Bentham himself, and leaves 5 or 6 inches lung, are common. The venation is oblique.

Flowers. - Renantherous. The bud has a pointed operculum and is often curved; often nearly falcate when unripe. Sometimes the operculum is markedly pale-coloured; this is accentuated in dried specimens

Fruit. - The fruits may be arranged under three forms, which pass into one another:-

(a) Urceolate (the type).

(b) Egg-shaped.

(c) Nearly spherical, open-mouthed.

\section{Notes supplementary to the description.}

As regards the shape of the fruits, we have-

(a) Urceolate.-This is the commonest Port Jackson form, and must, we think, be regarded as the type. It is probably the form corresponding to the leaves secured by White. It is found in the Blue Mountains, Goulburn, Braidwood, Moruya, and throughout the range of the species generally.

(b) Egg-shaped.-The range of this form is probably co-extensive with the species. We have egg-shaped fruits from Port Jackson, the Blue Mountains and the Mudgee district, and south to Thirlmere, Picton to Bargo and Ulladulla.

(c) Nearly spherical.-These occur at Manly, Port Jackson, and some other places elsewhere in this State. Some of Mr. Howitt's Gippsland specimens in my opinion also fall under this group. The fruits are very small, not exceeding 2 lines in diameter.

This form may, perhaps, be confused with E. mumerosa, Maiden, if individual fruits be alone examined, but the leaves of the latter are much narrower, are thinner, duller, full of oil dots (the leaves reek with oil), and the twigs are rusty-tuberculate. 

Benth. :

In the "Flora Australiensis," iii, p. 207, we find mentioned, var. laxiflora,

Pedicels rather long. Fruit more obovoid, the rim more depressed. Manly Beach, Twofold Bay, Camden, Macleay and Clarence.

I have been trying to ascertain what this so-called variety really is. No specimens are so labelled in the Melbourne Herbarium, although it contains specimens from the Macleay and Clarence. Specimens from the other localities mentioned do not, in my opinion, answer satisfactorily to Bentham's brief description. They probably are referable to one of the many departures from the strict type of the species. Probably they are nearest to the egg-shaped fruits already referred to.

In a paper "On the essential oil and the presence of a solid camphor or stearoptene in the 'Sydney Peppermint,' Eucalyptus piperita, Sm," * Messrs. Baker and Smith announce the discovery of a solid camphor named Eudesmol in this oil, and also in the oil of E. macrorrhyncha, F.V.M. The paper does not bear brief abstraction.

\section{SYNONYMS.}

Metrosideros aromatica, Salisb. Prod. Stirp. in hort Chapel Allerton (1796), p. 351.

M. foliis alternis : laminis late ovatis, acuminatis, subtus glaucis, tenuibus. Sponte nascentem juxta Port Jackson legit, Dav. Burton.

A specimen of "Metrosideros," "Peppermint tree" from Port Jackson received from Banks, and now in Herb. Vindob. ex Herb. Jacq., although in leaf only is E. piperita, Sm.

[E. piperata, Stokes, in Bot. Mat. Med. iii, 69, is a misspelling of piperita.

E. piperita var. pauciflora, DC., Prod. iii, 219, is Sieber's No. $470=$ E. coriacen, A. Cunn. (Hooker's Fl. Tas. i, 136)].

\section{RANGE.}

THIs species is almost confined to New South Wales.

North and South Coast districts; as far north as the Myall Lakes, but the northern limit is uncertain. At Bullahdelah there are many large trees of this species, consequently it is not likely that this place represents its northern boundary.

- Proc, Roy. Soc, N.S.W., xxxi, 195 (1897). 
I have not seen any indubitable E. piperita from Queensland. There are plants in the Melbourne Herbarium from the Macleay and Clarence Rivers attributed to $E$. piperita, but they have no fruits, and the determination requires confirmation.

It is found on the Dividing Range and its spurs, being especially plentiful on the Blue Mountains. It is found west at least as far as Mudgee.

The typical form is found at least as far south as Moruya, but trees which are considered to belong to this species occur, as already indicated, as far south as Gippsland, Victoria.

"No. 32, Eucalyptus piperita, Smith.-DC., lc. iii, p. 219, n. 29. St. Kilda (Müll.)," Miq. Kruidk. Arch. iv, 137. St. Kilda is near Melbourne, and the locality requires confirmation.

It occurs on poor, rocky, sandstone land generally; is usually an indication of poor soil. It is very abundant in the Port Jackson district and in the Counties of Cumberland and Camden, New South Wales, generally.

Southern Localities. -The "Stringybark of Camden," No. 124, 50-100 feet, W. Macarthur (1854), in Herb. Kew, is E. piperita. It was numbered 48 in the Catalogue of New South Wales Exhibits of Southern Timbers at the Iondon Exhibition of 1862, where Sir William Macarthur gives the aboriginal name (Cumberland and Camden) as "Bour-rougne," and its diameter as 24-54 inches. He adds: "Not equal in stature or in hardness to the coast variety" (doubtless of Stringybark).

Common about Hill Top (J.H.M.); Belmore Falls, Moss Vale (W. Forsyth); Barber's Creek, now Tallong (H. J. Rumsey and J.H.M.).

"Messmate." Wood of a yellowish colour; when fresh much inclined to ring. Urceolate, shape of fruit very pronounced, reminding one a good deal of those of $E$. trachyphloia, from which the species differs in almost every other respect See fig. 8, Plate 45, Wingello (J. L. Boorman). At Wingello we also have it with fruits less pronouncedly urceolate and broader, more luxuriant foliage. From the same place, with the fruits nearly pilular-i.e., scarcely urceolate at all.

Conjola, near Milton (W. Heron); Currawang Creek, near Nelligen (W. Baeuerlen); Messmate and Almond-leaved Stringybark of the Clyde River (W. Baeuerlen).

Mr. Forester J. S. Allan, long stationed at Moruya, speaks of it as occurring " on the coast ranges; not plentiful." This would refer to the southern part of the State. I have never seen it, at least in its typical form, south of the Clyde River.

Western Localities. - This is a common tree by the roadside most of the way going over the Blue Mountains, but does not continue much beyond the sandstone area towards Wallerawang (R. H. Cambage and J.H.M.). 
Mt. Wilson.-Here we have fruits less urceolate; the typical and less urceolate forms existing side by side.

Curricudgy Mountain, Rylstone District (R. T. Baker).

Northern Localities.-Gosford (H. Blacket). "Not very plentiful; scattered in places along the coast and slopes of Dividing Range and New England; somewhat gregarious in habit. Height 100 feet, diameter 2 feet 6 inches" (Mr. Forester Rudder, Booral).

Very scarce in the Kempsey District (Mr. Forester Macdonald). locality).

I have not personally seen it further north than Bullahdelah (Mr. Rudder's

As regards Queensland, while admitting it into his "Queensland Flora,". p. 613, Mr. F. M. Bailey says :-

There is some doubt as to whether the normal form of this species has been met with in Queensland. Some years ago, however, I gathered a specimen off a tree at Highfields, which Baron Mueller at the time considered the normal form, and now I have none of the specimens to refer to.

\section{AFFINITIES.}

1. With E. eugenioides. (Compare Part VIII, p. 240.)

In the "Flora Australiensis" $E$. engenioides is reduced to a variety of $E$. piperita, and even in the "Encalyptographia" the Baron almost expresses doubts as to whether finally Bentham's opinion that both should be regarded as forms of one species may not have to be adopted. His figure of $E$. piperita is incorrect, as has already been printed out. A comparison of the two types as they occur near Sydney must convince the most incredulous as to the distinctness of the two species. Nevertheless there are certain forms which, judging from herbarium specimens or fruits alone, are intermediate.

Howitt in his "Eucalypts of Gippsland" (Trans. R.S. Vict., Vol. ii, Part I, p. 87) speaks of the "near alliance" of E. piperita and E. eugenioides. Speaking" generally, the two species are very distinct and are not to be mistaken one for the other. 'I'hey differ markedly in their seedlings, in the venation of the mature leaves, and in the odour of the same; in their bark and timbers.

Howitt has figured a number of fruits in his Plate 13 which he attributes to E. piperitu, viz., Nos.6-19, Nos. 20 and 21 being referred to E. eugenioides. Nos. 6 to 9 are possibly, yet doubtfully, referable to $E$. piperita; as regards the remainder I would suggest that they belong to $E$. eugenioides without any doubt. I would also invite attention to Mr. Howitt's excellent drawings of seedlings on Plate 14. Nos. 1 and 4 seem to me to belong to identical species, viz., $L$. eugenioides. I never saw hairs on a piperita seedling. 
I would draw attention to the following specimens :-

(a) Bark fibrous; not so fibrous as that of a typical Stringybark, and perhaps little more fibrous than that of the ordinary $E$. piperita. The fruits nearly globular and showing a mottled appearance, due to unequal shrinkage of the outer layers of cells of the fruit. The orifice small, the rim depressed and not very prominent. The specimens, which are from Port Jackson, precisely match some labelled, in Baron von Mueller's hand writing, "Stringybark, E. piperita, Twofold Bay." The fruits figured in the "Eucalyptographia " are not very dissimilar to them. They have short pedicels and are frequently sessile. The Port Jackson-Twofold Bay specimens may for convenience be referred to as $\mathbf{A}$. The texture of the leares of $\mathbf{A}$ and the prominence of the veins are perhaps intermediate between typical $E$. piperita and E. eugenioides, as is also the amount of essential oil so characteristic of $E$. piperita. The fruits of $E$. piperita have a very thin rim; in $\mathbf{A}$ it is a little broader, in typical E. eugenioides it is well defined. The size of the orifice of $\mathrm{A}$ is intermediate between the two species named. The shape of the fruits of $\mathrm{A}$ is less ovoid than those of $E$. piperita, and less hemispherical than those of typical $E$. eugenioides. At the same time it is referable to $E$.engenioides without doubt.

(b) In 1879 Mr. A. W. Howitt sent to Baron von Mueller from Walhalla, Gippsland, specimens with the following note: "Tree locally known as Stringybark; the specimen is taken from a tree split for palings, and I am informed that the wood is sound and durable, and both saws and splits well." The Baron labelled these specimens "E. eugenioides, Sieb.," and also "E. piperita, Sm., var. eugenioides." Some identical specimens sent by Mr. Howitt from the Tambo River were labelled by the Baron " $\boldsymbol{E}$. eugenioides, Sieb.," and he adds, "To this the specific name E. pilularis would well apply." This is certainly E. eugenioides.

(c) Following is Mr. Howitt's note on other specimens:-“A Stringybark growing on the clayey flats (Post-Pliocene?) at Toongabbie, near the foot of the hills. Grows to a moderately large tree-say, 100 feet. Native name Yangoura." The late Baron von Mueller labelled this specimen "E. piperita." It undoubtedly bears the closest resemblance to the Port Jackson and Twofold Bay specimens just referred to. Some of the fruits are a little more ovoid than those of the Port Jackson and Twofold Bay specimens, but that appears to be because they are riper; specimens less mature from the three localities cannot be separated. This is E. eugenioides.

At Wingello, N.S.W., there is an interesting tree known as "Messmate," one of two or three local trees which display variation. This particular "Messmate" has fruits with rather thicker rim than normal piperita, and some fruits even display a rim like eugenioides. It would be difficult, from fruits and leaves alone, 
to say whether this specimen is eugenioides or piperita, but the buds, bark, and timber display a closer tendency towards typical piperita, under which species I have accordingly arranged it. See fig. 8, Plate 45.

2. With E. pilularis, Sm.

It is elear, on reading Mueller's description of E. piperita in "Eucalyptographia," that he has not had typical New South Wales specimens in his mind, for he describes it as having both "stem and branches covered with fibrous outside grey and rough bark," and he mentions, as one of the means of distinguishing it from E. pilularis, "its rough bark extending to the branches (Pachyphloiæ)," whereas the typical E. piperita is only a "half-barked" tree like E. pilularis.

In the same work, under $E$. pilutaris, he lays emphasis on the globular fruits of E.piperita, in contradistinction to those of E. pilularis. The matter is referred to at p. 300 .

At Oatley, George's River, near Sydney (J. H. Camfield), we have a form apparently normal piperita in every respect, except that the fruits are very coarse and large, thick-rimmed, and nearly pilular. They certainly show affinity to $E$. pilularis, for which the fruits could be readily mistaken. I would eall them an intermediate form.

3. With E. obliqua, L'Hérit.

I mention these two species together because they are so referred to in "Eucalyptographia," but would point out that they have really very little in common. Reference to the shape of the buds, the venation of the leaves, and the coarseness of the foliage of $E$. obliqua alone show that the two species have no very close affinity. 


\section{DESCRIPTION. \\ XXXIII. Eucalyptus Sieberiana, F.v.M.}

Described and figured in "Eucalyptographia," Decade ii (1879). I have seen the type, and the fruits depicted are not quite satisfactory. It is very rarely that the fruits are so small as shown on the plate, nor is the drawing of them good.

This is the species referred to as E. virgata, Sieb. (B.Fl. iii, 202), in part. I would suggest consideration of my remarks on this subject in Part IX, p. 275, of this work.

It may be described as follows :-

Vernacular names.- " Mountain Ash" is its usual name. It attains its greatest luxuriance in mountain districts, and its timber is thought to resemble Ash. It is sometimes called "Black Ash," but this name should be reserved for $E$. stellulata. In Tasmania it is sometimes called "White-top Ironbark," but in that State there are no true Ironbarks. It has been also called Blackbutt, but that name should be reserved for E. pilularis. It was called "Yowut" by the aborigines of the Gippsland District, according to Howitt. It has been called "Messmate" or "Stringybark" at the Dromedary, N.S.W.; but the use of such names for this species is to be deprecated.

Bark.-In young trees the bark somewhat resembles "Stringybark" when viewed from a little distance. Hence the tree has been sometimes called Stringybark with a qualifying adjective. In older trees the bark becomes denser, darker coloured, more furrowed, and rugged in character. The casual observer might be excused if he took the tree for an "Ironbark," but a closer examination would show the bark to be neither dense nor tough enough. The small branches are smooth.

The smooth bark of saplings appears always to be glaucous.

Timber.-Pale-coloured and fissile, less variable perhaps than that of many of the Eucalypts. Very suitable for inside work, but not durable when not protected from the weather.

Juvenile leaves.-The seedling leaves are vertically arranged; of the same colour on both sides; glaucous, and larger than those of E. piperita. The venation is rather acute with the midrib. Seedling and sucker leaves are glaucous, dull-coloured on drying, and have the veins more spreading than is the case in the mature foliage.

Mature leaves. - The leaves are usually smooth, shining, and coriaceous; they are more or less falcate. The venation is spreading.

Leaves from Mt. Wilson in the west and Barber's Creek in the south are hooked; probably this will be found to be no unusual character.

Buds clavate.

Operculum.-Hemispherical or slightly umbonate. Pale-coloured opercula are often observed in the Blue Mountains. Double opercula sometimes occur in this species.

Inflorescence.-Frequently ocellate; this is sometimes a useful guide in distinguishing this from allied species.

Fruits.-Pear-shaped, usually a little oblique, the rim sometimes slightly concave, particularly when ripe. Edge of rim frequently sharp. Sometimes the plane of the rim is not at right-angles to the axis of the fruit. Shining. The rim usually well defined and often dark as in E. homastoma.

\section{Notes supplementary to the description.}

There is a narrow-leaved form, both at the Sugarloaf Mountain (Braidwood) and at the Dromedary. Tasmanian specimens appear to have longer, narrower, and more falcate leaves. There is a broad-leaved and very glaucous form in the Snowy Mountains. 
The fruit is more hemispherical in some Tasmanian specimens.

Apparently the fruits attain their largest size on the Blue Mountains. It would appear that the fruits of E. Sieberiona are usually more pear-shaped and larger in New South Wales.

\section{SYNONYMS.}

Is "Eucalyptographia," under E. Sieberiana, F.v.M., Mueller gives E. virgata, Sieb., as a synonym. It is not proper to state it so. Mueller thought, when describing it, he was suppressing the "misleading" name virgata for it. The explanation is that E. virgata, Sieber, was for many years confused by Bentham, by Mueller, and other botanists with the tree Mueller, in spite of himself, properly separated from virgata under the name Sieberiana. I have explained the situation under E. virgata, at Part IX, p. 275, of this work, and need not repeat myself here.

I know no true synonyms of E. Sieberiana, F.v.M.

\section{RANGE.}

Tasmania, Victoria, and New South Wales. It occurs in the Snowy Mountains (near the Victorian Border), at an elevation of 4-5,000 feet, and thence northward along the ranges west at least as far as Mudgee. On the Snowy Mountains it is interesting to observe that $E$. Sieberiana is always found on slopes with a southern aspect.

The species loves high, rocky, stony mountain ranges, on poor barren ground, and never takes to grassy localities.

In his "Second Census," Mueller records this species from South Australia, but, under E. vitrea, p. 167, Part VI, and p. 189, Part VII, of this work, I have shown that this is founded on a misapprehension. E. Sieberiana should be struck out of the flora of that State until additional evidence is forthcoming.

In Tasmania it is chiefly found near the north-east coast. Mueller quotes in his "Eucalyptographia" :-

"Frequent on granitic coast-ridges and in valleys of rather sandy or stony soil as well as on slatehills, from Falmouth to George's Bay, occurring also on hills of the sandstone fo mation north of St. Mary's (Bissill, Simson), and on East Mount Field at elevations of from 1,000 to 1,500 feet."

As regards Victoria, he says :-

"In the forests towards the Upper Yarra waters and of Gippsland, ascending to 4,000 feet elevation, extending along the Genoa up to the White Rock Mountains." 
Dr. A. W. Howitt, in an official (unpublished) report, says :-

"The Rough-barked Mountain Ash of Gippsland (E. Sieberiana) is known also by the trivial names of "Gumtop," "Silvertop," and "Bastard Ironbark." White Ironbark grows from near the sea level to an elevation of about 3,500 feet, where it abruptly ceases. It is found extensively as the main forest tree in many parts of Gippsland as at Walhalla, Wilson's Promontory, the Omeo Road, Gelantipy, \&c. It also grows in places in the northern fall of the Divide."

Following is a note by him on the same tree :-

"Yowut" or "Mountain Ash," near the top of the ridge half way from Eaglehawk to the Thomson River. The bark is deeply eroded, but not so deeply as the Ironbark in Western Victoria. It becomes smoother in the upper part of the bole and the limbs are always more or less smooth. The extreme twigs are reddish in colour. The young saplings have often in the upper part a smooth bluish-grey bark. The branches shoot up pretty straight.

\section{New South Wales.}

It is plentiful about Port Jackson, Broken Bay, Port Hacking, and Counties of Cumberland and Camden generally. It is common on the Blue Mountains.

Southern Localities. - "Eucalyptus virgata, Sieb., 'Mountain Ash.' Tree, 120-150 ft. Bark, persistent, ridged. Eden, New South Wales (Oldfield)." Oldfield's specimens from this locality in several herbaria are E. Sieberiana, F.v.M.

Nos. 266 and 370 of S. Mossman, Tororago (Tarago?), Twofold Bay (it is really near Braidwood, but on the old road to 'Twofold Bay), in Herb. Cant. Specimens collected in 1854, presumably for the Paris Exhibition.

On the cliffs at Eden, also Pipe Clay to Eden (J.H.M.). The lower parts of the filaments (especially before expansion) are purple, giving the flowers an ornamental "eye."

From 4-ã,000 feet on dry ridges, Snowy Mountains (resembling the Victorian specimen) (W. Baeuerlen); Nimitybelle (A. Rudder), and Tantawanglo Mountain (W. Baeuerlen). In both these adjacent localities known as "Mountain Ash" and "Black Ash."

Copy of original label of Mr. C. S. Wilkinson, late New South Wales Government Geologist :-

No. 6, "Stringybark, Messmate." Trees up to 4 feet in diameter growing straight and lofty, the trunk covered with deeply furrowed fibrous bark of dark-brown colour, resembling that on Ironbark, but not so hard. Branches and boughs smooth and white. Dromedary Ranges, 1,500 feet above sea-level. Formation Silurian, 2nd November, 1878.

This is E. Sieberiana and is referred to in "Eucalyptographia" (under E. Sieberiana), and also by me in Proc. Linn. Soc. N.S.W., xxix, 759 (1904).

Conjola (W. Heron); Sugar Loaf Mountain, Braidwood (W. Baeuerlen); Reedsdale, near Braidwood (H. Deane); Queanbeyan (H. Deane); Jervis Bay (J.H.M.) ; Iron Pot Creek, Badgery's Crossing to Nowra (W. Forsyth); Cambewarra Mountain (J. V. de Coque). 
"White-topped Messmate," Kangaloon. "Grows on rich soil; inferior" timber. Carefully distinguished locally between "Black-topped Messmate," a good timber which grows on poor soil" (J. Bruce). I can see no botanical difference in the two sets of specimens, and Mr. Bruce's observation is an illustration of what has been often remarked "Good timber, poor soil," and vice versâ.

"White Ash." Hoskinstown (W. Daniel); Box Point to Barber's Creek, also Nye's Hill, Wingello (J. L. Boorman and J.H.M.) ; Bowral to Bullio (R. H. Cambage and J.H.M.) ; "Stringybark," Mittagong (W. W. Froggatt) ; Berrima (J. L. Boorman and J.H.M.) ; Hill Top (J.H.M.) ; Appin (J.H.M.).

Western Localities.-Has on the Blue Mountains a range very similar to that of $E$. piperita, and is confined to the more barren parts of the mountains.

Mt. Wilson (Jesse Gregson); Jenolan Caves and Black Range generally (W. Blakely).

I have seen specimens from the Mudgee district (Forester C. Marriott), but there are none in this Herbarium.

I have seen no E. Sieberiana specimens north of the above localities, but certainly expect to hear of such in the mountain ranges going north from the places named.

\section{AFFINITIES.}

1. With E. virgata, Sieb.

This has been dealt with under E. virgata, in Part IX.

2. With E. Luehmanniana, F.v.M., var. altior, Deane and Maiden.

Dealt with under E. Luehmanniana in Part IX. E. Sieberiana has a rugged black bark; the variety of Luehmanniana is a Ribbony Gum. Sometimes the unripe fruit and herbarium specimens generally very strongly resemble those of E. Sieberiana, but I think the drawings in the last and present Parts will put botanists on their guard.

3. With E. Consideniana, E.v.M.

Will be dealt with under $E$. Consideniana.

4. With E. hoemastoma, Sm.

Mueller, in "Eucalyptographia," speaking of E. Sieberiana and E. hcemastoma, states that "the stem bark of the former is far more ridged than that of the latter, the veins of the leaves of $E$. Sieberiana are less spreading and less prominent; while the fruit is usually longer, more exactly semiovate and never verging towards an 
hemispheric form." In regard to these statements, I would observe that $E$. hamastoma is a smooth-barked tree, and that those rough-barked trees which were thought to show some transition towards $E$. Sieberiana (as well as to other species) have since been shown to belong to other species.

The Sydney or depauperate form is often confused with $E$. hremasloma, as the young trees often have the appearance of White Gum if the butts be not carefully examined, and they are often so small that it is not easy to detect the rough bark.

If $E$. Sieberiana leaves be crushed in the warm hand, they evolve a slight odour of peppermint which is not observable in E. hamastama.

In the "Flora Australiensis," Bentham also draws attention to the affinity between E. Sieberiana and E. hemastoma, and lays some stress on the differences between their anthers. I am of opinion that it is impossible to distinguish the two species by means of their anthers.

\section{With E. coriacea, A. Cunn.}

Both Bentham and Mueller compare E. Sieberiana and E. coriacea. The closest similarity appears to be in the shape of the fruits. For fruits of E. coriacea, see Plates 26 and 27, Part $V$ of this work. They are coarser and more fleshy than those of $E$. Sieberiana; the coarse, fleshy, spreading veins of $E$. curiacea are also characteristic and quite different from those of $E$. Sieberiana. In addition, $E$. coriacea is a smooth-barked tree, while $E$. Sieberiana is rough-barked.

6. With E. obliqua, L'Hérit, var. alpina, Maiden (E. delegatensis, R. T. Baker).

'I'his is that "Mountain Ash" which, in the high Southern Ranges of New South Wales, and also in Victoria, "succeeds" E. Sieberiana at a higher elevation than the latter attains. It is the $E$. Sieberiana (b) of A. W. Howitt ; see also p. 69, Part II, and p. 177, Part VI, of this work. I desire to pay a further visit to this tree in the field, after which I will again refer to it and contrast it with E. Sieberiana.

7. With E. vitrea, R. T. Baker.

Mueller, "Eucalyptographia" (under E. Sieberiana) says :-

. . . occurring also on low moist sandy tracts between the Glenelg River and Mount Gambier and Lake Bonney (Dr. Wehl).

in the cripply Stringybark forests near Lake Bonney (this is in South Australia ; a long narrow bexly of water running parallel with the coast-line, north from Cape Banks, and not very far from the Victorian border.-J.H.M.), dwarfed to 10 or 12 feet, though amply flowering.

I am of opinion that these specimens come nearest to or are referable to E. vitrea, R. T. Baker ; see pp. 164-7, Part VI, and p. 189, Part VII, of this work.

Since the above was written I have received specimens from Penola Forest, S.A. (not far from the Victorian border), from Mr. Walter Gill, with the following notes :-

what everything indicates to be $\boldsymbol{L}$. Sieberiana. It is a stunted form and weeping habit, and grows in low-lying country under water in winter.

"The Eucalypts of Gippsland. Trans. Roy. Soc. Vich, ii, 94 (1890). 
They have certainly affinity to E. Sieberiana, but I think the specimens are referable to $E$. vitrea, not quite typical, which is not to be surprised at. Note the low-lying habitat, which is a character of vitrea and not of Sieberiana.

In addition to Mr. H. B. Williamson's specimens, referred to at p. 166, Part VI, I have an interesting. one from him labelled "No. 933," from Portland, Victoria. "Height 10 feet, probably from a young tree." Mr. Williamson had no more definite information to give me concerning these specimens, which seem referable to $E$. vitreu, but they have remarkably broad coarse foliage, and most botanists would, pardonably, refer them at once to $E$ coriasea. These specimens would appear to strengthen my view that E. vitrea is a coriacea hybrid. Portland is not far from the other South Australian localities cited.

I think that the deseriptions and figures given of $E$. vitrea and $E$. Sieberiana should put botanists on their guard in regard to two forms presenting a good deal of external resemblance, so far as herbarium specimens are concerned. 


\section{DESCRIPTION.}

\section{Eucalyptus Consideniana, Maiden.}

A TREE of medium height.

Juvenile leaves.-Narrow-lanceolate, petiolate, soon becoming alternate. A conmon size is a length of 3 inches with a width of $\frac{1}{2}$ inch. I have them, however, both shorter and broader. They are narrower than those of E. Sieberiana, F.v.M., or E. piperita, Sm. Of a rather strong peppermint odour, and often of a silvery appearance. The young branchlets and seedling stems angular.

Mature leaves.-Commonly oblique and falcate, broadly lanceolate. I have them up to 9 inches in length, and nearly 2 inches in greatest width; they are rather thick in texture. Colour equally green on both sides, dull or shiny, blue-green or a bright sap-green. Veins strongly marked, spreading from the base, the intramarginal vein at a considerable distance from the edge, often looped (brachydodromous). "Leaves hang straight down" (Cambage).

Buds.-Usually clavate and sometimes with pointed opercula.

Flowers.-Anthers uniform.

Fruits, - Usually pyriform in shape, often nearly conical, rather more than $\frac{1}{4}$ inch in diameter. The valves often well sunk below the rim, but the points of the valves occasionally protruding. Sometimes the rim is slightly domed and the valves rather more exserted. The rim broad, smooth, well-defined, and usually red in colour.

A medium sized tree with grey tough bark to the tips of the branches, said bark being of that sub-fibrous character well known in Australia as "peppermint," very like that of E. piperita, but very different from that of E. Sieberiana.

Timber:-Wood pale-coloured, with kino rings, remarkably like that of the common Sydney Peppermint (E. piperita, Sm.). "Soft and ringy; not nearly so good as Mountain Ash, E. Sieberiana" (Boorman).

\section{Notes supplementary to the description.}

I name this species in honour of First-Assistant Surgeon D. Considen, one of the founders of Australia. In reviewing the "Historical Records of New South Wales" (Vol. I, Part 2) in the Sydney Morning Herald of 23rd July, 1892, I drew attention to the fact that Considen's letter, dated 18th November, 1788, to Sir Joseph Banks, is perhaps the most interesting one in the collection to the student of economic botany. From the following passage it, would appear that Considen was the founder of the eucalyptus oil industry: "We have a large peppermint tree, which is equal, if not superior, to our English peppermint. I have sent you a specimen of it. If there is any merit in applying these and many other simples to the benefit of the poor wretches here, I certainly claim it, being the first who discovered and recommended them." At this time a bottle of Eucalyptus oil was sent to Sir Joseph Banks by Governor Phillip. I further wrote in the review : "I think that some effort should be made to rescue the name of the tirst user of Australian plants from oblivion. I trust that at least a species will be named after the pioneer before many months are over."

I regret that the matter slipped my memory on more than one occasion, but I now dedicate to his memory a species very closely allied to that from which he distilled the first Australian eucalyptus oil. (Proc. Limn. Soc. N.S.WI., 475, 1904.) 
The species can be most conveniently distinguished by its pyriform fruits and "peppermint" bark; the narrow sucker-leaves are also characteristic. Mr. R. H. Cambage, who has prominently brought this tree under my notice, gives the local names as "Peppermint" or "White Mahogany"; Mr. Boorman as "Messmate."

In Gippsland it seems more of a Stringybark; with rough bark here, as elsewhere, right up to the very tips of the branches. It has a yellowish cast on the bark, which is perhaps rougher than that of the type, but certainly smoother than that of the stringybarks. "Yertchuk" trees have patches of bark thinner than that of the remainder of the bark, and "rubbed looking" and Peppermint-like.

\section{RANGE.}

In coastal and coast-range districts of New South Wales, and Gippsland, Victoria, extending in the former State, as far as is known at present, from the Clyde River in the south, across the country to near Goulburn, thence viâ Burragorang to the Blue Mountains (Wolgan), and the Penang Mountain near Gosford. Doubtless the species will be found in localities intermediate between the Clyde River and Gippsland.

\section{New South Wales.}

Southern Districts.-Nelligen, Clyde River (J. L. Boorman). This is the most southerly locality known to me in New South Wales.

"Looks like a Peppermint (piperita); has rough grey bark." On sandy ground, Burrill, Milton (R. H. Cambage).

Grows on sandy, rather barren soil. Grey bark right out on branches, something like that of E. piperita. Nearest affinity nay be E. Sieberiana, but it is distinct from that species in the bark. Leaves hang straight down. Timber fairly hard. Pigeon House, Milton, to within 100 feet of the top (R. H. Cambage).

Rather stunted trees, bark rough, soft, from the base up to tips of branches, grey in colour. Leaves not so large as $E$. Sieberiana, but the bark differing both in texture and colour. The wood is soft and ringy, not nearly so good as "Mountain Ash" (Sieberiana) which it in many respects resembles, partly in the fruit, but more like piperita in bark. Wingello (J. L. Boorman).

Following is a report made on a subsequent visit to Wingello :-

"Messmate." Medium sized trees, rough bark to the tips of the branches, not ribbony. In appearance reminds one of $E$. Sieberiana, but smoother and softer in the bark, having an affinity to a Stringybark. Distributed abundantly over an area of half a mile in the vicinity of Kingston's saw-mills, Wingello (J. L. Boorman).

"Fairly smooth, fibrous bark, something like piperitc and distinct from the rough bark of Sieberiana" (top of Mountain, east of Burragorang, 3 or 4 miles). Hawkesbury Sandstone (R. H. Cambage).

Top of Barrengarry Mountain. Medium sized trees. Poor sandstone, rocky soil (R. H. Cambage and J.H.M.). 
Western Localities.-Mr. Cambage and I found E. Consideniana in full bloom (November, 1904) and not rare near the 40-mile post on the road from Sydney, $4 \frac{1}{2}$ miles east of Springwood. This the nearest locality to Sydney so far.

'The Valley, near Springwood (H. Deane and J.H.M.); Faulconbridge; common near the 10-mile post (road), and the last tree observed near the road was near the western boundary of Portion 12, Parish of Linden (nearly midway between Linden and Woodford Stations). In full flower at 10 feet high, and the only Eucalypt in full flower in the district (12th November). (R. H. Cambage and J.H.M.)

On Hawkesbury Sandstone, top of mountain, north of Wolgan shale Mine. "Growing near E. piperita, E. Sieberiana, E. eugenioides, E. punctata. The most north-western locality known to me" (R. H. Cambage).

Northern Locality.-Penang Mountain, Gosford (J.H.M. and J. L. Boorman).

"Very like a Peppermint in appearance, only the bark is not so stringymore flaky, white srnooth limbs. A fair sized tree and scarce." Penang (A. Murphy).

VICTORIA.

In his "Eucalypts of Gippsland," Trans. Roy. Soc. Vict., ii, 82, 84, 85, Dr. (then Mr.j A. W. Howitt speaks of a broad-leaved form of E. amygdalinu, known to the aborigines as "Katakatak" or "Yertchuk." This is his E. amygdalina (d). He also mentions a broad-leaved amygdalina (b) which is $E$. dives, Schauer (E. amygdalina, Labill.; var. latifolia, Deane and Maiden).

As regards the "Yertchuk," (variety d) I have received excellent specimens from Dr. Howitt, and refer them to E. Consideniana.

What Dr. Howitt (loc. cit.) says about the "Yertchuk" is as follows :-

It grows most freely upon the rather poor sandy and clay lands of the littoral tracts, but I have also observed it in the mountains - for instance, where poor sandy tracts occur, as well as on the quartz grits and conglomerates at Wild Horse Creek, Wentworth River, on the Upper Silurian sediments, betwe-n Toongabbie and Walhalla, the Silurian sediment in the Tambo Valley Road, the Upper Devonian formations of the Insolvent Track, the Devonian porphyries at Gelantipy, and the Silurian formations at Delegate River.

It rarely grows more than 100 fert in height, but is generally a rather small tree, often stunted. The burk classes it with the Striugybarks, for it is fibrous and persistent up to the smaller branches, somewhat resembling that of E. obliqua, but thinner, more fissile, and lighter in colour. For roofing purposes the bark is worthless, and the timber of no value for splitting or sawing, having the soft, veiny character of some types of amygdalina.

The seedlings have opposed, narrow, lauceolar leaves, with, occasionally, tufts of hairs and frequently wavy margins.

The opposed character of the leaves is not maintained beyond the first two or three pairs, and the leaves then become ovate lanceolar, resembling, in their pointed and unequal-sided form, those of $E$. obliqua, though rarely as large. They are thick in consistence, of a dull green, and not shiny, in the latter trait resembling those of $E$. Sieberiana.

The umbels have numerous buds, with the typical form of $E$. amygdalina, to which also the shape of the calyx tube, the short style, and depressed lid belong. The fruit is ovate, top-shaped, with a flat and slightly convex margin, and small deltoid valves.

The tree is found at a height of 100 feet above sea level at Merriman's Creek. and the Bairnsdale to Buchan Road, to 2,500 feet at the Upper Wentworth River. I have not observed it on the mountain plateaux, even where they descend to the latter height, and conclude that it is a littoral species which ascends the coast ranges. 


\section{AFFINITIES.}

1 and 2. With E. piperita, Sm., and E. Sieberiana, F.v.M.

'The closest affinity of this species is to E. Sieberiana and E.piperita; in fact, it is possible that it is a hybrid between these two species.

In expressing this opinion, I desire to make a note inculcating caution. It is sometimes difficult to properly assign the use of names; for the fact is, all species have probably arrived at their present development largely by means of hybridism. The following will illustrate what I mean :-

E. Consideniana perhaps has E. piperita and E. Sieberiana blood in its veins. We therefore might perhaps explain its position by saying that it is a hybrid between these two. But if $E$. Consideniana had been described first, it perhaps would not have occurred to botanists to describe, say, E. piperita as a hybrid of it.

Dr. Howitt writes to me: "I have been turning over in my mind your remarks re possible hybridisation in 'Yertchuk.' I am doubtful about it, because it forms a considerable part of the forests in a stretch of some 20 miles. In one part there is $E$. Sieberiana, but not elsewhere. I do not know of E. piperita, but E. eugenioides occurs throughout the forests together with another Stringybark."

Since the above was written, I have had the opportunity, in the company of Mr. J. L. King, who travelled a good deal with Dr. Howitt in Gippsland, of inspecting the Yertchuk country from the head of Dead Horse Creek to near Boggy Creek. The prevailing eucalypt is E. Sieberiana, with a little E. eugenioides. There is no E. piperita, as Dr. Howitt states. Yertchuk may be a hybrid still, i.e., between $E$. Sieberiana and $E$. engenioides, the slight differences between the New South Wales and Victorian trees being perbaps explained by the absence of E. piperita in Gippsland.

Of course, hybridism is merely an explanation of the origin of $E$. Consideniana to begin with; the type once established and coming true from seed, it would become propagated in time in districts in which neither of its reputed first parents (piperita and Sieberiana) are to be found. I will discuss the matter again when dealing with the general subject of hybridisation in Eucalypts.

With E. piperita, Sm

The bark is fibrous like that of $E$. piperita, and the general appearance of the tree reminds one of that species.

E. piperita fruits in large masses or bunches, while $E$. Consideniana is a comparatively shy fruiter.

With E. Sieberiana, F.v.M.

The leaves, buds, and fruits are reminiscent of E. Sieberiann, though the leaves are perhaps thinner. The narrow juvenile foliage leaves, however, separate $E$. Consideniana from any with which it is most likely to be confounded. The Penang fruits are not perfectly typical; they show more than ordinary resemblance to those of E. Sieberiana. 
The Blue Mountains trees of $E$. Sieberiana have not, as a rule, the furrowed Ironbark-looking bark of the typical form, and, speaking in general terms, the bark of $E$. Consideniana presents some resemblance also to the bark of the trees of E. Sieberiana, with which it is associated.

3. With E. Andrewsi, Maiden.

Compare pp. 195, 196, Part VII of this work. 'The fruits of $E$. Consideniana are conoid to pyriform. 'Those of $E$. Andrewsi may be conoid, but they are smaller in size than those of Consideniuna. Both are "Messmates," and the affinities of the two species require more working out in the field. At present we have a gap between the localities of $E$. Consideniana (going north) and those of $E$. Andrewsi. If possible, I want to see if either or both species occur in this gap, and, if they grow together, whether the fruits of $E$. Consideniana become smaller. The two species have marked dissimilarities, and cannot be confused in their typical forms.

4. With E. virgata, Sieb., var. stricta.

That the species possesses affinity to this variety there is no doubt.

In some fruits the base of the capsule is remarkably constricted, the whole being pear-shaped; the rim is broad and somewhat sunk in some specimens. Since this was first observed, the fruit has been found to be more domed when fully ripe, and hence the similarity to var. stricta is less strong. What was described later as E. Consideniana was referred to by Mr. Deane and myself as a variety of E. stricta in Proc. Linn. Soc. N.S.W., 1900, p. 109.

5. With E. regnans, F.v.M., var. fastigata.

Its affinity to this variety is considerable, in points other than that of the shape of the fruit. The barks of the two trees are not very dissimilar, but $E$. Consideniana prefers drier, rockier situations than E. regnans, var. fastigata. It was referred to by Mr. Deane and myself as a pyriform-fruited fastigata in Proc. Linn. Soc. N.S.W., 1901.

6. With E. hamastoma, Sm.

The fruit is somewhat like that of $E$. hamastoma in shape, particularly the large-fruited, coastal Sydney form, which is typical. Of course, E. hemastoma is a Gum (i.e. a smooth-barked species). 


\section{DESCRIPTION.}

\section{Eucalyptus hæmastoma, Sm.}

Trans. Linn. Soc. iii (1797), 286. See also "Eucalyptographia" (Mueller).

Following is the original description :-

Operculo hemispharico depresso mucronulato, umbellis lateralibus, terminalibusque: pedunculis compressis, raraulis angulatis, fructu subgloboso.

The leares are coriaceous, lanceolate, terminating in a long linear point. little point.

Flowers in umbels, not capitula, their covers depressed at the top, but suddenly terminating in a

Fruit globose, cut off at the summit, its orifice surrounded by a broad deep-red border.

This species has a great affinity with the Leptospermum umbellatum of Gaertner, but I dare not assert it to be the same.

The type form.-'The species is found in two principal forms-a coarse form (the type), and a slender one; the latter with small flowers and fruits, and known as variety micrantha in consequence.

As regards the type, the leaves, flowers, and fruits are alike larger, and the leaves thicker, but, as a rule, the tree itself does not attain the magnitude of its variety.

Witl Bentham's amplified description of the species as given in B.Fl. iii, 212, I, in the main, agree, so that it will only be necessary to add a few notes.

Ternacular names. - "Thite Gum " is the commonest and most appropriate name for this species.

Bark.-Smooth, with a few ribbony flakes near the butt.

Timber,-Red, and of an inferior character, though a fairly lasting timber for posts in the districts in which it grows.

Jurenile leares.-Broadly lanceolate, somewhat similar in shape to the adult leaves, only larger; 4 to 6 inches long by $1 \frac{1}{4}$ inch broad, are measurements of some from the Sydney district.

Mature Ieares.-Coriaceous, thick, spreading, and veins very distinct, oblique, and several starting from near the base of the leaf. As in the case of some other species, the mature foliage of trees growing close to the sea is very coarse and thick.

Peduncles.-Angular and flattened.

Calyx-tube.-Much longer than the operculum and insensibly tapering into the pedicel.

Operculum.-Pointed when young, becoming more hemispherical as maturity is approached. Often the buds may be described as clavate.

Fruits.-Speaking generally, the shape of the fruits reminds one of a pear. The rim is more or less domed and usually brownish or red (hence the specific name). I do not agree that, speaking at all generally, "the capsule is slightly depressed," as stated at B.Fl. iii, 212.

Pedicels not so thin, being more tapering than is the case with var. micrantha.

Sometimes the fruits are hardly pear-shaped, but this is unusual. We have some nearly hemispherical, but much larger than those of var. micrantha. At the same time, there are fruits which undoubtedly show transition between $E$. homastoma and its variety micrantha.

The anther is reniform and is figured at fig. $14 \mathrm{~d}$, plate 47 . It seems to differ very little whether typical or var. micrantha. 


\section{Varieties.}

(1) The small-fruited form (variety micrantha).

Vernacular names. - "White Gum " is a very common name. It, however, in one or other of the many districts in which it occurs, usually goes under some name referring to the softness or brittleness of its timber, e.g., "Cabbage Gum," "Snappy Gum," "Brittle Gum," "Brittle Jack."

Bark. - Smooth, right to the ground. The colour of the bark is usually white, but sometimes, particularly in localities comparatively remote from the sea, the bark is at certain seasons of the year yellowish. I have seen the trunk as yellow as if washed with yellow ochre. Away from the sea, also, the bark appears to have a greater tendency to peel off in patches, giving it more or less a spotted appearance.

Timber.-Soft, red. An excellent timber for fencing posts, and in some districts, especially the southern table-land, preferred for this purpose. At the same time, excellence is comparative, and in the coast districts we find other timbers of special merit.

Jurenile leaves.-Nearly ovate, then nearly oblong (rounded at both ends), and with crenulate margins. As growth proceeds, they become attenuate at both ends and somewhat falcate.

The seedling leaves tend to be vertical, and therefore are equally green (blue-green) on both sides. The twigs are red, as also in mature specimens. Venation less acute than in E. Sieberiana.

They then become alternate, ovate-lanceolate, very acuminate, a little oblique, up to 6 inches long and $2 \frac{1}{2}$ inches broad. The intramarginal vein much removed from the edge. From this stage the foliage gradually develops into the mature stage.

Mature leaves. - These vary somewhat, which is not a matter for surprise, considering the extensive range of the tree. They are often thick and glossy. Those from Bargo Brush are of this character, and $5 \frac{1}{2}$ inches long and 1 to $1 \frac{1}{2}$ broad. Those from Queanbeyan are narmw-lanceolate. Some in the Sydney district are quite small, usually not exceeding 3 by $\frac{1}{2}$ inch. The foliage of many trees in the Mudgee district is quite sparse. In the Macleay and Hastings districts the trees frequently have broadish, lanceolate long leaves up to 7 inches by $1 \frac{1}{2}$. Sonetimes the leaves are hooked at the ends, a character more general in Eucalypts than was at one time supposed.

But there is no doubt that the leaves of this form pass insensibly into those of the normal species. Specimens from the Blue Mountains (e.g., Mt. Victoria) show this transition very clearly.

Operculum.- Nearly hemispherical or with a small umbo; perhaps less pointed than in the typical form.

Fruits.-The fruits are usually as flat-topped (they are but rarely slightly domed) as in any species of Eucalyptus, and therefore are not satisfactorily represented in the tigure of $E$. hamastoma in the "Eucalyptographia." The fruits are small, nearly hemispherical, rarely tapered below, have thin pedicels, and are nsually numerous. Some from Queanbeyan are $3 \frac{6}{2}$ of an inch in diameter. Those from Bargo, \&c.. have flat tops and sharp rims. Some from the Mudgee district and South Coast afford instances of slight doming of the fruits. Occasionally they are depressed hemispherical-almost tazza-shaped. They are often pale-coloured and with markedly red mouths.

I have fruits from Mt. Wilson which, though quite small, taper like those of normal hamastoma, and are in some respects connecting links.

Size.-Usually 30 or 40 feet in height, with a trunk diameter of 2 or 3 feet.

Mr. Andrew Murphy, in sending me specimens from Morisset, has tried to differentiate between the type-form and the small-fruited form in the following words :-

"1. Broad-leaved White Gum, similar to narrow-leaved variety in appearance, much larger tree, generally grows in high dry country. Both these Gums are similar to $E$. coriucea. Large fruits."

\section{"2. Narrow-leaved White Gum. A very white bark to the ground. Straight tree. Small fruits."}


But I repeat that the two forms run into each other and represent, in my view, climatic and soil differences only.

(2) var. capitata, var. nov.

In some cases, trees belonging to this species have fruits in dense heads. In these trees the foliage is coarser and larger than that of var. micrantha usually is; at the same time, the fruits, while numerous in the head, have thicker pedicels than those of var. micrantha; as regards size, the fruits are intermediate between the type and its variety. The bark is smooth.

This form, for which I propose the name variety capitata, is figured at 6 , Plate xxx, Proc. Linn. Soc. N.S.W., xxii (1897), by Mr. Deane and myself, under var. micrantha.

The type is Mt. Victoria, 1st April, 1889 (J. H. Maiden). There are closely allied forms, not strictly capitate, and it occurs on the Blue Mountains and the Hawkesbury Ranges.

\title{
SYNONYMS.
}

\author{
1. E. mierantha, DC. \\ 2. E. signata, F.v.M.
}

1. E. mierantha, DC. Following is the original description :-

Operculo conico cupulae longitudine, pedunculis angulatis petioli longitudine axillaribus et subterminalibus, umbellis 15-20-floris, foliis oblongis coriaceis basi attenuatis longè acuminatis nervulis antè marginem confluentibus. In Novâ-Hollandiâ, Sieb., plant ex. n. 497. Folia utrinquè lucida, petiolo semipollicari, laminâ 6-7 poll. longâ, pollicem latâ, venis penniformibus. Alabastra ovoidea generis minima. (Prod. iii, 217.)

I have examined Sieber's No. 497, and it is var. micrantho.

2. E. signata, F.v.M. This is described in Journ. Linn. Soc. iii, 85 (1859). Mueller quotes for his type specimens, - "In hills and wooded grassy hills near the Brisbane River." Also Macarthur's Sydney Woods, Paris Exhibition, No. 163 in herb. Hook. He also states that it is called "Spotted Gum" in the Moreton Bay district.

I have a specimen of Mueller's type from Kew, besides which I saw it at Kew. It is typical var. micrantha.

Macarthur's specimen was exhibited under No. 163 for the Paris Exhibition of 1855 and under No. 30 for the London Exhibition of 1862 . His label is, "Aboriginal name in Cumberland and Camden, 'Caarambuy.' Known as 'White Gum.' Diameter, 24-40 inches. Height, 60-80 feet. Not much valued, being generally of crooked growth." This also is typical var. micrantha. 
Following is a doubtful form, and I am not yet satisfied as to whether it can be separated from var. micrantha, although the authors think the two forms are identical.

E. Rossii, R. T. Baker and H. G. Smith, "Research on the Eucalypts," p. 70 (1902). See also Proc. Linn. Soc. N.S.W., xxviii, 352 (1903).

The authors give E. micrantha, DC., as a synonym, and state, "Research on the Eucalypts," p. 71: "Leaves were obtained (for oil) from Cow Flat, Bathurst." In the following year Mr. Baker (op. cit., xxviii, 352) says: "Camboon is the only locality I have collected it" (so that we really have two localities). Bungendore (see oil analysis) is a third locality. See also xxi, 448.

The authors, op. cit., p. 71, say: "The oil had no resemblance to that of E. hamastoma of Smith, the 'Scribbly Gum' of the coast."

Under E. hemasloma, Sm., the authors give E. signata, F.v.M., as a synonym, and this is identical with E. micrantha, DC., as already shown.

The analyses of the oils of E. hemastoma and E. Rossii, as given by the authors, are herewith :-

\begin{tabular}{|c|c|c|c|c|c|c|}
\hline Species. & $\begin{array}{l}\text { Whence } \\
\text { collectert } \\
\text { for oil. }\end{array}$ & $\begin{array}{l}\text { Specific } \\
\text { gravity } \\
\text { ai } 15^{\circ} \mathrm{C} \text {. }\end{array}$ & $\begin{array}{l}\text { Specific } \\
\text { rotation } \\
{[\mathrm{a}]_{\mathrm{D}}}\end{array}$ & $\begin{array}{l}\text { Saponifi- } \\
\text { cation } \\
\text { number. }\end{array}$ & $\begin{array}{l}\text { Solubility } \\
\text { in } \\
\text { Alcohol. }\end{array}$ & Constituents found. \\
\hline ha'mastoma... & $\begin{array}{l}\text { Barber's Cleek, N.S. W. } \\
\text { Gosford. }\end{array}$ & 0.9195 & $\begin{array}{c}-32.77^{\circ} \\
\text { (first } \\
\text { fraction). }\end{array}$ & $5 \cdot 1$ & Insoluble & $\begin{array}{l}\text { Phellandrene, } \\
\text { eucalyptol, } \\
\text { sesquiterpene. }\end{array}$ \\
\hline Rossii & $\begin{array}{l}\text { Cow Flat, Bathurst; } \\
\text { Bungendore. }\end{array}$ & $\begin{array}{c}0.9168 \\
\text { to } \\
0.9215\end{array}$ & $\begin{array}{l}+7 \cdot 8^{\circ} \\
\text { to } \\
+7 \cdot 9^{\circ}\end{array}$ & 7.95 & $\begin{array}{l}11 \text { vols. } \\
70 \% \text { to } \\
1 \frac{1}{1} \text { vols. } \\
70 \%\end{array}$ & $\begin{array}{l}\text { Eucalyptol, pinene, } \\
\text { sesquiterpene. } \\
\text { pepjermint ketone, }\end{array}$ \\
\hline
\end{tabular}

The type specimens (from Camboon) have pale-coloured foliage. An umbel of flowers and a leaf are figured by $M r$. Deane and myself at fig. 14, Plate xxxi, and an umbel of fruits from the Grenfell District is figured at fig. 13 of the same Plate (Proc. Linn. Soc. N.S.W., xxii, 1897). In the legend of the Plate the Grenfell fruits are described as haring "thin long pedicels and flat-topped sharprimmed fruits. Sometimes there are twenty in a head."

The Grenfell and Camboon specimens have much in common, and, except in the number of flowers in an umbel (not a very definite character), I see no difference between them. As regards the sharp-rimmed fruits of the Grenfell specimens, we have them sometimes not sharp, and they seem identical with those of Camboon.

Camboon timber " is very hard, red coloured, and durable, and is far superior to that of $E$. hcemostoma" (R. T. Baker). Mr. Forester Postlethwaite, who collected the Grenfell specimens and was a sound bushman, says: "Quality of timber indifferent." 
I have specimens which are very close to Mr. Baker's E. Rossii from Adelong (also from a local forester who did not append his name to them).

The anther of (?) E. Rossii is depicted at fig. 15, Plate 47 , and it seems to be more compact, less reniform, and with the cells less divergent than those of $E$. hemnstoma usually are. Compare figure $14 \mathrm{~d}$ of the same Plate.

I do not see my way to withdraw $E$. Rossii from E. homastoma, var. micrantha, with such evidence as I have at present. It seems that the Grenfel] specimens connect the coastal specimens of var. micrantha, and both Camboon and Grenfell have more or less western climatic influence, so that we expect some difference.

\section{RANGE.}

THE specimens are all var. micranthx unless the contrary is indicated.

The typical species apparently does not extend beyond the Hawkesbury sandstone, and is most abundant not far from Port Jackson, the Hawkesbury and George's River, and the ridges and broken country in the vicinity. While the range is not very precisely defined at present (I have it from the Newcastle District), that of the variety micrantha is undoubtedly very much more extensive.

Besides New South Wales, it is also found in Queensland, and in our own State it extends from north to south, and from the coast across the table-land to at least as far south as Tumut, and west to the head of the Castlereagh River.

It is common in the National Park as well as around Port Jackson and County of Cumberland generally, and we have all sizes of fruits from as small to as large as seen anywhere.

No. 4,754, of Robert Brown (1802-5), distributed by J. J. Bennett in 1876, is var. micrantha.

Southern Localities.-Cambewarra, fruits of medium size (W. Baenerlen); Badgery's Crossing to Nowra, fruits intermediate (W. Forsyth and A. A. Hamilton); Nowra (J. V. de Coque); Jervis Bay, fruits nearly as large as those of the type (J.H.M.) ; Bankstown and Cabramatta, very small fruits (J. L. Boorman); Appin, on cold sandy flats (J.H.M.); with large fruits near the type, Cataract Dam (E. Cheel); flats, Picton to Bargo (J.H.M.); Hill Top, on flats and also on ridges. Fruits sometimes a little pear-shaped (J.H.M.); Wingello, fruits of intermediate size (J. L. Boorman); Barber's Creek (J.H.M.) ; "Brittle Jack," Pomeroy; Goulburn (H. Deane); Bungendore, fruits medium size (A. W. Howitt); granite hills, near Bungendore, south of Lake George. The thickening of the pedicels gives the fruits an almost conical form (W. S. Campbell); "Brittle Gum," filiform fruit stalks, Queanbeyan (H. Deane); Adelong, Hills S.W. (光 mile) from Mt. Horeb Railway Station (R. H. Cambage); Cooma (on gneiss) (R. H. Cambage). 


\section{J. L. Boorman).}

Western Localities.-Penrith, with unusually small fruits (J.H.M. and

The small-fruited form continues the whole way across the Mountains, and is confined to the poor soil, avoiding the deep valleys.

Mt. Wilson, on the sandstone (Jesse Gregson). Some of these specimens have flat-topped and rather large fruits, and resemble a good deal those from Grenfell referred to nnder $\boldsymbol{E}$. Rossii. They also have affinity to var. capitata as regards the shape of the fruits.

Capertee (J. L. Boorman). In fruit only, and may be compared with the Camboon specimens (see $E$. Rossii); Mudgee No. 10 F.; Apsley (R. H. Cambage) Perth (J. L. Boorman).

"Near the head of the Castlereagh River, which extends the range of the species further towards the westward than it has previously been found in this latitude. It is a large tree, and is locally known as "Cabbage Gum" (W. Forsyth).

Northern Localities.-Berowra, large fruits (J.H.M. and J. L. Boorman); Tuggerah Lakes (J.L.B.); Morisset (A. Murphy); Dudley, near Newcastle, with fruits as large as ever found near Sydney (Jesse Gregson); Belmont, near Neweastle (Jesse Gregson); Raymond Terrace (A. Rudder); Failford to Forster (J.H.M.); Port Macquarie (G. R. Brown); Port Macquarie to Kempsey (J.H.M.); Moonambah, Brunswick River (W. Baeuerlen); "Tumble-down Gum," Hillgrove and Enmore, Armidale District (J. F. Campbell); Emmaville (J. L. Boorman).

\section{QUEENSLAND.}

"Spotted Gum," type of E. signata, F.v.M. Brisbane River, from F. v. Mueller, from Kew.

"White or Sugar Gum," of no utility. Maryborough (W. H. Williams).

"Eucalyptus scarcely distinct from E. hamastoma, Sm., Moreton Bay, 1824, A.C." This specimen of Allan Cunningham in Herb. Cant. ex herb. Lindl. is var. micrantha.

Archer's Station, Rockhampton (Leichhardt).

\section{AFFINITIES.}

1. With E. Sieberiana.

As regards the vernacular names in the "Flora Australiensis," Cunningham's name of "Blackbutt" is a misnomer, and has probably arisen from confusion of the species with the "Mountain Ash" (E. Sieberiana), and the name of "Mountain Ash" for E. hemastoma has probably arisen through too close reliance upon herbarium specimens, those of $E$. hemastoma and $E$. Sieberiana being frequently difficult to discriminate unless complete material be available.

As compared with $E$. Sieberiana, there is a close affinity in juvenile foliage. See E. Sieberiana, p. 306. 
2. With E. virgata, Sieb.

Herbarium specimens sometimes exhibit a good deal of similarity. I have a flat-topped fruit (not quite ripe) of the large-fruited kind of hamastoma from Peat's-road, Hawkesbury River, which was named E. virgata by an excellent authority.

3. With E. Luehmanniana, F.v.M.

The juvenile leaves present a good deal of resemblance. There is a closer resemblance between typical hemastoma and Luehmanniana, variety altior, which it may be sufficient to draw attention to.

4 ' With E. coriacea, A. Cunn.

The large-fruited or typical hamastoma may resemble those of E. coriacea a good deal, but the venation of the leaves is different. E. hremastoma has clean white stems much after the appearance of $E$. coriacea.

5. With E. Gunnii, Hook, f., var. maculosa.

This will be dealt with when the variety is reached.

In 1901 (Proc. Linn. Soc., N.S.W., p. 125), Mr. Deane and I described, under the name of $E$. hemastoma, Sm., var. montana, a shrubby plant only 2 or 3 feet high, from Mt. Victoria, collected by myself. 'The bark of so small a shrub was no guide, and the blood-red rims decided us to place it with $E$. hamastomaa pardonable error, as it obviously strongly resembles that species.

Since then, however, I have obtained typical $E$. amygdalina, var. nitida, and I find that these specimens precisely match Gunn's No. 808, e.g., Currie's River, Tasmania. The pale-brown fruits with the dark red-brown rims arrest attention. The only point in which I can distinguish the Mt. Victoria specimens from those of Currie's River consists in the more obvious oil-glands of those from Mt. Victoria, but this may be in a measure owing to the age (over 60 years) of the Tasmanian specimens. The similarity of the specimens is remarkable when it is borne in mind that the Tasmanian specimens are mostly from the sea-coast, while Mt. Victoria is an inland mountain locality. In a paper* I have given very definite evidence of the absolute similarity of many Tasmanian and New South Wales forms, and this is an additional example.

$E$. hemastoma, var. micrantha, differs in the erect, less falcate foliage of $E$. amygdalina, var. nitida. Both forms show oil-dots very abundantly. E. amygdalina, var. nitida, shows these dots far more abundantly than $E$. hemastoma, var. micrantha, as a rule, whose leaves are generally thicker, but in mountain specimens it is sometimes not possible to separate them on these grounds.

The fruits are less brown, less sessile, and with a rather more marked rim than those of var. nitida.

As regards amygdalina generally, the rims of the fruit are thinner; amygdalina has tibrous, and homastoma a smooth bark; but in dwarf mountain forms it is sometimes difficult to speak about bark.

"A second contribution towards a "Flora of Mt. Kosciusko."-(Agric. Gaz. N.S. W., 1899.) 


\section{DESCRIPTION.}

\section{Eucalyptus siderophloia, Benth.}

(B.Fl. iii, 220.) Re-described by Mueller in the "Eucalyptographia," with a plate.

\section{Notes supplementary to the description.}

A "coarse" species - that is to say, having coarse foliage, coarse fruits (as compared with the other Ironbarks, paniculata and crebra), and coarsely furrowed bark. Altogether a very sturdy tree, reminding one, in this respect, of the British Oak.

The buds are often, when young, of the "egg in egg-cup" shape-that is to say, the operculum is of noticeably less diameter than the calyx. The fruits have exsert valves, which is usually quite sufficient to distinguish this from other Ironbarks.

The "She Ironbark" (Woolls) given as a name for this species in the "Flora Australiensis" arose from a mixture of specimens of $E$. paniculata with those of E. siderophloia from Parramatta.

There is a Brachyscelid gall common on the leaves and branchlets of this species, which Mr.W.W. Froggatt tells me is Opisthoscelis Maskelli, Froggatt. It has been found at Homebush, Newcastle, Maitland, Stroud to Gloucester, \&c. I have never found it on any other species of Eucalyptus, and it, therefore, has some diagnostic value, in the present state of our knowledge.

\section{Varieties.}

(1.) Var. (:) rostrata, Benth. Operculum $\frac{1}{4}$ to $\frac{1}{2}$ in. long; capsule valves more prominent-Port Jackson, "Ironbark" R. Brown, Caley; "Greater Ironbark," Backhouse; "Large-leaved Ironbark," Woolls (B.Fl. iii, 220).

I find E. siderophloia on the whole very uniform in eharacter. It is a rostrate budded species, with a certain amount of variation in the length of the operculum, it is true, and which Bentham allows.

I have Woolls' specimens labelled by him var. rostrata, and they are the ordinary form. All Port Jackson specimens are rostrate-budded. It is rostratebudded to Central Queensland. I agree with Bentham in his doubt as to the value of the name var. rostrata, and go further and say that it is a name whose use can only result in confusion.

[Specimens which most literally conform to Bentham's original description of E. siderophloia are some mixed ones of E. paniculata and E. siderophloia collected by Woolls at Parramatta.

'The description also applies more or less well to the Padd j's Hill, Woy Woy, Taree to Wollamba, and Port Macquarie specimens referred to under "Range." 
These are, however, exceptional, and I follow Mueller (see figure of E. siderophloia in the "Eucalyptographia") in looking upon E. siderophloia as having a rather long operculum, and the fruit as having well exserted valves. There is no room for a variety rostrata.]

(2.) Var. glanca, Deane and Maiden. Proc. Linn. Soc. N.S.W., xxiv, 461

\title{
Following is the original description :-
}

This is the glaucous interior form of the species, which goes under the names of "Blue-leaf Tronbark" (in allusion to its glaucous foliage) and "Broad-leaf Ironbark," in allusion to its broad sucker-leares.

Its operculum is shorter than that of the normal species, but the fruit of var. glanca and of the type are precisely similar except as regards glaucousness.*

Dubbo District (H. Deane, Nor., 1892 ; J. V. de Coque and J. L. Boorman, Nov., 1897). This form (from, fragments in our possession) will probably be found to have extended range easterly, and more particulary northerIy of the Dubbo District.

"Broad-leaf Ironbark." Mr. J. V. de Coque recently drew attention to this tree, and pointed out that its timber is inferior to that of the other Ironbarks of the Dubbo District. Its timber is of an inferior quality, both as regards "ringing" and "splitting" (cracking), so much so that the timber-getters nerer cut it except for rails. Mr. Boorman points out that it grows on slightly elevated lands, and is confined to such situations only. When growing in the forest it can readily be noted by its glaucous appearance.

The "Blue-leaf Ironbark" is not really different from the preceding, although local people point out differences in breadth and glaucousness of leaves.

It bears a strong superficial resemblance to a specimen in the National Herbarium, Melbourne (in bud only), collected by Charles Stuart in "New England, 1,000-1,500 feet." (New England is nerar as low as this, so that, if the heights be correct, it must have been collected during an ascent.) His label further states: "30-40 feet, bark very rugose and deeply furrowed, flowers light yellow; Mountain Ironbark, No. 128." It bears a label in Mueller's handwriting " $E$. leucoxylon," and is probably the par. pallens of Bentham (B.Fl. iii, 210). Ample botanical material is desirable of these aberrant forms; at the same time it is not suggested for a moment that there are not two glaucous species, $\uparrow$ the stamens and stigma of $E$. siderophloia and E. leucoxylon (really sideroxylon) being very different.

In addition to the localities above enumerated, I have it from-

"On the sides of hills and out of the crevices of rock, all over the district, not perhaps plentiful, but widely scattered over the hills." A stunted tree, Gungal, near Merriwa (J. L Boorman).

\section{SYNONYMS.}

\author{
1. E. fibrosa, F.v.M. \\ 2. E. ornata, Sieb. \\ Note on E. persicifolia, DC.
}

1. E. fibrosa, F. Muell, in Journ. Liren. Soc. iii, 87, from the Brisbane, is only known from specimens in young bud, in which state $I$ am unable to distinguish them from the var. rostrata of E. siderophlcia. F. Mueller, however, designates it as a Stringybark. It may, therefore, prove to be distinct. (B.F1. iii, 220.)

e Speaking generally, the var. glauca has fruits smaller than those of the normal form, but this is not a character to be relied upon. I have specinens collected on the Harvey Range, Peak Hill district, by J. L. Boorman. with fruits just as large as those of the type.

+ Since the above was written, I have described a new glaucous species as $E$. Caleyi, and its similarities and dissimilarities to $E$. siderophloia, var. glauca, will be dealt with when speaking of $E$. Caleyi. 
In the "Eucalyptographia" Mueller says the bark of $E$. fibrosa " now proves far less fibrous than that of the real Stringylark trees," and he consents to its being considered a synonym of E. siderophloia.

I have dealt with the matter at p. 34, Part I of this work. I had overlonked Mueller's remark (made after he had reinvestigated the bark), and am now of opinion that E. fibrosa, F.v.M., is a synonym of E. siderophloia, Benth. The name was, however, most unfortunate, as the bark of E. siderophloia is never fibrous.

2. E. ornata, Sieb., P1. Exs. Quoted by Bentham in B.Fl. iii, 208 (I cannot find the original description).

A specimen from Herb. Oldfield in Herb. Kew, labelled "Eucalyptus resinifera, Large-leaved Ironbark, Parramatta, New South Wales, W. Woolls," was examined by Bentham for the "Flora Australiensis," and is the E. siderophloia, Benth., var. (?) rostrata, of B.Fl. iii, 220. (It bears the provisional pencil name, in Bentham's hand writing, of "ornata, var.")

'The original specimens were gathered by Woolls, at Cabramatta, near Parramatta, and are in the Woollsian Herbarium presented by me to the Sydney Herbarium. Cf. p. 33, Part I of this work.

Note on E. persicifolia, DC. "E. persicifolia, DC., Prod. iii, 217, and F. Muell., Fragm. ii, 61 (in part only), not of Lodd." These are the words of Bentham, quoting synonyms, in describing E. siderophloia. I have gone into the matter in Part I, p. 32, and arrived at the conclusion that E. persicifolia is a synonym of E. pilularis, Sm. I have reinvestigated the matter, and see no reason to alter my opinion.

\section{RANGE.}

Benthay gives it as Port Jackson to Moreton Bay, while Bailey speaks of it as found in Southern Queensland.

It is, however, found at least as far south as the borders of the Counties of Cumberland and Camden, New South Wales; and since the trees in that locality are of considerable size, I do not doubt that search will show that it oceurs at least as far south as the County of Camden.

In Queensland it is found as far north as Rockhampton. In its glaucous form it occurs as far west as the Dubbo District.

\section{New SoUTH WAles.}

We have it in the National Herbarium, Sydney, from a number of localities in the County of Cumberland, south, west, and north of Sydney. It has been almost exterminated from the suburbs of Sydney, partly because it yields a valuable timber and partly because of the natural progress of settlement. 
It is fairly common still at Homebush and Flemington, Bankstown to Cabramatta (the Railway Station); Cabramatta (the Cabramatta of the "Flora Australiensis," where Woolls collected, and now called Rossmore, since the name has been given to a railway station several miles away); Smithfield.

Specimens of twigs and timber were sent by the late Sir William Macarthur to the Paris Exhibition of 1855 and the London Exhibition of 1862, under the following numbers:-

(a) 137 (Paris), 4 (London).

(b) $137 \mathrm{~b}$ (Paris), 5 (London).

They both belong to this species, although some local variation caused Sir William to think they were different.

With reference to the aboriginal name given by Macarthur, it is interesting to note that George Caley, who collected for Sir Joseph Banks in the County of Cumberland, 1800-1810, called it "Derrobarry," evidently the same word, and I believe that Macarthur's names were obtained quite independently.

Sir William Macarthur furnished the following information :--

(a) "Terri-barri" (aboriginal name); "Broad-leaved rough Ironbark" or "Rough-leaved Rough-barked Ironbark" (local names, Counties of Cumberland and Camden), Diameter in inches, 24-48; height in feet, 80-120. From Appin; common in Cumberland. One of the strongest and most durable of timbers. "This tree has been proposed for their emblem by the colonists of New South Wales.

(b) "Ironbark." Diameter in inches, 24-48; height in feet, 80-120. From Appin; distinguishable by its very rough bark in broad deep longitudinal furrows, its very broad leaves, its smooth bark on the young branches, and the different grain of its wood.

Turning to the west it is more or less abundant to the foot of the Blue Mountains-e.g., Rooty Hill, St. Mary's, Penrith, Emu Plains, Richmond.

It extends to the Capertee Valley (J.H.M. and J. L. Boorman) and Murrumbo, Rylstone District (R. T. Baker), with somewhat blunter opercula, and showing transit to the variety glauca found much more to the west.

In the north it is much more abundant, and practically all the supply of this timber comes thence.

Following are some records of northern specimens in the Sydney Herbarium:-

"Red Ironbark." Height 50 feet, diameter 1 foot. Clarence Town (A. Rudder); Paterson, the commonest Ironbark of the district (J. L. Boorman); Jones' Flat, 12 miles south of Stroud (J.H.M.); Bullahdelah (A. Rudder). "Red Tronbark," Lawrence, Clarence River (J. V. de Coque); Myrtle Creek, County of Richmond (W. P. Pope).

E 
It has been already stated that $E$. siderophloia is a species very uniform in character, and the following specimens from central coastal New South Wales display as much difference from the normal form as is known to me (variety glauca excepted).

(a) Raymond Terrace to Stroud (Red Ironbark).

Some of these trees have fruits with exserted valves, and also fruits strikingly like those of $E$. paniculato in shape,-valves hardly, if at all, exserted, and the orifice in some cases somewhat contracted. For example, at Paddy's Hill, 14 miles north of Raymond Terrace, we have these paniculata-like fruits, with valves of fruit not exsert (J.H.M.).

Woy Woy.-Similar to preceding (A. Murphy), and with buds probably not so long in the operculum, but they are not ripe in either case.

(b) With short operculum with a tendency to a beak, like $E$. rostrata, but not long like $E$. tereticornis or $E$. resinifera. Taree to Wollamba (No. 291, Forest Department) sent as "Narrow-leaved Ironbark." The leaves of most trees are narrower as the top of the tree is reached. It is not E. paniculata.

Specimens sent as "Red Ironbark," Port Macquarie, by Forest Ranger G. R. Brown, are similar.

\section{QUEENSLAND.}

Moreton Bay (James Backhouse, 1836).

Near Brisbane, where it is said to be sometimes known as "Yellow Ironbark" (P. MacMahon).

Taylor's Range (F. M. Bailey). E. resinifera grows in the district, and has buds with long opercula also.

"Red Ironbark," Rockhampton and North Rockhampton. I see no difference between these and Port Jackson specimens (A. Murphy).

\section{AFFINITIES.}

1. With E. pilularis, Sm.

"When the operculum is short, specimens in bud only are much like those of the Blackbutt (E. pilularis) with which they appear to have been confounded, both by De Candolle and F. Mueller, although distinguished by all collectors; when the flowers are open the anthers give a ready character, and the venation of the leaves is somewhat different." (B.Fl. iii, 220.)

The fruits, bark, and timber of the two species are very different, but specimens in bud, and even young bud (and the early collectors sometimes were only able to obtain such) sometimes show the similarity to which Bentham refers. 
2. With E. cornuta, Labill.

"Stamens almost straight in bud, only slightly flexuose, thus imitating those of the E. cormuta and its allies; hence the anthers not concealed before the expansion of the flower by the inflection of the filaments."

(Mueller in "Eucalyptographia" under E. siderophloia).

The anthers and other characters of the two species are, however, very different, and the differences in other respects are very marked.

3. With E. hemiphloia, F.v.M., var. albens ( $E$. albens).

"Evidently allied" (Benth.). The affinity is not close, and will be referred to when $E$. hemiphloia is dealt with.

4 and 5. With E. crebra, F.v.M., and E. paniculata, Sm.

"Evidently allied to E. crebra and the other Ironbarks" (Benth.).

It is most readily distinguished from the other Ironbarks (E. paniculata and $E$. crebra, being the species with which it is most likely to be confused), by its coarseness of foliage and the flattish, broad ridges of the bark. In E. crebra the inflorescence and fruits are much smaller. In E. paniculata the anthers are very different and the fruits have not the valves exsert, but the latter is a character which must be used with eaution. See p. 328.

5. With E. resinifera, Sm.

"The rostrate variety, when in young bud, resembles $E$. resinifera, and even $E$. tereticornis, but the venation, and still more the anthers, distinguish it." (B.Fl. iii, 220).

The species most likely to be confused with E. siderophloia in herbarium specimens is E. resinifera, Sm., the proof being that such confusion actually does take place, the two species being often mixed by botanists, particularly when leaves and buds are alone available. See fig. 27, Plate 47. The two trees cannot be confused in the field, the bark of $E$. resinifera being fibrous and the timber very different. 


\section{DESCRIPTION. \\ XXXVII. Eucalyptus Boormani, Deane and Maiden:}

Proc. Linn. Soc. N.S.W., xxvi, 339 (1901).

Bark.-Dark in colour, often very dark grey and even black. In texture scaly, sometimes hard scaly, and even in parts nouly as rugged as an Ironbark, but never as soft as a Box. The rough bark extends to the small branches.

'Timloxl'. - Pale reddish-brown in colour, hard and durable, and, according to the testimony of many observer's, while of an Fronbark character, even superior to the Ironbarks of the district in which it grows.

Surker leaves.- Broak and coarse, nearly orbicular, but early becoming lanceolate.

Mature leaves. - Ovate-lanceulate to lanceolate, usually 3 to 6 inches long, and over 1 inch in breadth; veins fine and rather spresding, the intram roinal vein usually quite close to the edge. Texture of the leaf coriaceous and tongh, like that of $E$. siderophloin.

Buds.-- The buds and stmons appear to us not to differ from those of E. sidercphloia.

Opreroulum.--Conical, like that of $E$. siderophloik, but we have not observed the operculum much to exceed the calyx, which is very commonly the case in E. siderophloia, especially in var. rostrata.

Fruits.-Nearly semiovate, often slightly angular, usually presenting a gond deal of resemblance to those of $E$. siderophloia, but the valves (which usually number four, and sometimes five) scarcely exserted. About three to four lines in diameter, and not contracting at the orifice. Sometimes so subcylindrical in whape as to exhibit considerable resemblance to thuse of typical E. hemiphloia, F.v.M. (op. cit.).

\section{Notes supplementary to the description.}

Named in honour of John Luke Boorman, Collector, Botanic Gardens, Sydney, who, in regard to this and other species, has prosecuted inquiries in an intelligent and painstaking manner.

The name "Black Box" seems to be most generally in use for this species; the even better name of "Ironbark Box" (which certainly indicates its affinities) is nearly as frequently in use. At Lue it is also called "She Ironbark," its difference from the ordinary Ironbarks being thus recognised.

This seems to me to be a natural hybrid between $E$. siderophloia, Benth., and E. hemiphloia, F.v.M. The evidence available is published by Mr. Henry Deane and myself in Proc. Linn. Soc. N.S.W., xxv, p. iii (1900), and xxvi, p. 339 (1901). Luter on, xxx, 1. 194 (1905), I drew attention to the remarkable discovery by George Caley (botanical collector in New South Wales, 1800-1810), of hybridisation between E. siderophloia and E. hemiphloia.

As it is my intention to publish, later on, an account of hybridisation in Eucalyptus, with necessary illustrations, I will not present the evidence at this place. 


\section{RANGE.}

Bankstown and Cabramatta districts; thence across country to Penrith. It has also been found at Lue, on the Mudgee line.

\section{AFFINITIES.}

1. With E. leptophleba, F.v.M.

It seems to have its closest affinity to E. leptophleba (dreprnophylla). Further investigations may even cause it to be looked upon as a southern form of the Queensland species; but the latter is always described as an Ironbark, and the imperfect specimens of the type that I have hitherto had the opportunity of seeing present differences in the fruit and leaves which caused Mr. Deane and me to form the opinion that the interests of science would best be served in giving the former a name.

2 and 3. With E. siderophloia, Benth., and E. hemiphloia, F.v.M.

When young it has the flattish bark often seen in young E. siderophloia. The foliage, inflorescence, and fruits show obvious resemblance to that species, while its other resemblances to this species, and also to E. hemiphloia, have been already referred to.

\section{With E. affinis, Deane and Maiden.}

It has undoubted affinity to E. affinis, particularly in the timber and bark. At Lue they are both called "Black Box," and so far as specimens in my possession go, I cannot separate the trees, either in timber or bark, except with difficulty; the leaves also are much alike in texture and venation, but the fruits are very dissimilar. 


\section{DESCRIPTION. \\ XXXVIII. Eucalyptus leptophleba, F.v.M.}

Journ. Linn. Soc., iii, 86 (1859).

'Te original description is in Latin, and may be translated as follows :-

A tree; the branches below nearly terete, and above slightly angled; leaves alternate, scar'cely petiolate, falcate-lanceolate, without evident oil-dots, very finely veined, intramarginal vein but little removed from the edge; umbels axillary and terminal, 3-5 flowered, in pairs, in threes, or in panicles ; peduncles angled; pedicels shorter; the tube of the calyx semiovate; fruits semiovate, not ribbed, 4-5 celled; the valves deltoid, acuminate, and sunk below the rim.

Habitat.-In grass land near the Gilbert River. Flowering in summer.

A small or large tree; bark of a dirty grey, rugose, fissured on the trunk and persistent on the branches. Leaves mostly 3-5 inches long, up to 1 inch broad. Primary peduncles equalling or exceeding the petioles. Pedicels of the calyx variable, shorter than the tube. Fruit 3-4 lines long, not contracted at the orifice. Valves with tips scarcely exserted. Near to E. patellaris.

It is briefly described in B.Fl. iii, 221.

\section{Notes supplementary to the description.}

E. leptophleba, or Blackbutt, is a large tree of quick growth, rising to a height of about 100 feet, with a diameter of 3-4 feet; bark dark, persistont, and separating. into numerous small pieces (similar to that of $E$. tesselaris) on the trunk, grey, smnoth, and deciduous on the branches. This tree has the general appearance of $E$. tereticornis, with the bark of $E$. tesselaris and the fruit of $E$. crebra. The wood is red, hard, and durable, but not much used, in consequence of being generally hollow in the centre. It is only known from Queensland, and is dispersed through the scrubby country westward from Gaganjo.(P. O'shanesy, Rockhampton).

"Yudhulwan" is the aboriginal name, according to Mr. O'Shanesy.

Attention is invited to the fact that this species is variously described as "Tronbark" and "Box." This is not the only Ironbark which becomes a Box as tropical regions are approached, and E.crebra and E.melanophloia may be mentioned in this connection. It would appear that the outer bark becomes flatter and more fibrous, or softer and more flaky, in warm regions.

The silky sheen of Ieaves of E. leptophleba (or drepanophylla) appears to be a character.

The kino of E. diepanophylla is described by C. Mannich in Journ. Pharm., Chim., (6) xvi, 216; abstract in Pharm. Journ., xv (4), 523 (November, 1902).

\section{SYNONYM.}

E. drepanophylla, F.v.M., in B.Fl. iii, 221 (1866).

In the "Eucalyptographia," under E. siderophloia, Mueller speaks of " $E$. drepanophylla, which may be perhaps a mere variety of the imperfectly-known E. leptophleba." 
In the "Second Census," E. leptophleba is suppressed, but E. drepanophylla is recognised.

"E. drepanophylla includes as a variety E. leptophleba." (J. G. Luehmann, in Proc. A.A.A.S., 530, 1898.)

This cannot be, as $E$. leptophleba is the older name, but it is additional testimony that the species are the same.

E. leptophleba, F.v.M., and E. drepanophylla, F.v.M., are imperfectlyknown species, but there seems no doubt at all that one is a synonym of the other, and therefore E. leptophleba, the older name, must stand. E. drepanophylla is more fully described, and it is not necessary to redescribe it until more field knowledge is available This is work for Queensland botanists, and suites of specimens from various localities should be collected, and juvenile leaves should be especially remembered, since at present these are unknown.

\section{RANGE.}

E. leptophleba is found in Queensland, though I believe it may occur in New South Wales. The type comes from the Gilbert River.

The following are specimens referred to E. leptophleba by Mueller himself :-

(a) Trinity Bay (Cairns). Fruit rather more spherical than those of drepanophylla usually are.

(b) In bud, from Rockingham Bay (Dallachy).

(c) A specimen of small conoid fruits, stated to have been collected by O'Shanesy between the Dawson and Mackenzie Rivers, differing from any other fruits, I have seen labelled by Mueller either leptophleba or drepanophylla.

I doubt the correctness of the naming of this specimen.

Bentham gives the following localities and vernacular names for $E$. drepanophylla:-

N. Australia.-N.W. coast, A. Cunningham.

Queensland.-E. coast (A. Cunningham); Keppel Bay and Shoalwater Bay (R. Brown); Burdekin Expedition (Fitzalan); Port Denison, "Ironbark-tree" (Fitzalan, Dallachy) ; Bowen River, "Ironbark," (Bowman).

The specimens from the N.W. coast that I have seen are in young fruit the style still persistent), and with a few stamens on one flower. In my view, they are doubtful. 
I have seen specimens of the following, named by Mueller, and chiefly in the Melbourne and Calcutta herbaria:-

S.E. Carpentaria, "Box tree," in fruit-only (E. Palmer); Sources of the South Coen River, York Peninsula, in fruit (Stephen Johnson) ; "North Coast," R. Br., 1802-5, not in fruit, pale-coloured operculum; Endeavour River, N. Holland, Lieutenant King (afterwards Admiral P. P. King) ex herb. Lambert in herb. Cant.; Palmer River, in fruit only (collector?); Daintree River (Fitzalan), in flower only; Cleveland Bay (Townsville), in bud, pale-coloured operculum (S. Johnson); Edgecumbe (? Range), near Port Denison, a poor stunted tree, 20 feet high (Dallachy); Port Denison, in flower (Fitzalan); Ravenswood, Burdekin River, in fruit (S. Johnson); Mt. Elliot (S.W. of Bowling Green Bay), in flower only (Fitzalan); Stuart River (Nanango District), with the ordinary subcylindrical, and with more hemispherical fruits (S. Johnson).

\section{AFFINITIES.}

E. drepanophylla differs from E. crebra chiefly in the large flowers, and in the larger, harder, and more globular fruit. From E. leptophleba it is chiefty distinguished by the leaves not so thick, with more oblique veins. It is not impossible, however, that $E$. melanophloia, drepanophylla, trachyphloia, leptophleba, and crebra, all of them Ironbarks, may be but forms of one species. (B.Fl. iii, 221.)

In the specimens I have seen, the leaves of $E$. drepanophylla are thicker, if anything, rather than "not so thick" as those of E. leptrphleba; indeed, I do not think they differ at all. Almost without exception, the fruits of E. drepanophylla, determined by Mueller himself, are sub-cylindrical. The words " more globular" seem to me inappropriate in the connection in which they are used.

E. melanophloia, trachyphloia (a Bloodwood), and crebra are good species, and certainly different. E. leptophleba (drepanophylla) is again different, though closest to crebra of the species mentioned.

E. drepanophylla, which may be perhaps a mere variety of the imperfectly-known $E$. leptophleba, is still nearer to $E$. siderophloia than $E$. crebra; it is generally of more stunted growth; its leaves are narrower, of a paler hue, more opaque, usually also more curved and provided with stomata of almost equal number on either page; the flower-stalks are less angular and rather thinner; the lid is blunter, and only of about the same length as that of the calyx-tube; the filaments show a somewhat inflected curvature while in bud; the style is shorter; and bears a slightly broader stigma.-(Under $E$. siderophloia, in Mueller's "Eucalyptographia.") 


\section{DESCRIPTION. XXXIX. Eucalyptus Behriana, F.v.M.}

Following is the original description of the species :-

Fruticose; leaves alternate, coriaceous, somewhat shining, lanceolate or ovate, acute, slightly oblique, thinly reined, dotted; umbels pedunculate, panicled, few-flowered; flowers small, nearly sessile; lid hemispherical, blunt or minutely apiculate; tube of the calyx obconical, bell-shaped, nearly twice as long as the lid; fruit half-orate, sessile, not contracted at the top, valves of the capsule enclosed; seeds brown, streaked.

In arid plains and on stony hills near the Avoca, Murray, and Gawler Rivers, and in Bacchus Marsh.-Trans. Fic. Inst., i (1855), 34.

At about the same time Mueller sent specimens to Miquel, who was then engaged on his "Stirpes Novo-Hollandas." The latter independently described the species, and as his description is published in Ned. Kruidk., Arch. iv, 140 (1856,* not 185.9, as mentioned in B.Fl.), an excessively rare work, I quote it here:-

39. Eucalyptus Behriana, Ferd. Müll. E. pruinosa, Behr. Herb. non Schauer. Fruticosa, ramulis teretiusculis summo apice compresso-angulatis foliisque subtus pruinosis, his ovato-lanceolatis inæquilateris acuminatis, basi in petiolum contractis, coriaceis, pennivenizs, umbellis capitatis paucifloris ( $1-7$ floris), in paniculis axillaribus lateralibus et terminalibus confertis, pedunculis umbellarum teretiusculis, calycis tubo parvo obconico turbinato, operculo hemisphærico mutico vel apiculato quam tubus duplo breviore.

In Nova Hollandia australi legit cl. Dr. Behr., autumno. Teste Cl. Müller prope E. polyanthemos inserenda. Frutex 6-12 pedalis. Folia ad 3 poll, longa $\frac{1}{2}$ lata.

It is figured in the "Eucalyptographia," but the figure is not a very good one.

\section{Notes supplementary to the description.}

$E$. Behriana is always a Mallee. It grows in scrubs, and usually is 5 to 10 feet high, though it sometimes forms small trees, which have rarely a diameter of as much as 9 inches. The bark is alwars smooth, and commonly of a dirty-white colour, or, according to one observer, of "a dark oily-]ooking green." The timber is red. The flowers and fruit are small, with a panicled inflorescence, the opercula being blunt, and the fruit shiny and dark coloured. It bears seed abundantly. The leaves are comparatively broad, and are thick and shiny.

Notes on variations in this species will be found in the description under Plate 48.

\section{SYNONYM.}

E. pruinosa, Behr, non Schauer. See above. I have seen a specimen.

- 1856 is the date of the green paper-covered paper Part mainly occupied by Miquel's paper. 


\section{RANGE.}

IT has hitherto been recorded from a few localities in South Australia, and certain of the drier parts of Victoria and New South Wales.

Besides those localities mentioned in the original description, Mueller quotes ("Eucalyptographia") "in the hilly forest region of Wirrabara, near Crystal Brook, and Mount Remarkable on deep marly clay-soil" (J. E. Brown), and quotes Dr. Behr, "in the scrubs of Sandarac-Cypresses (Callitris) near the Gawler River."

Prof. Ralph Tate, in his "Flora of South Australia," states that it is found in the northern agricultural areas, the Port Lincoln District, Kangaroo Island, and south of the Murray Desert. A few more specific South Australian localities are desirable.

\section{VICTORIA.}

Bacchus Marsh (Mueller), a type locality; Swan Hill, Murray River (J. G. Luehmanu), 1890; Mallee District (C. Walter), 1889; Inglewood and Wedderburn (J. Blackburn); Yarram Biack (C. Walter), 1886; Wimmera (J. Reader); Nhill (St. Eloy D’Alton).

\section{New South Wales.}

"Mallee," Wyalong (H. Deane), about 1890.

Wyalong (Forester J. G. Postlethwaite), April, 1892. Height 20 feet; diameter 6 inches.

Wyalong (W. S. Campbell), October, 1901.

20-30 feet, with one or two dozen stems of 3 to 4 inches in diameter springing from one root. Barmedman and other stations in the Lachlan District (J. Duff).

Leaves smooth, green, and shining; flowers small. Grows in scrubs 5 to 10 feet high, sometimes small trees, rarely up to 9 inches in diameter. Bark, dirty white, smooth. Broad green-leaf Mallee, (R. H. Cambage, Wyalong and Barmedman, September, 1900.)

"Broad-leaf Mallee," Wyalong (J. L. Boorman).

\section{AFFINITIES.}

1. With E. bicolor, A. Cunn.

Mueller ("Eucalyptographia") defines the difference between E. Behriana and $E$. bicolor (largiflorens) to be-

(1) The bark of the latter persists.

(2) The leaves are conspicuousīy narrower, of thinner consistence, of duller hue, finer veined, and better provided with oil-dots. 
(3) Its panicles are more spreading.

(4) The lids (at least often) are double, and the stamens not constantly all fertile.

In the field the species are at once separated by the large size of $E$. bicolor, which has rough bark up to the small branches. The timber of both is red. In the herbarium, I imagine that they would be readily separated by the broad shiny leaves of E. Behriana, to mention no other characters. I do not attach much importance to No. 4 as characters.

\section{With E. hemiphloia, F.v.M.}

Mueller ("Eucalyptographia") says :-

E. Behriana approaches closely to E. hemiphloin, from which it mainly differs in-

1. Ferer attaining the stately dimensions of that species.

2. Bark remaining smooth from succession of outer layers.

3. The leares are as a rule (subject, howerer, to exceptions) shorter and broader.

t. The panicles are less ample, by which means the umbels are not rarely arranged in a racemous manner.

5. The flowers and fruits are smaller, their stalklets are less abbreriated, the lid is shorter and blunter, and the fruit-ralres are less deeply enclosed.

'To which mav be added: Their timbers are totally different, that of L. Behriana being of a red colour; that of $E$. hemiphloia is the ordinary palecoloured Box, whose appearance and properties are thoroughly well known. The flowers of E. Behriana are small, with short filaments.

In the field the species could never be confused for a moment, but as expert botanists have confused them (i.e., E. Behriona with forms attributed to E. hemiphloia, - my var. microcarpa) in the herbarium, it is idle to contend that they do not possess some degree of similarity. Perhaps this note will be the means of causing attention to be given to the matter.

3. With E. odorata, Behr.

Under E. Behriana, F.v.M., Bentham (B.Fl. iii, 214) describes a var. purpurascens, F.r.M., originall collected by Wilhelmi at Lake Wangaroo (Tangary), South Australia. At p. 217 (under E. hemiphloia) he refers to South Australian specimens (Memor? Core and Kangaroo Island, R. Bromn; Port Lincoln, Wilhelmi), and sayjs:- "In Mr. Brown's South Australian specimens the leaves are smaller, but in Wilhelmi's they are the same as in the northern ones, and I can find no character to distinguish them. Both R. Brown and F. Yueller had given them the W[S. name of E. purpurascens. R. Brown's plant (collected 1802-5) was distributed from the British Museum under the number 4,735.

I have examined the trpe, labelled br Mueller "E. purpurascens, Ferd. M. Scrub of Port Lincoln, January, 1855. 4-6 feet. Carl Wilhelmi." Afterwards the same specimen was labelled by Mueller "E. hemiphloia, var.," with the note: "Pedicels none; lid short and blunt." All these specimens referred to $E$. Behriana 
and $E$. hemiphloia are, in my opinion, identical. They are usually easily recognised by their purple tilaments, and belong to E. odorata, Behr. Judging from herbarium specimens alone, it is easy to see how botanists warered, placing them at one time under $E$. hemiphloia and at another under E. Behriana. I will deal with the matter subsequently, when dealing with $E$. odorata. (I have recently visited the type-locality.) I then propose also to deal with the affinity of E. Behriana to E. odorata in general.

4. With E. incrassata, Labill., var. dumosa, F.r.M.

Both are Mallees, and often much of the same size. The leaves of both are thickish, those of $E$. Behriana are broader. The inflorescence of var. dumosa is less paniculate, the anthers sharply different, while the fruit of var. dumosa is usually noticeably larger. The operculum of var. dumosa is usually ribbed. See also Part IV of this work. 


\section{DESCRIPTION. \\ XL. Eucalyptus populifolia, Hook.}

Tне species was described* in Hooker's Icones Plantarum, t. 879 (1852), and the description was, of course, accompanied by a plate. Following is this description :-

Ramis gracilibus teretibus, foliis longe petiolatis subrhombeo-orbicularibus obtusissimis basi subcuneatis tenue penninerviis nervis obliquis approximatis margine paulum incrassatis, pedunculis axillaribus solitariis vel foliis delapsis subpaniculatis subquinquefloris, fcuetu (vix maturo) turbinato laevi, pedicellis teretibus. Hab., Wide Bay district, north-eastern Australia, Mr. Bidwill (n. 76).

The lid or operculum of the calyx I have not seen, but the leaves alone will readily distinguish this species from any with which we have hitherto been acquainted.

The type accordingly came from what we now know as Queensland. The species is, however, more widely diffused in New South Wales.

Mueller's description, in English, will be found in the "Eucalyptographia."

Bentham (B.Fl. iii, 214) confused it with E. polyanthemos, Schauer.

\section{Notes supplementary to the description.}

Mueller, in the "Eucalyptographia," emphasises the following points:Leaves orbicular-ovate or roundish, very shining (the leaves may, however, be narrow.-J.H.M.); umbels paniculate; anthers roundish-ovate, opening below the summit by pores; fruits very small.

There are many gradations of size and width of leaf. The species is usually very easily recognised, but the narrow lanceolate leaves may be a pitfall in some cases; they then sometimes show affinity to $E$. bicolor.

The type, as figured by Hooker, shows slightly urceolate fruits, but scarcely urceolate in "Eucalyptographia."

For notes as to certain variations in the species, see the descriptions (at $p$ 348) referring to Plate 48.

It is commonly known as "Bimbil" (aberiginal name) ("Bibble" is a corruption), or "Glossy- or Shiny-leaved Box." Sometimes the leaves are strikingly Poplar-like (hence the specific name), while the resemblance to a Poplar is enhanced by the upright habit, for it is one of the most compact, straight-growing trees of the genus.

It has rough bark except to the very ultimate branchlets. Other notes on this tree will be given under the localities.

- See note below, under E. alba, p. 342 . 


\section{SYNONYMS.}

1. E. micrantha, A. Cunn., non DC.

2. E. populnea, F.v.M.

3. E. largiflorens, F.v.M., var. parviflora, Benth.

4. E. bicolor, A. Cunn., var parviflora, F.v. M.

Ђ. E. polyunthemos, Schauer, var. populifolia, F.v.M.

1. E. mierantha, A. Cunn, non DC.

I cannot trace that this species was ever described. A number of Cunningham's specimens have, however, been distributed in various herbaria under this name, amongst others those from the Peach Valley, Lachlan River, $\frac{199}{1817}$ June. sometimes called by Cunningham "Bastard Box," but not to be confused with E. bicolor, A. Cunn.

2. E. populnea, F.v.M.

$$
\text { (E. populifolia, Hook., * in Mitch. Trop. Austr., p. 204, non Desfont.) }
$$

Arborea, ramulis tenuibus teretiusculis laevibus, foliis alternis longe petiolatis ovato-vel rhombeourbicularibus apice obtusis vel emarginatis basi acutiusculis utrinque nitentibus concoloribus pellucide punctatis subtiliter venosis, umbellis $3-7$ floris axillaribus vel lateralibus solitariis vel simpliciter paniculatis, pedunculis calycem vix excedentibus alabastris clavato-ovatis, calycis minuti tubo ecostato in pedicellum brevissimum attenuato operculi hemisphaerico mutici longitudinem duplo excedente, fructibus parvis turbinato-obconicis, valvis inclusis seminibus.

Hab. in tractu orientali Nova-Hollandia subtropicæ passim sylvas constituens praesertim in collibus fertilioribus. Anth., Oct.-Dec.

Arbor mediocris; cortice sordide fusco-cinereo in trunco ramisque persistente rugoso et rimulosa. Petioli tenues teretiusculi saepe 1 inch longi. Folia $1 \frac{1}{2}-3$ uncias longa, 1-3 uncias lata, nonnunquam longitudine latiora. Pedunculi partiales 2-4 uncias longi. Calycis tubus circiter $1 \frac{1}{2}$ unciam metiens. Stamina albida 1 unciam vix longiora. Fructus maturus deest. (Journ. Linn. Soc., iii, 93 (1859).)

3. E. largiflorens, F.v.M., var. parviflora, Benth.

A specimen in the Melbourne Herbarium, labelled "Box-tree of Suttor River," bears the further label "E. largiflorens, F.v.M., var. parviflora, Benth.," which was afterwards properly cancelled by Mueller for E. populifolia. It is the form with the narrower, longer leaves common in the species. It is not the No. 2 "Gum-topped Box" from Suttor River, Bentham, in B.Fl. iii, 222, under E. crebra, which is $E$. acmenioides, Schauer.

The fruits are immature, but they and the flowers do not appear to be smaller than usual.

4. E. bicolor, A. Cunn., var. parviflora, F.v.M.

"Flowers much smaller. Stamens not 1 line long. Burdekin River, F. Mueller" (B.Fl. iii, 215).

Similar to the preceding, and the same remarks as to immaturity of fruit apply. Labelled E. populifolia by Mueller in Herb. Melb. I have received a duplicate specimen from Kew, and in this view I concur.

5. E. polyanthemos, Schauer, var. populifolia, F.v.M.

Mueller distributed a number of specimens under this name. 


\section{RANGE.}

IT seems to be confined to New South Wales and Queensland. It is a dry country or interior species. It does not appear to have been recorded from South Australia; but in view of the New South Wales localities I have indicated, which approach the South Australian border, I should not be surprised to hear of its occurrence in the latter State.

\section{New South WaLes.}

Wentworth (Mrs. Forde). This is the specimen in regard to which Dr. Woolls ("Plants of New South Wales," p. 52) announced E. Behriana as occurring in New South Wales, and I believe his determination was based on the plate of E. Behriana as depicted in "Eucalyptographia," which it matches very well. (It is, however, not a very good plate.) The plant is, however, E. populifolia.

"Hay district. 'Glossy-leaved Box.' Native name 'Geral' (Lower Lachlan). This is our second largest tree, attaining a height of 40 or 50 feet, with a diameter of $\mathbf{3}$ feet. It is peculiar to the back country, and is easily distinguished from the Box growing on the plains and along the banks of streams by its round and glossy leaves. As a rule, this tree grows near spots where water collects after rain and is almost invariably found bordering cane or Lignum (Muehlenbeckia Cunninghamii) swamps" (K. H. Bennett).

I have also received it from the same locality (Ivanhoe), from A. G. Little through H. Deane.

Mossgiel (John Bruckner). Labelled E. hemiphloia by Mueller.

Zara, via Hay (Miss Edith Officer). Lanceolate leaves, some of them narrow; reddish flowers, and with specially paniculate inflorescence. This remarkable specimen may show hybridisation with $E$. bicolor and I will deal with it on another occasion.

Narrandera, labelled "White Box" (F. R. Condell); Warrii (J.S. Taylor).

E. populifolia was not noticed south of the Wyalong district, but from this point northwards it is one of the commonest trees in the interior. Although usually known as "Bimble Box," I was informed that away to the westward of Wyalong it bears the name of "Minty Box"; but as I did not visit the locality indicated, I cannot be certain of the species. (R. H. Cambage.)

Euabalong (J. L. Boorman), with both narrow and broad leaves; "Bimbil" or "White Box." Egg-shaped leaves. Very hollow and gnarled (Forest Rangel" Kidston and J.H.M., Condobolin); Bogan Gate (J. L. Boorman); Cobar (Andra); Mt. Boppy (J. L. Boorman); "Mallee Box," Nymagee (J. Wharton Cox); "Bembil Box," Nyngan (District Forester C. Marriott).

Coolabah (R. N. Peacock and J. L. Boorman); Marrar Creek via Girilambone (T. E. Grigg). 
Bourke (O. C. MacDougall and J.H.M.); plentiful along the Western Line from Mumbil to Bourke (J. L. Boorman); North Bourke'(A. Murphy). Most of the specimens with narrow lanceolate leaves and the foliage more drooping than usual.

Tarcoon (J. T. Boorman); Brewarrina, "Bibble Box" with very paniculate inflorescence (C. J. McMaster).

"Bibble or Round-leaved Box." Near Mitchell's Out-station, Dunlop, \&c., louth (R, Etheridge).

"Bastard Box," W. Baüerlen, Tarella, Wilcannia, August, 1887, No. 62. Bark persistent; tree, 30-50 feet. Some of the leaves are large and coarse ; similar leaves are found in the Bourke district. Others are lanceolate, and even narrow lanceolate; Wilcannia (H. V. Jackson); White Cliffs (E. P. O'Reilly); Cobham Lake (W. Baüerlen); 'Tinapagee, Wanaaring (R. T. Dalton).

Minore (J. L. Boorman); Narromine (R. Helms); Tomingley to Narromine (J.H.M.) ; Dubbo (C. J. MeMaster).

"Poplar-leaved Box." Small spreading tree on the Castlereagh (W. Woolls); on the plains near Baradine (W. Forsyth); "Box," Wee Waa, Burren Junction (J. L. 13oorman).

"Bibble Box," "Broad-leaf Box," or "Peppermint Box." Useful for fencing purposes, \&c. Strong and durable. Habitat, open forests and low flats. Plentiful in some localities. Flowering period varies. (Forest Ranger McGee, Narrabri); Narrabri, common (J.H.M.); Moree (J. L. Boorman); Gungal, Merriwa, apparently scarce in the district (J. L. Boorman).

\section{QUEENSLAND.}

Blackall, Barcoo (Bailey); Crocodile Creek (Bowman); Lake Elphinstone, Rockhampton (Amalia Dietrich); Rockhampton (R. Simmons); Chinchilla (Bailey); Dalby and other parts of South Queensland (Bailey); Darling Downs (Bailey); Gayndah (S. A. Lindeman).

"Scrub Box-tree" of Burdekin River (E. largiflorens, F.v.M., var. parviflora, Benth. (B.Fl. iii, 215).

"Box-tree" of Suttor River (E. largiflorens, F.v.M., var. parviflora, Benth. (B.Fl. iii, 215).

\section{AFFINITIES.}

1. With $E$ alba, Reinw.

The name $E$. populifolius was nriginally used (with Hooker as author) in Mitchell's "Tropical Australia," p. 204, foot-note (1848). Mitchell's specimens were 
collected near Mt. Owen, adjacent to the River Maranoa, Queensland. I have seen Mitchell's specimens, and will give a figure (sufficient to bring out the characters) under E. alba, Reinw.

Bentham (B.Fl. iii, 243) has a note on these specimens, which, he says, belong -more probably to E. platyphylla than to E.polyanthemos. The fact is, that they are indubitable platyphylla, which is a synonym of E. alba.

I will discuss the matter when I figure $E$. alba, but it appears to me that E. populifolius, Hook. (1848), is a synonym of E. alba, and that E. populifolius, Hook. (1852), is the "Bimbil" ог "Glosst-leaved Box," and must fall, were it not that it has been in universul use for orer half a century, and there seems to be a general consensus of opinion amongst botanists that names so used should stand, irrespective of the laws of strict priority. (Vienna Code.) The next oldest name is, of course, E. populnea, F.r.M.

$E$. alba has leaves of a Poplar shape, but usually much larger than those of E. populifolia, and less shiny. The fruits and buds are quite different and the trees differ in other obrious and important particulars-e.g., the smooth or flaky bark of E. alba as compared with the fibrous bark of E. populifolia.

2. With E. bicolor, A. Cumn.

A "Drooping Box" of the river-flats of the interior. Its drooping habit would at once distinguish it from normal E. populifolia; so would its lanceolar, dull (often pale) leares, and its red timber. The barks of both trees are Box-like; the fruits of $E$. biculor are larger and more sub-cylindrical than those of E. populifolia.

3. With E. Behriana, F.T.M.

E. populifolia is a larger tree; its habit is erect and Poplar-like; it has a rough (Box-like) bark. In all these particulars it differs from E. Bchriana. The leaves of $E$. populifolia sometimes resemble those of $E$. Behrianc in shape and lustre (see p. 341); the inflorescences are sufficiently similar (the filaments of both are short) to put one on one's guard, though the fruits are dissimilar. Usually the inflorescence of $E$. Behrianc is more paniculate, and the fruits more crlindrical and darker in colour. 


\section{DESCRIPTION. \\ Doubtful Species.*}

E. Bowmani, F.r.M., in B.Fl. iii, 219 (1866). Named in honour of Edward Macarthur Bowman. He was the eldest son of Dr. James Bowman, of Ravensworth, Hunter River, and nephew of Mr. James and Sir William Macarthur, of Camden Park, Now South Wales. He obtained his botanical training from the latter gentleman.

\section{Notes supplementary to the deseription.}

Bentham (loc. cit.) says: "I have some hesitation in describing the species without having seen the fruit."

It is indeed imperfectly known. Only a few leaves, buds, and anthers of the type are in existence, at all events in Australia.

\section{RANGE.}

QUEENSLAND, where it was collected by the late E. Bowman in only one locality, which may have been the Suttor River, where Bowman collected other Eucalypts; but this is surmise.

\section{AFFINITIES.}

1. With E. hemiphloia, F.v.M.

"Probably includes E. Bowmani, described from insufficient material." (J. G. Luehmann, Proc. Aust. Adv. Science, vol. 7, p. 526, 1898.)

I think this opinion is the correct one, on the material available. It is, at all events, closely allied to E. hemiphloia. I have no proof that it is a distinct species, and publish the drawing and these few notes in order that the origin of E. Bowmani may, if possible, be traced. I do not think any useful purpose would be served in discussing further, at present, the possible affinities of this plant.

2. With E. hemiphloia, var. albens, and E. cladocalyx, F.v.M. (corynocalyx).

Bentham (loc. cit.) says: "It seems to be allied to $E$. albens and $E$. corynocaly $x$, but differs from both in the shape of the flowers." 
3. With E. siderophloia, Benth.

Chiefly different from $E$. siderophloia in less shining leaves with about equal numbers of stomata. on each side, mostly solitary umbels on a broadly-compressed stalk, absence of stalklets, the lid not longpointed, the filaments while in bud more twisted, and possibly also in bark and fruit. The tree from Mount Elliott referred to by Bentham under $E$. Bowmani, belongs to $E$. drepanophylla.--(Under $E_{\text {. }}$. siderophloia, in Mueller's "Eucalsptographia."

\section{With E. Baileyana, F.v.M.}

Tnder $\boldsymbol{E}$. Baileyana, F.v.M., Mueller, in "Eucalyptographia," points out certain differences between that species and $E$. Bowmani, but inasmuch as Mueller himself included two species under $E$. Baileyana, " his figure being a composite one, with fruits of $E$. Baileyana and flowers and leaves of $E$. engeniodes, the comparison in question is of no value. It has no close aftinity to $E$. Baileyana.

\section{Explanation of Plates (45-48). \\ PLATE 45. \\ E. piperita, Sm.}

1a, 1b. „urenile leares (seedlings). Linden, Blue Mountains, N.S.W. (R. H. Cambage aud J.H.M.)

2. Juvenile leares. Hornsby, near sydney. (E. H. F. Swain.)

3a. Ieaf : $3 b$, buds (note the sharp operculum and the somerwat falcate twist of each bud in this species): $3 c$, tlowers; $3 d$, fruits (oroid).

4. Buds. Corricudgy Mountain, near Rylstone. (R. T. Baker.)

5. Fruits, almost spherical. Lawson, Blue Mountains. ( $J$. H. Camfield.)

6. Fraits, typically urceolate in shape. Wingello, N.S.W. (J. L. Boorman.)

Ta. Fruits of $\boldsymbol{E}$. piperita (Port Jackson); $\bar{T} b$, fruits of $\boldsymbol{E}$. engenioides (Lane Core, Port Jackson); $7 c$, fruits (Hurstrille, Sydney) which appear to be intermediate in character between $7 a$ and 76 . See p. 305.

$8 \pi$. Juvenile leaves; $8 b$, leaf in the intermediate stage; $8 c$, mature leaf and buds $8 d, 8 e$, fruits of a "Messmate." Wingello, N.S.W. (J. L. Boorman.) This plant is not typical of E. viperita and is discussed at p. 304 .

9. Reniform anthers of E. piperita.

\section{E. Sieberiana, F.v.M}

10a, 10b. Juvenile leaves (seedlings). Blackheath, Blue Mountains, N.S.W. (K. H. Cambage and J.H.M.)

11. Leaf, intermediate stage. Cox's River, Blue Mountains. (R. H. Cambage and J.H.M.)

12. Buds. Badgery's Crossing to Nowra, N.S.W. (W. Forsyth and A. A. Hamilton.)

13. Fruits. Twofold Bay, N.S.W. (Oldfield). Seen by Bentham and marked by him E. virgata, Sieb. The error is explained at p. 308.

14a. Mature leaf; $14 b$, buds; $14 c$, fruits. Dromedary Range, N.S.W. (C.S. Wilkinson.) This is the specimen formerly labelled E. homastoma by Mueller, and the error is explained at p. 308 .

15. Reniform anther of $\boldsymbol{E}$. Sieberiana.

* I have published a plate of E. Baileyana in Part 35 of my "Forest Flora of New Sonth Wales," and have re-described the species. 


\section{PLATE 46. \\ E. Consideniana, Maiden.}

1 $a$. Mature leaf; $1 b$, buds; $1 c$, fruits. Stradbroke, South Gippsland, Victoria. (A. W. Howitt.)

$2 a$. Juvenile leaf; $2 b$, mature leaf. Boggy Creek, Gippsland. (A. W. Howitt.)

3", 3b. Juvenile leaves; 3c, fruits of type. Pigeon House, Milton, N S.W. (R. H. Cambacre.)

t. Buds. Top of mountains east of Burragorang. ( $\mathrm{R}$. H. Cambage.)

5. Fruit. Top of Barrengarry Mountain, N.S.W. (J.H.M.)

$6 a$. Mature leaf; $6 b$, buds; $6 r$, fruits. Wingello, N.S.W. (J. L. Boorman.)

7i. Buds; 76 , back and front view of anther; $7 c$, fruits. Blaxland to Valley Heights, Blue Muuntains, N.S.W. (R. H. Cambage and J.H.M.)

sir. Buds (with operculum rather more pointed than in the type); $8 b$, fruits. Mountain north of Wolgan Shale Mine, N.S.W. (R. H. Crmbage.)

$9 u$. Buds; $9 b$, fruits (more spherical in shape than in the type, and also with sunk rim). Penang, Gosford. (.J.H.M.”and J. L. Boorman.)

$$
\text { L. hremustoma, Sm. }
$$

10. Twig, showing buds and leaf, being portion of Sieber's No. 497 (Fl. Noræ Holl.), which is the type of E. micrentha, DC

11. Fac-simile of a portion of PI. 5, Fr micrantha, DC., "Mémoire sur la Famille des Myrtacées," par Aug. Pyr. De Candolle. Figure of the type.

1:. Juvenile leaf of E. hoemastoma, Sm., var, micranthr. Blackheath, Blue Mountains, N.S.W. (J.H.M.)

13. Intermediate leaf of var. micrantha. Port Macquarie, N.S.W. (J.H.M.)

14a, 14b. Flattened hemispherical fruits (aberrant) of var. micrantha. Moruya, N.S.W. (J. S. Allan.)

15. Fruits of var, micrantha, Queanbeyan, N.S.W. (H. Deane.)

16. Mature leaf and fruits of var. micrantha. Bankstown, N.S.W. (J. L. Boorman.)

17 a, 17b. Buds; $17 c, 17 d$, fruits (note the difterence in size). Mt. Wilson, N.S.W. (Jesse Gregson and J.H.M.)

\section{PLA'I'E 47.}

L. hemastoma, Sm.(concluded.)

1. Fruit of var, micranthe. Failfurd to Forster. N.s. W. (J.H.M.)

$\because$ Fruits of var. micranthe. Port Macquarie to Kempsey. N.S.W. (J.H.M.) : $n$, 3b. Fruits of var. micrantha. Brisbane. (F. M. Bailey.)

1. Fruits of rar. micrantha. (? loc.) (Teichhardt.)

j. Fruits of var, micranthr. Maryboroush, Queensland. (W. H. Williams.)

bic. Mature leaf ; $6 b$, buds ; $6 c$, fruits of $E$. signata, F.V.M. Brisbane River. See p. 319.

7a, 7b. Fruits of var. micranthe. Grenfell, N.S.W. (F. R. Postlethwaite.)

si. Nature leaf; 8b, fruits of var. micrantha. Head of the Castlereagh River, N.S.W. (W. Forsyth.)

9.. Mature leaf; $9 b$, buds; $9 c$, flowers; $9 d$, fruits of $E$. Rossii. (R. T. Baker.) Camboon, N.S.W. (R. T. Baker.) See p. 320.

10. Pear-shaped fruits of var. micrantha, near Bungendore, south of Lake George, N.S.W. (W. S. Campbell.)

11a. Mature leaf; $11 b$, fruit (intermediate in size) of E. hemastoma. Thornleigh, Sydney. (W. W. Froggatt. 
12. Fruits (intermediate) of E. hemastoma. Hornsby, Sydney. (E. H. F. Swain.)

13a. Buds: 13b, fruits; $13 c$, top view of fruit (showing marked rim) of E. hemastoma. Middle Harbour, Sydney- (J. H. Camfield.)

1ta. Leaf; $1+b$, buds; 1tr, fruits; $14 d$, anthers of typical $E$. hemastoma. Middle Harbour, Sydney. (J. H. Camfield.) Note the large size of the fruits, and also the great variation in the sizes of the fruits.

15. Anther of (?) E. Rossii. Adelong, N.S.W. See p. 321, and compare the shape of the anther with $1 \pm d$, var. capitata, Maiden (var. nor.)

16a. Twig with leaf and fruits; $16 b$, side view of a fruit. Mt. Victoria, N.S.W. (J.H.M.)

17. Head of fruits. Mt. Victoria. (J.H.M.) Approaching var, capitate. See p. 319.

18a. Leaf; $18 b$, fruits of a form of $E$. anygdalina (near var. nitida) also from Mt. Victoria, N.S.W. (J.H.M.) This is a form called E. hemastoma, Sm., var. montana. (Deane and Yaiden.) See Part VI, p. 163 of this work. The leaves are narrower, but note the general resemblance of the fivits to those of $E$. hemastoma var. capitata.

\section{E. siderophloia, Benth.}

19. Large, broadly ovate juvenile leaf. Smithfield, Sydney. (J.H.M.)

20a. Buds; 20b, anthers (3 drawings). Cabramatta, N.S.W. (W. Woolls.)

21. Fruits. Bankstown, Sydney. (J. L. Boorman.)

22. Fruits. Paterson, N.S.W. (J. L. Boorman.)

23. Fruits. Bullahdelah, N.S.W. (A. Rudder.)

24. Mature leaf. Flemington, Sydney, (J.H.M.)

25. Fruits. Jones' Flat, Stroud, N.S.T. (J.H.M.)

26a. Buds; 26b, anther, "Yellow Tronbark." Brisbane, Queensland. (P. MacMahon.)

27. Buds, Taylor's Range, Q. (F. H. Bailey.) These belong to E. resinifera, Sm., and are placed here for comparison between $20 a$ and $26 a$. It will be seen that examination of buds alone of $E$. siderophloic and E. resinifera must be conducted with caution.

28. Fruits. Rockhampton, Q. (A. Murphy).

$$
\text { E. siderophloia, Benth., var. glauca. }
$$

29. Jurenile leaf. Dubbo-Coonamble Road, N.S.W. (J. L. Boorman.)

30. Fruits. Dubbo. (H. Deane.)

31. Fruits. Dubbo, with valves less exsert. (J. L. Boorman.)

32. Mature leaf. Minore, Dubbo. (J. L. Boorman.)

$33 a$. Buds (note the comparatively short-pointed operculum); 33b, buds (note the "egg in egg-cup " shape which is common enough in the normal form also, although a separate figure has not been given): $33 c$, fruits. All from Gungal, near Merriwa, N.S.W. (J. L. Boorman.) See p. 325.

\section{PLA'IE 4S.}

\section{E. Bowmani, F.v.MI.}

1r. Ieaf with immature fruit; $1 b$, fiont and back view of anther, from fragiment of type. "Queensland." (Bowman.)

E. Boormani, Deane and Maiden.

2a. Juvenile leaf; $2 b$, mature leaf; $2 c$, buds; $2 d$, anthers; $2 e$, fruits from type. Bankstown and Cabramatta. (J. L. Boorman.) 


\section{E. leptophleba, F.v.M.}

3 Mature leaf. South Coen River, Q. (Stephen Johnson.)

4a. Buds; 4b, anthers. Port Denison, Q. (J. Dallachy.)

5. Fruits. Endeavour River, Q. (Lieut. King, in Herb. Cambridge, ex Herb. Aylmer Lambert.)

\section{E. Behriana, F.v.M.}

(iı. Juvenile leaf (in opposite stage); $6 b$, leaf (in intermediate stage); $6 c$, fruits (note their unusual conoid shape); $6 d$, fruits (note their definedrim). All from Wyalong, N.S.W. (J. T. Boorman.)

7. Fruits. Swan Hill, Victoria. Note their small size. (J, G. Luehmann.)

$\therefore$ Buds. Yarram Biack, V. (C. Walter.) (Note the marked paniculate inflorescence.)

9. Very young buds. Inglewood, V (J. Blackburne.) Note their angularity.

10. Anthers. Barmedman, N.S.W. (J. Duff.)

\section{E. populifolia, Hook.}

llu. Juvenile leaf (in opposite stage); 1 lb, fruits. Coolabah, N.W.W. (J. L. Boorman.)

I:a. Broadest.mature leaf; $12 b$, average leaf of a tree at Bogan Gate, N.S.W. (J. L. Boorman.)

1:3. Mature leaf. Gungal, near Merriwa, N.S.W. (J. L. Boorman.)

11. Mature leaf. North Bourke, N.s.W. (A. Murphy.) (Note its lanceolate shape.)

1.). Buds. Timapagee, Wanaaring, N.S.W. (R.J. Dalton.) (Note the conical opercula.)

16. Fruits. Cobar, N.S.W. (J. L. Boorman.) (Note tlieir well-defined rims.)

17. Anther. Bulgandramine, Nirromine, N.S.W. (A. R. Samuels.)

1.i. Leaf with flowers and immature fruits; $18 b$, anther's. Fragment of the trpe of "E. bicolor, A. Cunn. var. proviftora, Muell." Burdekin River, Q. (From Kew.) Compare the leaf of 14, and see pp. 339 and 340 . 
The following species of Eucalyptus are illustrated in my "Forest Flora of New South Wales"* with larger twigs than is possible in the present work; photographs of the trees are also introduced wherever possible. Details in regard to their economic value, \&c., are given at length in that work, which is a popular one. The number of the Part of the Forest Flora is given in brackets:-

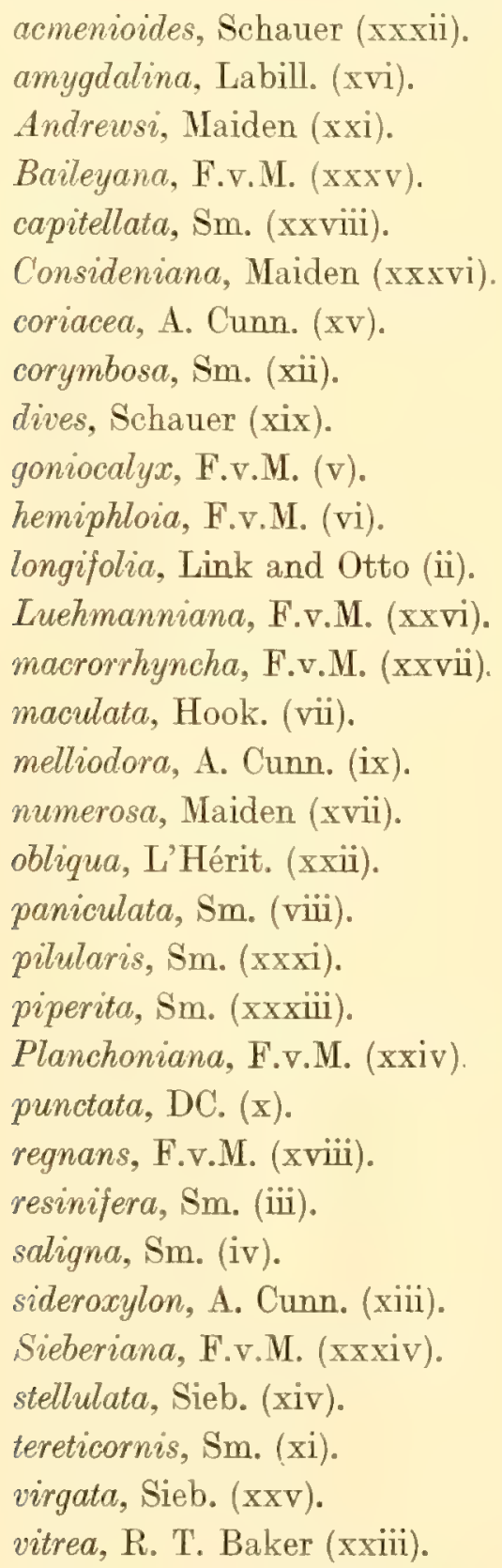

P. This Part (X) completes Vol. 1 of the "Critical Revision of the genus Eucalyptus," and an index and title page to the volume will be issued in due course.

* Government Printer, Sydney. 4to. Price 1s. per part (10s. per 12 parts); each part containing 4 plates and othu illustrations. 



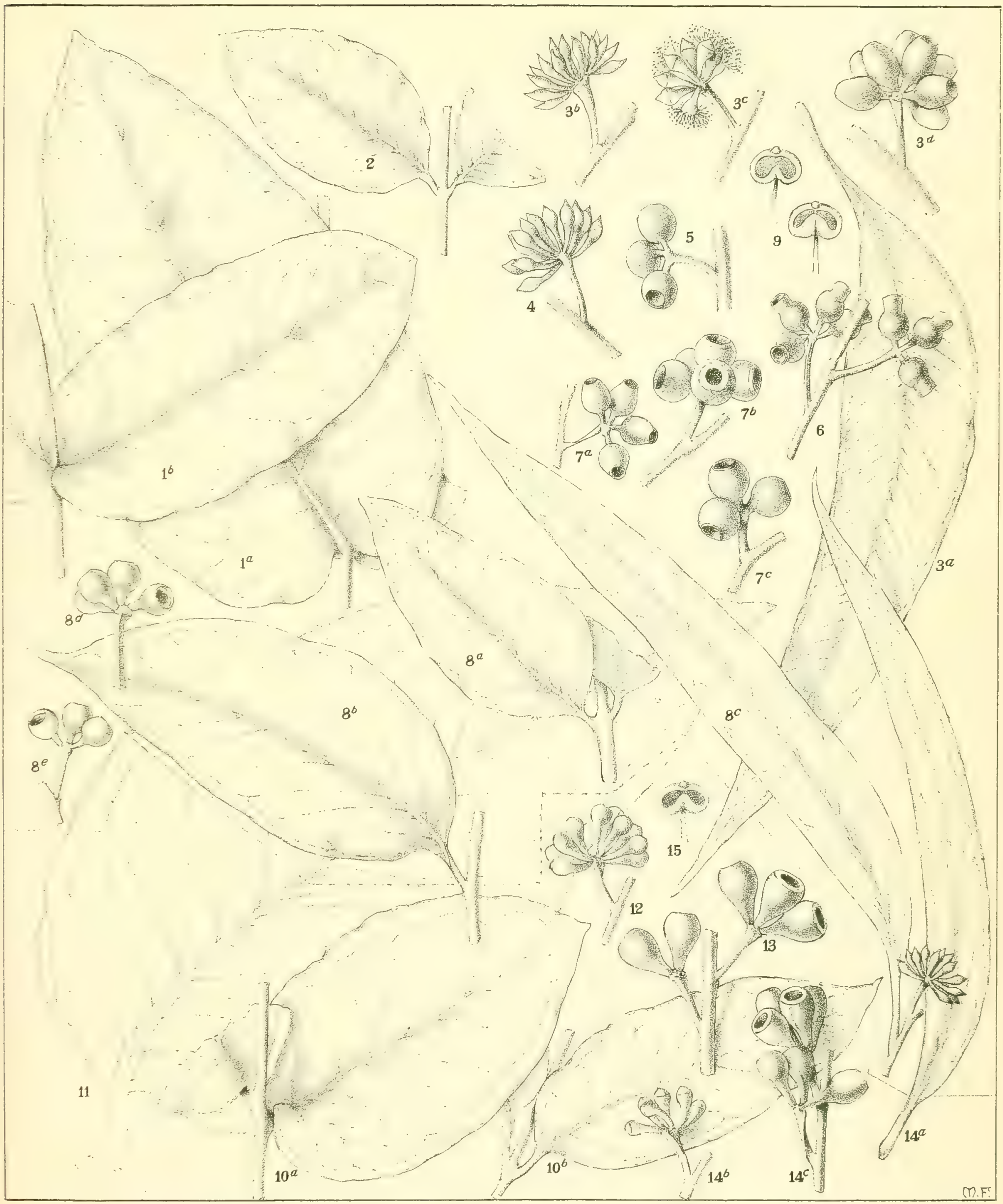

E. PIPERITA, Sm. (1-9).

E. SIEBERIANA, F.v.M. (10-15). 



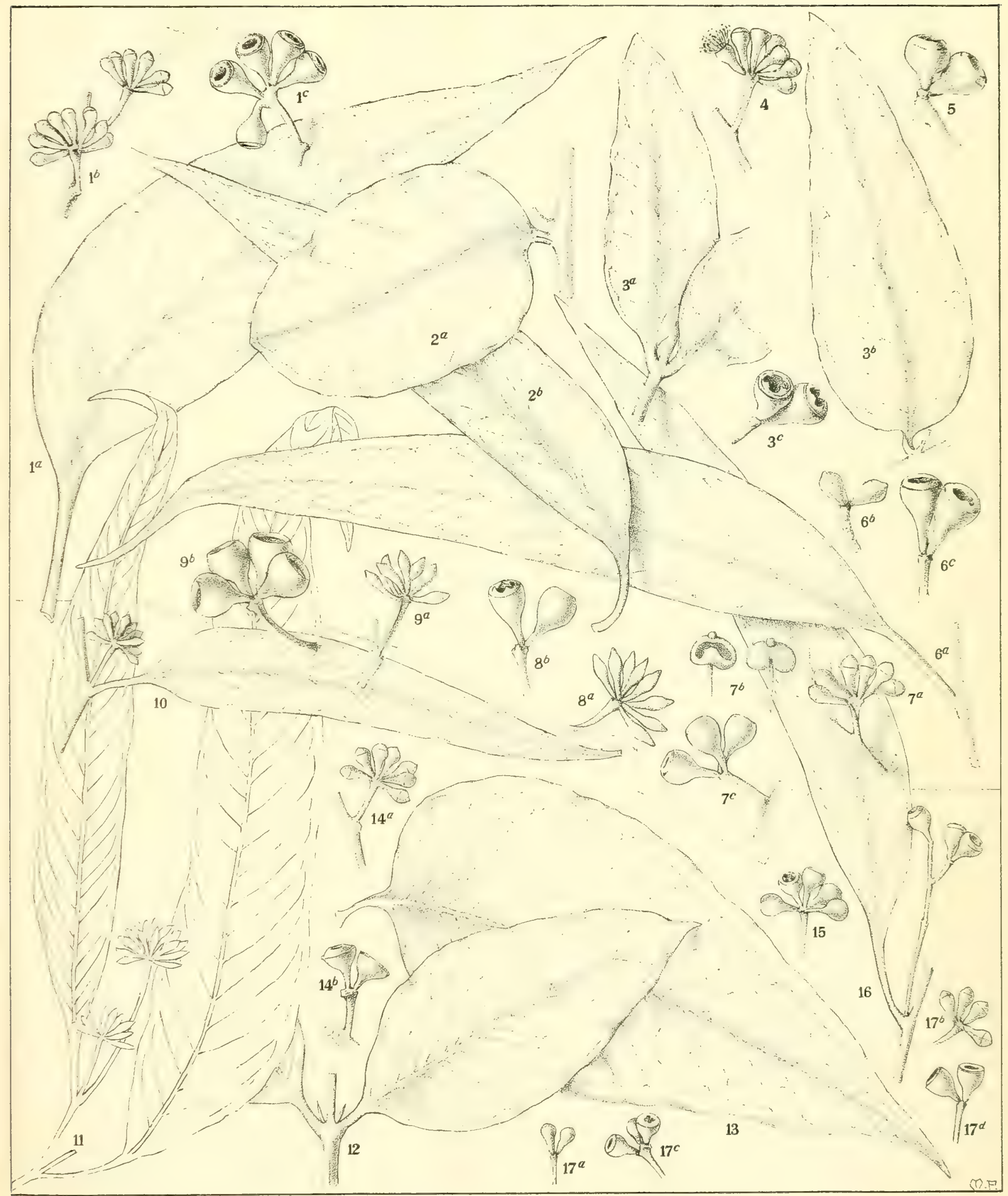

E. CONSIDENIANA, Maiden (1-9).

E. HÆMASTOMA, Sm. (10-17). 



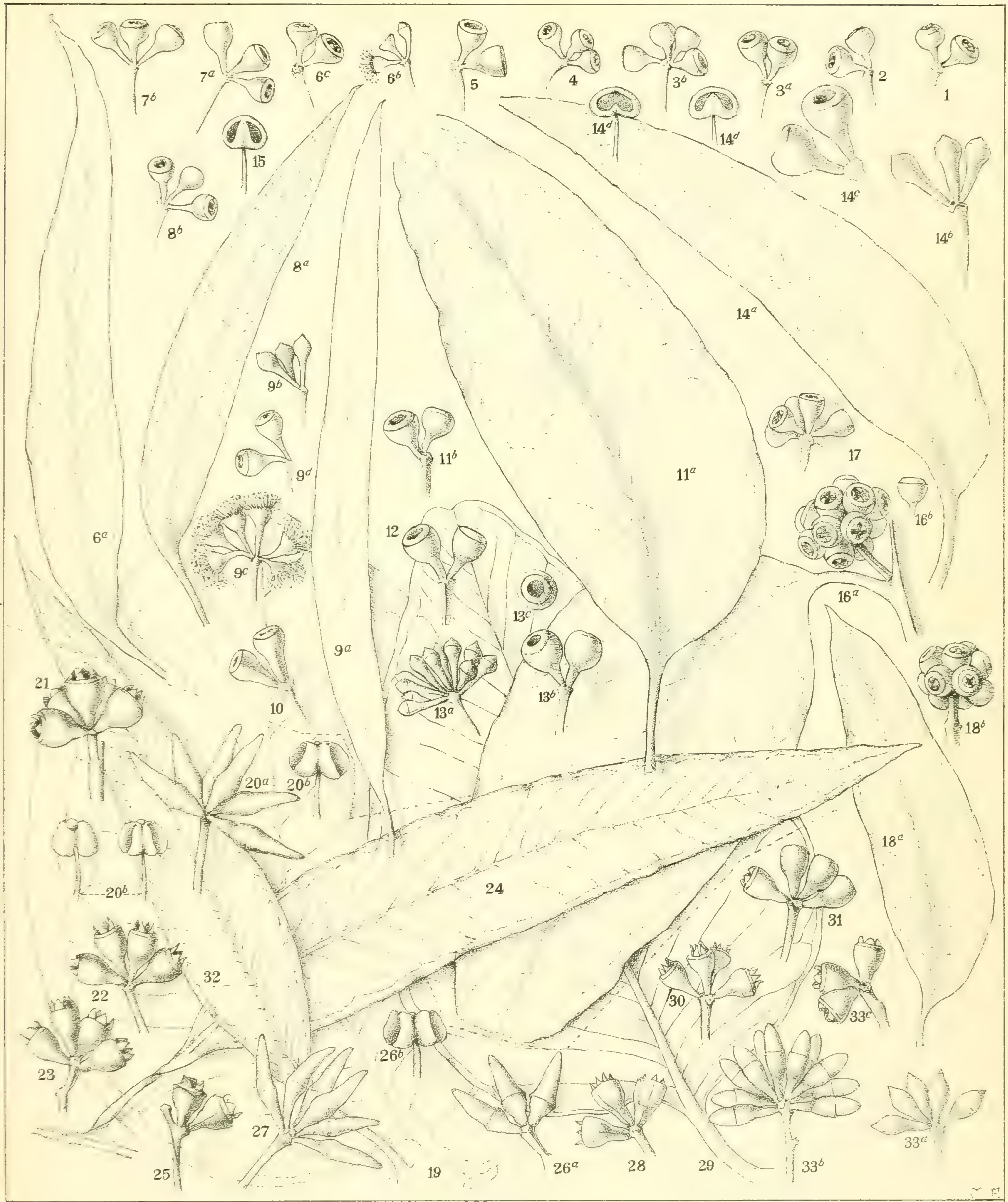

E. Hemastoma, Sm. and Vars. (1-18).

E. SIDEROPHLOIA, Benth. (19-83). 



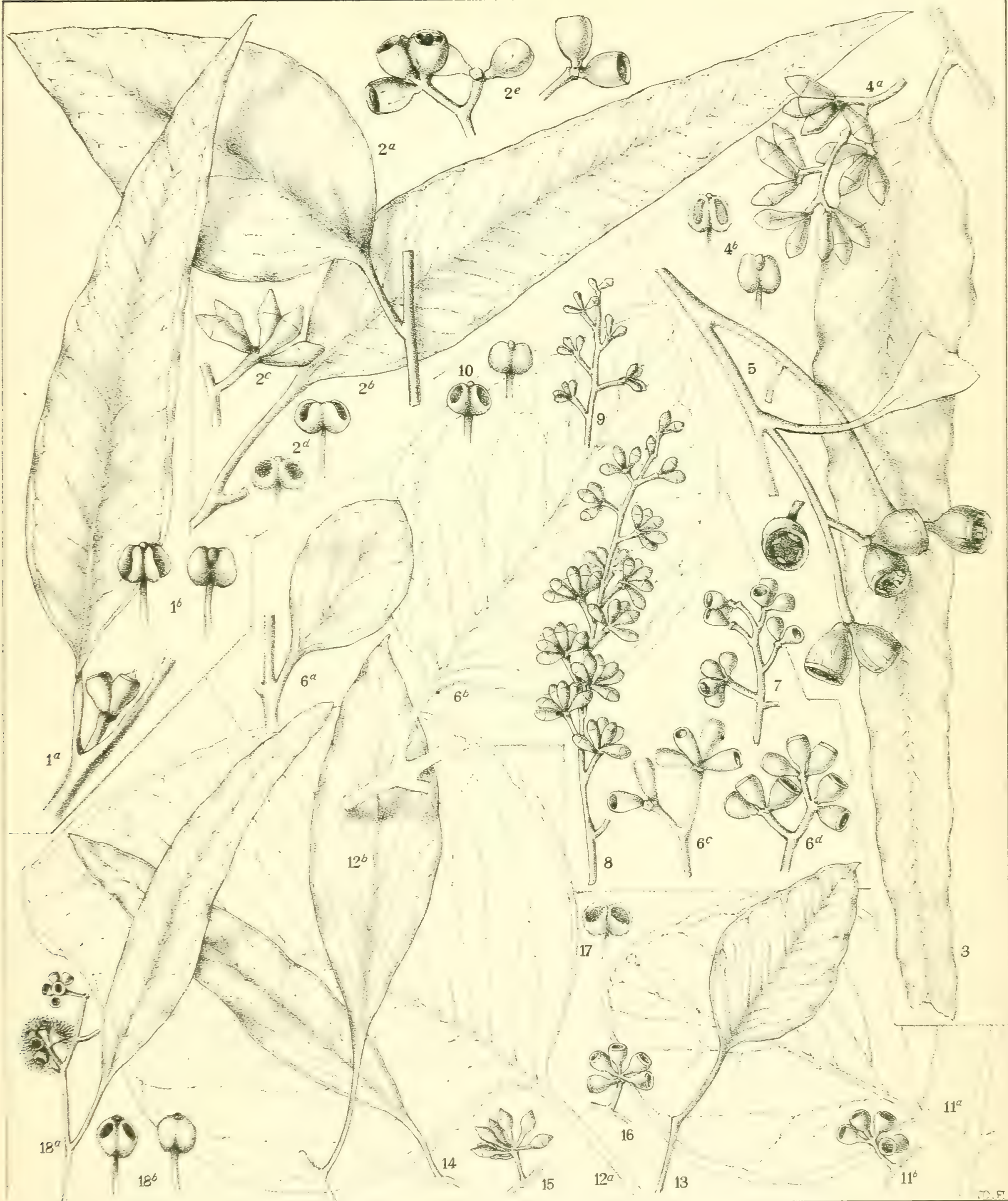

E. BOIVMANI, F.v.M (1).

E. BOORMANI, D. \& M. (2).

E. LEPTOPHLEBA, F.v. M. (3-5).

E. BEHRIANA, F.v.M. (6-10). 

The following species of Eucalyptus are illustrated in my "Forest Flora of New South Wales"* with larger twigs than is possible in the present work; photographs of the trees are also introduced wherever possible. Details in regard to their economic value, \&c., are given at length in this work, which is a popular one. The number of the Part of the Forest Flora is given in brackets:-

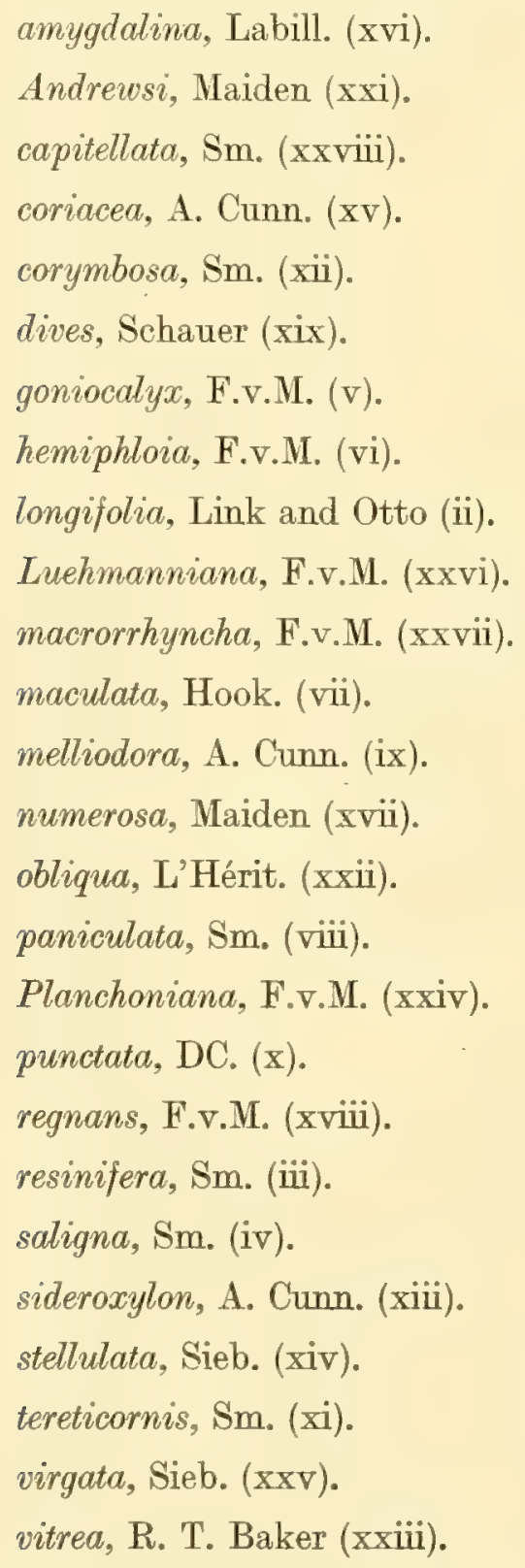

* Government Printer, Sydney. 4to. Price 1s. per part (10s. per 12 parts'; 3qch part containing 4 plates and other illustrations. 
Part I-1. Eucalyptus pilularis, Sm., and var. Muelleriana, Maiden.

Plates, 1-4. (Issued March, 1903.)

II-2. Eucalyptus obliqua, L'Héritier.

Plates, 5-8. (Issued May, 1903.)

III-3. Eucalyptus calycogona, Turczaninow.

Plates, 9-12. (Issued July, 1903.)

IV - 4. Eucalyptus incrassata, Labillardière.

5. Eucalyptus frecunda, Schauer.

Plates, 13-24. (Issued June, 1904.)

V--6. Eucalyptus stellulata, Sieber.

7. Eucalyptus coriacea, A. Cunn.

8. Eucalyptus coccifera, Hook. f.

Plates, 25-28. (Issued November, 1904.)

VI-9. Eucalyptus amygdalina, Labillar Jière.

10. Eucalyptus linearis, Dehnhardt.

11. Eucalyptus Risdoni, Hook. f.

Plates, 29-32. (Issued April, 1905.)

VII-12. Eucalyptus regnans, F.v.M.

13. Eucalyptus vitellina, Naudin, and Eucalyptus vitrea, R. T. Baker.

14. Eucalyptus dives, Schauer.

15. Eucalyptus Andrewsi, Maiden.

16. Eucalyptus diversifolia, Bonpland.

Plates, 33-36. (Issued October, 1905.)

VIII-17. Eucalyptus capitellata, Sm.

18. Eucalyptus Muelleriana, Howitt.

19. Eucalyptus macrorrhyncha, F.v.M.

20. Eucalyptus eugenioides, Sieber.

21. Eucalyptus marginata, Sm.

22. Eucalyptus buprestium, F.v.M.

23. Eucalyptus sepulcralis, F.v.M.

Plates, 37-40. (Issued March, 1907.) 




SMITHSONIAN INSTITUTION LIBRARIES

39088001968 ?

nhbot qQK 495.M9M217
v. 1 A critical revision of the genus 